\author{
UNIVERSIDADE DE SÃO PAULO \\ ESCOLA DE ENGENHARIA DE SÃO CARLOS \\ DEPARTAMENTO DE GEOTECNIA
}

\title{
Avaliação das Alterações da Rede de Drenagem em Sub-bacias e Microbacias do Alto e Baixo Rio Capivari (Louveira e Rafard/SP)
}

\author{
Sara Fernanda Silva Rodrigues
}

Dissertação apresentada à Escola de

Engenharia de São Carlos da Universidade de São Paulo, Como parte dos requisitos para a obtenção do Título de Mestre em Geotecnia

Orientador: Prof. Dr. José Eduardo Rodrigues

São Carlos - SP

2003 
Aos meus pais Maria e Fernando por todo seu amor, carinho, dedicação, apoio e confiança 
De tudo ficaram três coisas:

A certeza de que estamos sempre começando ...

A certeza de que precisamos continuar ...

A certeza de que seremos sempre interrompidos ...

Fernando Pessoa 


\section{Agradecimentos}

À Deus, pela vida, pela oportunidade de aprendizado diário e por ter me permitido o fechamento de mais uma etapa de crescimento profissional.

Aos meus pais, Maria e Fernando, e irmão Alex que estiveram presentes em todos os momentos me incentivando, me apoiando e me estimulando a prosseguir na caminhada.

Ao amigo e orientador Prof. José Eduardo Rodrigues pela amizade, orientação, apoio, confiança e estímulo.

À FAPESP, por disponibilizar os recursos financeiros utilizados nessa pesquisa.

Ao CNPq, pelo fornecimento da bolsa de mestrado, durante a realização da pesquisa.

Ao Departamento de Geotecnia da Escola de Engenharia de São Paulo pela infra-estrutura física que disponibilizou para a efetivação da pesquisa e ao quadro de funcionários que facilitou a sua execução, em especial ao Oscar, Zé Luiz, Décio e Antônio, por acompanharem com dedicação os trabalhos de campo e laboratoriais; ao técnico de informática Herivelto, pela dedicação e presteza em todos os momentos; e a Maristela, Neiva, Alvaro e Rosa, pela paciência, auxílio e atenciosa dedicação nos anos de convívio.

Aos professores Lázaro Valentim Zuquette, Nilson Gandolfi e Reinaldo Lorandi pelas sugestões, críticas e avaliações.

Aos professores do Departamento da Geotecnia pela oportunidade de aprendizado e em especial ao Prof Orecio Monje Vilar pelas lições de vida.

Aos géologos Holden Amorim e Rogério Ribeiro pelas discussões e sugestões durante o desenvolvimento da pesquisa e pelas suas prestimosas amizades.

Aos amigos Dirlene Gomes, Indira Queiroz, Jorge Avelar, Helano Fonteles, Domingos Borges, Juliana Silveira, Leonardo Silveira, Maurício Giambastiani, Isabel Salcedo Fernanda Silva Sandra Fernandes, Holden Amorim e Rogério Ribeiro que além do alicerce formado pela amizade, constituíram a minha família me dando o apoio e o estímulo para continuar a caminhada.

Aos colegas da Geotecnia pela oportunidade de convivência e de aprendizado. 


\section{SUMÁRIO}

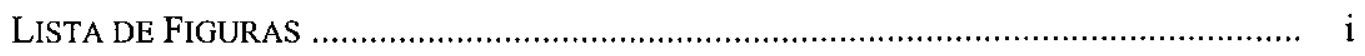

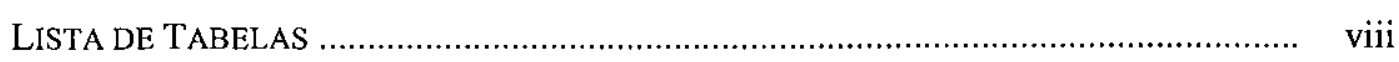

LISTA DE ABREVIATURAS E SIGLAS …......................................................

LISTA DE SÍMBOLOS ................................................................................... xvii

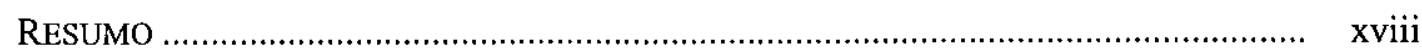

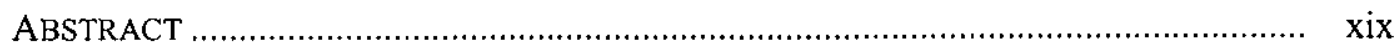

1. INTRODUÇÃO ..............................................................................................

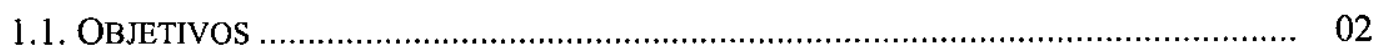

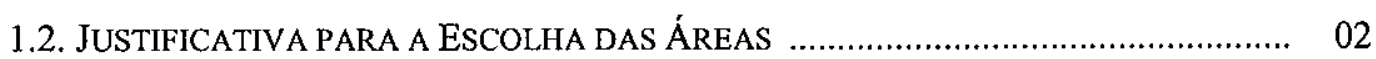

2. REVISÃo BIBLIOGRÁFICA .................................................................................. 04

2.1. O MEIO AMBIENTE E O ECODESENVOLVIMENTO ............................................. 04

2.2. ALTERAÇÃO, IMPACTO E DEGRADAÇÃo AMBIENTAL ….................................. 06

2.3. INDICADORES E GEOINDICADORES …..................................................... 11

2.4. BACIA HIDROGRÁFICA: SISTEMA INTEGRADO ............................................ 16

2.5. METODOlogia DE MAPEAMENTO GEOTÉCNICO (EESC/USP) .......................... 20

2.6. MÉTodo de COLLARES (2000) PARA AVALIAÇÃo DAS ALTERAÇõES EM REDE

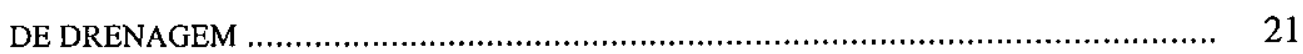

2.6.1. Levantamento de Uso e Ocupação ........................................................... 21

2.6.2. Levantamento das Atividades Modificadoras do Meio Físico ....................... 22

2.6.3. Análise Temporal de Intervenções Antrópicas ........................................... 23

2.6.4. Análise Temporal da Morfometria da Rede de Drenagem ........................... 24

2.7. ANÁLISE MORFOMÉTRICA DE BACIAS HIDROGRÁFICAS ................................. 25

2.7.1. Hierarquia Fluvial ................................................................................... 27

2.7.2. Parâmetros Morfométricos …………......................................................... 28

2.7.2.1. Variáveis Lineares ............................................................................ 28

2.7.2.2. Variáveis Areais ............................................................................ $\quad 30$

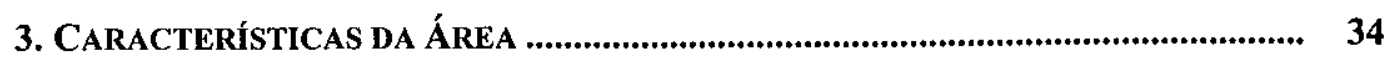

3.1. LOCALIZAÇÃO E VIAS DE ACESSO........................................................... 34

3.1.1. Área 1 - Alto Rio Capivari ................................................................... 34

3.1.2. Área 2 - Baixo Rio Capivari ............................................................... 36

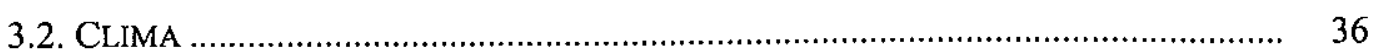




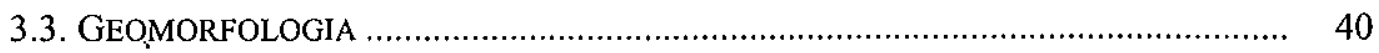

3.3.1. Área 1 - Alto Rio Capivari ................................................................... 40

3.3.2. Área 2 - Baixo Rio Capivari ……............................................................ 40

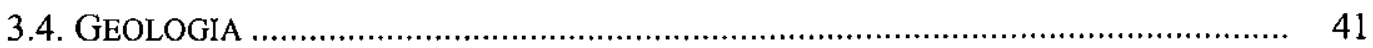

3.4.1. Área 1 - Alto Rio Capivari .................................................................... 41

3.4.1.1. Gnaisses ......................................................................................... 41

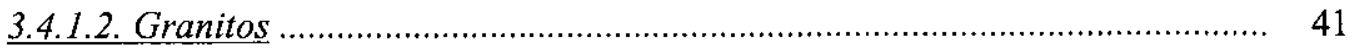

3.4.2. Área 2 - Baixo Rio Capivari ………................................................... 42

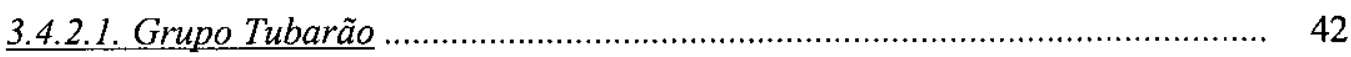

3.4.2.1.1. Subgrupo Itararé .......................................................................... 42

3.4.2.2. Rochas Intrusivas associadas a Formação Serra Geral (Jurrássico-

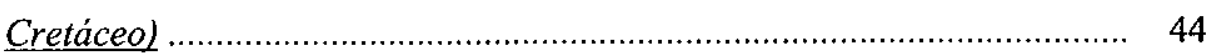

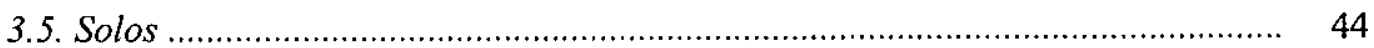

3.6. Recursos Hidricos ................................................................................. 44

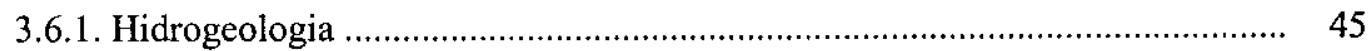

3.6.1.1. Área 1-Alto Rio Capivari ................................................................... 45

3.6.1.1.1. Sistema Aqüifero Cristalino ............................................................... 45

3.6.1.2. Área 2 - Baixo Rio Capivari ……..................................................... 46

3.6.1.2.1. Sistema Aqüiffero Tubarão ................................................................. 46

3.6.1.2.2. Sistema Aqüífero Diabásio .............................................................. 46

3.6.2. Hidrologia ..................................................................................... 46

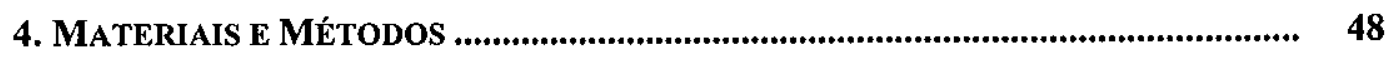

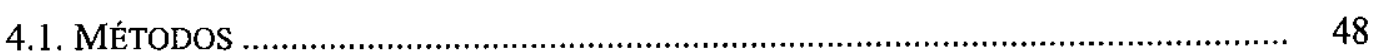

4.2. OBTENÇÃo E PROCESSAMENTO DAS INFORMAÇ̃̃ES …................................... 50

4.2.1. Fotointerpretação ............................................................................... 50

4.2.2. Levantamento de Campo …..................................................................... 51

4.2.3. Ensaios Laboratoriais ......................................................................... 52

4.2.4. Tratamento de Dados em Ambiente Digital .................................................. 53

4.2.5. Elaboração de Documentos Cartográficos ...................................................... 54

4.2.5.1. Mapa de Documentação ……............................................................... 54

4.2.5.2. Carta de Declividade ……................................................................... 54

4.2.5.3. Mapa da Rede de Drenagem .............................................................. 57

4.2.5.3.1. Escaneamento ................................................................................ 57

4.2.5.3.2. Georeferenciamento e Mosaicagem ................................................... 57 
4.2.5.3.3. Vetorização e Criação de Topologias .................................................. 58

4.2.5.4. Mapa de Uso e Ocupação ……............................................................ 58

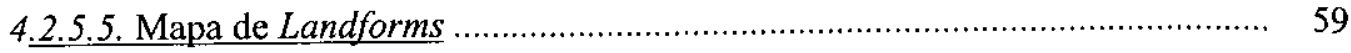

4.2.5.6. Mapa de Substrato Rochoso ……...................................................... 59

4.2.5.7. Mapa de Materiais Inconsolidados ……................................................ 59

4.2.6. Procedimento de Análise das Microbacias Hidrográficas ............................ 59

5. DoCUMENTOS CARTOGRÁficos ElaBorados ................................................... 61

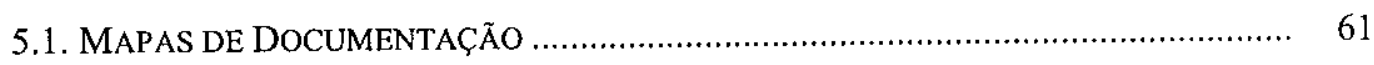

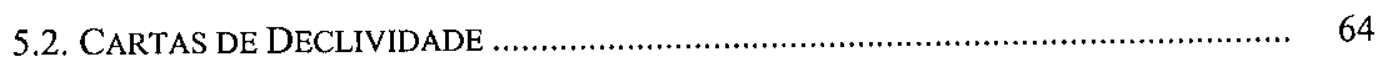

5.3. MAPAS DA REDE DE DRENAGEM …...................................................... 68

5.3.1. Área 1 - Alto Rio Capivari ........................................................................ 68

5.3.2. Área 2 - Baixo Rio Capivari ...................................................................... 71

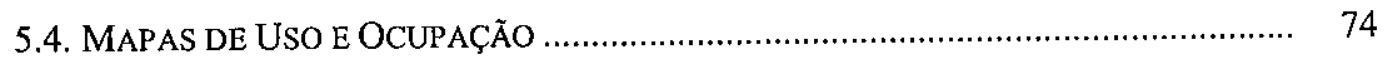

5.4.1. Área 1 - Alto Rio Capivari ........................................................................ 74

5.4.2. Área 2 - Baixo Rio Capivari ..................................................................... 78

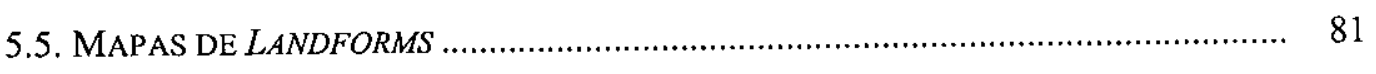

5.5.1. Descrição dos Landforms ….................................................................... 84

5.5.5.1. Área 1-Alto Rio Capivari ……........................................................ 84

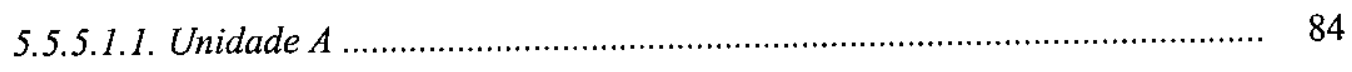

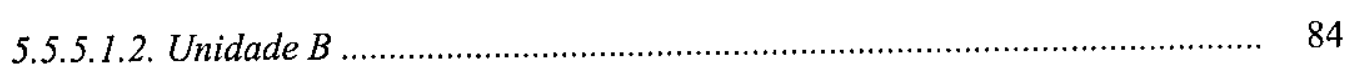

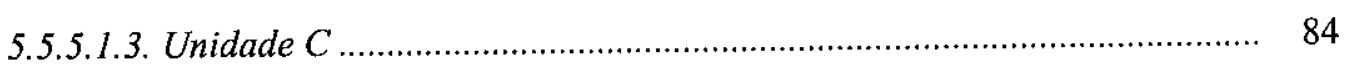

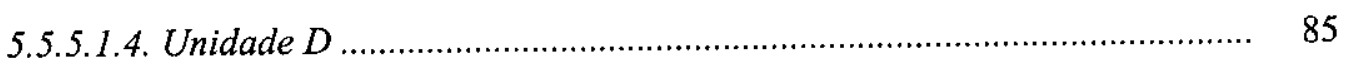

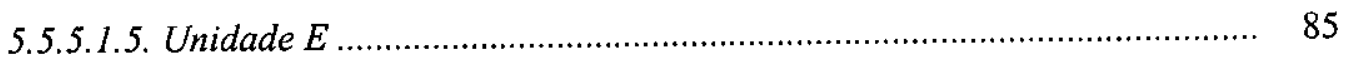

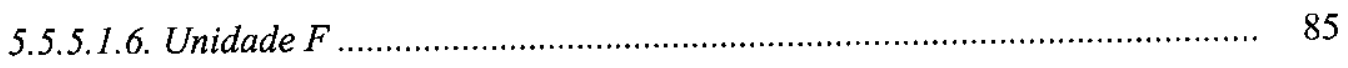

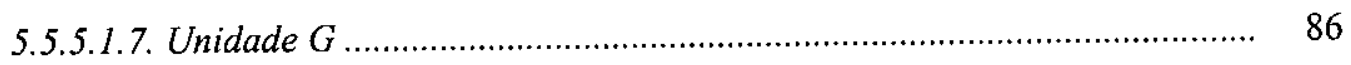

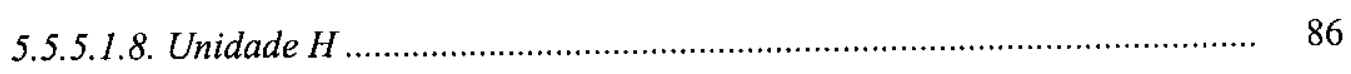

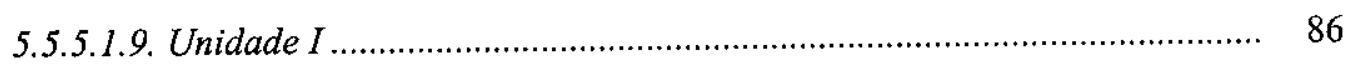

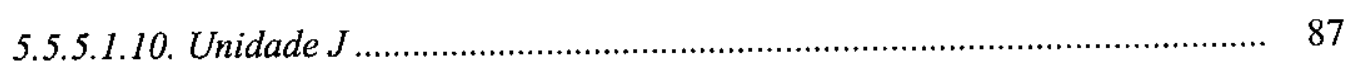

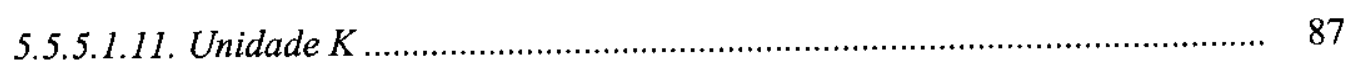

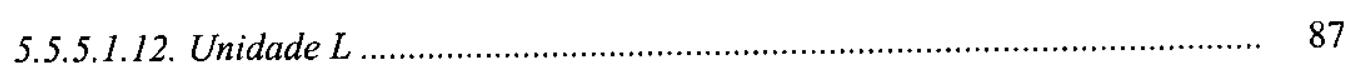

5.5.5.1.13. Unidade M ......................................................................... 87

5.5.5.2. Área 2-Baixo Rio Capivari …........................................................ 88

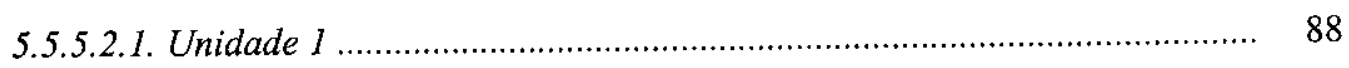

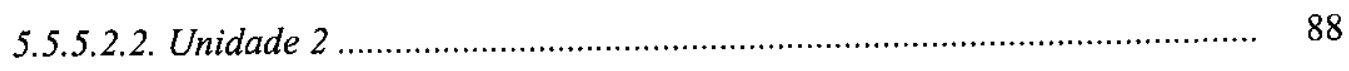


5.5.5.2.3. Unidade 3

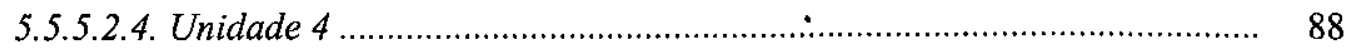

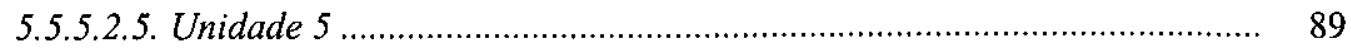

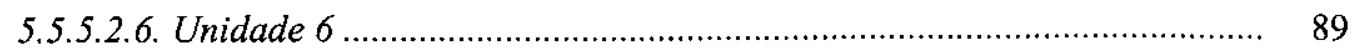

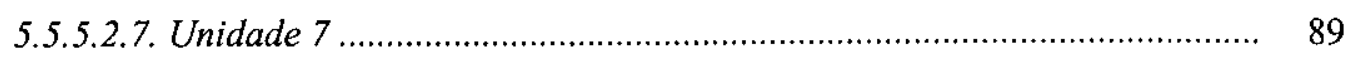

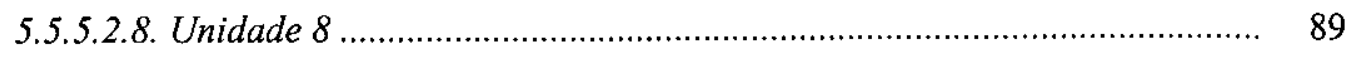

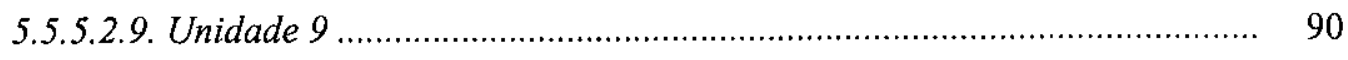

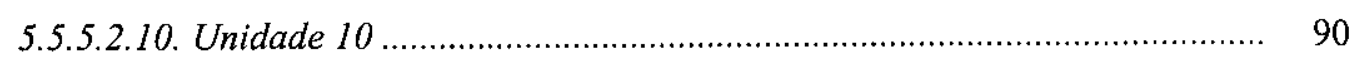

5.5.5.2.11. Unidade 11 .............................................................................. 90

5.5.5.2.12. Unidade 12 …......................................................................... 90

5.6. MAPAS DE SUBSTRATO ROCHOSO …................................................... 90

5.6.1. Área 1 - Alto Rio Capivari ...................................................................... 90

5.6.1.1. Complexo Amparo (Proterozóico Inferior) ............................................. 93

5.6.1.2. Suíte Granítica Morungaba (Proterozóico Inferior) ................................ 93

5.6.2. Área 2 - Baixo Rio Capivari .................................................................... 93

5.6.2.1. Subgrupo Itararé (Carbonifero Superior - Permiano) ........................... 93

5.6.2.2. Rochas Intrusivas (Jurássico - Cretáceo) .............................................. 94

5.7. MAPAS DE MATERIAIS INCONSOLIDADOS ................................................... 94

5.7.1. Área 1-Alto Rio Capivari ……............................................................. 98

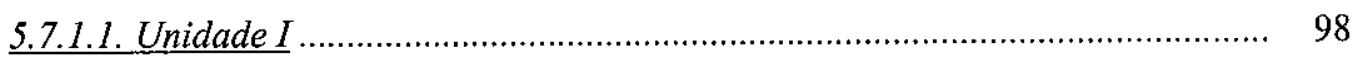

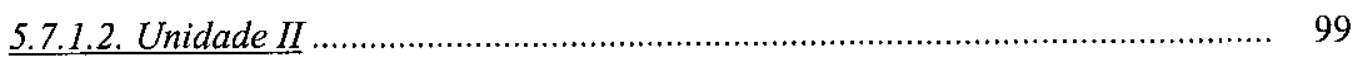

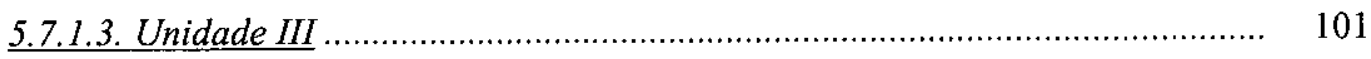

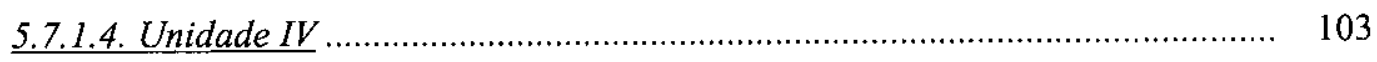

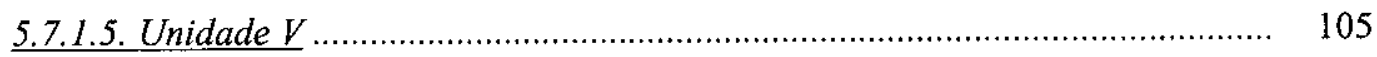

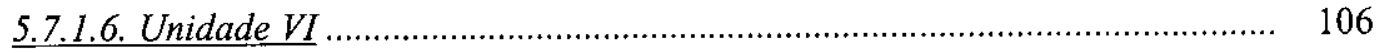

5.7.1.7. Unidade VII ............................................................................... 107

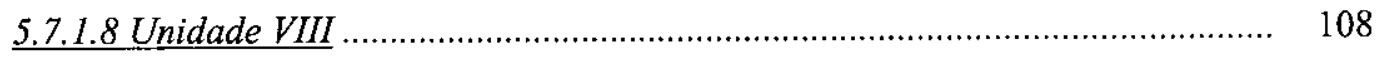

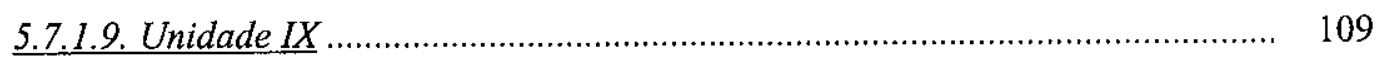

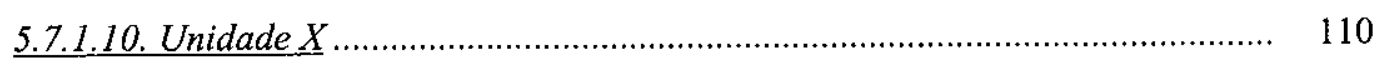

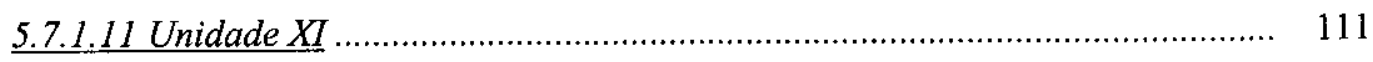

5.7.1.12. Unidade XII …......................................................................... 113

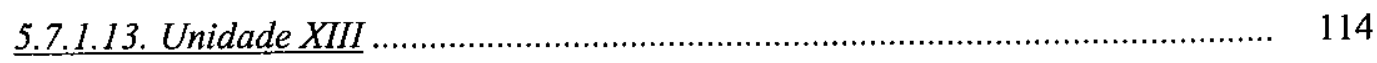

5.7.1.14. Unidade XIV ........................................................................... 115

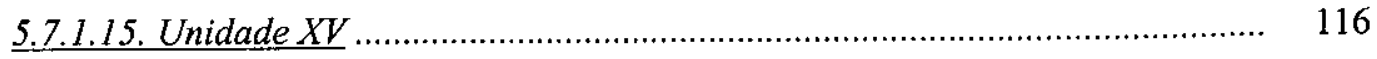

5.7.1.16 Unidade XVI ........................................................................... 117 
5.5.5.2.1. Unidade A1

5.5.5.2.2. UnidadeA 2

5.5.5.2.3. Unidade $A 3$

5.5.5.2.4. Unidade A4

5.5.5.2.5. Unidade A5

5.5.5.2.6. Unidade $A 6$

5.5.5.2.7. Unidade $A 7$

5.5.5.2.8. Unidade $A 8$

5.5.5.2.9. Unidade $A 9$ 126

5.5.5.2.10. Unidade $A 10$ 128

5.5.5.2.11. Unidade A11

6. AValiaÇão das alteraÇões nas Sub-Bacias Hidrográficas 131

6.1. ÁREA 1 - ALTO RIO CAPIVARI

6.1.1. Verificação das Alterações na Rede de Drenagem nas Sub-Bacias Hidrográficas por meio da Análise Morfométrica

6.1.2. Verificação Temporal de Modificações de Atividades Antrópicas

6.1.3. Considerações Parciais - Sub-Bacias da Área 1 ........................................... 145

6.2. ÁREA 2 - BAIXO RIO CAPIVARI .............................................................. 146

6.1.1. Verificação das Alterações na Rede de Drenagem nas Sub-Bacias Hidrográficas por meio da Análise Morfométrica .................................... 146

6.2.2. Verificação Temporal de Modificações de Atividades Antrópicas ................ 155

6.2.3. Considerações Parciais - Sub-Bacias da Área 2 ....................................... 160

7. AVAliaÇão das Alterações nas MicroBacias HidrográfiCaS ............ 162

7.1. CONSIDERAÇÕES INICIAIS .......................................................................... 162

7.2. PRINCIPAIS VARIÁVEIS MORFOMÉTRICAS APLICADAS NA ANÁLISE TEMPORAL 168

7.3. ÁREA 1 - ALTO RIO CAPIVARI ............................................................... 171

7.3.1. Compartimentação das Microbacias ........................................................... 171

7.3.2. Faixas de Distribuição para as Variáveis Morfométricas ............................. 172

7.3.2.1. Indice de Forma (k) ...................................................................... 173 
7.3.2.3. Densidade Hidrográfica $(D h)$........................................................... 175

7.3.2.4. Textura Topográfica (Tt) ……........................................................... 176

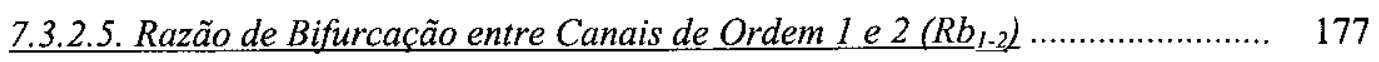

7.3.2.6. Razão entre Comprimentos Médios dos Canais de Ordem 2 e 1 (Rlm 2 2.12 ... 178

7.3.3. Relação entre as Variáveis Morfométricas .................................................. 179

7.3.4. Avaliação das Taxas de Variação dos Principais Índices Morfométricos ...... 181

7.3.5. Análise da Influência dos Dados Morfométricos Obtidos para 1972 Quanto à

Taxa de Variação

7.3.6. Avaliação da Influência do Meio Físico (geologia, landforms e materiais inconsolidados) na Taxa de Variação dos Índices Morfométricos

7.3.7. Avaliação da Influência das Características de Uso e Ocupação nas Alterações Temporais

7.3.8. Considerações Parciais - Microbacias da Área 1 198

7.3.8.1. Quanto às Características Morfométricas da Área 1

7.3.8.2. Quanto às Relações Obtidas para as Taxas de Variação dos Principais Índices Morfométricos da Área I ............................................................ 198

7.3.8.3.- Quanto à Influência do Meio Físico da Area 1 ...................................... 199

7.3.8.4.-Quanto à Influência das Atividades Antrópicas na Área 1 ...................... 199

7.4. ÁREA 2 - BAIXO RIO CAPIVARI ............................................................ 200

7.4.1. Compartimentação das Microbacias ....................................................... 200

7.4.2. Faixas de Distribuição para as Variáveis Morfométricas .............................. 201

7.4.2.1. Índice de Forma $(k)$.................................................................... 201

7.4.2.2. Densidade de Drenagem (Dd) .......................................................... 202

7.4.2.3. Densidade Hidrográfica $(D h)$.......................................................... 203

7.4.2.4. Textura Topográfica (Tt) .................................................................. 204

7.4.2.5. Razão de Bifurcação entre Canais de Ordem 1 e 2 (Rb $\left.b_{1-2}\right)$....................... 205

7.4.2.6. Razão entre Comprimentos Médios dos Canais de Ordem 2 e 1 (Rlm 2 2-1) ... 206

7.4.3. Relação entre as Variáveis Morfométricas ................................................... 207

7.4.4. Avaliação das Taxas de Variação dos Principais Índices Morfométricos ...... 209

7.4.5. Análise da Influência dos Dados Morfométricos Obtidos para 1972 Quanto à Taxa de Variação. 
7.4.6. A̧valiação da Influência do Meio Físico (geologia, landforms e materiais inconsolidados) na Taxa de Variação dos Índices Morfométricos

7.4.7. Avaliação da Influência das Características de Uso e Ocupação nas Alterações Temporais ............................................................................. 219

7.4.8 Considerações Parciais - Microbacias da Área 2 …….................................. 225

7.4.8.1. Quanto às Caracteristicas Morfométricas da Área 2 .............................. 225

7.4.8.2. Quanto às Relações Obtidas para as Taxas de Variação dos Principais Índices Morfométricos da Área 2 ............................................................. 225

7.4.8.3. Quanto à Influência do Meio Físico da Área 2 ..................................... 226

7.4.8.4. Quanto à Influência das Atividades Antrópicas na Área 2 ….................. 227

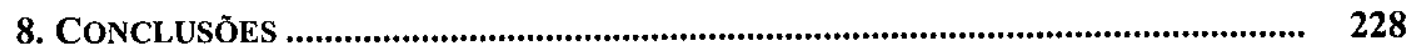

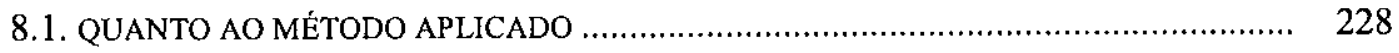

8.2. QUANTO À ANÁLISE MORFOMÉTRICA TEMPORAL …....................................... 229

8.3. QUANTO AS CAUSAS DA ALTERAÇÃO DA REDE DE DRENAGEM ........................ 230

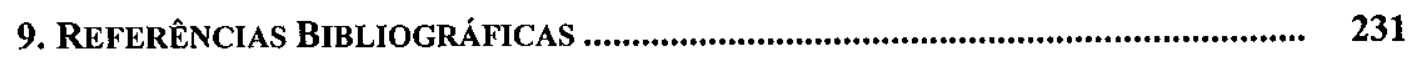




\section{LISTA DE FIGURAS}

\section{CAPÍtULO 2}

Figura 2.1 - Alteração a partir da intervenção de um processo tecnológico sobre um processo do meio físico

Figura 2.2 - $\quad$ Etapas de estudo de impacto ambiental ................................................... 08

Figura 2.3 - Geoindicador: ferramenta de auxílio no monitoramento integrado ....... 13

Figura 2.4 - Geoindicador: Um Componente Dinâmico no Geossistema ................... 14

Figura 2.5 - Bacia Hidrográfica: Um Sistema Integrado Aberto ............................... 16

Figura 2.6 - Direção do fluxo energético da bacia hidrográfica ................................ 17

Figura 2.7 - Componentes naturais do meio biótipo ................................................. 19

Figura 2.8 - Componentes naturais do meio físico ................................................. 19

Figura 2.9 - Componentes socioeconômicos .......................................................... 20

Figura 2.10 - Esquema adotado no processamento da imagem de satélites ................. 22

Figura 2.11 - Seqüência dos procedimentos adotados para a obtenção do banco de dados georeferenciados com as atividades modificadoras do meio ....... 23

Figura 2.12 - Seqüência de procedimentos adotados para análise temporal de intervenções antrópicas

Figura 2.13 - Seqüência de procedimentos adotados para análise temporal das modificações da rede de drenagem

\section{CAPÍTULO 3}

Figura 3.1 - Localização das áreas de estudo …...................................................... 35

Figura 3.2 - $\quad$ Principais vias de acesso .............................................................. 36

Figura 3.3 - Precipitação Anual entre o período de 1937 a 1994 obtida na Estação Meteorológica de Vinhedo ............................................................. 37

Figura 3.4 - Precipitação Média Mensal entre os períodos de 1937 a 1994 referentes a Estação Meteorológica de Vinhedo .................................. 38

Figura 3.5 - Precipitação Anual entre o período de 1953 a 1997 obtida nas estações meteorológicas de Capivari e Usina Bom Retiro .................................. 39

Figura 3.6 - Precipitação Média Mensal entre o período de 1953 a 1997 obtida nas estações meteorológicas de Capivari e Usina Bom Retiro

\section{CAPÍtUlO 4}

Figura 4.1 - Seqüência de procedimentos metodológicos empregados 49

Figura 4.2 - Ficha de campo utilizada para o cadastro das informações 


\section{CAPÍtUlO 5}

Figura 5.1 - Mapa de Documentação da Área de Estudo 1 …..................................... 62

Figura 5.2 - Mapa de Documentação da Área de Estudo 2 …................................... 63

Figura 5.3 - $\quad$ Carta de Declividade da Área de Estudo 1 ............................................. 66

Figura 5.4 - C Carta de Declividade da Área de Estudo 2 ........................................... 67

Figura 5.5 - $\quad$ Mapa da Rede de Drenagem da Área 1 referente a 1972 ...................... 69

Figura 5.6 - $\quad$ Mapa da Rede de Drenagem da Área 1 referente a 1995 ...................... 70

Figura 5.7 - $\quad$ Mapa da Rede de Drenagem da Área 2 referente a 1972 _...................... 72

Figura 5.8 - $\quad$ Mapa da Rede de Drenagem da Área 2 referente a 1995 ....................... 73

Figura 5.9 - Mapa de Uso e Ocupação da Área 1 referente a 1972 ........................... 76

Figura 5.10 - Mapa de Uso e Ocupação da Área 1 referente a 1995 ........................... 77

Figura 5.11 - Mapa de Uso e Ocupação da Área 2 referente a 1972 .......................... 79

Figura 5.12 - Mapa de Uso e Ocupação da Área 2 referente a 1995 ........................... 80

Figura 5.13 - Mapa de Landforms da Área 1 ....................................................... 82

Figura 5.14 - Mapa de Landforms da Área 2 _...................................................... 83

Figura 5.15 - Mapa de Substrato Rochoso da Área 1 ............................................... 91

Figura 5.16 - Mapa de Substrato Rochoso da Área 2 …............................................. 92

Figura 5.17 - Mapa de Materiais Inconsolidados da Área 1 ...................................... 96

Figura 5.18 - Mapa de Materiais Inconsolidados da Área 2 ........................................ 97

\section{CAPÍTULO 6}

Figura 6.1 - Registro do Número de Canais obtidos para os anos de 1972 e 1995 por sub-bacia analisada da Área 1 ...................................................... 134

Figura 6.2 - Hierarquia Fluvial das sub-bacias da Área 1 ....................................... 135

Figura 6.3 - Comprimento dos Canais por sub-bacia da Área 1 referente a 1972 e 1995 ...................................................................................... 135

Figura 6.4 - Taxa de Variação de Nt e N1 para as sub-bacias da Área 1 ................... 136

Figura 6.5 - Taxa de Variação de Lt e L1 para as sub-bacias da Área 1 .................... 136

Figura 6.6 - Registro dos valores de Comprimento Médio dos Canais expresso em porcentagens para as sub-bacias da Área 1 ........................................ 137

Figura 6.7 - Resultados obtidos para os anos de 1972 e 1995 de Densidade de Drenagem para cada Sub-Bacia da Área 1 .......................................... 137

Figura 6.8 - Registro obtido para densidade hidrográfica nas sub-bacias em Louveira para os anos de 1972 e 1995 ................................................ 138 
Figura 6.9 - Registro obtido para textura topográfica nas sub-bacias estudadas em Louveira para os anos de 1972 e 1995

Figura 6.10 - Registro obtido para Razão entre Comprimentos Médios do Canais de Ordem 2 e 1 nas sub-bacias estudadas em Louveira para os anos de 1972 e 1995

Figura 6.11 - Registro obtido para Razão de Bifurcação dos Canais de Ordem 1 e 2 nas sub-bacias estudadas em Louveira para os anos de 1972 e 1995 .

Figura 6.12 - Modificações observadas nas classes de atividades antrópicas da SubBacia Ribeirão do Moinho (B1)

Figura 6.13 - Modificações observadas nas classes de atividades antrópicas da SubBacia Córrego Sopezol (B2)

Figura 6.14 - Modificações observadas nas classes de atividades antrópicas da SubBacia Córrego Sopezol (B3)

Figura 6.15 - Modificações observadas nas classes de atividades antrópicas da SubBacia Córrego Sopezol (B4)

Figura 6.16 - Hierarquia das sub-bacias estudadas na Área 2

Figura 6.17 - Registro do Número de Canais da Área 2 obtido para os anos estudados por sub-bacia

Figura 6.18 - Taxa de Variação para Nt e N1 das sub-bacias da Área 2 ..................... 150

Figura 6.19 - Comprimento dos Canais por sub-bacia da Área 2 ............................... 150

Figura 6.20 - Taxa de Variação de Lt, L1, L2 e L3 para as sub-bacias da Área 2 ....... 151

Figura 6.21 - Taxa de Variação para Lm1 e Lm2 das sub-bacias da área 2 ............... 151

Figura 6.22 - Resultados obtidos para os anos de 1972 e 1995 de Densidade de Drenagem por sub-bacia referentes à Área 2

Figura 6.23 - Registro obtido para densidade hidrográfica nas sub-bacias estudadas em Rafard para os anos de 1972 e 1995

Figura 6.24 - Registro obtido para textura topográfica nas sub-bacias estudadas em Rafard para os anos de 1972 e 1995

Figura 6.25 - Registro obtido para Razão entre Comprimentos Médios dos Canais de Ordem 2 e 1 nas sub-bacias estudadas em Rafard para os anos de 1972 e 1995

Figura 6.26 - Registro obtido para Razão de Bifurcação dos Canais de Ordem 1 e 2 nas sub-bacias estudadas em Rafard para os anos de 1972 e 1995 
Figura 6.27 - Modificações observadas nas classes de atividades antrópicas nas SubBacias em Rafard (SP)

Figura 6.28 - Taxa de Variação das áreas de plantio de cana entre 1972 e 1995 ........ 158

Figura 6.29 - Taxa de Variação das áreas de pasto entre 1972 e 1995 ......................... 158

Figura 6.30 - Taxa de Variação para a classe mata/reflorestamento entre 1972 e 1995

Figura 6.31 - Taxa de Variação para a classe Hortifruti entre 1972 e 1995

\section{CAPÍtULO 7}

Figura 7.1 - Microbacias Delimitadas para a Área 1 em 1972 ................................. 163

Figura 7.2 - $\quad$ Microbacias Delimitadas para a área 1 em 1995 ................................... 164

Figura 7.3 - $\quad$ Microbacias Delimitadas para a área 2 em 1972 …................................. 165

Figura 7.4 - Microbacias Delimitadas para a área 2 em 1995 .................................. 166

Figura 7.5 - Dendrograma das taxas de variações das microbacias da área 1 entre os anos de 1972 e 1995 .......................................................................... 170

Figura 7.6 - Dendrograma das taxas de variações das microbacias da área 2 entre os anos de 1972 e 1995 ................................................................. 170

Figura 7.7 - Classes de Área para as microbacias estudadas na região de Louveira . 172

Figura 7.8 - $\quad$ Valores do Índice de Forma (k) para as microbacias estudadas na região de Louveira

Figura 7.9 - Valores de Densidade de Drenagem (Dd) para as microbacias estudadas na região de Louveira

Figura 7.10 - Valores de Densidade Hidrográfica (Dh) para as microbacias estudadas na região de Louveira ........................................................... 175

Figura 7.11 - Valores de Textura Topográfica (Tt) para as microbacias estudadas na região de Louveira

Figura 7.12 - Valores da Razão de Bifurcação entre canais de Ordem 1 e $2\left(\mathrm{Rb}_{1-2}\right)$ para as microbacias estudadas na região de Louveira

Figura 7.13 - Valores da Razão entre Comprimentos Médios dos canais de Ordem 2 e $1\left(\mathrm{Rlm}_{2-1}\right)$ para as microbacias estudadas na região de Louveira

Figura 7.14 - Relação entre área e densidade de drenagem referente a 1972 na região de Louveira

Figura 7.15 - Relação entre área e densidade hidrográfica referente a 1972 na região de Louveira 
Figura 7.16 - Relação entre densidade de drenagem e densidade hidrográfica referente a 1972 na Área 1

Figura 7.17 - Dendrograma dos dados de taxas de variações maiores que $10 \%$ de densidade de drenagem e densidade hidrográfica entre 1972 e 1995 .... 183

Figura 7.18 - Relação entre a Taxa de Variação de Densidade de Drenagem e Densidade Hidrográfica (\%) para as microbacias da Área 1

Figura 7.19 - Saída do software Curve Expert 1.3 mostrando a relação entre taxa de Variação de Densidade de Drenagem (x) e a taxa de variação de Densidade Hidrográfica (y) para a Área 1

Figura 7.20 - Fórmula proposta para as taxas de variação dos índices densidade de drenagem (x) e densidade hidrográfica (y) pelo software Curve Expert 1.3 para a área de Louveira

Figura 7.21 - Dendrograma dos dados de taxas de variações maiores que 10\% dos índices $\mathrm{Rlm}_{2-1}$ e $\mathrm{Rb}_{1-2}$ entre 1972 e 1995 para a Área 1

Figura 7.22 - Relação entre a taxa de variação dos índices $\operatorname{Rlm}_{2-1}$ e $\mathrm{Rb}_{1-2}$ entre os anos de 1972 e 1995 para a Área 1

Figura 7.23 - Relação entre a $\Delta$ Dd e Dd para as microbacias estudadas na área de Louveira

Figura 7.24 - Relação entre a $\Delta \mathrm{Dh}$ e Dh para as microbacias estudadas na área de Louveira

Figura 7.25 - Relação entre a Taxa de Variação de Dd (a) e Dh (b) e as unidades de Landform da Área 1

Figura 7.26 - Relação entre a Taxa de Variação de Dd (a) e Dh (b) com as unidades de Materiais Inconsolidados da Área 1

Figura 7.27 - Taxa de variação das principais classes de uso e ocupação na área de Louveira

Figura 7.28 - Relação entre as taxas de variação de Dd (a) e Dh (b) com as porcentagens de áreas urbanizadas

Figura 7.29 - Relação entre as taxas de variação de Dd (a) e Dh (b) com as porcentagens das áreas de pastagens da Área 1

Figura 7.30 - Relação entre as taxas de variação de Dh com as taxas de variação das áreas de pasto, agrícolas e de crescimento urbano

Figura 7.31 - Classes de Área para as microbacias estudadas na região de Rafard ..... 200 
Figura 7.32 - Valores do Índice de Forma (k) para as microbacias estudadas na região de Rafard

Figura 7.33 - Valores de Densidade de Drenagem (Dd) para as microbacias estudadas na região de Rafard

Figura 7.34 - Valores de Densidade Hidrográfica (Dh) para as microbacias estudadas na região de Rafard

Figura 7.35 - V Valores de Textura Topográfica (Tt) para as microbacias estudadas na região de Rafard

Figura 7.36 - V Valores da Razão de Bifurcação entre canais de Ordem 1 e $2\left(\mathrm{Rb}_{1-2}\right)$ para as microbacias estudadas na região de Rafard

Figura 7.37 - Valores da Razão entre Comprimentos Médios dos canais de Ordem 1 e $2\left(\operatorname{Rlm}_{2-1}\right)$ para as microbacias estudadas na região de Rafard

Figura 7.38 - Relação entre área e densidade de drenagem referente a 1972 para as microbacias da Área 2

Figura 7.39 - Relação entre área e densidade hidrográfica referente a 1972 para as microbacias da Área 2

Figura 7.40 - Relação entre densidade de drenagem e densidade hidrográfica referente a 1972 para as microbacias da Área 2

Figura 7.41 - Dendrograma dos dados de taxas de variações maiores que 10\% de densidade de drenagem e densidade hidrográfica entre 1972 e 1995 para as microbacias da Área 2

Figura 7.42 - Relação entre a Taxa de Variação de Densidade de Drenagem e Densidade Hidrográfica (\%) para as microbacias da Área 2

Figura 7.43 - Dendrograma dos dados de taxas de variações maiores que $10 \%$ dos índices $\operatorname{Rlm}_{2-1}$ e Rb R-2 $_{1-2}$ entre 1972 e 1995 para as microbacias da Área 2212

Figura 7.44 - Relação entre a taxa de variação dos índices $\operatorname{Rlm}_{2-1}$ e $\mathrm{Rb}_{1-2}$ entre os anos de 1972 e 1995 para as microbacias da Área 2

Figura 7.45 - Relação entre a $\Delta \mathrm{Dd}$ e Dd para as microbacias estudadas na área de Rafard

Figura 7.46 - Relação entre a $\Delta \mathrm{Dh}$ e Dh para as microbacias estudadas na área de Rafard

Figura 7.47 - Relação entre a Taxa de Variação de Dd (a) e Dh (b) com as litologias pertinentes as microbacias da Área 2 
Figura 7.48 - Relação entre a Taxa de Variação de Dd (a) e Dh (b) e as unidades de landforms das microbacias da Área 2

Figura 7.49 - Relação entre a Taxa de Variação de Dd (a) e Dh (b) e as unidades de materiais inconsolidados das microbacias da Área 2

Figura 7.50 - Taxa de variação das principais classes de uso e ocupação na Área de Rafard

Figura 7.51 - Relação entre as taxas de variação de Dd (a) e Dh (b) com as porcentagens das áreas destinadas ao cultivo de cana nas microbacias 222 da Área de Rafard/SP

Figura 7.52 - Relação entre as taxas de variação de Dh com a taxa de variação de áreas de pasto, hortifruti e de cultivo de cana 


\section{LISTA DE TABELAS}

\section{CAPÍtUlO 2}

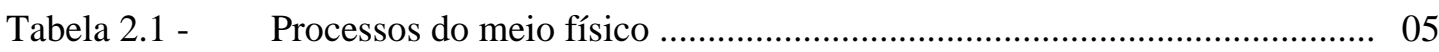

Tabela 2.2 - Atividades modificadoras do meio relacionadas aos processos tecnológicos .................................................................................... 06

Tabela 2.3 - $\quad$ Algumas medidas de recuperação do meio físico em diferentes tipos de áreas degradadas .......................................................................... 10

Tabela 2.4 - Prováveis conseqüências das atividades humanas sobre o meio

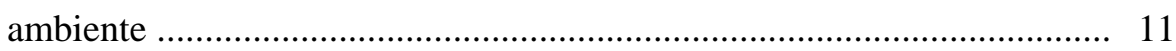

Tabela 2.5 - Geoindicadores: Influência Natural x Influência Humana ....................... 14

Tabela 2.6 - Geoindicadores de mudanças ambientais na Zona Tropical Úmida ......... 15

Tabela 2.7 - $\quad$ Entrada (input) e saída (output) de energia no sistema .............................. 18

Tabela 2.8 - Classes propostas para Textura Topográfica …...................................... 35

\section{CAPÍtUlO 4}

Tabela 4.1 - Resumo quantitativo dos ensaios laboratoriais realizados

\section{CAPÍtUlO 5}

Tabela 5.1 - Classes de Declividade propostas para as áreas 1 e 2

Tabela 5.2 - $\quad$ Alguns parâmetros morfométricos obtidos paras as sub-bacias da Área 1 em 1995

Tabela 5.3 - $\quad$ Alguns parâmetros morfométricos obtidos paras as sub-bacias da Área

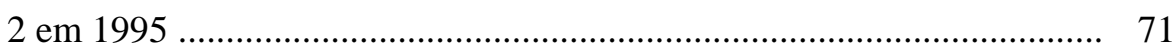

Tabela 5.4 - $\quad$ Tipos de atividades antrópicas desenvolvidas na Área 1 em 1995 ........... 75

Tabela 5.5 - C Classes de Atividades Antrópicas definidas para a Área 2 em 1995 ........ 78

Tabela 5.6 - Perfil de alteração proposto pela BSSI 5930:1981 …............................... 95

Tabela 5.7 - Caracterização textural do material inconsolidado do Horizonte V da

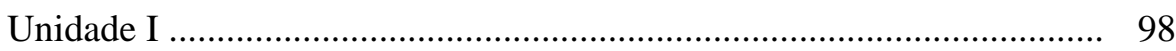

Tabela 5.8 - $\quad$ Índices Físicos obtidos para o material inconsolidado do Horizonte V da Unidade I

Tabela 5.9 - Caracterização da fração fina do material inconsolidado do Horizonte V da Unidade I usando o Método de Adsorção de Azul de Metileno 
Tabela 5.10 - Caracterização textural do material inconsolidado do Horizonte V da Unidade II

Tabela 5.11 - $\quad$ Índices Físicos obtidos para o material inconsolidado do Horizonte V da Unidade II

Tabela 5.12 - Caracterização da fração fina do material inconsolidado do Horizonte V da Unidade II usando o Método de Adsorção de Azul de Metileno

Tabela 5.13 - Caracterização textural do material inconsolidado do Horizonte V da Unidade III

Tabela 5.14 - Índices Físicos obtidos para o material inconsolidado do Horizonte V da Unidade III

Tabela 5.15 - Caracterização da fração fina do material inconsolidado do Horizonte V da Unidade III usando o Método de Adsorção de Azul de Metileno ....... 102

Tabela 5.16 - Caracterização textural do material inconsolidado do Horizonte VI da Unidade IV

Tabela 5.17 - I Índices Físicos obtidos para o material inconsolidado do Horizonte VI da Unidade IV

Tabela 5.18 - Caracterização da fração fina do material inconsolidado do Horizonte VI da Unidade IV usando o Método de Adsorção de Azul de Metileno .. 104

Tabela 5.19 - Caracterização textural do material inconsolidado do Horizonte VI da Unidade V

Tabela 5.20 - I Índices Físicos obtidos para o material inconsolidado do Horizonte VI da Unidade V

Tabela 5.21 - Caracterização da fração fina do material inconsolidado do Horizonte VI da Unidade V usando o Método de Adsorção de Azul de Metileno ... 106

Tabela 5.22 - Caracterização textural do material inconsolidado do Horizonte VI da Unidade VI 106

Tabela 5.23 - Índices Físicos obtidos para o material inconsolidado do Horizonte VI da Unidade VI 107

Tabela 5.24 - Caracterização da fração fina do material inconsolidado do Horizonte VI da Unidade VI usando o Método de Adsorção de Azul de Metileno .. 107 
Tabela 5.25 - Caracterização textural do material inconsolidado do Horizonte VI da Unidade VII .

Tabela 5.26 - $\quad$ Índices Físicos obtidos para o material inconsolidado do Horizonte VI da Unidade VII 108

Tabela 5.27 - Caracterização da fração fina do material inconsolidado do Horizonte VI da Unidade VII usando o Método de Adsorção de Azul de Metileno . 108

Tabela 5.28 - Caracterização textural do solo residual da Unidade VIII ........................ 109

Tabela 5.29 - Índices Físicos obtidos para o solo residual da Unidade VIII .................. 109

Tabela 5.30 - C Caracterização da fração fina do solo residual da Unidade VIII usando o Método de Adsorção de Azul de Metileno 109

Tabela 5.31 - Caracterização textural do solo residual da Unidade IX 110

Tabela 5.32 - I Índices Físicos obtidos para solo residual da Unidade IX 110

Tabela 5.33 - Caracterização da fração fina do solo residual da Unidade IX usando o Método de Adsorção de Azul de Metileno 110

Tabela 5.34 - Caracterização Textural do material retrabalhado da Unidade X 111

Tabela 5.35 - Índices Físicos obtidos para o material retrabalhado da Unidade X .........

Tabela 5.36 - Caracterização da fração fina do material retrabalhado da Unidade X usando o Método de Adsorção de Azul de Metileno

Tabela 5.37 - Caracterização textural do material inconsolidado do Horizonte V da Unidade XI ...

Tabela 5.38 - Índices Físicos obtidos para o material inconsolidado da Unidade XI ..... 112

Tabela 5.39 - Caracterização da fração fina da Unidade XI usando o Método de Adsorção de Azul de Metileno

Tabela 5.40 - Caracterização textural do material inconsolidado do Horizonte VI da Unidade XII

Tabela 5.41 - I Índices Físicos obtidos para o material inconsolidado do Horizonte VI da Unidade XII 114

Tabela 5.42 - Caracterização da fração fina do material inconsolidado do Horizonte VI da Unidade XII usando o Método de Adsorção de Azul de Metileno . 114 
Tabela 5.43 - $\quad$ Caracterização textural do material inconsolidado do Horizonte VI da Unidade XIII

Tabela 5.44 - $\quad$ Índices Físicos obtidos para o material inconsolidado do Horizonte VI da Unidade XIII

Tabela 5.45 - Caracterização da fração fina do material inconsolidado do Horizonte VI da Unidade XII usando o Método de Adsorção de Azul de Metileno . 115

Tabela 5.46 - Caracterização textural do Material Inconsolidado da Unidade XIV ....... 115

Tabela 5.47 - Índices Físicos do material inconsolidado da Unidade XIV .................... 116

Tabela 5.48 - Caracterização da Fração fina da Unidade XIV usando o Método de Adsorção de Azul de Metileno

Tabela 5.49 - Caracterização textural do Material Inconsolidado da Unidade XV ........ 116

Tabela 5.50 - Índices Físicos obtidos para o material inconsolidado da Unidade XV ... 117

Tabela 5.51 - Caracterização da Fração fina da Unidade XV usando o Método de Adsorção de Azul de Metileno ............................................................ 117

Tabela 5.52 - Caracterização textural do solo residual da Unidade A2 ......................... 118

Tabela 5.53 - Índices Físicos obtidos para o solo residual da Unidade A2 ................... 118

Tabela 5.54 - Caracterização da fração fina do solo residual da Unidade A2 usando o Método de Adsorção de Azul de Metileno ............................................ 119

Tabela 5.55 - Caracterização textural do solo residual da Unidade A3 ......................... 119

Tabela 5.56 - Índices Físicos obtidos para o solo residual da Unidade A3 ................... 119

Tabela 5.57 - Caracterização da fração fina do solo residual da Unidade A3 usando o Método de Adsorção de Azul de Metileno ............................................. 120

Tabela 5.58 - Caracterização textural do solo residual da Unidade A4 .......................... 120

Tabela 5.59 - Índices Físicos obtidos para o solo residual da Unidade A4 ................... 121

Tabela 5.60 - Caracterização da fração fina do solo residual da Unidade A4 usando o Método de Adsorção de Azul de Metileno ............................................ 121

Tabela 5.61 - Caracterização textural do solo residual e solo retrabalhado da Unidade A5 122

Tabela 5.62 - $\quad$ Índices Físicos obtidos para o solo residual da Unidade A5 
Tabela 5.63 - Caracterização da fração fina do solo residual e retrabalhado da Unidade A5 usando o Método de Adsorção de Azul de Metileno ........... 123

Tabela 5.64 - Caracterização textural do solo residual da Unidade A6 ......................... 123

Tabela 5.65 - Índices Físicos obtidos para o solo residual da Unidade A6 ................... 124

Tabela 5.66 - Caracterização da fração fina do solo residual da Unidade A6 usando o Método de Adsorção de Azul de Metileno .............................................. 124

Tabela 5.67 - Caracterização textural do solo residual da Unidade A7 .......................... 124

Tabela 5.68 - Índices Físicos obtidos para o solo residual da Unidade A7 ................... 125

Tabela 5.69 - Caracterização da fração fina do solo residual da Unidade A7 usando o Método de Adsorção de Azul de Metileno ............................................. 125

Tabela 5.70 - Caracterização textural do solo residual da Unidade A8 ......................... 125

Tabela 5.71 - Índices Físicos obtidos para o solo residual da Unidade A8 ................... 126

Tabela 5.72 - Caracterização da fração fina do solo residual da Unidade A8 usando o Método de Adsorção de Azul de Metileno ............................................. 126

Tabela 5.73 - Caracterização textural do solo residual da Unidade A9 ......................... 127

Tabela 5.74 - I Índices Físicos obtidos para o solo residual da Unidade A9 ................... 127

Tabela 5.75 - Caracterização da fração fina do solo residual da Unidade A9 usando o Método de Adsorção de Azul de Metileno ............................................ 128

Tabela 5.76 - Caracterização textural do solo residual da Unidade A10 ....................... 128

Tabela 5.77 - Índices Físicos obtidos para o solo residual da Unidade A10 ................. 128

Tabela 5.78 - Caracterização da fração fina do solo residual da Unidade A10 usando o Método de Adsorção de Azul de Metileno ............................................. 129

Tabela 5.79 - Caracterização textural do solo residual e do material retrabalhado da Unidade A11 .............................................................................. 129

Tabela 5.80 - I Índices Físicos obtidos para o solo residual e retrabalhado da Unidade

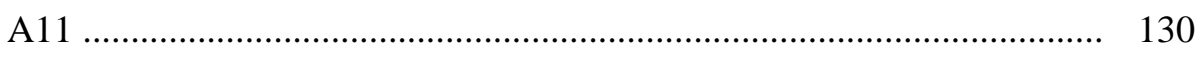

Tabela 5.81 - Caracterização da Fração fina do solo residual e retrabalhado da Unidade A11 usando o Método de Adsorção de Azul de Metileno ......... 130 


\section{CAPÍTULO 6}

Tabela 6.1 - Grupos das Variáveis Morfométricas ...................................................... 132

Tabela 6.2 - Parâmetros morfométricos obtidos para as sub-bacias da Área 1 ............ 132

Tabela 6.3 - Taxa de variação dos índices morfométricos expressa em \% para a Área 1 .

Tabela 6.4 - Distribuição areal das classes de uso e ocupação por sub-bacia ............... 141

Tabela 6.5 - $\quad$ Parâmetros morfométricos obtidos para as sub-bacias da Área 2 ........... 147

Tabela 6.6 - Taxa de variação dos índices morfométricos expressa em \% da Área 2 .. 148

Tabela 6.7 - Distribuição areal das classes de uso e ocupação por sub-bacia ............... 156

\section{CAPÍtULO 7}

Tabela 7.1 - $\quad$ Microbacias delimitadas por área de estudo

Tabela 7.2 - Matrizes de Correlação obtidas para as áreas de estudo

Tabela 7.3 - $\quad$ Estatísticas Descritivas e Faixas de Distribuição para os dados de k das Microbacias da Área 1

Tabela 7.4 - $\quad$ Estatísticas Descritivas e Faixas de Distribuição para os dados de Dd das Microbacias da Área 1

Tabela 7.5 - $\quad$ Estatísticas Descritivas e Faixas de Distribuição para os dados de Dh das Microbacias da Área 1

Tabela 7.6 - Estatísticas Descritivas e Faixas de Distribuição para os dados de Tt das Microbacias da Área 1

Tabela 7.7 - $\quad$ Estatísticas Descritivas e Faixas de Distribuição para os dados de $\mathrm{Rb}_{1-2}$ das Microbacias da Área 1

Tabela 7.8 - Estatísticas Descritivas e Faixas de Distribuição para os dados de Rlm das Microbacias da Área 1

Tabela 7.9 - Classificação das Microbacias da Área 1 quanto ao uso e ocupação para 1972 e 1995

Tabela 7.10 - $\quad$ Estatísticas Descritivas e Faixas de Distribuição para os valores de k das Microbacias da Área 2 
Tabela 7.11 - $\quad$ Estatísticas Descritivas e Faixas de Distribuição para os valores de Dd das Microbacias da Área 2 ..................................................................... 202

Tabela 7.12 - $\quad$ Estatísticas Descritivas e Faixas de Distribuição para os valores de Dh das Microbacias da Área 2 ................................................................ 203

Tabela 7.13 - Estatísticas Descritivas e Faixas de Distribuição para os valores de Tt das Microbacias da Área 2 ............................................................... 204

Tabela 7.14- $\quad$ Estatísticas Descritivas e Faixas de Distribuição para os valores de $\mathrm{Rb}_{1-2}$ das Microbacias da Área 2 ............................................................... 205

Tabela 7.15 - Estatísticas Descritivas e Faixas de Distribuição para os valores de $\mathrm{Rlm}_{2-1}$ das Microbacias da Área 2 ..................................................... 206

Tabela 7.16 - Classificação das Microbacias da Área 2 quanto ao uso e ocupação para 1972 e 1995 


\section{RESUMO}

Rodrigues, S. F. S (2002). Avaliação das Alterações da Rede de Drenagem em SubBacias e Microbacias do Alto e Baixo Rio Capivari (Louveira e Rafard/SP). São Carlos, 2002. 245 p. Dissertação de Mestrado - Escola de Engenharia de São Carlos, Universidade de São Paulo.

Este trabalho tem por objetivo avaliar as alterações temporais na rede de drenagem em sub-bacias e microbacias hidrográficas de terrenos cristalinos e sedimentares, que integram, respectivamente, a Bacia do Alto e Baixo Rio Capivari e compreendem parte do Município de Louveira e Rafard (SP). A metodologia aplicada foi baseada na análise conjunta da morfometria da área e no levantamento das características do meio físico e das atividades antrópicas. Os elementos de análise foram obtidos por meio de fotografias aéreas na escala de 1:25.000, para dois períodos (1972 e 1995), associados a trabalhos de campo e ensaios laboratoriais. Os resultados obtidos demonstraram que as mudanças no número e nos comprimentos dos canais de Ordem 1 foram as mais significativas na rede de drenagem e determinaram as demais modificações na sua estrutura interna, principalmente nos índices densidade de drenagem e densidade hidrográfica. As alterações na área do Alto Rio Capivari estão associadas diretamente as modificações e/ou implantação de atividades antrópicas. As alterações na área sedimentar são condicionadas pela geologia e intensivo cultivo de cana de açúcar e/ou pastagens. Foram elaborados para as duas áreas de estudo, os seguintes documentos cartográficos: Mapa de Documentação; Mapa de Substrato Rochoso; Carta de Declividade; Mapa de Materiais Inconsolidados e Mapa de Landforms. Além destes foram gerados os mapas de Uso e Ocupação e Rede de drenagem para as duas épocas analisadas, 1972 e 1995.

a Palavras-Chave: microbacias hidrográficas, morfometria, rede de drenagem, fotografias aéreas, Capivari 


\begin{abstract}
Rodrigues, S. F. S (2002). Evaluation of drainage network alterations in the High and Low Capivari River microbasins and sub-basins (Louveira and Rafard/SP). São Carlos, 2002. 245 p. Dissertação de Mestrado - Escola de Engenharia de São Carlos, Universidade de São Paulo.

This work was proposed to evaluation the drainage networks time changes in the crystallines and sedimentaries hydrographic microbasins and sub basins, situated in the High and Low Capivari River (Louveira and Rafard/SP). The methodological approach has consisted in the analysis of the morphometry, identification of physical environmental element and human activities. The components were identified, for aerial photo, scale 1:25.000, between 1972 and 1995, and were associated field activities and laboratories tests. The results were showed first-order channel number and length were the morphometric variables which most contributed to the drainage systems changes with direct influence in the index drainage density and hydrographic density. These alterations in the area of Capivari High River sub-basins and microbasins were associated with the human activies installations or the changes. These changes in the area of Capivari Low River were associated with geology and sugar-cane raising. Also, the following cartographic documents were elaborated for two studies areas: Documentation Map, Geological Map, Declivities Chart, Unconsolidated Materials Map and Landforms Map. The Drainage Network Map and the Land Use Map were created for two analysis times, 1972 and 1995.
\end{abstract}

- Key-words: watershed, morphometry, drainage network, photo aerial, Capivari 


\section{INTRODUÇÃO}

No Brasil, o quadro ambiental atual retrata uma ocupação urbana desordenada caracterizada principalmente pela ineficiência dos serviços de saneamento básico de água, esgoto, coleta e disposição de resíduos. Na agricultura, a situação não é menos crítica na medida em que há um aumento no registro do número de processos erosivos acelerados e de alterações na qualidade do solo. O setor industrial é considerado uma das atividades com elevado potencial de contaminação dos componentes naturais (ar, água e solo), quer pela disposição direta de seus efluentes sobre esses recursos, quer pelo acondicionamento inadequado de seus resíduos.

Os inúmeros problemas ambientais e suas conseqüências cada vez mais evidentes, assim como as dificuldades de recuperação das áreas afetadas levam entidades governamentais a instituírem políticas de planejamento físico e de ordenamento territorial. A premissa básica das medidas a serem efetivadas deve abranger o inter-relacionamento entre os recursos hídricos com as demais peculiaridades geoambientais e sócio-culturais tendo em vista alcançar e garantir a qualidade de vida da sociedade, a qualidade do desenvolvimento socioeconômico, e a conservação das suas reservas de capital ecológico - água doce e biodiversidade em particular (Rebouças, 1997).

Dessa forma, o planejamento e a gestão ambiental devem considerar os aspectos quantitativos e qualitativos das fases aérea, superficial e subterrânea do ciclo hidrológico, os usos múltiplos da conservação e proteção dos demais recursos ambientais, o uso de agrotóxicos e fertilizantes, e o manejo do solo e da água em harmonia com os planos diretores de desenvolvimento regional e municipal.

Nesse contexto, as bacias hidrográficas, unidades biogeográficas com alto grau de integridade funcional, ou seja, áreas com características geológicas, hidrológicas e ecológicas únicas, são adotadas como unidades de planejamento (Barrow, 1998). 
Dessa forma, os estudos geoambientais cujo enfoque principal é a intervenção do homem na natureza representam não somente ferramentas de planejamento, mas ainda auxiliam na busca de estratégias alternativas rumo ao desenvolvimento sustentável (Sobreira, 1995).

A presente pesquisa enfoca o estudo comparativo das modificações temporais da rede de drenagem por meio de fotografias aéreas como um instrumento de verificação das alterações da morfometria dos canais condicionadas por atividades antrópicas ou processos naturais ocorridos em bacias hidrográficas.

\section{1 - OBJETIVOS}

Essa pesquisa tem como proposta fundamental aplicar e testar a metodologia de Collares (2000), com a finalidade de verificar as alterações temporais na rede de drenagem em sub-bacias e microbacias hidrográficas do Alto e Baixo Rio Capivari. Os objetivos específicos deste trabalho são:

- Verificar a adequabilidade da metodologia acima citada para áreas de terrenos sedimentar e cristalino na escala de 1:25.000;

- Avaliar as alterações na rede de drenagem das unidades de estudo, por meio da caracterização morfométrica obtida para dois períodos, 1972 e 1995;

- Avaliar a influência das atividades antrópicas sobre as alterações da rede de drenagem definidas para as unidades de estudo; e,

- Estabelecer relações quanto a influência do meio físico sobre as alterações da rede de drenagem definidas para as microbacias.

\section{2 - JUSTIFICATIVA PARA A ESCOLHA DAS ÁREAS}

Para a aplicação do método na escala de 25.000 foram escolhidas duas áreas de estudos com aproximadamente $54 \mathrm{~km}^{2}$ cada, compostas por 9 sub-bacias, sendo quatro (4) no Alto Rio Capivari compreendendo parte dos municípios de Louveira e Jundiaí (SP) e cinco (5) no baixo Rio Capivari em Rafard (SP).

Três pontos foram considerados para esta escolha:

- Áreas geologicamente distintas;

- Forma de uso e ocupação dos terrenos diferentes, e; 
- Áreas com sub-bacias com diferentes graus de alteração na rede de drenagem determinadas na pesquisa de Collares (2000), em escala regional, ou seja, sub-bacias com alterações altamente significativas (sub-bacias córregos Corrupira e São Francisco), medianamente significativas (sub-bacias córregos Vale das Vinhas, Sopezol, Borão, Alto Retiro e Santa Rita) e pouco significativas (sub-bacias Ribeirão do Moinho e Córrego Itapeva). 


\section{REVISÃO BIBLIOGRÁFICA}

\section{1 - O MEIO AMBIENTE E O ECODESENVOLVIMENTO}

Nas últimas décadas verificou-se uma preocupação crescente com o meio ambiente pela sociedade, resultado de uma nova percepção da interação entre ele e o homem. As novas bases teóricas buscam uma estratégia de desenvolvimento cujo paradigma principal é conciliar o desenvolvimento das atividades socioeconômicas no ambiente, com mínimos danos, por meio de instrumentos legais que viabilizem essa tarefa. Essa postura contrapõe-se ao antigo modelo de desenvolvimento econômico que considerava a natureza apenas como fonte infinita de recursos a serem explorados.

Nesse contexto foram criadas políticas ambientais baseadas no ecodesenvolvimento, ou seja, no processo de transformação do meio ambiente com a ajuda de técnicas ecologicamente prudentes, concebidas em função das potencialidades do meio, impedindo o desperdício inconsiderado dos recursos e cuidando para que sejam empregados na satisfação das necessidades de todos os membros da sociedade, dada a diversidade dos ambientes naturais e dos contextos culturais (Sachs apud Moreira, 1990).

Para a efetivação dessas estratégias de desenvolvimento há a necessidade de se entender o que é o meio ambiente e os processos que o condicionam.

A Lei Federal $n^{\circ}$ 6938/81 (Política Nacional do Meio Ambiente) refere-se ao meio ambiente como "um conjunto de condições, leis, influências e interações de ordem física, química e biológica que permite, abriga e rege a vida em todas as suas formas”, e o considera um patrimônio público a ser necessariamente assegurado e protegido, tendo em vista o uso coletivo. 
Um outro conceito definido por Cunha \& Guerra (1996), retrata o meio ambiente como o espaço em que há o desenvolvimento da vida vegetal e animal (incluindo o homem) sujeito a transformações pelo processo histórico de ocupação numa determinada época e sociedade. Observa-se, portanto, que a relação entre natureza e homem vem a ser um processo dinâmico caraterizado por ações e fenômenos que condicionam a evolução do meio ambiente. Esses processos resultam da interação entre os componentes ambientais (meio físico, biológico e socioeconômico) por meio de troca e conversão de grandes quantidades de matéria e energia (Fornasari Filho et al, 1992; Sobral, 1996).

Fornasari Filho et al (1990) subdividem em dois os processos do ambiente decorrentes das interações dos componentes do meio físico:

- Processos do Meio Físico (Tabela 2.1) referem-se ao desenvolvimento e sucessão de fenômenos potencializados pela interação de componentes materiais e tipos de energia, que podem ser deflagrados, acelerados ou retardados por agentes físicos, químicos e biológicos (fauna e flora) ou humanos, num determinado ambiente; e,

- Processos Tecnológicos correspondem ao conjunto de técnicas aplicadas em operações que caracterizam a implantação, o funcionamento ou a desativação de uma atividade modificadora do meio ambiente (implantação de obras civis ou recursos naturais - Tabela 2.2).

Tabela 2.1 - Processos do meio físico (adaptado de Fornasari Filho et al, 1992)

\begin{tabular}{|c|c|}
\hline \multicolumn{2}{|c|}{ PROCESSOS DO MEIO FÍSICO } \\
\hline $\begin{array}{l}\text { Processos da Hidrosfera } \\
\text { - Escoamento das águas em superfície } \\
\text { - Mnundação }\end{array}$ & $\begin{array}{l}\text { 2. Exógenos } \\
\text { A) Intempéricos } \\
\text { - Carstificação } \\
\text { - Circulação de gases no solo e na rocha } \\
\text { - Expansão de solo ou rocha } \\
\text { - Interações físico-químicas na água, no solo e } \\
\text { na rocha } \\
\text { - Processos pedogenéticos } \\
\text { B) De Movimento de Massa } \\
\text { - Corrida de massa } \\
\text { - Deposição de sedimentos ou partículas } \\
\text { - Erosão eólica } \\
\text { - Erosão pela água } \\
\text { - Escorregamento } \\
\text { - Movimento de bloco } \\
\text { - Rastejo de solo } \\
\text { - Subsidência }\end{array}$ \\
\hline
\end{tabular}


Tabela 2.2 - Atividades modificadoras do meio relacionadas aos processos tecnológicos (adaptado de Fornasari Filho et al, 1992)

\begin{tabular}{ll}
\hline \multicolumn{2}{c}{ ATIVIDADES MODIFICADORAS DO MEIO AMBIENTE } \\
\hline - Aeroporto & Irrigação \\
- Agroindústria & Linha de transmissão \\
- Aterro sanitário & Mineração \\
- Canagens & Porto \\
- Dutovia & Projeto urbanístico \\
- Rodovião de cursos d'água & - Unidade industrial \\
\hline
\end{tabular}

\section{2. - ALTERAÇÃO, IMPACTO E DEGRADAÇÃO AMBIENTAL}

A atuação de processos tecnológicos no curso da dinâmica dos processos naturais causa modificações no meio ambiente, denominadas de alterações ambientais (Figura 2.1). Normalmente são relacionadas a projetos de estudos de obras a serem implantadas ou a situações de degradação ambiental que necessitam ser identificadas, corrigidas, controladas e se possível revertidas (Bitar \& Fornasari Filho, 1990).

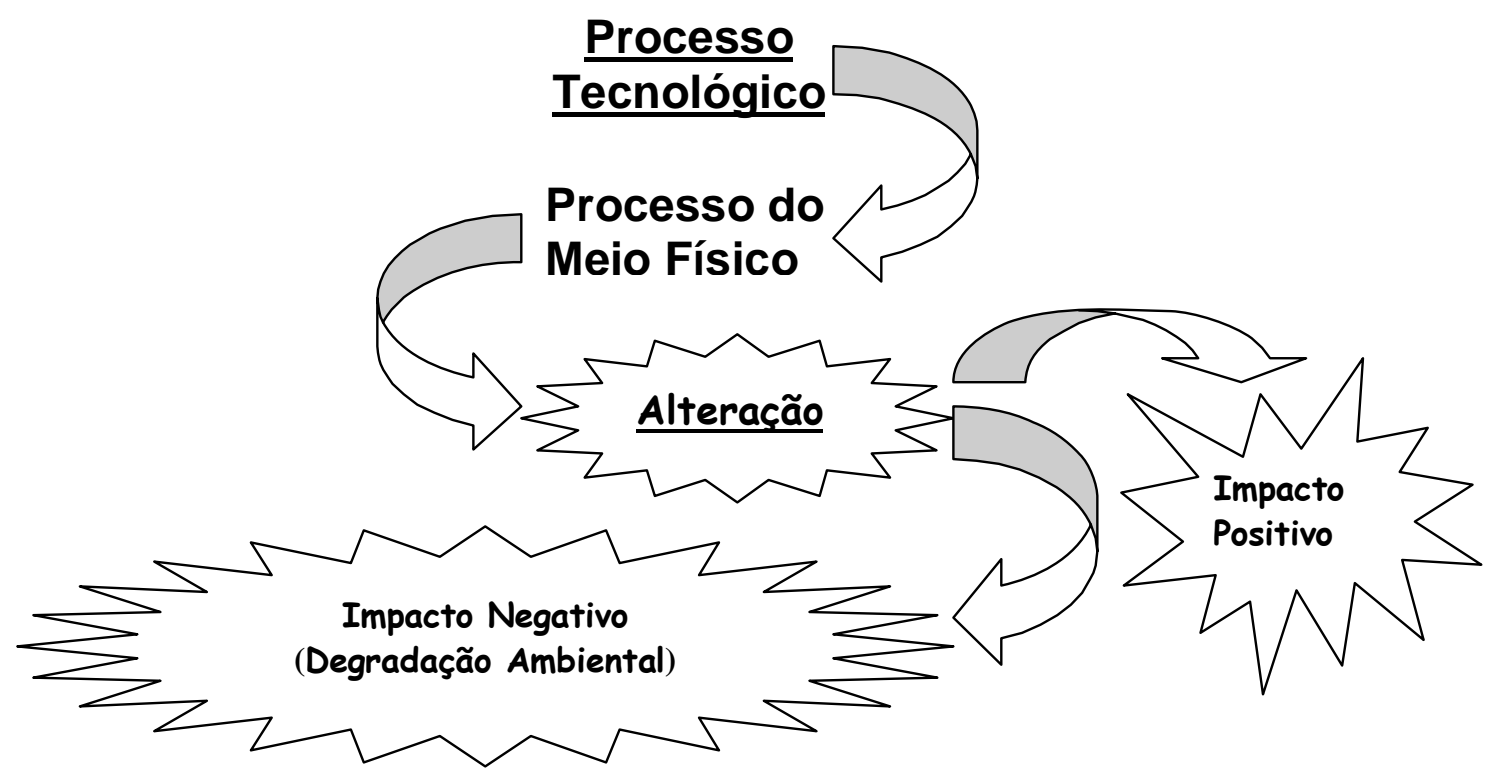

Figura 2.1 - Alteração a partir da intervenção de um processo tecnológico sobre um processo do meio físico (Adaptado de Collares, 1996)

Há, portanto, a necessidade de uma identificação clara, precisa e eficiente na previsão das alterações significativas no meio físico em termos qualitativos e quantitativos. 
Duinker \& Beandles (1989) propõem os seguintes parâmetros para a determinação e avaliação das alterações ambientais:

- A importância dos atributos ambientais a serem alterados;

- A distribuição das alterações no tempo e no espaço;

- A magnitude das alterações e;

- A confiabilidade das alterações previstas e medidas.

Segundo Bitar et al (1990 a), a alteração ambiental quando julgada significativa é considerada impacto ambiental e pode ser definida como favorável (impacto positivo) ou não (impacto negativo) ao ecossistema e à sociedade humana.

De acordo com a resolução CONAMA n 01/86, impacto ambiental é “qualquer alteração das propriedades físicas, químicas e biológicas do meio ambiente, causada por qualquer forma de matéria ou energia resultante das atividades humanas que, direta ou indiretamente, afetam":

I. $\quad$ A saúde, a segurança e o bem estar da população;

II. As atividades sociais e econômicas;

III. A biota;

IV. As condições estéticas e sanitárias do meio ambiente e;

V. A qualidade dos recursos ambientais.

Tommasi (1994), considera o impacto positivo ou benéfico, quando resulta de uma melhoria da qualidade ou de uma característica ambiental e impacto negativo ou adverso, como resultado de um dano à qualidade de uma variável ambiental.

Conforme Leite et al (1990), a qualificação dos impactos provocados por uma atividade modificadora depende de cada um dos seus aspectos e das características do ambiente. Deve-se considerar a sua potencialização na medida em que seus efeitos podem ser acentuados ou minimizados em função das características socioeconômicas já instauradas na área do projeto a ser ou já implantado.

Segundo Aguiar (1994), os impactos ambientais pode ser subdivididos, conforme as circunstâncias que o geram, em:

1. Impactos de ocupação são aqueles gerados pela simples implantação de uma obra, podem ser irreversíveis ou modificadores;

2. Impactos produzidos pela emissão de contaminantes no ar, água, solo e subsolo;

3. Impactos de difusão são relacionados às seqüelas resultantes da implantação e desenvolvimento de uma atividade na vizinhança; e,

4. Impactos produzidos pela extração de recursos naturais. 
Fornasari Filho et al (1992) definiram as etapas de elaboração de estudo de impacto ambiental (EIA) em: caracterização da atividade modificadora do meio, diagnóstico ambiental, avaliação do impacto ambiental, mitigação dos impactos ambientais (Figura 2.2).

De acordo com Collares (1996), na etapa de avaliação de impacto ambiental (AIA) é que são previstas as alterações, as suas repercussões e sua significância, levando à sua identificação como benéficas ou adversas.

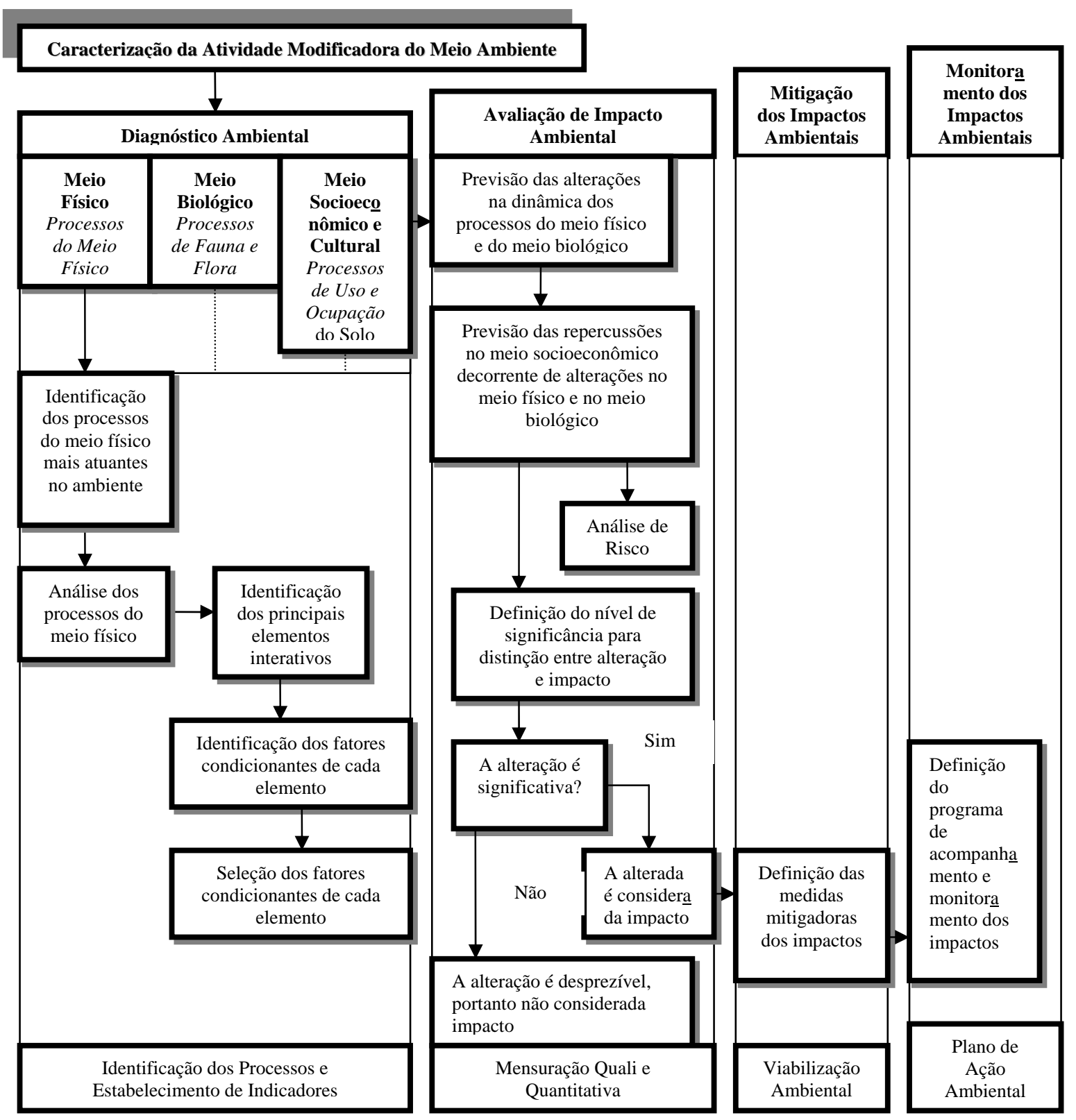

Figura 2.2 - Etapas de estudo de impacto ambiental (Modificada de Fornasari Filho et al, 1992) 
Ao conjunto de processos que causam danos ao meio ambiente, caracterizando perdas ou redução de algumas de suas propriedades tais como a qualidade ou capacidade produtiva dos recursos ambientais, denomina-se degradação ambiental (Decreto Federal 97632/89).

O conceito de degradação está associado às alterações ambientais negativas ou adversas geradas por atividades ou intervenções humanas. No contexto urbano deve ser incluído o efeito negativo ao uso do solo em face da sua função efetiva, planejada ou potencial (Bitar, 1997).

Dessa forma a degradação do solo refere-se “a uma alteração adversa das características do solo em relação aos seus diversos usos possíveis, tanto os estabelecidos em planejamento quanto os potenciais” (ABNT, 1989).

Lal et al (1989), diferenciam processos e fatores da degradação do solo. Os processos correspondem às ações e interações químicas físicas e biológicas que afetam a capacidade de autoregulação do solo e sua produtividade, como compactação, erosão acelerada, desertificação, salinização, lixiviação e acidificação e os fatores compreendem os agentes e os catalisadores naturais ou induzidos pelo homem (agricultura, indústria, urbanização e mineração), que deflagram os processos e causam alterações nas propriedades dos solos e nos seus atributos de sustentação da vida.

Nesse contexto, uma área degradada representa um segmento do ambiente que sofreu situações de degradação dadas por diferentes tipos de intervenção no meio físico (Bitar \& Braga, 1995). De acordo com a União Internacional para a Conservação da Natureza (UICN apud Bitar, 1997), as áreas degradadas constituem ecossistemas cuja diversidade, produtividade e condição para habitação estão reduzidas, e são consideradas insustentáveis, sendo submetidas a processos de recuperação ou reabilitação no intuito de torná-las potencialmente sustentáveis.

Os projetos ou ações que visam estabelecer algum tipo de uso do solo nas áreas degradadas em conformidade com as condições ambientais e culturais da circunvizinhança têm diversas denominações dentre delas pode-se citar: recuperação, reabilitação, reestruturação, remodelamento e revitalização (Almeida \& Bruna, 1996).

Destacam-se aqui três conceitos propostos por Box (apud ABNT, 1989):

- Restauração: associado à idéia da reconstituição exata das condições locais, tais como eram antes de serem alteradas pela intervenção;

- Recuperação: associado à idéia de que o local alterado seja trabalhado de modo que as condições ambientais sejam semelhantes às anteriores a intervenção; e, 
- Reabilitação: associado á idéia de que a área degradada seja passível de utilização, produção, ocupação ou conservação ambiental, de acordo com projeto prévio e em condições compatíveis com a ocupação circunvizinha, ou seja, trata do reaproveitamento da área para outra finalidade.

A Tabela 2.3 apresenta algumas medidas de recuperação em relação a um fator de degradação (Bitar \& Braga, 1995).

Tabela 2.3 - Algumas medidas de recuperação do meio físico em diferentes tipos de áreas degradadas (Bitar \& Braga, 1995)

\begin{tabular}{|c|c|c|}
\hline $\begin{array}{l}\text { Tipo de Área } \\
\text { Degradada }\end{array}$ & $\begin{array}{c}\text { Principais Processos de Degradação } \\
\text { (Meio Físico) }\end{array}$ & $\begin{array}{c}\text { Algumas Medidas Corretivas } \\
\text { (Meio Físico) }\end{array}$ \\
\hline $\begin{array}{l}\text { Mineracão } \\
\text { Abandonada } \\
\text { em Regióes } \\
\text { Urbanas }\end{array}$ & $\begin{array}{l}\text { Escoamento das águas superficiais } \\
\text { Escosão por sulcos e ravinas } \\
\text { Deposição de sedimentos e partículas }\end{array}$ & $\begin{array}{l}\text { - Revegetação } \\
\text { - Captação e condução das águas } \\
\text { superficiais } \\
\text { - Estabilização de taludes e } \\
\text { blocos }\end{array}$ \\
\hline $\begin{array}{l}\text { Depósito de } \\
\text { Resíduos } \\
\text { Industriais e } \\
\text { Urbanos }\end{array}$ & $\begin{array}{l}\text { Interações físico-químicas no solo } \\
\text { (poluição do solo) } \\
\text { - Escoamento das águas superficiais } \\
\text { Movimentação das águas de } \\
\text { subsuperfície }\end{array}$ & $\begin{array}{l}\text { Prospecção do depósito } \\
\text { Remoção total ou parcial, } \\
\text { transporte e disposição dos } \\
\text { resíduos } \\
\text { - } \begin{array}{l}\text { Tratamento in situ do solo } \\
\text { Descontaminação } \\
\text { remediação do solo }\end{array}\end{array}$ \\
\hline $\begin{array}{l}\text { Ocupacão } \\
\text { Habitacional } \\
\text { de encostas } \\
\text { em situacões } \\
\text { de risco }\end{array}$ & $\begin{array}{l}\text { Escorregamento } \\
\text { - Escoamento das águas em superfície }\end{array}$ & $\begin{array}{l}\text { Captação e condução das águas } \\
\text { superficiais } \\
\text { Estabilização da encosta (com } \\
\text { ou sem estruturas de } \\
\text { contenção) } \\
\text { - Revegetação }\end{array}$ \\
\hline $\begin{array}{l}\text { Bocorocas } \\
\text { Urbanas ou } \\
\underline{\text { Rurais }}\end{array}$ & $\begin{array}{l}\text { Erosão por boçorocas } \\
\begin{array}{l}\text { Movimentação das águas de } \\
\text { subsuperfície }\end{array}\end{array}$ & $\begin{array}{l}\text { Controle do uso e ocupação } \\
\text { Captação e condução das águas } \\
\text { superficiais } \\
\text { Drenagem das águas de } \\
\text { subsuperfície } \\
\text { Estabilização dos taludes da } \\
\text { boçoroca ou aterramento }\end{array}$ \\
\hline $\begin{array}{l}\frac{\text { Ocupação }}{\text { Agrícola }} \\
\underline{\text { Irrigada }}\end{array}$ & $\begin{array}{l}\text { Adensamento e compactação do solo } \\
\text { Acidificação do solo por lixiviação }\end{array}$ & $\begin{array}{l}\text { - Controle da irrigação } \\
\text { - } \text { Aragem profunda do solo } \\
\text { - Correção da acidez do solo }\end{array}$ \\
\hline $\begin{array}{l}\text { Cursos e } \\
\text { Corpos D'água } \\
\text { Assoreados } \\
\end{array}$ & $\begin{array}{l}\text { Deposição de partículas e sedimentos } \\
\text { - Enchentes e inundações }\end{array}$ & $\begin{array}{l}\text { - Controle da erosão a montante } \\
\text { - Dragagem dos sedimentos } \\
\text { Obras hidráulicas }\end{array}$ \\
\hline
\end{tabular}

Os métodos ou estratégias de recuperação a serem implementadas são definidos após a delimitação da magnitude da degradação (Bitar et al, 1992; Bitar, 1997).

Dentre as tecnologias aplicadas para estabilizar o meio, pode-se citar (Bitar \& Braga, 1995; Bitar, 1997): 
- Tecnologias de revegetação: envolvem desde a fixação localizada de espécies vegetais até a implantação de reflorestamentos extensivos, tanto para fins de preservação e conservação quanto para objetivos econômicos;

- Tecnologias geotécnicas: envolvem a execução de obras de engenharia que visem a estabilidade física do ambiente; e,

- Tecnologias de remediação: envolvem o uso de técnicas de tratamento que visem eliminar, neutralizar, imobilizar, confinar ou transformar elementos ou substâncias contaminantes presentes no ambiente e assim alcançar a estabilidade química do ambiente.

\section{3 - INDICADORES E GEOINDICADORES}

A partir do momento em que se definem parâmetros ou indicadores das mudanças ambientais causadas pelo homem, é provável que as seqüelas das atividades humanas sobre o meio sejam mais facilmente visualizadas e conseqüentemente contribuam para uma análise efetiva do ambiente em busca do desenvolvimento sustentável (Tabela 2.4).

Tabela 2.4 - Prováveis conseqüências das atividades humanas sobre o meio ambiente (Neimanis \& Kerr, 1996)

\begin{tabular}{|c|c|}
\hline PARÂMETROS A SEREM CONSIDERADOS & PROVÁVEIS CONSEQÜÊNCIAS \\
\hline Sistema de Suporte da Vida Ecolóqica & $\begin{array}{l}\text { Depleção da camada de Ozônio } \\
\text { Mudanças climáticas } \\
\text { (ontaminantes tóxicos no ambiente } \\
\text { - Mudança na biodiversidade } \\
\text { - Mudanças no ecossistema marinho } \\
\text { Mudanças no ecossistema florestal }\end{array}$ \\
\hline Qualidade de Vida do Homem & $\begin{array}{l}\text { Qualidade ambiental urbana (qualidade do ar, } \\
\text { saneamento básico, enfatizando o tratamento } \\
\text { de lixo e uso das águas e espaços verdes } \\
\text { urbanos) } \\
\text { - Qualidade da água }\end{array}$ \\
\hline Sustentabilidade dos Recursos Naturais & $\begin{array}{l}\text { Mudanças na fauna marinha afetando a pesca } \\
\text { - Desmatamento } \\
\text { - Degradação do solo }\end{array}$ \\
\hline Fatores que Influenciam Neqativamente & $\begin{array}{l}\text { Consumo de energia } \\
\text { Transporte } \\
\text { - Cresção de lixo urbano e industrial } \\
\text { - Crento populacional desordenado }\end{array}$ \\
\hline
\end{tabular}


Idealmente, os indicadores ambientais devem medir a integridade, a estabilidade e a sustentabilidade dos ambientes físicos e biológicos. O monitoramento de tais parâmetros representa o julgamento do estado em que se encontra o meio ambiente em relação a rápidas mudanças ou à sua estabilidade no tempo (Berger, 1996).

Nesse contexto, o papel do indicador é determinar as mudanças e a atuação de processos naturais na formação da paisagem e do meio físico em geral (solos, rochas, águas superficiais e subterrâneas). Deve-se ainda considerar medidas que descrevam os processos atuantes em superfície e em subsuperfície. Cabe ressaltar que processos físicos, tais como escorregamentos, erosão costeira ou fluvial, podem ser intensificados ou não pela ação humana (Goudie, 1990).

De acordo com Ruitenbeek (1991), os indicadores devem tanto ser uma ferramenta descritiva para monitorar condições passadas e presentes, como devem refletir ligações entre o comportamento econômico humano e o grau de vigor e produtividade do ecossistema. Neimanis \& Kerr (1996) sugerem os seguintes critérios de análise:

1. Validade Científica: O indicador deve ser relevante no entendimento científico do sistema ou do elemento a ser descrito;

2. Os dados avaliados pelo indicador devem corresponder a diferentes períodos no tempo;

3. O indicador deve responder imediatamente às mudanças impostas pelos processos naturais e antrópicos;

4. As informações obtidas pelo indicador devem ser representativas do fenômeno como um todo;

5. O indicador deve ser facilmente reconhecido inclusive por pessoas que não sejam especialistas;

6. Os dados a serem adquiridos pelo indicador devem ser de fácil obtenção e fundamentais ao usuário potencial;

7. O indicador deve estabelecer limites na análise dos dados; e,

8. O indicador deve ter aplicação regional.

No monitoramento ambiental integrado tem-se aplicado o uso de geoindicadores para auxiliar no diagnóstico das mudanças ambientais. Dessa forma, torna-se uma ferramenta de auxílio que permite assegurar tanto o desenvolvimento sustentável como a gestão do ecossistema, assim como possibilita uma maior compreensão do impacto ambiental e dos riscos associados aos processos atuantes (Berger, 1996) (Figura 2.3). 


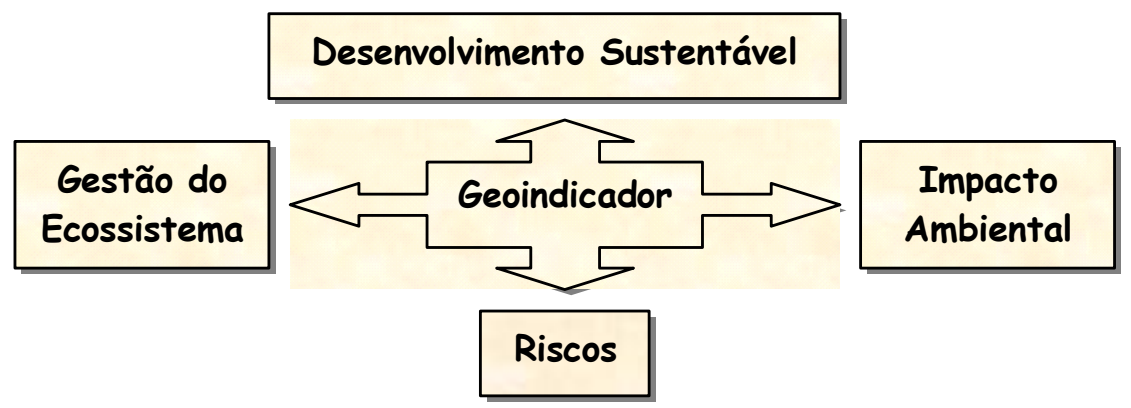

Figura 2.3 - Geoindicador: ferramenta de auxílio no monitoramento integrado (adaptado de Berger, 1996)

A COGEOENVIRONMENT (1995) define geoindicadores como medidas de magnitude, de freqüência, de taxas e tendências de processos ou fenômenos geológicos que ocorrem em períodos de 100 anos ou menos, na superfície terrestre ou próximo à ela, sujeitos a variações significativas para a compreensão das mudanças ambientais rápidas. Os geoindicadores medem os eventos catastróficos e os mais graduais, mas evidentes no intervalo de uma vida humana.

Dessa forma, o conceito de geoindicador está associado à sensibilidade da paisagem, ou seja, a magnitude potencial de mudança de um sistema geomorfológico e a sua ampla capacidade de resistir ou se modificar diante da atuação interativa dos processos físicos, químicos e biológicos no tempo (Thomas \& Allison, 1993).

Os geoindicadores podem, portanto, auxiliar na mensuração das mudanças das características dinâmicas do ambiente terrestre (Figura 2.4). Devem ser considerados conjuntamente com os parâmetros biológicos, meteorológicos e hidrológicos apropriados de forma a contribuírem para o melhor entendimento das mudanças ambientais e sustentabilidade (Jones, 1993). 


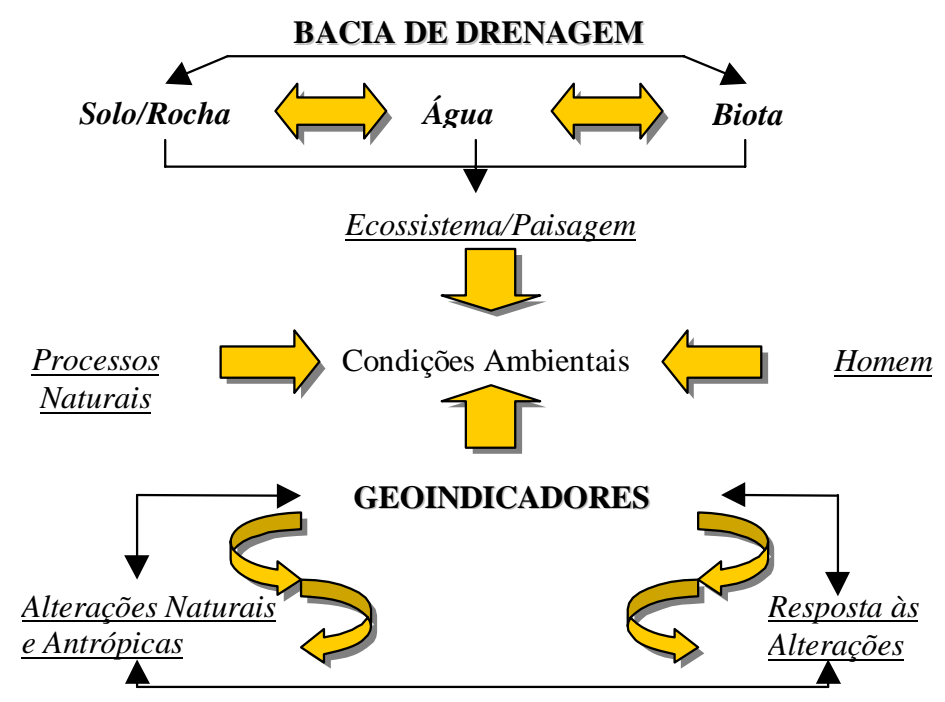

Figura 2.4 - Geoindicador um componente dinâmico no geossistema (Berger, 1996)

$\mathrm{Na}$ Tabela 2.5 são apresentados os geoindicadores propostos pela COGEOENVIRONMENT (1995), suas tendências naturais e as influências antrópicas nas alterações destes atributos.

Tabela $2.5-$ Geoindicadores: Influência Natural $\quad$ x Influência Humana (COGEOENVIRONMENT, 1995)

\begin{tabular}{|c|c|c|}
\hline GEOINDICADORES & $\begin{array}{c}\text { INFLUÊNCIA } \\
\text { NATURAL }\end{array}$ & $\begin{array}{c}\text { INFLUENCIA } \\
\text { HUMANA }\end{array}$ \\
\hline $\begin{array}{l}\text { - Química do Coral e Padrão de Crescimento } \\
\text { - Formação de Duricrust em Desertos } \\
\text { - Formação e Reativação de Dunas } \\
\text { - Magnitude, Duração e Freqüência de Tempestade de Areia } \\
\text { - Flutuações de Geleiras } \\
\text { - Qualidade da Água } \\
\text { - Química da Água na Zona Não-Saturada } \\
\text { - Nível do Lençol Freático } \\
\text { - Atividade Cárstica } \\
\text { - Nível e Salinidade dos Lagos } \\
\text { - Nível Relativo do Mar } \\
\text { - Seqüência e Composição dos Sedimentos } \\
\text { - Sismicidade } \\
\text { - Posição da Linha de Costa } \\
\text { - Deslizamento } \\
\text { - Erosão de Solos e Sedimentos } \\
\text { - Qualidade do Solo } \\
\text { - Fluxo de Água } \\
\text { - Morfologia do Canal } \\
\text { - Transporte e Deposição dos Sedimentos } \\
\text { - Comportamento da Temperatura da Subsuperfície } \\
\text { - Qualidade da Água Superficial } \\
\text { - Extensão, Estrutura e Hidrologia de Terras Alagadas } \\
\text { - Erosão Eólica }\end{array}$ & 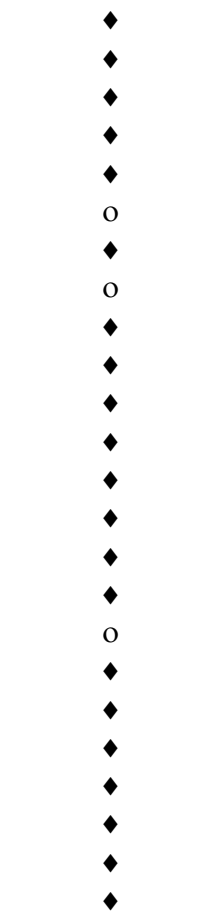 & $\begin{array}{l}\bullet \\
\text { o } \\
\mathrm{o} \\
\mathrm{o} \\
- \\
\bullet \\
\bullet \\
\bullet \\
\bullet\end{array}$ \\
\hline
\end{tabular}

- Fortemente influenciado pelo ou com importante utilidade para

o Pode ser influenciado pela ou tem alguma utilidade para

- Nenhuma influência substancial na, ou utilidade para 
Coltrinari \& McCall (1998), propõem geoindicadores que indicam mudanças ambientais nas zonas tropicais úmidas, apresentados na Tabela 2.6.

Tabela 2.6 - Geoindicadores de mudanças ambientais na Zona Tropical Úmida (Coltrinari \& McCall, 1998)

\begin{tabular}{|c|c|c|c|c|}
\hline Indicador & Natural & Antropogênica & $\begin{array}{c}\text { Freqüência } \\
\text { (Anos) }\end{array}$ & $\begin{array}{c}\text { Dados } \\
\text { Necessários }\end{array}$ \\
\hline $\begin{array}{l}\text { Meteorologia } \\
\text { - Observaç̃oes meteorológicas } \\
\text { Padronizadas } \\
\text { - Precipitação } \\
\text { - Tormentas }\end{array}$ & $\mathrm{x}$ & $\mathrm{X}$ & $1-50+$ & OM \\
\hline $\begin{array}{l}\text { Hidrologia } \\
\text { - Carga de sedimentos } \\
\text { - Cheias (frequêencia e volume), etc } \\
\text { Processos de Erosão e Deposicão }\end{array}$ & $\mathrm{x}$ & $\mathrm{X}$ & $1-50+$ & $\mathrm{MH}$ \\
\hline $\begin{array}{l}\text { Fluvial } \\
\text { - Mudanças no padrão de drenagem } \\
\text { e no perfil do canal } \\
\text { - Erosão/sedimentação por atividade } \\
\text { Antrópica (mineração, culturas, etc) } \\
\text { - Erosão do solo (escorregamentos, } \\
\text { Ravinamentos, erosão generalizada) } \\
\text { - Deltas (como arquivos das s } \\
\text { Mudança na bacia) } \\
\text { - Costas }\end{array}$ & $\mathrm{x}$ & $\mathrm{X}$ & $1-50+$ & OM, F, I, TC \\
\hline $\begin{array}{l}\text { Vegetação } \\
\text { - Distribuição } \\
\text { - Deflorestação } \\
\text { - Mudanças no uso do solo (inclusive } \\
\text { Inundação de florestas por barragens) }\end{array}$ & $\mathrm{x}$ & $\mathrm{X}$ & $1-5$ & $\mathrm{~F}, \mathrm{I}$ \\
\hline $\begin{array}{l}\text { Solo (incluindo conteúdo de matéria } \\
\text { Orgânica, estrutura, permeabilidade) }\end{array}$ & $\mathrm{x}$ & $\mathrm{X}$ & $10-50+$ & EL, TC \\
\hline $\begin{array}{l}\text { Química (Dados Básicos) } \\
\text { - Solos } \\
\text { - Água superficial } \\
\text { - Água subsuperficial } \\
\text { - Ar (incluindo chuva ácida) }\end{array}$ & $\mathrm{x}$ & $\mathrm{X}$ & $5+$ & EL, TC \\
\hline $\begin{array}{l}\text { Sismicidade * } \\
\text { - Freqüência } \\
\text { - Localização } \\
\text { - Magnitude }\end{array}$ & $\mathrm{x}$ & $\mathrm{X}$ & -- & \\
\hline Erupcões Vulcânicas * & $\mathrm{x}$ & $\mathrm{X}$ & -- & \\
\hline $\begin{array}{l}\text { Legenda } \\
\text { OM - Observações Meteorológicas } \\
\text { MH - Medidas Hidrológicas } \\
\text { EL - Ensaios de Laboratório } \\
\text { TC - Trabalho de Campo } \\
\text { F - Fotointerpretação } \\
\text { I - Imagens de Satélite } \\
\text { * - Monitoramento para Riscos Associac }\end{array}$ & correg & os, cheias, etc) & & \\
\hline
\end{tabular}




\section{4 - BACIA HIDROGRÁFICA: SISTEMA INTEGRADO}

A bacia hidrográfica é considerada uma unidade ou sistema geomorfológico que resulta da interação entre processos e landforms que se agrupam para formar uma paisagem complexa. Compõe-se de divisores de água, encostas, redes de drenagem e um canal principal de maior extensão (Chorley et al, 1984).

Diversos autores (Silveira, 1993; Ritter et al 1995, Cunha \& Guerra, 1996), definem esse sistema como área finita de captação natural de água precipitada, onde os escoamentos convergem para um único ponto que pode ser outro rio de hierarquia superior ou igual, lago, reservatório ou oceano.

Dessa forma, a bacia hidrográfica (Figura 2.5) pode ser contextualizada como um sistema físico aberto em que há a atuação de processos naturais ou antrópicos no ambiente e como resposta, podem ser observadas mudanças no meio físico. Essas modificações resultam da busca de um equilíbrio dinâmico observado pelo input e output de massa e energia do sistema (Chorley et al, 1984; Cunha \& Guerra, 1996; Ross, 1996).

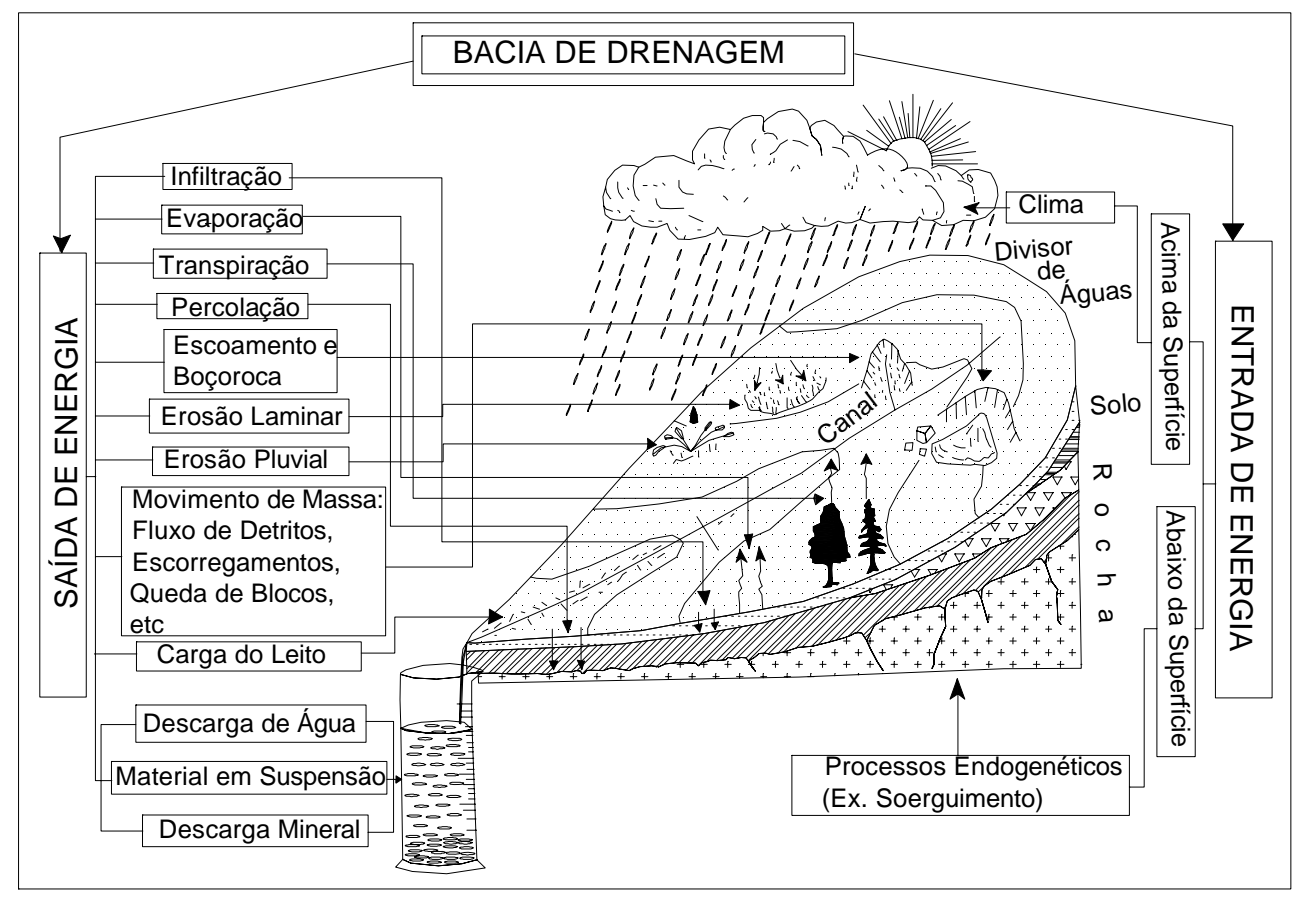

Figura 2.5 - Bacia Hidrográfica: Um Sistema Integrado Aberto (modificado de Rawat, 1987)

A entrada de energia (input) no sistema é caracterizada pela: energia termal do sol, energia cinética e potencial da precipitação, energia potencial do soerguimento e da atividade ígnea e atividade química e física resultantes do intemperismo. Enquanto a saída de energia 
(output) é representada pelo: transporte de água, sedimento e material dissolvido (Ross, 1996).

O fluxo energético resulta da saída de água, de sedimento e de material dissolvido, e permite subdividir a bacia em três partes de acordo com o processo atuante predominante: erosão, transporte e sedimentação (Figura 2.6). A zona 1 representa a porção da bacia mais alta, onde predominantemente ocorrem os processos erosivos e de movimentação de massa; a 2, considerada zona de transporte representa a área de transição entre as zonas 1 e 3; e a 3 que corresponde a porção mais baixa da bacia é denominada de zona de deposição (Chorley et al, 1984).

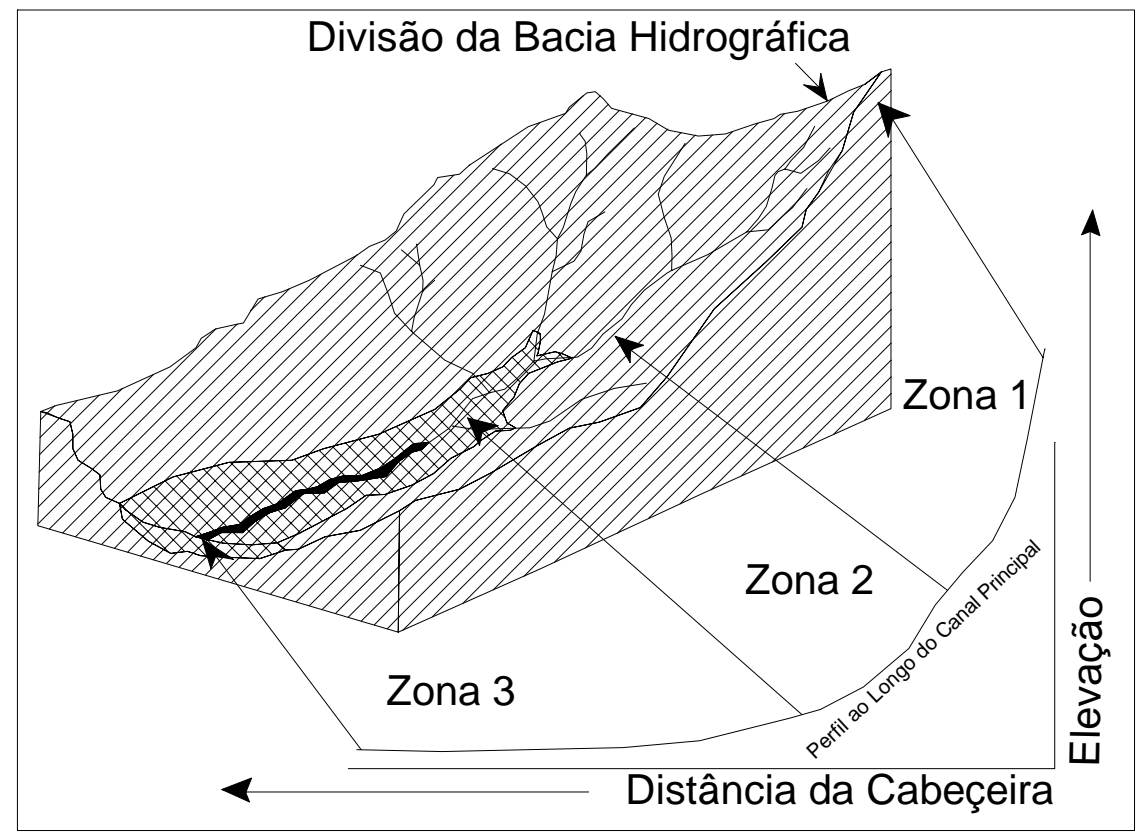

Figura 2.6 - Direção do fluxo energético da bacia hidrográfica (FPC, 1996)

De acordo com Ross (1996), a troca energética resulta das características hidrológicas e morfológicas da bacia sendo controlada por variáveis independentes (propriedades intrínsecas do meio físico) e variáveis dependentes (efeitos observados em função de modificações das variáveis independentes).

Dentre as variáveis independentes pode-se citar: o tempo, o relevo, a geologia e o clima. Enquanto as variáveis dependentes são: a vegetação (tipo e densidade); hidrologia (escoamento superficial e carga de sedimentos produzida por unidade de área dentro da zona 1), morfologia do sistema deposicional, rede de drenagem, encostas e vales; posição do relevo e características dos sedimentos (Chorley et al, 1984). 
Em função das mudanças de entrada e saída de energia, há constantes ajustes nos elementos das formas e nos processos associados, os quais podem ser catalisados pelo homem. A Tabela 2.7 apresenta os parâmetros que condicionam a entrada de energia na bacia hidrográfica (input), os parâmetros intrínsecos a ela e as prováveis respostas às mudanças no sistema (output) (Rawat, 1987).

Tabela 2.7 - Entrada (input) e saída (output) de energia no sistema (Rawat, 1987)

\begin{tabular}{|c|c|c|c|}
\hline \multicolumn{4}{|c|}{ BACIAS HIDROGRÁFICAS } \\
\hline $\begin{array}{l}\text { Entrada de Energia } \\
\text { (input) }\end{array}$ & & Características da Bacia & Saída de Energia (output) \\
\hline $\begin{array}{l}\text { A) } \text { Processos Exógenos } \\
\text { - Precipitação } \\
\text { - Temperatura } \\
\text { - Umidade }\end{array}$ & 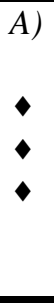 & $\begin{array}{l}\text { Características Físicas } \\
\text { Morfometria } \\
\text { Geologia } \\
\text { Rocha, resistência da rocha, } \\
\text { densidade de juntas, fraturas, } \\
\text { acamamentos e xistosidades }\end{array}$ & $\begin{array}{ll}\text { A) } & \text { Processos Hidrológicos } \\
& \text { Transpiração } \\
& \text { Evaporação } \\
& \text { Infiltração } \\
& \text { Percolação } \\
& \text { Fluxo do canal } \\
& \text { Fluxo de subsuperfície }\end{array}$ \\
\hline $\begin{array}{ll}\text { B) } & \frac{\text { Processos }}{\text { Endógenos }} \\
& \text { História tectônica } \\
\text { Morfotectônica } \\
\text { Neotectônica }\end{array}$ & & $\begin{array}{l}\text { Características Culturais } \\
\text { Distribuição da população } \\
\text { Padrão de uso do solo } \\
\text { Mineradoras } \\
\text { Tipo de obras implantadas } \\
\text { Indústrias }\end{array}$ & $\begin{array}{l}\text { B) Processos Geomorfológicos } \\
\text { Erosão em encostas } \\
\text { Boçorocas, ravinas e sulcos } \\
\text { Erosão do canal } \\
\text { Maior ou menor carga de fundo } \\
\text { material em suspensão e } \\
\text { dissolvido } \\
\text { Movimentos de massa (rastejo, } \\
\text { fluxo de lama, escorregamentos, } \\
\text { fluxo de detritos, queda de } \\
\text { blocos, solifluxão e avalanche) }\end{array}$ \\
\hline
\end{tabular}

De uma forma mais ampla, Barrow (1998) conceitua as bacias hidrográficas como unidades biogeográficas com alto grau de integridade funcional que representam sistemas relativamente homogêneos, mesmo quando sua seção inferior, superior e intermediária têm condições naturais e atividades distintas. Cada bacia, portanto, apresenta características geológicas, hidrológicas e ecológicas únicas de forma que essas unidades possam ser caracterizadas como unidades de paisagem operacional amplamente usada para fins de planejamento e manejo integrado ao buscar a manutenção da qualidade ambiental e ao propor a instauração do desenvolvimento sustentável.

A atuação do homem no meio físico deve ser analisada de forma criteriosa nos estudos ambientais e deve envolver a bacia de drenagem como unidade de planejamento e gerenciamento ambiental e, apesar da clara ênfase na questão dos recursos hídricos, é necessário que o planejamento contemple todos os componentes naturais (água, solo, relevo, subsolo, flora e fauna) (figuras 2.7 e 2.8) e os componentes socioeconômicos (Figura 2.9) (Pires \& Santos, 1995; Souza et al, 1997; Ross et al, 1998). As metas principais a serem 
alcançadas são: a) o desenvolvimento sustentável da bacia; b) a melhoria da qualidade ambiental e de vida das populações; e, c) a preservação ambiental (Souza et al, 1997).

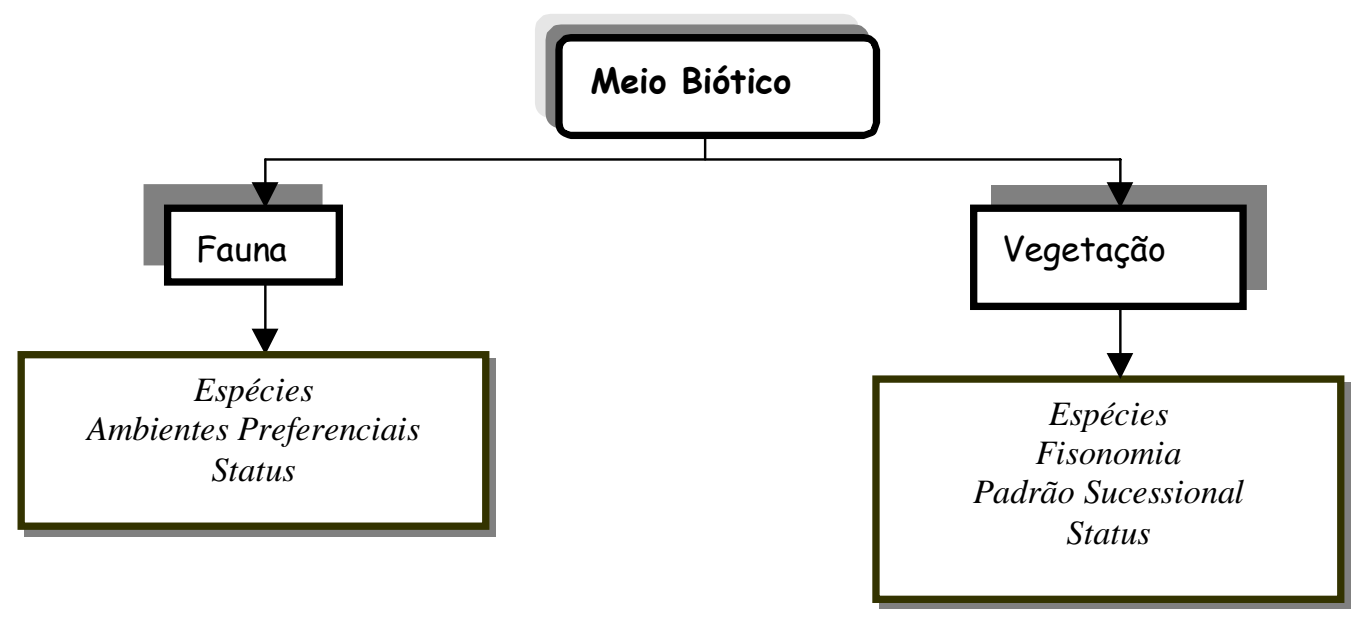

Figura 2.7 - Componentes naturais do meio biótico (Souza et al, 1997)

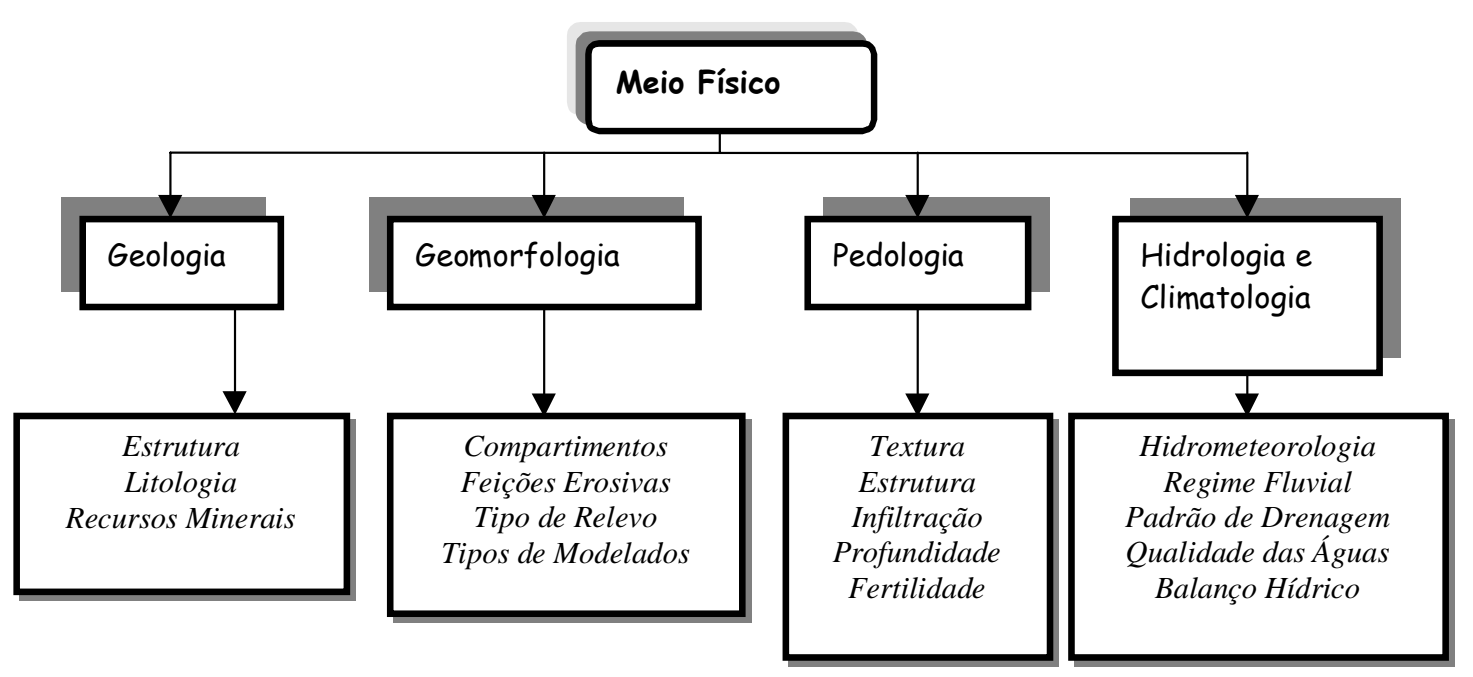

Figura 2.8 - Componentes naturais do meio físico (Souza et al, 1997) 


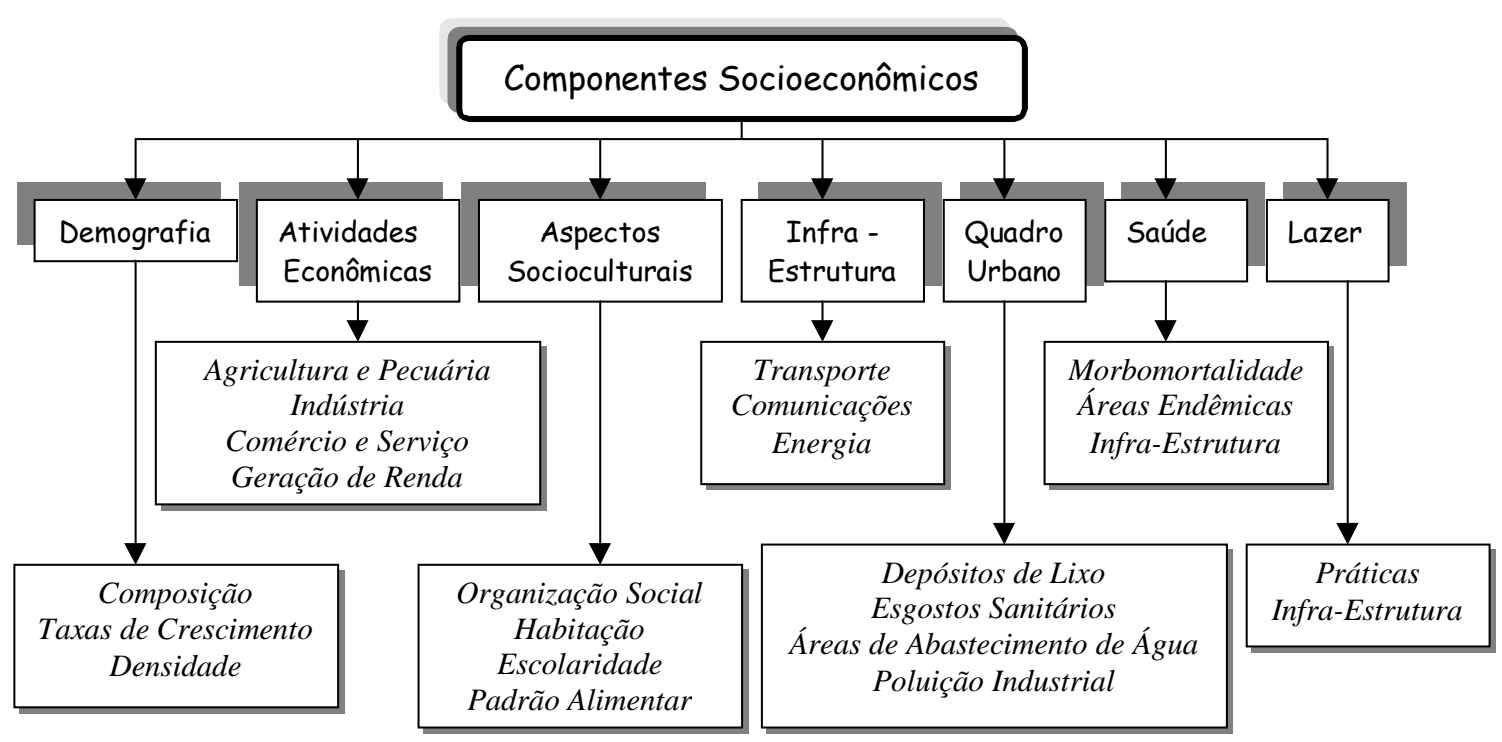

Figura 2.9 - Componentes socioeconômicos (Souza et al, 1997)

\section{5 - METODOLOGIA DE MAPEAMENTO GEOTÉCNICO (EESC/USP)}

A metodologia de mapeamento geotécnico desenvolvida na Escola de Engenharia de São Carlos - USP foi proposta inicialmente por Zuquette (1987).

Esta metodologia visa atender as condições socioeconômicas do país por meio de mapeamentos geotécnicos que sejam simples de executar e apresentem baixo custo.

De forma genérica, o mapeamento geotécnico proposto tem caráter preventivo e solicita a produção de dados básicos e fundamentais sobre o meio físico. O objetivo a ser alcançado é a elaboração de uma série de documentos cartográficos sobre o meio físico que associado a outros documentos relativos ao meio ambiente, permitam uma avaliação da ocupação antrópica e suas seqüelas e consequentemente a priorização e hierarquização das áreas quanto à sua adequabilidade.

Os mapas e cartas temáticas são classificados por Zuquette (1987) como:

- Documentos básicos fundamentais tem a finalidade de registrar as características dos componentes do meio físico, por meio da variação espacial de atributos do mesmo;

- Documentos fundamentais de síntese tem por objetivo sintetizar as informações de uma dada região;

- Cartas derivadas e interpretativas correspondem ao produto da análise das características de cada divisão básica do meio em questão, podendo ter uma ou mais finalidades; 
- Carta de prognóstico de riscos leva em consideração a interação das características dos constituintes do meio ambiente, considerando as relações entre os diferentes de ocupação.

Os documentos são elaborados a partir de um grupo de atributos, analisados por mecanismos que definem e auxiliam na determinação das unidades homogêneas. Os atributos a serem mapeados e as respectivas classificações dependem da finalidade do trabalho a ser realizado e a escolha adequada influencia diretamente na eficiência, na qualidade e na possibilidade dos usuários utilizarem as informações.

Os atributos são definidos como qualidades intrínsecas dos componentes do meio físico e podem ser caracterizados direta ou indiretamente por meio de correlações com ensaios de caracterização.

De acordo com Zuquette (1993) é importante admitir um critério rigoroso na seleção de atributos a serem considerados e suas respectivas classificações, as quais devem atender as finalidades e as escalas de trabalho. Os atributos de cada componente do meio físico devem ser hierarquizados para o detalhamento da região. A priorização adequada dos atributos pode proporcionar uma maior confiabilidade na caracterização dos problemas de determinada área, possibilitando a exclusão de alguns atributos do meio físico, em função da sua pouca ou nenhuma expressão ou pela impossibilidade de obtenção dos dados ou ainda pela sua baixa confiabilidade.

\section{6 - MÉTODO DE COLLARES (2000) PARA AVALIAÇÃO DAS ALTERAÇÕES EM REDE DE DRENAGEM}

Collares (2000), apresenta e aplica um método para avaliar as alterações em componentes da paisagem de bacias hidrográficas em escala regional.

O método consiste no levantamento das características de uso e ocupação do terreno por meio de técnicas de geoprocessamento e na análise temporal de alterações em rede de drenagem de sub-bacias com base em variáveis morfométricas.

\subsection{1 - Levantamento do Uso e Ocupação}

Essa etapa de trabalho consiste no levantamento das atividades antrópicas de uma determinada área. Collares (2000) define as seguintes classes de uso e ocupação:

- Centro urbano

- Ocupação medianamente adensada (periferia das cidades e pequenos núcleos urbanos) 
- Ocupação pouco adensada (concentrações de chácaras e ocupações dispersas)

- Hortifruti e outras culturas (pantações)

- Cana (áreas de plantações de cana em diferentes estágios de plantio)

- Pastagem/Mata Capoeira

- Mata nativa/Reflorestamento

- Solo exposto (área com solo descoberto por mineração, áreas de empréstimos ou disposição de lixo)

- Represas

Para o auxílio no levantamento das atividades antrópicas foram utilizados os programas ENVI $3.0{ }^{\circledR}$, para o processamento de imagens de satélite Landsat-TM e obtenção do mapa de uso e ocupação e o programa Autocad Map 3.0 ® para o processamento dos dados referentes às atividades modificadoras do meio físico e os dados obtidos a partir da fotointerpretação (Figura 2.10).

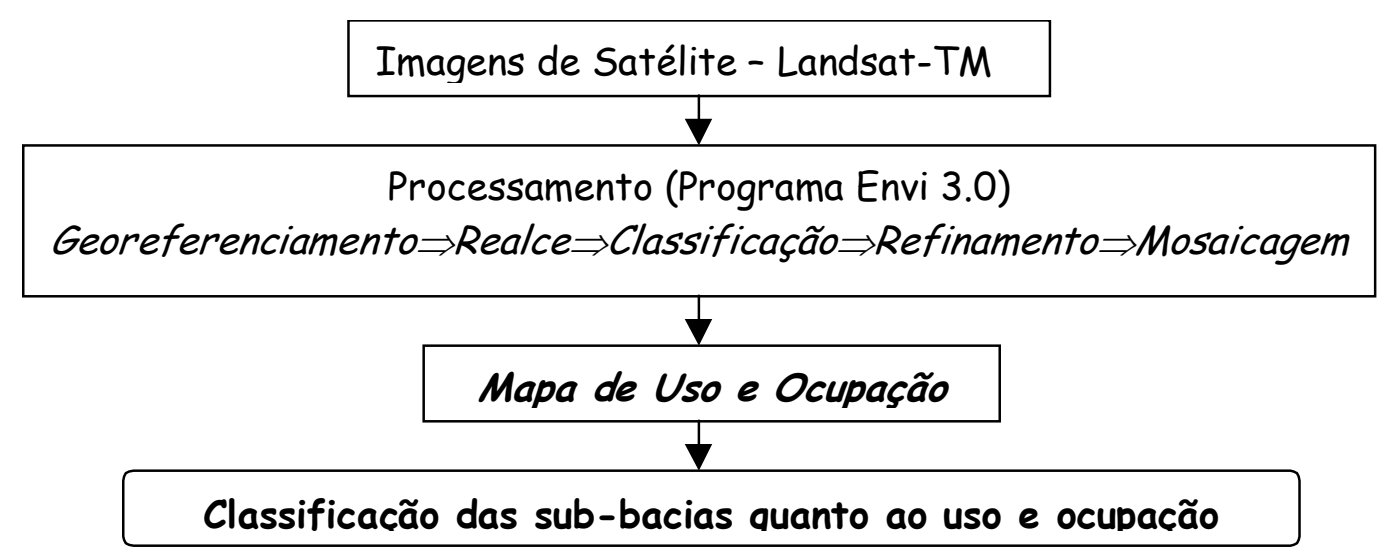

Figura 2.10 - Esquema adotado no processamento da imagem de satélites (modificado de Collares, 2000)

\subsection{2 - Levantamento das Atividades Modificadoras do Meio Físico}

Nessa etapa são levantadas as potenciais atividades pontuais responsáveis pelas modificações na paisagem e na qualidade das águas na Bacia do Rio Capivari (industrias, áreas de mineração, granjas, dentre outros). Após o levantamento, os dados são inseridos num banco de dados e conectados a uma base georeferenciada (Figura 2.11). 


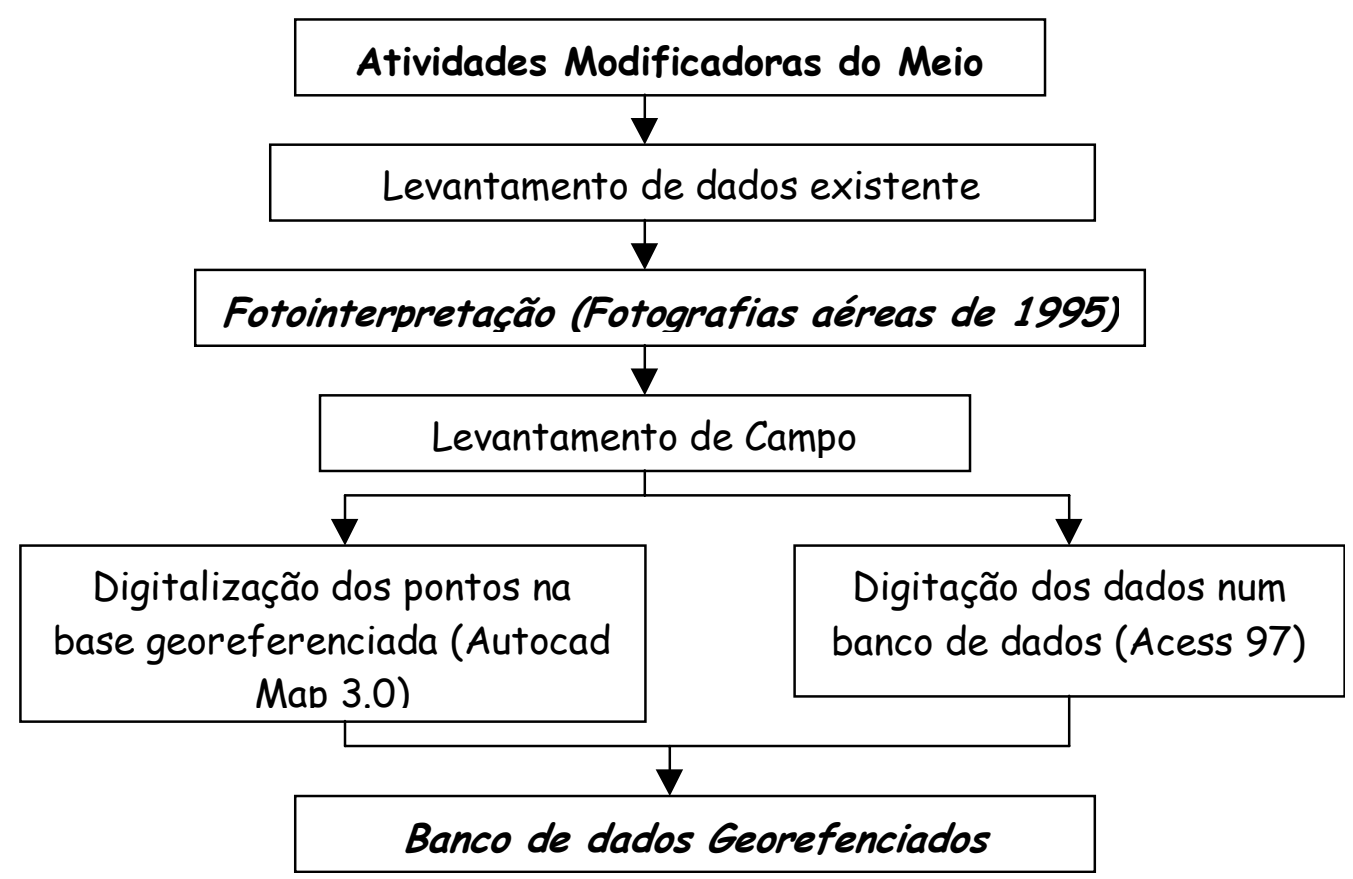

Figura 2.11 - Seqüência dos procedimentos adotados para a obtenção do banco de dados georeferenciados com as atividades modificadoras do meio (modificado de Collares, 2000)

\subsection{4 - Análise Temporal de Intervenções Antrópicas}

O objetivo dessa etapa foi determinar a abrangência da área ocupada pelas classes de atividades antrópicas. Collares (2000) define microbacias rurais como aquelas em que mais de 70\% da área estão ocupados por pastagens, cana de açúcar e/ou hortifruti, urbanas quando mais do que $60 \%$ da área representam a soma das classes urbanas e mistas onde não há um predomínio acentuado nem das classes rurais ou nem das classe urbana.

As microbacias rurais podem ser subdivididas em agrícolas, aquelas em que mais de 70\% da área está ocupada por cana de açúcar e/ou hortifruti, não agrícolas onde mais de 70\% da área está ocupado por pastagens e parcialmente agrícolas onde mais de 70\% da área está ocupada por pastagens e culturas agrícolas.

Para a efetivação da análise temporal são utilizadas fotografias aéreas na escala de 1:25.000 datadas de 1972 e 1995.(Figura 2.12). 


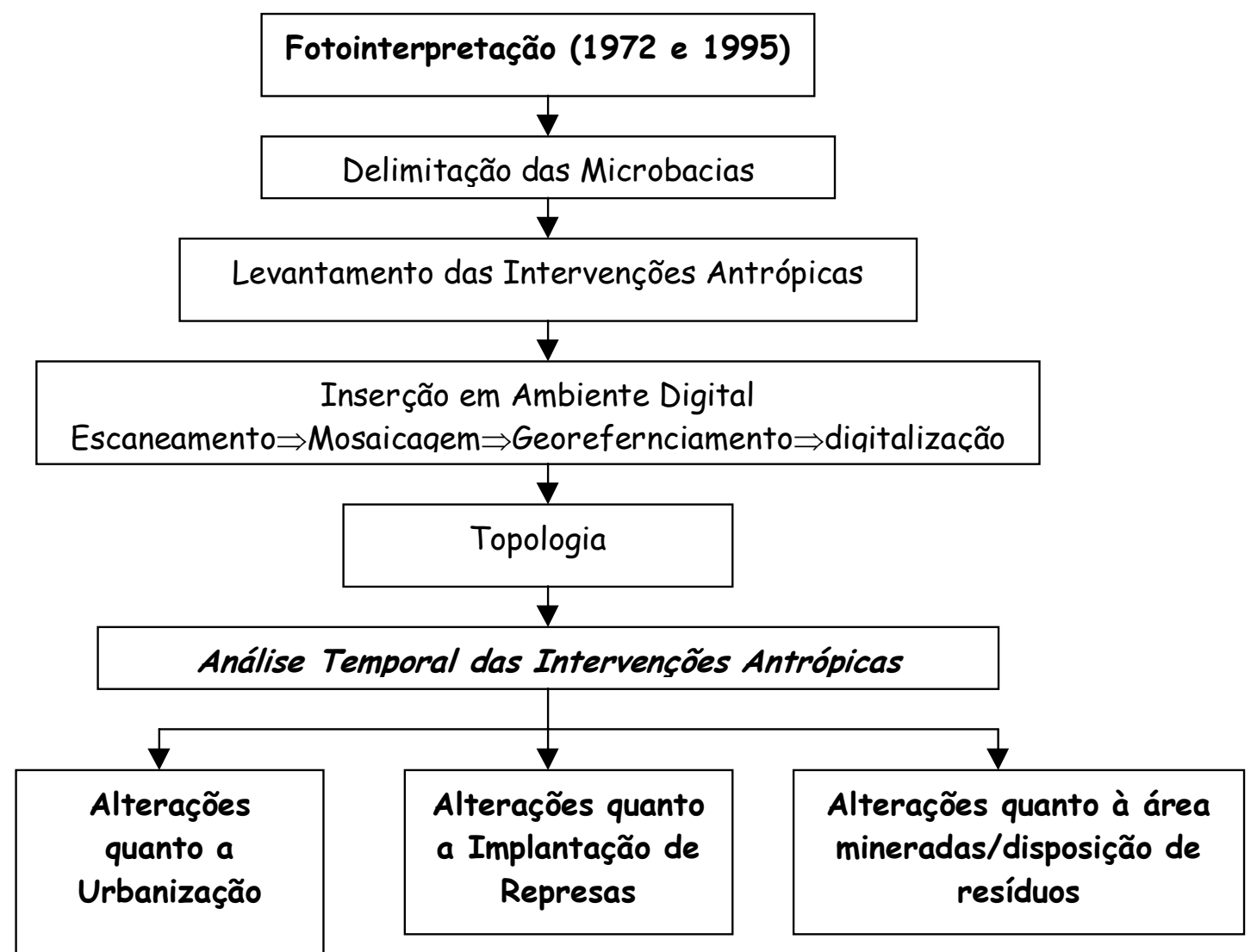

Figura 2.12 - Seqüência de procedimentos adotados para análise temporal de intervenções antrópicas (modificado de Collares, 2000)

\subsection{5 - Análise Temporal da Morfometria da Rede de Drenagem}

Essa etapa consiste no levantamento da significância das alterações ocorridas em microbacias, com base em variáveis morfométricas da rede de drenagem, com posterior agrupamento das microbacias conforme o grau de alteração a que foram submetidas (Figura 2.13).

A hierarquização dos canais na rede de drenagem é efetuada conforme a classificação proposta por Strahler (1957), com modificação, uma vez que são considerados os canais pluviais e fluviais.

Para a determinação das variáveis morfométricas, as rede de drenagem são digitalizadas, georeferenciadas e transformadas em topologias com o auxílio do programa Autocad Map 3.0 ®. 
Para avaliar a significância das alterações ocorridas nas microbacias e agrupa-las conforme o grau de alteração utiliza-se como ferramenta alguns procedimentos estatísticos multivariados com o auxílio do software Statistica 5.5 ®.

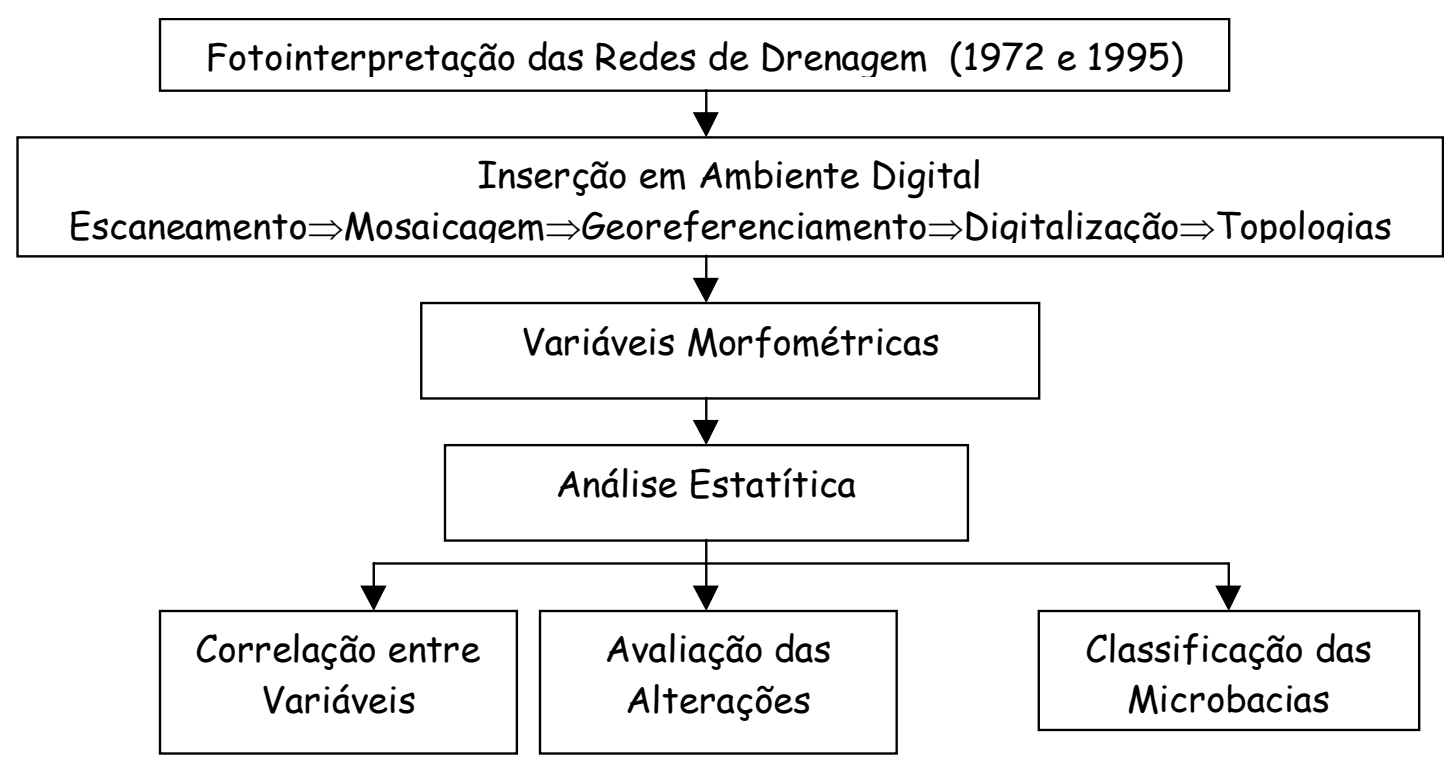

Figura 2.13 - Seqüência de procedimentos adotados para análise temporal das modificações da rede de drenagem (modificado de Collares, 2000)

\section{7 - ANÁLISE MORFOMÉTRICA DE BACIAS HIDROGRÁFICAS}

A análise morfométrica vem a ser uma ferramenta importante na caracterização temporal da rede de drenagem, por permitir a visualização das mudanças ocorridas na sua configuração, forma e quantidade de canais.

Segundo o Guia de Procedimentos de análise de canais de drenagem proposto pelo Governo do Canadá (Forest Practice Code, 1996), qualquer alteração no meio físico pode ser rapidamente refletida na morfologia e morfometria dos canais na rede de drenagem. Este código destaca as mudanças no comprimento dos rios, no suprimento de sedimentos e água, no padrão, forma e gradiente dos canais, na vegetação, no leito, na confluência e na instabilidade lateral dos canais.

Dessa forma, a adoção da rede de drenagem como principal geoindicador e quantificador das alterações sofridas no meio físico, baseia-se na sua capacidade de permitir avaliações e mensurações das modificações ocorridas nas bacias hidrográficas. 
Segundo Machado (1982), o desenvolvimento ordenado do sistema de drenagem sofre um reajuste quando submetido a novas condições ambientais, de forma que todos os eventos registrados repercutem direta ou indiretamente nos rios.

Nesse contexto, registra-se um acréscimo nos estudos que consideram a análise morfométrica para predizer ou descrever os processos do meio físico em bacias hidrográficas, por exemplo, picos de inundação, taxa de sedimentação e estimativa de taxas de erosão. Essa preocupação ocorre principalmente em áreas de intensa modificação pelas ações antrópicas, com o intuito de analisar o estádio de degradação da área (Piedade \& Carvalho, 1981).

O método aplicado para descrever a geometria da paisagem é a seleção de certas variáveis geométricas diagnósticas que podem ser racionalizadas em termos de processos ou história de formação. Soares \& Fiori (1976) afirmam que as formas de relevo e de drenagem serão diferentes quando resultam de situações historicamente diferentes na evolução geológica, mesmo que os seus ambientes de formação sejam idênticos.

As medidas quantitativas da geometria na superfície do terreno estão representadas por um conjunto de propriedades que definem as características areais lineares e de relevo da bacia. Essas variáveis são correlacionáveis com a ordem do canal e com várias combinações dessas características. Dois tipos básicos de escala são usados para descrever a morfometria da bacia ou características da rede de drenagem (Strahler, 1952, 1957). O primeiro refere-se à escala linear normalmente mensurada pela comparação do tamanho das unidades topográficas. Os parâmetros podem incluir o comprimento do canal de qualquer ordem, o relevo, a extensão do perímetro da bacia e outras medidas. O segundo tipo consiste em números adimensionais, freqüentemente derivados de razões de parâmetros de extensão, que permitem a realização de comparações entre bacias ou redes, tais como a razão de comprimento, razão de bifurcação e razão de relevo.

Segundo Politano et al (1995), os valores das principais características quantitativas de bacias hidrográficas não variam de modo proporcional à medida que há mudança sucessiva na sua classificação em virtude do grau de magnitude. Portanto, os estudos ambientais que envolvem a comparação de bacias hidrográficas devem, necessariamente, ser realizados fundamentando-se numa mesma ordem de magnitude. 


\subsection{1 - Hierarquia Fluvial}

A ordem de canais está diretamente associada à hierarquização das bacias. Dentre os diversos autores que propuseram sistemas de classificação de canais, pode-se citar Horton (1945), Strahler (1957) e Shreve (1966).

Horton (op. cit.) propõe os seguintes critérios de ordenação dos canais:

- O rio principal é representado pelo canal de maior ordem, e permanece nesse grau hierárquico desde a sua nascente até sua foz;

- Canais de primeira ordem são aqueles que não possuem tributários;

- Canais de segunda ordem recebem somente tributários de primeira ordem;

- Canais de terceira ordem recebem tributários de primeira e segunda ordem; e,

- Canais de quarta ordem recebem tributários de terceira ordem e de ordem inferior e assim sucessivamente.

Strahler (op. cit.) implementa modificações à hierarquização dos canais propostos por Horton (1945), cujos critérios apresentados são:

- Os canais de primeira ordem, considerados os menores, são os que não têm tributários;

- Os canais de segunda ordem surgem da confluência de canais de primeira ordem e só recebem afluentes de primeira ordem; e,

- Os canais de terceira ordem surgem da confluência de canais de segunda ordem e recebem afluentes de primeira e segunda ordem e assim sucessivamente.

Ao analisar as propostas anteriores, Shreve (op. cit.) conclui que a ordenação dos canais resulta do estabelecimento da ordem da bacia hidrográfica, a qual corresponde à maior ordem atribuída a um de seus segmentos. O autor sugere um novo método de estruturação da rede de drenagem, o qual baseia-se na soma da magnitude dos canais em confluência. Essa classificação é mais usada na descrição hidrodinâmica da bacia de drenagem e freqüentemente incorpora procedimentos estatísticos para a estimativa da descarga dos rios.

O estabelecimento das ordens de canais leva Horton (1945) a concluir que certos parâmetros lineares da bacia estão proporcionalmente relacionados à sua ordenação e que esses podem ser expressos como uma relação básica da composição de drenagem. 


\subsection{2 - Parâmetros Morfométricos}

\subsubsection{1 - Variáveis Lineares}

\section{a) Razão de Bifurcação (Rb)}

A Morfometria Linear está baseada na Razão de Bifurcação, a qual é definida como a relação entre o Número de Canais de uma dada ordem $\left(\mathrm{N}_{\mathrm{i}}\right)$ pelo número de ordem superior $\left(\mathrm{N}_{\mathrm{i}+1}\right)$. Pode ser expressa pela fórmula 1:

$$
R_{b}=\frac{N_{i}}{N_{i+1}}
$$

De acordo com Horton (1945), a razão de bifurcação é regida pela lei do número de canais, a qual representa uma série geométrica inversa constituída pela soma dos números de canais de cada ordem, cujo primeiro termo é a unidade da primeira ordem.

Segundo Strahler (1952), a Razão de Bifurcação é altamente estável e geralmente constante para todas as ordens de rios, com pequena escala de variações de uma região para outra, exceto em áreas com forte controle estrutural. Esse valor adimensional varia entre 3 a 5 em áreas geologicamente homogêneas.

Estudos voltados para a diferenciação de solos mostram altos valores obtidos para a razão de bifurcação $(\mathrm{Rb})$ em solos menos permeáveis e vice-versa, o que demonstra a influência da natureza dos solos sobre essa variável (França, 1968; Guimarães et al, 1989).

Num estudo baseado em avaliação temporal por meio de fotografias aéreas, Piedade \& Carvalho (1981) mostram que essa variável pode ser aplicada para definir o estádio evolutivo de erosões, onde o aumento dos valores de $\mathrm{R}_{\mathrm{b}}$ indicam maiores entalhamentos dos canais e valores de Rb com pouca variação ou que sofrem decréscimo, sugerem erosões ou num estádio de intensidade menor ou num estádio de equilíbrio.

\section{b) Número Total de Canais (Nt) e Número de Canais por Ordem (Ni)}

O Número Total de Canais (Nt) representa a soma do rio principal e de todos os seus tributários e o número de canais por ordem $(\mathrm{Ni})$, a somatória dos canais por ordem. 
De acordo com Collares (2000), essas variáveis permitem uma avaliação primária das alterações ocorridas na bacia (perda ou ganho de canais) e são particularmente importantes quando se analisam suas inter-relações, por meio da razão de bifurcação.

\section{c) Comprimento Total da Rede de Drenagem $\left(L_{t}\right)$, Comprimento Total dos Canais por Ordem $\left(L_{i}\right)$ e Comprimento médio dos Canais por Ordem $\left(L_{i}\right)$}

Em relação ao comprimento dos canais destacam-se as seguintes variáveis:

- $\mathrm{L}_{\mathrm{i}}$, representa a soma total dos comprimentos dos canais de cada ordem, expressa em $\mathrm{km}$;

- $\mathrm{L}_{\mathrm{t}}$ constitui o somatório do comprimento de todos os cursos d'água de uma bacia, expresso em km; e,

- $\mathrm{Lm}_{\mathrm{i}}$ representa o comprimento médio dos segmentos de rios quantificado pela razão entre a soma dos comprimentos dos canais de cada ordem $\left(\mathrm{L}_{\mathrm{i}}\right)$ pelo número de segmentos encontrados na respectiva ordem $\left(\mathrm{N}_{\mathrm{i}}\right)$, expresso em km. Pode ser calculado pela equação 2:

$$
L m_{i}=\frac{L_{i}}{N_{i}}
$$

Segundo França (1968), o comprimento dos rios é mais preponderante a um controle estrutural do que o número de rios. Collares (2000) ressalta a importância destas variáveis numa avaliação primária das alterações em termos de perda ou ganho na extensão de caminhos para o escoamento linear das águas na bacia.

\section{d) Razão entre Comprimentos Médios (RIm)}

Similarmente, à razão de bifurcação, a razão entre os comprimentos médios é regida pela lei dos comprimentos dos canais como uma série geométrica direta cujo primeiro termo é o comprimento médio dos canais de primeira (Horton, 1945).

A razão entre os comprimentos médios é a relação entre o comprimento médio dos canais de uma dada ordem $\left(\mathrm{Lm}_{\mathrm{i}}\right)$ pelo comprimento médio do canal da ordem imediatamente superior $\left(\mathrm{Lm}_{\mathrm{i}+1}\right)$. Pode ser calculado pela fórmula 3:

$$
R \operatorname{lm}=\frac{L m_{i}}{L m_{i+1}}
$$


Essa variável é influenciada pelo comportamento hidrológico da região, e possibilita comparações e diferenciações do comportamento hídrico dos solos, por refletir as relações infiltração/deflúvio (Guimarães et al, 1989).

De acordo com Collares (2000), tanto a razão de bifurcação quanto a razão entre comprimentos médios são variáveis pouco utilizadas em análises geoambientais por refletirem apenas a estruturação interna dos canais na bacia, mas são de grande valia em análises temporais comparativas. As mudanças (taxa de perda ou de ganho expressa em porcentagem) podem indicar alterações internas nas bacias, mesmo quando estas não apresentam variações no número de canais ou em variáveis dimensionais.

\subsubsection{2 - Variáveis Areais}

\section{a) Área (A) e Perímetro (P)}

A unidade fundamental dos elementos areais é a área de uma bacia de drenagem de uma dada ordem. Isto se justifica pela influência direta no escoamento dos canais de uma dada ordem, incluindo todas as áreas de bacias de tributários de menor ordem bem como seus interflúvios.

A área da bacia, o número e comprimento dos canais estão diretamente associados com a ordem do canal (Schumm, 1956). Assim como a área e o comprimento total da rede de drenagem guardam relativa proporcionalidade, decorrente da interação solo-relevo (Piedade et al, 1984).

A área é uma variável independente e conjuntamente com o perímetro da bacia representa parâmetros básicos para o cálculo de outras variáveis morfométricas. Esses parâmetros são definidos com base na linha que delimita o divisor de águas das bacias.

\section{b) Índice de Forma (K)}

O Índice de Forma resulta da relação entre o perímetro da bacia e a sua área. O valor obtido depende apenas da forma da bacia (Gandolfi, 1968 e 1971). Pode ser calculado pela equação 4:

$$
K=\frac{P}{2 \sqrt{\pi A}}
$$




\section{c) Densidade de Drenagem (Dd)}

A Densidade de Drenagem é considerada um dos parâmetros areais mais importantes, por refletir a interação entre os processos climáticos responsáveis pela quantidade de água disponível e os litológicos, topográficos e de vegetação que controlam a distribuição subsequente da água na bacia (Knighton, 1984). Essa variável permite estabelecer a freqüência e a extensão dos canais disponíveis para o escoamento linear das águas e materiais detríticos e o grau de dissecação do relevo resultante da atuação da rede de drenagem (Collares, 2000).

Horton (1945), utiliza o parâmetro densidade de drenagem para quantificar a dissecação fluvial pela relação entre o comprimento total dos canais e a área da bacia hidrográfica. Essa variável pode ser expressa pela fórmula 5:

$$
D d=\frac{L_{t}}{A}
$$

Na soma dos comprimentos devem ser medidos tanto os rios perenes como os canais intermitentes (Cristofoletti, 1969; 1970).

Politano et al (1991), ao aplicarem a análise morfométrica para solos podzólicos vermelhos-amarelos constatam que existe uma correlação entre a densidade de drenagem e a declividade e verificam que em bacias com declividades mais acentuadas têm-se maiores valores de Dd e que, conjuntamente, há uma diminuição das áreas das bacias de primeira ordem. Tais observações corroboram as idéias propostas por Cristofoletti (1969; 1970), nas quais a topografia em bacias de menor porte é caracterizada por declividades acentuadas e os canais de ordem inferior encontram-se nessas áreas elevando os valores de Dd.

Cristofoletti (1969) utiliza a seguinte classificação para a densidade de drenagem em bacias hidrográficas: baixa (Dd < 7,5); Média (Dd 7,5 - 10) e Alta (Dd>10).

A distribuição espacial da densidade de rios é fundamental para definição de unidades ecológicas, geológicas ou geomorfológicas numa bacia, contribuindo principalmente para o entendimento do seu processo de formação (Ferreira, 1999).

Segundo a Food Agriculture Organization - FAO (1995), apenas a urbanização e a agricultura são capazes de provocar alterações consideráveis na densidade de drenagem em bacias hidrográficas. 


\section{d) Densidade Hidrográfica (Dh)}

Horton (1945) define densidade hidrográfica com a denominação de freqüência dos rios, que corresponde à relação entre o número de rios ou cursos d'água com a área da bacia hidrográfica. E pode ser calculada pela equação 6:

$$
D h=\frac{N}{A}
$$

Christofoletti (1969), recomenda a adoção de N como o número total de canais de ordem 1 em substituição ao número total de canais, pois este último pode levar a resultados errados quanto ao comportamento hidrográfico da bacia.

Collares (2000) considera que as variações temporais nos valores de Dh devem refletir modificações nas demais variáveis morfométricas ou mesmo na ordem hierárquica da bacia.

\section{e) Textura Topográfica (Tt)}

A Textura Topográfica representa o grau de dissecação ou entalhamento de uma superfície do terreno. Smith (1950 apud França, 1968) utiliza-a para expressar o espaçamento entre canais de drenagem em mapas topográficos com curvas de nível. Pode ser expressa pela equação (7) logarítmica entre a razão de texturas e a densidade de drenagem:

$$
\log \mathrm{Tt}=0,219649+1.115 \log \mathrm{Dd}
$$

França (1968) apresenta um quadro correlacionando as razões de textura média com índices expressos em km (Tabela 2.13).

Tabela 2.8 - Classes propostas para Textura Topográfica (França, op. cit.)

\begin{tabular}{c|c}
\hline Classe da Textura Topográfica & $\begin{array}{c}\text { Razão de Textura Média } \\
\text { (perímetro expresso em km) }\end{array}$ \\
\hline Grosseira & $<2,5$ \\
Média & $2,5-6,2$ \\
Fina & $>6,2$ \\
\hline
\end{tabular}


Gandolfi (1968, 1971) considera essa variável como um indicador do estádio erosivo da região por ser dependente de vários fatores que atuam na drenagem da topografia, classificados como: fatores naturais (clima, vegetação, tipo de substrato, hidrologia) e fatores acidentais (relacionados à escala de trabalho empregada).

Politano et al (1991) demonstram, por meio de estudos morfométricos das bacias que o comprimento médio e o número de segmentos de rios por unidade de área, a Dd, a Dh e a $\mathrm{Tt}$ apresentam os valores mais altos para relevos dissecados. 


\section{CARACTERÍSTICAS DA ÁREA}

\section{1 - LOCALIZAÇÃO E VIAS DE ACESSO}

As áreas de estudo estão localizadas na região centro-leste do Estado de São Paulo e integram a Bacia do Rio Capivari (Figura 3.1). Compõem-se de nove (9) sub-bacias hidrográficas, sendo quatro (4) no Alto Rio Capivari (Área 1) em Louveira (SP) e cinco (5) no Baixo Rio Capivari (Área 2) em Rafard (SP).

\subsection{1 - Área 1 - Alto Rio Capivari}

A área de estudo 1 é composta pelas sub-bacias hidrográficas Ribeirão do Moinho, córregos Sopezol, Vale das Vinhas e Corrupira e ocupa aproximadamente 54 km².

Estas sub-bacias localizam-se nos municípios de Louveira e Jundiaí (SP) e integram a porção do Alto Rio Capivari, entre as coordenadas UTM 292.000 e 303.000 (E-W) e 7442.000 e 7447.000 (N-S), compreendendo 9 folhas topográficas na escala 1:10.000 confeccionadas pelo Instituto Cartográfico Geográfico do Estado de São Paulo em 1979 (IGC-SP).

As principais vias de acesso são a Rodovia Anhanguera (SP-330), Bandeirantes (SP-348) e SP - 324 (Figura 3.2). 


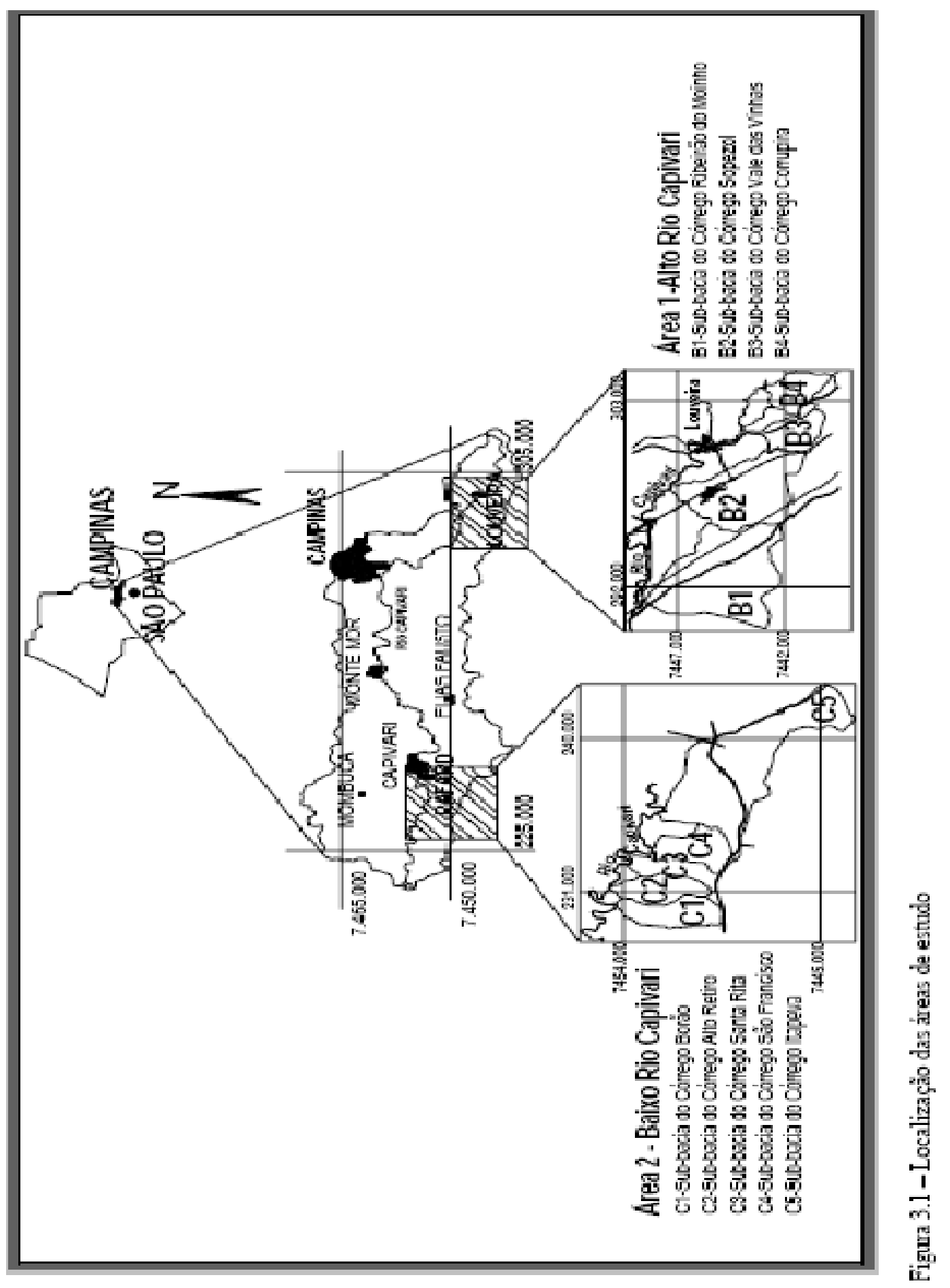




\subsection{2 - Área 2 - Baixo Rio Capivari}

As sub-bacias hidrográficas córregos Borão, Alto Retiro, Santa Rita, São Francisco e Itapeva estão inseridas na Área 2 e ocupam aproximadamente 58 km².

Estas sub-bacias localizam-se no Município de Rafard e integram a porção do Baixo Rio Capivari, entre as coordenadas UTM 231.000 e 240.000 (E-W) e 7445.000 e 7454.000 (N-S), compreendendo 12 folhas topográficas na escala de 1:10.000, confeccionadas pelo Instituto Cartográfico Geográfico do Estado de São Paulo em 1979 (IGC-SP). 
As principais vias de acesso são: a Rodovia do Açúcar (SP-308), a partir de Piracicaba, a Rodovia Jornalista Francisco Proença (SP-201) que liga Campinas a Tietê e a SP-127, que liga Piracicaba a Tietê (Figura 3.2).

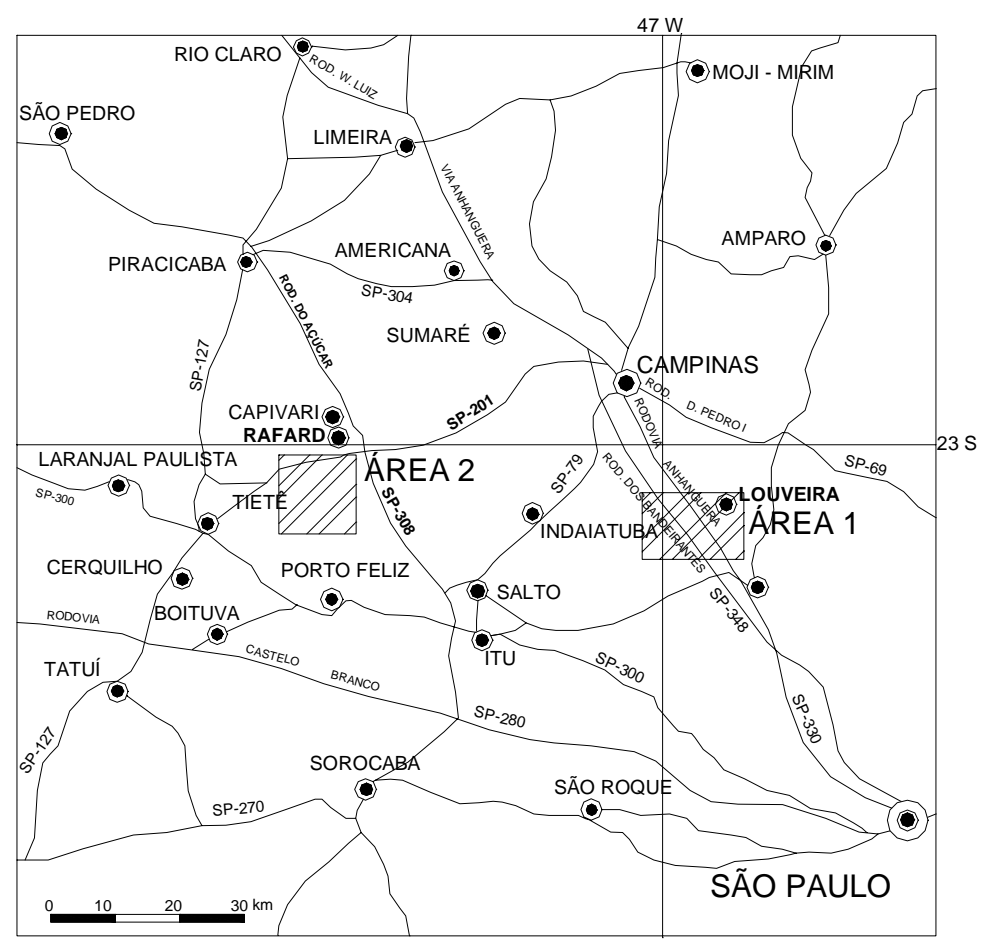

Figura 3.2 - Principais vias de acesso (Macari, 1995).

\section{2 - CLIMA}

Segundo Setzer (1966), na Bacia do Rio Capivari o clima predominante é do tipo Cwa (Classificação de Koeppen), ou seja, clima mesotérmico de inverno seco com temperaturas superiores a $22^{\circ} \mathrm{C}$ nos meses mais quentes.

$\mathrm{Na}$ área de estudo 1 referente a Louveira, os dados pluviométricos coletados entre 1937 e 1994 na Estação de Vinhedo pelo Departamento de Água e Energia Elétrica (DAEE, 1988) mostraram que a pluviosidade média anual na área é de $1300 \mathrm{~mm}$ e as precipitações variaram entre 700 mm à 2500 mm (Figura 3.3).

Na média histórica das precipitações mensais referentes aos dados obtidos para os 57 anos, destacaram-se dois períodos, o primeiro marcado por baixas precipitações que podem atingir até $80 \mathrm{~mm}$ e que se estende de abril a setembro, e o segundo caracterizado por um 
regime chuvoso entre os meses de outubro a março, com maiores índices pluviométricos entre Dezembro e Janeiro, em torno de 200mm (Figura 3.4).

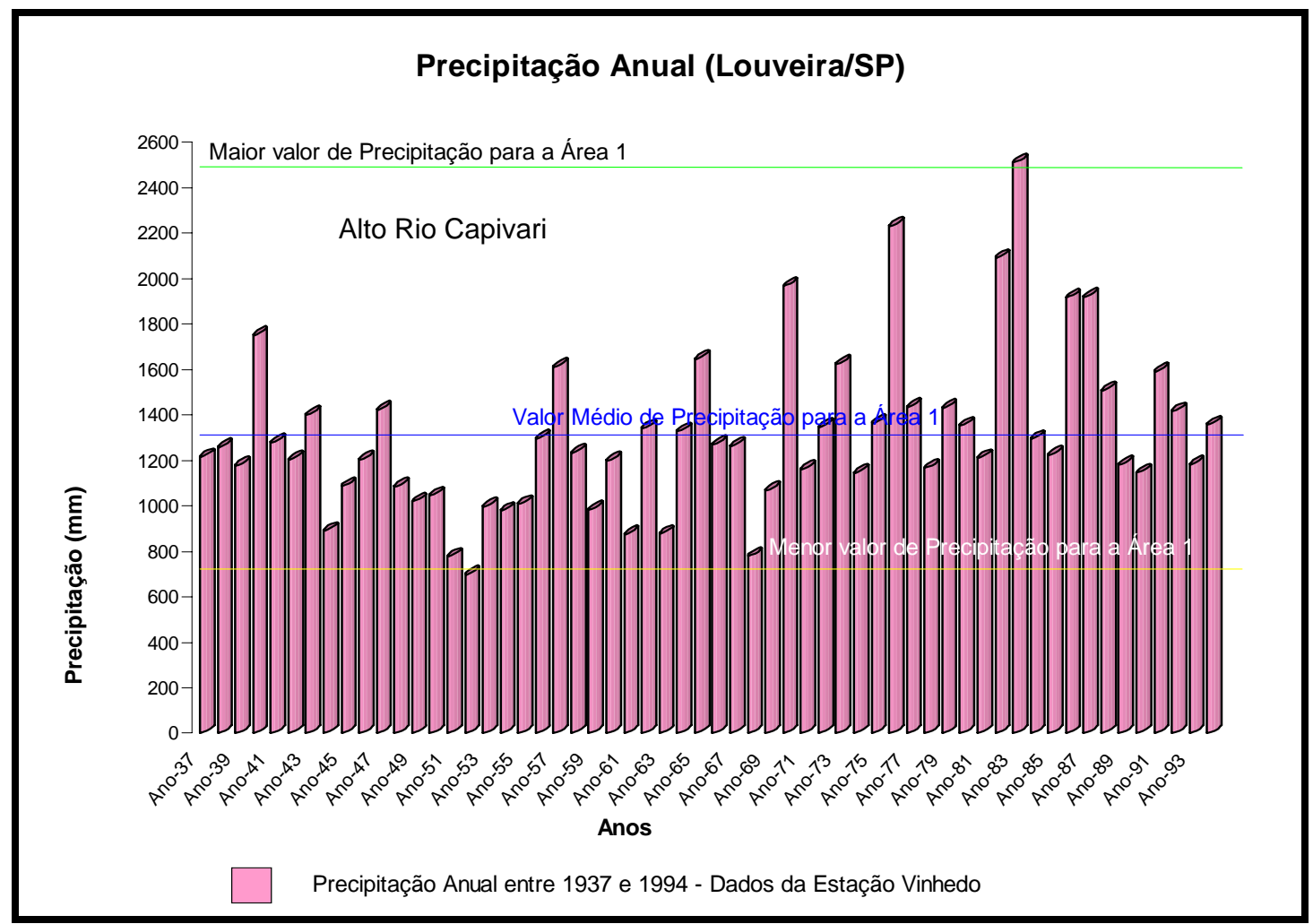

Figura 3.3 - Precipitação Anual entre o período de 1937 a 1994 obtida na Estação Meteorológica de Vinhedo (Adaptado do DAEE, 1998). 


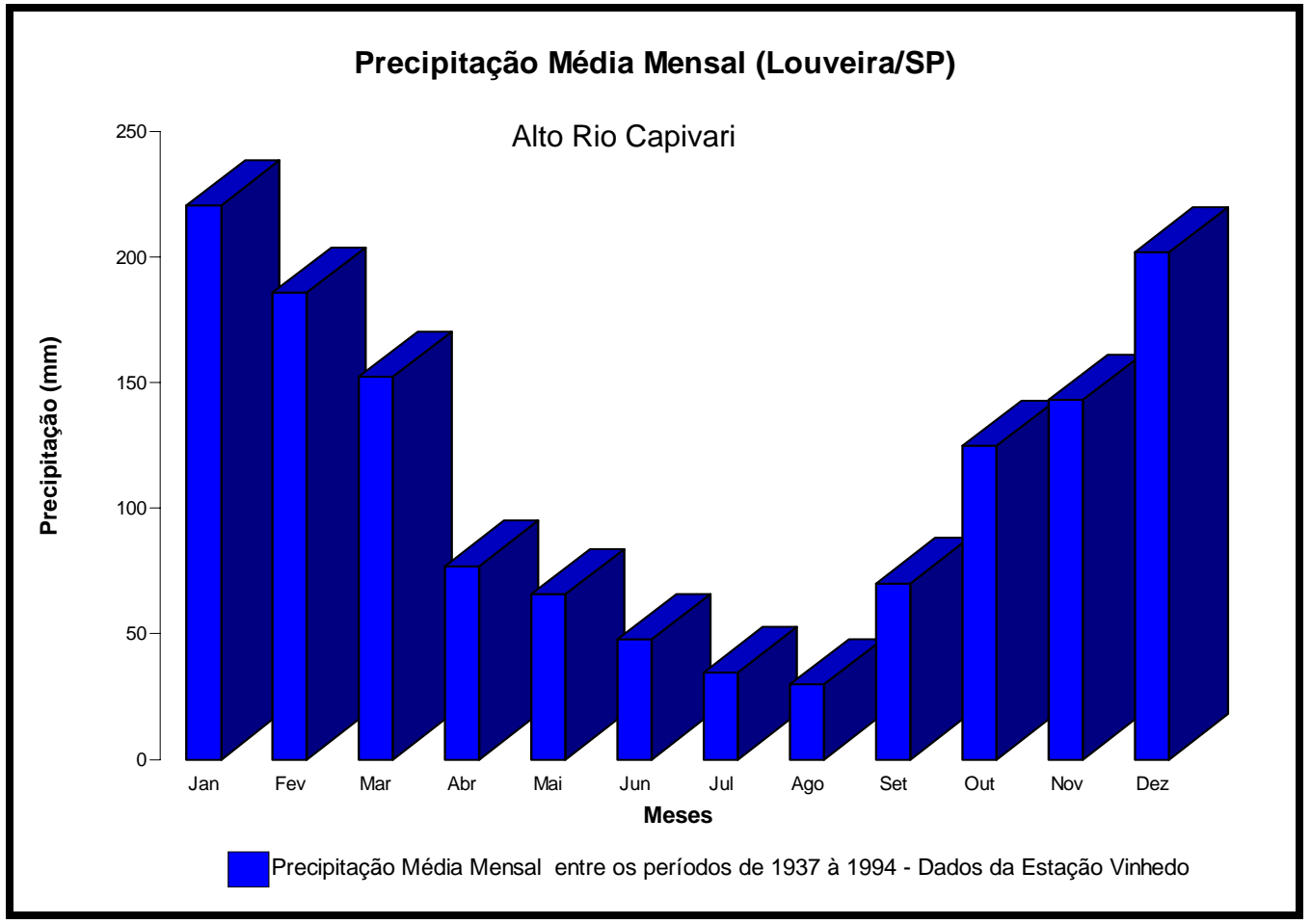

Figura 3.4 - Precipitação Média Mensal entre os períodos de 1937 a 1994 referentes a Estação Meteorológica de Vinhedo (DAEE, 1998).

Para a Área 2 (Rafard/SP), utilizou-se os dados pluviométricos coletados entre 1953 e 1997 nas estações de Capivari e da Usina Bom Retiro pelo Departamento de Água e Energia Elétrica (DAEE, 1988). A Figura 3.5 mostra valores médios anuais de pluviosidade em torno de $1200 \mathrm{~mm}$, com precipitações variando entre $800 \mathrm{~mm}$ a $2000 \mathrm{~mm}$.

Similarmente a área 1, pode-se observar na Figura 3.6 que a média histórica das precipitações mensais referentes aos dados obtidos para os 44 anos foi marcada por dois regimes, o primeiro considerado seco, que se estende entre abril a setembro, em que as precipitações podem atingir até $80 \mathrm{~mm}$, e o segundo, chuvoso, entre os meses de outubro a março, com maiores índices pluviométricos entre Dezembro e Janeiro, em torno de 200mm. 


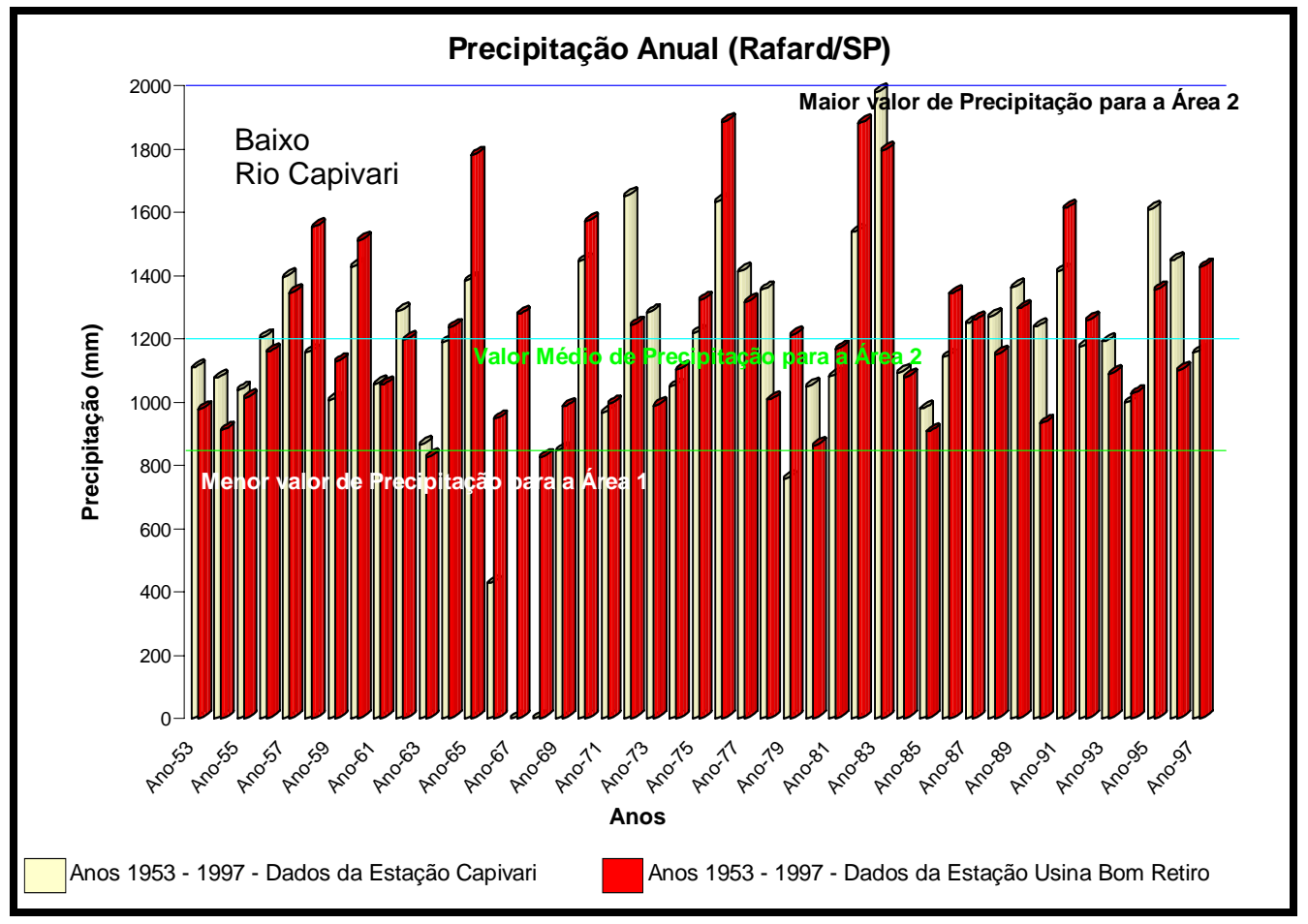

Figura 3.5 - Precipitação Anual entre o período de 1953 a 1997 obtida nas estações meteorológicas de Capivari e Usina Bom Retiro (DAEE, 1998).

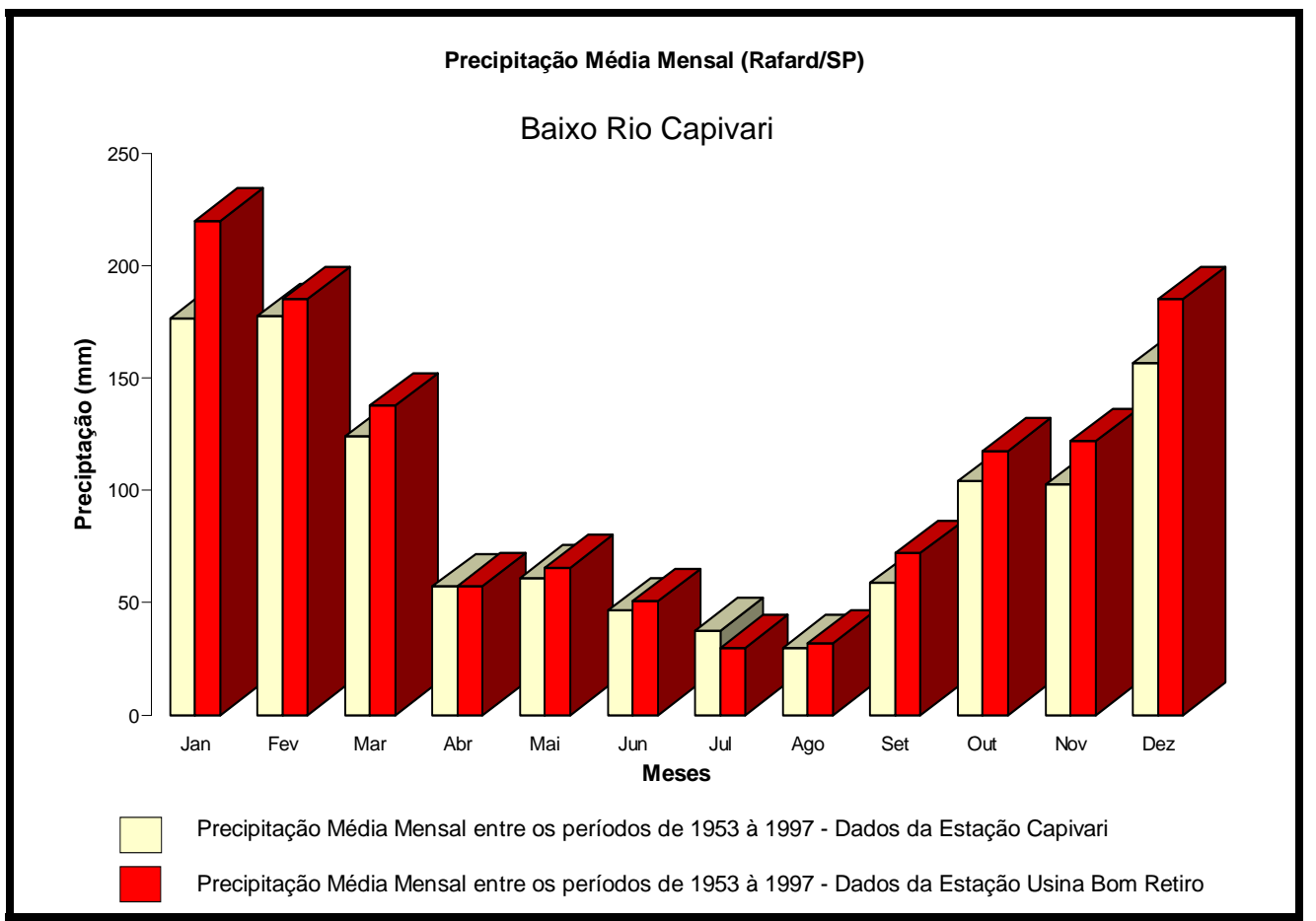

Figura 3.6 - Precipitação Média Mensal entre o período de 1953 a 1997 obtida nas estações meteorológicas de Capivari e Usina Bom Retiro (DAEE, 1998). 


\section{3 - GEOMORFOLOGIA}

\subsection{1 - Área 1 - Alto Rio Capivari}

A área de estudo 1 está situada numa região de transição entre os compartimentos geomorfológicos Planalto Atlântico e Depressão Periférica, sendo sustentada pelas rochas gnaíssicas e graníticas do Complexo Amparo e Suite Granítica Morungaba, respectivamente. O relevo constitui-se de colinas e morrotes, com altitudes variando entre 630 e 960 metros e declividades predominantes de 10 a 30\%. As formas de relevo tendem a apresentar topos mais alongados e vales mais estreitos devido a um controle estrutural mais evidente na drenagem e a um controle litológico, que origina uma menor espessura da cobertura do solo (IPT, 1881a; IG, 1993).

Cristofoletti (1968) descreve as formas de relevo associadas a gnaisses como colinas amorreadas, com topos planos e vertentes retílineas, convexo-retilíneas e convexo-retilíneoconcâvas, com declividades predominantes de 10 a 20\% e vales de fundo plano e amplo. Para as rochas graníticas, definiu uma morfologia amorreada, com topos convexos e aplainados, perfis das vertentes predominantemente convexos, declividades superiores a $20 \%$ e vales entalhados profundamente.

O padrão de drenagem apresenta nas áreas cristalinas um traçado dentrítico retangular, com influência tectônica nítida observada pela orientação das diacláses e fraturas (Cristofoletti, 1968).

\subsection{2 - Área 2 - Baixo Rio Capivari}

A área de estudo 2 está localizada na Província Geomorfológica Depressão Periférica, dentro da unidade morfológica Zona do Médio Tietê, onde afloram rochas sedimentares do Grupo Tubarão e rochas intrusivas associadas à Formação Serra Geral. As formas de relevo são constituídas essencialmente por colinas, com altimetria entre 480 e 640m e declividades predominantes entre 5 e 20\%. O padrão de drenagem nessa área foi descrito como dentrítico (Almeida, 1964).

Segundo Almeida (op. cit.), essa região foi submetida a um ciclo erosivo evolutivo, arrasando o relevo, que permitiu pequeno destaque em áreas com corpos intrusivos de diabásio de maiores dimensões.

Cristofoletti (1968) descreve as formas de relevo associadas aos diabásios como colinosos, com vertentes convexas; convexo-retilíneas-convexas; e convexo-suavemente 
concâvas-convexas. Apresentam baixa densidade hidrográfica, entre 4 a 5 N1/km², devido a uma maior extensão ocupada pelas colinas e menor amplitude altimétrica.

Os relevos associados ao Subgrupo Itararé, do Grupo Tubarão, são predominantemente colinosos, caracterizados por vertentes com desenvolvimento exagerado dos trechos convexos, podendo ser convexo-concâvas, convexo-retilíneo-concâvas e existem declividades geralmente entre 8 e $12 \%$ (Cristofoletti, 1968).

\section{4 - GEOLOGIA}

\subsection{1 - Área 1 - Alto Rio Capivari}

A área de pesquisa referente aos municípios de Louveira e Jundiaí encontra-se inserida na Província Mantiqueira no Setor Central (Hasui \& Oliveira, 1984). No que se refere à constituição geológica ocorrem rochas cristalinas pré-cambrianas (gnaisses e granitos) do Complexo Amparo e Suíte Granítica Morungaba.

\subsubsection{1 - Gnaisses}

As rochas gnaíssicas que afloram na área de estudo 1, pertencem ao complexo granulítico-migmatítico-gnaíssico, denominado de "Amparo", foram datadas no Arqueano/Proterozóico Inferior e constituem o substrato da borda oriental da Bacia do Paraná (IPT, 1981b).

Esse complexo é formado por uma série de gnaisses e migmatitos normalmente bandados, que incluem leptinitos, quartzitos, anfibolitos e metaultrabasitos, subordinadamente, formando faixas paralelas de direção NNE-SSW ((DNPM, 1979; DNPM/CPRM, 1984).

\subsubsection{2 - Granitos}

O IPT (1981b) define essas rochas como pertencentes à suíte granítica indiferenciada, de idade proterozóica, caracterizando-as como corpos intrusivos com granulação fina a grossa e textura freqüentemente hipidiomórfica, com possíveis ocorrências de granitóides máficos e intermediários.

O DNPM/CPRM (1984) define essas rochas como pertencentes ao Maciço Morungaba, caracterizando-as como plutônicas ácidas do Proterozóico Inferior, 
interpretadas como tardi a pós-cinemático brasiliano. Os principais constituintes envolvem rochas graníticas (porfiróides acizentadas e rosadas), granodioríticas e quartzo-monzoníticas.

\subsection{2 - Área 2 - Baixo Rio Capivari}

A área de pesquisa 2 referente ao Município de Rafard está inserida na porção nordeste da Bacia do Paraná. Geologicamente é constituída por rochas sedimentares do Carbonífero Superior - Permiano Inferior (Grupo Tubarão - Formação Itararé) e intrusivas básicas de idade mesozóica.

\subsubsection{1 - Grupo Tubarão (Carbonifero Superior - Permiano Inferior)}

White (1906 apud Ferreira, 1997) descreve na Bacia do Paraná uma seqüência composta por sedimentos glaciais recobertos por depósitos pós glacial no Estado de Santa Catarina, a qual denominou de "Série Tubarão".

Barbosa \& Almeida (1949) são os primeiros pesquisadores que propuseram uma subdivisão à Série Tubarão, em São Paulo, na região do Vale do Rio Tietê. Com base em seções aflorantes e numa única sondagem em Araquã (SP) discriminaram da base para o topo, as formações Itu (arenitos, tilitos, varvitos e camadas de carvão), Capivari (arenitos e siltitos claros, com intercalações de folhelhos), Gramadinho (tilitos, intercalando arenitos e varvitos com seixos abundantes), Tietê (predominante arenitos) e Itapeninga (siltitos, tilitos e arenitos). Dentre essas, as quatro primeiras formações são consideradas glaciais e a última, pós glacial.

Petri (1964) adota a designação litoestratigráfica de Grupo Tubarão em substituição ao termo "Série” e subdividiu-o em Subgrupo Itararé, para os depósitos glaciais e Formação Tatuí, para as seqüências pós-glaciais. De acordo com Soares (1972), esta divisão é a mais aceita para o Grupo Tubarão no Estado de São Paulo, tanto no aspecto de mapeamento como sob considerações paleogeográficas.

Com base em dados palinológicos, Daemon \& Quadros (1970) determinam o intervalo deposicional compreendido entre o Carbonífero Superior - Permiano Inferior para o Grupo Tubarão.

\subsubsection{1 - Subgrupo Itararé}

O Subgrupo Itararé é a unidade litoestratigráfica mais espessa da Bacia do Paraná, com aproximadamente $1400 \mathrm{~m}$ de espessura na região do depocentro paulista. 
A denominação Itararé foi proposta primeiramente por Oliveira (1926 apud Ferreira, 1997) para uma seqüência de depósitos glaciais descritas no Paraná similar aos sedimentos descritos por White (1906 apud Ferreira, op. cit.).

O Subgrupo Itararé pode ser subdivido em São Paulo por Soares et al (1977) em três pacotes, baseados nas porcentagens de arenitos: o inferior, o médio e o superior. No pacote superior, reconheceram quatro associações litológicas geneticamente distintas e interdigitadas entre si. A Associação I constitui-se de arenitos e pelitos imaturos, fluviais (fáceis de canal e de transbordamento), lacustres e paludais, com raras camadas de carvão e calcário; a Associação II constitui-se de diamictitos maciços ou incipientemente acamados, arenitos e ritmitos de origem glacial e retrabalhados em planícies aluviais periglaciais, ou ainda em ambiente litorâneo; a Associação III constitui-se de arenitos e siltitos com boa seleção, estruturas de corrente e de movimentos gravitacionais, depositados em plataforma deltaica; e a Associação IV constitui-se de arenitos lamíticos imaturos, lamitos ritmitos com abundantes feições de deslize, depositados em águas calmas, porém submetidos à ação de escorregamentos e correntes de turbidez.

Souza Filho (1986) subdivide o Subgrupo Itararé em 7 unidades litoestratigráficas na região de Campinas: a) Unidade I constituída por arenitos em granocrescência ascendente; b) Unidade II, por lamitos, c) Unidade III, por lamitos e diamictitos; d) Unidade IV, por arenitos; e) Unidade V, por arenitos e diamictitos; f) Unidade VI por arenitos com marcas onduladas; e g) Unidade VII, por diamictitos vermelhos.

Stevaux et al (1987) definem quatro associações faciológicas para o Subgrupo Itararé na Bacia Hidrográfica do Baixo Rio Capivari (SP). Na primeira associação ocorrem conglomerados, lamitos e diamictitos; na segunda associação, ritmitos, lamitos e arenitos maciços; na terceira, arenitos lenticulares e lamitos; e na quarta, arenitos com estratificação cruzada acanalada, lamito carbonoso e arenito quartzoso.

Apesar das inúmeras propostas de subdivisões para o Subgrupo Itararé (Soares et al, 1977; Saad, 1977; Santos, 1979; Gama Jr et al, 1980; Fúlfaro et al, 1984, Caetano-Chang, 1984; Souza Filho, 1986; Stevaux et al, 1987; Pires \& Petri, 1991), na prática estas são pouco aplicáveis face à dificuldade em estabelecer equivalência entre os corpos litológicos devido a inexistência lateral entre os pacotes rochosos e o conteúdo relativamente escasso de fósseis.

Dessa forma, Pires (2001) propõe considerar o Subgrupo Itararé como uma unidade indivisível, visto que os seus depósitos não permitem uma subdivisão em unidades litoestratigráficas formais. 


\subsubsection{2 - Rochas Intrusivas associadas a Formação Serra Geral (Jurrássico - Cretáceo)}

De acordo com IPT (1981b), os corpos intrusivos de diabásio dispostos na forma de diques e sills estão associados a derrames de basaltos toleíticos de idade juro-cretássica (Formação Serra Geral). As espessuras dos sills variam de centímetros a metros, onde os mais espessos podem ocupar até $900 \mathrm{~km}^{2}$ e podendo atingir em extensão até 15 km².

\section{5 - SOLOS}

Na área 1, os solos resultantes de gnaisses são areno-argilosos, com a presença de frações grossas em todos os perfis devido à alta resistência de minerais como quartzo e feldspato. São denominados em pedologia de podzólicos vermelhos-amarelos. Sua textura é em geral areno-argilosa fina em superfície e argilosa em subsuperfície, apresentam horizontes bem diferenciados com espessuras variando entre 0,5 á 1,5 m e são caracterizados como impermeáveis e homogêneos (Oliveira et al,1979; IG, 1993).

As rochas graníticas também produzem solos podzólicos vermelho-amarelo com textura grossa, havendo predominância de cascalhos e areias grossas nos horizontes superiores dos perfis de solo (em torno de 70\%) enquanto que silte e argila aumentam em profundidade. Seus horizontes são facilmente separáveis tanto pela cor como pela textura. A coloração vermelho escura é característica do horizonte A e a vermelho amarelada do B. Suas espessuras variam enter 1,5 a $2 \mathrm{~m}$ e apresentam uma drenagem boa a moderada. (Cristofoletti, 1968; Oliveira et al,1979; IG, 1993).

Na área 2, os solos derivados de diabásios ou basaltos são solos argilosos a muito argilosos, profundos, friáveis, com elevada porosidade e permeabilidade, de consistência dura e drenagem boa, denominados de Latossolos Roxos Eutróficos. Caracterizam-se por grande homogeneidade vertical, elevada fertilidade na agricultura e elevados teores de óxidos de ferro. Esta última característica é a responsável pela cor vermelha escura ou vermelha muito escura (Cristofoletti, op. cit.; Oliveira et al, op. cit.; IG, op. cit.).

Segundo Oliveira et al (1979), os solos derivados do Subgrupo Itararé são essencialmente arenosos ou areno-siltosos, recebem a denominação de litólicos e sua espessura raramente ultrapassa $30 \mathrm{~cm}$, sendo sua textura relacionada diretamente ao litotipo de origem.

O IG (1993) destaca os seguintes tipos de solos associados aos sedimentos do Subgrupo Itararé: 
- Latossolo vermelho - amarelo com textura média, alta permeabilidade associada a ritmitos, arenitos finos e lamitos;

- Podzólico vermelho-amarelo com textura arenosa a silto - arenosa média, alta permeabilidade e espessuras médias de $2 \mathrm{~m}$, derivado das associações de ritmitos, arenitos finos, siltitos, diamictitos e lamitos; e,

- Latossolo vermelho - amarelo associado às areias quartzosas podzólicas profundas com textura arenosa fina, alta permeabilidade e grande espessura associada a arenitos.

\section{6 - RECURSOS HÍDRICOS}

Em decorrência da água ser um recurso natural finito e vulnerável serão enfocadas aqui as características hidrológicas e hidrogeológicas de ambas as áreas.

\subsection{1 - Hidrogeologia}

\subsubsection{1 - Área 1 - Alto Rio Capivari}

\subsubsection{1 - Sistema Aqüífero Cristalino}

Segundo IG (1993), o sistema aqüífero cristalino, sustentado por rochas cristalinas do embasamento, é uma unidade de extensão regional, heterogênea e anisotrópica. Nesse sistema, a água subterrânea pode ser captada pelo manto de alteração ou pelas descontinuidades rúpteis.

O manto de alteração tem comportamento similar a um aqüífero sedimentar, e representa um aqüífero livre. Suas características principais são porosidade granular, constituição arenosa a argilosa dependente da composição mineralógica da rocha de origem e espessura variável entre 10 a $40 \mathrm{~m}$, excepcionalmente podendo chegar a $70 \mathrm{~m}$.

Nas descontinuidades rúpteis, a água circula por meio das fissuras e fraturas abertas resultantes da atividade tectônica imposta à área.

Para esse aqüífero, os valores de capacidade específica encontram-se entre 0,002 a 7 $\mathrm{m}^{3} / \mathrm{h} / \mathrm{m}$ e de transmissividade entre 1 a $100 \mathrm{~m}^{2} /$ dia (DAEE, 1982). 


\subsubsection{2 - Área 2 - Baixo Rio Capivari}

\subsubsection{1 - Sistema Aqüífero Tubarão}

O Sistema Aqüífero Tubarão é o mais explotado na região sendo representado pelas rochas sedimentares do Subgrupo Itararé, constituído geologicamente por uma complexa associação de litofáceis de ambiente predominantemente glacial, com contribuições fluviais, lacustres, deltáicas e marinhas, as quais se interdigitam lateralmente.

As intercalações e interdigitações das camadas influem diretamente no sistema caracterizando-o como um aqüífero livre a semiconfinado, heterogêneo, descontínuo, fortemente anisotrópico. Apresenta extensão regional e pode atingir espessuras de até $400 \mathrm{~m}$ (IG, 1993; Lopes, 1994.).

Para esse aqüífero, os valores de capacidade específica encontram-se entre 0,002 a $7,5 \mathrm{~m}^{3} / \mathrm{h} / \mathrm{m}$ e de transmissividade entre 0,3 a $40 \mathrm{~m}^{2} /$ dia (Lopes, op. cit.; DAEE, 1982).

\subsubsection{2 - Sistema Aqüífero Diabásio}

O Sistema Aqüífero Diabásio é encontrado mais raramente e constitui-se de rochas intrusivas básicas associadas à Formação Serra Geral, que atravessam a seqüência sedimentar do Subgrupo Itararé. Essas características geológicas permitem caracterizá-lo como um aqüífero livre a semiconfinado, de extensão limitada, heterogêneo, descontínuo, anisotrópico e fissurado com espessuras que podem atingir até 180 m (IG, 1993; Lopes, 1994).

Para esse aqüífero, os valores de capacidade específica encontram-se entre 0,001 a 4 $\mathrm{m}^{3} / \mathrm{h} / \mathrm{m}$ e de transmissividade entre 0,2 a $50 \mathrm{~m}^{2} /$ dia (Lopes, op. cit.; DAEE, 1982).

\subsection{2 - Hidrologia}

O Município de Rafard é dotado de vários corpos d’água como rios, córregos, cursos intermitentes, represas. Os cursos d’água mais representativos na área de estudo e no seu entorno são:

- Rios Capivari e Tietê;

- Córregos Borão, Alto Retiro, Santa Rita, São Francisco, Itapeva e São Francisco II e Ribeirão do Fundo, situados na margem esquerda do Rio Capivari; e, 
- Córregos do Engenho d’água, Barroquinho, da Fazenda, dos Cardosos, Água Branca, da fazenda Teófilo de Lima, Plínio Leite e Ribeirão José Leite situados na margem direita do Rio Tietê.

A área 2 situada nos municípios de Louveira e Jundiaí apresenta os seguintes cursos d'água mais representativos:

- Rios Capivari e Jundiaí;

- Ribeirão do Moinho e córregos Sopezol, Vale das Vinhas, Corrupira e Fazenda Rio da Prata na margem esquerda do Rio Capivari;

- Córregos do Passarinho, do Mestre Gonzaga, do Paraíso, da Água do Barreiro, do Ruzzo, da Cana do Reino, do Engenho Seco e da Fazenda Santa Cândida, na margem direita do Rio Capivari; e,

- Córrego Chapadão, na margem direita do Rio Jundiaí. 


\section{MATERIAIS E MÉTODOS}

\section{1 - MÉTODOS}

Para a avaliação das alterações na rede de drenagem das sub-bacias hidrográficas, quanto à influência de seus condicionantes naturais e antrópicos, foram empregados dois métodos:

- O proposto por Collares (2000), com o objetivo de verificar as alterações temporais na rede de drenagem envolvendo o levantamento e o processamento de informações referentes à drenagem e às atividades antrópicas em épocas distintas; e,

- O proposto pela Escola de Engenharia de São Carlos, desenvolvido para mapeamento geológico-geotécnico, visando o levantamento das seguintes informações do meio físico: substrato rochoso, materiais inconsolidados, declividade e feições de relevo da região.

Essa pesquisa baseou-se no desenvolvimento de atividades que envolveram o levantamento de dados sobre o meio físico e avaliação da rede de drenagem e atividades antrópicas, com o intuito de obter uma análise das alterações sofridas na rede de drenagem nas áreas estudadas (Figura 4.1). 


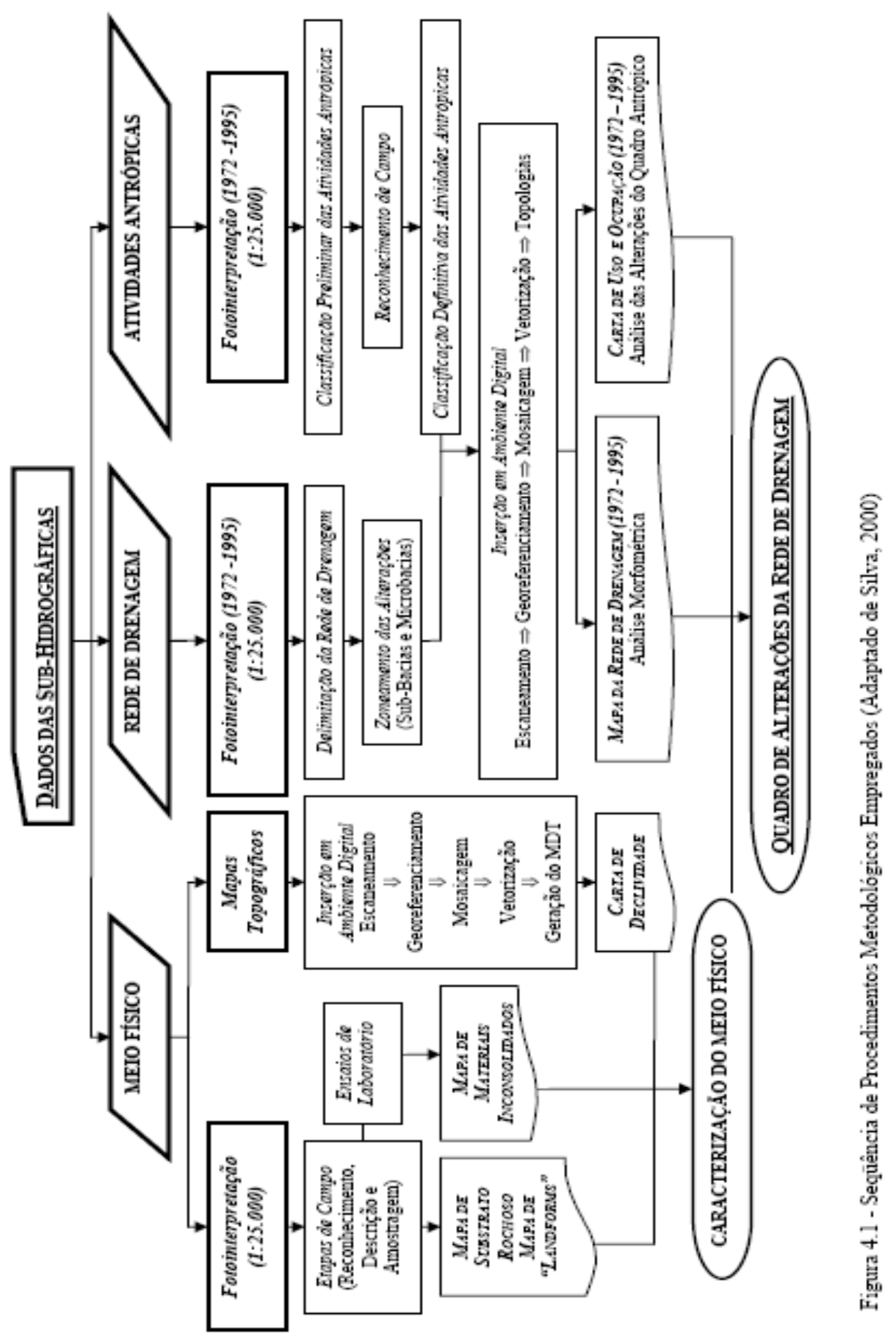




\section{2 - OBTENÇÃO E PROCESSAMENTO DAS INFORMAÇÕES}

As atividades desenvolvidas durante a pesquisa consistiram em etapas de escritório, laboratório e campo, com o intuito de gerar os seguintes documentos cartográficos para ambas as áreas: Mapa de Documentação, Carta de Declividade, Mapa de Landforms, Mapa de Substrato Rochoso, Mapa de Materiais Inconsolidados, Mapa da Rede de Drenagem e de Uso e Ocupação para os anos de 1972 e 1995.

\subsection{1 - Fotointerpretação}

A fotointerpretação foi uma ferramenta fundamental durante todo o desenvolvimento da pesquisa, pois permitiu obter informações tanto sobre a natureza dos terrenos (substrato rochoso e materiais inconsolidados) e relevo como sobre a rede de drenagem e os tipos de atividades antrópicas desenvolvidos na região.

O material utilizado consistiu de fotografias aéreas referentes a duas épocas distintas (1972 e 1995), películas transparentes, canetas coloridas de ponta fina, estereoscópios de espelho e de bolso (Carl Zeiss).

A fotointerpretação da rede de drenagem caracterizou-se pela observação e identificação dos cursos d’água fluviais e pluviais na área, com enfoque ao registro das mudanças observadas na morfologia e morfometria dos canais em 1972 e 1995.

Extraíram-se os canais de drenagem manualmente das fotografias aéreas, os quais foram hierarquizados segundo a classificação proposta por Strahler (1957). Além dos canais de drenagem, outras informações foram registradas como os limites e as represas das subbacias e o limite das microbacias de Ordem 3.

Quanto as atividades antrópicas, definiram-se calsses para os anos de 1972 e 1995, as quais foram diferenciadas pelos contrastes existentes nos padrões de cinza, nos padrões texturais e nas formas geométricas associadas segundo Belcher (1948).

Posteriormente, as classes obtidas para 1995 foram confirmadas por meio de um trabalho de campo e os referentes a 1972 foram comparadas aos diversos tipos de atividades registradas nas folhas topográficas do Instituto Geográfico e Cartográfico do Estado de São Paulo, confeccionadas em 1979.

Para a obtenção dos dados do meio físico utilizaram-se os conjuntos de fotoaéreas referentes ao ano de 1972. Cabe ressaltar, que a fotointerpretação preliminar auxiliou na execução dos trabalhos de campo, os quais consistiram no reconhecimento e descrição das unidades fotointerpretadas e coleta de material. 


\subsection{2 - Levantamento de Campo}

Nessa etapa foram realizados trabalhos de campo para a confirmação da fotointerpretação e caracterização do meio físico. Para agilizar o levantamento e cadastro dos dados de campo elaborou-se uma planilha de fácil manuseio (Figura 4.2).

\begin{tabular}{|c|c|c|}
\hline \multicolumn{3}{|c|}{ FICHA DE CAMPO } \\
\hline \multicolumn{3}{|c|}{ DADOS GERAIS } \\
\hline $\begin{aligned} \text { ÁREA: } & \square \text { Louveira } \\
& \square \text { Capivari }\end{aligned}$ & SUB-BACIA: & PONTO No: \\
\hline \multicolumn{3}{|l|}{ Coordenadas UTM: } \\
\hline \multicolumn{3}{|l|}{ Atividade Antrópica: } \\
\hline \multicolumn{3}{|l|}{ Cobertura Vegetal: } \\
\hline \multicolumn{3}{|l|}{ Referência: } \\
\hline \multicolumn{3}{|c|}{ LANDFORM ASSOCIADO } \\
\hline Tipo do Relevo: & Forma da Encosta: & Forma do Topo: \\
\hline Expressão Geográfica: & Forma do Vale: & Amplitude: \\
\hline Fotografia: $\square$ Sim $\square$ Não & $N^{o:}$ Foto: & \\
\hline \multicolumn{3}{|c|}{ SUBSTRATO ROCHOSO } \\
\hline \multicolumn{3}{|l|}{ Rocha: } \\
\hline \multicolumn{3}{|l|}{ Mineralogia: } \\
\hline Grau de Alteração: & \multicolumn{2}{|c|}{ Grau de Fraturamento } \\
\hline Espessura: & Continuidade Lateral: & Estruturas: \\
\hline \multicolumn{3}{|l|}{ Relações de Contato: } \\
\hline Fotografia: $\square$ Sim $\square$ Não & $N^{o:}$ Foto: & \\
\hline \multicolumn{3}{|c|}{ MATERIAL INCONSOLIDADO } \\
\hline Textura: & Cor: & Gênese: \\
\hline Espessura: & \multicolumn{2}{|l|}{ Grau de Alteração: } \\
\hline \multicolumn{3}{|c|}{ Amostragem: $\square$ Ausente $\square$ Deformada $\square$ Anel $\square$ Amostra de Rocha } \\
\hline Fotografia: $\square$ Sim $\square$ Não & $N^{o:}$ Foto: & \\
\hline
\end{tabular}

Figura 4.2 - Ficha de campo utilizada para o cadastro das informações

As atividades de campo foram efetuadas em três fases. A primeira consistiu num reconhecimento preliminar da área. Na segunda fase descreveram-se as características do substrato rochoso, materiais inconsolidados, formas de relevo e tipos de uso e ocupação, para cada ponto de observação. 
Para os afloramentos rochosos levou-se em consideração a litologia, descrição textural, grau de alteração e fraturamento, relações de contato entre litologias e entre litologia e material inconsolidado, espessura, continuidade lateral e possíveis estruturas.

Os materiais inconsolidados foram caracterizados por meio de análise táctil-visual, coloração, espessura, origem (residual ou retrabalhado), gênese, presença de linha de seixos e posição no relevo.

As formas de relevo foram descritas por sua expressão geográfica, amplitude, forma de topos e vales e forma das vertentes seguindo a proposta de Lollo (1996).

A terceira fase consistiu na coleta de amostras deformadas e indeformadas dos materiais inconsolidados.

Para cada ponto de coleta retirou-se de 3 a $4 \mathrm{~kg}$ de amostra deformada e sempre que possível uma amostra indeformada. As amostras indeformadas foram obtidas por meio do Método do Anel proposto por Zuquette (1987), o qual consiste na cravação de um cilindro de PVC de $10 \mathrm{~cm}$ x 5cm (diâmetro/altura) no material inconsolidado, com o objetivo de evitar deformações em sua estrutura e posteriormente foram acondicionadas para que não houvesse perda da umidade de campo.

Entretanto o horizonte saprolito que comumente ocorre na área de Louveira apresentou um empecilho para o uso do método do anel por não permitir a cravação do cilindro com a finalidade de se definir os índices físicos e massa específica desses materiais, foram retiradas amostras irregulares com martelo ou picareta, com dimensões similares às do cilindro, para uso do método da balança hidrostática em laboratório, também foram acondicionadas para conservação da umidade de campo.

Foram descritos um total de 89 pontos para a área de pesquisa 1 (Louveira/SP), com 57 amostras deformadas e 49 indeformadas. Para a área de estudo 2 (Rafard/SP) foram descritos um total de 52 pontos, dos quais foram coletadas 25 amostras deformadas e 23 indeformadas.

\subsection{3 - Ensaios Laboratoriais}

Para a caracterização geotécnica dos materiais utilizaram-se os seguintes ensaios:

- Análise granulométrica com a finalidade de classificação do solo segundo a ABNT NBR 7181/84;

- Determinação da massa específica dos sólidos $\left(\rho_{\mathrm{s}}\right)$ segundo a ABNT - NBR 6508/84;

- Determinação da massa específica seca de campo $\left(\rho_{\mathrm{DC}}\right)$ por meio do método do anel de volume conhecido (Zuquette, 1987); 
- Determinação da massa específica aparente de amostras indeformadas com emprego da balança hidrostática (ABNT - NBR-10838) para as amostras do horizonte saprolito; e,

- Caracterização da fração fina dos materiais Inconsolidados pelo Método de Adsorção de Azul de Metileno (Pejon, 1992).

Esses ensaios foram realizados nos laboratórios do Departamento de Geotecnia da Escola de Engenharia de São Carlos - USP e foram escolhidos devido à sua importância para a pesquisa e pela relativa rapidez de execução, pela simplicidade e pelos baixos custos.

A Tabela 4.1 apresenta o total do número de ensaios de laboratório realizados por área.

Tabela 4.1 - Resumo quantitativo dos ensaios laboratoriais realizados

\begin{tabular}{|c|c|}
\hline \multicolumn{2}{|c|}{ ÁREA DE PESQUISA 1 (LOUVEIRA - SP) } \\
\hline ENSAIO LABORATORIAL & QUANTIDADE \\
\hline Análise Granulométrica & 57 \\
\hline Determinação da Massa Específica Seca & 57 \\
\hline Determinação da Massa Específica dos Sólidos & 49 \\
\hline Caracterização da Fração Fina & 35 \\
\hline Total de Ensaios & 218 \\
\hline \multicolumn{2}{|c|}{ ÁREA DE PESQUISA 1 I (RAFARD - SP) } \\
\hline ENSAIO LABORATORIAL & QUANTIDADE \\
\hline Análise Granulométrica & 24 \\
\hline Determinação da Massa Específica Seca & 24 \\
\hline Determinação da Massa Específica dos Sólidos & 23 \\
\hline Caracterização da Fração Fina & 24 \\
\hline Total de Ensaios & 95 \\
\hline Total de Ensaios Realizados & 293 \\
\hline
\end{tabular}

\subsection{4 - Tratamento de Dados em Ambiente Digital}

Foram utilizados softwares que permitiram a automação na elaboração dos mapas e cartas por meio da compilação dos resultados obtidos e uma base cartográfica georeferenciada.

Os softwares utilizados foram AUTOCAD MAP ®, CADOVERLAY 2000, IDRISI 3.2 e SURFER 7.0, por serem de fácil manipulação e rapidez na execução. 


\subsection{5 - Elaboração De Documentos Cartográficos}

\subsubsection{1 - Mapa de Documentação}

Para a elaboração de cada um dos mapas de documentação foi utilizada uma base cartográfica digital.

Na composição da base para a área 1 utilizou-se as folhas topográficas Bairro do Poste (SF-23-Y-C-III-1-SO-A), Bairro Rio Acima. (SF-23-Y-C-III-1-NO-F), Bairro Tapera Grande (SF-23-Y-C-III-1-NO-D), Fazenda Serra Azul (SF-23-Y-C-II-2-NE-F), Itapeva (SF23-Y-C-II-2-SE-B), Jundiaí 1 (SF-23-Y-C-III-1-SO-B), Louveira (SF-23-Y-C-III-1-NO-E), Vinhedo 2 (SF-23-Y-C-II-2-NE-D) e Vinhedo 3 (SF-23-Y-C-III-1-NO-C); e para a área 2, as folhas Bairro do Tanquinho (SF-23-Y-C-I-2-NE-F), Bairro Frio (SF-23-Y-A-IV-4-SE-E), Bairro Sete Fogões (SF-23-Y-C-I-2-NE-E), Bom Sucesso (SF-23-Y-C-I-2-NO-D), Capivari I (SF-23-Y-A-IV-4-SE-F), Costa Rica (SF-23-Y-C-I-2-NO-B), Fazenda Barnabé (SF-23-YC-I-2-NE-D), Fazenda Santa Lídia (SF-23-Y-C-I-2-NE-C), Limoeiro (SF-23-Y-C-I-2-NEA), Pirapora (SF-23-Y-C-I-2-NO-F), Rafard. (SF-23-Y-C-I-2-NE-B) e Toledos (SF-23-Y-AIV-4-SO-F). Essas folhas topográficas foram confeccionadas pelo Instituto Cartográfico Geográfico do Estado de São Paulo (IGC, 1979), na escala de 1:10.000.

Os procedimentos adotados para a confecção da base cartográfica foram:

- Escaneamento das cartas topográficas no formato tiff;

- Inserção de cada carta no formato RASTER IMAGE no ambiente do AUTOCAD MAP ${ }^{\circledR}$ como um arquivo distinto;

- Georeferenciamento das cartas por meio dos comandos ROTATE e MOVE no módulo MODIFY;

- Acondicionamento das cartas num mesmo arquivo formando um mosaico por meio do Comando INSERT BLOCK, módulo INSERT;

- Digitalização das informações de interesse na área de estudo; e,

- Transformação da escala de 1:10.000 por meio do comando SCALE para a escala de trabalho 1:25.000.

Para o mapa de documentação foram adicionadas apenas as informações referentes à localização espacial da área das sub-bacias hidrográficas

\subsubsection{2 - Carta de Declividade}

A carta de declividade foi gerada com a utilização do Sistema de Informação Geográfica IDRISI. 
Inicialmente, foi criada a base cartográfica digital, na qual foram tomados os seguintes cuidados:

- Digitalização das curvas de níveis, para as quais foi adotada uma eqüidistância de 10m, e os pontos de cota isolados; e,

- Digitalização das cartas na forma de um retângulo, com o cuidado de ultrapassar a área de estudo devido a prováveis erros nas bordas durante a criação do modelo digital.

Depois dessa etapa, criou-se um arquivo no formato DXF no AUTOCAD MAP ${ }^{\circledR}$ contendo apenas as curvas de nível e pontos de cota isolado, o qual foi convertido para um arquivo de extensão XYZ pelo programa de Conversão XYZ.

Posteriormente, inseriu-se esse arquivo no programa SURFER para geração do modelo digital de terreno (MDT). Foram definidos 5 tipos de modelos para a elaboração do modelo, referentes as seguintes operações de interpolação: mínima curvatura, função de base radial, krigagem, vizinho natural e o inverso da distância ao quadrado. Para se definir o melhor método a ser adotado sobrepôs-se os mapas resultantes das operações de interpolação na carta topográfica digitalizada. Para a área 1, o modelo gerado pela função de base radial foi o mais similar a topografia original (Figura 4.3), enquanto para a área 2 o método de krigagem se mostrou mais adequado (Figura 4.4).

A adoção da eqüidistância de $10 \mathrm{~m}$ entre as curvas de nível permitiu que, durante o processo de interpolação, as malhas regulares formadas apresentassem um espaçamento de 20/20m.

Cabe lembrar, que o arquivo de extensão $G R D$ inicialmente gerado, deve ser importado do SURFER com formato ASCII, única extensão aceita pelo software IDRISI.

A seqüência de procedimentos adotado no IDRISI consiste em:

- Inserção do arquivo no software por meio da seguinte seqüência de comandos FILE $\Rightarrow$ IMPORT/EXPORT $\Rightarrow$ SOFTWARE ESPECIFIC FORMATS $\Rightarrow$ SRFIDRIS, onde o arquivo GRD é transformado em IMG;

- Geração da superfície topográfica pelo comando SURFACE ANALYSIS, módulo ANALYSIS;

- Geração do primeiro mapa de declividades definido pelo programa no comando SLOPE, módulo ANALYSIS; e,

- Geração do mapa de declividades final baseada na reclassificação final do operador, por meio do comando RECLASS, módulo ANALYSIS. 


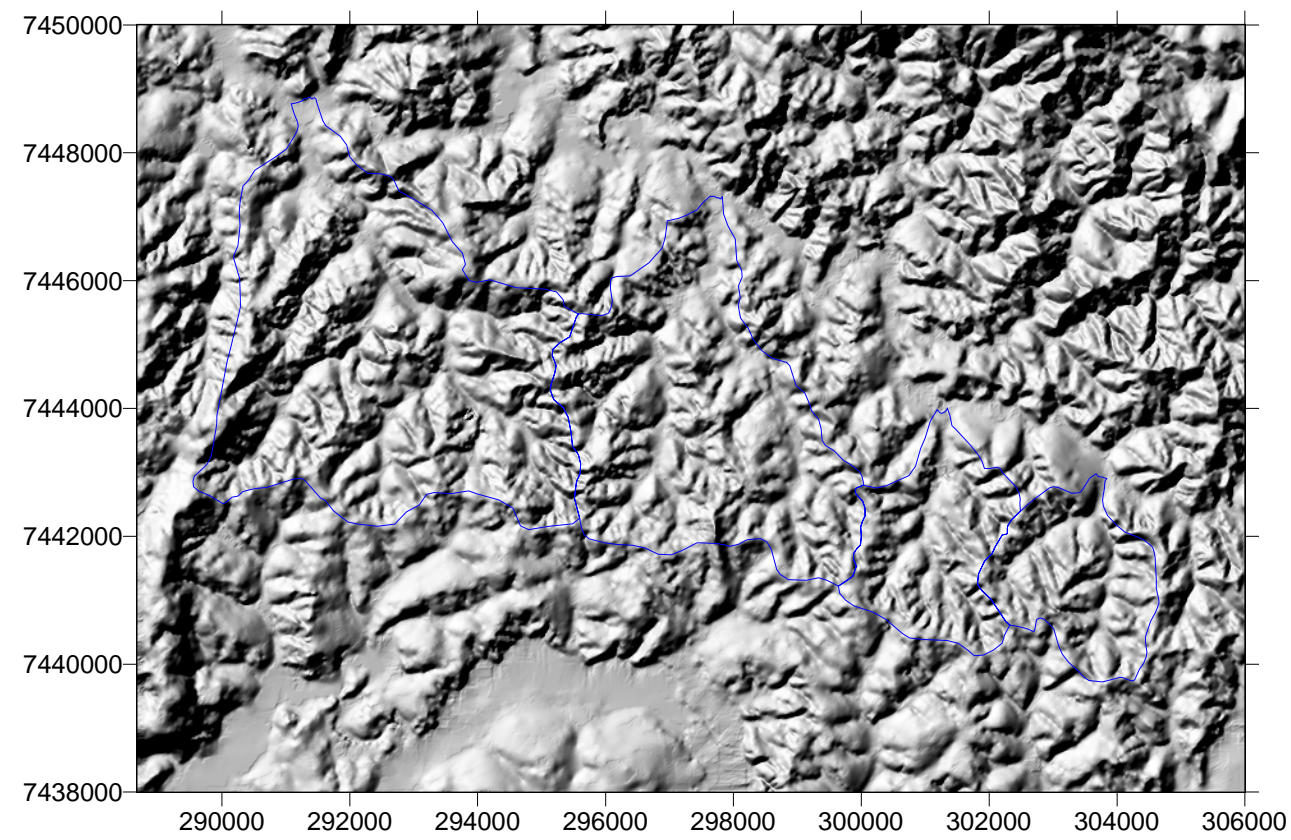

Figura 4.3 - Modelo Digital de Terreno para a Área 1 - Método de Interpolação Função de Base Radial

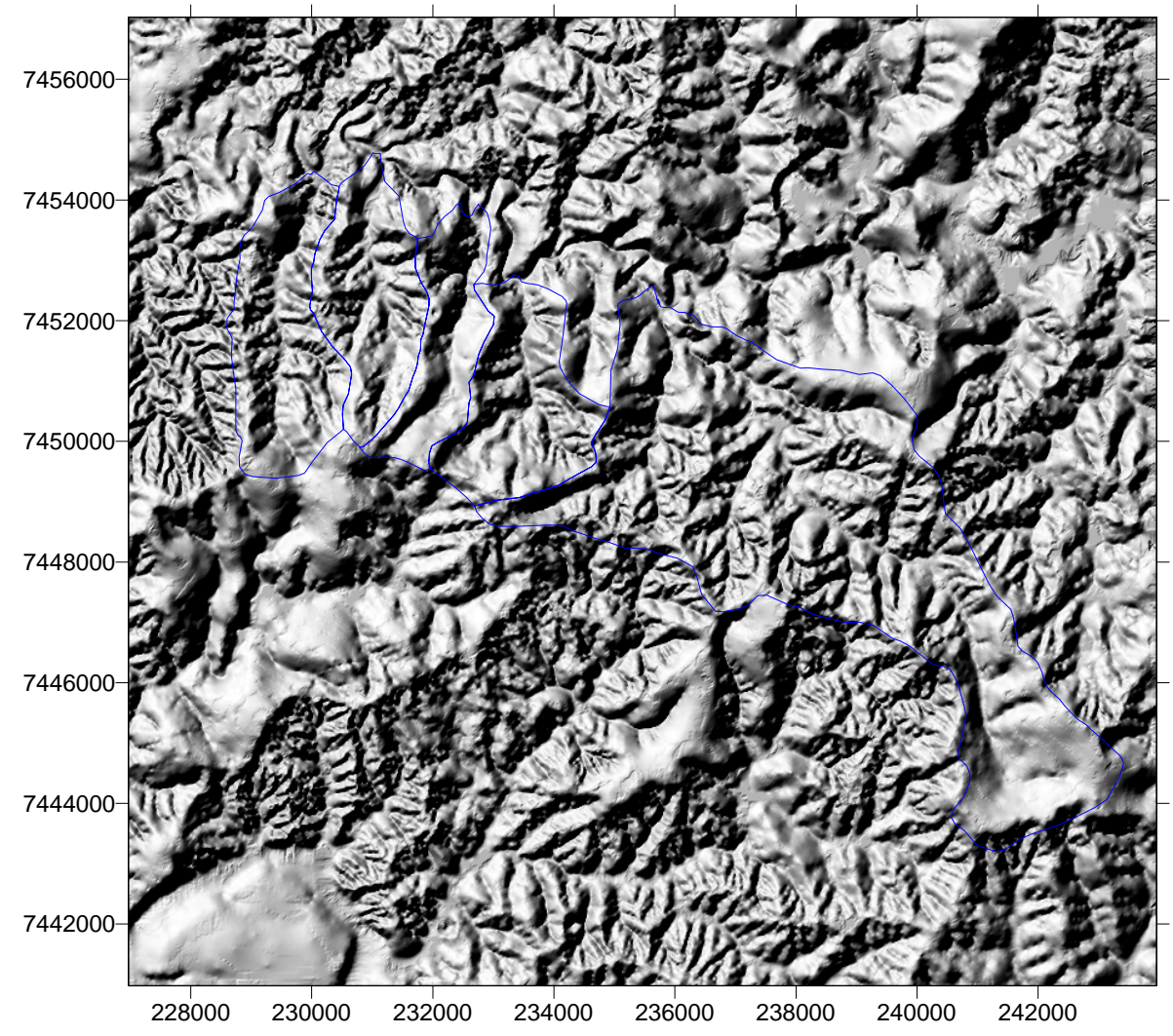

Figura 4.4 - Modelo Digital de Terreno para a Área 2 - Método de Interpolação Função Krigagem 


\subsubsection{3 - Mapa da Rede de Drenagem}

O mapa da rede de drenagem foi obtido por meio da fotointerpretação e o procedimento digital adotado para a sua confecção consistiu nas etapas de escaneamento, georeferenciamento, mosaicagem, vetorização e criação de topologias.

\subsubsection{1 - Escaneamento}

Cada conjunto de fotografias e seus respectivos overlays fotointerpretados foram escaneados com resolução de 200 dpi, no formato JPG, com aproveitamento de até $80 \%$ de sua área total. O recorte de suas bordas dependeu da área de recobrimento entre elas, visando diminuir as distorções.

Além da fotointerpretação, foram registrados nos overlays para cada fotoaérea 6 a 20 pontos de controle escolhidos com base nos mapas topográficos de escala 1:10.000, com o intuito de auxiliar durante a etapa de mosaicagem e georeferenciamento.

Recomenda-se que os pontos representem entroncamentos de estradas, uma vez que dificilmente sofrem modificações com o tempo, de forma que no conjunto de fotos referentes a 1972 e 1995, sejam facilmente identificados. Outra sugestão é distribuí-los uniformemente nas áreas centrais e laterais.

\subsubsection{2 - Georeferenciamento e Mosaicagem}

Para a realização dos processos de georeferenciamento e mosaicagem foi utilizado o programa acessório CADOVERLAY do software AUTOCAD MAP ®. Esse software foi adotado em função da fácil manipulação e otimização do tempo.

Para o processo de georeferenciamento adotou-se, inicialmente, a divisão da tela do programa AUTOCAD MAP ${ }^{\circledR}$ em duas janelas. Uma destinada ao mosaico das folhas cartográficas georeferenciadas, onde também foram destacados os mesmos pontos de controle registrados nas fotos aéreas e utra destinada à inserção das fotos aéreas no formato RASTER IMAGE.

Para a subdivisão da tela utilizaram-se os comandos VIEW $\Rightarrow$ TILED $\Rightarrow$ VIEWPORTS $\Rightarrow 2$ VIEWPORTS $\Rightarrow V$. As fotos aéreas foram inseridas por meio dos comandos INSERT $\Rightarrow$ RASTER IMAGE $\Rightarrow$ ATTACH. Por meio dos comandos IMAGE $\Rightarrow R U B E R S H E E T$, atribuídos ao AUTOCAD MAP ${ }^{\circledR}$ devido ao uso conjunto com o programa acessório CADOVERLAY, correlacionaram-se os pontos coincidentes nos mapas topográficos com os das fotos. E no final do processo as fotos foram sobrepostas sobre a base cartográfica 
georeferenciada. Ao mesmo tempo em que se efetuou o processo de georeferenciamento, criou-se o foto mosaico.

\subsubsection{3 - Vetorização e Criação de Topologias}

Após a criação do fotomosaico, procedeu-se a digitalização das demarcações efetuadas na fotointerpretação. Um layer distinto foi criado para cada ordem de canal por sub-bacia hidrográfica e microbacia analisada, assim como para os limites de cada sub-bacia e microbacia hidrográfica. Esse procedimento foi adotado por otimizar e facilitar o processamento das informações para obtenção dos dados numéricos,por meio da criação de topologias.

Foram criadas topologias de rede para os canais de drenagem e topologias de polígono para os limites de cada sub-bacia e microbacia por meio dos comandos $M A P \Rightarrow C R E A T E \Rightarrow T O P O L O G Y \Rightarrow C R E A T E \Rightarrow N E T W O R K / P O L I G O N$. No primeiro tipo de topologia foram obtidos os parâmetros número total de canais, comprimento total da rede de drenagem, número de canais por ordem e comprimento de canais por ordem e no segundo os parâmetros área e perímetro da bacia. Esses parâmetros podem ser visualizados no comando TOPOLOGY - ADMINISTRATOR, do módulo MAP.

As demais variáveis morfométricas foram calculadas a partir das variáveis primárias determinadas pelas topologias.

\subsubsection{4 - Mapa de Uso e Ocupação}

O Mapa de Uso e Ocupação foi elaborado por meio da classificação supervisionada, ou seja, fotointerpretação preliminar da área de estudo com confirmação posterior pelos trabalhos de campo para os dados mais atuais e para os dados referentes a $1972 \mathrm{com}$ confirmação nas folhas topográficas do IGC (1979). O procedimento adotado para a sua confecção em ambiente digital consistiu nas etapas de escaneamento, georeferenciamento, mosaicagem, vetorização e criação de topologias.

As três primeiras etapas são similares às anteriormente descritas para o mapa de rede de drenagem.

O processo de vetorização consistiu na digitalização das classes de atividades antrópicas definidas para ambos os períodos, no qual um layer distinto foi criado para cada atividade por sub-bacia hidrográfica. A criação de topologias referiu-se apenas à de polígonos, com o intuito de se quantificar a área para cada atividade. 


\subsubsection{5 - Mapa de Landforms}

O Mapa de Landforms foi elaborado a partir da aplicação da Técnica de avaliação de Terreno segundo Lollo (1996), a qual permitiu definir unidades de landforms por meio de trabalhos de fotointerpretação, observações de campo e análise da base cartográfica. As etapas no ambiente digital consistiram de escaneamento, de georeferenciamento, de mosaicagem e de vetorização. As três primeiras etapas são similares às anteriormente descritas. Para cada sub-bacia foram digitalizadas, num layer distinto, as unidades de landforms definidas.

\subsubsection{6 - Mapa de Substrato Rochoso}

O Mapa de Substrato Rochoso apresenta as unidades rochosas definidas, seus contatos e possíveis estruturas. Para sua elaboração foi necessário fotointerpretação da área e trabalhos de campo e posterior confirmação por meio da análise do levantamento dos dados já anteriormente executados na região. O procedimento digital adotado para a sua confecção consistiu nas etapas de escaneamento, de georeferenciamento, de mosaicagem, de vetorização e de criação de topologias. As três primeiras etapas são similares às anteriormente descritas. O processo de vetorização consistiu na digitalização das unidades rochosas, onde foi criado um layer distinto para cada unidade por sub-bacia hidrográfica.

\subsubsection{7 - Mapa de Materiais Inconsolidados}

O Mapa de Materiais Inconsolidados apresenta as unidades de materiais inconsolidados. Foi elaborado segundo os procedimentos sugeridos por Zuquette (1987), os quais se baseiam na análise do mapa de substrato rochoso, na aerofotointerpretação com uso do mapa de landforms, em trabalhos de campo, na classificação táctil-visual e nos ensaios laboratoriais. Sua confecção no ambiente do software AUTOCAD MAP ${ }^{\circledR}$ consistiu das etapas de escaneamento, de georeferenciamento, de mosaicagem e de vetorização. As três primeiras etapas são similares às já anteriormente descritas. Para cada sub-bacia foram digitalizadas as unidades de materiais inconsolidados identificadas num layer distinto.

\subsection{6 - Procedimento de Análise das Microbacias Hidrográficas}

Com o objetivo de obter um maior detalhamento sobre as alterações ocorridas subdividiu-se as áreas estudadas em microbacias de Ordem 3. 
A escolha do zoneamento em bacias de Ordem 3 foi baseada na obtenção de resultados positivos em estudos anteriores que usaram a morfometria em análises temporais (França, 1968, Carvalho et al, 1981, Silva, 2000; Siqueira, 2001).

Nessa pesquisa, os resultados obtidos para as microbacias enfocadas foram analisados de acordo com a sequência de procedimentos, abaixo relacionada:

- Definição de faixas de distribuição das variáveis morfométricas referentes a 1972, com o intuito de compreender a geometria da rede de drenagem na área de estudo no período inicial da análise;

- Avaliação de possíveis inter-relações existentes entre os parâmetros morfométricos;

- Avaliação das inter-relações entre as taxas de variação obtidas para os principais índices morfométricos;

- Avaliação da influência dos dados morfométricos da composição da rede de drenagem referentes a 1972 na taxa de variação obtida para cada índice;

- Avaliação da influência do meio físico (substrato rochoso, landforms e materiais inconsolidados) na taxa de variação dos índices morfométricos ao longo do período analisado (1972-1995);

- Avaliação da influência de características de uso e ocupação nas alterações temporais; e,

- Identificação das microbacias com alterações mais pronunciadas.

A análise seqüencial proposta permitiu caracterizar as microbacias, onde o quadro de alterações da rede de drenagem foi mais pronunciado e relacioná-lo tanto às atividades de uso e ocupação quanto às características do meio físico. 


\section{DOCUMENTOS CARTOGRÁFICOS ELABORADOS}

\section{1 - MAPAS DE DOCUMENTAÇÃO}

Os Mapas de Documentação das áreas de estudo 1 e 2 foram elaborados com 0 objetivo de apresentarem a disposição espacial das informações referentes à pesquisa que são as seguintes (figuras 5.1 e 5.2 ):

- Coordenadas UTM;

- Vias de acesso, ferrovia e duto;

- Limites das bacias;

- Principal centro urbano; e,

- Pontos de observação e amostragem efetuados nas etapas de campo. 


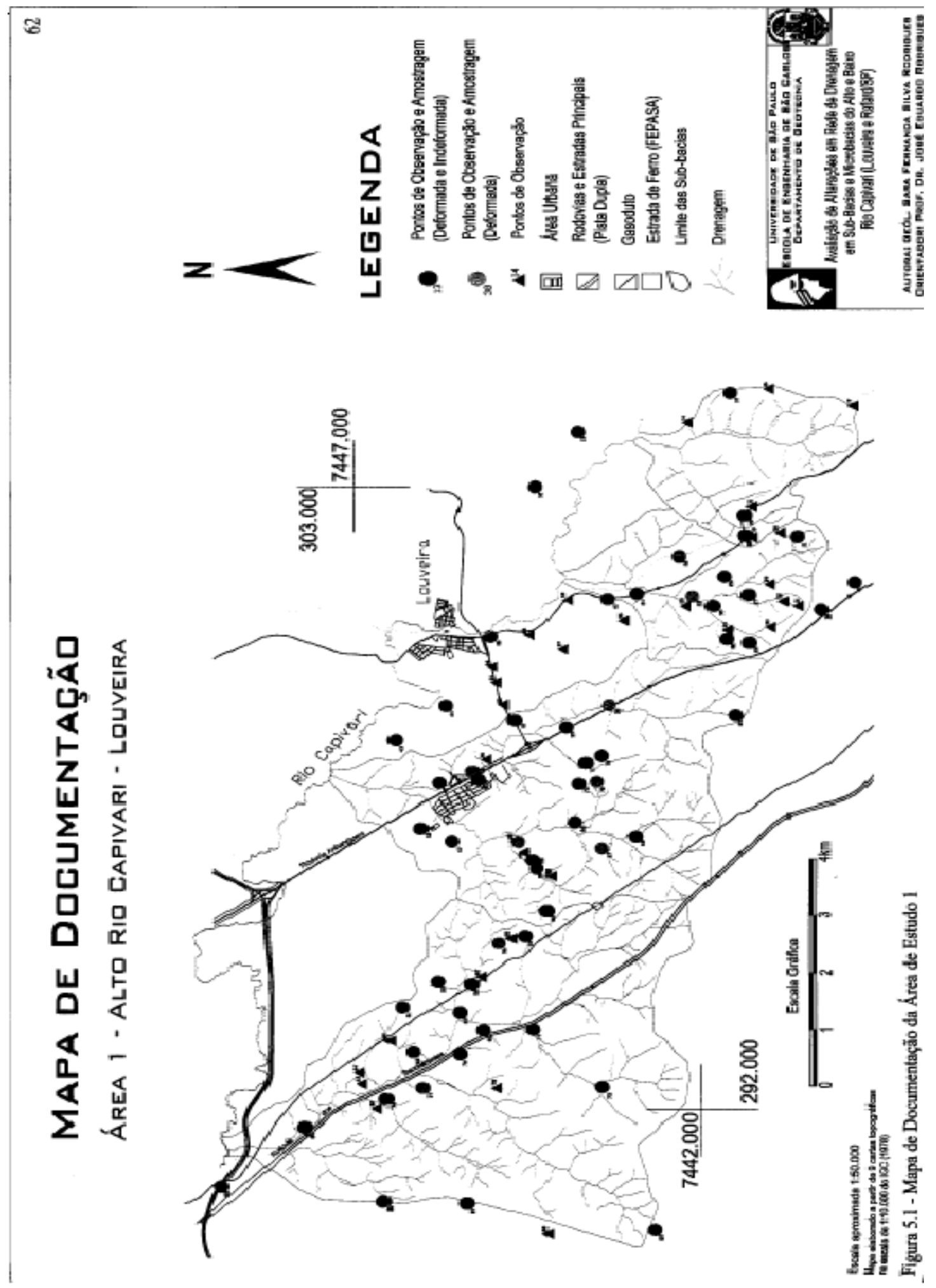

Figura 5.1 - Mapa de Documentação da Área de Estudo 1 


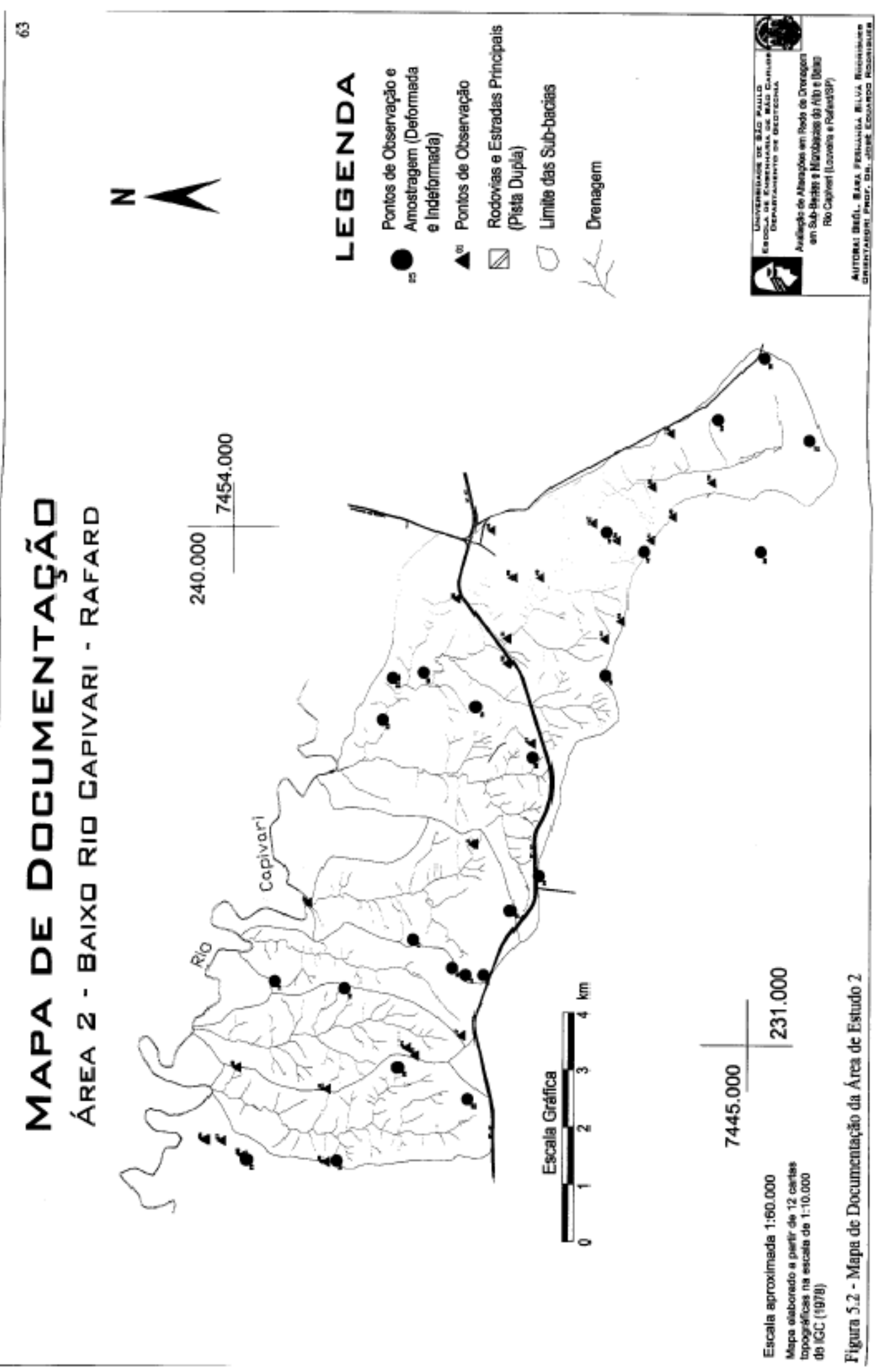

Figura 5.2 - Mapa de Documentação da Área de Estudo 2 


\section{2 - CARTAS DE DECLIVIDADE}

As Cartas de Declividade consistiram basicamente na delimitação de áreas que apresentassem valores de inclinação do terreno num mesmo intervalo ou classe de declividade.

As classes de declividade foram previamente escolhidas em função da escala do mapeamento, da inclinação do terreno, da finalidade da carta e dos valores limites de declividade para o melhor aproveitamento da área em questão e seguiram as sugestões propostas por De Biasi (1970), Zuquette (1987), IPT (1991) e IG (1993).

Sete classes de declividade foram definidas para o área do Alto Rio Capivari (1) enquanto a área do Baixo Rio Capivari (2) foi subdividida em 6 intervalos(Tabela 5.1).

Tabela 5.1 - Classes de Declividade propostas para as áreas 1 e 2

\begin{tabular}{|c|c|c|c|}
\hline \multicolumn{2}{|c|}{ ÁREA 1 - ALTO RIO CAPIVARI } & \multicolumn{2}{|c|}{ ÁREA 2 -BAIXO RIO CAPIVARI } \\
\hline CLASSE & INTERVALOS (\%) & CLASSE & INTERVALOS (\%) \\
\hline 1 & $<2$ & 1 & $<2$ \\
\hline 2 & $2-5$ & 2 & $2-5$ \\
\hline 3 & $5-10$ & 3 & $5-10$ \\
\hline 4 & $10-20$ & 4 & $10-20$ \\
\hline 5 & $20-30$ & 5 & $20-30$ \\
\hline 6 & $30-40$ & 6 & $>30$ \\
\hline 7 & $>40$ & & \\
\hline
\end{tabular}

Os intervalos de declividade definidos mostraram que as cinco primeiras classes se repetem para as duas áreas, e são descritas a seguir:

- A Classe 1 refere-se a terrenos planos ou quase planos, onde o escoamento superficial é muito lento ou lento, são áreas sujeitas a inundações o que as torna impróprias para instalações de saneamento e canalizações subterrâneas e recomendadas para a implantação de aeroportos internacionais e para atividades agrícolas intensivas;

- A Classe 2 constitui-se de terrenos com declividades suaves com escoamento superficial lento ou médio são áreas favoráveis ao uso agrícola mecanizado e sujeitas a processos erosivos que requerem práticas simples de conservação. Esta classe é recomendada para a implantação de aeroportos locais, rodovias e ferrovias principais;

- A Classe 3 caracteriza-se por terrenos inclinados geralmente com escoamento superficial médio ou rápido, corresponde ao limite máximo para a implantação de obras de saneamento básico, ferrovias e indústrias. Para o uso agrícola intensivo 
recomenda-se medidas preventivas mais complexas a serem adotadas com o intuito de evitar problemas de erosão;

- A Classe 4 compõe-se de terrenos muito inclinados, com escoamento superficial rápido ou muito rápido que podem apresentar problemas de erosão superficial, é recomendada tanto para culturas perenes, pastagens ou reflorestamentos como para a implantação de sistema viário local e obras de engenharia simples, como residências;

- A Classe 5 refere-se a terrenos fortemente inclinados com escoamento superficial muito rápido, sujeitos a erosão superficial, todavia ainda é recomendável para esse intervalo de declividade a ocupação de encostas sem projetos especiais.

As áreas com declividades superiores a 30\% caracterizam-se por terrenos íngremes com escoamento superficial muito rápido, com desenvolvimento de solos muito rasos e extremamente susceptíveis a erosão ou a movimentos de massa; o recomendável é evitá-las para qualquer atividade de uso e ocupação.

Pode-se também registrar para ambas as regiões estudadas que:

- Os intervalos maiores que $20 \%$, correspondentes às faixas de declividades altas, estão relacionados às regiões das cabeceiras dos cursos dos canais de primeira ordem; e,

- As áreas com intervalos entre 10 a 20\%, referentes à classe 4, são predominantes. 


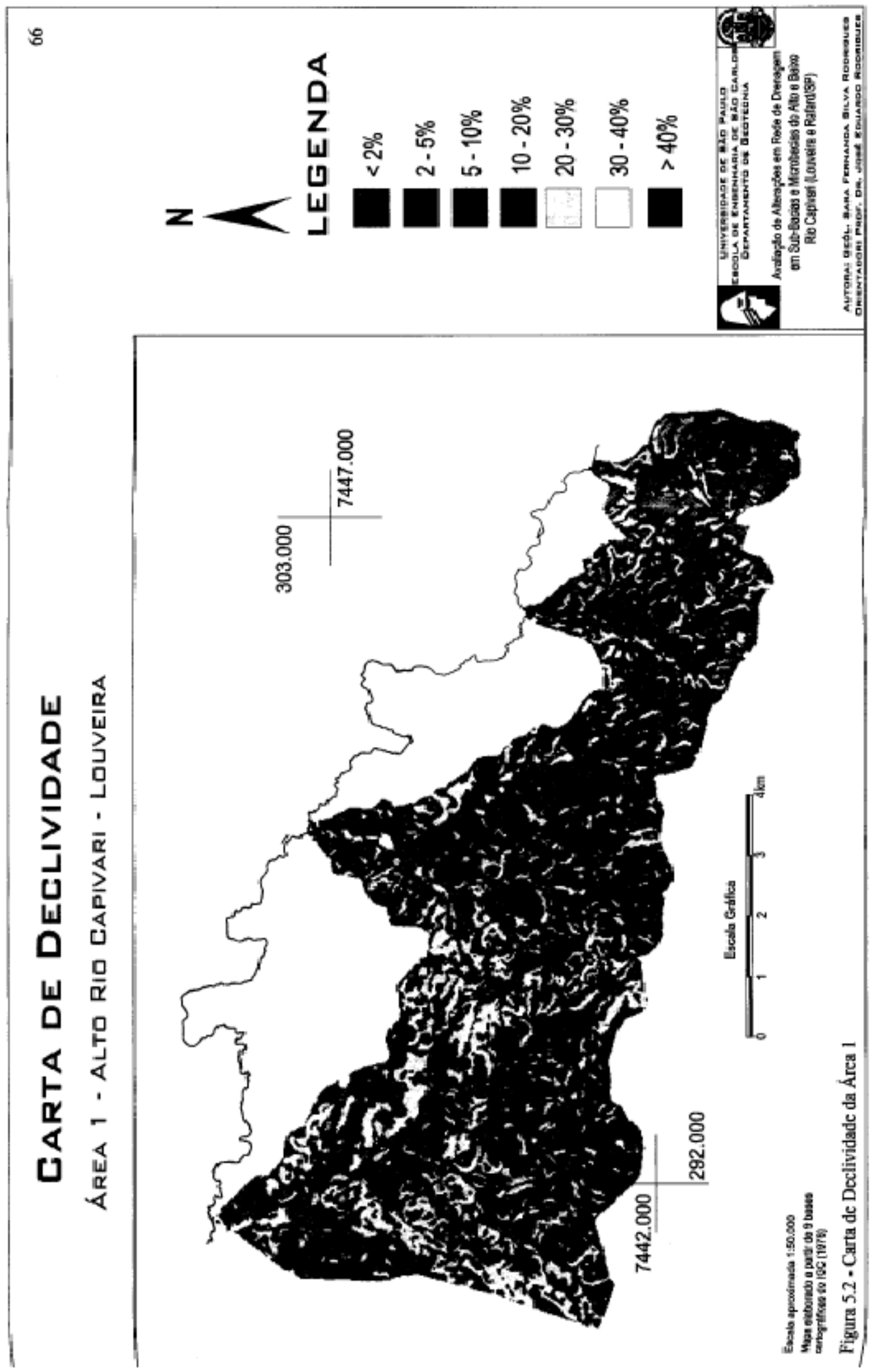

Figura 5.3 - Carta de Declividade da Área de estudo 1 


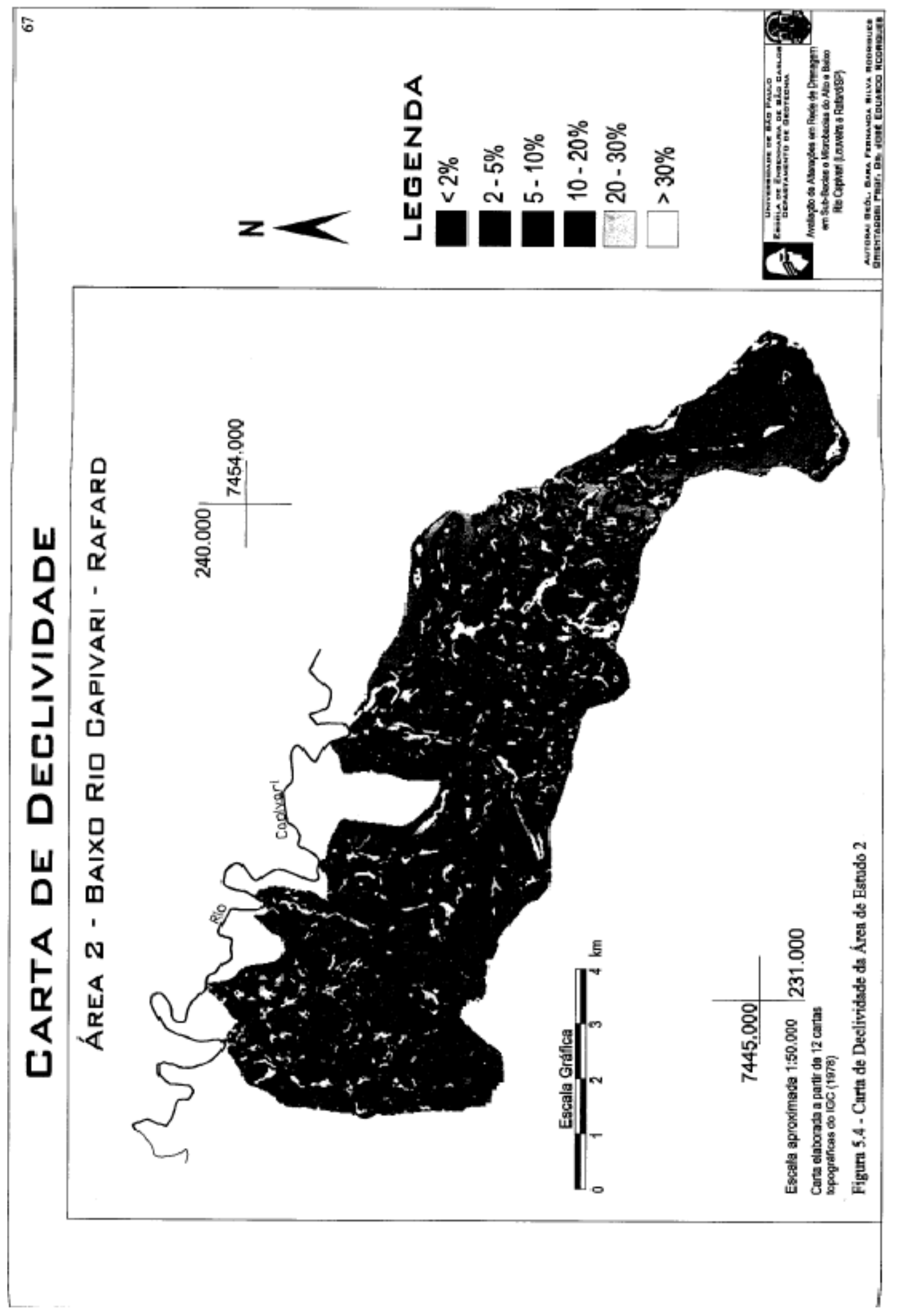

Figura 5.4 - Carta de Declividade da Área de Estudo 2 


\section{3 - MAPAS DA REDE DE DRENAGEM}

Nessa pesquisa, a finalidade da elaboração dos mapas da rede de drenagem para os anos de 1972 e 1995, foi a obtenção de suas variáveis morfométricas, de acordo com os procedimentos descritos no Item 4.2.5.3.

\subsection{1 - Área 1 - Alto Rio Capivari}

Os mapas da rede de drenagem para esta área de estudo dos anos de 1972 e 1995 são apresentados nas figuras 5.5 e 5.6, respectivamente.

Foram delimitadas 4 sub-bacias: Ribeirão do Moinho, Córrego Sopezol, Córrego Vale das Vinhas e Córrego Corrupira. Verificou-se que a rede de drenagem das sub-bacias apresentaram padrões de drenagem dentrítico, sub-dentrítico e retangular; e caracterizaramse por uma baixa densidade de drenagem $\left(<7,5 \mathrm{~km} / \mathrm{km}^{2}\right)$ e alta densidade hidrográfica (7 à $\left.15 \mathrm{~N} 1 / \mathrm{km}^{2}\right)$.

Quanto à hierarquização da sub-bacias, em 1995, registrou-se a Ordem 4 para a SubBacia Córrego Vale das Vinhas e Ordem 5, para as demais. A Tabela 5.2 apresenta alguns parâmetros morfométricos obtidos para 1995.

Tabela 5.2 - Alguns parâmetros morfométricos obtidos paras as sub-bacias da área 1 para 1995

\begin{tabular}{l|cccc}
\hline \multirow{2}{*}{ PARÂMETROS MORFOMÉTRICOS } & \multicolumn{3}{c}{ SUB-BACIAS HIDROGRÁFICAS } \\
\cline { 2 - 5 } & $\begin{array}{c}\text { Ribeirão } \\
\text { do Moinho }\end{array}$ & $\begin{array}{c}\text { Córrego } \\
\text { Sopezol }\end{array}$ & $\begin{array}{c}\text { Córrego } \\
\text { Vale das } \\
\text { Vinhas }\end{array}$ & $\begin{array}{c}\text { Córrego } \\
\text { Corrupira }\end{array}$ \\
\hline$\quad$ Número Total de Canais (Nt) & 458 & 325 & 103 & 96 \\
- Número de Canais de Ordem 1 (N1) & 332 & 236 & 78 & 66 \\
- Número de Canais de Ordem 2 (N2) & 92 & 68 & 20 & 22 \\
- Número de Canais de Ordem 3 (N3) & 24 & 16 & 4 & 5 \\
- Número de Canais de Ordem 4 (N4) & 9 & 4 & 1 & 2 \\
$\quad$ Comprimento Total da Rede de Drenagem (Lt - & 125,64 & 88,66 & 31,97 & 27,08 \\
km) & & & & - \\
\hline
\end{tabular}




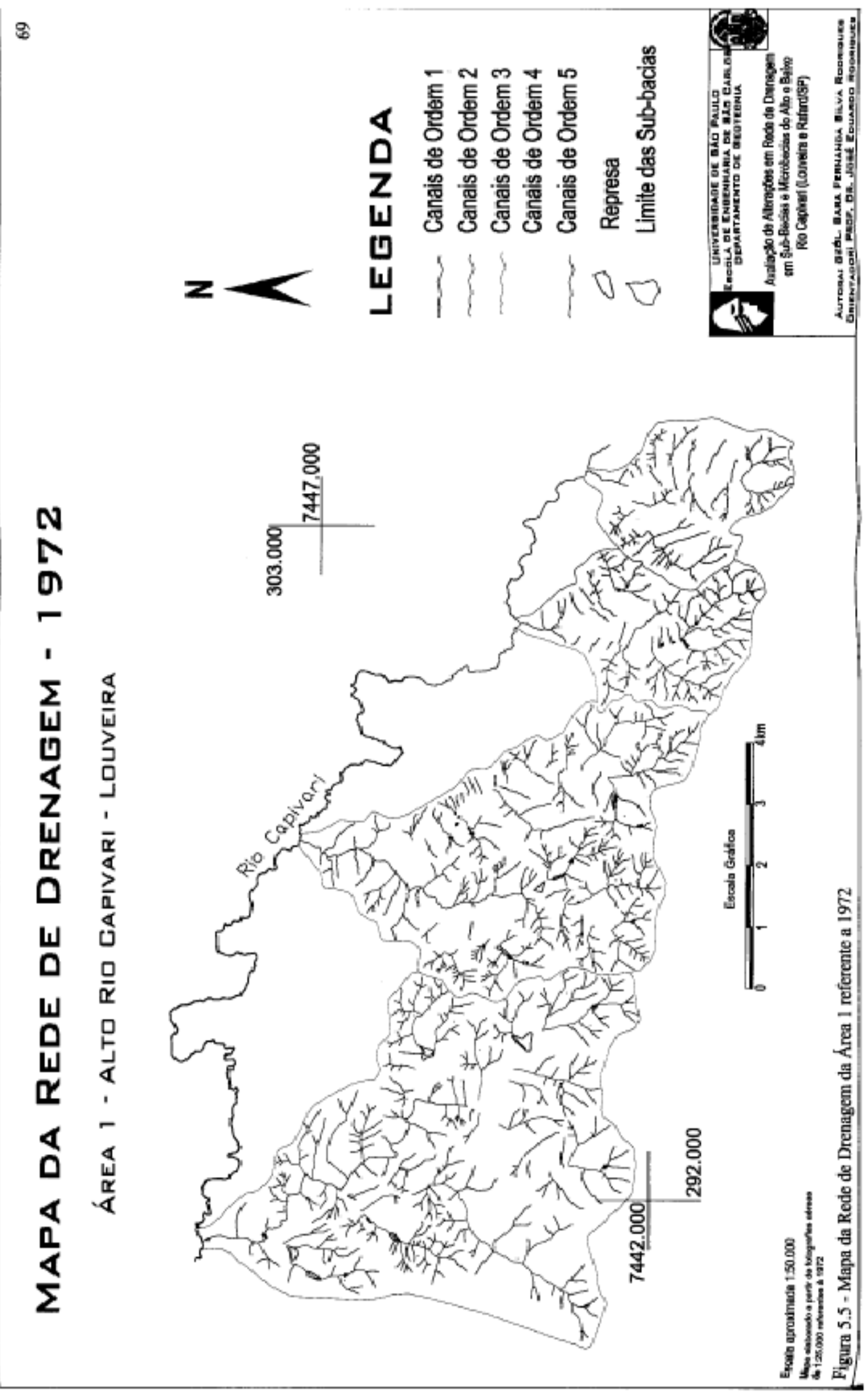

Figura 5.5 - Mapa da Rede de Drenagem da Área 1 referente a 1972 


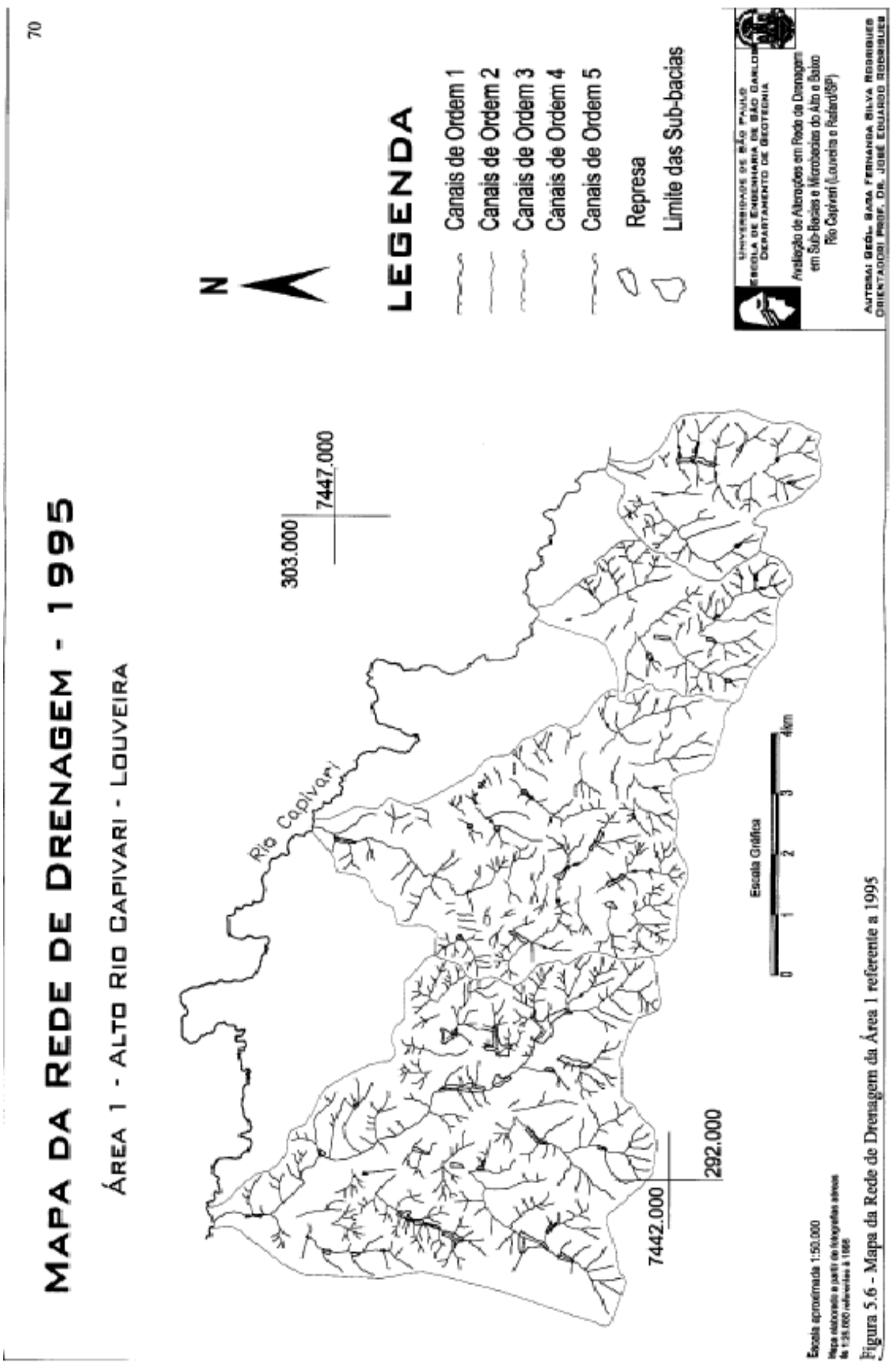

Figura 5.6 - Mapa da Rede de Drenagem da Área 1 referente a 1995 


\subsection{2 - ÁREA 2 - BAIXO RIO CAPIVARI}

As figuras 5.7 e 5.8 mostram os mapas da rede de drenagem para a área de pesquisa 2, respectivos aos anos de 1972 e 1995.

Nesta área, com $52 \mathrm{~km}^{2}$, foram definidas 5 sub-bacias: Córrego Borão, Córrego Alto Retiro, Córrego Santa Rita, Córrego São Francisco e Córrego Itapeva.

A rede de drenagem das sub-bacias caracterizou-se por: padrões de drenagem dentrítico, sub-dentrítico, sub-pararalelo e sub-retangular; baixa a muito baixa densidade de drenagem e alta densidade hidrográfica (7 à 15 N1/km²).

A classificação hierárquica das sub-bacias não sofreu modificação ao longo do período estudado, sendo 5 para a Sub-Bacia Córrego Itapeva e 4 para todas as demais. A Tabela 5.3 mostra alguns parâmetros morfométricos obtidos para 1995.

Tabela 5.3 - Alguns parâmetros morfométricos obtidos paras as sub-bacias da área 2 para 1995

\begin{tabular}{|c|c|c|c|c|c|}
\hline \multirow[b]{2}{*}{ PARÂMETROS MORFOMÉTRICOS } & \multicolumn{5}{|c|}{ SUB-BACIAS HIDROGRÁFICAS } \\
\hline & $\begin{array}{l}\text { Córrego } \\
\text { Borão }\end{array}$ & $\begin{array}{c}\text { Córrego } \\
\text { Alto } \\
\text { Retiro }\end{array}$ & $\begin{array}{c}\text { Córrego } \\
\text { Santa } \\
\text { Rita }\end{array}$ & $\begin{array}{c}\text { Córrego } \\
\text { São } \\
\text { Francisco }\end{array}$ & $\begin{array}{l}\text { Córrego } \\
\text { Itapeva }\end{array}$ \\
\hline - Número Total de Canais (Nt) & 125 & 119 & 50 & 82 & 399 \\
\hline - Número de Canais de Ordem 1 (N1) & 97 & 90 & 37 & 64 & 307 \\
\hline - $\quad$ Número de Canais de Ordem 2 (N2) & 25 & 23 & 10 & 14 & 70 \\
\hline - Número de Canais de Ordem 3 (N3) & 2 & 5 & 2 & 3 & 18 \\
\hline - Número de Canais de Ordem 4 (N4) & 1 & 1 & 1 & 1 & 3 \\
\hline - Número de Canais de Ordem 5 (N5) & - & - & - & - & 1 \\
\hline $\begin{array}{l}\text { Comprimento Total da Rede de Drenagem } \\
(\mathrm{Lt}-\mathrm{km})\end{array}$ & 28,00 & 28,10 & 11,57 & 23,94 & 109,90 \\
\hline
\end{tabular}




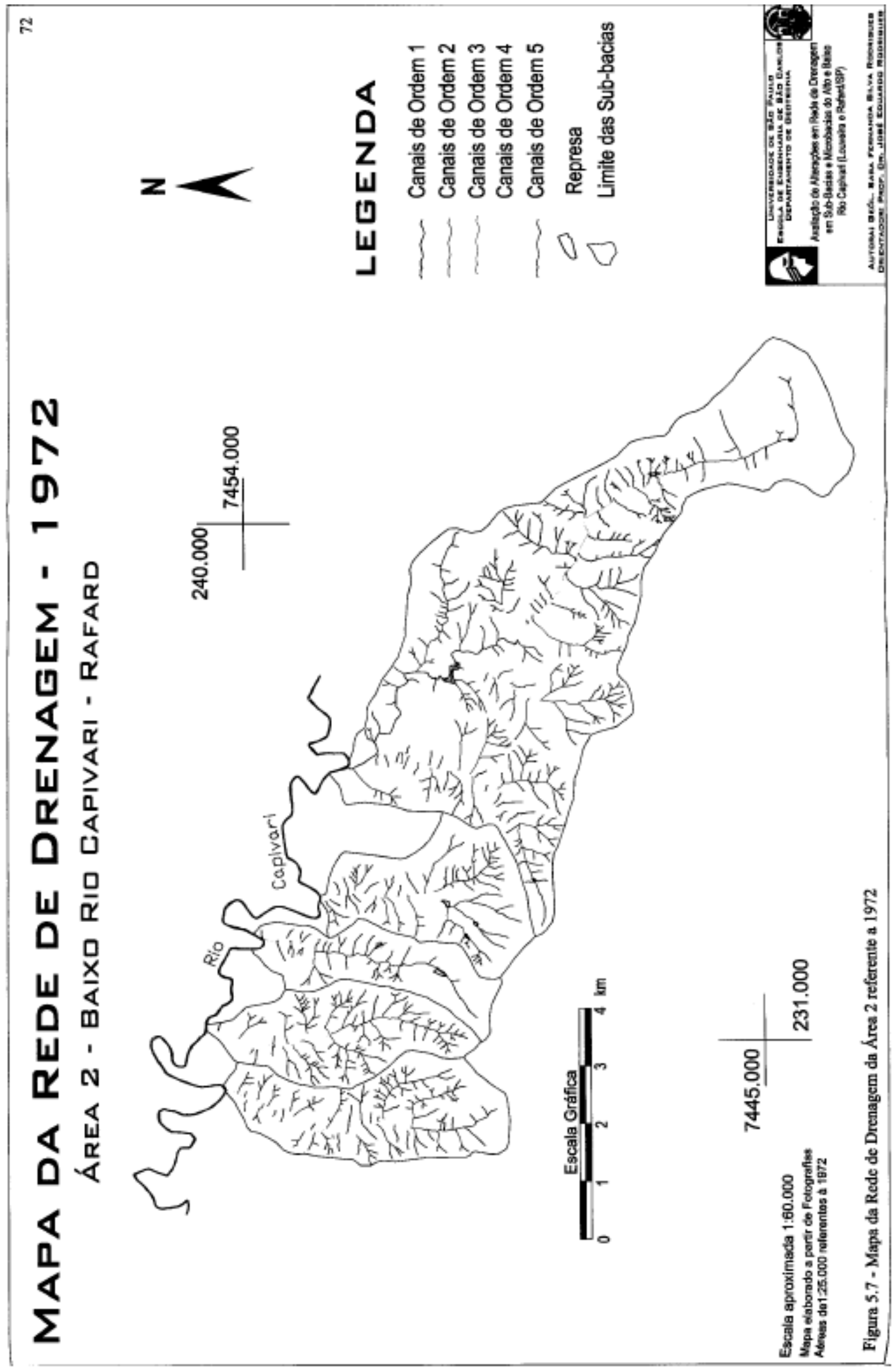

Figura 5.7 - Mapa da Rede de Drenagem da Área 2 referente a 1972 


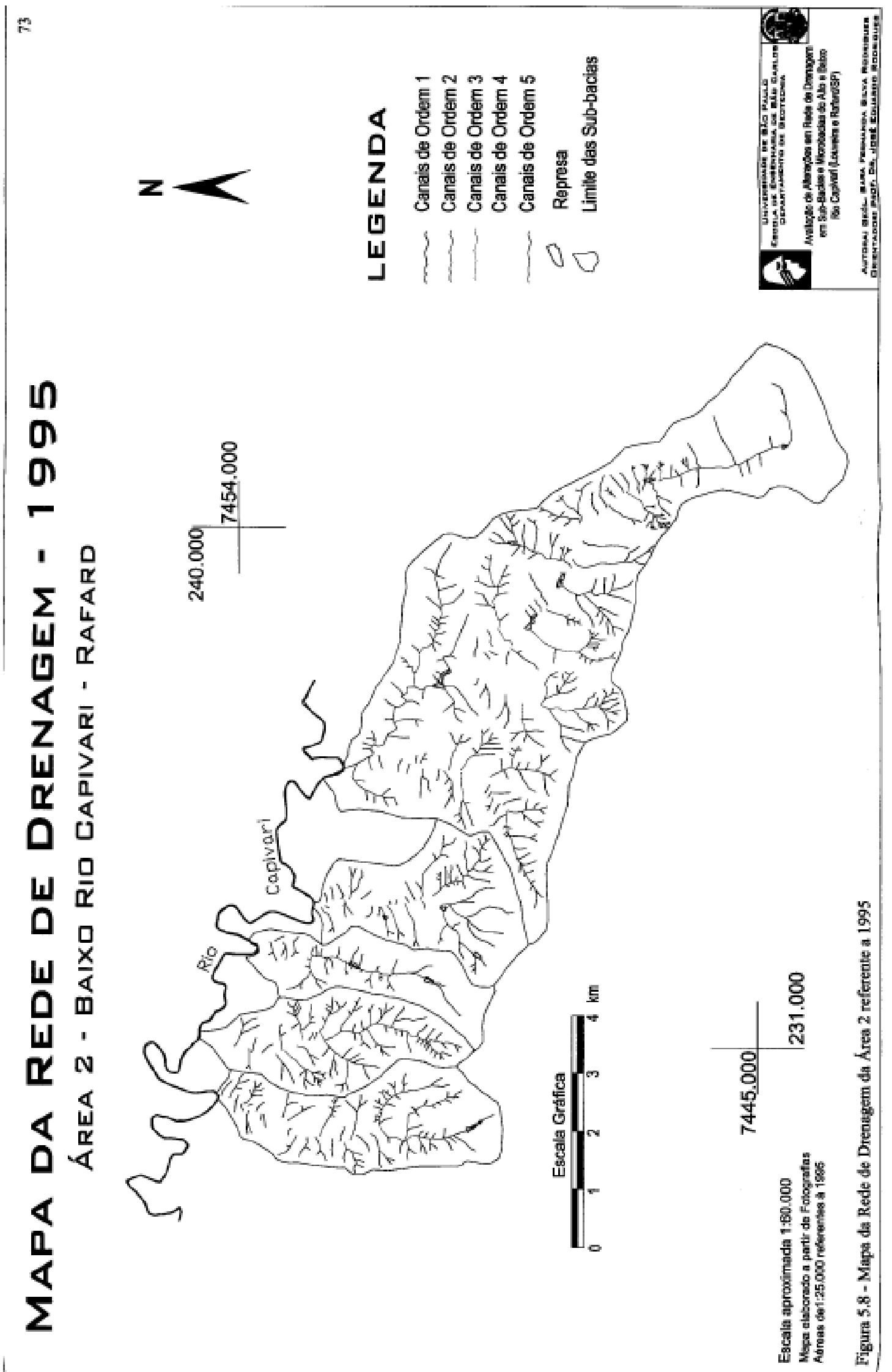

Figura 5.8 - Mapa da Rede de Drenagem da Área 2 referente a 1995 


\section{4 - MAPAS DE USO E OCUPAÇÃO}

Os Mapas de Uso e Ocupação foram elaborados com o objetivo de apresentar as diversas atividades antrópicas vigentes nas áreas de estudo e suas distribuições areais para os anos de 1972 e 1995.

\subsection{1 - Área 1 - Alto Rio Capivari}

Os Mapas de Uso e Ocupação para a área de pesquisa 1, referentes aos anos de 1972 e 1995 são apresentados nas figuras 5.9 e 5.10, respectivamente.

Definiu-se 10 tipos de classes de atividades antrópicas em 1995, como mostra a Figura 5.10, baseando-se nas terminologias propostas por Collares (2000), com algumas modificações.

As classes definidas foram: área industrial, alta urbanização, baixa urbanização, média urbanização, pesqueiro, hortifruti, mata/reflorestamento, pasto/mata capoeira, explotação de material de construção e represa, descritas a seguir e sumarizadas na Tabela 5.4 .

- Área Industrial: classe destinada a áreas ocupadas por indústrias isoladas ou parques industriais. Ocorre localmente nas sub-bacias Córrego Sopezol e Córrego Vale das Vinhas e apresenta uma pequena distribuição areal de 1,4\%;

- Baixa Urbanização: áreas caracterizadas por urbanização pouco adensada, caracterizada pela presença de chácaras e/ou sítios distribuídos esparsadamente e ausência de ruas pavimentadas. Ocupam 4,2 \% da área de estudo e ocorrem mais expressivamente nas sub-bacias córregos Corrupira e Vale das Vinhas e de forma mais restrita na Sub-Bacia Córrego Sopezol;

- Média Urbanização: áreas caracterizadas por pequenos núcleos urbanos desenvolvidos irregularmente. Ocorrem localmente na porção sudeste da Sub-Bacia Ribeirão do Moinho, aglutinadas ao longo da Rodovia Bandeirantes e ocupam 0,9 \% da área total de estudo;

- Alta Urbanização: áreas caracterizadas por urbanização muito adensada, com concentrações de edificações residenciais e comerciais, ruas pavimentadas e pouca arborização. Ocupam 3,4 \% da área total e ocorrem na porção centro-norte da Sub-Bacia Córrego Sopezol; 
- Pesqueiro: áreas caracterizadas pela retirada da mata nativa ao longo das áreas represadas para implantação de lagoas artificiais de pesca. Ocorrem de forma restrita nas sub-bacias córregos Sopezol e Vale das Vinhas compreendendo 0,3\% da área total;

- Hortifruti: áreas destinadas ao cultivo de hortaliças e frutas. Essa atividade de caráter econômico representa uma característica marcante na área de estudo conhecida principalmente pela produção de uvas, figos e morangos. Ocupam 30,8\% da área total;

- Mata/Reflorestamento: classe que engloba áreas ocupadas ou por mata nativa (cerrado), muitas vezes representadas por capões esparsos ou próximos aos rios; e/ou por mata ciliar preservada ao longo dos principais canais de drenagem e/ou por matas reflorestadas principalmente por pinus e eucaliptos, próximo às cabeceiras dos córregos. Sua presença é bem distribuída na área de estudo, ocupando 27,1\% da área em questão. O intenso cultivo agrícola, a urbanização crescente, a implantação da área industrial e a exposição do solo para implantação de pastagens e pesqueiros foram as atividades responsáveis pela retirada da vegetação primária;

- Pasto/Mata Capoeira: classe correspondente a áreas ocupadas por vegetação rasteira (pastagens) e subordinadamente por vegetação pouco densa e de médio porte (capoeira). Ocupam 29,7\% da área total, entretanto apresentam-se mais concentradas na Sub-Bacia Ribeirão do Moinho enquanto nas demais ocorre localmente;

- Explotação de Material de Construção: áreas destinadas a explotação de materiais para a construção civil apresentam-se de forma restrita nas sub-bacias Ribeirão do Moinho, córregos Sopezol e Corrupira ocupando 0,71\% da área total; e,

- Represa: classe na qual enquadram-se todos os corpos d’água presentes (represas e lagos) e representam 1,4\% da área de estudo.

Tabela 5.4 - Tipos de atividades antrópicas desenvolvidas na área 1 em 1995

\begin{tabular}{l|cc}
\hline \multicolumn{1}{c}{ CLASSES DE USO E OCUPAÇão } & \multicolumn{2}{c}{ DISTRIBUIÇão AREAL } \\
\cline { 2 - 3 } & $\mathbf{k m}^{2}$ & \% \\
\hline Área Industrial & 0,78 & 1,4 \\
Baixa Urbanização & 2,29 & 4,2 \\
Média Urbanização & 0,49 & 0,9 \\
Alta Urbanização & 1,87 & 3,4 \\
Crescimento Urbano & 5,43 & 9,9 \\
Pesqueiro & 0,16 & 0,3 \\
Hortifruti & 16,9 & 30,8 \\
Mata/Reflorestamento & 14,8 & 27,1 \\
Pasto/ Mata Capoeira & 16,3 & 29,7 \\
Explotação de Material de Construção & 0,39 & 0,7 \\
Represa & 0,79 & 1,4 \\
\hline
\end{tabular}




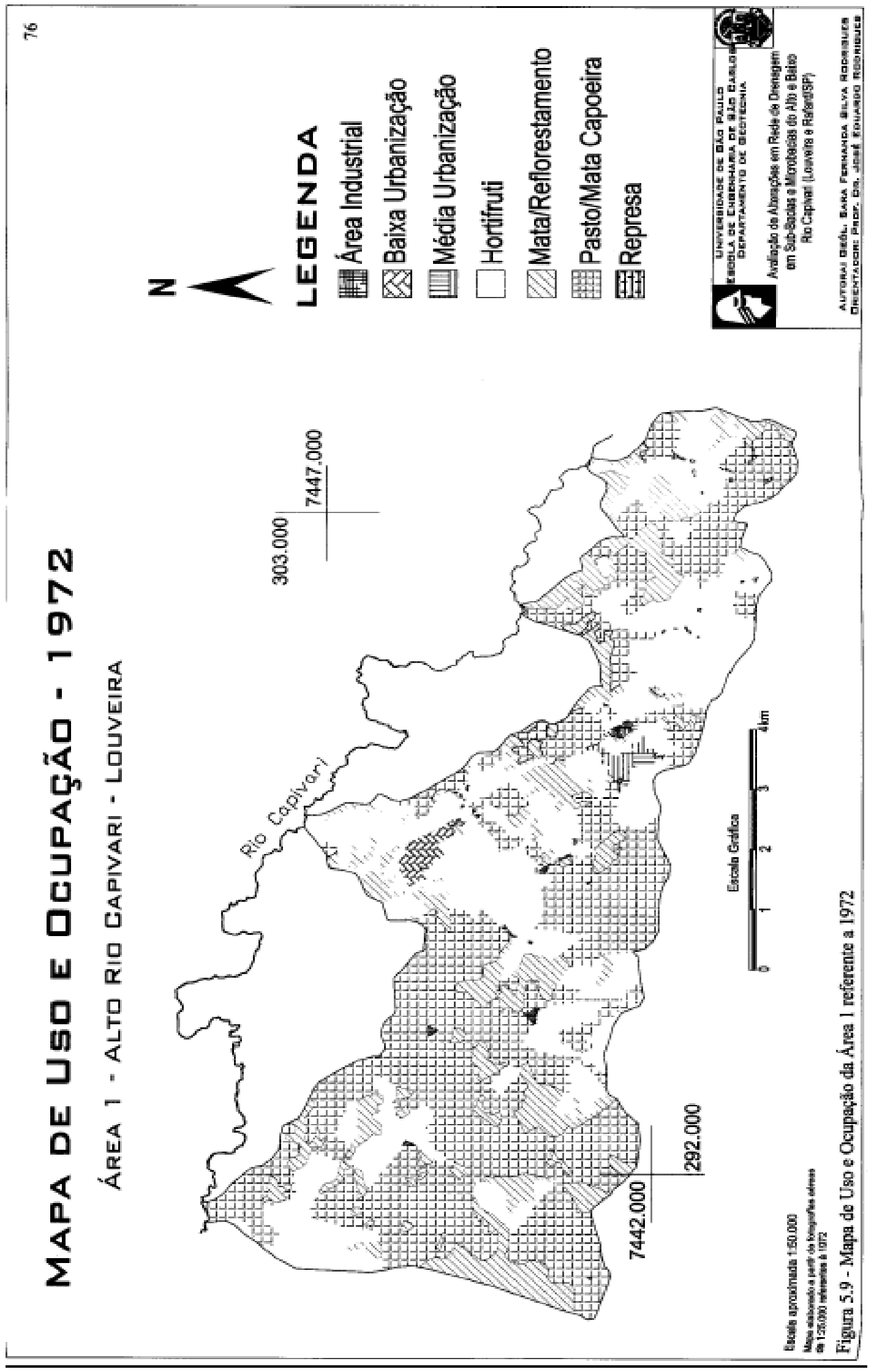

Figura 5.9 - Mapa de Uso e Ocupação da Área 1 referente a 1972 


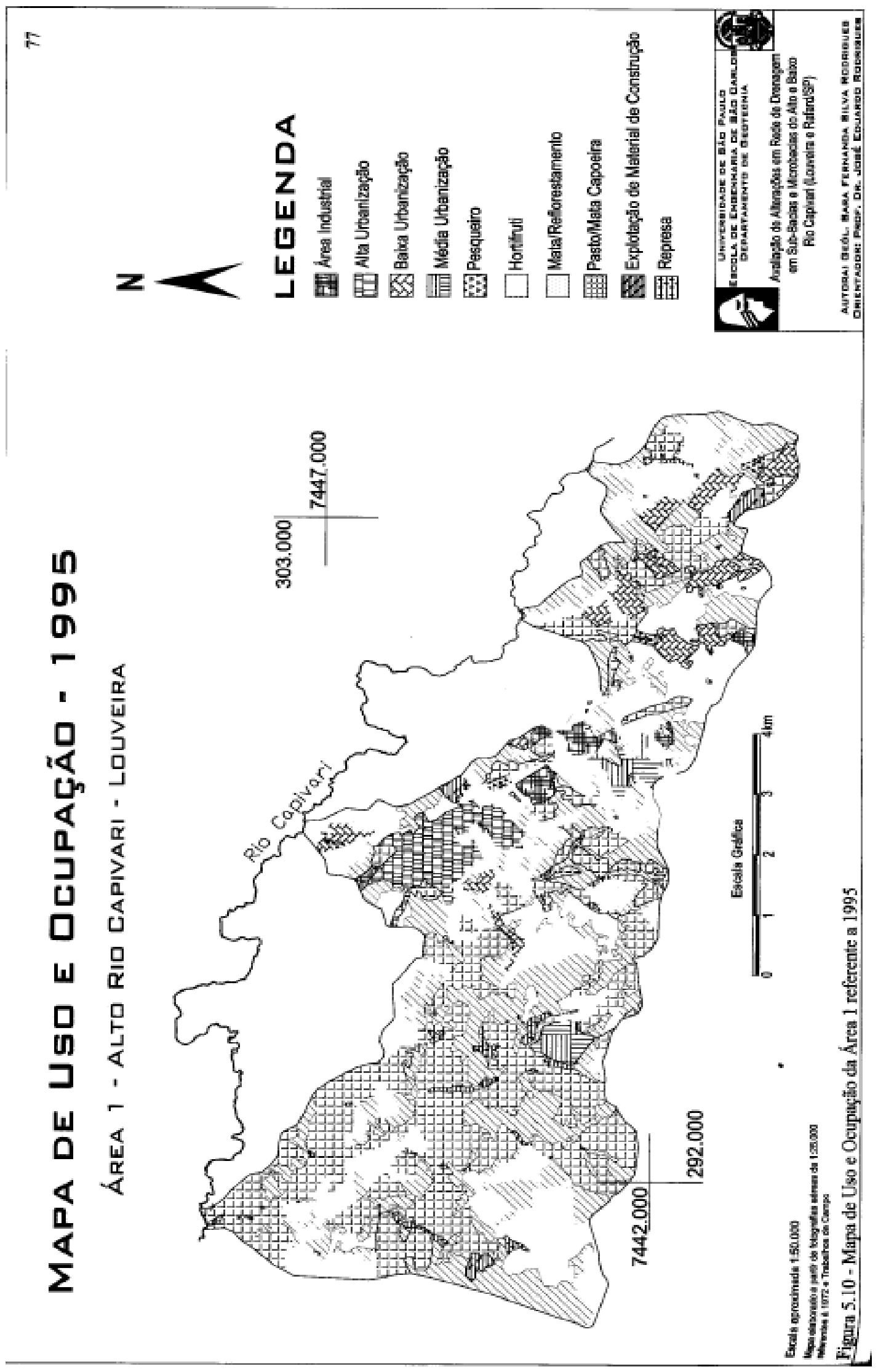

Figura 5.10 - Mapa de Uso e Ocupação da Área 1 referente a 1995 


\subsection{2 - Área 2 - Baixo Rio Capivari}

Com base nas terminologias de Collares (2000) foram definidas para esta área de estudo 5 classes de uso e ocupação do meio físico: Culturas Indiferenciadas, Hortifruti, Mata/Reflorestamento, Pasto/Mata Capoeira e Represa.

Os mapas de Uso e Ocupação referentes a Rafard, para os anos de 1972 e 1995, são apresentados nas figuras 5.11 e 5.12 , respectivamente.

As atividades definidas referem-se aos dois períodos estudados e são a seguir descritas e também sumarizadas na Tabela 5.5:

- Culturas Indiferenciadas: Esta classe constitui a principal atividade antrópica registrada na área de estudo e ocupa quase toda a sua totalidade com 82,8 \% (Tabela 5.5). Corresponde às regiões ocupadas pela lavoura da cana de açúcar em suas várias fases de maturação (cana pronta para o corte, cana em fase de amadurecimento e área preparada para o plantio da cana);

- Mata/Reflorestamento: esta classe engloba áreas ocupadas pela vegetação de cerrado como capões esparsos ou pela mata ciliar preservada ao longo dos canais principais e por áreas reflorestadas principalmente eucaliptos próximos às cabeceiras dos rios. Ocupam 12,2\% da área de pesquisa 2 . O cultivo agrícola é o principal responsável pela retirada da vegetação primária, mas a essa atividade pode-se somar a exposição do solo para uso em pastagens;

- Hortifruti: Esta classe apresenta pequena distribuição areal de 0,2 \% com ocorrência restrita apenas à Sub-Bacia Córrego Santa Rita. Essas áreas destinam-se ao cultivo de tomates;

- Pasto/Mata Capoeira: Ocorrem de forma restrita nas sub-bacias Córregos Borão e Itapeva e ocupam apenas 4,6 \% da área total da bacia; e,

- Represa: apresentam pequena distribuição areal de 0,2 \%.

Tabela 5.5 - Classes de Atividades Antrópicas definidas para a área 2 em 1995

\begin{tabular}{l|cc}
\hline \multicolumn{1}{c}{ CLASSES DE USO E OCUPAÇÃO } & \multicolumn{2}{c}{ DISTRIBUIÇÃO AREAL } \\
\cline { 2 - 3 } & $\mathbf{k m}^{\mathbf{2}}$ & $\boldsymbol{\%}$ \\
\hline Hortifruti & 0,12 & 0,2 \\
Culturas Indiferenciadas & 43,66 & 82,8 \\
Mata/Reflorestamento & 6,33 & 12,2 \\
Pasto/Mata Capoeira & 2,44 & 4,6 \\
Represa & 0,15 & 0,2 \\
\hline
\end{tabular}




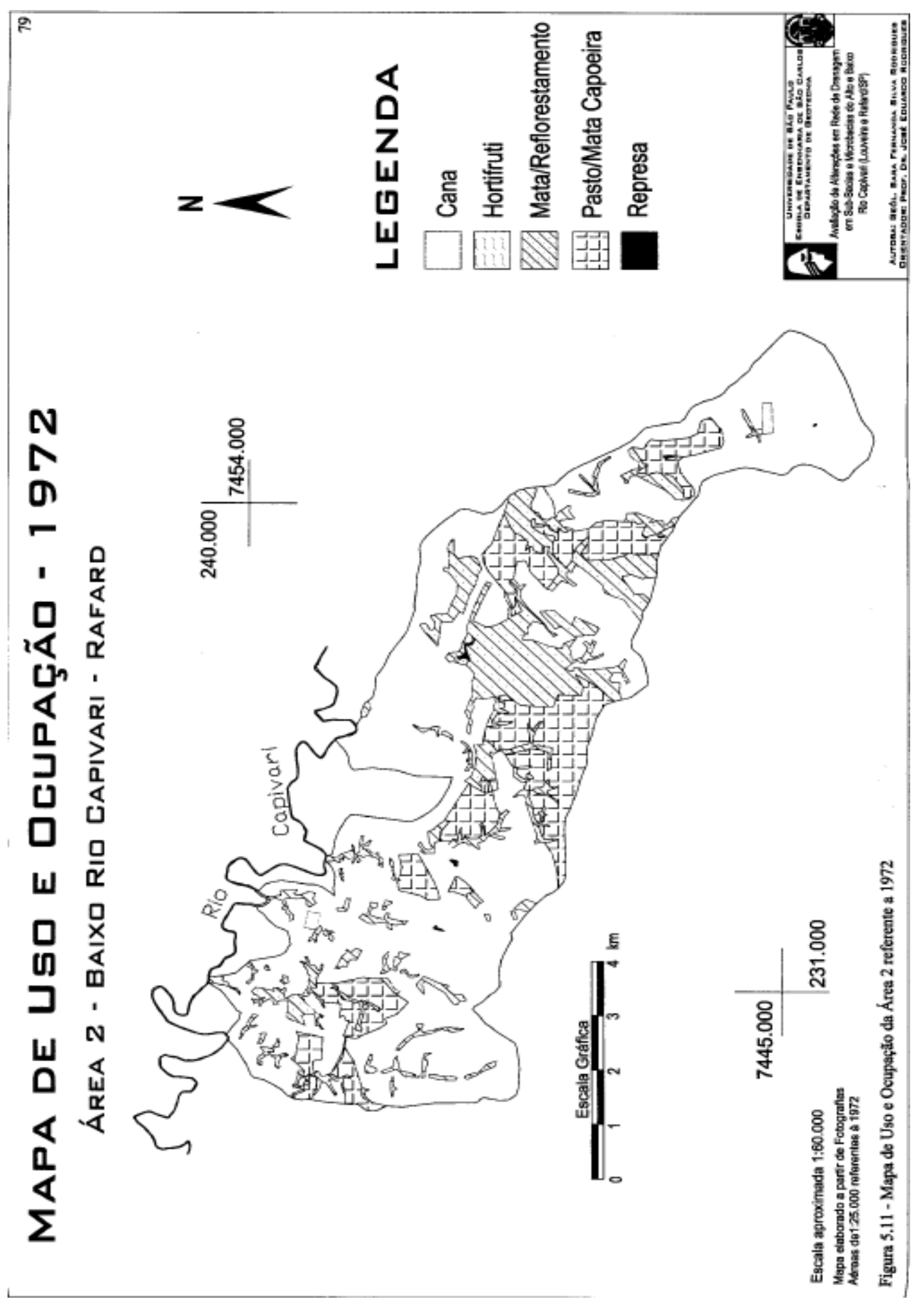

Figura 5.11 - Mapa de Uso e Ocupação da Área 2 referente a 1972 


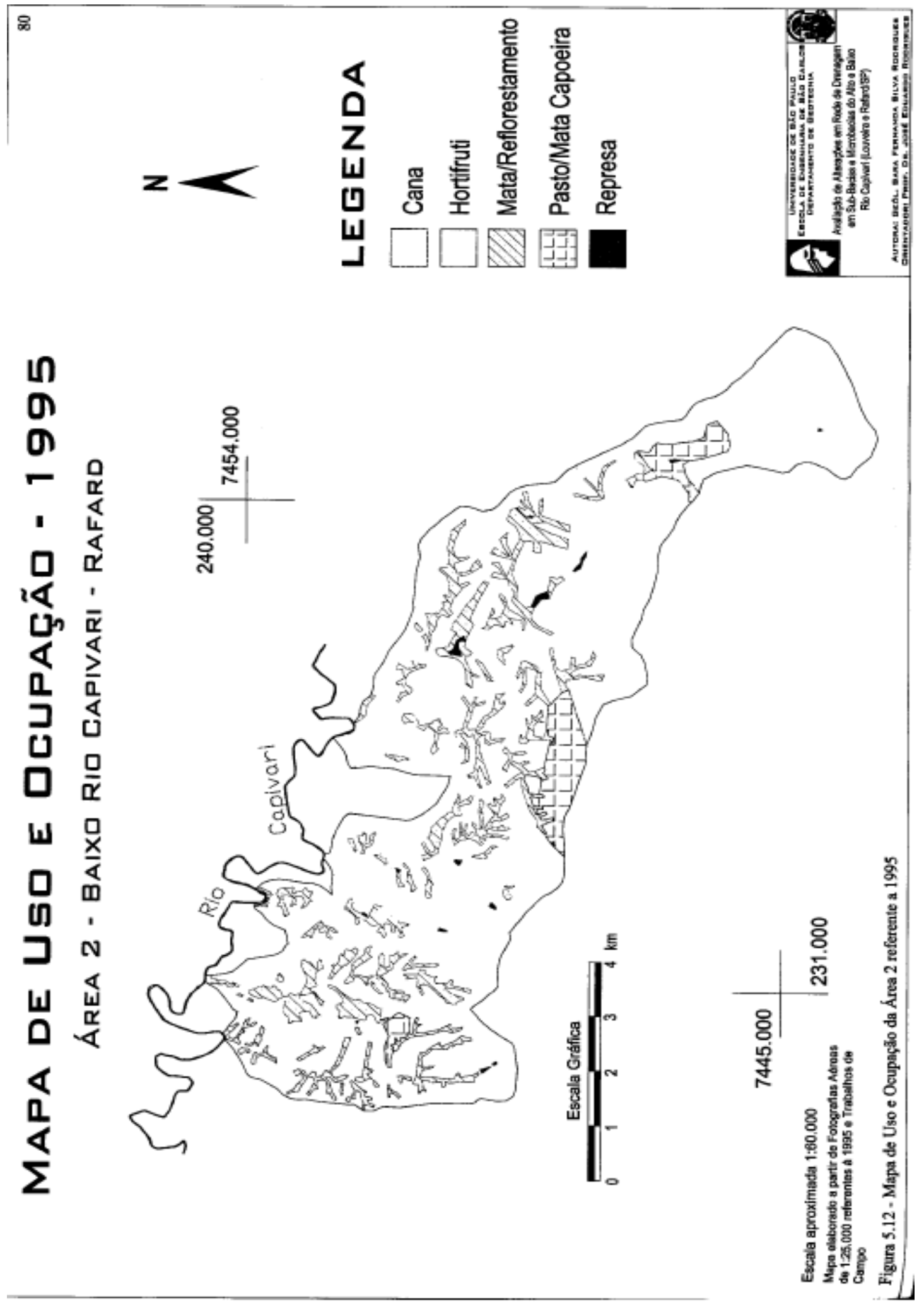

Figura 5.12 - Mapa de Uso e Ocupação da Área 2 referente a 1995 


\section{5 - MAPAS DE LANDFORMS}

Os mapas de Landforms foram elaborados com o intuito de compartimentar o terreno em unidades distintas por meio das feições de relevo e dos materiais associados o que inclui o substrato rochoso e os materiais inconsolidados.

A área 1 representa uma região de relevo dissecado com formas colinosas e amorreadas e foram atribuídas a um único sistema de terreno. As feições de relevo nessa área são condicionadas pelas rochas cristalinas pré-cambrianas e seus materiais inconsolidados e provavelmente também aos vários ciclos geotectônicos que nela atuaram, posto que uma das características mais nítidas nas fotos aéreas é a estruturação marcante no sentido NE-SW e NW-SE.

A região foi subdividida em 13 unidades de relevo por meio da forma dos topos, vales e vertentes, pela extensão e amplitude, assim como pela declividade e pelo padrão e densidade de drenagem (Figura 5.13).

A área 2, similarmente à anterior, foi englobada num único sistema de terreno constituído por formas de relevo colinosas, condicionadas quase que unicamente pelas rochas sedimentares do Subgrupo Itararé e pelos materiais inconsolidados a ela associados. A compartimentação reflete a heterogeneidade e as alternâncias lateral e vertical dos principais litotipos dessa unidade litoestratigráfica. Foram definidas 12 unidades de relevo para a região (Figura 5.14). 


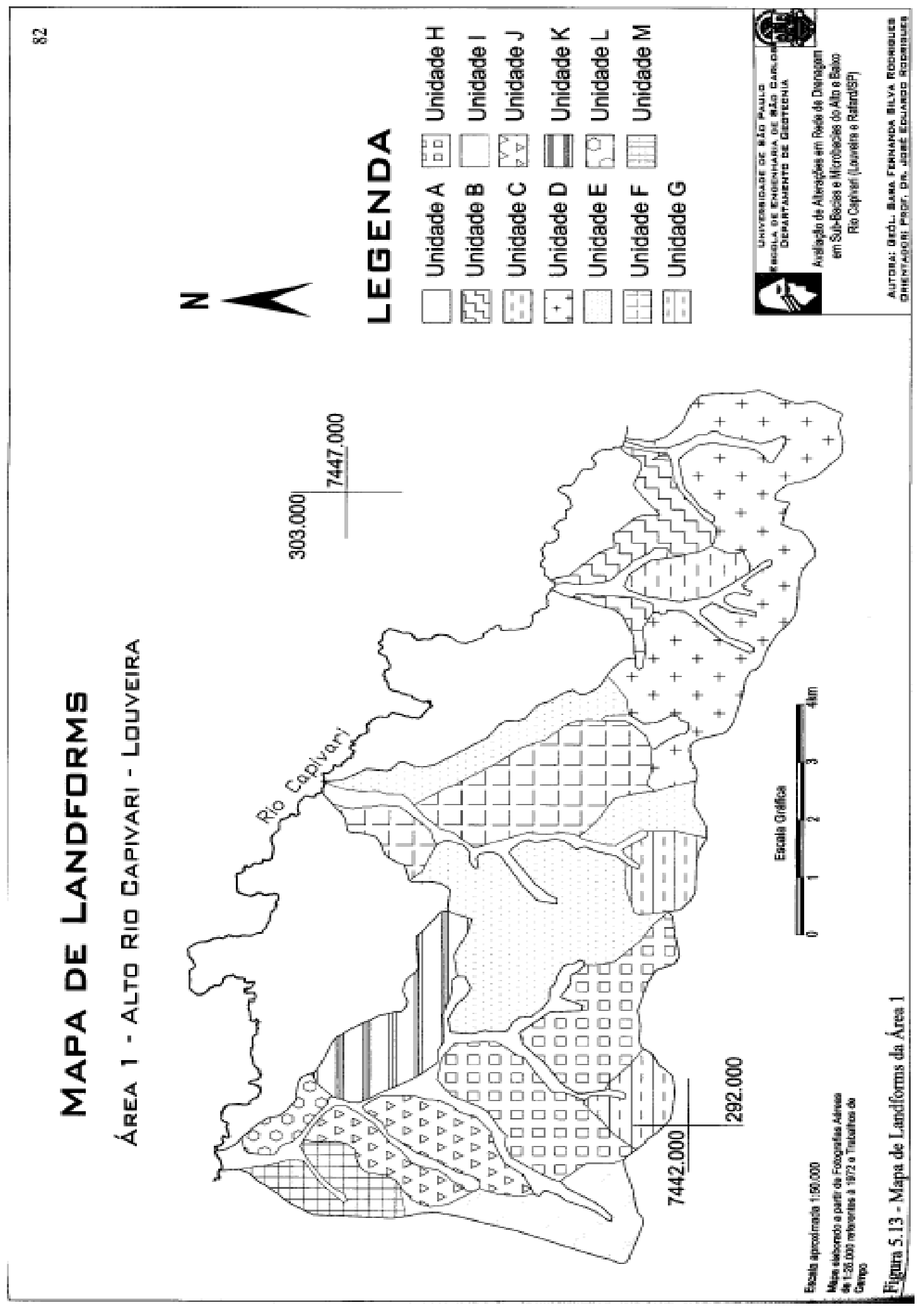

Figura 5.13 - Mapa de Landforms da Área 1 


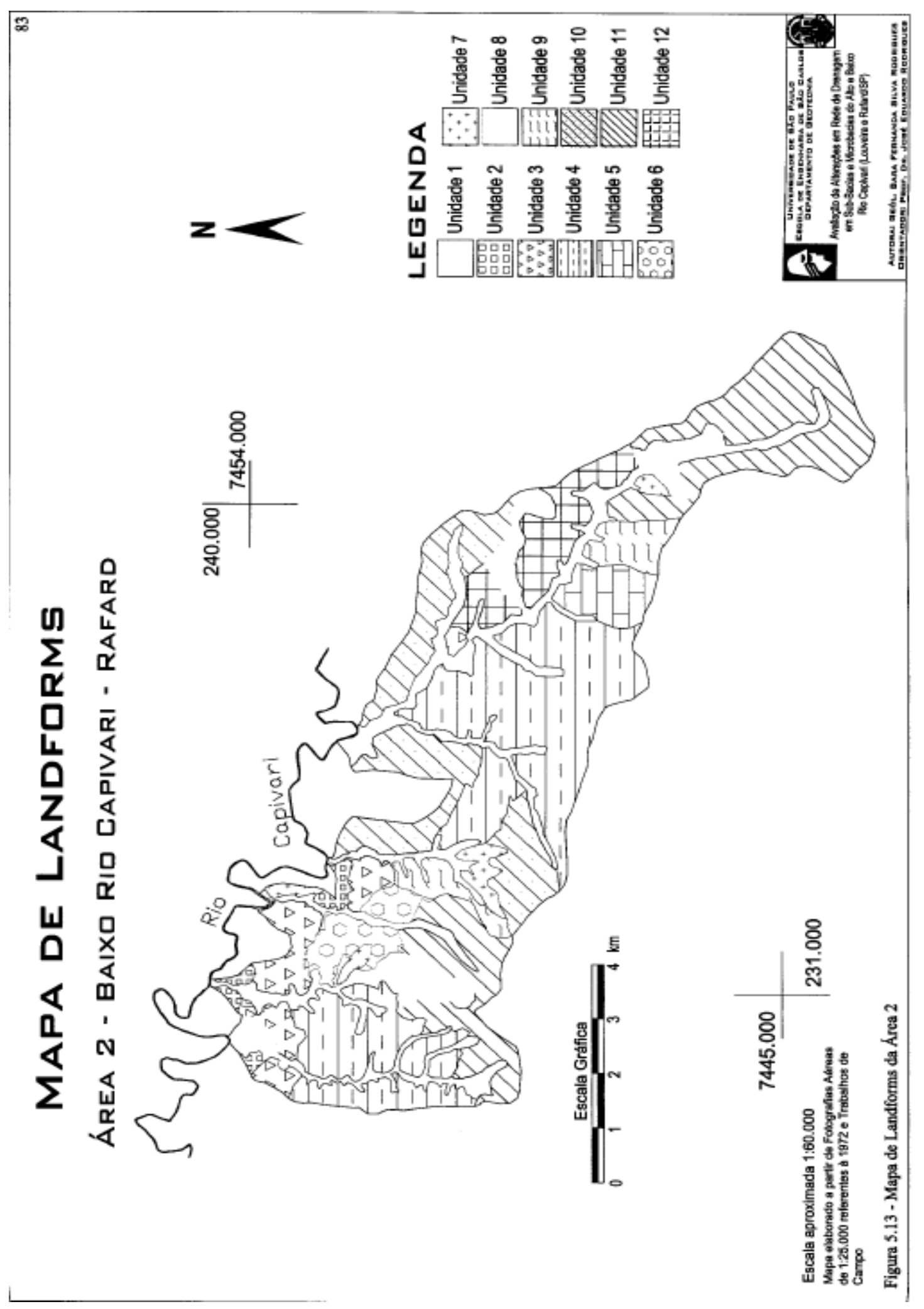

Figura 5.14 - Mapa de Landforms da Área 2 


\subsection{1 - Descricão dos Landforms}

\subsubsection{1 - Área 1 - Alto Rio Capivari}

\subsubsection{1 - Unidade A}

Essa unidade com aproximadamente 10\% da área total está representada em todas as sub-bacias da área 1 (Ribeirão do Moinho, Córrego Sopezol, Córrego Vale das Vinhas e Córrego Corrupira). Geomorfologicamente, caracteriza-se por vales abertos de fundo aplainado, baixa freqüência de canais, baixas declividades que variam de 0 a $5 \%$.

Apresentam depósitos aluviais sobrepostos ao substrato rochoso, constituídos por uma camada contínua de material argiloso com intercalação de areia grossa a fina e níveis de cascalho.

\subsubsection{2 - Unidade B}

Essa unidade ocupa aproximadamente 4\% da área total. Localiza-se a norte e noroeste das sub-bacias Córrego Vale das Vinhas e Córrego Corrupira, respectivamente. Caracteriza-se por morrotes amplos de topos angulosos e encostas convexas - retilíneas com alta freqüência de canais e padrão de drenagem sub-retangular e sub-dentrítico. Estes morrotes apresentam, principalmente, declividades moderadas a altas, entre 10 a 30\%, entretanto em alguns setores chegam a ser superiores a $30 \%$.

O substrato rochoso está constituído por biotita-gnaisses e o perfil de alteração nesta unidade caracteriza-se por dois estádios de alteração: nas porções côncavas, predominam solos com estruturação primária; e nos topos, rochas moderadamente alteradas a altamente decompostas.

\subsubsection{3 - Unidade C}

Essa unidade apresenta pequena expressão areal (2\% da área total), localiza-se na porção centro-leste da Sub-bacia Córrego Vale das Vinhas. Está representada por colinas médias de topo arredondado e encostas convexas - retilíneas - côncavas com alta freqüência de canais, declividades moderadas (10-20\%) e padrão de drenagem subparalelo assimétrico.

Geologicamente, está constituída por granito gnaisses e está associada às unidades de materiais inconsolidados XI e XII. 


\subsubsection{4 - Unidade D}

Em termos areais, a unidade $\mathrm{D}$ é uma das mais representativas com aproximadamente $18 \%$ da área total e engloba quase toda a Sub-bacia Córrego Corrupira, as porções sul e sudoeste da Sub-Bacia Córrego Vale das Vinhas e pequena parte da área sudeste da Sub-Bacia Córrego Sopezol. Constitui-se de colinas pequenas a médias de topo anguloso a arredondado e encostas convexas - côncavas e retilíneas - côncavas com alta freqüiência de canais, apresentando declividades moderadas (10-20\%) e padrão de drenagem sub-retangular e sub-dentrítico.

O substrato rochoso homogêneo caracteriza-se por biotita-gnaisses que deram origem ao seguinte perfil de alteração: rochas moderadamente alteradas a altamente decompostas (horizontes IV e V) e solos areno-siltosos e areno-argilosos, resultado de uma completa decomposição da rocha (Horizonte VI), mas ainda preservando as estruturas reliquiares da rocha.

\subsubsection{5 - Unidade E}

Similar à anterior, esta é uma das unidades de maior representação areal com aproximadamente 18\% da área total. Localiza-se nas sub-bacias Córrego Sopezol e Ribeirão do Moinho.

A unidade E está representada por morrotes médios de topos arredondados a angulosos, com encostas convexas - côncavas, alta freqüência de canais e padrão de drenagem dentrítico. Suas declividades são moderadas a altas (entre 10 a 30\%), e em algumas porções chega a ultrapassar 30\%.

Registrou-se as unidades de materiais inconsolidados I, II, IV, V e VII associadas a substrato rochoso constituído por biotita-gnaisses.

\subsubsection{6 - Unidade F}

Essa unidade ocupa aproximadamente $10 \%$ da área total e situa-se na porção noroeste-sudeste da Sub-Bacia Córrego Sopezol. Caracteriza-se por colinas pequenas a médias de topos ondulados a arredondados e encostas convexas - côncavas com alta freqüência de canais, apresentando declividades moderadas (10-20\%) e padrão de drenagem sub-retangular e sub-dentrítico. 
Em termos de geologia está sustentada por biotita-gnaisses e apresentam o perfil de alteração composto pelos horizontes: IV (rochas moderadamente alteradas), V (rochas altamente decompostas), VI (solo com estruturas reliquiares) e VII (solo residual).

\subsubsection{7 - Unidade G}

Essa unidade apresenta-se localmente a sudoeste da Sub-Bacia Córrego Sopezol e ao sul da Sub-Bacia Ribeirão do Moinho, com aproximadamente 5\% da área total. Compreende áreas com colinas médias a pequenas de topos arredondados e encostas convexas - côncavas com alta freqüência de canais, padrão de drenagem dentrítico e declividades médias (10$20 \%)$.

Está associada a biotita-gnaisses e às unidades de materiais inconsolidados I, V e X.

\subsubsection{8 - Unidade H}

Unidade com considerável expressão areal, aproximadamente $12 \%$ da área total e situada na porção sudeste da Sub-Bacia Ribeirão do Moinho. Caracteriza-se por colinas amplas a médias com topos arredondados a angulosos e encostas convexas - côncavas bem dissecadas, com alta freqüência de canais, apresentando declividades médias a altas (entre 10 e 30\%) e padrão de drenagem sub-dentrítico.

Essa unidade constitui-se de biotita-gnaisses e os materiais inconsolidados associados são pertencentes às unidades III e VII.

\subsubsection{9 - Unidade I}

A unidade localiza-se na porção sudoeste da Sub-Bacia Ribeirão do Moinho e ocupa aproximadamente 2,6 $\mathrm{km}^{2}$ da área de estudo. Está composta por morrotes amplos a médios de topo angulosos e encostas convexas -retilíneas - côncavas bem dissecadas, com baixa freqüência de canais, apresentando declividades altas (superiores a 20\%).

Geologicamente, está sustentada por granito-gnaisses e em termos de materiais inconsolidados apresenta solos saprolíticos de textura argilo-arenosa, ou seja, aqueles com a presença de estruturas primárias da rocha (horizonte VI). 


\subsection{0 - Unidade J}

Essa unidade apresenta aproximadamente 6\% da área total e ocupa a porção central da Sub-Bacia Ribeirão do Moinho. Está constituída por morrotes amplos a médios, alongados de topo anguloso e encostas retilíneas - côncavas bem dissecadas e entalhadas com alta freqüência de canais, apresentando declividades moderadas a altas (entre 10 e $30 \%)$.

Em termos de geologia está composto por biotita-gnaisses no qual foi possível definir o seguinte perfil: transição entre o maciço de rocha e de solo, caracterizado por rochas moderadamente alteradas a alteradas e maciços de solo com foliação gnaíssica reliquiar.

\subsection{1 - Unidade K}

Essa unidade ocupa aproximadamente 5,5\% da área total e situa-se na porção nordeste da Sub-Bacia do Ribeirão do Moinho. Caracteriza-se por morrotes médios a pequenos, topo anguloso a arredondado e encostas convexas - retilíneas - côncavas e convexas - côncavas bem entalhadas com alta freqüência de canais, apresentando declividades moderadas a altas (entre 10 e 30\%) e padrão de drenagem dentrítico a subparalelo.

Em termos de geologia está constituída por gnaisses porfiróides para os quais foram encontrados os seguintes materiais inconsolidados associados: solos saprolíticos siltoarenosos (horizonte VI) e solos residuais argilo - arenosos (horizonte VII).

\subsection{2 - Unidade L}

Essa unidade localiza-se na porção norte da Sub-Bacia Ribeirão do Moinho com aproximadamente 1,5\% da área total. Está formada por colinas médias de topo anguloso e encostas convexas - côncavas com moderada freqüência de canais, apresentando declividades moderadas (10 -20\%) e padrão de drenagem sub-dentrítico.

As rochas associadas a esses relevos são feldspato alcalino-gnaisses moderadamente a completamente decompostos.

\subsection{2 - Unidade $M$}

A unidade situa-se na porção noroeste da Sub-Bacia Ribeirão do Moinho com aproximadamente 3\% da área total. Caracteriza-se por colinas médias de topos aplainados e 
encostas convexas - côncavas com baixa freqüência de canais, apresentando declividades baixas moderadas (entre 5 e 20\%) e padrão de drenagem sub-dentrítico a subparalelo.

As rochas associadas são granito-gnaisses moderadamente alterados a altamente decompostos.

\subsubsection{2 - Área 2 - Baixo Rio Capivari}

\subsubsection{1 - Unidade 1}

Essa unidade tem aproximadamente $14 \%$ da área total e foi descrita nas cinco subbacias hidrográficas córregos Borão, Alto Retiro, Santa Rita, São Francisco e Itapeva. Compreende vales abertos com encostas côncavas, baixa freqüência de canais e declividades de até $5 \%$.

Em termos de materiais inconsolidados há presença de depósitos aluviais.

\subsubsection{2 - Unidade 2}

A unidade 2 apresenta uma pequena expressão areal com aproximadamente $1 \%$ da área total e localiza-se nas porções norte das sub-bacias córregos Borão e Alto Retiro e na porção nordeste da Sub-Bacia Santa Rita e noroeste da Sub-Bacia São Francisco. Caracteriza-se por colinas médias a pequenas de topos aplainados a ondulados, encostas côncavas, baixa freqüência de canais, declividades baixas a moderadas (entre 5 a 10\%) e padrão de drenagem dentrítico.

\subsubsection{3 - Unidade 3}

A unidade 3 está representada em todas as sub-bacias e compreendem uma área com aproximadamente 5\% da área total. Está constituída por colinas médias de topo anguloso com encostas côncavas - retilíneas - côncavas e convexas -retilíneas - côncavas, baixa freqüência de canais, declividades moderadas (10 - 20\%) e padrão de drenagem dentrítico.

\subsubsection{4 - Unidade 4}

Em termos areais, a unidade 4, é uma das mais representativas da área de estudo com aproximadamente $26 \%$ da área total e engloba as porções central da Sub-Bacia Córrego do 
Borão, oeste da Sub-Bacia Córrego Alto Retiro e sudeste da Sub-Bacia Córrego São Francisco e setores oeste e noroeste da Sub-Bacia Córrego Itapeva. Compreende colinas pequenas de topo arredondado a anguloso e encostas convexas - retilíneas com alta frequiência de canais, declividades moderadas (entre 10 e 20\%) e padrão de drenagem dentrítico.

\subsubsection{5 - Unidade 5}

Localiza-se na porção central da Sub-Bacia Itapeva com aproximadamente 3\% da área total. Está caracterizada por colinas pequenas de topos aplainados a suavemente ondulados com baixa freqüência de canais, encostas convexas - côncavas, declividade entre 10 - 30\% e padrão de drenagem sub-dentrítico.

\subsubsection{6 - Unidade 6}

A unidade ocupa aproximadamente 3\% da área total e localiza-se na porção centroleste, central e centro sul das sub-bacias córregos Alto Retiro, Santa Rita e São Francisco, respectivamente. Caracteriza-se por colinas amplas de topos arredondados a suavemente ondulados e encostas convexas - côncavas com baixa freqüência de canais, declividades moderadas (10 a 20\%) e padrão de drenagem sub-dentrítico.

\subsubsection{7 - Unidade 7}

Localiza-se nas porções norte da Sub-Bacia Santa Rita e centro-leste da Sub-Bacia Alto Retiro com aproximadamente $2 \%$ da área total. Caracteriza-se por colinas pequenas a médias de topos angulosos e encostas convexas - retilíneas - côncavas com baixa freqüência de canais, declividades moderadas a altas (10 - 30\%) e padrão de drenagem sub-dentrítico.

\subsubsection{8 - Unidade 8}

Essa unidade foi identificada nas porções nordeste da Sub-Bacia Córrego Borão, centro-sul da Sub-Bacia Córrego Alto Retiro, em áreas isoladas da Sub-Bacia Córrego Itapeva e ocupa aproximadamente 5\% da área total. Representada por encostas convexas côncavas, dissecadas, ravinadas, com alta freqüência de canais, declividades baixas a moderadas (5 - 20\%) e padrão de drenagem dentrítico. 


\subsubsection{9 - Unidade 9}

Essa unidade está localizada na porção central da Sub-Bacia Córrego Itapeva com aproximadamente $4 \%$ da área total. Está representada por colinas médias de topos arredondados e encostas convexa-concâvas com baixa freqüência de canais, declividades moderadas (10 - 30\%) e padrão de drenagem sub-dentrítico a subparalelo.

\subsection{0 - Unidade 10}

Essa unidade ocupa aproximadamente 13\% da área total e está representada nas subbacias córregos São Francisco e Itapeva. Constituem-se de morrotes amplos de topos angulosos e encostas convexas - retilíneas - côncavas e convexas - retilíneas, com baixa freqüência de canais, declividades moderadas a altas (entre 10 e 30\%) e padrão de drenagem sub-dentrítico.

\subsection{1 - Unidade 11}

A unidade 11 está representada na porção sul das sub-bacias córregos Borão, Alto Retiro, Santa Rita e Itapeva com aproximadamente 18\% da área total. Caracteriza-se por encostas côncavas, convexas - côncavas amplas com baixa freqüência de canais, declividades suaves a moderadas (entre 5 e 20\%) e padrão de drenagem sub-dentrítico e subparalelo.

\subsection{2 - Unidade 12}

A unidade 12 compreende aproximadamente 6\% da área total e está localizada na porção centro-leste da Sub-Bacia Córrego Itapeva. Caracteriza-se por colinas de topos angulosos ou suavemente ondulados com encostas convexas -côncavas, com média freqüência de canais, declividades moderadas (10-20\%) e padrão de drenagem subdentrítico.

\section{6 - MAPAS DE SUBSTRATO ROCHOSO}

Os mapas de Substrato Rochoso objetivaram a representação dos litotipos existentes, seus contatos e possíveis estruturas (Figuras 5.15 e 5.16). 
$\bar{a}$
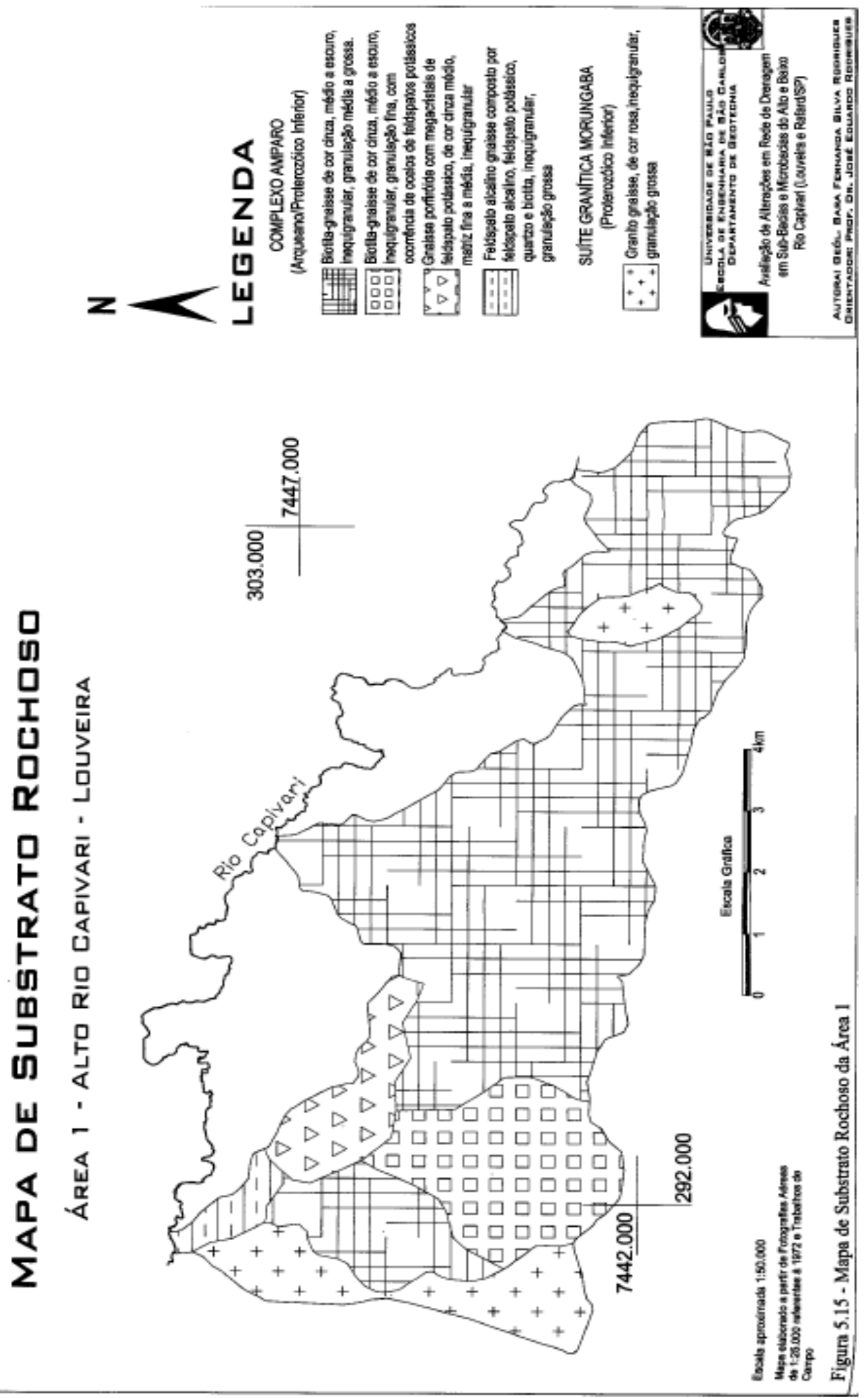

Figura 5.15 - Mapa de Substrato Rochoso da Área 1 


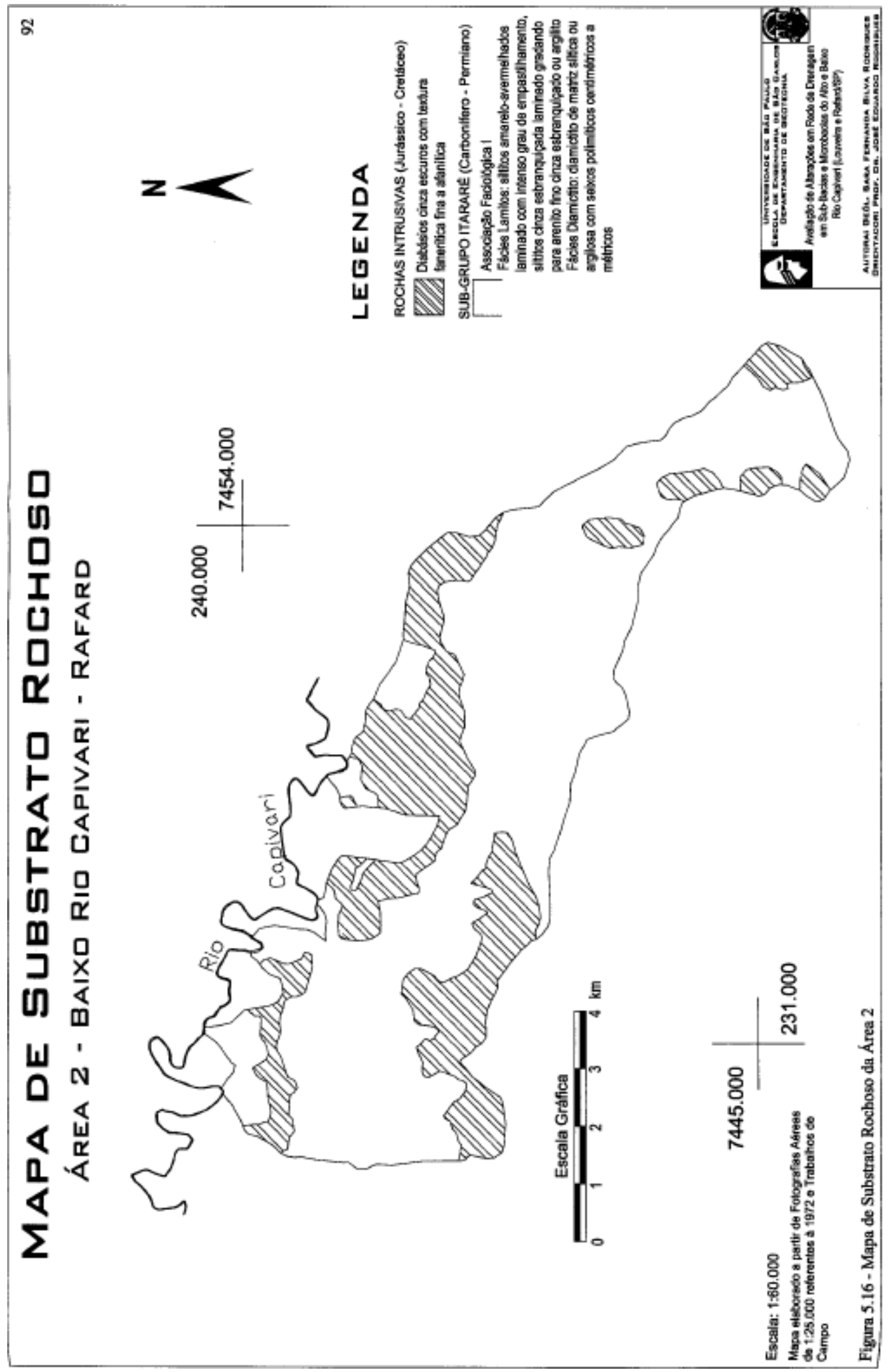

Figura 5.16 - Mapa de Substrato Rochoso da Área 2

\subsection{1 - Área 1 - Alto Rio Capivari}




\subsubsection{1 - Complexo Amparo (Proterozóico Inferior)}

O Complexo Amparo representa 89\% (48,73 km²) da área estudada. Essa região é composta por rochas gnáissicas de biotita - gnaisses, gnaisse porfiróide e feldspato alcalino gnaisse, com predomínio do primeiro litotipo, os quais são descritos abaixo:

- biotita-gnaisses de coloração cinza média a escura, com textura grano-lepidoblástica e composição mineralógica de quartzo, feldspatos e biotitas. Foram subdivididos em dois tipos: 1) com granulação média a grossa e 2) com granulação fina e ocorrência de ocelos de feldspatos potássicos de até $1 \mathrm{~mm}$;

- gnaisses porfiróides de coloração cinza médio, apresentam textura porfiroblástica, seus megacristais de feldspato potássico $(7$ a $10 \mathrm{~cm}$ ) encontram-se imersos numa matriz de textura grano-lepidoblástica fina a média; e,

- feldspato alcalino gnaisse, de cor amarela - acinzentada composto por feldspato alcalino, feldspato potássico, quartzo e biotita, inequigranular, textura grano-lepidoblástica grossa.

As foliações gnáissicas encontradas nessas rochas têm direção NE-SW.

\subsubsection{2 - Suíte Granitica Morungaba (Proterozóico Inferior)}

A Suíte Granítica Morungaba representa 11\% (6,02 $\left.\mathrm{km}^{2}\right)$ da área de estudo. A região é composta por rochas graníticas de coloração rosa-acinzentada, com textura inequigranular grossa.

\subsection{2 - ÁREA 2 - BAIXO RIO CAPIVARI}

\subsubsection{1 - Subgrupo Itararé (Carbonífero Superior - Permiano)}

Com base nos trabalhos de campo foi possível reconhecer a associação faciológica I descrita por Stevaux et al (1987), as rochas que a compõem interdigitam-se entre si. Pode-se subdividi-la da seguinte forma (Figura 5.16):

- Fácies Lamitos: siltitos amarelos-avermelhados laminados com intenso grau de empastilhamento, com espessuras de até $2 \mathrm{~m}$ de exposição, siltitos cinza esbranquiçados laminados gradando para arenitos finos cinza esbranquiçados e argilitos em tons avermelhados com até 5m de exposição; 
- Fácies Diamictito: diamictito de matriz silto-arenosa ou areno-argilosa com seixos polimíticos de rochas metamórficas e ígneas do embasamento da Bacia do Paraná, centimétricos a métricos, com exposição de 1 à 2 metros.

\subsubsection{2 - Rochas Intrusivas (Jurássico - Cretáceo)}

Essa unidade representa $30 \%$ da área de estudo, composta por rochas básicas intrusivas que ocorrem na forma de sills ou diques, ou seja, concordantes ou discordantes ao Sub-Grupo Itararé. Os diabásios de coloração cinza escura apresentam uma textura fanerítica fina a afanítica.

Os sills mostraram espessuras de até $5 \mathrm{~m}$, com intenso fraturamento vertical e subvertical, em alguns perfis é possível ver todo o perfil de alteração, já os diques com orientação NW, subverticalizados apresentaram-se bastante intemperizados e com espessuras em torno de $1,3 \mathrm{~m}$.

\section{7 - MAPAS DE MATERIAIS INCONSOLIDADOS}

As unidades obtidas para os mapas de materiais inconsolidados da área 1 basearamse nos seguintes critérios: gênese (residual ou retrabalhado), textura (arenosa, siltosa, argilosa ou composições), rocha de origem e nível de alteração.

Para a área 1 (Alto Rio Capivari) foram caracterizados um total de 16 unidades. Observou-se que os materiais inconsolidados nessa região estão condicionados principalmente à textura da rocha, à composição dos minerais e à granulação das rochas (Figura 5.17).

Na área 2 (Baixo Rio Capivari) foram definidas 11 unidades de materiais inconsolidados. Essa classificação foi condicionada à rocha de origem, à textura, à caracterização da fração fina e ao perfil de alteração (Figura 5.18).

Na presente pesquisa, com o intuito de identificar os horizontes do perfil de alteração, utilizou-se a classificação baseada nas propostas da British Standards for Site Investigation (BS 5930:1981) - BSSI (1981 apud Price, 1993) (Tabela 5.6).

Tabela 5.6 - Perfil de alteração proposto pela BSSI 5930:1981 (1981 apud Price, 1993)

\begin{tabular}{c|c|c} 
GRAU DE & CLASSIFICAÇÃO & DESCRIÇÃo
\end{tabular}




\begin{tabular}{c|c|l}
\hline ALTERAÇão & Solo Residual & $\begin{array}{l}\text { Toda a rocha está alterada para solo. Estruturas e } \\
\text { texturas destruídas }\end{array}$ \\
\hline VII & Completamente decomposta & $\begin{array}{l}\text { Todo maciço acha-se alterado para solo (saprolito). } \\
\text { Estruturas e texturas intactas }\end{array}$ \\
\hline$V$ & Altamente Decomposta & $\begin{array}{l}\text { Mais de 50\% da rocha está decomposta para solo } \\
\text { (saprolito) e descolorida. Possibilidade da presença de } \\
\text { alguma rocha fresca formando uma malha descontínua }\end{array}$ \\
\hline$I V$ & Moderadamente Alterada & $\begin{array}{l}\text { Menos de 50\% da rocha encontra-se totalmente } \\
\text { decomposta e descolorida. A rocha fresca constitui uma } \\
\text { malha contínua. }\end{array}$ \\
\hline$I I I$ & Levemente Alterada & $\begin{array}{l}\text { A alteração progride ao longo da maioria das } \\
\text { descontinuidades, com leve alteração do maciço } \\
\text { rochosos como um todo }\end{array}$ \\
\hline$I I$ & Fracamente Alterada & $\begin{array}{l}\text { Alteração limitada à superfície das descontinuidades } \\
\text { maiores. }\end{array}$ \\
\hline Rocha Sã & Nenhum sinal de alteração visível \\
\hline
\end{tabular}


2

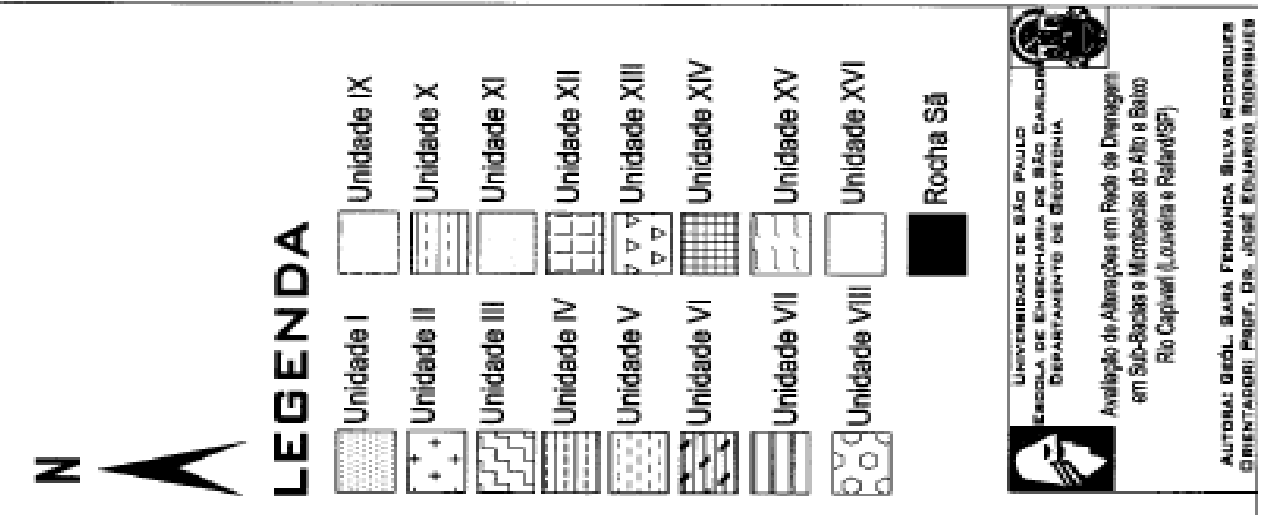

in

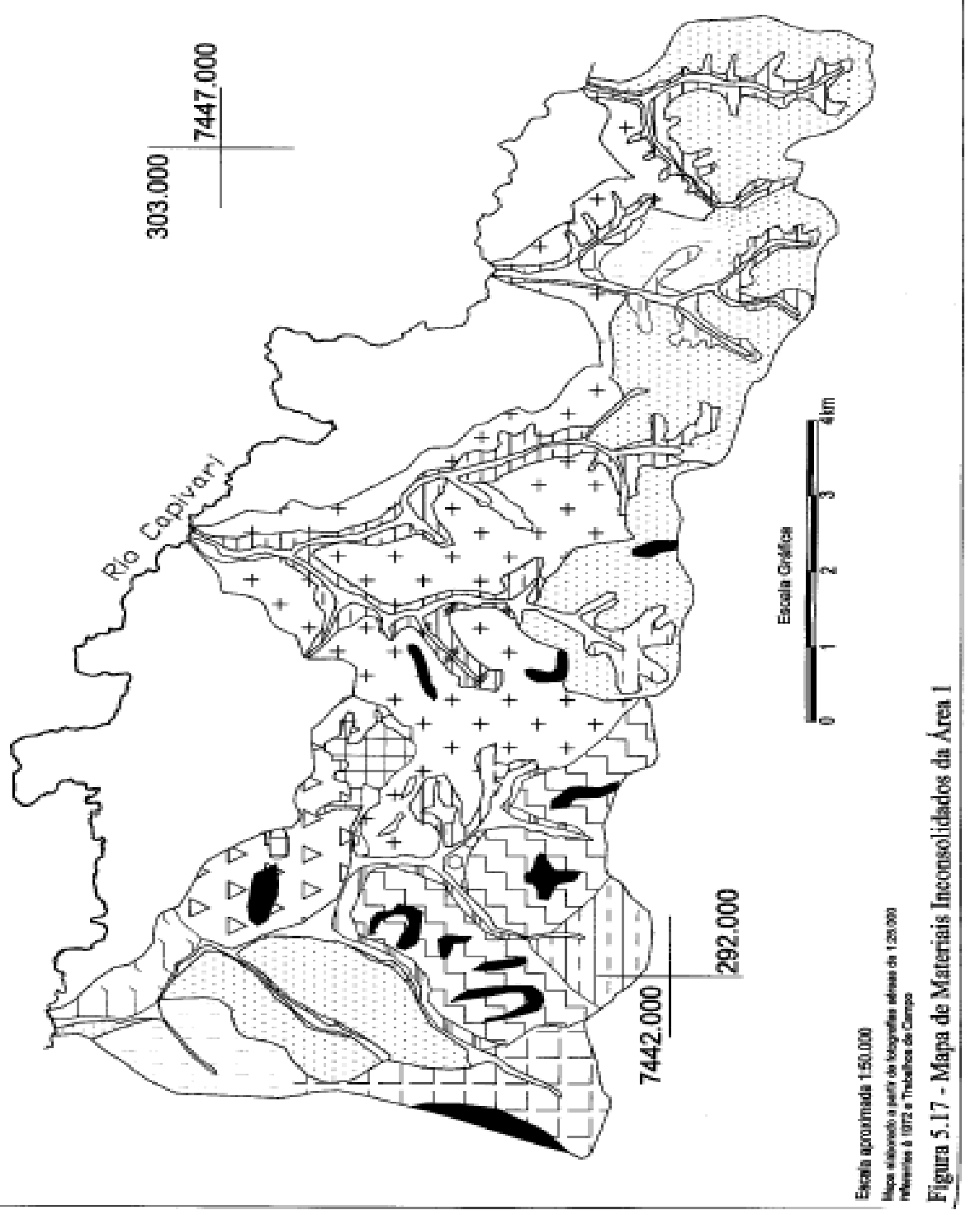

Figura 5.17 - Mapa de Materiais Inconsolidados da Área 1 


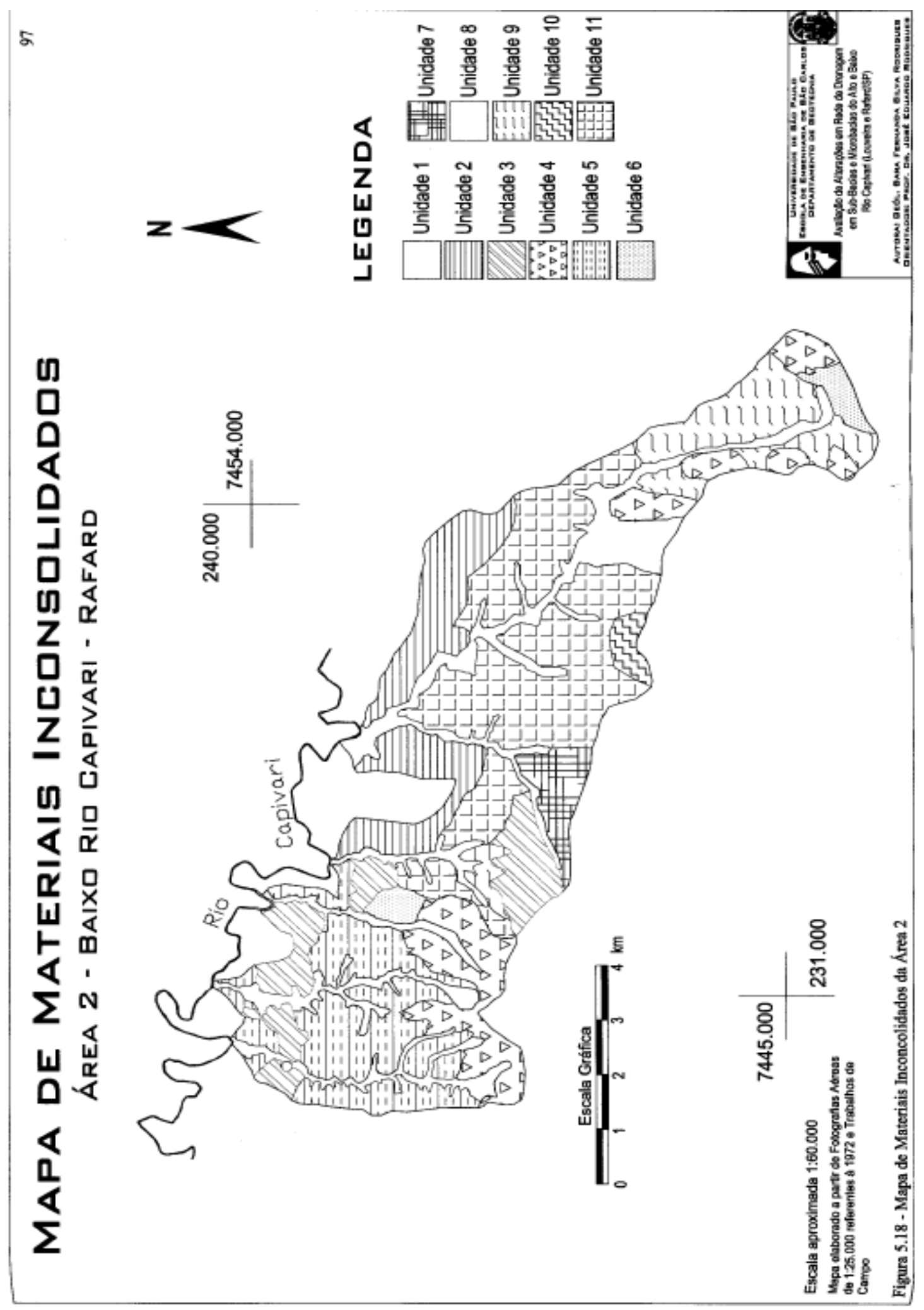

Figura 5.18 - Mapa de Materiais Inconsolidados para a Área 2 


\subsection{1 - Área 1 - Alto Rio Capivari}

\subsubsection{1 - Unidade I (Biotita Gnaisse - Material Areno-Siltoso I)}

Em termos areais, a unidade I é uma das mais representativas na área de estudo 1, com aproximadamente 13,1 $\mathrm{km}^{2}$ da área total. Ocorre em quase toda a Sub-Bacia Córrego Corrupira, no setor sul das sub-bacias Córrego Vale das Vinhas e Córrego Sopezol; e na porção noroeste da Sub-Bacia Ribeirão do Moinho.

Essa unidade é constituída por materiais resultantes da alteração de biotita-gnaisses, os quais estão associados aos landforms D, E, G e J.

Observou-se no perfil de alteração dessa unidade, rochas moderadamente alteradas a altamente decompostas, marcadas por uma foliação gnaíssica expressiva. Esse nível do perfil representa a transição entre o maciço rochoso e de solo, o que permitiu definir-lhes como Horizontes IV e V.

Esse material está exposto em cortes de estrada com espessuras entre 3 a $6 \mathrm{~m}$ e foi descrito nos pontos 7, 8, 9, 15, 20, 21, 27, 67 e 76. Os materiais do Horizonte V foram caracterizados por uma coloração vermelho-amarelada e textura areia média a fina siltosa, predominantemente, mas pode ser silto-arenosa (Tabela 5.7), com porcentagens de argila inferiores a $20 \%$.

Tabela 5.7 - Caracterização textural do material inconsolidado do Horizonte V da Unidade I

\begin{tabular}{|c|c|c|c|c|c|c|c|}
\hline \multirow[t]{3}{*}{ AMOSTRA } & \multicolumn{6}{|c|}{ COMPOSIÇÃO } & \multirow[t]{3}{*}{ CLASSIFICAÇÃO } \\
\hline & \multicolumn{3}{|c|}{ Areia (\%) } & \multirow{2}{*}{$\begin{array}{c}\text { Total de } \\
\text { Areia (\%) }\end{array}$} & \multirow{2}{*}{$\begin{array}{l}\text { Total de } \\
\text { Silte (\%) }\end{array}$} & \multirow{2}{*}{$\begin{array}{c}\text { Total de } \\
\text { Argila (\%) }\end{array}$} & \\
\hline & Grossa & Média & Fina & & & & \\
\hline $7 M$ & 12,1 & 35,9 & 19 & 67,0 & 25 & 8 & $\begin{array}{l}\text { areia média a fina } \\
\text { siltosa }\end{array}$ \\
\hline $8 M$ & 4,6 & 29,7 & 25,3 & 59,6 & 30,4 & 10,0 & “ \\
\hline $9 M$ & 12,1 & 31,9 & 17 & 61,0 & 32,0 & 7,0 & “ \\
\hline $15 M$ & 5 & 28 & 21 & 54,0 & 37,0 & 9,0 & “ \\
\hline $20 M$ & 10 & 38 & 16 & 64 & 30,2 & 5,8 & “ \\
\hline $27 M$ & 8,3 & 33,2 & 27,7 & 69,2 & 21,5 & 9,2 & “ \\
\hline $67 M$ & 11,7 & 23,0 & 19,1 & 53,8 & 34,1 & 12,0 & “ \\
\hline $76 M$ & 5,3 & 17,3 & 18,6 & 41,1 & 41,9 & 16,9 & silto-arenosa \\
\hline $77 M$ & 14,4 & 19,5 & 17,1 & 51,0 & 29,2 & 19,8 & $\begin{array}{l}\text { areia média a fina } \\
\text { siltosa }\end{array}$ \\
\hline
\end{tabular}

Os índices físicos obtidos para o material inconsolidado do Horizonte V da Unidade I mostraram que os valores de massa específica $\left(\rho_{\mathrm{s}}\right)$ variam de 2,669 a 2,717 g/ $\mathrm{cm}^{3}$; massa 
A unidade 2 é bem expressiva na área de estudo 1 com aproximadamente 13,5 km². Ocorre em quase toda a Sub-Bacia Córrego Sopezol, no setor norte das sub-bacias Córrego Vale das Vinhas e Córrego Corrupira e na porção sudeste da Sub-Bacia Ribeirão do Moinho.

Os materiais desta unidade, similar à anterior, também são oriundos da alteração de biotita-gnaisses e estão associados aos landforms B, E e F.

Em relação ao perfil de alteração, definiram-se os horizontes IV e V, que foram caracterizados por uma transição entre solo e rocha, com espessuras entre 1,5 a 10 m. Essa unidade foi descrita nos pontos 1, 12, 24, 36, 44, 53, 54, 70 e 72.

Os materiais inconsolidados do Horizonte $\mathrm{V}$ apresentaram uma coloração vermelhoamarelada, com texturas classificadas como: areia média a grossa siltosa, areia grossa a fina siltosa e areia grossa a média siltosa (Tabela 5.10) e porcentagens de argila inferiores a 18\%.

Tabela 5.10 - Caracterização textural do material inconsolidado do Horizonte V da Unidade II

\begin{tabular}{|c|c|c|c|c|c|c|c|}
\hline \multirow[t]{3}{*}{ AMOSTRA } & \multicolumn{6}{|c|}{ COMPOSIÇÃO } & \multirow{3}{*}{ CLASSIFICAÇÃO } \\
\hline & \multicolumn{3}{|c|}{ Areia (\%) } & \multirow{2}{*}{$\begin{array}{c}\text { Total de } \\
\text { Areia (\%) }\end{array}$} & \multirow{2}{*}{$\begin{array}{l}\text { Total de } \\
\text { Silte (\%) }\end{array}$} & \multirow{2}{*}{$\begin{array}{c}\text { Total de } \\
\text { Argila (\%) }\end{array}$} & \\
\hline & Grossa & Média & Fina & & & & \\
\hline$\overline{1 M}$ & 22,4 & 29,2 & 18,9 & 70,5 & 24,4 & 5,1 & $\begin{array}{c}\text { areia média a grossa } \\
\text { siltosa }\end{array}$ \\
\hline $12 M$ & 56,3 & 22,1 & 7,6 & 85,9 & 10,2 & 3,9 & $\begin{array}{c}\text { areia grossa a média } \\
\text { siltosa }\end{array}$ \\
\hline $24 M$ & 42,1 & 26,6 & 10,2 & 78,9 & 16,8 & 4,2 & “ \\
\hline $36 M$ & 15,2 & 24,3 & 14,4 & 53,8 & 35,9 & 10,3 & $\begin{array}{c}\text { areia média a grossa } \\
\text { siltosa }\end{array}$ \\
\hline $44 M$ & 35,4 & 32,3 & 11,0 & 78,7 & 17,3 & 4,0 & $\begin{array}{c}\text { areia grossa a média } \\
\text { siltosa }\end{array}$ \\
\hline $53 M$ & 22,4 & 22,4 & 16,7 & 61,5 & 31,5 & 7,0 & $\begin{array}{c}\text { areia média a grossa } \\
\text { siltosa }\end{array}$ \\
\hline $54 M$ & 20,2 & 15,4 & 16,3 & 52,0 & 33,7 & 14,3 & $\begin{array}{c}\text { areia grossa a fina } \\
\text { siltosa }\end{array}$ \\
\hline $70 M$ & 13,5 & 19,6 & 11,5 & 44,6 & 37,8 & 17,6 & $\begin{array}{c}\text { areia média a grossa } \\
\text { siltosa }\end{array}$ \\
\hline $72 M$ & 47,0 & 22,4 & 9,3 & 78,7 & 15,1 & 6,2 & $\begin{array}{c}\text { areia grossa a média } \\
\text { siltosa }\end{array}$ \\
\hline
\end{tabular}

Os índices físicos obtidos para esse material mostraram que os valores de massa específica $\left(\rho_{\mathrm{s}}\right)$ variam de 2,646 a $2,807 \mathrm{~g} / \mathrm{cm}^{3}$, massa específica seca $\left(\rho_{\mathrm{d}}\right)$ entre 1,386 a 1,973 $\mathrm{g} / \mathrm{cm}^{3}$, índice de vazios (e) de 0.35 a 0,95 e porosidade (n) entre 0,26 a 0,49 (Tabela 5.11). 
Tabela 5.11 - Índices Físicos obtidos para o material inconsolidado do Horizonte V da Unidade II

\begin{tabular}{c|cccccc}
\hline \multirow{2}{*}{ AMOSTRA } & \multicolumn{7}{c}{ Índices Físicos } \\
\cline { 2 - 7 } & $\boldsymbol{\rho}_{\mathbf{s}}\left(\mathbf{g} / \mathbf{c m}^{\mathbf{3}}\right)$ & $\boldsymbol{w} \mathbf{( \% )}$ & $\boldsymbol{\rho}_{\boldsymbol{d}}\left(\mathbf{g} / \mathbf{c m}^{\mathbf{3}}\right)$ & $\boldsymbol{e}$ & $\boldsymbol{n}$ & $\mathbf{S r}(\mathbf{\%})$ \\
\hline $1 M$ & 2,807 & 3,20 & 1,870 & 0,50 & 0,33 & 17,93 \\
$12 M$ & 2,672 & 1,82 & 1,973 & 0,35 & 0,26 & 13,77 \\
$24 M$ & 2,671 & 2,49 & 1,864 & 0,43 & 0,30 & 15,38 \\
$36 M$ & 2,784 & 0,81 & 1,892 & 0,47 & 0,32 & 4,82 \\
$44 M$ & 2,706 & 2,11 & 1,671 & 0,62 & 0,38 & 9,23 \\
$53 M$ & 2,761 & 5,95 & 1,785 & 0,55 & 0,35 & 30,09 \\
$54 M$ & 2,709 & 18,81 & 1,386 & 0,95 & 0,49 & 53,39 \\
$70 M$ & 2,672 & 5,17 & 1,545 & 0,73 & 0,42 & 18,93 \\
$72 M$ & 2,646 & - & - & - & - & - \\
\hline
\end{tabular}

Os valores de CTC e Acb desta unidade indicaram uma composição mineralógica de caulinita (Tabela 5.12).

De acordo com os valores obtidos para Vb, para os materiais inconsolidados do Horizonte V foi sugerido um comportamento laterítico $(<1,5 \mathrm{~g} / 100 \mathrm{~g}$ solo) e em termos de atividade, os valores de Acb indicaram argilas pouca ativas a normais.

Tabela 5.12 - Caracterização da fração fina do material inconsolidado do Horizonte V da Unidade II usando o Método de Adsorção de Azul de Metileno

\begin{tabular}{|c|c|c|c|c|c|c|}
\hline \multirow[t]{2}{*}{ AMOSTRA } & \multicolumn{6}{|c|}{ CARACTERIZAÇÃO DA FRAÇÃo FINA } \\
\hline & $\begin{array}{l}\text { CTC } \\
\text { (meq/ } \\
100 g)\end{array}$ & $\begin{array}{c}S E \\
\left(m^{2} / g\right)\end{array}$ & $\begin{array}{c}\mathrm{Vb}(\mathrm{g} / \mathbf{1 0 0 g} \\
\text { solo) }\end{array}$ & $\begin{array}{c}\text { Acb } \\
\text { (g/100g } \\
\text { argila) }\end{array}$ & $\begin{array}{c}\text { Atividade das } \\
\text { Argilas } \\
\text { (1) }\end{array}$ & $\begin{array}{c}\text { Comportamento } \\
\text { Laterítico } \\
\text { (2) }\end{array}$ \\
\hline $1 M$ & - & - & - & - & - & - \\
\hline $12 M$ & 0,8 & 6,62 & 0,27 & 6,68 & Normal & Laterítico \\
\hline $24 M$ & - & - & - & - & - & - \\
\hline $36 M$ & 1,5 & 11,4 & 0,47 & 5,27 & Normal & Laterítico \\
\hline $44 M$ & - & - & - & - & - & - \\
\hline $53 M$ & - & - & - & - & - & - \\
\hline $54 M$ & 2,4 & 18,57 & 0,76 & 5,31 & Normal & Laterítico \\
\hline $70 M$ & 16 & 12,45 & 0,51 & 3,02 & Pouco Ativa & “ \\
\hline $72 M$ & 1 & 8,18 & 0,33 & 5,93 & Normal & “ \\
\hline $\begin{array}{l}\text { CTC-Capac } \\
\text { SE - Superfí } \\
\text { (1) Estimado } \\
\text { (2) Estimado }\end{array}$ & $\overline{d e T}$ & & 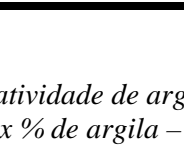 & $\begin{array}{l}V b-M \\
A c b-I ́ n \\
(A c b x\end{array}$ & $\begin{array}{l}\text { de Azul de Metilen } \\
\text { de Atividade da Fr } \\
\text { argila) - Lautrin ( }\end{array}$ & $\begin{array}{l}\text { orvida em 100g de solo } \\
\text { Argila } \\
\text { apud Pejon, 1992) }\end{array}$ \\
\hline
\end{tabular}

\subsubsection{3 - Unidade III (Biotita Gnaisse - Material Areno-Siltoso III)}


Essa unidade situa-se no setor centro-sul da Sub-Bacia Ribeirão do Moinho, com aproximadamente $5,27 \mathrm{~km}^{2}$. Os materiais inconsolidados são resultantes de biotita-gnaisses com presença de ocelos de feldspato potássico, apresentam uma textura predominantemente lepido-granoblástica e granulação bem fina e estão associados à unidade de landform H.

Observou-se no perfil de alteração, que as rochas passaram de moderadamente alteradas para altamente decompostas, com preservação da foliação gnaíssica (Horizonte IV e V). Sua espessura varia entre 3 a $4 \mathrm{~m}$ e foi descrito nos pontos 79 e 83.

Os materiais inconsolidados do Horizonte V caracterizam-se por coloração vinhoamarronzado e texturas que variam de areia média a fina siltosa e areia fina a média siltosa (Tabela 5.13), com porcentagens de argila entre 7 a 15\%.

Tabela 5.13 - Caracterização textural do material inconsolidado do Horizonte V da Unidade III

\begin{tabular}{|c|c|c|c|c|c|c|c|}
\hline \multirow[t]{3}{*}{ AMOSTRA } & \multicolumn{6}{|c|}{ COMPOSIÇÃO } & \multirow[t]{3}{*}{ CLASSIFICAÇÃO } \\
\hline & \multicolumn{3}{|c|}{ Areia (\%) } & \multirow{2}{*}{$\begin{array}{c}\text { Total de } \\
\text { Areia (\%) }\end{array}$} & \multirow{2}{*}{$\begin{array}{l}\text { Total de } \\
\text { Silte (\%) }\end{array}$} & \multirow{2}{*}{$\begin{array}{c}\text { Total de } \\
\text { Argila (\%) }\end{array}$} & \\
\hline & Grossa & Média & Fina & & & & \\
\hline $79 M$ & 12,6 & 25,3 & 17,9 & 55,8 & 29,5 & 14,7 & $\begin{array}{c}\text { areia média a fina } \\
\text { siltosa }\end{array}$ \\
\hline $83 M$ & 6,8 & 21,6 & 31,6 & 60 & 32,4 & 7,6 & $\begin{array}{l}\text { areia fina a média } \\
\text { siltosa }\end{array}$ \\
\hline
\end{tabular}

A Tabela 5.14 mostra os índices físicos obtidos para o material inconsolidado do Horizonte V da Unidade III.

Tabela 5.14 - Índices Físicos obtidos para o material inconsolidado do Horizonte V da Unidade III

\begin{tabular}{c|cccccc}
\hline \multirow{2}{*}{ AMOSTRA } & \multicolumn{6}{c}{ Índices Físicos } \\
\cline { 2 - 7 } & $\boldsymbol{\rho}_{\mathbf{s}}\left(\mathbf{g} / \mathbf{c m}^{\mathbf{3}}\right)$ & $\boldsymbol{w}(\mathbf{\%})$ & $\boldsymbol{\rho}_{\mathbf{d}}\left(\mathbf{g} / \mathbf{c m}^{3}\right)$ & $\boldsymbol{e}$ & $\boldsymbol{n}$ & $\mathbf{S r}(\%)$ \\
\hline $79 M$ & 2,855 & 5,03 & 1,870 & 0,53 & 0,35 & 27,24 \\
$83 M$ & 2,745 & 7,38 & 1,714 & 0,60 & 0,38 & 33,64 \\
\hline
\end{tabular}

Na caracterização da fração fina determinou-se um comportamento laterítico para o material inconsolidado ( $\mathrm{Vb}<$ a 1,5 g/100g solo) composto por caulinita baseando-se nos valores obtidos de CTC e Acb e a atividade das argilas, normal (Tabela 5.15).

Tabela 5.15 - Caracterização da fração fina do material inconsolidado do Horizonte V da Unidade III usando o Método de Adsorção de Azul de Metileno

\begin{tabular}{|c|c|c|c|c|c|c|}
\hline \multirow{2}{*}{ AMOSTRA } & \multicolumn{6}{|c|}{ CARACTERIZAÇÃO DA FRAÇÃO FINA } \\
\hline & $\begin{array}{l}\text { CTC } \\
\text { (meq/ } \\
100 g)\end{array}$ & $\begin{array}{c}\boldsymbol{S} \boldsymbol{E} \\
\left(\mathrm{m}^{2} / \mathrm{g}\right)\end{array}$ & $\begin{array}{c}\text { Vb }(g / 100 g \\
\text { solo })\end{array}$ & $\begin{array}{c}\text { Acb } \\
(g / 100 g \\
\text { argila) }\end{array}$ & $\begin{array}{c}\text { Atividade das } \\
\text { Argilas } \\
\text { (1) }\end{array}$ & $\begin{array}{c}\text { Comportamento } \\
\text { Laterítico } \\
\text { (2) }\end{array}$ \\
\hline
\end{tabular}




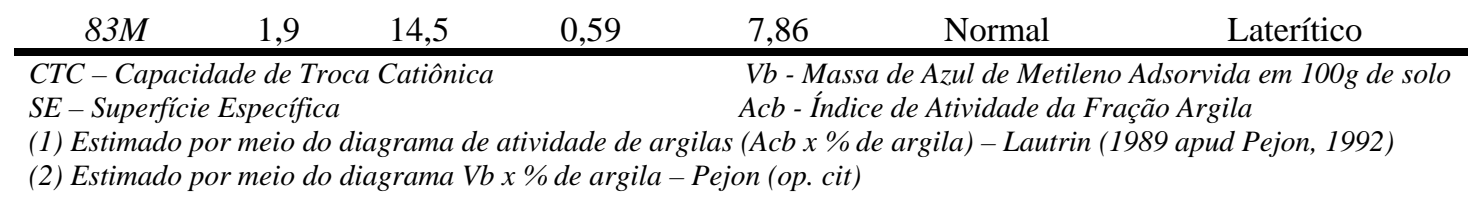

\subsubsection{4 - Unidade IV (Biotita Gnaisse - Material Areno-Siltoso IV)}

A unidade IV ocupa aproximadamente $3,88 \mathrm{~km}^{2}$ da área total. Ocorre em todas as sub-bacias estudadas e seus materiais inconsolidados também são originados da alteração de biotita-gnaisses e estão associados aos landforms B, D, E e F.

No perfil descrito para esse material observou-se que a rocha está completamente alterada para solo, mas há a preservação da foliação gnaíssica da rocha de origem, mais nitidamente nos veios de quartzo, por serem mais resistentes à alteração. As observações pertinentes à alteração permitiu enquadrá-la no Horizonte VI. Sua espessura variou entre $3 \mathrm{a}$ $4 \mathrm{~m}$ e foi descrita nos pontos 32, 38, 39, 41, 42, 45, 46, 47, 73 e 81.

O Horizonte VI, da Unidade IV, caracteriza-se por uma coloração marromavermelhada e texturas: areia média a fina siltosa, areia fina a média siltosa e silto-arenosa (Tabela 5.16), com porcentagens de argila entre 4 a $20 \%$.

Tabela 5.16 - Caracterização textural do material inconsolidado do Horizonte VI da Unidade IV

\begin{tabular}{|c|c|c|c|c|c|c|c|}
\hline \multirow[t]{3}{*}{ AMOSTRA } & \multicolumn{6}{|c|}{ COMPOSIÇÃO } & \multirow[t]{3}{*}{ CLASSIFICAÇÃO } \\
\hline & \multicolumn{3}{|c|}{ Areia (\%) } & \multirow{2}{*}{$\begin{array}{c}\text { Total de } \\
\text { Areia (\%) }\end{array}$} & \multirow{2}{*}{$\begin{array}{l}\text { Total de } \\
\text { Silte (\%) }\end{array}$} & \multirow{2}{*}{$\begin{array}{c}\text { Total de } \\
\text { Argila (\%) }\end{array}$} & \\
\hline & Grossa & Média & Fina & & & & \\
\hline $32 M$ & 3,9 & 12,1 & 25 & 41 & 46 & 13 & silto-arenosa \\
\hline $38 M$ & 10,2 & 33,8 & 22,5 & 66,5 & 28,6 & 4,9 & $\begin{array}{l}\text { areia média a fina } \\
\text { siltosa }\end{array}$ \\
\hline $39 M$ & 13,4 & 39,8 & 19,0 & 72,1 & 19,5 & 8,5 & “ \\
\hline $41 M$ & 14,1 & 33,3 & 21,9 & 69,3 & 22,3 & 8,4 & “ \\
\hline $42 M$ & 18,7 & 27,3 & 22,9 & 68,9 & 28,1 & 3,0 & “ \\
\hline $45 M$ & 5,5 & 17,9 & 21,5 & 44,8 & 44,9 & 10,2 & silto-arenosa \\
\hline $46 M$ & 7,2 & 25,9 & 30,4 & 63,5 & 32,5 & 4,0 & $\begin{array}{l}\text { areia fina a média } \\
\text { siltosa }\end{array}$ \\
\hline $47 M$ & 9,8 & 36,5 & 18,2 & 64,6 & 29,4 & 6,1 & $\begin{array}{l}\text { areia média a fina } \\
\text { siltosa }\end{array}$ \\
\hline $66 M$ & 10,3 & 20,7 & 15,2 & 46,2 & 33,1 & 20,7 & “ \\
\hline $73 M$ & 10,2 & 17,6 & 15,3 & 43,0 & 36,6 & 20,3 & “ \\
\hline $81 M$ & 12,5 & 25,7 & 15,4 & 53,7 & 26,5 & 19,9 & “ \\
\hline
\end{tabular}

A Tabela 5.17 apresenta os índices físicos obtidos para o material areno-siltoso. Seus intervalos de massa específica $\left(\rho_{\mathrm{s}}\right)$ variaram de 2,684 a 2,805 g/ $\mathrm{cm}^{3}$; massa específica seca $\left(\rho_{\mathrm{d}}\right)$ entre 1,090 a $1,384 \mathrm{~g} / \mathrm{cm}^{3}$; índice de vazios (e) de 0,66 a 1,51; e porosidade (n) entre 0,40 a 0,60 . 
Tabela 5.17 - Índices Físicos obtidos para o material inconsolidado do Horizonte VI da Unidade IV

\begin{tabular}{c|cccccc}
\hline \multirow{2}{*}{ AMOSTRA } & \multicolumn{7}{c}{ Índices Físicos } \\
\cline { 2 - 7 } & $\boldsymbol{\rho}_{\mathbf{s}}\left(\mathbf{g} / \mathbf{c m}^{\mathbf{3}}\right)$ & $\boldsymbol{w} \mathbf{( \% )}$ & $\boldsymbol{\rho}_{\boldsymbol{d}}\left(\mathbf{g} / \mathbf{c m}^{\mathbf{3}}\right)$ & $\boldsymbol{e}$ & $\boldsymbol{n}$ & $\mathbf{S r} \mathbf{( \% )}$ \\
\hline $32 M$ & 2,805 & 20,05 & 1,384 & 1,03 & 0,51 & 54,74 \\
$38 M$ & 2,684 & - & - & - & - & - \\
$39 M$ & 2,690 & 6,67 & 1,625 & 0,66 & 0,40 & 27,37 \\
$41 M$ & 2,732 & 6,96 & 1,585 & 0,72 & 0,42 & 26,26 \\
$42 M$ & 2,717 & 7,70 & 1,568 & 0,73 & 0,42 & 28,57 \\
$45 M$ & 2,741 & 13,54 & 1,090 & 1,51 & 0,60 & 24,49 \\
$46 M$ & 2,703 & 17,09 & 1,195 & 1,26 & 0,56 & 36,59 \\
$47 M$ & 2,729 & 11,51 & 1,308 & 1,09 & 0,52 & 28,89 \\
$66 M$ & 2,714 & 0,36 & 1,857 & 0,46 & 0,32 & 2,10 \\
$73 M$ & 2,745 & 13,93 & 1,258 & 1,18 & 0,54 & 32,34 \\
$81 M$ & 2,757 & 13,21 & 1,247 & 1,21 & 0,55 & 30,09 \\
\hline
\end{tabular}

Pelos resultados obtidos para a caracterização da fração fina da Unidade IV, apresentados na Tabela 5.18, foi possível fazer algumas considerações:

- Os valores de $\mathrm{Vb}$ inferiores a 1,5 g/100g de solo indicaram um comportamento laterítico para o material inconsolidado;

- Os valores de Acb sugerem que a atividade das argilas varia de pouco ativa a normal (Lautrin, 1989 apud Pejon, 1992); e,

- Os baixos valores de CTC demonstram na composição o predomínio de caulinita na composição mineralógica.

Tabela 5.18 - Caracterização da fração fina do material inconsolidado do Horizonte VI da Unidade IV usando o Método de Adsorção de Azul de Metileno

\begin{tabular}{c|cccccc}
\hline AMOSTRA & \multicolumn{5}{c}{ CARACTERIZAÇão DA FRAÇão FINA } \\
\cline { 2 - 7 } & $\begin{array}{c}\boldsymbol{C T C} \\
(\mathrm{meq} /\end{array}$ & $\begin{array}{c}\boldsymbol{S E} \\
\left(\mathrm{m}^{2} / \mathrm{g}\right)\end{array}$ & $\begin{array}{c}\boldsymbol{V b}(\mathrm{g} / 100 \mathrm{~g} \\
\text { solo })\end{array}$ & $\begin{array}{c}\text { Acb } \\
(\mathrm{g} / 100 \mathrm{~g} \\
\text { argila })\end{array}$ & $\begin{array}{c}\text { Atividade das } \\
\text { Argilas } \\
(1)\end{array}$ & $\begin{array}{c}\text { Comportamento } \\
\text { Laterítico } \\
(2)\end{array}$ \\
\hline $32 M$ & 3,8 & 29,43 & 1,2 & 9,15 & Normal & Laterítico \\
$38 M$ & - & - & - & - & - & - \\
$39 M$ & 1,7 & 13,11 & 0,54 & 6,23 & Normal & Laterítico \\
$41 M$ & 1,8 & 14,09 & 0,58 & 6,86 & Normal & “ \\
$42 M$ & - & - & - & - & - & - \\
$45 M$ & - & - & - & - & - & - \\
$46 M$ & - & - & - & - & - & - \\
$47 M$ & - & - & - & - & - & Laterítico \\
$66 M$ & 3 & 23,54 & 0,96 & 5,72 & Normal & " \\
$73 M$ & 2 & 15,59 & 0,64 & 3,22 & Pouco Ativa &
\end{tabular}




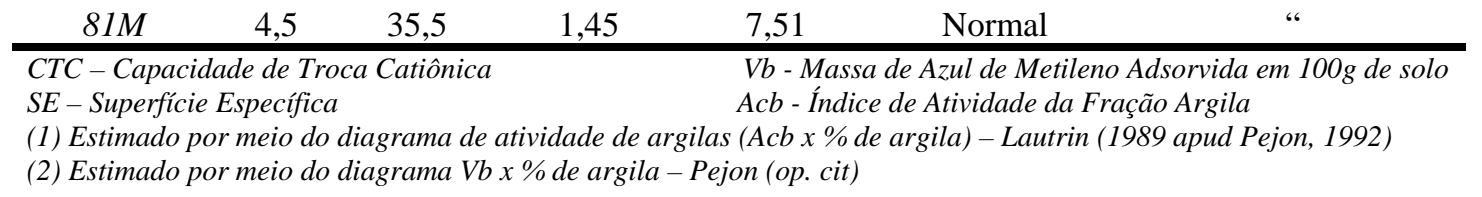

\subsubsection{5 - Unidade V (Biotita Gnaisse - Material Areno-Argiloso I)}

A Unidade V apresenta pequena expressão areal, com aproximadamente 0,91 km² e ocorre em áreas isoladas nas sub-bacias Córrego Sopezol e Córrego Vale das Vinhas. Seus materiais inconsolidados são oriundos da alteração de biotita-gnaisses, com textura predominantemente lepido-granoblásticas com granulação fina e estão associados aos landforms D e G.

Representa o Horizonte VI, descrito como um maciço de solo com estruturação original da rocha, observa-se que a foliação gnaíssica foi mais preservada próximo aos veios de quartzo. O perfil foi descrito nos pontos 35 e 68.

O material foi caracterizado por coloração marrom-avermelhada, textura areia fina a média argilosa (Tabela 5.19), porcentagens de argila em torno de $30 \%$ e espessuras entre 1,5 a $4 \mathrm{~m}$.

Tabela 5.19 - Caracterização textural do material inconsolidado do Horizonte VI da Unidade V

\begin{tabular}{c|ccc|ccc|c}
\hline \multirow{2}{*}{ MMOSTRA } & \multicolumn{5}{|c|}{ COMPOSIÇão } & \multirow{2}{*}{ CLASSIFICAÇÃo } \\
\cline { 2 - 6 } & \multicolumn{3}{|c|}{ Areia (\%) } & $\begin{array}{c}\text { Total de } \\
\text { Areia (\%) }\end{array}$ & $\begin{array}{c}\text { Total de } \\
\text { Silte (\%) }\end{array}$ & $\begin{array}{c}\text { Total de } \\
\text { Argila (\%) }\end{array}$ & \\
\cline { 2 - 7 } & Grossa & Média & Fina & \\
\hline $35 M$ & 10,3 & 24,9 & 15,7 & 50,9 & 15,7 & 33,4 & areia média a fina \\
$68 M$ & 11,6 & 25,7 & 13,8 & 51,1 & 19,7 & 29,2 & argilosa \\
\hline
\end{tabular}

A Tabela 5.20 mostra os índices físicos definidos para esse material.

Tabela 5.20 - Índices Físicos obtidos para o material inconsolidado do Horizonte VI da Unidade $\mathrm{V}$

\begin{tabular}{c|cccccc}
\hline \multirow{2}{*}{ AMOSTRA } & \multicolumn{7}{c}{ Índices Físicos } \\
\cline { 2 - 7 } & $\boldsymbol{\rho}_{\mathbf{s}}\left(\mathbf{g} / \mathbf{c m}^{\mathbf{3}}\right)$ & $\boldsymbol{w} \mathbf{~ ( \% )}$ & $\boldsymbol{\rho}_{\mathbf{d}}\left(\mathbf{g} / \mathbf{c m}^{\mathbf{3}}\right)$ & $\boldsymbol{e}$ & $\boldsymbol{n}$ & $\mathbf{S r}(\%)$ \\
\hline $35 M$ & 2,707 & 7,08 & 1,508 & 0,80 & 0,44 & 26,55 \\
$68 M$ & 2,728 & 10,47 & 1,374 & 0,99 & 0,50 & 28,98 \\
\hline
\end{tabular}

Para a fração fina pode-se definir que em relação a composição e ao comportamento do material inconsolidado, as características obtidas foram similares às obtidas para as demais unidades: presença de caulinita e valores de $\mathrm{Vb}$ menores que $1,5 \mathrm{~g} / 100 \mathrm{~g}$ de solo que indicam um comportamento laterítico, respectivamente. Quanto à atividade as argilas variaram de inativas a normais (Tabela 5.21). 
Tabela 5.21 - Caracterização da fração fina do material inconsolidado do Horizonte VI da Unidade V usando o Método de Adsorção de Azul de Metileno

\begin{tabular}{|c|c|c|c|c|c|c|}
\hline \multirow[t]{2}{*}{ AMOSTRA } & \multicolumn{6}{|c|}{ CARACTERIZAÇÃO DA FRAÇÃO FINA } \\
\hline & $\begin{array}{l}C T C \\
(m e q / \\
100 g)\end{array}$ & $\begin{array}{c}\boldsymbol{S E} \\
\left(\mathrm{m}^{2} / g\right)\end{array}$ & $\begin{array}{c}\text { Vb }(g / 100 g \\
\text { solo })\end{array}$ & $\begin{array}{l}\text { Acb } \\
(g / 100 g \\
\text { argila) }\end{array}$ & $\begin{array}{l}\text { Atividade das } \\
\text { Argilas } \\
\text { (1) }\end{array}$ & $\begin{array}{l}\text { Comportamento } \\
\text { Laterítico } \\
\text { (2) }\end{array}$ \\
\hline $35 M$ & 1,1 & 8,7 & 0,36 & 1,15 & Inativo & Laterítico \\
\hline $68 M$ & 4,9 & 38,03 & 1,55 & 5,73 & Normal & Laterítico \\
\hline \multicolumn{7}{|c|}{$\begin{array}{lc}\text { CTC - Capacidade de Troca Catiônica } & \text { Vb - Massa de Azul de Metileno Adsorvida em 100g de sc } \\
\text { SE - Superfície Específica } & \text { Acb - Índice de Atividade da Fração Argila } \\
\text { (1) Estimado por meio do diagrama de atividade de argilas (Acb x \% de argila) - Lautrin (1989 apud Pejon, 1992) } \\
\text { (2) Estimado por meio do diagrama } V b \times \text { de argila - Pejon (op. cit) }\end{array}$} \\
\hline
\end{tabular}

\subsubsection{6 - Unidade VI (Biotita Gnaisse - Material Areno-Argiloso II)}

A Unidade VI está localizada numa pequena porção da Sub-Bacia Córrego Sopezol, com aproximadamente $0,47 \mathrm{~km}^{2}$. Seus materiais inconsolidados resultam da alteração de biotita-gnaisses e estão associados à Unidade de landform E.

A alteração da rocha enquadra-se no Horizonte VI, com preservação da foliação no maciço de solo. Suas espessuras variam entre 0,5 a $3 \mathrm{~m}$.

Os materiais inconsolidados foram descritos nos pontos 48, 49, 50, 51 e 52 e apresentam coloração amarela-avermelhada, texturas areia grossa a fina silto-argilosa, siltoarenosa e areia grossa a média argilosa (Tabela 5.22) e porcentagens de argila entre 12 a $38 \%$.

Tabela 5.22 - Caracterização textural do material inconsolidado do Horizonte VI da Unidade VI

\begin{tabular}{|c|c|c|c|c|c|c|c|}
\hline \multirow[t]{3}{*}{ AMOSTRA } & \multicolumn{6}{|c|}{ COMPOSIÇÃO } & \multirow[t]{3}{*}{ CLASSIFICAÇÃO } \\
\hline & \multicolumn{3}{|c|}{ Areia (\%) } & \multirow{2}{*}{$\begin{array}{c}\text { Total de } \\
\text { Areia (\%) }\end{array}$} & \multirow{2}{*}{$\begin{array}{l}\text { Total de } \\
\text { Silte (\%) }\end{array}$} & \multirow{2}{*}{$\begin{array}{c}\text { Total de } \\
\text { Argila (\%) }\end{array}$} & \\
\hline & Grossa & Média & Fina & & & & \\
\hline $48 M$ & 21,0 & 13,4 & 14,8 & 49,2 & 25,4 & 25,4 & $\begin{array}{l}\text { areia grossa a fina } \\
\text { silto-argilosa }\end{array}$ \\
\hline $50 M$ & 18,5 & 21,4 & 9,3 & 49,2 & 12,4 & 38,4 & $\begin{array}{l}\text { areia média a } \\
\text { grossa argilosa }\end{array}$ \\
\hline $51 M$ & 9,6 & 12,5 & 16,2 & 38,3 & 49,5 & 12,1 & silto-arenoso \\
\hline
\end{tabular}

A Tabela 5.23 apresenta os índices físicos obtidos para o material inconsolidado da Unidade VI. 
Tabela 5.23 - Índices Físicos obtidos para o material inconsolidado do Horizonte VI da Unidade VI

\begin{tabular}{c|cccccc}
\hline \multirow{2}{*}{ AMOSTRA } & \multicolumn{7}{c}{ Índices Físicos } \\
\cline { 2 - 7 } & $\rho_{\boldsymbol{s}}\left(\mathbf{g} / \mathbf{c m}^{\mathbf{3}}\right)$ & $\boldsymbol{w} \mathbf{( \% )}$ & $\boldsymbol{\rho}_{\boldsymbol{d}}\left(\mathbf{g} / \mathbf{c m}^{\mathbf{3}}\right)$ & $\boldsymbol{e}$ & $\boldsymbol{n}$ & $\mathbf{S r}(\%)$ \\
\hline $48 M$ & 2,694 & - & - & - & - & - \\
$50 M$ & 2,722 & 7,52 & 1,590 & 0,71 & 0,42 & 28,76 \\
$51 M$ & 2,691 & 14,84 & 1,121 & 1,40 & 0,58 & 28,48 \\
\hline
\end{tabular}

Na caracterização da fração fina por meio dos índices (CTC, Vb e Acb) obtidos pelo ensaio de adsorção de azul de metileno determinou-se: comportamento laterítico para o material inconsolidado apresenta um comportamento laterítico composto por caulinita e quanto à atividade, as argilas apresentaram-se inativas a normais (Tabela 5.24).

Tabela 5.24 - Caracterização da fração fina do material inconsolidado do Horizonte VI da Unidade VI usando o Método de Adsorção de Azul de Metileno

\begin{tabular}{|c|c|c|c|c|c|c|}
\hline \multirow[t]{2}{*}{ AMOSTRA } & \multicolumn{6}{|c|}{ CARACTERIZAÇÃO DA FRAÇÃO FINA } \\
\hline & $\begin{array}{l}\text { CTC } \\
(\text { meq/ } \\
100 g)\end{array}$ & $\begin{array}{c}\boldsymbol{S E} \\
\left(\mathrm{m}^{2} / \mathrm{g}\right)\end{array}$ & $\begin{array}{c}\text { Vb }(g / 100 g \\
\text { solo })\end{array}$ & $\begin{array}{l}\text { Acb } \\
(g / 100 g \\
\text { argila) }\end{array}$ & $\begin{array}{l}\text { Atividade das } \\
\text { Argilas } \\
\quad(1)\end{array}$ & $\begin{array}{l}\text { Comportamento } \\
\text { Laterítico } \\
\text { (2) }\end{array}$ \\
\hline $48 M$ & 3,7 & 29,32 & 1,2 & 5 & Normal & Laterítico \\
\hline $50 M$ & 2,2 & 116,84 & 0,69 & 1,92 & Inativa & Laterítico \\
\hline $51 M$ & 3,2 & 25,11 & 1,03 & 8,5 & Normal & Laterítico \\
\hline \multicolumn{7}{|c|}{$\begin{array}{lc}\text { CTC - Capacidade de Troca Catiônica } & \text { Vb - Massa de Azul de Metileno Adsorvida em 100g de sc } \\
\text { SE - Superfície Específica } & \text { Acb - Índice de Atividade da Fração Argila } \\
\text { (1) Estimado por meio do diagrama de atividade de argilas (Acb } \% \text { de argila) - Lautrin (1989 apud Pejon, 1992) } \\
\text { (2) Estimado por meio do diagrama Vb x\% de argila - Pejon (op. cit) }\end{array}$} \\
\hline
\end{tabular}

\subsubsection{7 - Unidade VII (Biotita Gnaisse - Material Argilo-Arenoso)}

A unidade VII localiza-se na porção central e no setor sudeste da Sub-Bacia Ribeirão do Moinho, com aproximadamente $0,74 \mathrm{~km}^{2}$. Os materiais estão associados aos landforms $\mathrm{H}$ e são resultantes da alteração de biotita-gnaisses com ocelos.

Essa unidade representa o Horizonte VI, que foi caracterizado por apresentar rochas completamente decompostas para solo, ou seja, um maciço de solo com preservação das estruturas e texturas originais. Sua espessura variou entre 3 a $4 \mathrm{~m}$ e foi descrita no ponto 76.

Os materiais inconsolidados apresentam uma coloração marrom escura e textura argilo-arenosa (Tabela 5.25), com porcentagens de argila em torno de $40 \%$.

Tabela 5.25 - Caracterização textural do material inconsolidado do Horizonte VI da Unidade VII 


\begin{tabular}{cccc|ccc|c}
\cline { 2 - 7 } & \multicolumn{3}{c|}{ Areia (\%) } & Total de & Total de & Total de \\
Areia (\%) & Silte (\%) & Argila (\%) & \\
\cline { 2 - 8 } & Grossa & Média & Fina & 29,0 & 26,4 & 44,6 & argilo-arenosa \\
\hline 76,2 & 8,6 & 16,2 & & &
\end{tabular}

Os índices físicos obtidos para o material inconsolidado da Unidade VII são apresentados na Tabela 5.26.

Tabela 5.26 - Índices Físicos obtidos para o material inconsolidado do Horizonte VI da Unidade VII

\begin{tabular}{c|cccccc}
\hline \multirow{2}{*}{ AMOSTRA } & \multicolumn{5}{c}{ Índices Físicos } \\
\cline { 2 - 6 } & $\rho_{\mathrm{s}}\left(\mathbf{g} / \mathbf{c m}^{\mathbf{3}}\right)$ & $\boldsymbol{w}(\%)$ & $\rho_{d}\left(\mathbf{g} / \mathbf{c m}^{3}\right)$ & $\boldsymbol{e}$ & $\boldsymbol{n}$ & Sr (\%) \\
\hline $76 M$ & 2,720 & 15,32 & 1,372 & 0,98 & 0,50 & 42,43 \\
\hline
\end{tabular}

Os valores de $\mathrm{Vb}$ menores que $1,5 \mathrm{~g} / 100 \mathrm{~g}$ de solo indicam um comportamento laterítico, com pouca atividade das argilas e baixos valores de CTC (Tabela 5.27). Na composição mineralógica da fração argila, tem-se como mineral predominante caulinita segundo Lautrin (1989 apud Pejon, 1992).

Tabela 5.27 - Caracterização da fração fina do material inconsolidado do Horizonte VI da Unidade VII usando o Método de Adsorção de Azul de Metileno

\begin{tabular}{|c|c|c|c|c|c|c|}
\hline \multirow[t]{2}{*}{ AMOSTRA } & \multicolumn{6}{|c|}{ CARACTERIZAÇÃO DA FrAÇÃO FINA } \\
\hline & $\begin{array}{c}\text { CTC } \\
\text { (meq/ } \\
100 g)\end{array}$ & $\begin{array}{c}\boldsymbol{S E} \\
\left(\mathrm{m}^{2} / \mathrm{g}\right)\end{array}$ & $\begin{array}{c}\mathbf{V b}(g / 100 g \\
\text { solo })\end{array}$ & $\begin{array}{c}\text { Acb } \\
(g / 100 g \\
\text { argila) }\end{array}$ & $\begin{array}{c}\text { Atividade das } \\
\text { Argilas } \\
\text { (1) }\end{array}$ & $\begin{array}{c}\text { Comportamento } \\
\text { Laterítico } \\
(2)\end{array}$ \\
\hline $76 M$ & 3,6 & 28,33 & 1,16 & 2,64 & Pouco Ativa & Laterítico \\
\hline $\begin{array}{l}\text { CTC-Capaci } \\
\text { SE-Superfíci } \\
\text { (1) Estimado } p \\
\text { (2) Estimado p }\end{array}$ & $\begin{array}{l}\text { e de Tro } \\
\text { specífica } \\
\text { meio do }\end{array}$ & a Catiônic & $d$ & $\begin{array}{l}V b-M a \\
A c b-I ́ n d \\
\text { s (Acb } \times \% \\
\text { ion (op. ci }\end{array}$ & $\begin{array}{l}\text { de Azul de Metilen } \\
\text { de Atividade da Fr } \\
\text { argila) - Lautrin }\end{array}$ & $\begin{array}{l}\text { sorvida em } 100 \mathrm{~g} \text { de solo } \\
\text { Argila } \\
\text { apud Pejon, 1992) }\end{array}$ \\
\hline
\end{tabular}

\subsubsection{8 - Unidade VIII (Biotita Gnaisse - Material Argilo-Arenoso II)}

Essa unidade apresenta pequena expressão areal, com aproximadamente 0,2 $\mathrm{km}^{2}$ da área total. Localiza-se em pequenos setores na Sub-Bacia Ribeirão do Moinho. Seus materiais inconsolidados são oriundos da alteração de biotita-gnaisses e estão associados aos landforms E e H.

Nessa unidade descreveu-se um maciço de solo, onde a estruturação primária foi totalmente destruída, caracterizando o horizonte como Solo Residual (VII). Sua espessura varia entre 1,5 a 2 m e foi descrita nos pontos 65 e 74.

Os materiais inconsolidados caracterizam-se por uma coloração marrom escura, textura argilo-arenosa (Tabela 5.28) e porcentagens de argila em torno de 50\%. 
Tabela 5.28 - Caracterização textural do solo residual da Unidade VIII

\begin{tabular}{c|ccc|ccc|c}
\hline \multirow{2}{*}{ AMOSTRA } & \multicolumn{6}{c|}{ COMPOSIÇÃo } & CLASSIFICAÇÃo \\
\cline { 2 - 7 } & \multicolumn{3}{|c|}{ Areia (\%) } & $\begin{array}{c}\text { Total de } \\
\text { Areia (\%) }\end{array}$ & $\begin{array}{c}\text { Total de } \\
\text { Silte (\%) }\end{array}$ & $\begin{array}{c}\text { Total de } \\
\text { Argila } \\
\text { (\%) }\end{array}$ & \\
\cline { 2 - 7 } & Grossa & Média & Fina & & & \\
\hline $65 M$ & 8,5 & 11,8 & 13,6 & 34,0 & 15,7 & 50,3 & Argilo-arenosa \\
$74 M$ & 12,6 & 9,8 & 8,3 & 30,7 & 19,9 & 49,4 & “ \\
\hline
\end{tabular}

Os índices físicos definidos para esse material são apresentados na Tabela 5.29.

Tabela 5.29 - Índices Físicos obtidos para o solo residual da Unidade VIII

\begin{tabular}{c|cccccc}
\hline AMOSTRA & \multicolumn{7}{c}{ Índices Físicos } \\
\cline { 2 - 7 } & $\boldsymbol{\rho}_{\mathbf{s}}\left(\mathbf{g} / \mathbf{c m}^{\mathbf{3}}\right)$ & $\boldsymbol{w} \mathbf{( \% )}$ & $\rho_{d}\left(\mathbf{g} / \mathbf{c m}^{\mathbf{3}}\right)$ & $\boldsymbol{e}$ & $\boldsymbol{n}$ & $\mathbf{S r}(\%)$ \\
\hline $65 M$ & 2,729 & 16,06 & 1,296 & 1,11 & 0,52 & 39,65 \\
$74 M$ & 2,801 & 18,90 & 1,568 & 0,79 & 0,44 & 67,38 \\
\hline
\end{tabular}

Os valores de $\mathrm{Vb}$ inferiores a 1,5 g/100g sugerem um comportamento laterítico. As argilas são pouco ativas, com baixos valores de CTC que indica a presença de caulinita (Tabela 5.30).

Tabela 5.30 - Caracterização da fração fina do solo residual da Unidade VIII usando o Método de Adsorção de Azul de Metileno

\begin{tabular}{|c|c|c|c|c|c|c|}
\hline \multirow[t]{2}{*}{ AMOSTRA } & \multicolumn{6}{|c|}{ CARACTERIZAÇÃO DA FrAÇÃo FINA } \\
\hline & $\begin{array}{l}\text { CTC } \\
\text { (meq/ } \\
100 \mathrm{~g}) \\
\end{array}$ & $\begin{array}{c}S \boldsymbol{S E} \\
\left(\mathrm{m}^{2} / \mathrm{g}\right)\end{array}$ & $\begin{array}{l}\boldsymbol{V} \boldsymbol{b}(\mathrm{g} / 100 \mathrm{~g} \\
\text { solo })\end{array}$ & $\begin{array}{c}\text { Acb } \\
\text { (g/100g } \\
\text { argila) } \\
\end{array}$ & $\begin{array}{c}\text { Atividade das } \\
\text { Argilas } \\
\text { (1) }\end{array}$ & $\begin{array}{c}\text { Comportamento } \\
\text { Laterítico } \\
\text { (2) }\end{array}$ \\
\hline $65 M$ & 2,2 & 17,05 & 0,7 & 1,49 & Pouco Ativa & Laterítico \\
\hline $74 M$ & 4,3 & 33,36 & 1,36 & 2,85 & Pouco Ativa & Laterítico \\
\hline \multicolumn{7}{|c|}{$\begin{array}{lc}\text { CTC - Capacidade de Troca Catiônica } & \text { Vb - Massa de Azul de Metileno Adsorvida em 100g de sol } \\
\text { SE - Superfície Específica } & \text { Acb - Índice de Atividade da Fração Argila } \\
\text { (1) Estimado por meio do diagrama de atividade de argilas (Acb x \% de argila) - Lautrin (1989 apud Pejon, 1992) } \\
\text { (2) Estimado por meio do diagrama Vb x \% de argila - Pejon (op. cit) }\end{array}$} \\
\hline
\end{tabular}

\subsubsection{9 - Unidade IX (Biotita Gnaisse - Material Areno-Argiloso III)}

A Unidade IX ocorre em pequenas porções da Sub-Bacia Córrego Sopezol, com aproximadamente $0,25 \mathrm{~km}^{2}$. Seus materiais são originados da alteração de biotita-gnaisses e estão associados aos landforms D e F.

Essa unidade foi descrita nos pontos 69 e 71 e é caracterizada por um horizonte de solo residual (Horizonte VII) em que as estruturas primárias foram completamente destruídas 
Apresenta coloração marrom escura, textura areno-argilosa (Tabela 5.31) e espessuras que variam entre 1,5 a $3 \mathrm{~m}$.

Tabela 5.31 - Caracterização textural do solo residual da Unidade IX

\begin{tabular}{|c|c|c|c|c|c|c|c|}
\hline \multirow[t]{3}{*}{ AMOSTRA } & \multicolumn{6}{|c|}{ COMPOSIÇÃo } & \multirow[t]{3}{*}{ CLASSIFICAÇÃO } \\
\hline & \multicolumn{3}{|c|}{ Areia (\%) } & \multirow{2}{*}{$\begin{array}{c}\text { Total de } \\
\text { Areia (\%) }\end{array}$} & \multirow{2}{*}{$\begin{array}{l}\text { Total de } \\
\text { Silte (\%) }\end{array}$} & \multirow{2}{*}{$\begin{array}{c}\text { Total de } \\
\text { Argila (\%) }\end{array}$} & \\
\hline & Grossa & Média & Fina & & & & \\
\hline $69 M$ & 12,8 & 25,2 & 16,9 & 55,0 & 9,4 & 35,6 & Areno-argilosa \\
\hline $71 M$ & 9,4 & 18,0 & 17,6 & 45,1 & 12,4 & 42,5 & \\
\hline
\end{tabular}

A Tabela 5.32 mostra os índices físicos obtidos para o material inconsolidado da Unidade IX.

Tabela 5.32 - Índices Físicos obtidos para solo residual da Unidade IX

\begin{tabular}{c|cccccc}
\hline \multirow{2}{*}{ AMOSTRA } & \multicolumn{7}{c}{ Índices Físicos } \\
\cline { 2 - 7 } & $\boldsymbol{\rho}_{\mathbf{s}}\left(\mathbf{g} / \mathbf{c m}^{\mathbf{3}}\right)$ & $\boldsymbol{w} \mathbf{( \% )}$ & $\boldsymbol{\rho}_{\boldsymbol{d}}\left(\mathbf{g} / \mathbf{c m}^{\mathbf{3}}\right)$ & $\boldsymbol{e}$ & $\boldsymbol{n}$ & $\boldsymbol{S r}(\boldsymbol{\%})$ \\
\hline $69 M$ & 2,719 & 16,75 & 1,088 & 1,5 & 0,60 & 30,36 \\
$71 M$ & 2,695 & 13,34 & 1,475 & 0,83 & 0,45 & 43,46 \\
\hline
\end{tabular}

Na caracterização da fração fina, os valores de Vb inferiores a 1,5 g/100g de solo indicam um comportamento laterítico; os valores de Acb sugerem uma atividade normal para as argilas e os baixos valores de CTC (Tabela 5.33) indicam caulinita na composição mineralógica da fração argila.

Tabela 5.33- Caracterização da fração fina do solo residual da Unidade IX usando o Método de Adsorção de Azul de Metileno

\begin{tabular}{|c|c|c|c|c|c|c|}
\hline \multirow[t]{2}{*}{ AMOSTRA } & \multicolumn{6}{|c|}{ CARACTERIZAÇÃO DA FRAÇÃO FINA } \\
\hline & $\begin{array}{l}\text { CTC } \\
\text { (meq/ } \\
100 g)\end{array}$ & $\underset{\left(\mathrm{m}^{2} / g\right)}{\boldsymbol{S E}}$ & $\begin{array}{c}\text { Vb }(g / 100 g \\
\text { solo })\end{array}$ & $\begin{array}{c}\text { Acb } \\
(g / 100 g \\
\text { argila) }\end{array}$ & $\begin{array}{c}\text { Atividade das } \\
\text { Argilas } \\
\text { (1) }\end{array}$ & $\begin{array}{c}\text { Comportamento } \\
\text { Laterítico } \\
(2)\end{array}$ \\
\hline $69 M$ & 3,4 & 26,38 & 1,08 & 3,13 & Normal & Laterítico \\
\hline $71 M$ & - & - & - & - & - & - \\
\hline $\begin{array}{l}\text { CTC-Capaci } \\
\text { SE - Superfíci } \\
\text { (1) Estimado } p \\
\text { (2) Estimado p }\end{array}$ & $\begin{array}{l}\text { e de Tro } \\
\text { pecíficc } \\
\text { neio do } \\
\text { neio do }\end{array}$ & Catiônic & aec & $\begin{array}{l}V b-M a \\
A c b-I ́ n c \\
\text { Acb } \times \% \\
\text { on (op. ci }\end{array}$ & $\begin{array}{l}\text { de Azul de Metiler } \\
\text { de Atividade da F } \\
\text { argila)-Lautrin }\end{array}$ & $\begin{array}{l}\text { sorvida em } 100 \mathrm{~g} \text { de solo } \\
\text { Argila } \\
\text { apud Pejon, 1992) }\end{array}$ \\
\hline
\end{tabular}

\subsubsection{0 - Unidade X (Biotita Gnaisse - Material Areno-Argiloso IV)}

Ocorre na porção sul da Sub-Bacia Ribeirão do Moinho, com aproximadamente 1,3 $\mathrm{km}^{2}$. Essa unidade refere-se a materiais retrabalhados originados de biotita-gnaisses e estão associados ao landform G. Sua presença foi identificada por meio de uma linha de seixos centimétrica. 
Foram caracterizados por coloração amarelada, com espessuras entre 0,5 a 1,7 m e foram descritos no ponto $48 \mathrm{M}$ (st) e $75 \mathrm{M}$. Esses materiais se caracterizam por uma textura areno-argilosa a argilo-arenosa (Tabela 5.34), onde as porcentagens de argila variam entre 35 a $52 \%$.

Tabela 5.34 - Caracterização Textural do material retrabalhado da Unidade X

\begin{tabular}{c|ccc|ccc|c}
\hline \multirow{2}{*}{ AMOSTRA } & \multicolumn{6}{|c|}{ COMPOSIÇÃo } & \multirow{2}{*}{ CLASSIFICAÇÃo } \\
\cline { 2 - 6 } & \multicolumn{3}{|c|}{ Areia (\%) } & Total de & Total de & Total de & \\
\cline { 2 - 6 } & Areia (\%) & Silte (\%) & Argila (\%) & \\
\hline $48 M(s t)$ & 8,1 & 9,1 & 14,3 & 31,5 & 16,4 & 52,1 & Argilo-arenosa \\
$75 M$ & 20,5 & 20,4 & 9,6 & 50,4 & 13,8 & 35,8 & Areno-argilosa \\
\hline
\end{tabular}

A Tabela 5.35 apresenta os índices físicos obtidos para a Unidade X.

Tabela 5.35 - Índices Físicos obtidos para o material retrabalhado da Unidade X

\begin{tabular}{c|cccccc}
\hline \multirow{2}{*}{ AMOSTRA } & \multicolumn{7}{c}{ Índices Físicos } \\
\cline { 2 - 7 } & $\rho_{\mathbf{s}}\left(\mathbf{g} / \mathbf{c m}^{\mathbf{3}}\right)$ & $\boldsymbol{w}(\mathbf{\%})$ & $\boldsymbol{\rho}_{\mathbf{d}}\left(\mathbf{g} / \mathbf{c m}^{\mathbf{3}}\right)$ & $\boldsymbol{e}$ & $\boldsymbol{n}$ & $\mathbf{S r}(\%)$ \\
\hline $48 M(\mathrm{st})$ & 2,736 & 19,57 & 1,361 & 1,01 & 0,50 & 53,00 \\
$75 M$ & 2,784 & 14,98 & 1,630 & 0,71 & 0,41 & 58,94 \\
\hline
\end{tabular}

A Tabela 5.36 mostra um comportamento laterítico para o material ( $\mathrm{Vb}<1,5 \mathrm{~g} / 100 \mathrm{~g}$ solo), argilas inativas a pouco ativas e valores de CTC e Acb indicaram caulinita na composição da fração fina.

Tabela 5.36 - Caracterização da fração fina do material retrabalhado da Unidade X usando o Método de Adsorção de Azul de Metileno

\begin{tabular}{|c|c|c|c|c|c|c|}
\hline \multirow{2}{*}{ AMOSTRA } & \multicolumn{6}{|c|}{ CARACTERIZAÇão DA FrAÇÃO FINA } \\
\hline & $\begin{array}{l}\text { CTC } \\
\text { (meq/ } \\
100 \mathrm{~g})\end{array}$ & $\begin{array}{c}S \boldsymbol{S E} \\
\left(\mathrm{m}^{2} / g\right)\end{array}$ & $\begin{array}{l}\boldsymbol{V} \boldsymbol{b}(\mathrm{g} / 100 \mathrm{~g} \\
\text { solo })\end{array}$ & $\begin{array}{c}\text { Acb } \\
\text { (g/100g } \\
\text { argila) }\end{array}$ & $\begin{array}{l}\text { Atividade das } \\
\text { Argilas } \\
\text { (1) }\end{array}$ & $\begin{array}{c}\text { Comportamento } \\
\text { Laterítico } \\
\text { (2) }\end{array}$ \\
\hline $\begin{array}{c}48 M(s t) \\
75 M\end{array}$ & $\begin{array}{l}4,2 \\
3,7\end{array}$ & $\begin{array}{l}33,22 \\
28,83\end{array}$ & $\begin{array}{l}1,36 \\
1,18\end{array}$ & $\begin{array}{l}2,68 \\
3,41\end{array}$ & $\begin{array}{c}\text { Inativa } \\
\text { Pouco Ativa }\end{array}$ & $\begin{array}{c}\text { Laterítico } \\
\text { “ }\end{array}$ \\
\hline $\begin{array}{l}\text { CTC-Capaci } \\
\text { SE - Superfíci } \\
\text { (1) Estimado } p \\
\text { (2) Estimado } p\end{array}$ & & & & $\begin{array}{l}V b-M a \\
A c b-I ́ n c \\
A(A c b y o\end{array}$ & $\begin{array}{l}\text { e Azul de Metilen } \\
\text { le Atividade da F } \\
\text { rrila) - Lautrin }\end{array}$ & $\begin{array}{l}\text { orvida em } 100 \mathrm{~g} \text { de sc } \\
\text { Argila } \\
\text { apud Pejon, 1992) }\end{array}$ \\
\hline
\end{tabular}

\subsubsection{1 - Unidade XI (Granito Gnaisse - Material Areno-Siltoso V)}

Essa unidade apresenta aproximadamente $2,82 \mathrm{~km}^{2} \mathrm{da}$ área total. Localiza-se no setor centro-leste da Sub-Bacia Córrego Vale da Vinhas e na porção noroeste da Sub-Bacia Ribeirão do Moinho. 
Os materiais inconsolidados presentes resultam da alteração de granito-gnaisses e estão associados ao landform C.

A alteração da rocha varia de moderadamente alterada a altamente decomposta, enquadrando-se nos horizonte IV e V, com espessuras entre 1,5 a $10 \mathrm{~m}$. Os materiais do Horizonte V caracterizam-se por uma coloração rosa-amarronzado e textura areia grossa a média siltosa (Tabela 5.37), com baixas porcentagens de argila (4 a 12\%). Foram descritos nos pontos 22, 26, 28, 85, e 86 .

Tabela 5.37 - Caracterização textural do material inconsolidado do Horizonte V da Unidade XI

\begin{tabular}{c|ccc|ccc|c}
\hline \multirow{2}{*}{ AMOSTRA } & \multicolumn{6}{|c|}{ COMPOSIÇÃo } & CLASSIFICAÇÃo \\
\cline { 2 - 7 } & \multicolumn{3}{|c|}{ Areia (\%) } & $\begin{array}{c}\text { Total de } \\
\text { Areia (\%) }\end{array}$ & $\begin{array}{c}\text { Total de } \\
\text { Silte (\%) }\end{array}$ & $\begin{array}{c}\text { Total de } \\
\text { Argila (\%) }\end{array}$ \\
\cline { 2 - 7 } & Grossa & Média & Fina & \\
\hline $22 M$ & 37,9 & 27,3 & 8,9 & 74,1 & 19,4 & 6,4 & areia grossa a média \\
& & & & & & & siltosa \\
$26 M$ & 39,8 & 16,5 & 9,3 & 65,6 & 27,5 & 6,9 & " \\
$28 M$ & 45,2 & 26,8 & 7,2 & 79,3 & 16,6 & 4,1 & " \\
$85 M$ & 23,4 & 13,8 & 11,0 & 48,2 & 42,4 & 9,4 & " \\
$86 M$ & 24,6 & 16,1 & 11,7 & 52,3 & 35,5 & 12,2 & \\
\hline
\end{tabular}

Os índices físicos obtidos mostraram valores de massa específica $\left(\rho_{\mathrm{s}}\right)$ variando de 2,652 a 2,752 g/ $\mathrm{cm}^{3}$; massa específica seca $\left(\rho_{\mathrm{d}}\right)$ entre 1,457 a $1,887 \mathrm{~g} / \mathrm{cm}^{3}$; índice de vazios (e) de 0,46 a 0,94; e porosidade (n) entre 0,31 a 0,48 (Tabela 5.38).

Tabela 5.38 - Índices Físicos obtidos para o material inconsolidado da Unidade XI

\begin{tabular}{c|cccccc}
\hline \multirow{2}{*}{ AMOSTRA } & \multicolumn{7}{c}{ ÍNDICES FísICOS } \\
\cline { 2 - 7 } & $\rho_{\boldsymbol{s}}\left(\mathbf{g} / \mathbf{c m}^{\mathbf{3}}\right)$ & $\boldsymbol{w} \mathbf{( \% )}$ & $\boldsymbol{\rho}_{\boldsymbol{d}}\left(\mathbf{g} / \mathbf{c m}^{\mathbf{3}}\right)$ & $\boldsymbol{e}$ & $\boldsymbol{n}$ & $\mathbf{S r} \mathbf{( \% )}$ \\
\hline $22 M$ & 2,666 & 5,65 & 1,827 & 0,46 & 0,31 & 32,78 \\
$26 M$ & 2,680 & 13,86 & 1,382 & 0,94 & 0,48 & 39,54 \\
$28 M$ & 2,660 & 2,97 & 1,887 & 0,41 & 0,29 & 19,30 \\
$85 M$ & 2,752 & 10,55 & 1,590 & 0,73 & 0,42 & 39,71 \\
$86 M$ & 2,652 & 9,54 & 1,457 & 0,82 & 0,45 & 30,86 \\
\hline
\end{tabular}

O material inconsolidado foi caracterizado como laterítico ( $\mathrm{Vb}<1,5 \mathrm{~g} / 100 \mathrm{~g}$ solo), sua fração fina apresenta uma atividade normal (Tabela 5.39) e em termos de composição os valores de CTC indicaram o predomínio de caulinita. 
Tabela 5.39 - Caracterização da fração fina da Unidade XI usando o Método de Adsorção de Azul de Metileno

\begin{tabular}{|c|c|c|c|c|c|c|}
\hline \multirow[t]{2}{*}{ AMOSTRA } & \multicolumn{6}{|c|}{ CARACTERIZAÇÃO DA FRAÇÃO FINA } \\
\hline & $\begin{array}{l}\text { CTC } \\
(\text { meq/ } \\
100 g)\end{array}$ & $\begin{array}{c}\boldsymbol{S E} \\
\left(\mathrm{m}^{2} / \mathrm{g}\right)\end{array}$ & $\begin{array}{c}\text { Vb }(g / 100 g \\
\text { solo })\end{array}$ & $\begin{array}{l}\text { Acb } \\
(g / 100 g \\
\text { argila) }\end{array}$ & $\begin{array}{l}\text { Atividade das } \\
\text { Argilas } \\
\quad(1)\end{array}$ & $\begin{array}{l}\text { Comportamento } \\
\text { Laterítico } \\
(2)\end{array}$ \\
\hline $22 M$ & 1,2 & 9,46 & 0,39 & 5,84 & Normal & Laterítico \\
\hline $26 M$ & - & - & - & - & - & - \\
\hline $28 M$ & - & - & - & - & - & - \\
\hline $85 M$ & - & - & - & - & - & - \\
\hline $86 M$ & - & - & - & - & - & - \\
\hline \multicolumn{7}{|c|}{$\begin{array}{lc}\text { CTC - Capacidade de Troca Catiônica } & \text { Vb - Massa de Azul de Metileno Adsorvida em 100g de solo } \\
\text { SE - Superfície Específica } & \text { Acb - Índice de Atividade da Fração Argila } \\
\text { (1) Estimado por meio do diagrama de atividade de argilas (Acb x \% de argila) - Lautrin (1989 apud Pejon, 1992) } \\
\text { (2) Estimado por meio do diagrama } \mathrm{Vb} \text { x \% de argila - Pejon (op. cit) }\end{array}$} \\
\hline
\end{tabular}

\subsubsection{2 - Unidade XII (Granito Gnaisse - Material Argiloso)}

A unidade XII ocupa porções restritas na Sub-Bacia Córrego Sopezol e no setor sudoeste da Sub-Bacia Ribeirão do Moinho, com aproximadamente 2,73 km².

Similarmente à unidade anterior, os materiais também são oriundos de granitognaisses e estão associados ao landform C.

Esses materiais foram descritos nos pontos 23, 87 e 89 como Horizonte VI, caracterizado pela presença de maciço de solo, com a preservação das estruturas originais e com espessuras entre 1,7 a 2 m. Caracterizam-se por uma coloração marrom-avermelhada, texturas argilo-arenosa, silto-argilosa e areno-argilosa (Tabela 5.40) e porcentagens de argila em torno de $20,3 \%$.

Tabela 5.40 - Caracterização textural do material inconsolidado do Horizonte VI da Unidade XII

\begin{tabular}{c|ccc|ccc|c}
\hline \multirow{2}{*}{ AMOSTRA } & \multicolumn{6}{|c|}{ CoMPOSIÇão } & \multirow{2}{*}{ CLASSIFICAÇÃo } \\
\cline { 2 - 5 } & \multicolumn{3}{|c|}{ Areia (\%) } & Total de & Total de & Total de & \\
\cline { 2 - 6 } & Areia (\%) & Silte (\%) & Argila (\%) & \\
\hline $23 M$ & 10,5 & 18,9 & 12,6 & 42,1 & 11,6 & 46,3 & argilo-arenosa \\
$87 M$ & 1,9 & 2,3 & 10,1 & 14,3 & 49,4 & 36,3 & silto-argilosa \\
$89 M$ & 9,7 & 16,4 & 15,4 & 41,5 & 24,6 & 33,8 & areno-argilosa \\
\hline
\end{tabular}

Os índices físicos obtidos para esse material são apresentados na Tabela 5.41. 
Tabela 5.41 - Índices Físicos obtidos para o material inconsolidado do Horizonte VI da Unidade XII

\begin{tabular}{c|cccccc}
\hline \multirow{2}{*}{ AMOSTRA } & \multicolumn{7}{c}{ ÍNDICES FísICOS } \\
\cline { 2 - 7 } & $\rho_{\mathbf{s}}\left(\mathbf{g} / \mathbf{c m}^{\mathbf{3}}\right)$ & $\boldsymbol{w} \mathbf{( \% )}$ & $\boldsymbol{\rho}_{\boldsymbol{d}}\left(\mathbf{g} / \mathbf{c m}^{\mathbf{3}}\right)$ & $\boldsymbol{e}$ & $\boldsymbol{n}$ & $\mathbf{S r}(\%)$ \\
\hline $23 M$ & 2,729 & - & - & - & - & - \\
$87 M$ & 2,669 & 27,14 & 0,964 & 1,77 & 0,64 & 40,97 \\
$89 M$ & 2,761 & 12,62 & 1,372 & 1,01 & 0,50 & 27,37 \\
\hline
\end{tabular}

Os valores de Vb indicaram comportamento laterítico para o material. Constituído por caulinita e quanto à atividade variaram pouco ativas a inativas (Tabela 5.42).

Tabela 5.42 - Caracterização da fração fina do material inconsolidado do Horizonte VI da Unidade XII usando o Método de Adsorção de Azul de Metileno

\begin{tabular}{|c|c|c|c|c|c|c|}
\hline \multirow[t]{2}{*}{ AMOSTRA } & \multicolumn{6}{|c|}{ CARACTERIZAÇÃO DA FRAÇÃO FINA } \\
\hline & $\begin{array}{l}\text { CTC } \\
\text { (meq/ } \\
100 \mathrm{~g})\end{array}$ & $\begin{array}{c}\boldsymbol{S E} \\
\left(\mathrm{m}^{2} / g\right)\end{array}$ & $\begin{array}{c}\text { Vb }(g / 100 g \\
\text { solo })\end{array}$ & $\begin{array}{c}\text { Acb } \\
(g / 100 g \\
\text { argila) }\end{array}$ & $\begin{array}{c}\text { Atividade das } \\
\text { Argilas } \\
\text { (1) }\end{array}$ & $\begin{array}{c}\text { Comportamento } \\
\text { Laterítico } \\
\text { (2) }\end{array}$ \\
\hline $23 M$ & 1,6 & 12,4 & 0,51 & 1,15 & Inativa & Laterítico \\
\hline $87 M$ & - & - & - & - & - & - \\
\hline $89 M$ & 3,7 & 29,35 & 1,2 & 3,69 & Pouco Ativa & Laterítico \\
\hline $\begin{array}{l}\text { CTC-Capac } \\
\text { SE - Superfíc } \\
\text { (1) Estimado }\end{array}$ & de Ti & & & $\begin{array}{l}V b-M a \\
A c b-I ́ n c \\
(A c b \times \%\end{array}$ & $\begin{array}{l}\text { e Azul de Metilen } \\
\text { de Atividade da Fr } \\
\text { argila) - Lautrin }\end{array}$ & $\begin{array}{l}\text { sorvida em } 100 \mathrm{~g} \text { de s} \\
\text { o Argila } \\
\text { g apud Pejon, 1992) }\end{array}$ \\
\hline
\end{tabular}

\subsubsection{3 - Unidade XIII (Gnaisse Porfiróide - Material Silto-Arenoso VI)}

Essa unidade ocorre na porção sudeste da Sub-Bacia Córrego Ribeirão do Moinho, com aproximadamente 2,74 $\mathrm{km}^{2}$. Os materiais inconsolidados presentes são originários de Gnaisses porfiróides e estão associados ao landform K, com espessuras em torno de $4 \mathrm{~m}$. A unidade foi descrita no ponto 60 .

Foi caracterizado como um maciço de solo, com preservação da estruturação primária, de coloração amarelo amarronzado e textura silto-arenosa (Horizonte VI), com porcentagens de argila em torno de 12\% (Tabela 5.43).

Tabela 5.43 - Caracterização textural do material inconsolidado do Horizonte VI da Unidade XIII

\begin{tabular}{c|ccc|ccc|c}
\hline \multirow{2}{*}{ AMOSTRA } & \multicolumn{6}{|c|}{ CoMPOSIÇão } & \multirow{2}{*}{ CLASSIFICAÇÃo } \\
\cline { 2 - 7 } & \multicolumn{3}{|c|}{ Areia (\%) } & Total de & Total de & Total de \\
Areia (\%) & Silte (\%) & \\
\cline { 2 - 8 } & Argila (\%) & \\
\hline $60 \mathrm{M}$ & 4,3 & 10,1 & 18,1 & 32,5 & 54,9 & 12,6 & Silto - arenosa \\
\hline
\end{tabular}


A Tabela 5.44 apresenta os índices físicos obtidos para esse material.

Tabela 5.44 - Índices Físicos obtidos para o material inconsolidado do Horizonte VI da Unidade XIII

\begin{tabular}{c|cccccc}
\hline \multirow{2}{*}{ AMOSTRA } & \multicolumn{7}{|c}{ ÍNDICES FÍsICOS } \\
\cline { 2 - 7 } & $\rho_{\mathbf{s}}\left(\mathbf{g} / \mathbf{c m}^{\mathbf{3}}\right)$ & $\boldsymbol{w}(\%)$ & $\rho_{\mathbf{d}}\left(\mathbf{g} / \mathbf{c m}^{3}\right)$ & $\boldsymbol{e}$ & $\boldsymbol{n}$ & $\operatorname{Sr}(\%)$ \\
\hline $60 M$ & 2,640 & 9,21 & 1,235 & 1,14 & 0,53 & 21,37 \\
\hline
\end{tabular}

$\mathrm{O}$ valor de $\mathrm{Vb}$ inferior a 1,5 g/100g solo do material inconsolidado indica um comportamento laterítico. Os baixos valores de CTC, corroborado pelos valores de Acb, sugerem o predomínio da caulinita e atividade normal para as argilas (Tabela 5.45).

Tabela 5.45 - Caracterização da fração fina do material inconsolidado do Horizonte VI da Unidade XII usando o Método de Adsorção de Azul de Metileno

\begin{tabular}{|c|c|c|c|c|c|c|}
\hline \multirow[t]{2}{*}{ AMOSTRA } & \multicolumn{6}{|c|}{ CARACTERIZAÇÃO DA FRAÇÃO FINA } \\
\hline & $\begin{array}{l}\boldsymbol{C T C} \\
\text { (meq/ } \\
100 \mathrm{~g})\end{array}$ & $\begin{array}{c}S E \\
\left(m^{2} / g\right)\end{array}$ & $\begin{array}{l}\boldsymbol{V b}(g / 100 g \\
\text { solo })\end{array}$ & $\begin{array}{c}\text { Acb } \\
\text { (g/100g } \\
\text { argila) }\end{array}$ & $\begin{array}{l}\text { Atividade das } \\
\text { Argilas } \\
\text { (1) }\end{array}$ & $\begin{array}{l}\text { Comportamento } \\
\text { Laterítico } \\
\text { (2) }\end{array}$ \\
\hline $60 M$ & 3,1 & 24,25 & 0,99 & 7,75 & Normal & Laterítico \\
\hline \multicolumn{4}{|c|}{$\begin{array}{l}\text { CTC - Capacidade de Troca Catiônica } \\
\text { SE - Superfície Específica }\end{array}$} & \multicolumn{3}{|c|}{$\begin{array}{l}\text { Vb- Massa de Azul de Metileno Adsorvida em 100g de solo } \\
\text { Acb - Índice de Atividade da Fração Argila }\end{array}$} \\
\hline \multicolumn{7}{|c|}{$\begin{array}{l}\text { (1) Estimado por meio do diagrama de atividade de argilas (Acb } \times \% \text { de argila) - Lautrin (1989 apud Pejon, } \\
\begin{array}{ll}\text { 1992). } & \text { (2)Estimado por meio do diagrama Vb } \times \% \text { de argila - Pejon (op. } \\
\text { cit) }\end{array}\end{array}$} \\
\hline
\end{tabular}

\subsubsection{4 - Unidade XIV (Gnaisse Porfiróide - Material Argiloso II)}

A Unidade XIV ocorre na porção sudeste da Sub-Bacia Ribeirão do Moinho, com aproximadamente $0,73 \mathrm{~km}^{2}$ e estão associados ao landform $\mathrm{K}$.

Seus materiais inconsolidados resultaram da alteração de gnaisses porfiróides em solos residuais (Horizonte VII). Apresentam espessuras entre 3 a 4 m, coloração marrom avermelhada e texturas areno-argilosa e argilo-arenosa (Tabela 5.46). Foram descritos nos pontos 56, 58, 59 e 61

Tabela 5.46 - Caracterização Textural do Material Inconsolidado da Unidade XIV

\begin{tabular}{|c|c|c|c|c|c|c|c|}
\hline \multirow[t]{3}{*}{ AMOSTRA } & \multicolumn{6}{|c|}{ COMPOSIÇÃO } & \multirow[t]{3}{*}{ CLASSIFICAÇÃO } \\
\hline & \multicolumn{3}{|c|}{ Areia (\%) } & \multirow{2}{*}{$\begin{array}{c}\text { Total de } \\
\text { Areia (\%) }\end{array}$} & \multirow{2}{*}{$\begin{array}{l}\text { Total de } \\
\text { Silte (\%) }\end{array}$} & \multirow{2}{*}{$\begin{array}{c}\text { Total de } \\
\text { Argila (\%) }\end{array}$} & \\
\hline & Grossa & Média & Fina & & & & \\
\hline $56 M$ & 7,3 & 10,8 & 15,4 & 33,4 & 17,4 & 49,2 & Areno - argilosa \\
\hline $58 M$ & 11,9 & 15,1 & 17,7 & 44,7 & 27,1 & 28,2 & Argilo - arenosa \\
\hline $59 M$ & 9,3 & 8,1 & 13,4 & 30,8 & 18,6 & 50,6 & “ \\
\hline $61 M$ & 8,8 & 12,5 & 16,4 & 37,6 & 18,3 & 44,1 & “ \\
\hline
\end{tabular}

A Tabela 5.47 apresenta os índices físicos obtidos para esse material. 
Tabela 5.47 - Índices Físicos do material inconsolidado da Unidade XIV

\begin{tabular}{c|cccccc}
\hline \multirow{2}{*}{ AMOSTRA } & \multicolumn{7}{c}{ Índices Físicos } \\
\cline { 2 - 7 } & $\boldsymbol{\rho}_{\mathbf{s}}\left(\mathbf{g} / \mathbf{c m}^{\mathbf{3}}\right)$ & $\boldsymbol{w} \mathbf{( \% )}$ & $\boldsymbol{\rho}_{\boldsymbol{d}}\left(\mathbf{g} / \mathbf{c m}^{\mathbf{3}}\right)$ & $\boldsymbol{e}$ & $\boldsymbol{n}$ & $\mathbf{S r}(\%)$ \\
\hline $56 M$ & 2,736 & - & - & - & - & - \\
$58 M$ & 2,756 & 8,88 & 1,560 & 0,77 & 0,43 & 31,94 \\
$59 M$ & 2,816 & 19,40 & 1,434 & 0,96 & 0,49 & 56,66 \\
$61 M$ & 2,886 & 24,40 & 1,019 & 1,83 & 0,65 & 38,44 \\
\hline
\end{tabular}

A caracterização da fração argilosa indica presença de caulinita e ilita, com pouca atividade e sugere um comportamento laterítico para o material inconsolidado ( $\mathrm{Vb}<1,5$ g/100g solo) (Tabela 5.48).

Tabela 5.48 - Caracterização da Fração fina da Unidade XIV usando o Método de Adsorção de Azul de Metileno

\begin{tabular}{|c|c|c|c|c|c|c|}
\hline \multirow[t]{2}{*}{ Amostra } & \multicolumn{6}{|c|}{ CARACTERIZAÇÃO DA FRAÇÃO FINA } \\
\hline & $\begin{array}{l}\text { CTC } \\
(\mathrm{meq} / \\
100 \mathrm{~g})\end{array}$ & $\begin{array}{c}\boldsymbol{S E} \\
\left(\mathrm{m}^{2} / \mathrm{g}\right)\end{array}$ & $\begin{array}{c}\mathbf{V b}(g / 100 g \\
\text { solo })\end{array}$ & $\begin{array}{l}\text { Acb } \\
(g / 100 g \\
\text { argila) }\end{array}$ & $\begin{array}{l}\text { Atividade das } \\
\text { Argilas } \\
\quad(1)\end{array}$ & $\begin{array}{l}\text { Comportamento } \\
\text { Laterítico } \\
\text { (2) }\end{array}$ \\
\hline $56 M$ & - & - & - & - & - & - \\
\hline $58 M$ & 3,7 & 29,32 & 1,2 & 4,53 & Pouco Ativa & Laterítico \\
\hline $59 M$ & - & - & - & - & - & - \\
\hline $61 M$ & 4 & 31,65 & 1,29 & 3 & Pouco Ativa & Laterítico \\
\hline \multicolumn{7}{|c|}{$\begin{array}{lc}\text { CTC - Capacidade de Troca Catiônica } & \text { Vb - Massa de Azul de Metileno Adsorvida em 100g de sol } \\
\text { SE - Superfície Específica } & \text { Acb - Índice de Atividade da Fração Argila } \\
\text { (1) Estimado por meio do diagrama de atividade de argilas (Acb x \% de argila) - Lautrin (1989 apud Pejon, 1992) } \\
\text { (2) Estimado por meio do diagrama } \mathrm{Vb} \times \% \text { de argila - Pejon (op. cit) }\end{array}$} \\
\hline
\end{tabular}

\subsubsection{5 - Unidade XV (Feldspato Alcalino Gnaisse - Material Areno-Siltoso VI)}

Ocorre na porção norte da Sub-Bacia Ribeirão do Moinho, com aproximadamente $0.91 \mathrm{~km}^{2}$. Seus materiais têm como rochas de origem feldspatos alcalino-gnaisses e estão associados ao landform L.

O perfil de alteração foi caracterizado por solos com estruturação primária reliquiar (Horizonte VI). Seus materiais inconsolidados apresentam uma coloração amarelada, textura areno-siltosa (Tabela 5.49), porcentagens de argila em torno de $9 \%$ e espessuras em torno de 7m. Foram descritos no ponto 84.

Tabela 5.49 - Caracterização Textural do Material Inconsolidado da Unidade XV

\begin{tabular}{c|ccc|ccc|c}
\hline AMOSTRA & \multicolumn{5}{|c|}{ CoMPOSIÇão } & CLASSIFICAÇÃo \\
\cline { 2 - 7 } & \multicolumn{3}{|c|}{ Areia (\%) } & Total de & Total de & Total de & \\
\cline { 2 - 7 } & Greia (\%) & Silte (\%) & Argila (\%) & \\
\hline $84 M$ & 16,7 & 17,5 & 20,6 & 54,7 & 36,2 & 9,1 & Areia fina a média \\
\hline
\end{tabular}


A Tabela 5.50 apresenta os dados obtidos para os índices físicos desse material.

Tabela 5.50 - Índices Físicos obtidos para o material inconsolidado da Unidade XV

\begin{tabular}{c|cccccc}
\hline \multirow{2}{*}{ AMOSTRA } & \multicolumn{7}{|c}{ ÍNDICES FÍSICOS } \\
\cline { 2 - 7 } & $\rho_{s}\left(\mathbf{g} / \mathbf{c m}^{3}\right)$ & $w(\%)$ & $\rho_{d}\left(\mathbf{g} / \mathbf{c m}^{3}\right)$ & $\boldsymbol{e}$ & $\boldsymbol{n}$ & $\operatorname{Sr}(\%)$ \\
\hline $84 M$ & 2,736 & 20,25 & 1,330 & 1,06 & 0,51 & 52,43 \\
\hline
\end{tabular}

A caracterização da fração fina indicou: um comportamento laterítico (Vb $<1,5$

g/100g solo), argilas normais e na composição mineralógica da fração argila, predomínio de caulinita (Tabela 5.51).

Tabela 5.51 - Caracterização da Fração fina da Unidade XV usando o Método de Adsorção de Azul de Metileno

\begin{tabular}{|c|c|c|c|c|c|c|}
\hline \multirow[t]{2}{*}{ AMOSTRA } & \multicolumn{6}{|c|}{ CARACTERIZAÇÃO DA FRAÇÃO FINA } \\
\hline & $\begin{array}{l}\text { CTC } \\
\text { (meq/ } \\
100 g)\end{array}$ & $\begin{array}{c}\mathbf{S E} \\
\left(m^{2} / g\right)\end{array}$ & $\begin{array}{c}\boldsymbol{V b}(g / 100 g \\
\text { solo })\end{array}$ & $\begin{array}{c}\text { Acb } \\
(g / 100 g \\
\text { argila) }\end{array}$ & $\begin{array}{c}\text { Atividade das } \\
\text { Argilas } \\
\text { (1) }\end{array}$ & $\begin{array}{c}\text { Comportamento } \\
\text { Laterítico } \\
(2)\end{array}$ \\
\hline $84 M$ & 2,9 & 22,89 & 0,94 & 8,75 & Normal & Laterítico \\
\hline $\begin{array}{l}\text { CTC-Capaci } \\
\text { SE - Superfíci } \\
\text { (1) Estimado } \\
\text { (2) Estimado } p\end{array}$ & $\begin{array}{l}\text { e de Tro } \\
\text { pecífica } \\
\text { neio do }\end{array}$ & a Catiônic & . & $\begin{array}{l}V b-M a \\
A c b-I n d \\
(A c b \times \%\end{array}$ & $\begin{array}{l}\text { de Azul de Metilen } \\
\text { de Atividade da Fr } \\
\text { argila) - Lautrin ( }\end{array}$ & $\begin{array}{l}\text { sorvida em } 100 \mathrm{~g} \text { de so } \\
\text { Argila } \\
\text { apud Pejon, 1992) }\end{array}$ \\
\hline
\end{tabular}

\subsubsection{6 - Unidade XVI (Aluvião)}

Esses depósitos são constituídos por materiais finos e arenosos associados ao landform A. Ocupam uma área de aproximadamente $3,66 \mathrm{~km}^{2}$ e ocorrem em todas as subbacias estudadas.

\subsection{2 - ÁREA 2 - BAIXO RIO CAPIVARI}

\subsubsection{1 - Unidade A1 (Aluvião)}

A unidade A1 corresponde a aproximadamente $7,56 \mathrm{~km}^{2}$ da área de estudo, representa os materiais aluvionares, constituídos por areias, siltes e argilas intercaladas junto as margens dos rios.

\subsubsection{2 - Unidade A2 (Diabásio - Material Argilo-Siltoso I)}

A unidade A2 com aproximadamente $6 \mathrm{~km}^{2}$, ocorre na porção superior das subbacias córregos São Francisco e Itapeva. 
Essa unidade é constituída por materiais resultantes da alteração de Diábasios, os quais estão associados ao landform 10.

Observou-se nessa unidade, perfil caracterizado por horizontes com rochas levemente alteradas a moderadamente alteradas, horizonte com preservação de núcleos de rocha envoltos em matriz argilosa e acima deste um outro horizonte de solo residual com respectivas espessuras de exposição de 7, 4 e 3m

Esse material foi coletado nos pontos 2 e 3. O solo residual apresenta coloração marrom avermelhada, textura argilo-siltosa (Tabela 5.52), com porcentagens de argila entre 40 e $50 \%$.

Tabela 5.52 - Caracterização textural do solo residual da Unidade A2

\begin{tabular}{|c|c|c|c|c|c|c|c|}
\hline \multirow[t]{3}{*}{ AMOSTRA } & \multicolumn{6}{|c|}{ COMPOSIÇÃO } & \multirow{3}{*}{$\begin{array}{c}\text { CLASSIFICAÇÃO } \\
\text { DO } \\
\text { SOLO RESIDUAL }\end{array}$} \\
\hline & \multicolumn{3}{|c|}{ Areia (\%) } & \multirow{2}{*}{$\begin{array}{c}\text { Total de } \\
\text { Areia (\%) }\end{array}$} & \multirow{2}{*}{$\begin{array}{l}\text { Total de } \\
\text { Silte (\%) }\end{array}$} & \multirow{2}{*}{$\begin{array}{c}\text { Total de } \\
\text { Argila (\%) }\end{array}$} & \\
\hline & Grossa & Média & Fina & & & & \\
\hline$A M 2$ & 1,3 & 6,4 & 16,0 & 23,8 & 25,1 & 51,2 & Argilo-siltosa \\
\hline AM3 & 2,6 & 8,2 & 12,2 & 23,0 & 36,5 & 40,5 & \\
\hline
\end{tabular}

A Tabela 5.53 apresenta os índices Físicos obtidos para o solo residual dessa unidade.

Tabela 5.53 - Índices Físicos obtidos para o solo residual da Unidade A2

\begin{tabular}{c|cccccc}
\hline \multirow{2}{*}{ AMOSTRA } & \multicolumn{7}{c}{ Índices Físicos do Solo Residual } \\
\cline { 2 - 7 } & $\boldsymbol{\rho}_{\mathbf{s}}\left(\mathbf{g} / \mathbf{c m}^{\mathbf{3}}\right)$ & $\boldsymbol{w}(\%)$ & $\boldsymbol{\rho}_{\mathbf{d}}\left(\mathbf{g} / \mathbf{c m}^{\mathbf{3}}\right)$ & $\boldsymbol{e}$ & $\boldsymbol{n}$ & $\boldsymbol{S r}(\%)$ \\
\hline$A M 2$ & 2,908 & 16,53 & 1,721 & 0,69 & 0,41 & 69,68 \\
$A M 3$ & 2,890 & 23,90 & 1,465 & 0,97 & 0,49 & 71,01 \\
\hline
\end{tabular}

A caracterização da fração fina mostra valores de CTC moderados (Tabela 5.54), indicando presença de caulinita, ilita e haloisita. Os valores de Acb mostram quanto à atividade, argilas normais. E os valores de $\mathrm{Vb}$ menores que 1,5 g/ 100g solo indicam comportamento laterítico para o solo. 
Tabela 5.54 - Caracterização da fração fina do solo residual da Unidade A2 usando o Método de Adsorção de Azul de Metileno

\begin{tabular}{|c|c|c|c|c|c|c|}
\hline \multirow[t]{2}{*}{ AMOSTRA } & \multicolumn{6}{|c|}{ CARACTERIZAÇÃO DA FrAÇÃo FINA } \\
\hline & $\begin{array}{l}\text { CTC } \\
\text { (meq/ } \\
100 g) \\
\end{array}$ & $\begin{array}{c}\boldsymbol{S E} \\
\left(m^{2} / g\right)\end{array}$ & $\begin{array}{c}\boldsymbol{V b}(g / 100 g \\
\text { solo })\end{array}$ & $\begin{array}{c}\text { Acb } \\
(g / 100 g \\
\text { argila) }\end{array}$ & $\begin{array}{c}\text { Atividade das } \\
\text { Argilas } \\
\text { (1) }\end{array}$ & $\begin{array}{c}\text { Comportamento } \\
\text { Laterítico } \\
(2)\end{array}$ \\
\hline AM2 & 9,5 & 74 & 1,15 & 6,57 & Normal & Laterítico \\
\hline AM3 & 7,2 & 56 & 1,28 & 5,97 & Normal & “ \\
\hline $\begin{array}{l}\text { CTC-Capac } \\
\text { SE-Superfíc } \\
\text { (1) Estimado } \\
\text { (2) Estimado }\end{array}$ & $\begin{array}{l}\text { e de Tro } \\
\text { pecífica }\end{array}$ & Catiônic & & $\begin{array}{l}\text { Vb-Ma } \\
\text { Acb-Índ } \\
\text { (Acb } \times \% \\
\text { on (op. ci }\end{array}$ & $\begin{array}{l}\text { e Azul de Metilen } \\
\text { le Atividade da Fr } \\
\text { Irgila) - Lautrin ( }\end{array}$ & $\begin{array}{l}\text { sorvida em } 100 \mathrm{~g} \text { de so } \\
\text { Argila } \\
\text { apud Pejon, 1992) }\end{array}$ \\
\hline
\end{tabular}

\subsubsection{3 - Unidade A3 (Diabásio - Material Argilo-Siltoso II)}

A unidade A3 localiza-se nas sub-bacias córregos Santa Rita e São Francisco com aproximadamente $4 \mathrm{~km}^{2}$ e engloba os materiais resultantes da alteração de diábasios, os quais estão associados aos landforms 3 e10.

O perfil de alteração descrito, similar ao da unidade anterior, foi diferenciado pelas características da fração fina. As amostras de caracterização do solo residual foram coletadas nos pontos 10, 14 e 19 .

O solo residual apresenta coloração marrom avermelhada, textura argilo-siltosa (Tabela 5.55), com porcentagens de argila em torno de $40 \%$.

Tabela 5.55 - Caracterização textural do solo residual da Unidade A3

\begin{tabular}{|c|c|c|c|c|c|c|c|}
\hline \multirow[t]{3}{*}{ AMOSTRA } & \multicolumn{6}{|c|}{ COMPOSIÇÃO } & \multirow{3}{*}{$\begin{array}{c}\text { CLASSIFICAÇÃO } \\
\text { DO } \\
\text { SOLO RESIDUAL }\end{array}$} \\
\hline & \multicolumn{3}{|c|}{ Areia (\%) } & \multirow{2}{*}{$\begin{array}{c}\text { Total de } \\
\text { Areia (\%) }\end{array}$} & \multirow{2}{*}{$\begin{array}{l}\text { Total de } \\
\text { Silte (\%) }\end{array}$} & \multirow{2}{*}{$\begin{array}{c}\text { Total de } \\
\text { Argila (\%) }\end{array}$} & \\
\hline & Grossa & Média & Fina & & & & \\
\hline AM10 & 2,0 & 8,7 & 12,2 & 22,9 & 28,4 & 48,7 & Argilo-siltosa \\
\hline AM14 & 0,5 & 7,5 & 16,0 & 24,0 & 29,0 & 47,0 & “ \\
\hline AM19 & 0,9 & 8,1 & 15,0 & 24,0 & 28,0 & 48,0 & “ \\
\hline
\end{tabular}

Os índices físicos obtidos para o solo residual da Unidade A3 mostram valores de massa específica $\left(\rho_{\mathrm{s}}\right)$ variando entre 2,822 a $2,962 \mathrm{~g} / \mathrm{cm}^{3}$, massa específica seca $\left(\rho_{\mathrm{d}}\right)$ entre 1,292 a $1,490 \mathrm{~g} / \mathrm{cm}^{3}$, índice de vazios (e) de 0,89 a 1,29 e porosidade (n) entre 0,47 a 0,56 (Tabela 5.56).

Tabela 5.56 - Índices Físicos obtidos para o solo residual da Unidade A3

\begin{tabular}{c|cccccc}
\hline AMOSTRA & \multicolumn{7}{|c}{ Índices Físicos do Solo Residual } \\
\cline { 2 - 7 } & $\boldsymbol{\rho}_{\mathbf{s}}\left(\mathbf{g} / \mathbf{c m}^{\mathbf{3}}\right)$ & $\boldsymbol{w}(\mathbf{\%})$ & $\boldsymbol{\rho}_{\mathbf{d}}\left(\mathbf{g} / \mathbf{c m}^{\mathbf{3}}\right)$ & $\boldsymbol{e}$ & $\boldsymbol{n}$ & $\mathbf{S r}(\mathbf{\% )}$ \\
\hline AM10 & 2,822 & 19,88 & 1,490 & 0,89 & 0,47 & 65,78 \\
AM14 & 2,962 & 15,72 & 1,292 & 1,29 & 0,56 & 36,03 \\
AM19 & 2,926 & 17,17 & 1,418 & 1,06 & 0,52 & 47,24 \\
\hline
\end{tabular}


Na caracterização da fração fina: os valores de CTC baixos (Tabela 5.57), indicam presença de caulinita; os valores de Acb mostram inatividade das argilas e os valores de $\mathrm{Vb}$ menores que 1,5 g/ 100g solo sugerem um comportamento laterítico para o solo.

Tabela 5.57 - Caracterização da fração fina do solo residual da Unidade A3 usando o Método de Adsorção de Azul de Metileno

\begin{tabular}{|c|c|c|c|c|c|c|}
\hline \multirow[t]{2}{*}{ AMOSTRA } & \multicolumn{6}{|c|}{ CARACTERIZAÇÃO DA FRAÇÃO FINA } \\
\hline & $\begin{array}{l}\text { CTC } \\
\text { (meq/ } \\
100 \mathrm{~g}) \\
\end{array}$ & $\begin{array}{c}\boldsymbol{S E} \\
\left(\mathrm{m}^{2} / \mathrm{g}\right)\end{array}$ & $\begin{array}{c}\text { Vb }(g / 100 g \\
\text { solo })\end{array}$ & $\begin{array}{c}\text { Acb } \\
(g / 100 g \\
\text { argila) }\end{array}$ & $\begin{array}{c}\text { Atividade das } \\
\text { Argilas } \\
\text { (1) }\end{array}$ & $\begin{array}{c}\text { Comportamento } \\
\text { Laterítico } \\
(2)\end{array}$ \\
\hline AM10 & 3,6 & 28 & 1,15 & 2,44 & Inativas & Laterítico \\
\hline AM14 & 3,8 & 30 & 1,23 & 2,65 & Inativas & “ \\
\hline AM19 & 4 & 31 & 1,28 & 2,74 & Inativas & “ \\
\hline $\begin{array}{l}\text { CTC-Capaci } \\
\text { SE - Superfíci } \\
\text { (1) Estimado } p \\
\text { (2) Estimado } p\end{array}$ & $\begin{array}{l}\text { de de Tro } \\
\text { Específica } \\
\text { meio do } \\
\text { meindo }\end{array}$ & & 2 do & $\begin{array}{l}\text { Vb-Massc } \\
\text { Acb-Índic } \\
\text { s (Acb } \times \% d \\
\text { jon (op. cit) }\end{array}$ & $\begin{array}{l}\text { le Azul de Metilen } \\
\text { de Atividade da Fr } \\
\text { argila)-Lautrin ( }\end{array}$ & $\begin{array}{l}\text { sorvida em } 100 \mathrm{~g} \text { de solo } \\
\text { Argila } \\
\text { apud Pejon, 1992) }\end{array}$ \\
\hline
\end{tabular}

\subsubsection{4 - Unidade A4 (Diabásio - Material Argilo-Arenoso)}

Essa unidade situa-se na porção sul de todas as sub-bacias estudadas com aproximadamente $5,5 \mathrm{~km}^{2}$, os materiais inconsolidados que a constituem são provenientes da alteração de diábasios e estão associados ao landform 11.

Seu perfil de alteração caracteriza-se pela exposição de: horizontes com núcleos de rochas envoltos por matriz argilosa de até 3m; e horizontes de solo residual mais evoluídos com até $5 \mathrm{~m}$. A amostragem de solo residual foi efetuada nos pontos 15, 25, 32 e 48.

O solo residual caracteriza-se por uma coloração marrom avermelhada, textura argilo-arenosa a areno-argilosa (Tabela 5.58), com porcentagens de argila entre 35 a 45\%.

Tabela 5.58 - Caracterização textural do solo residual da Unidade A4

\begin{tabular}{|c|c|c|c|c|c|c|c|}
\hline \multirow[t]{3}{*}{ AMOSTRA } & \multicolumn{6}{|c|}{ COMPOSIÇÃO } & \multirow{3}{*}{$\begin{array}{c}\text { CLASSIFICAÇÃO } \\
\text { DO } \\
\text { SOLO RESIDUAL }\end{array}$} \\
\hline & \multicolumn{3}{|c|}{ Areia (\%) } & \multirow{2}{*}{$\begin{array}{c}\text { Total de } \\
\text { Areia (\%) }\end{array}$} & \multirow{2}{*}{$\begin{array}{l}\text { Total de } \\
\text { Silte (\%) }\end{array}$} & \multirow{2}{*}{$\begin{array}{c}\text { Total de } \\
\text { Argila (\%) }\end{array}$} & \\
\hline & Grossa & Média & Fina & & & & \\
\hline AM15 & 0,0 & 7,0 & 28,0 & 35,0 & 25,0 & 40,0 & Argilo-Arenosa \\
\hline AM25 & 2,5 & 12,4 & 27,4 & 42,2 & 21,3 & 36,5 & Areno-Argilosa \\
\hline AM32 & 3,0 & 15,0 & 22,0 & 40,0 & 14,5 & 45,5 & Argilo-Arenosa \\
\hline AM48 & 2,0 & 10,2 & 22,0 & 34,2 & 30,7 & 35,1 & “ \\
\hline
\end{tabular}

Os índices físicos obtidos para o solo residual da Unidade A4 mostram valores de massa específica $\left(\rho_{\mathrm{s}}\right)$ variando entre 2,681 a $2,758 \mathrm{~g} / \mathrm{cm}^{3}$, massa específica seca $\left(\rho_{\mathrm{d}}\right)$ entre 0,977 a $1,511 \mathrm{~g} / \mathrm{cm}^{3}$, índice de vazios (e) de 0,83 a 1,78 , e porosidade (n) entre 0,45 a 0,64 (Tabela 5.59). 
Tabela 5.59 - Índices Físicos obtidos para o solo residual da Unidade A4

\begin{tabular}{c|cccccc}
\hline \multirow{2}{*}{ AMOSTRA } & \multicolumn{7}{c}{ Índices Físicos do Solo Residual } \\
& $\boldsymbol{\rho}_{\mathbf{s}}\left(\mathbf{g} / \mathbf{c m}^{\mathbf{3}}\right)$ & $\boldsymbol{w} \mathbf{( \% )}$ & $\boldsymbol{\rho}_{\boldsymbol{d}}\left(\mathbf{g} / \mathbf{c m}^{\mathbf{3}}\right)$ & $\boldsymbol{e}$ & $\boldsymbol{n}$ & $\boldsymbol{S r}(\%)$ \\
\hline AM15 & 2,758 & 14,94 & 1,511 & 0,83 & 0,45 & 49,92 \\
$A M 25$ & 2,715 & 13,98 & 0,977 & 1,78 & 0,64 & 21,33 \\
$A M 32$ & 2,747 & 14,28 & 1,169 & 1,35 & 0,57 & 29,05 \\
$A M 48$ & 2,681 & 16,53 & 1,221 & 1,20 & 0,54 & 37,04 \\
\hline
\end{tabular}

De acordo com os valores obtidos para $\mathrm{Vb}$, o solo residual apresenta um comportamento laterítico; os valores de CTC baixos sugerem composição mineralógica predominante; e os valores de Acb mostram argilas inativas, e corroboram com os valores encontrados para CTC quanto à mineralogia da fração fina (Tabela 5.60).

Tabela 5.60 - Caracterização da fração fina do solo residual da Unidade A4 usando o Método de Adsorção de Azul de Metileno

\begin{tabular}{|c|c|c|c|c|c|c|}
\hline \multirow{2}{*}{ AMOSTRA } & \multicolumn{6}{|c|}{ CARACTERIZAÇÃO DA FRAÇÃO FINA } \\
\hline & $\begin{array}{l}\text { CTC } \\
\text { (meq/ } \\
100 \mathrm{~g}) \\
\end{array}$ & $\begin{array}{c}S E \\
\left(m^{2} / g\right)\end{array}$ & $\begin{array}{c}\mathbf{V b}(\mathrm{g} / 100 \mathrm{~g} \\
\text { solo })\end{array}$ & $\begin{array}{c}\text { Acb } \\
(g / 100 g \\
\text { argila) }\end{array}$ & $\begin{array}{c}\text { Atividade das } \\
\text { Argilas } \\
\text { (1) }\end{array}$ & $\begin{array}{c}\text { Comportamento } \\
\text { Laterítico } \\
\text { (2) }\end{array}$ \\
\hline AM15 & 3,8 & 29 & 1,2 & 3,01 & Inativas & Laterítico \\
\hline AM25 & 1,2 & 9,2 & 0,38 & 2,07 & “ & “ \\
\hline AM32 & 2,5 & 19 & 0,79 & 2,74 & “ & “ \\
\hline AM48 & 1,2 & 9,1 & 0,37 & 2,06 & “ & “ \\
\hline TC - Сара & de $\operatorname{Tr}$ & & 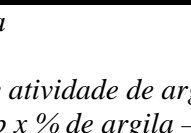 & $\begin{array}{c}V b-1 \\
A c b-1\end{array}$ & $\begin{array}{l}\text { e Azul de Metiler } \\
\text { de Atividade } F\end{array}$ & $\begin{array}{l}\text { sorvida em } 100 \mathrm{~g} \text { de } \\
\text { Argila } \\
\text { apud Pejon, 1992) }\end{array}$ \\
\hline
\end{tabular}

\subsubsection{5 - Unidade A5 (Rochas Intercaladas - Sub-Grupo Itararé - Material Silto-Arenoso)}

A unidade A5 compreende quase que a totalidade da área das sub-bacias Córrego Borão e Alto Retiro, mas também são presentes na porção central da Sub-Bacia Córrego Santa Rita e localmente na Sub-Bacia Córrego São Francisco com aproximadamente 7,6 km² da área total de estudo.

Seus materiais resultam da alteração de rochas intercaladas como os siltitos amareloavermelhados intercalados com siltitos cinza esbranquiçados e por vezes diamictitos com matriz silto-arenosa com presença predominantemente de seixos de quartzo e estão associados aos landforms 2, 6,7 e 8.

Está constituído por perfis de alteração pouco espessos (1,5m). Observou-se que tanto os siltitos quanto a matriz síltica dos diamictitos sofrem intenso processo de empastilhamento e rapidamente passam para um solo residual pouco espesso (até $1 \mathrm{~m}$ ). Sobre o perfil residual, descreveu-se material retrabalhado com até $1 \mathrm{~m}$ de exposição. 
O solo residual caracteriza-se por uma coloração amarelada, textura silto-arenosa a areno-siltosa (Tabela 5.61), com porcentagens de argila entre 17 e $28 \%$ enquanto o solo retrabalhado apresenta coloração cinza esbranquiçada, textura areno-siltosa, com porcentagem de argila em torno de $14 \%$.

Tabela 5.61 - Caracterização textural do solo residual e solo retrabalhado da Unidade A5

\begin{tabular}{|c|c|c|c|c|c|c|c|}
\hline \multirow{3}{*}{ AMOSTRA } & \multicolumn{6}{|c|}{ COMPOSIÇÃO } & \multirow{3}{*}{$\begin{array}{c}\text { CLASSIFICAÇÃO } \\
\text { DO } \\
\text { SOLO RESIDUAL } \\
\end{array}$} \\
\hline & \multicolumn{3}{|c|}{ Areia (\%) } & \multirow{2}{*}{$\begin{array}{c}\text { Total de } \\
\text { Areia (\%) }\end{array}$} & \multirow{2}{*}{$\begin{array}{l}\text { Total de } \\
\text { Silte (\%) }\end{array}$} & \multirow{2}{*}{$\begin{array}{c}\text { Total de } \\
\text { Argila (\%) }\end{array}$} & \\
\hline & Grossa & Média & Fina & & & & \\
\hline AM18 & 1,2 & 10,8 & 22,0 & 34,0 & 44,2 & 21,8 & Silto-Arenosa \\
\hline AM22 & 1,6 & 10,4 & 22,0 & 34,0 & 38,0 & 28,0 & Areno-Siltosa \\
\hline AM29 & 2,6 & 12,4 & 33,0 & 48,0 & 34,6 & 17,4 & “ \\
\hline \multirow[t]{3}{*}{ AMOSTRA } & \multicolumn{6}{|c|}{ COMPOSIÇÃO } & \multirow{3}{*}{$\begin{array}{c}\text { CLASSIFICAÇÃo } \\
\text { DO SOLO } \\
\text { RETRABALHADO }\end{array}$} \\
\hline & \multicolumn{3}{|c|}{ Areia (\%) } & \multirow{2}{*}{$\begin{array}{c}\text { Total de } \\
\text { Areia (\%) }\end{array}$} & \multirow{2}{*}{$\begin{array}{l}\text { Total de } \\
\text { Silte (\%) }\end{array}$} & \multirow{2}{*}{$\begin{array}{c}\text { Total de } \\
\text { Argila (\%) }\end{array}$} & \\
\hline & Grossa & Média & Fina & & & & \\
\hline AM31 & 4,6 & 25,3 & 38,3 & 68,1 & 18,1 & 13,8 & Areno-Siltosa \\
\hline
\end{tabular}

Os índices físicos só foram obtidos para o solo residual da Unidade A5 (Tabela 5.62). Para o material retrabalhado obteve-se apenas valor da massa específica de 2,95 $\mathrm{g} / \mathrm{cm}^{3}$.

Tabela 5.62 - Índices Físicos obtidos para o solo residual da Unidade A5

\begin{tabular}{c|cccccc}
\hline \multirow{2}{*}{ AMOSTRA } & \multicolumn{5}{c}{ Índices Físicos do Solo Residual } \\
\cline { 2 - 7 } & $\boldsymbol{\rho}_{\mathbf{s}}\left(\mathbf{g} / \mathbf{c m}^{\mathbf{3}}\right)$ & $\boldsymbol{w} \mathbf{( \% )}$ & $\boldsymbol{\rho}_{\mathbf{d}}\left(\mathbf{g} / \mathbf{c m}^{\mathbf{3}}\right)$ & $\boldsymbol{e}$ & $\boldsymbol{n}$ & $\operatorname{Sr}(\%)$ \\
\hline$A M 18$ & 2,658 & 8,06 & 1,673 & 0,59 & 0,37 & 36,38 \\
$A M 22$ & 2,750 & 14,24 & 1,446 & 0,90 & 0,47 & 43,43 \\
$A M 29$ & 2,744 & 6,52 & 1,420 & 1,07 & 0,52 & 17,9 \\
\hline
\end{tabular}

A caracterização da fração fina para ambos os materiais mostram valores de CTC baixos (Tabela 5.63), indicando presença de caulinita; os valores de Acb mostram argilas inativas a pouco ativas para o solo residual; e para o retrabalhado atividade normal, e corroboram com os valores de CTC quanto à composição. Os valores de Vb menores que 1,5 g/ 100g solo indicam comportamento laterítico para os materiais definidos. 
Tabela 5.63 - Caracterização da fração fina do solo residual e retrabalhado da Unidade A5 usando o Método de Adsorção de Azul de Metileno

\begin{tabular}{|c|c|c|c|c|c|c|}
\hline \multirow[t]{2}{*}{ AMOSTRA } & \multicolumn{6}{|c|}{ CARACTERIZAÇÃO DA FRAÇÃO FINA DO SOLO RESIDUAL } \\
\hline & $\begin{array}{l}\text { CTC } \\
\text { (meq/ } \\
100 \mathrm{~g})\end{array}$ & $\begin{array}{c}\boldsymbol{S E} \\
\left(\mathrm{m}^{2} / g\right)\end{array}$ & $\begin{array}{c}\text { Vb }(g / 100 g \\
\text { solo })\end{array}$ & $\begin{array}{c}\text { Acb } \\
(g / 100 g \\
\text { argila) }\end{array}$ & $\begin{array}{c}\text { Atividade das } \\
\text { Argilas } \\
\text { (1) }\end{array}$ & $\begin{array}{c}\text { Comportamento } \\
\text { Laterítico } \\
(2)\end{array}$ \\
\hline AM18 & 2,1 & 16 & 0,67 & 3,07 & Pouco ativa & Laterítico \\
\hline AM22 & 2,2 & 17 & 0,69 & 2,5 & Inativa & “ \\
\hline AM29 & 2,2 & 17 & 0,71 & 4,06 & Pouco Ativa & “ \\
\hline
\end{tabular}

\begin{tabular}{|c|c|c|c|c|c|c|}
\hline \multirow[t]{2}{*}{ AMOSTRA } & \multicolumn{6}{|c|}{ CARACTERIZAÇÃo DA FRAÇÃo FINA DO SOLO RESIDUAL } \\
\hline & $\begin{array}{c}\text { CTC } \\
\text { (meq/ } \\
100 g) \\
\end{array}$ & $\begin{array}{r}\boldsymbol{S} \boldsymbol{E} \\
\left(\mathrm{m}^{2} / \mathrm{g}\right)\end{array}$ & $\begin{array}{r}\boldsymbol{V b}(g / 100 g \\
\text { solo })\end{array}$ & $\begin{array}{r}\text { Acb } \\
(g / 100 g \\
\text { argila })\end{array}$ & $\begin{array}{c}\text { Atividade das } \\
\text { Argilas } \\
\text { (1) }\end{array}$ & $\begin{array}{c}\text { Comportamento } \\
\text { Laterítico } \\
(2)\end{array}$ \\
\hline AM31 & 1,8 & 14 & 0,58 & 4,42 & Normal & Laterítico \\
\hline $\begin{array}{l}\text { CTC-Capaci } \\
\text { SE - Superfíci } \\
\text { (1) Estimado } p \\
\text { (2) Estimado } p\end{array}$ & $\begin{array}{l}\text { de de Tro } \\
\text { specífica } \\
\text { meio do c }\end{array}$ & atiônica & 3 & $\begin{array}{l}\text { Vb-Massc } \\
\text { Acb-Índic } \\
\text { (Acb } \times \% d\end{array}$ & $\begin{array}{l}\text { de Azul de Metiler } \\
\text { de Atividade da F } \\
\text { argila)-Lautrin }\end{array}$ & $\begin{array}{l}\text { sorvida em } 100 \mathrm{~g} \text { de solo } \\
\text { Argila } \\
\text { apud Pejon, 1992) }\end{array}$ \\
\hline
\end{tabular}

\subsubsection{6 - Unidade A6 (Itararé - Material Areno-Siltoso)}

Essa unidade está representada na porção sul da Sub-Bacia Itapeva, com área de aproximadamente $1 \mathrm{~km}^{2}$ Os materiais inconsolidados resultam da alteração de arenitos finos cinza esbranquiçados e estão associados ao landform 11.

A unidade A6 caracteriza-se por perfis de alteração de até $2 \mathrm{~m}$, com exposição de corpos de arenito moderadamente alterados $(1,5 \mathrm{~m})$ e presença de solo residual $(1,5 \mathrm{~m})$. A amostragem do solo residual dessa unidade foi efetuada no ponto 37.

O solo residual apresenta coloração cinza esbranquiçado, textura silto-arenosa (Tabela 5.64), com porcentagens de argila de até 9,5\%.

Tabela 5.64 - Caracterização textural do solo residual da Unidade A6

\begin{tabular}{|c|c|c|c|c|c|c|c|}
\hline \multirow[t]{3}{*}{ AMOSTRA } & \multicolumn{6}{|c|}{ COMPOSIÇÃO } & \multirow{3}{*}{$\begin{array}{c}\text { CLASSIFICAÇÃO } \\
\text { DO } \\
\text { SOLO RESIDUAL }\end{array}$} \\
\hline & \multicolumn{3}{|c|}{ Areia (\%) } & \multirow{2}{*}{$\begin{array}{c}\text { Total de } \\
\text { Areia (\%) }\end{array}$} & \multirow{2}{*}{$\begin{array}{l}\text { Total de } \\
\text { Silte (\%) }\end{array}$} & \multirow{2}{*}{$\begin{array}{c}\text { Total de } \\
\text { Argila (\%) }\end{array}$} & \\
\hline & Grossa & Média & Fina & & & & \\
\hline ÂM13 & 0 & 40 & 42 & 82,0 & 8,0 & 10,0 & Arenosa \\
\hline AM37 & 2,5 & 24,5 & 45 & 72,0 & 18,5 & 9,5 & Areno-siltosa \\
\hline
\end{tabular}

Os índices Físicos obtidos para o solo residual dessa unidade estão apresentados na Tabela 5.65. 
Tabela 5.65 - Índices Físicos obtidos para o solo residual da Unidade A6

\begin{tabular}{c|cccccc}
\hline \multirow{2}{*}{ AMOSTRA } & \multicolumn{7}{c}{ Índices Físicos do Solo Residual } \\
\cline { 2 - 7 } & $\rho_{\mathbf{s}}\left(\mathbf{g} / \mathbf{c m}^{\mathbf{3}}\right)$ & $\boldsymbol{w}(\%)$ & $\rho_{d}\left(\mathbf{g} / \mathbf{c m}^{3}\right)$ & $\boldsymbol{e}$ & $\boldsymbol{n}$ & $\operatorname{Sr}(\%)$ \\
\hline$A M 13$ & 2,679 & 8,78 & 1,781 & 0,50 & 0,34 & 46,64 \\
$A M 37$ & 2,663 & & & & & \\
\hline
\end{tabular}

A caracterização da fração fina indica composição predominante de caulinita, argilas pouco ativas e comportamento laterítico (Tabela 5.66).

Tabela 5.66 - Caracterização da fração fina do solo residual da Unidade A6 usando o Método de Adsorção de Azul de Metileno

\begin{tabular}{|c|c|c|c|c|c|c|}
\hline \multirow[t]{2}{*}{ AMOSTRA } & \multicolumn{6}{|c|}{ CARACTERIZAÇÃO DA FRAÇÃO FINA DO SOLO RESIDUAL } \\
\hline & $\begin{array}{l}\text { CTC } \\
\text { (meq/ } \\
100 \mathrm{~g}) \\
\end{array}$ & $\begin{array}{c}\boldsymbol{S E} \\
\left(\mathrm{m}^{2} / g\right)\end{array}$ & $\begin{array}{l}\boldsymbol{V} \boldsymbol{b}(\mathrm{g} / 100 \mathrm{~g} \\
\text { solo })\end{array}$ & $\begin{array}{c}\text { Acb } \\
\text { (g/100g } \\
\text { argila) } \\
\end{array}$ & $\begin{array}{c}\text { Atividade das } \\
\text { Argilas } \\
\text { (1) }\end{array}$ & $\begin{array}{c}\text { Comportamento } \\
\text { Laterítico } \\
\text { (2) }\end{array}$ \\
\hline Am13 & 1 & 7,9 & 0,32 & 3 & Pouco Ativa & Laterítico \\
\hline AM37 & 1,1 & 8,6 & 0,35 & 3,56 & Pouco Ativa & Laterítico \\
\hline $\begin{array}{l}\text { CTC-Capa } \\
\text { SE-Superfí } \\
\text { (1) Estimado } \\
\text { (D) Fstimado }\end{array}$ & & & & $\begin{array}{l}V b-M \\
A c b-\hat{I}\end{array}$ & $\begin{array}{l}\text { e Azul de Metile } \\
\text { e Atividade da }\end{array}$ & $\begin{array}{l}\text { Prvida em 100g de s } \\
\text { Argila } \\
\text { apud Pejon, 1992) }\end{array}$ \\
\hline
\end{tabular}

\subsubsection{7 - Unidade A7 (Intercalado Itararé - Material Areno-Argilo- Siltoso)}

A unidade A7 com aproximadamente $1,4 \mathrm{~km}^{2}$ da área total está situada na porção oeste da Sub-Bacia Itapeva. Seus materiais inconsolidados provêm da alteração de arenitos finos intercalados com argilitos e estão associados ao landform 4.

Caracteriza-se por perfis de alteração de até $5 \mathrm{~m}$, com exposição de corpos de arenitos moderadamente a altamente alterados $(2 \mathrm{~m})$ e presença de solo residual $(3 \mathrm{~m})$. A amostragem do solo residual dessa unidade foi realizada no ponto 9.

O solo residual apresenta coloração vermelho-amarronzado, textura areno-argilosiltosa (Tabela 5.67), com porcentagens de argila de até 30\%.

Tabela 5.67 - Caracterização textural do solo residual da Unidade A7

\begin{tabular}{|c|c|c|c|c|c|c|c|}
\hline \multirow{3}{*}{ AMOSTRA } & \multicolumn{6}{|c|}{ COMPOSIÇÃO } & \multirow{3}{*}{$\begin{array}{c}\text { CLASSIFICAÇÃo } \\
\text { DO } \\
\text { SOLO RESIDUAL }\end{array}$} \\
\hline & \multicolumn{3}{|c|}{ Areia (\%) } & \multirow{2}{*}{$\begin{array}{c}\text { Total de } \\
\text { Areia (\%) }\end{array}$} & \multirow{2}{*}{$\begin{array}{l}\text { Total de } \\
\text { Silte (\%) }\end{array}$} & \multirow{2}{*}{$\begin{array}{c}\text { Total de } \\
\text { Argila (\%) }\end{array}$} & \\
\hline & Grossa & Média & Fina & & & & \\
\hline AM9 & 0,6 & 12,4 & 27,0 & 40,0 & 29,5 & 30,5 & Areno-argilo-siltosa \\
\hline
\end{tabular}

A Tabela 5.68 apresenta os índices Físicos obtidos para o solo residual dessa unidade. 
Tabela 5.68 - Índices Físicos obtidos para o solo residual da Unidade A7

\begin{tabular}{c|cccccc}
\hline \multirow{2}{*}{ AMOSTRA } & \multicolumn{7}{c}{ Índices Físicos } \\
\cline { 2 - 7 } & $\rho_{\mathrm{s}}\left(\mathbf{g} / \mathbf{c m}^{3}\right)$ & $\boldsymbol{w}(\%)$ & $\rho_{d}\left(\mathbf{g} / \mathbf{c m}^{3}\right)$ & $\boldsymbol{e}$ & $\boldsymbol{n}$ & $\operatorname{Sr}(\%)$ \\
\hline$A M 9$ & 2,647 & 7,55 & 1,445 & 0,83 & 0,45 & 24,02 \\
\hline
\end{tabular}

Os baixos valores de $\mathrm{Vb}$ e CTC sugerem inatividade das argilas e composição predominante da fração por caulinita, respectivamente e os valores de Vb inferiores à 1,5 g/ 100 g solo indicam um comportamento laterítico para o material(Tabela 5.69).

Tabela 5.69 - Caracterização da fração fina do solo residual da Unidade A7 usando o Método de Adsorção de Azul de Metileno

\begin{tabular}{|c|c|c|c|c|c|c|}
\hline \multirow[t]{2}{*}{ AMOSTRA } & \multicolumn{6}{|c|}{ CARACTERIZAÇÃO DA FRAÇÃO FINA DO SOLO RESIDUAL } \\
\hline & $\begin{array}{l}\text { CTC } \\
\text { (meq/ } \\
100 g) \\
\end{array}$ & $\begin{array}{c}\boldsymbol{S E} \\
\left(\mathrm{m}^{2} / \mathrm{g}\right)\end{array}$ & $\begin{array}{l}\boldsymbol{V} \boldsymbol{b}(\mathrm{g} / 100 \mathrm{~g} \\
\text { solo })\end{array}$ & $\begin{array}{c}\text { Acb } \\
\text { (g/100g } \\
\text { argila) } \\
\end{array}$ & $\begin{array}{l}\text { Atividade das } \\
\text { Argilas } \\
\text { (1) } \\
\end{array}$ & $\begin{array}{c}\text { Comportamento } \\
\text { Laterítico } \\
\text { (2) }\end{array}$ \\
\hline AM9 & 2 & 16 & 0,65 & 2,14 & Inativa & Laterítico \\
\hline $\begin{array}{l}\text { CTC - Capa } \\
\text { SE - Superfí } \\
\text { (1) Estimado }\end{array}$ & $\overline{d e} 7$ & & & $\begin{array}{l}V b-M a \\
A c b-I ́ I n c\end{array}$ & $\begin{array}{l}\text { e Azul de Metiler } \\
\text { le Atividade da F }\end{array}$ & $\begin{array}{l}\text { sorvida em 100g de sc } \\
\text { Argila } \\
\text { apud Pejon, 1992) }\end{array}$ \\
\hline
\end{tabular}

\subsubsection{8 - Unidade A8 (Intercalado Itararé - Material Areno-Siltoso II)}

A unidade A8 com aproximadamente1 $1 \mathrm{~km}^{2}$, localiza-se na porção central da SubBacia Itapeva. Seus materiais resultam da alteração de arenitos finos finamente laminados, intercalados com siltitos cinza esbranquiçados e argilitos e estão associados ao landform 9.

Caracteriza-se por perfis de alteração de até 1,5 m, com exposição da rocha com altamente alterada, no caso dos siltitos foi comum encontrá-los empastilhados passando para solo residual. A amostragem do solo residual dessa unidade foi efetuada no ponto 42.

O solo residual apresenta coloração cinza esbranquiçado, textura areno-siltosa (Tabela 5.70), com porcentagens de argila em torno de 13\%.

Tabela 5.70 - Caracterização textural do solo residual da Unidade A8

\begin{tabular}{|c|c|c|c|c|c|c|c|}
\hline \multirow{3}{*}{ AMOSTRA } & \multicolumn{6}{|c|}{ COMPOSIÇÃO } & \multirow{3}{*}{$\begin{array}{c}\text { CLASSIFICAÇÃO } \\
\text { DO } \\
\text { SOLO RESIDUAL }\end{array}$} \\
\hline & \multicolumn{3}{|c|}{ Areia (\%) } & \multirow{2}{*}{$\begin{array}{c}\text { Total de } \\
\text { Areia (\%) }\end{array}$} & \multirow{2}{*}{$\begin{array}{l}\text { Total de } \\
\text { Silte (\%) }\end{array}$} & \multirow{2}{*}{$\begin{array}{c}\text { Total de } \\
\text { Argila (\%) }\end{array}$} & \\
\hline & Grossa & Média & Fina & & & & \\
\hline AM42 & 2,6 & 16,6 & 35,3 & 54,6 & 32,3 & 13,1 & Areno-siltosa \\
\hline
\end{tabular}

Os índices Físicos obtidos para o solo residual dessa unidade estão apresentados na Tabela 5.71. 
Tabela 5.71 - Índices Físicos obtidos para o solo residual da Unidade A8

\begin{tabular}{c|cccccc}
\hline \multirow{2}{*}{ AMOSTRA } & \multicolumn{7}{c}{ Índices Físicos do Solo Residual } \\
\cline { 2 - 7 } & $\rho_{s}\left(\mathbf{g} / \mathbf{c m}^{3}\right)$ & $\boldsymbol{w}(\%)$ & $\rho_{d}\left(\mathbf{g} / \mathbf{c m}^{\mathbf{3}}\right)$ & $\boldsymbol{e}$ & $\boldsymbol{n}$ & $\operatorname{Sr}(\%)$ \\
\hline$A M 42$ & 2,638 & 7,84 & 1,715 & 0,54 & 0,35 & 38,45 \\
\hline
\end{tabular}

A caracterização da fração fina indica composição predominante de caulinita, argilas com atividade normal e comportamento laterítico para o solo (Tabela 5.72).

Tabela 5.72 - Caracterização da fração fina do solo residual da Unidade A8 usando o Método de Adsorção de Azul de Metileno

\begin{tabular}{|c|c|c|c|c|c|c|}
\hline \multirow[t]{2}{*}{ AMOSTRA } & \multicolumn{6}{|c|}{ CARACTERIZAÇÃO DA FRAÇÃO FINA DO SOLO RESIDUAL } \\
\hline & $\begin{array}{l}\text { CTC } \\
\text { (meq/ } \\
100 \mathrm{~g}) \\
\end{array}$ & $\begin{array}{c}\boldsymbol{S E} \\
\left(\mathrm{m}^{2} / \mathrm{g}\right) \\
\end{array}$ & $\begin{array}{c}\boldsymbol{V b}(\mathrm{g} / 100 \mathrm{~g} \\
\text { solo })\end{array}$ & $\begin{array}{c}\text { Acb } \\
\text { (g/100g } \\
\text { argila) } \\
\end{array}$ & $\begin{array}{c}\text { Atividade das } \\
\text { Argilas } \\
\text { (1) } \\
\end{array}$ & $\begin{array}{c}\text { Comportamento } \\
\text { Laterítico } \\
(2) \\
\end{array}$ \\
\hline AM42 & 2,1 & 16 & 0,67 & 4,99 & Normal & Laterítico \\
\hline $\begin{array}{l}\text { CTC - Capc } \\
\text { SE-Superfi } \\
\text { (1) Estimad }\end{array}$ & de $T$ & & & $\begin{array}{c}V b-M a s \\
A c b-I ́ n d\end{array}$ & $\begin{array}{l}\text { Azul de Metilen } \\
\text { e Atividade da Fr }\end{array}$ & $\begin{array}{l}\text { orvida em } 100 \mathrm{~g} \text { de sol } \\
\text { Argila } \\
\text { apud Pejon, 1992) }\end{array}$ \\
\hline
\end{tabular}

\subsubsection{9 - Unidade A9 (Intercalado Itararé - Material Areno-Silto- Argiloso)}

A unidade A9 está representada por uma área de aproximadamente $5 \mathrm{~km}^{2}$ na porção sul da Sub-Bacia São Francisco e Itapeva. Os materiais que a caracterizam provêm da alteração de siltitos amarelo-avermelhados intercalados com siltitos cinza esbranquiçados e estão associadas aos landforms 7, 8 e 11.

O processo de empastilhamento é comum nessa área de estudo, e como conseqüência, são formados solos pouco espessos, característica dessa unidade. Acima do perfil residual definiu-se um pacote de material retrabalhado.

O solo residual é caracterizado por uma coloração cinza escura, textura areno-siltoargilosa (Tabela 5.73), com porcentagens de argila em torno de $31 \%$ enquanto o solo retrabalhado apresenta coloração cinza esbranquiçada, textura similar a solo residual e porcentagens de argila em torno de $26 \%$. 
Tabela 5.73 - Caracterização textural do solo residual da Unidade A9

\begin{tabular}{|c|c|c|c|c|c|c|c|}
\hline \multirow{3}{*}{ AMOSTRA } & \multicolumn{6}{|c|}{ COMPOSIÇÃO } & \multirow{3}{*}{$\begin{array}{c}\text { CLASSIFICAÇão } \\
\text { DO } \\
\text { SOLO RESIDUAL }\end{array}$} \\
\hline & \multicolumn{3}{|c|}{ Areia (\%) } & \multirow{2}{*}{$\begin{array}{c}\text { Total de } \\
\text { Areia (\%) }\end{array}$} & \multirow{2}{*}{$\begin{array}{l}\text { Total de } \\
\text { Silte (\%) }\end{array}$} & \multirow{2}{*}{$\begin{array}{c}\text { Total de } \\
\text { Argila (\%) }\end{array}$} & \\
\hline & Grossa & Média & Fina & & & & \\
\hline AM38 & 5,4 & 19,2 & 19,3 & 44,0 & 29,5 & 26,5 & Areno-silto-argilosa \\
\hline \multirow[t]{3}{*}{ AMOSTRA } & \multicolumn{6}{|c|}{ COMPOSIÇÃo } & \multirow{3}{*}{$\begin{array}{c}\text { CLASSIFICAÇÃO } \\
\text { DO SOLO } \\
\text { RETRABALHADO }\end{array}$} \\
\hline & \multicolumn{3}{|c|}{ Areia (\%) } & \multirow{2}{*}{$\begin{array}{c}\text { Total de } \\
\text { Areia (\%) }\end{array}$} & \multirow{2}{*}{$\begin{array}{l}\text { Total de } \\
\text { Silte (\%) }\end{array}$} & \multirow{2}{*}{$\begin{array}{c}\text { Total de } \\
\text { Argila (\%) }\end{array}$} & \\
\hline & Grossa & Média & Fina & & & & \\
\hline AM33 & 0,8 & 11,8 & 22,1 & 34,7 & 33,9 & 31,3 & Areno-silto-argilosa \\
\hline
\end{tabular}

Os índices Físicos obtidos para o solo residual e retrabalhado da unidade são apresentados na Tabela 5.74 .

Tabela 5.74 - Índices Físicos obtidos para o solo residual da Unidade A9

\begin{tabular}{|c|c|c|c|c|c|c|}
\hline \multirow{2}{*}{ AMOSTRA } & \multicolumn{6}{|c|}{ Índices Físicos do Solo Residual } \\
\hline & $\rho_{\mathrm{s}}\left(\mathrm{g} / \mathrm{cm}^{3}\right)$ & $w(\%)$ & $\rho_{d}\left(\mathrm{~g} / \mathrm{cm}^{3}\right)$ & e & $n$ & $\mathrm{Sr}(\%)$ \\
\hline AM38 & 2,726 & 18,33 & 1,472 & 0,85 & 0,46 & 58,61 \\
\hline \multirow[t]{2}{*}{ AMOSTRA } & \multicolumn{6}{|c|}{ Índices Físicos do Solo Retrabalhado } \\
\hline & $\rho_{\mathrm{s}}\left(\mathrm{g} / \mathrm{cm}^{3}\right)$ & $w(\%)$ & $\rho_{d}\left(\mathrm{~g} / \mathrm{cm}^{3}\right)$ & $\bar{e}$ & $n$ & Sr (\%) \\
\hline AM33 & 2,709 & 13,50 & 1,556 & 0,74 & 0,43 & 49,37 \\
\hline
\end{tabular}

Para o solo residual a fração fina apresenta valores moderados de CTC, mesmo assim sugeriu caulinita para a sua composição. O valor de Acb indica uma atividade nociva das argilas e a presença de montmorilonita e ilita no material. $\mathrm{O}$ valor de $\mathrm{Vb}$ maior que 1,5 g/100 g solo propôs um comportamento não-laterítico do solo (Tabela 5.75).

Já a caracterização da fração fina do material retrabalhado apresenta baixos valores de CTC, sugerindo predomínio de caulinita, atividade normal para as argilas e comportamento laterítico para o solo. 
Tabela 5.75 - Caracterização da fração fina do solo residual da Unidade A9 usando o Método de Adsorção de Azul de Metileno

\begin{tabular}{|c|c|c|c|c|c|c|}
\hline \multirow[t]{2}{*}{ AMOSTRA } & \multicolumn{6}{|c|}{ CARACTERIZAÇÃO DA FRAÇÃO FINA DO SOLO RESIDUAL } \\
\hline & $\begin{array}{l}\text { CTC } \\
\text { (meq/ } \\
100 g)\end{array}$ & $\begin{array}{c}\boldsymbol{S E} \\
\left(\mathrm{m}^{2} / \mathrm{g}\right)\end{array}$ & $\begin{array}{c}\text { Vb }(g / 100 g \\
\text { solo })\end{array}$ & $\begin{array}{c}\text { Acb } \\
(g / 100 g \\
\text { argila) }\end{array}$ & $\begin{array}{c}\text { Atividade das } \\
\text { Argilas } \\
\text { (1) }\end{array}$ & $\begin{array}{c}\text { Comportamento } \\
\text { Laterítico } \\
(2)\end{array}$ \\
\hline AM38 & 6,3 & 50 & 2,03 & 7,83 & Nociva & Não Laterítico \\
\hline \multirow[t]{2}{*}{ AMOSTRA } & \multicolumn{6}{|c|}{ CARACTERIZAÇÃo DA FRAÇÃO FINA DO SOLO RETRABALHADO } \\
\hline & $\begin{array}{l}\text { CTC } \\
\text { (meq/ } \\
100 g)\end{array}$ & $\begin{array}{c}\boldsymbol{S} \boldsymbol{E} \\
\left(\mathrm{m}^{2} / \mathrm{g}\right)\end{array}$ & $\begin{array}{c}\text { Vb }(g / 100 g \\
\text { solo })\end{array}$ & $\begin{array}{c}\text { Acb } \\
(g / 100 g \\
\text { argila) }\end{array}$ & $\begin{array}{c}\text { Atividade das } \\
\text { Argilas } \\
\text { (1) }\end{array}$ & $\begin{array}{c}\text { Comportamento } \\
\text { Laterítico } \\
(2)\end{array}$ \\
\hline AM33 & 3,1 & 24 & 0,99 & 3,18 & Normal & Laterítico \\
\hline \multicolumn{7}{|c|}{$\begin{array}{lc}\text { CTC - Capacidade de Troca Catiônica } & \text { Vb - Massa de Azul de Metileno Adsorvida em 100g de sc } \\
\text { SE - Superfície Específica } & \text { Acb - Índice de Atividade da Fração Argila } \\
\text { (1) Estimado por meio do diagrama de atividade de argilas (Acb x \% de argila) - Lautrin (1989 apud Pejon, 1992) } \\
\text { (2) Estimado por meio do diagrama Vb } \% \text { de argila - Pejon (op. cit) }\end{array}$} \\
\hline
\end{tabular}

\subsubsection{0 - Unidade A10 (Itararé - Material Argilo-Arenoso II)}

A unidade A10 está representada por uma área de aproximadamente 0,6 $\mathrm{km}^{2}$ em porções isoladas das sub-bacias Itapeva. Seus materiais são resultantes da alteração argilitos e estão associados ao landform 4.

Caracteriza-se por perfis de alteração de até $5 \mathrm{~m}$, com exposição de corpos de rocha moderadamente a altamente alterados $(3 \mathrm{~m})$ e solo residual $(2 \mathrm{~m})$. Essa unidade foi descrita no ponto 45.

O solo residual apresenta coloração marrom avermelhado, textura argilo-arenosa (Tabela 5.76), com porcentagens de argila em torno de 39\%.

Tabela 5.76 - Caracterização textural do solo residual da Unidade A10

\begin{tabular}{|c|c|c|c|c|c|c|c|}
\hline \multirow[t]{3}{*}{ AMOSTRA } & \multicolumn{6}{|c|}{ COMPOSIÇÃO } & \multirow{3}{*}{$\begin{array}{c}\text { CLASSIFICAÇÃO } \\
\text { DO } \\
\text { SOLO RESIDUAL }\end{array}$} \\
\hline & \multicolumn{3}{|c|}{ Areia (\%) } & \multirow{2}{*}{$\begin{array}{c}\text { Total de } \\
\text { Areia (\%) }\end{array}$} & \multirow{2}{*}{$\begin{array}{l}\text { Total de } \\
\text { Silte (\%) }\end{array}$} & \multirow{2}{*}{$\begin{array}{c}\text { Total de } \\
\text { Argila (\%) }\end{array}$} & \\
\hline & Grossa & Média & Fina & & & & \\
\hline AM45 & 1,2 & 10,3 & 22,1 & 33,6 & 27,2 & 39,2 & Argilo-arenosa \\
\hline
\end{tabular}

Os índices Físicos obtidos para o solo residual dessa unidade estão apresentados na Tabela 5.77.

Tabela 5.77 - Índices Físicos obtidos para o solo residual da Unidade A10

\begin{tabular}{c|cccccc}
\hline \multirow{2}{*}{ AMOSTRA } & \multicolumn{7}{|c}{ Índices Físicos do Solo Residual } \\
\cline { 2 - 7 } & $\rho_{s}\left(\mathbf{g} / \mathbf{c m}^{3}\right)$ & $w(\%)$ & $\rho_{d}\left(\mathbf{g} / \mathbf{c m}^{3}\right)$ & $e$ & $\boldsymbol{n}$ & $\operatorname{Sr}(\%)$ \\
\hline$A M 45$ & 2,684 & 15,25 & 1,380 & 0,94 & 0,49 & 43,34 \\
\hline
\end{tabular}


A caracterização da fração fina indica composição predominante de caulinita, argilas inativas e comportamento laterítico para o material (Tabela 5.78).

Tabela 5.78 - Caracterização da fração fina do solo residual da Unidade A10 usando o Método de Adsorção de Azul de Metileno

\begin{tabular}{|c|c|c|c|c|c|c|}
\hline \multirow[t]{2}{*}{ AMOSTRA } & \multicolumn{6}{|c|}{ CARACTERIZAÇÃO DA FRAÇÃO FINA DO SOLO RESIDUAL } \\
\hline & $\begin{array}{l}\text { CTC } \\
\text { (meq/ } \\
100 g \text { ) }\end{array}$ & $\begin{array}{c}\boldsymbol{S E} \\
\left(\mathrm{m}^{2} / \mathrm{g}\right)\end{array}$ & $\begin{array}{c}\text { Vb }(g / 100 g \\
\text { solo })\end{array}$ & $\begin{array}{c}\text { Acb } \\
(g / 100 g \\
\text { argila })\end{array}$ & $\begin{array}{c}\text { Atividade das } \\
\text { Argilas } \\
\text { (1) }\end{array}$ & $\begin{array}{c}\text { Comportamento } \\
\text { Laterítico } \\
(2)\end{array}$ \\
\hline AM45 & 2,1 & 16 & 0,66 & 2,07 & Inativa & Laterítico \\
\hline $\begin{array}{l}\text { CTC-Capaci } \\
\text { SE - Superfíci } \\
\text { (1) Estimado } p \\
\text { (2) Estimado } p\end{array}$ & $\begin{array}{l}\text { e de Tro } \\
\text { specífica } \\
\text { meio do }\end{array}$ & Catiônica & 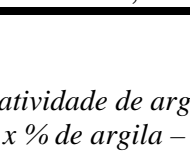 & $\begin{array}{l}\text { Vb-Mass } \\
\text { Acb-Índic } \\
\text { (Acb } \times \% d \\
\text { ion (op. cit) }\end{array}$ & $\begin{array}{l}\text { le Azul de Metilen } \\
\text { de Atividade da Fr } \\
\text { argila) - Lautrin ( }\end{array}$ & $\begin{array}{l}\text { sorvida em } 100 \mathrm{~g} \text { de solc } \\
\text { o Argila } \\
\text { 9 apud Pejon, 1992) }\end{array}$ \\
\hline
\end{tabular}

\subsubsection{1 - Unidade A11 (Itararé - Material Areno-Siltoso III)}

Em termos areais, essa é a unidade mais representativa com aproximadamente 12 $\mathrm{km}^{2}$ compreende a maior parte da área da Sub-Bacia Itapeva, e porções da sub-bacias Santa Rita e São Francisco. Seus materiais são provenientes da alteração de diamictitos intercalados com siltitos associadas aos landforms 4, 5, 9 e 12.

Caracteriza-se por perfis de alteração pouco espessos (2m). Observou-se que a matriz síltica dos diamictitos sofre intenso processo de empastilhamento e rapidamente passa para um solo residual pouco espesso (até $1 \mathrm{~m}$ ). Sobre o perfil residual, há material retrabalhado com até $1 \mathrm{~m}$ de exposição. A amostragem dessa unidade foi efetuada nos pontos $4,5,6$ e 8.

O solo residual caracteriza-se por coloração amarelada, textura areno-siltosa (Tabela 5.79) e porcentagens de argila em torno de $17 \%$ enquanto o solo retrabalhado cinza esbranquiçado apresenta textura areno-siltosa, com porcentagens de argila em torno de $10 \%$.

Tabela 5.79 - Caracterização textural do solo residual e do material retrabalhado da Unidade A11

\begin{tabular}{|c|c|c|c|c|c|c|c|}
\hline \multirow[t]{3}{*}{ AMOSTRA } & \multicolumn{6}{|c|}{ COMPOSIÇÃO } & \multirow{3}{*}{$\begin{array}{c}\text { CLASSIFICAÇÃO } \\
\text { DO } \\
\text { SOLO RESIDUAL }\end{array}$} \\
\hline & \multicolumn{3}{|c|}{ Areia (\%) } & \multirow{2}{*}{$\begin{array}{c}\text { Total de } \\
\text { Areia (\%) }\end{array}$} & \multirow{2}{*}{$\begin{array}{l}\text { Total de } \\
\text { Silte (\%) }\end{array}$} & \multirow{2}{*}{$\begin{array}{c}\text { Total de } \\
\text { Argila (\%) }\end{array}$} & \\
\hline & Grossa & Média & Fina & & & & \\
\hline AM5 & 2,3 & 14,5 & 30,4 & 47,3 & 36,0 & 16,7 & Areno-Siltosa \\
\hline AM6 & 5,4 & 17,8 & 23,5 & 46,8 & 36,3 & 16,9 & Areno-Siltosa \\
\hline \multirow[t]{3}{*}{ AMOSTRA } & \multicolumn{6}{|c|}{ COMPOSIÇÃo } & \multirow{3}{*}{$\begin{array}{c}\text { CLASSIFICAÇÃO } \\
\text { DO SOLO } \\
\text { RETRABALHADO }\end{array}$} \\
\hline & \multicolumn{3}{|c|}{ Areia (\%) } & \multirow{2}{*}{$\begin{array}{c}\text { Total de } \\
\text { Areia (\%) }\end{array}$} & \multirow{2}{*}{$\begin{array}{l}\text { Total de } \\
\text { Silte (\%) }\end{array}$} & \multirow{2}{*}{$\begin{array}{c}\text { Total de } \\
\text { Argila (\%) }\end{array}$} & \\
\hline & Grossa & Média & Fina & & & & \\
\hline AM4 & 8,6 & 16,1 & 36,6 & 61,3 & 28,0 & 10,8 & Areno-Siltosa \\
\hline AM8 & 3,6 & 25,4 & 34 & 63,0 & 26,5 & 10,5 & Areno-Siltosa \\
\hline
\end{tabular}


A Tabela 5.80 apresenta os índices Físicos obtidos para o solo residual e retrabalhado da Unidade A11.

Tabela 5.80 - Índices Físicos obtidos para o solo residual e retrabalhado da Unidade A11

\begin{tabular}{|c|c|c|c|c|c|c|}
\hline \multirow[t]{2}{*}{ AMOSTRA } & \multicolumn{6}{|c|}{ Índices Físicos do solo residual } \\
\hline & $\rho_{\mathrm{s}}\left(\mathrm{g} / \mathrm{cm}^{3}\right)$ & $w(\%)$ & $\rho_{d}\left(\mathrm{~g} / \mathrm{cm}^{3}\right)$ & $e$ & $n$ & $\mathrm{Sr}(\%)$ \\
\hline $\begin{array}{l}\text { AM5 } \\
\text { AM6 }\end{array}$ & $\begin{array}{l}2,753 \\
2,679\end{array}$ & $\begin{array}{c}9,47 \\
11,53 \\
\end{array}$ & $\begin{array}{l}1,681 \\
1,561\end{array}$ & $\begin{array}{l}0,64 \\
0,72\end{array}$ & $\begin{array}{l}0,39 \\
0,42 \\
\end{array}$ & $\begin{array}{l}40,88 \\
43,12\end{array}$ \\
\hline \multirow[t]{2}{*}{ AMOSTRA } & \multicolumn{6}{|c|}{ Índices Físicos do solo retrabalhado } \\
\hline & $\rho_{\mathrm{s}}\left(\mathrm{g} / \mathrm{cm}^{3}\right)$ & $w(\%)$ & $\rho_{d}\left(\mathrm{~g} / \mathrm{cm}^{3}\right)$ & $e$ & $n$ & $\operatorname{Sr}(\%)$ \\
\hline $\begin{array}{l}\text { AM4 } \\
\text { AM8 }\end{array}$ & $\begin{array}{l}2,766 \\
2,709\end{array}$ & $\begin{array}{l}5,40 \\
3,33\end{array}$ & $\begin{array}{l}1,651 \\
1,529\end{array}$ & $\begin{array}{l}0,68 \\
0,77\end{array}$ & $\begin{array}{l}0,40 \\
0,44\end{array}$ & $\begin{array}{l}22,10 \\
11,69\end{array}$ \\
\hline
\end{tabular}

A caracterização da fração fina, para ambos os materiais, mostra valores baixos de CTC que indica presença de caulinita na composição, atividade das argilas normal e comportamento laterítico para os solos (Tabela 5.81).

Tabela 5.81- Caracterização da Fração fina do solo residual e retrabalhado da Unidade A11 usando o Método de Adsorção de Azul de Metileno

\begin{tabular}{|c|c|c|c|c|c|c|}
\hline \multirow[t]{2}{*}{ AMOSTRA } & \multicolumn{6}{|c|}{ CARACTERIZAÇÃO DA FRAÇÃO FINA DO SOLO RESIDUAL } \\
\hline & $\begin{array}{l}\text { CTC } \\
\text { (meq/ } \\
100 g) \\
\end{array}$ & $\begin{array}{c}\boldsymbol{S E} \\
\left(\mathrm{m}^{2} / g\right)\end{array}$ & $\begin{array}{l}\boldsymbol{V b}(g / 100 g \\
\text { solo })\end{array}$ & $\begin{array}{c}\text { Acb } \\
\text { (g/100g } \\
\text { argila) } \\
\end{array}$ & $\begin{array}{c}\text { Atividade das } \\
\text { Argilas } \\
\text { (1) } \\
\end{array}$ & $\begin{array}{c}\text { Comportamento } \\
\text { Laterítico } \\
(2) \\
\end{array}$ \\
\hline AM5 & 3 & 24 & 0,97 & 5,88 & Normal & Laterítico \\
\hline AM6 & 4 & 31 & 1,26 & 7,47 & Normal & Latel \\
\hline \multirow[t]{2}{*}{ AMOSTRA } & \multicolumn{6}{|c|}{ CARACTERIZAÇÃo dA FRAÇÃo FINA dO SOLO RESIDUAL } \\
\hline & $\begin{array}{l}\text { CTC } \\
\text { (meq/ } \\
100 g)\end{array}$ & $\begin{array}{r}\boldsymbol{S E} \\
\left(\mathrm{m}^{2} / \mathrm{g}\right)\end{array}$ & $\begin{array}{r}\boldsymbol{V b}(g / 100 g \\
\text { solo })\end{array}$ & $\begin{array}{r}\text { Acb } \\
\text { (g/100g } \\
\text { argila) } \\
\end{array}$ & $\begin{array}{l}\text { Atividade das } \\
\text { Argilas } \\
\text { (1) }\end{array}$ & $\begin{array}{c}\text { Comportamento } \\
\text { Laterítico } \\
\text { (2) }\end{array}$ \\
\hline AM4 & 2,4 & 18 & 0,75 & 7,56 & Normal & Laterítico \\
\hline AM8 & 1,7 & 14 & 0,55 & 5,06 & Normal & Laterítico \\
\hline \multicolumn{7}{|c|}{$\begin{array}{lc}\text { CTC - Capacidade de Troca Catiônica } & \text { Vb - Massa de Azul de Metileno Adsorvida em 100g de sol } \\
\text { SE - Superfície Específica } & \text { Acb - Índice de Atividade da Fração Argila } \\
\text { (1) Estimado por meio do diagrama de atividade de argilas (Acb } x \% \text { de argila) - Lautrin (1989 apud Pejon, 1992) } \\
\text { (2) Estimado por meio do diagrama } V b \times \% \text { de argila - Pejon (op. cit) }\end{array}$} \\
\hline
\end{tabular}




\section{VERIFICAÇÃO DAS ALTERAÇÕES NAS SUB-BACIAS HIDROGRÁFICAS}

\section{1. - ÁREA 1 - ALTO RIO CAPIVARI}

\subsection{1 - Verificação das Alterações na Rede de Drenagem nas Sub- Bacias Hidrográficas por meio da Análise Morfométrica}

A verificação das alterações na rede de drenagem foi baseada nas mudanças das variáveis morfométricas obtidas para os anos de 1972 e 1995 e pelo registro da taxa de variação dos índices.

A taxa de variação dos índices morfométricos foi calculada pela subtração entre as porcentagens dos valores das variáveis obtidas em 1972 e as porcentagens dos valores das mesmas variáveis obtidas para 1995. Os valores de número total de canais, comprimento total da rede de drenagem, área, índice de forma, densidade de drenagem, densidade hidrográfica, textura topográfica, razão entre os comprimentos médios entre os canais de Ordem 2 e 1 e razão de bifurcação dos canais de Ordem 1 e 2 foram admitidos iguais a 100\% no período inicial de análise.

Quando registrado o aumento das porcentagens dos índices, a taxa de variação foi considerada positiva, quando encontrada redução das porcentagens, a taxa de valores foi considerada negativa.

Devido à adoção do método de Collares (2000), dividiu-se os índices morfométricos estudados em dois grupos (Tabela 6.1):

- O primeiro relacionado à morfologia, ou seja, aquele em que as variáveis não sofreram alterações temporais de curto prazo; e, 
- O segundo relativo à composição da rede de drenagem, ou seja, aquele cujas variáveis modificaram-se durante um breve período de tempo, refletindo as mudanças ocorridas na rede de drenagem das sub-bacias.

Tabela 6.1 - Grupos das Variáveis Morfométricas (modificado de Collares, 2000)

\begin{tabular}{l|l}
\multicolumn{1}{c|}{$\begin{array}{c}\text { VARIÁVEIS RELACIONADAS À REDE DE } \\
\text { DRENAGEM }\end{array}$} & \multicolumn{1}{c}{$\begin{array}{c}\text { VARIÁVEIS RELACIONADAS A } \\
\text { MORFOLOGIA }\end{array}$} \\
\hline $\mathbf{N t}$ - Número Total de Canais & A - Área da Bacia \\
$\mathbf{N i}$ - Número total de Canais por Ordem & $\mathbf{P}$ - Perímetro da bacia \\
$\mathbf{L t}$ - Comprimento Total da Rede de Drenagem & $\mathbf{K}$ - Índice de Forma \\
$\mathbf{L i}$ - Comprimento total dos canais por Ordem & \\
$\mathbf{L m i}$ - Comprimento médio dos canais por Ordem & \\
$\mathbf{R b}-$ Razão de bifurcação & \\
$\mathbf{R l m}$ - Razão entre comprimentos médios & \\
$\mathbf{D d}$ - Densidade de Drenagem & \\
$\mathbf{D h}$ - Densidade Hidrográfica & \\
$\mathbf{T t}-$ Textura Topográfica & \\
\hline
\end{tabular}

A Tabela 6.2 apresenta os resultados obtidos na análise morfométrica das sub-bacias Ribeirão do Moinho (B1), Córrego Sopezol (B2), Córrego Vale das Vinhas (B3) e Córrego Corrupira (B4), para os anos de 1972 e 1995.

Tabela 6.2 - Parâmetros morfométricos obtidos para as sub-bacias da Área 1

\begin{tabular}{|c|c|c|c|c|c|c|c|c|}
\hline \multirow{3}{*}{ PARÂMETROS MORFOMÉTRICOS } & \multicolumn{8}{|c|}{ SUB-BACIA } \\
\hline & \multicolumn{4}{|c|}{1972} & \multicolumn{4}{|c|}{1995} \\
\hline & B1 & B2 & B3 & B4 & B1 & B2 & B3 & B4 \\
\hline$\overline{\mathbf{A}-\text { Área da bacia }\left(\mathrm{Km}^{2}\right)}$ & 25,4 & 17,4 & 6,27 & 5,69 & 25,4 & $\overline{17,4}$ & $\overline{6,27}$ & 5,69 \\
\hline $\mathbf{P}$-Perímetro $(\mathrm{km})$ & 23,7 & 19,7 & 11,8 & 10,2 & 23,7 & 19,7 & 11,8 & 10,2 \\
\hline $\mathbf{K}$ - Índice de Forma & 1,33 & 1,33 & 1,33 & 1,21 & 1,33 & 1,33 & 1,33 & 1,21 \\
\hline $\mathbf{N t}$ - Número total de canais & 411 & 373 & 137 & 109 & 458 & 325 & 103 & 96 \\
\hline $\mathbf{N 1}$ - Número de canais de Ordem 1 & 293 & 277 & 105 & 82 & 332 & 236 & 78 & 66 \\
\hline $\mathbf{N 2}$ - Número de canais de Ordem 2 & 90 & 70 & 23 & 19 & 92 & 68 & 20 & 22 \\
\hline N3 - Número de canais de Ordem 3 & 21 & 20 & 6 & 5 & 24 & 16 & 4 & 5 \\
\hline N4 - Número de canais de Ordem 4 & 6 & 5 & 2 & 2 & 9 & 4 & 1 & 2 \\
\hline N5 - Número de canais de Ordem 5 & 1 & 1 & 1 & 1 & 1 & 1 & - & 1 \\
\hline Lt - Comprimento total da rede de Drenagem- $\mathrm{km}$ & 115 & 98,3 & 37,6 & 28,4 & 126 & 88,66 & 31,97 & 27,09 \\
\hline $\mathbf{L 1}$-Comprimento dos canais de Ordem $1-\mathrm{km}$ & 61,1 & 56,1 & 22,2 & 16,3 & 69,5 & 47,42 & 17,20 & 14,59 \\
\hline $\mathbf{L} 2$ - Comprimento dos canais de Ordem $2-\mathrm{km}$ & 27,5 & 19,4 & 8,04 & 7,01 & 30,2 & 20,84 & 8,13 & 7,46 \\
\hline L3 - Comprimento dos canais de Ordem $3-\mathrm{km}$ & 13,6 & 9,42 & 3,34 & 1,53 & 11,6 & 7,26 & 4,05 & 2,07 \\
\hline L4 - Comprimento dos canais de Ordem $4-\mathrm{km}$ & 6,41 & 8,36 & 3,26 & 2,81 & 7,54 & 9,93 & 2,59 & 2,31 \\
\hline L5 - Comprimento dos canais de Ordem $5-\mathrm{km}$ & 6,25 & 5 & 0,68 & 0,73 & 6,8 & 3,21 . & & 0,66 \\
\hline Lm1 - Comprimento médio dos Canais de Ordem $1-\mathrm{km}$ & 0,21 & 0,2 & 0,21 & 0,2 & 0,21 & 0,20 & 0,22 & 0,22 \\
\hline Lm2 - Comprimento médio dos Canais de Ordem 2 - Im & 0,31 & 0,28 & 0,35 & 0,37 & 0,33 & 0,31 & 0,41 & 0,34 \\
\hline$\overline{\mathbf{D d}-\text { Densidade de drenagem }\left(\mathrm{km} / \mathrm{km}^{2}\right)}$ & 4,52 & 5,65 & 5,99 & 4,99 & 4,94 & 5,10 & 5,1 & 4,76 \\
\hline Dh - Densidade hidrográfica $\left(\mathrm{N} 1 / \mathrm{km}^{2}\right)$ & 11,5 & 15,9 & 16,8 & 14,4 & 13,1 & 13,6 & 12,4 & 11,6 \\
\hline $\mathbf{T t}$ - Textura Topográfica $(\mathrm{km})$ & 8,91 & 11,5 & 12,3 & 10 & 9,77 & 10,2 & 10,2 & 9,54 \\
\hline $\begin{array}{c}\mathbf{R I m}_{(2-1)}-\text { Razão entre comprimentos médios de canais } \\
\text { de Ordem } 2 \text { e } 1\end{array}$ & 1,47 & 1,37 & 1,65 & 1,85 & 1,57 & 1,53 & 1,84 & 1,53 \\
\hline $\mathbf{R b}_{(1-2}-$ Razão de bifurcação entre canais de Ordem 1 e 2 & 3,26 & 3,96 & 4,57 & 4,32 & 3,61 & 3,47 & 3,9 & 3 \\
\hline
\end{tabular}


A Tabela 6.3 mostra a taxa de variação dos índices expressa em porcentagens para o período compreendido entre os anos de 1972 e 1995.

Tabela 6.3 -Taxa de variação dos índices morfométricos expressa em \% para a Área 1

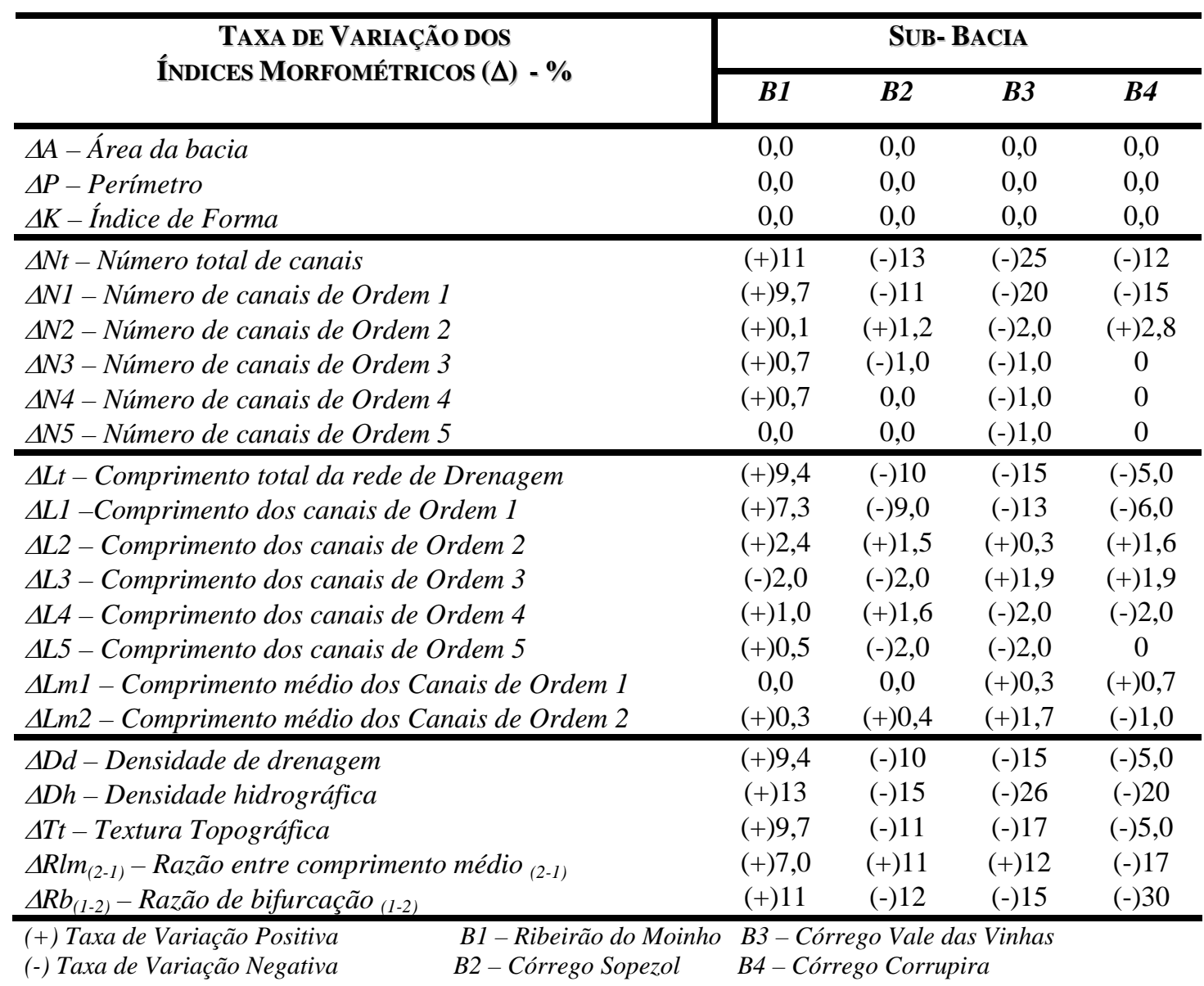

Conforme se observa nas tabelas 6.2 e 6.3, as variáveis área (A), perímetro (P) e índice de forma (k) não se modificaram ao longo do período estudado em todas as subbacias.

A área e perímetro das sub-bacias córregos Vale da Vinha e Corrupira apresentaram valores próximos a $6 \mathrm{~km}^{2}$ e $10 \mathrm{~km}$, respectivamente, enquanto para as demais sub-bacias situaram-se em torno de $20 \mathrm{~km}^{2}$ e $20 \mathrm{~km}$. O Índice de Forma mostrou valores uniformes $(1,21-1,33)$ em todas as sub-bacias.

Na estruturação interna da rede de drenagem das 4 sub-bacias foram observadas nítidas mudanças no número de canais de Ordem 1 e 2 (N1 e N2), conforme mostrado nas tabelas 6.2 e 6.3, enquanto nas demais ordens de canais as modificações foram pouco significativas (até 3\%) ou inexistentes (Figura 6.1). 
Dentre elas, as mudanças relacionadas ao aparecimento ou desaparecimento dos Canais de Ordem 1 foram as que mais influenciaram nas modificações do Número Total de Canais da rede de drenagem (Nt) das sub-bacias estudadas.

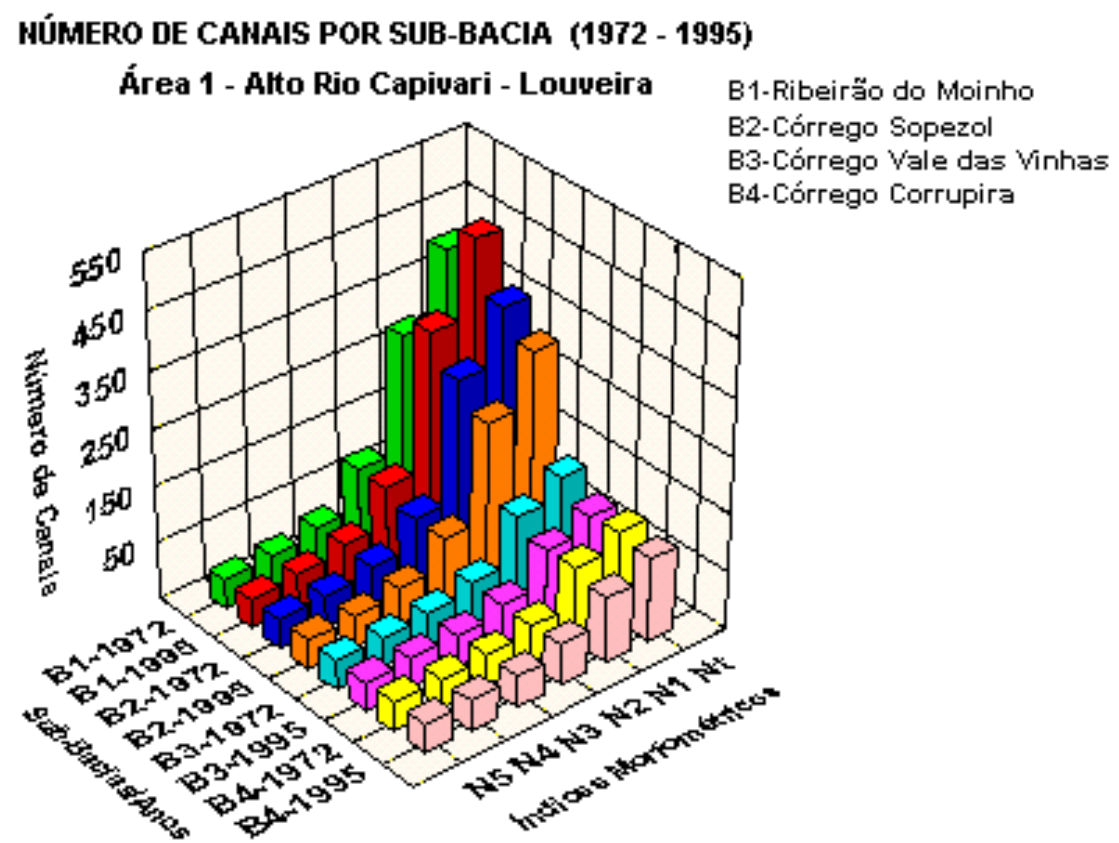

Nt-Número Total de Canais

N1-Número de Canais de Ordem 1

N2-Número de Canais de Ordem 2
N3-Número de Canais de Ordem 3 N4-Número de Canais de Ordem 4 N5-Número de Canais de Ordem 5

Figura 6.1 - Registro do Número de canais obtidos para os anos de 1972 e 1995 por subbacia analisada da Área 1

Outro ponto importante de registro foram as mudanças de alguns canais de Ordem 2 para Ordem 1 ou vice-versa. Tal fato contribui :

- para as modificações da hierarquia dos canais que foi nítida na Sub-Bacia Córrego Vale das Vinhas, pois levou à mudança na sua classificação hierárquica de Ordem 5, em 1972, para Ordem 4, em 1995 (Figura 6.2); e,

- para as modificações da extensão dos canais por ordem e, por conseguinte, no comprimento total da rede de drenagem (Figura 6.3).

Outro fator que contribuiu para a alteração do valor do comprimento total da rede de drenagem foi a redução ou aumento do número de canais de Ordem 1.

Em 1995, observou-se que a perda ou o aparecimento do número de canais de Ordem 1 e as modificações nas suas extensões, refletiram-se diretamente em mudanças nos índices Nt e Lt, as quais mostraram taxas de variação positivas para a Sub-Bacia Ribeirão do Moinho e taxas de variação negativa para as demais sub-bacias (Figuras 6.4 e 6.5). 
A Sub-Bacia Córrego Vale das Vinhas mostrou acentuada taxa de variação para os parâmetros número total de canais (Nt) e comprimento total da rede de drenagem (Lt) em relação às demais sub-bacias (Figura 6.3 e 6.4).

As alterações observadas nas variáveis Nt, Lt, N1 e L1 implicaram em mudanças nos valores de todos os demais parâmetros encontrados a partir deles.

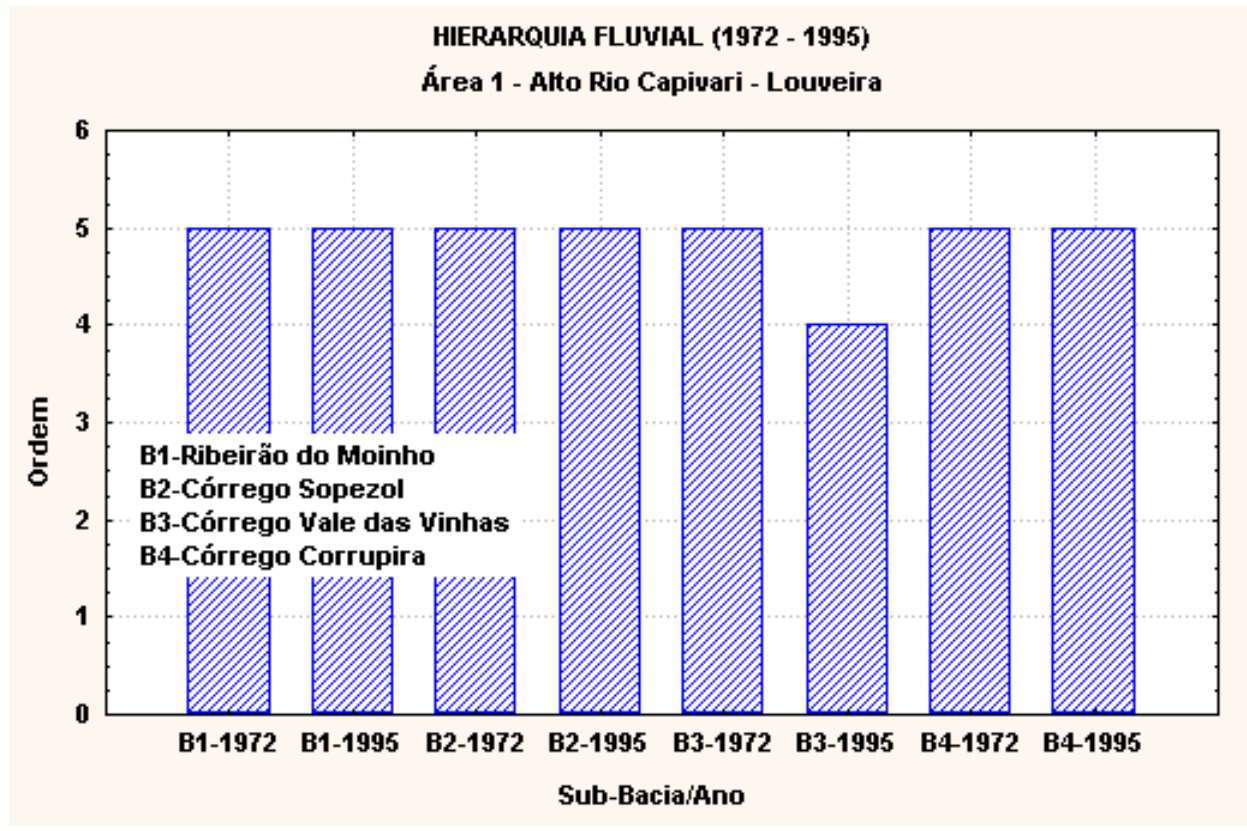

Figura 6.2 - Hierarquia Fluvial das sub-bacias estudadas da Área 1

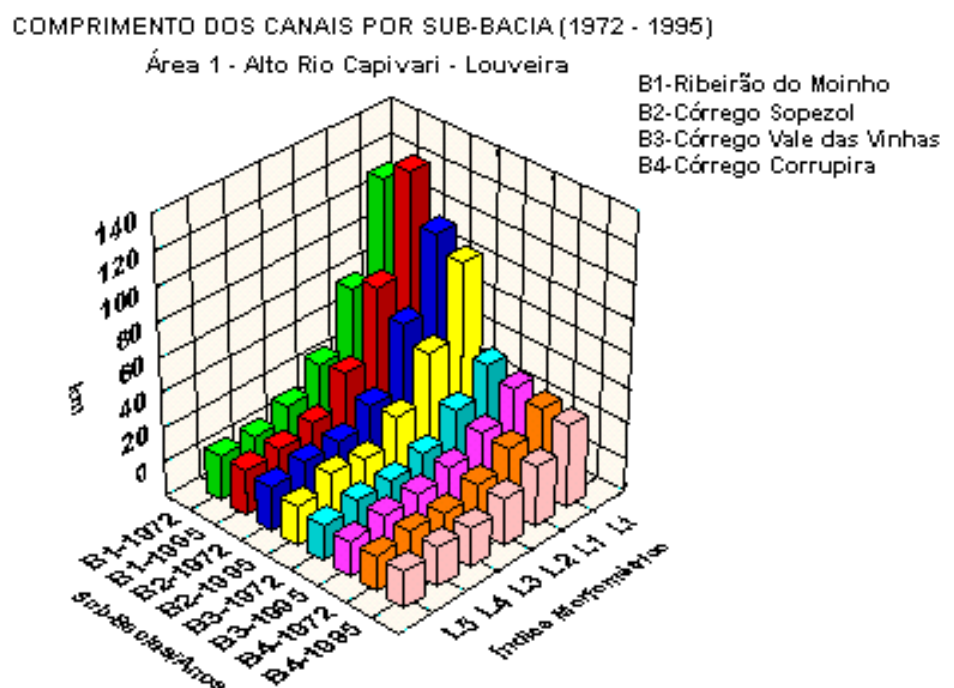




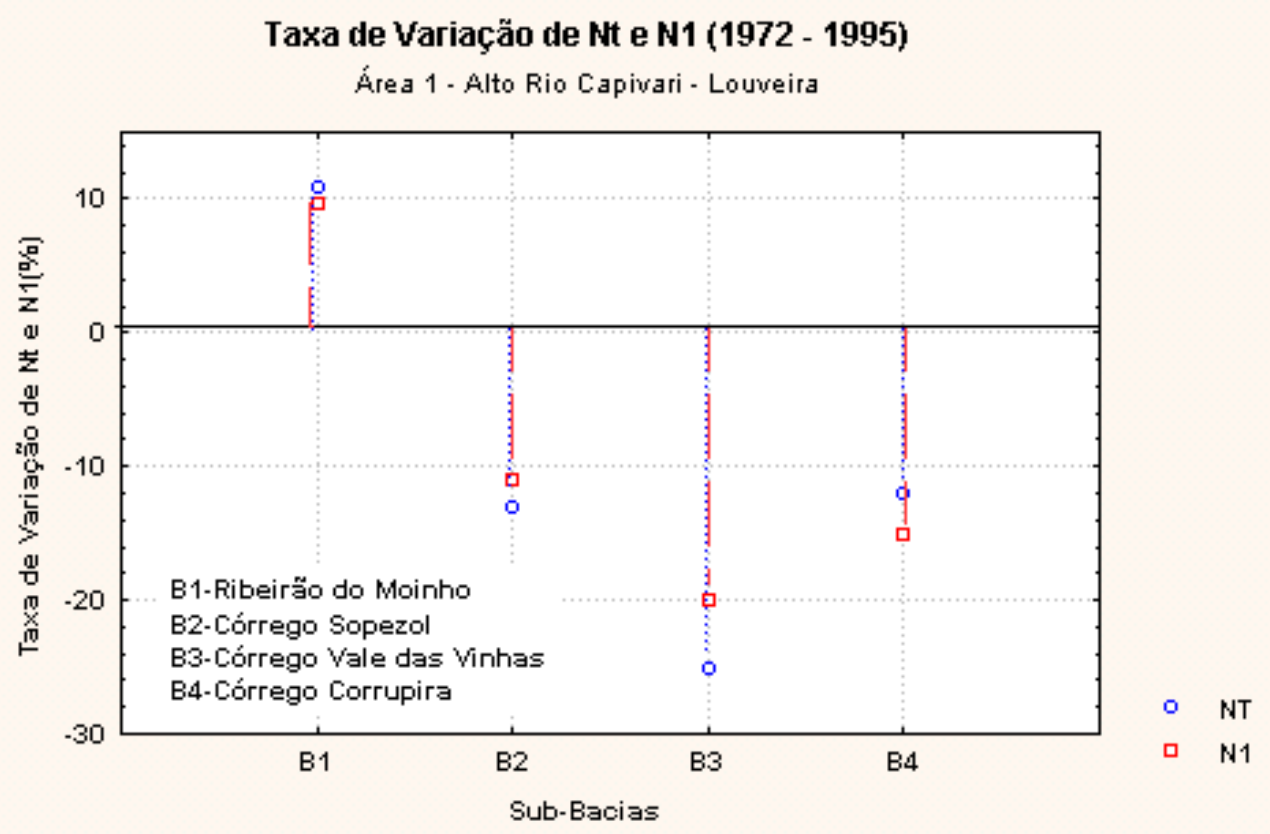

Figura 6.4 - Taxa de Variação de Nt e N1 para as sub-bacias da Área 1

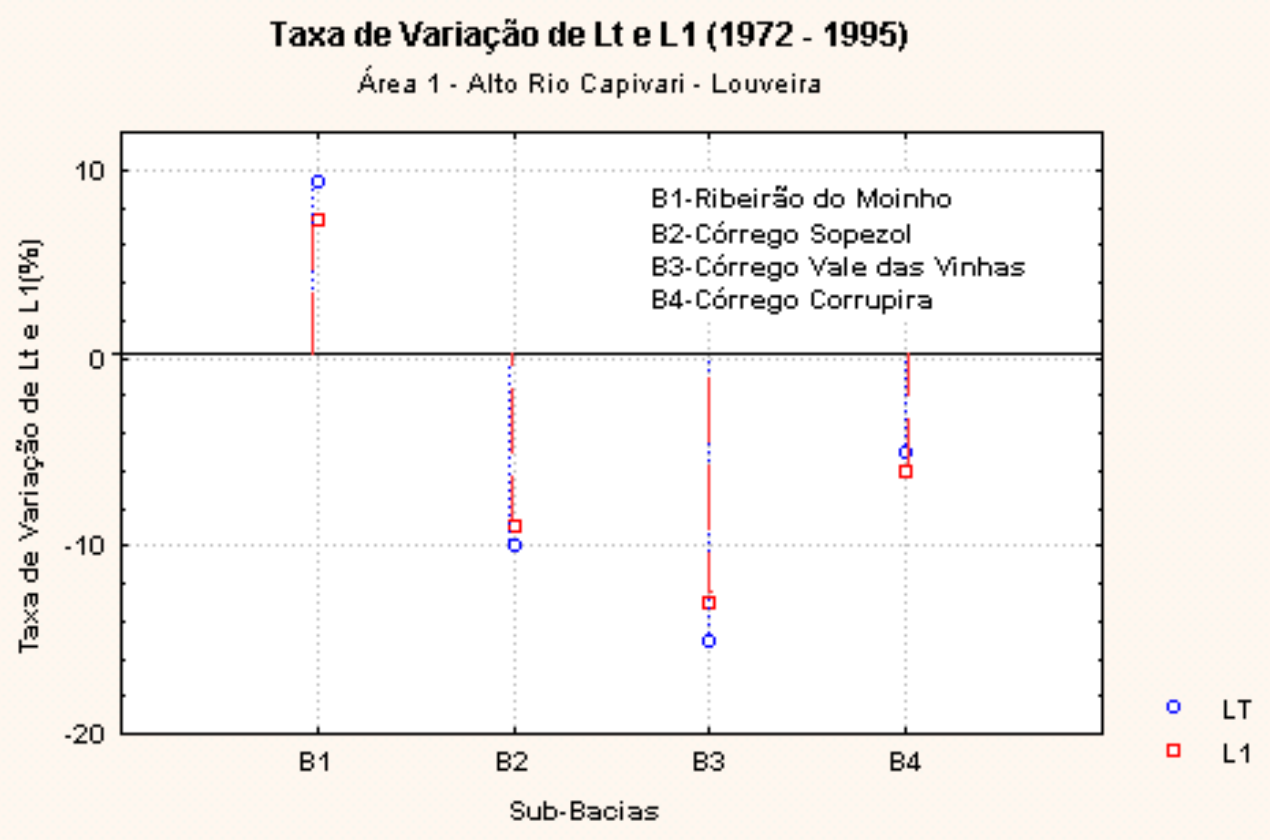

Figura 6.5 - Taxa de Variação de Lt e L1 para as sub-bacias da Área 1

Observou-se que a taxa de variação do índice comprimento médio dos canais de Ordem 1 e 2 foi inferior a 1\%, ao longo dos 23 anos nas sub-bacias estudadas (Tabela 6.3 e Figura 6.6). 


\section{Taxa de Variação do Compriménto Médio dos Canais (1972 - 1995)}

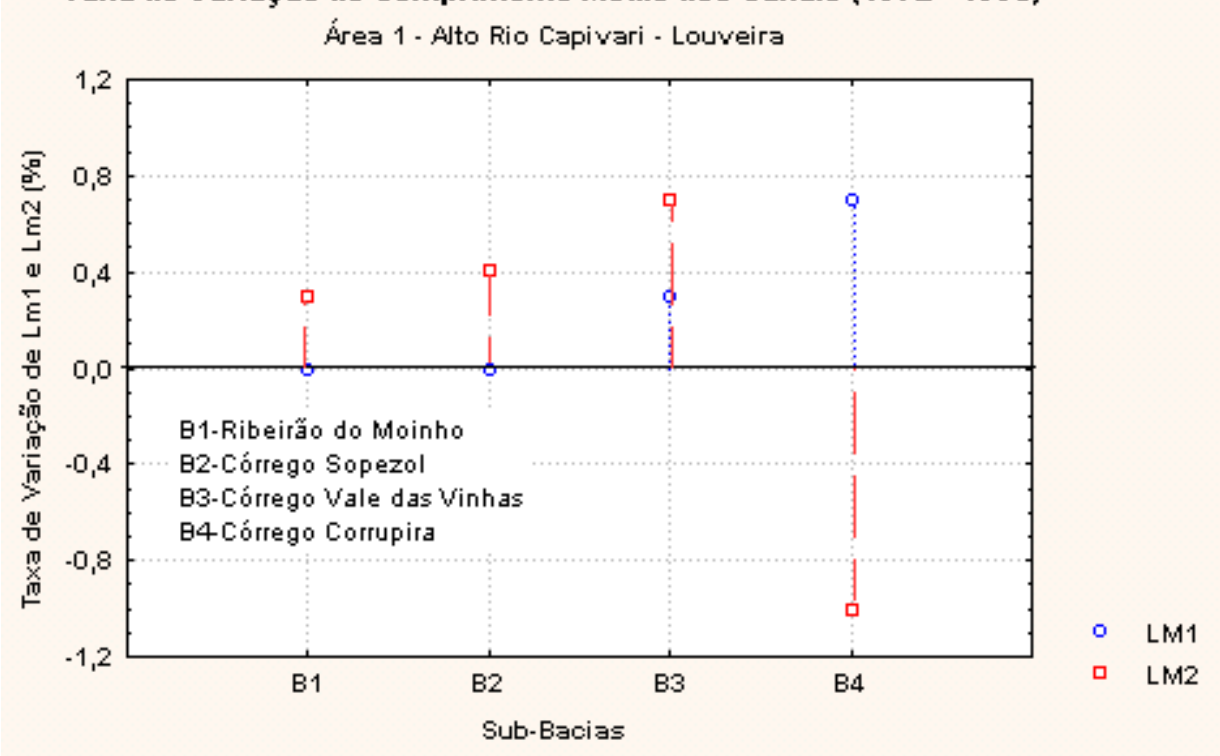

Figura 6.6 - Registro dos valores de Comprimento Médio dos Canais expresso em porcentagens para as sub-bacias da Área 1

O índice densidade de drenagem mostrou uma taxa de variação negativa para B2, B3 e B4, sendo mais acentuada na última sub-bacia. Para ambos os anos, 1972 e 1995, os valores obtidos indicaram uma baixa Dd conforme a classificação proposta por Cristofoletti (1969) (Figura 6.7).

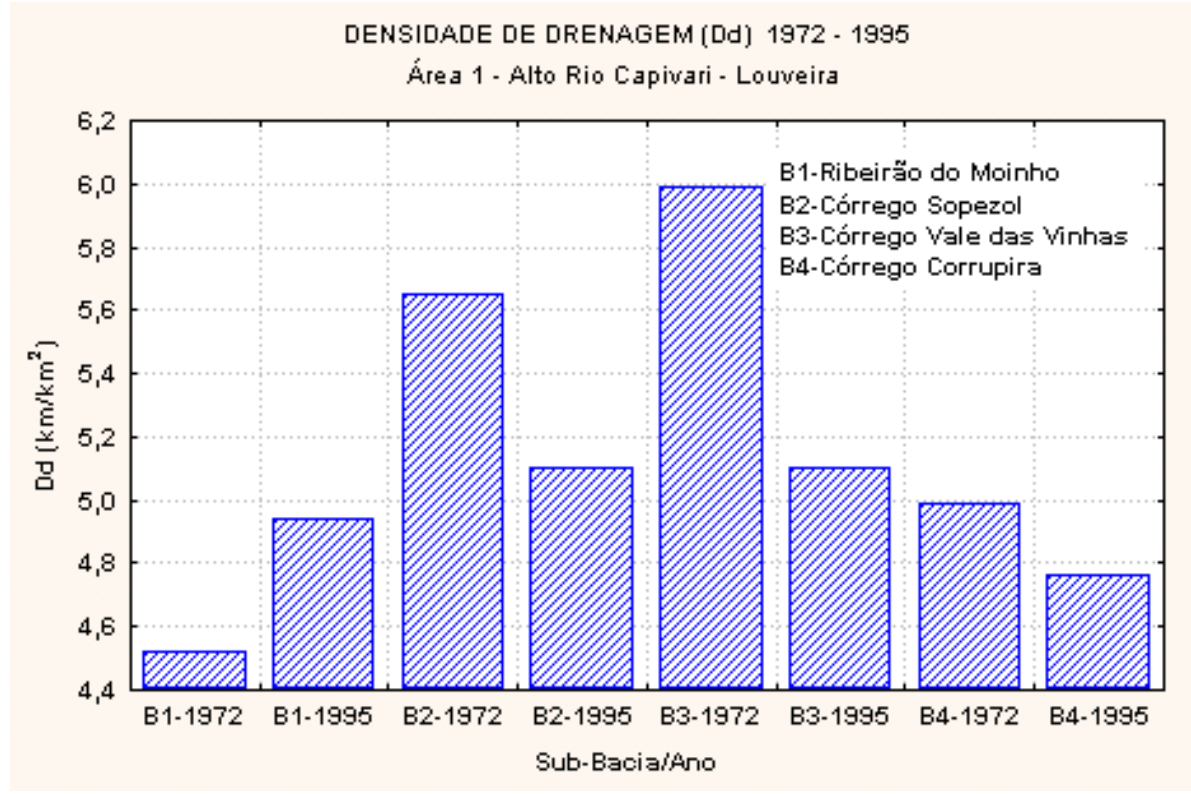

Figura 6.7 - Resultados obtidos para os anos de 1972 e 1995 de Densidade de Drenagem para cada Sub-Bacia da Área 1 
Quanto à Densidade Hidrográfica e baseando-se na classificação proposta por Lollo (1996), todas as sub-bacias apresentaram alta freqüência de canais em 1995 (Figura 6.8). Entretanto, em 1972, as sub-bacias Córrego Sopezol e Córrego Vale das Vinhas apresentaram muito alta freqüência de canais.

Os resultados obtidos para Textura Topográfica das sub-bacias permitiram enquadralas na classe fina para as duas épocas, de acordo com França (1968) (Figura 6.9). Seus valores variando entre 8 a $12 \mathrm{~km}$ podem indicar relevos altamente dissecados segundo estudo proposto por Politano et al (1991).

A Tabela 6.3 mostra uma taxa de variação positiva para Dd, Dh e Tt na Sub-Bacia Ribeirão do Moinho, indicando aumento do número e extensão dos canais de Ordem 1 ao passo que nas demais sub-bacias o processo foi contrário.

A razão de comprimento médio (2-1) mostrou, em 1995, redução no valor de 17\%, para a Sub-Bacia Córrego Corrupira; as demais sub-bacias apresentaram acréscimo em seus valores entre 7 a 12\% (Tabela 6.3 e Figura 6.10). Tais fatos ocorreram devido ao aumento nos valores do comprimento médio de Ordem 2 para as sub-bacias B1, B2 e B3 e redução na sub-bacia B4.

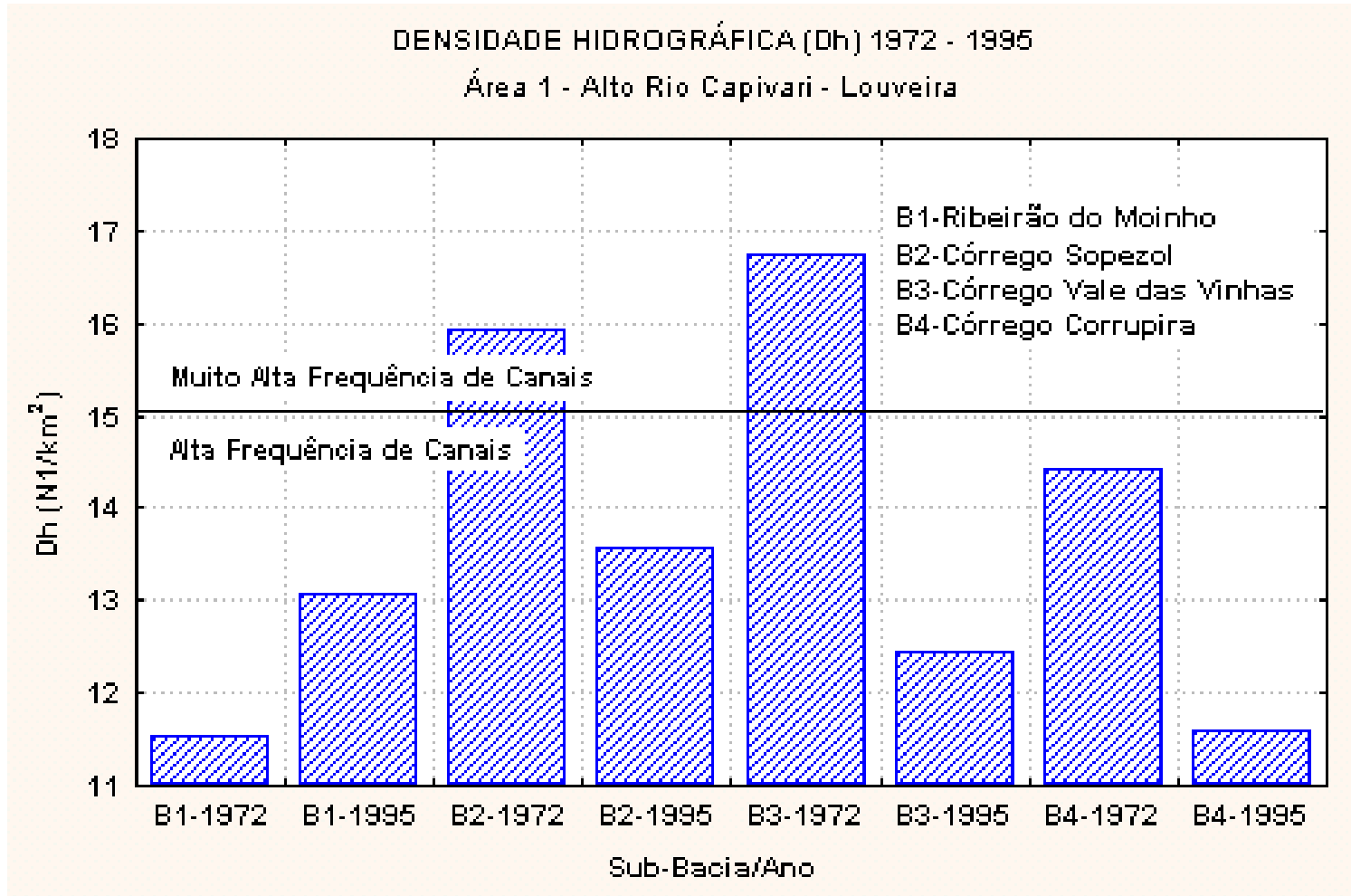

Figura 6.8 - Registro obtido para densidade hidrográfica nas sub-bacias no Alto Rio Capivari para os anos de 1972 e 1995 


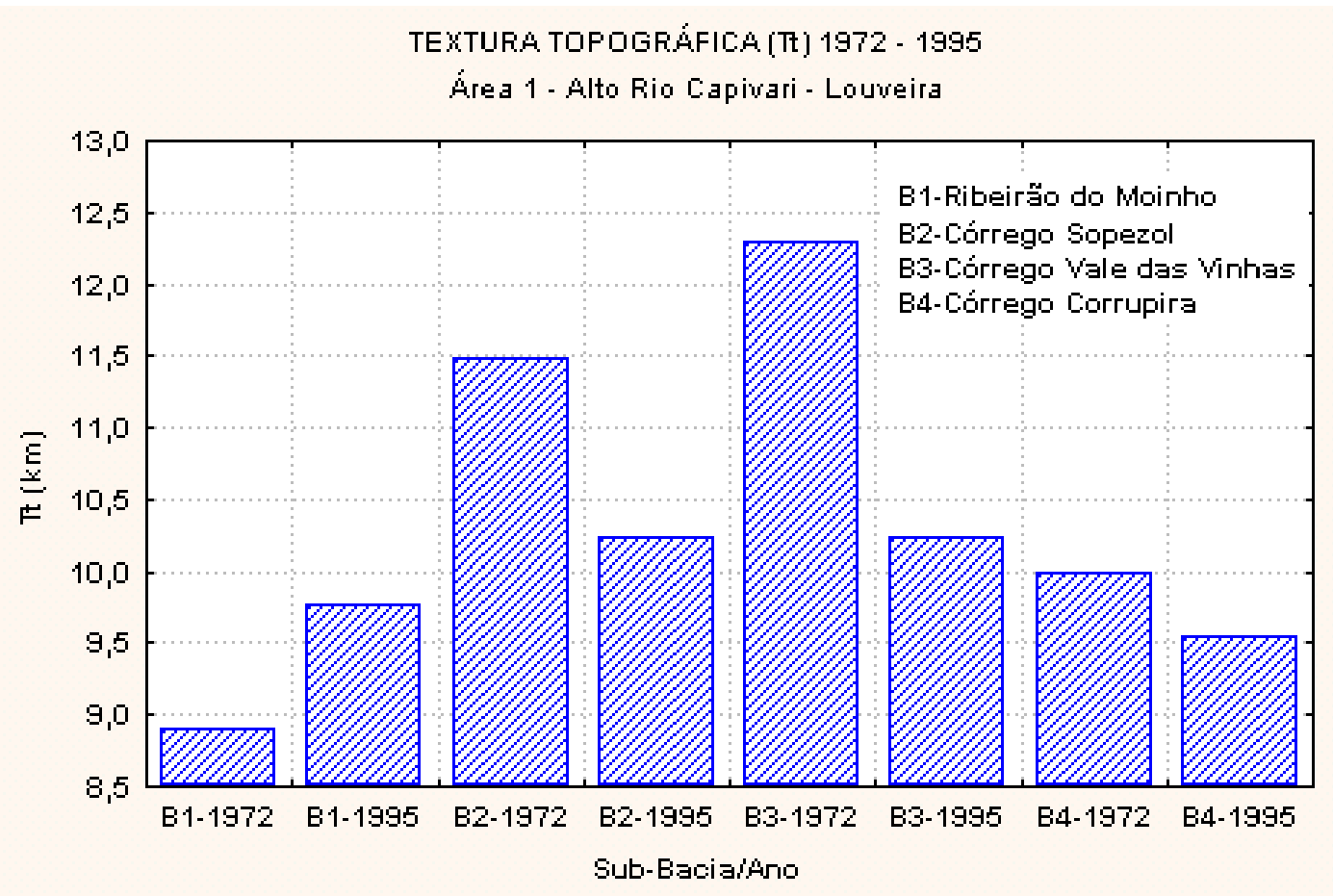

Figura 6.9 - Registro obtido para textura topográfica nas sub-bacias estudadas no Alto Rio Capivari para os anos de 1972 e 1995

RAZÃO ENTRE COMPRIMENTOS MÉDIOS DE CANAIS DE ORDEM 2 E 1 1972 1995 Área 1 - Alto Rio Capivari - Louveira

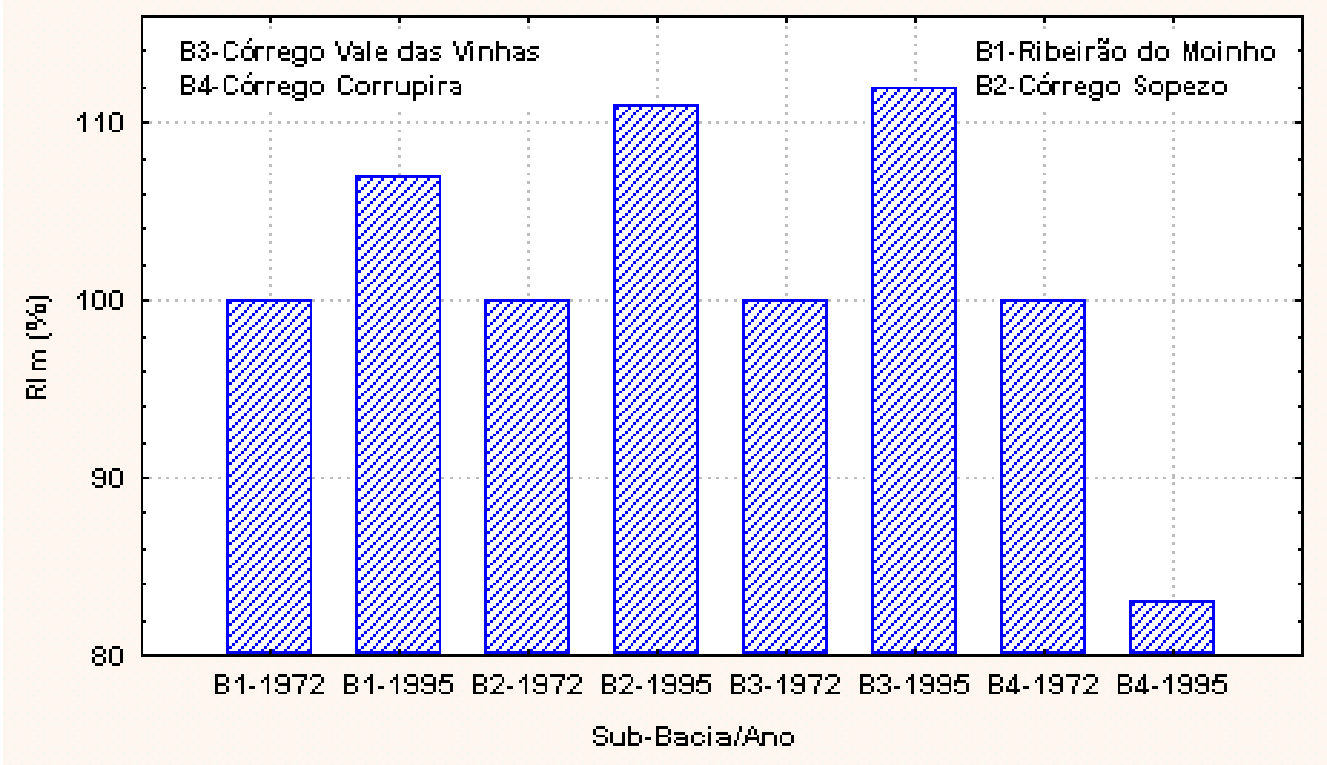

Figura 6.10 - Registro obtido para Razão entre Comprimento Médios dos canais de Ordem 2 e 1 nas sub-bacias estudadas no Alto Rio Capivari para os anos de 1972 e 1995 
O índice razão de bifurcação entre os canais de Ordem 1 e 2 apresentou para a SubBacia Ribeirão do Moinho, variação positiva em torno de 11\% que indicou um aumento no número dos canais de Ordem 1, enquanto nas demais sub-bacias, observou-se uma variação negativa, entre 12 a 30\%, devido ao desaparecimento dos números de canais de Ordem 1 (Tabela 6.3 e Figura 6.11).

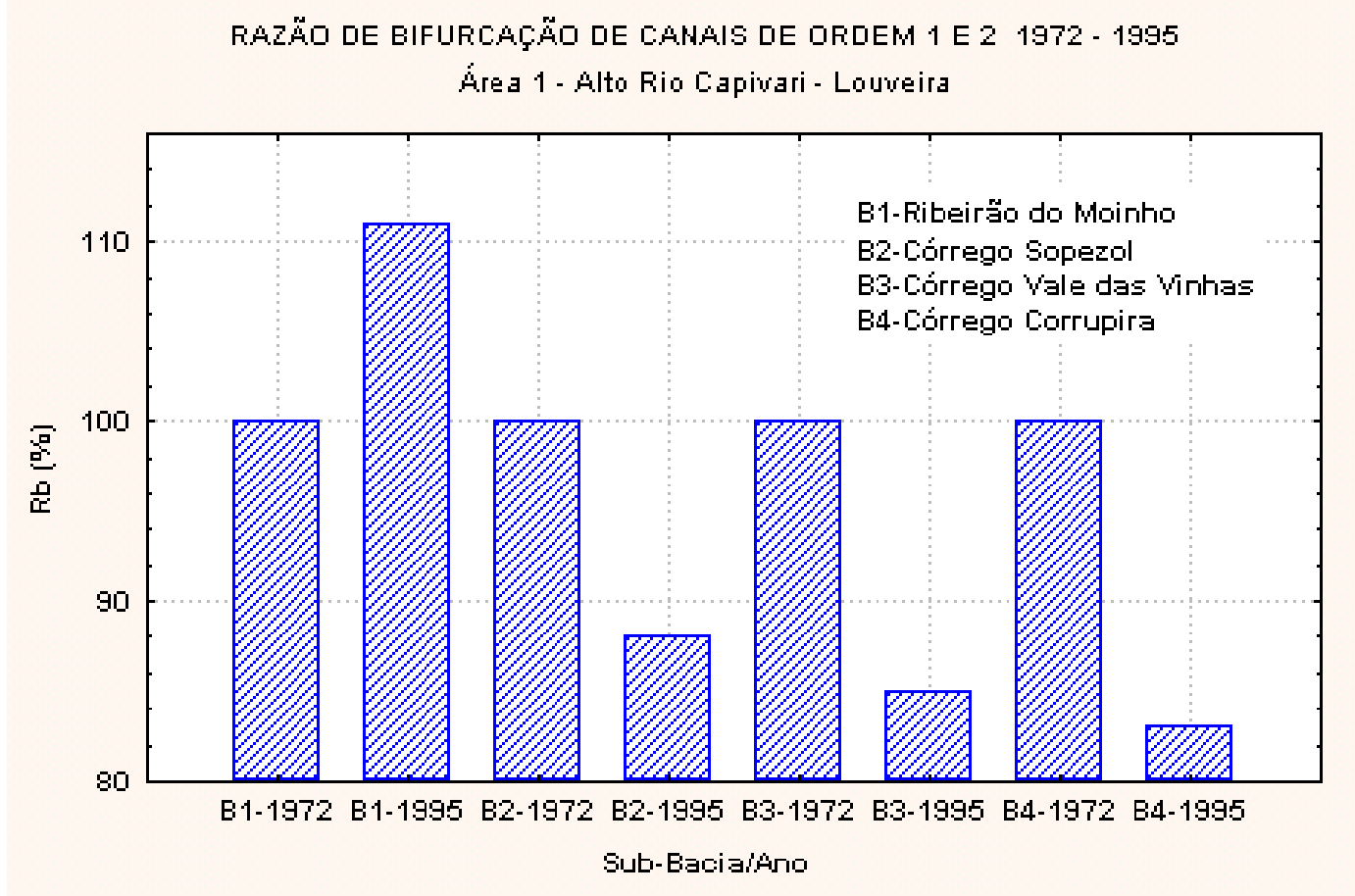

Figura 6.11 - Registro obtido para Razão de Bifurcação dos canais de Ordem 1 e 2 nas subbacias estudadas no Alto Rio Capivari para os anos de 1972 e 1995

As maiores reduções de $\mathrm{Rb}{ }_{(1-2)}$ foram observadas nas sub-bacias Córrego Vale das Vinhas (14,5\%) e Córrego Corrupira (30\%) (Tabela 6.3).

\section{$\underline{\text { 6.1.2 - Verificação Temporal de Modificações de Atividades Antrópicas }}$}

Ao longo dos 23 anos foram registradas modificações e/ou implantação de atividades antrópicas nas sub-bacias Ribeirão do Moinho (B1), Córrego Sopezol (B2), Córrego Vale das Vinhas (B3) e Córrego Corrupira (B4). Para facilitar a visualização dessas mudanças, foi necessário definir classes de uso e ocupação.

Para esta área, foram definidas 10 classes de uso e ocupação: Área Industrial (AI), Alta Urbanização (AU), Média Urbanização (MU), Baixa Urbanização (BU), Pesqueiro 
(PQ), Hortifruti (H), Mata/Reflorestamento (M), Pasto/Mata Capoeira (P), Explotação de Material de Construção (E) e Represa (R). A Tabela 6.4 mostra a distribuição areal das classes por sub-bacia para os períodos analisados e sua classificação quanto ao predomínio da atividade antrópica desenvolvida, segundo Collares (2000).

Tabela 6.4 - Distribuição areal das classes de uso e ocupação por sub-bacia.

\begin{tabular}{|c|c|c|c|c|c|}
\hline \multirow[t]{3}{*}{ SUB - BACIA } & \multirow[t]{3}{*}{ CATEGORIA } & \multicolumn{4}{|c|}{ DISTRIBUIÇÃo AREAL POR ClASSE } \\
\hline & & \multicolumn{2}{|c|}{1972} & \multicolumn{2}{|c|}{1995} \\
\hline & & $\mathrm{Km}^{2}$ & $\%$ & $\mathrm{~km}^{2}$ & $\%$ \\
\hline & Média Urbanização & - & - & 0,44 & 1,7 \\
\hline & Total (crescimento urbano) & - & - & 0,44 & 1,7 \\
\hline$\underline{\text { B1 }}$ & Hortifruti & 5,46 & 21,5 & 5,77 & 23 \\
\hline Ribeirão & Mata/Reflorestamento & 4,67 & 18,4 & 7,78 & 31 \\
\hline$\underline{\text { Do }}$ & Pasto/Mata Capoeira & 15,2 & 59,9 & 11,2 & 42 \\
\hline \multirow[t]{7}{*}{ Moinho } & Explotação & - & - & 0,11 & 0,4 \\
\hline & Represa & 0,05 & 0,2 & 0,55 & 2,2 \\
\hline & $\begin{array}{c}\text { Classificação proposta por } \\
\text { ColLARES (2000) }\end{array}$ & \multicolumn{4}{|c|}{$\begin{array}{l}\text { Rural Não Agrícola } \\
\text { predomínio de pastagens }\end{array}$} \\
\hline & Área Industrial & 0,07 & 0,4 & 0,7 & 4 \\
\hline & Alta Urbanização & - & - & 1,87 & 11 \\
\hline & Média Urbanização & 0,34 & 1,9 & 0,49 & 2,8 \\
\hline & Baixa Urbanização & 0,45 & 2,6 & 0,41 & 2,4 \\
\hline$\underline{\text { B2 }}$ & Total (crescimento urbano) & 0,86 & 4,9 & & 20,2 \\
\hline Córrego & Pesqueiro & - & - & 0,05 & 0,3 \\
\hline \multirow[t]{8}{*}{ Sopezol } & Hortifruti & 7,73 & 44 & 6,95 & 40 \\
\hline & Mata/Reflorestamento & 2,24 & 13 & 3,68 & 21 \\
\hline & Pasto/Mata Capoeira & 6,51 & 37 & 2,97 & 17 \\
\hline & Explotação & - & - & 0,11 & 0,7 \\
\hline & Represa & 0,06 & 0,3 & 0,14 & 0,8 \\
\hline & $\begin{array}{l}\text { Classificação proposta por } \\
\text { COLLARES (2000) }\end{array}$ & \multicolumn{2}{|c|}{$\begin{array}{c}\text { Rural Parcialmente Agrícola, não } \\
\text { há predomínio de pastagens ou } \\
\text { culturas agrícolas }\end{array}$} & \multicolumn{2}{|c|}{$\begin{array}{c}\text { Rural Agrícola com } \\
\text { instauração de focos } \\
\text { urbanos }\end{array}$} \\
\hline & Área Industrial & - & - & 0,08 & 1,3 \\
\hline & Baixa Urbanização & - & - & 1,09 & 17 \\
\hline B3 & Total (crescimento urbano) & - & - & 1.17 & 18.3 \\
\hline Córrego & Pesqueiro & - & - & 0,05 & 0,8 \\
\hline$\underline{\text { Vale }}$ & Hortifruti & 3,53 & 56,4 & 2,35 & 37 \\
\hline$\overline{\text { Das }}$ & Mata/Reflorestamento & 1,22 & 19,4 & 1,59 & 25 \\
\hline \multirow[t]{6}{*}{ Vinhas } & Pasto/Mata Capoeira & 1,5 & 24 & 1,08 & 17 \\
\hline & Represa & 0,01 & 0,2 & 0,03 & 0,5 \\
\hline & $\begin{array}{l}\text { Classificação proposta por } \\
\text { COLLARES (2000) }\end{array}$ & \multicolumn{2}{|c|}{ Rural Agrícola } & \multicolumn{2}{|c|}{$\begin{array}{c}\text { Rural Agrícola com } \\
\text { instauração de focos } \\
\text { urbanos }\end{array}$} \\
\hline & Baixa Urbanização & - & - & 0,79 & 14 \\
\hline & Total (crescimento urbano) & - & - & 0,79 & 14 \\
\hline & Pesqueiro & - & - & 0,05 & 0,9 \\
\hline$\underline{\text { B4 }}$ & Hortifruti & 1,83 & 32,1 & 1,81 & 32 \\
\hline Córrego & Mata/Reflorestamento & 1,19 & 20,8 & 1,78 & 31 \\
\hline \multirow[t]{4}{*}{ Corrupira } & Pasto/Mata Capoeira & 2,64 & 46,4 & 1,04 & 18 \\
\hline & Explotação & - & - & 0,16 & 2,8 \\
\hline & Represa & 0,04 & 0,72 & 0,06 & 1 \\
\hline & $\begin{array}{l}\text { Classificação proposta por } \\
\text { COLLARES (2000) }\end{array}$ & $\begin{array}{r}\text { Rural Parc } \\
\text { há predo } \\
\text { cul }\end{array}$ & $\begin{array}{l}\text { rícola, não } \\
\text { tagens ou } \\
\text { las }\end{array}$ & \multicolumn{2}{|c|}{$\begin{array}{c}\text { Rural Agrícola com } \\
\text { instauração de focos } \\
\text { urbanos }\end{array}$} \\
\hline
\end{tabular}

Obs: As categorias de maior percentagens que permitem classificar as sub-bacias estão destacadas em negrito. O crescimento urbano nas sub-bacias está destacado em itálico. 
Como pode ser observado nas figuras 6.10, 6.11, 6.12 e 6.13 e na Tabela 6.4, todas as sub-bacias são consideradas rurais com diferenças no predomínio do cultivo agrícola e/ou pastagens. Entretanto, verificou-se um crescimento urbano pronunciado em 1995 (14 a 20\%), principalmente, nas sub-bacias B2, B3 e B4, o qual caracterizou-se pelo aumento e/ou implantação de bairros periféricos, áreas comerciais e áreas industriais nos municípios de Louveira e Jundiaí e nas adjacências das vias de acesso, Rodovia Anhanguera e Bandeirantes.

Observou-se que as áreas de pastagens foram predominantes durante os 23 anos na Sub-Bacia Ribeirão do Moinho (Figura 6.12)

Outro ponto importante referente à Sub-Bacia Ribeirão do Moinho (Figura 6.12), e conjuntamente à Sub-Bacia Córrego Corrupira (Figura 6.15) foi o registro, em 1995, de valores percentuais da Classe Represa superior e igual a $1 \%$.

A construção dessas obras, comumente, interfere no regime natural do escoamento das águas, além de promover alterações no terreno com a retirada da mata ciliar e/ou remobilização do solo.

A Sub-Bacia Córrego Sopezol, em 1972, foi considerada Rural Parcialmente Agrícola, pois não havia predominância nem de áreas de pastagens e nem de áreas agrícolas, entretanto já naquele momento foram identificados focos de urbanização. Por outro lado em 1995, registrou-se o crescimento de áreas com cultivo agrícola e de áreas industriais e residenciais, o que permitiu classificá-la como Rural agrícola com focos crescentes de urbanização (Figura 6.13). Nesta sub-bacia verificou-se maior implantação e/ou modificação das atividades antrópicas, como indicado pela Tabela 6.4.

Assim como a Sub-Bacia Córrego Sopezol, também as sub-bacias Ribeirão do Moinho e Córrego Corrupira registraram a Classe Explotação de Materiais de Construção; nas duas primeiras o registro foi inferior a $1 \%$, entretanto na última já atinge 3\%. A implantação dessa atividade, normalmente, pode ser responsável por alto potencial de degradação.

A Sub-Bacia Córrego Vale das Vinhas foi considerada, em 1972, Rural Parcialmente Agrícola, ou seja, não havia predomínio nem de áreas de pastagens e nem de áreas de cultivo agrícola. Em 1995, entretanto, registrou-se predomínio de áreas agrícolas e o aparecimento das classes Área Industrial e Baixa Urbanização (Figura 6.14). 


\section{B1 - SUB-BACIA RIBEIRÃO DO MOINHO (Alto Rio Capivari - Louveira)}

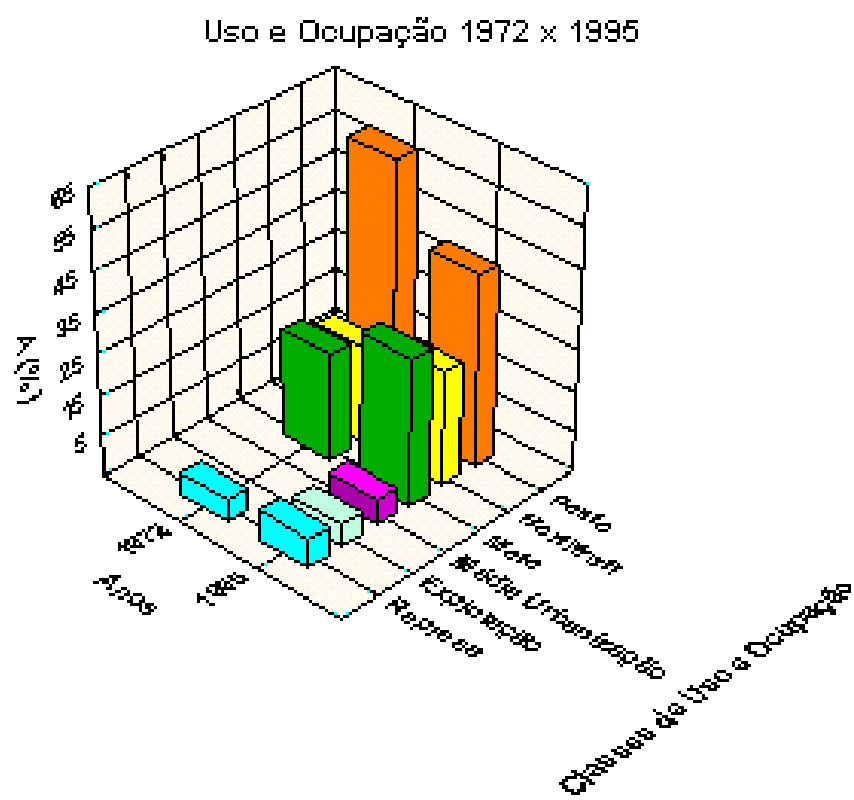

Figura 6.12 - Modificações observadas nas classes de atividades antrópicas da Sub-Bacia Ribeirão do Moinho (B1)

\section{B2 - SUB-BACIA CÓRREGo SOPEZOL (Alto Rio Capivari - Louveira)}

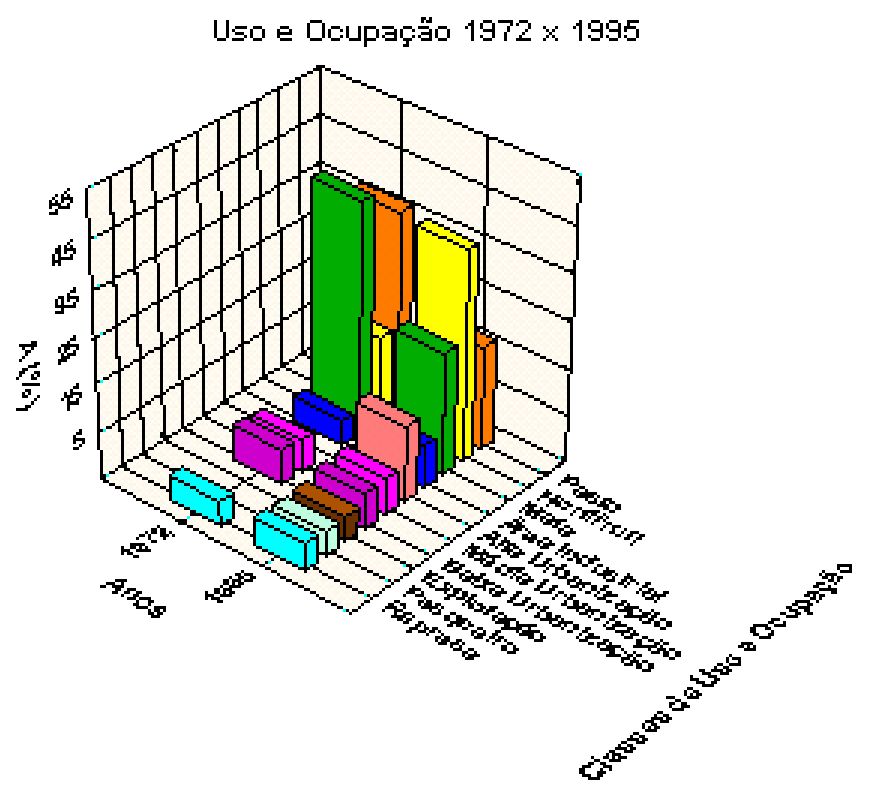

Figura 6.13 - Modificações observadas nas classes de atividades antrópicas da Sub-Bacia Córrego Sopezol (B2) 


\section{B3 - SUB-BACIA CÓRREGo vaLE DAS VIHHAS (Alto Rio Capivari - Louveira)}

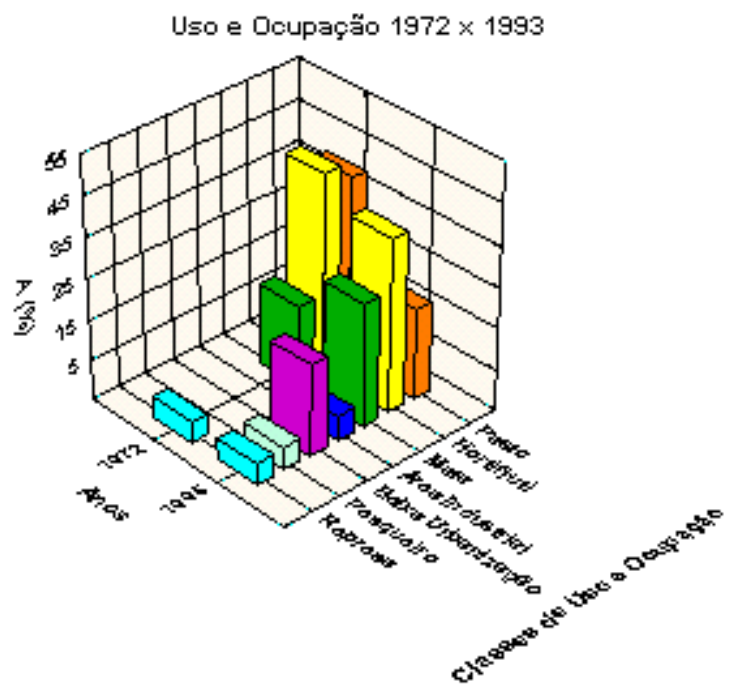

Figura 6.14 - Modificações observadas nas classes de atividades antrópicas da Sub-Bacia Córrego Sopezol (B3)

A Sub-Bacia Córrego Corrupira foi classificada em 1972 como Rural Não Agrícola, devido ao predomínio de áreas de pastagens, mas em 1995 passou a ser considerada como Rural Agrícola com início de processo de urbanização.

\section{B4 - SUB-BACIA CÓRREGo CORRUPIRA (Alto Rio Capivari - Louveira)}

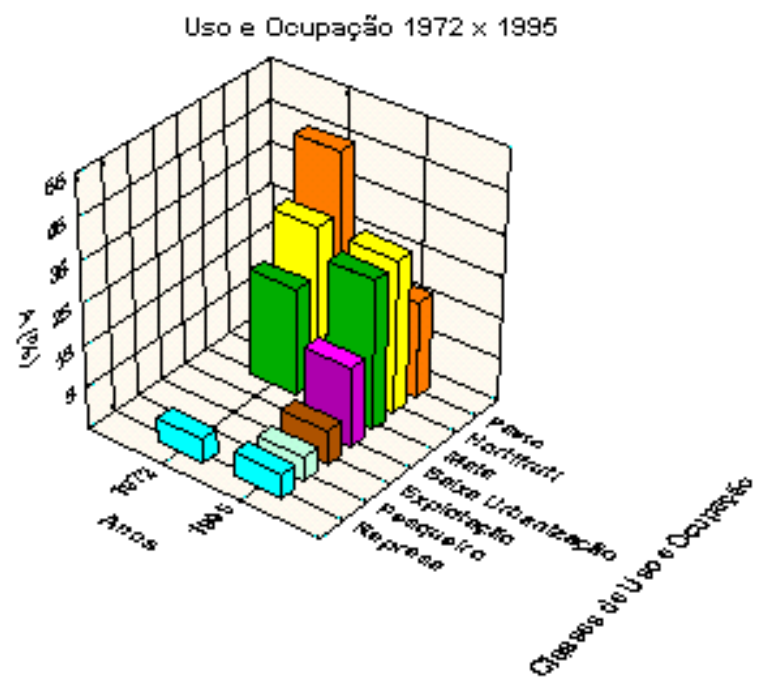

Figura 6.15 - Modificações observadas nas classes de atividades antrópicas da Sub-Bacia Córrego Sopezol (B4) 
Em 1995, um ponto importante a destacar foi o registro, em todas as sub-bacias, do aumento dos percentuais da classe mata/reflorestamento (Figuras 6.12, 6.13, 6.14 e 6.15) devido ao replantio de pinus e eucaliptos, principalmente próximo às cabeceiras dos córregos. Nessas áreas foram registradas modificações do número de canais e comprimento dos canais de Ordem 1, o que sugere que esses tipos de árvores não sejam solução mais adequada num processo de restauração ou conservação de áreas.

\subsection{3 - Considerações Parciais - Sub-Bacias da Área 1}

A análise morfométrica das sub-bacias estudadas para a Área 1, localizada no Alto Rio Capivari, mostrou inter-relação entre os parâmetros N1, Nt, Lt e L1 com influência direta nos índices densidade de drenagem e densidade hidrográfica. Assim como uma relação direta entre os índices textura topográfica e densidade de drenagem.

As alterações referentes ao aumento ou decréscimo do número de canais de Ordem 1 e de seus comprimentos foram as mais significativas e responsáveis pelas mudanças na geometria interna da rede de drenagem das sub-bacias.

Os índices comprimentos médios dos canais de Ordem 1 e 2 apresentaram alterações pouco significativas, ao longo do período analisado, para todas as sub-bacias.

A Sub-Bacia Córrego Vale das Vinhas (B3) apresentou as taxas de variação dos índices mais significativas ao longo do período estudado. Cabe destacar, o registro da mudança hierárquica de Ordem 5 para 4 entre 1972 e 1995 para essa sub-bacia.

A Sub-Bacia Córrego Corrupira (B4) mostrou perdas significativas nos canais de Ordem 1, que refletiram diretamente nos índices Razão de Bifurcação e Densidade Hidrográfica, uma vez que se registrou taxas negativas acentuadas dessas variáveis, 30 e $20 \%$, respectivamente.

A Sub-Bacia Ribeirão do Moinho (B1) caracterizou-se pelo aumento do número de canais de Ordem 1 e respectivos comprimentos, e conseqüentemente os demais índices dele decorrentes apresentaram alterações positivas.

A sub-bacia córrego Sopezol (B2) apresentou suas taxas de variações dos índices Nt, N1, Lt, L1, Dd, Dh, Tt, Rlm $2-1$ e Rb $b_{1-2}$ em torno de $10 \%$.

Quanto às alterações nas taxas das classes de atividades antrópicas pode-se definir para as sub-bacias que apresentaram as alterações mais significativas das variáveis morfométricas, B3 e B4, crescimento urbano acentuado, assim como a implantação de novas classes de atividades antrópicas. 
A essas sub-bacias deve ser atribuído o cultivo agrícola intensivo como possível fator de importância na deflagração das alterações da rede de drenagem. Particularmente para a Sub-Bacia Córrego Corrupira, tanto a implantação de áreas destinadas a explotação de material de construção como o registro de acréscimo das áreas de represas, que correspondem a fatores com alto potencial de degradação, contribuíram nas modificações da rede de drenagem.

As modificações da rede de drenagem da Sub-Bacia Córrego Sopezol podem ser associadas às alterações das suas classes de atividades antrópicas. Essa sub-bacia não só apresentou taxa de variação acentuada de crescimento urbano (15\%) ao longo do período estudado, mas também registrou todas as demais classes que podem causar degradação.

Na Sub-Bacia Ribeirão do Moinho, em 1995, foi observado um pequeno foco de urbanização e o registro do aumento de atividades com alto potencial de degradação como a implantação de um maior número de represas e áreas destinadas a explotação de material de construção civil. Nesta sub-bacia, registrou-se também a substituição de áreas de pasto por hortifruti. O acréscimo do número de canais ocorreu próximo às áreas de represas e de pastagens.

\section{2 - ÁREA 2 - BAIXO RIO CAPIVARI}

\subsection{1 - Verificacão das Alterações na Rede de Drenagem nas Sub- Bacias Hidrográficas por meio da Análise Morfométrica}

Similarmente a Área 1, os índices morfométricos analisados foram subdivididos em: Variáveis Relacionadas à Morfologia e Variáveis Relacionadas à Rede de Drenagem.

Os resultados obtidos na análise morfométrica das sub-bacias córregos Borão (C1), Alto Retiro (C2), Santa Rita (C3), São Francisco (C4) e Itapeva (C5), para os anos de 1972 e 1995 são apresentados na Tabela 6.5.

Para facilitar a observação das mudanças foram calculadas em porcentagens as taxas de variação no período estudado, as quais são apresentadas na Tabela 6.6. 
Tabela 6.5 - Parâmetros morfométricos obtidos para as sub-bacias da Área 2.

\begin{tabular}{|c|c|c|c|c|c|c|c|c|c|c|}
\hline \multirow[t]{3}{*}{ PARÂMETROS MORFOMÉTRICOS } & \multicolumn{10}{|c|}{ SUB-BACIA } \\
\hline & \multicolumn{5}{|c|}{1972} & \multicolumn{5}{|c|}{1995} \\
\hline & C1 & $C 2$ & C3 & C4 & C5 & C1 & C2 & C3 & C4 & C5 \\
\hline A-Área da bacia $\left(\mathrm{Km}^{2}\right)$ & 6,68 & 5,52 & 4,12 & 6,05 & 30,4 & 6,68 & 5,52 & 4,12 & 6,05 & 30,4 \\
\hline $\mathbf{P}-$ Perímetro $(\mathrm{km})$ & 12,3 & 10,9 & 11,5 & 11,4 & 32,4 & 12,3 & 10,9 & 11,5 & 11,3 & 32,4 \\
\hline K-Índice de Forma & 1,34 & 1,31 & 1,6 & 1,3 & 1,66 & 1,34 & 1,31 & 1,60 & 1,30 & 1,66 \\
\hline Nt-Número total de canais & 144 & 138 & 56 & 91 & 446 & 125 & 119 & 50 & 82 & 399 \\
\hline N1-Número de canais de Ordem 1 & 109 & 106 & 43 & 69 & 341 & 97 & 90 & 37 & 64 & 307 \\
\hline N2-Número de canais de Ordem 2 & 31 & 25 & 10 & 17 & 80 & 25 & 23 & 10 & 14 & 70 \\
\hline N3-Número de canais de Ordem 3 & 3 & 6 & 2 & 4 & 20 & 2 & 5 & 2 & 3 & 18 \\
\hline N4-Número de canais de Ordem 4 & 1 & 1 & 1 & 1 & 4 & 1 & 1 & 1 & 1 & 3 \\
\hline N5-Número de canais de Ordem 5 & - & - & - & - & 1 & - & - & - & - & 1 \\
\hline $\begin{array}{l}\text { Lt-Comprimento total da rede de } \\
\text { Drenagem }(\mathrm{km})\end{array}$ & 32,7 & 30,6 & 13,7 & 26,2 & 121 & 28,5 & 28,1 & 11,6 & 23,9 & 110 \\
\hline $\begin{array}{l}\text { L1-Comprimento dos canais de Ordem } \\
1-\mathrm{km}\end{array}$ & 17,6 & 16,9 & 8,21 & 14,8 & 64,5 & 15,6 & 15,3 & 6,57 & 13,5 & 59,1 \\
\hline $\begin{array}{l}\text { L2-Comprimento dos canais de Ordem } \\
2-k m\end{array}$ & 8,36 & 7,08 & 2,38 & 6,83 & 28,9 & 7,57 & 6,50 & 2,19 & 6,43 & 26,1 \\
\hline $\begin{array}{l}\text { L3-Comprimento dos canais de Ordem } \\
3-\mathrm{km}\end{array}$ & 2,66 & 4,16 & 1,9 & 1,94 & 12,2 & 1,83 & 3,83 & 1,70 & 1,39 & 10,7 \\
\hline $\begin{array}{l}\text { L4-Comprimento dos canais de Ordem } \\
4-\mathrm{km}\end{array}$ & 4,05 & 2,46 & 1,19 & 2,59 & 10,2 & 3,46 & 2,44 & 1,11 & 2,56 & 10,3 \\
\hline $\begin{array}{l}\text { L5-Comprimento dos canais de Ordem } \\
5-\mathrm{km}\end{array}$ & - & - & - & - & 5,28 & - & - & - & - & 3,73 \\
\hline $\begin{array}{l}\text { Lm1-Comprimento médio dos Canais } \\
\text { de Ordem } 1-k m\end{array}$ & 0,16 & 0,16 & 0,19 & 0,21 & 0,19 & 0,16 & 0,17 & 0,18 & 0,21 & 0,19 \\
\hline $\begin{array}{l}\text { Lm2-Comprimento médio dos Canais } \\
\text { de Ordem } 2-\mathrm{km}\end{array}$ & 0,27 & 0,28 & 0,24 & 0,4 & 0,36 & 0,3 & 0,28 & 0,22 & 0,46 & 0,37 \\
\hline Dd-Densidade de drenagem $\left(\mathrm{km} / \mathrm{km}^{2}\right)$ & 4,89 & 5,54 & 3,32 & 4,32 & 3,98 & 4,26 & 5,09 & 2,81 & 3,95 & 3,62 \\
\hline Dh Densidade hidrográfica $\left(\mathrm{N} 1 / \mathrm{km}^{2}\right)$ & 16,3 & 19,2 & 10,4 & 11,4 & 11,2 & 14,5 & 16,3 & 8,98 & 10,6 & 10,1 \\
\hline Tt-Textura Topográfica (km) & 9,77 & 11,2 & 6,3 & 8,51 & 7,76 & 8,31 & 10,2 & 5,24 & 7,76 & 6,92 \\
\hline $\begin{array}{l}\mathbf{R l m}_{(2-1)}-\text { Razão entre comprimento } \\
\text { médios de canais de Ordem } 2 \text { e } 1 \text { ) }\end{array}$ & 1,67 & 1,78 & 1,25 & 1,87 & 1,91 & 1,88 & 1,66 & 1,23 & 2,17 & 1,93 \\
\hline $\begin{array}{l}\mathbf{R b}_{(1-2)}-\text { Razão de bifurcação entre } \\
\text { canais de Ordem } 1 \text { e } 2\end{array}$ & 3,52 & 4,24 & 4,3 & 4,06 & 4,26 & 3,88 & 3,91 & 3,70 & 4,57 & 4,39 \\
\hline
\end{tabular}

A área (A) e o perímetro (P) das sub-bacias não sofreram mudanças ao longo do período estudado e consequentemente o índice de forma $(\mathrm{k})$ que foi obtido a partir dessas variáveis permaneceu com o mesmo valor (tabelas 6.5 e 6.6).

As sub-bacias córregos Borão (C1), Alto Retiro (C2), Santa Rita (C3) e São Francisco (C4) apresentaram pequena extensão areal, entre 5,52 a 6,68 $\mathrm{km}^{2}$ e perímetros em torno de $10 \mathrm{~km}$, em contraste com a Sub-Bacia Itapeva (C5) que conta com extensa área de aproximadamente $30 \mathrm{~km}^{2}$ e perímetro de 32,4 km (Tabela 6.5). 
Tabela 6.6 -Taxa de variação dos índices morfométricos expressa em \% da Área 2

\begin{tabular}{|c|c|c|c|c|c|}
\hline \multirow{2}{*}{$\begin{array}{c}\text { TAXA DE VARIAÇÃO DOS } \\
\text { Í́NDICES MORFOMÉTRICOS }(\Delta)-\%\end{array}$} & \multicolumn{5}{|c|}{ SUB- BACIA } \\
\hline & C1 & $C 2$ & C3 & C4 & C5 \\
\hline$\triangle A-$ Área da bacia & 0 & 0 & 0 & 0 & 0 \\
\hline$\Delta P$ - Perímetro & 0 & 0 & 0 & 0 & 0 \\
\hline$\Delta K$ - Índice de Forma & 0 & 0 & 0 & 0 & 0 \\
\hline$\Delta N t$ - Número total de canais & $(-) 13$ & $(-) 14$ & $(-) 11$ & $(-) 9,9$ & $(-) 11$ \\
\hline$\Delta N 1$ - Número de canais de Ordem 1 & $(-) 8,3$ & $(-) 12$ & $(-) 11$ & $(-) 5,5$ & $(-) 7,6$ \\
\hline$\triangle N 2$ - Número de canais de Ordem 2 & $(-) 4,2$ & $(-) 1,4$ & 0 & $(-) 3,3$ & $(-) 2,2$ \\
\hline$\triangle N 3$ - Número de canais de Ordem 3 & $(-) 0,7$ & $(-) 0,7$ & 0 & $(-) 1,1$ & $(-) 0,4$ \\
\hline$\triangle N 4$ - Número de canais de Ordem 4 & 0 & 0 & 0 & 0 & $(-) 0,2$ \\
\hline$\Delta N 5$ - Número de canais de Ordem 5 & - & - & - & - & 0 \\
\hline$\Delta L t-$ Comprimento total da rede de Drenagem & $(-) 13$ & $(-) 8,2$ & $(-) 16$ & $(-) 8,6$ & $(-) 9,1$ \\
\hline$\Delta L 1$-Comprimento dos canais de Ordem 1 & $(-) 6,1$ & $(-) 5,2$ & $(-) 12$ & $(-) 4,8$ & $(-) 4,5$ \\
\hline$\Delta L 2$ - Comprimento dos canais de Ordem 2 & $(-) 2,4$ & $(-) 1,9$ & $(-) 1,4$ & $(-) 1,5$ & $(-) 2,3$ \\
\hline$\Delta L 3$ - Comprimento dos canais de Ordem 3 & $(-) 2,5$ & $(-) 1,1$ & $(-) 1,5$ & $(-) 2,1$ & $(-) 1,2$ \\
\hline$\Delta L 4$ - Comprimento dos canais de Ordem 4 & $(-) 1,8$ & 0 & $(-) 0,6$ & $(-) 0,1$ & $(+) 0,1$ \\
\hline$\Delta L 5$ - Comprimento dos canais de Ordem 5 & - & - & - & - & $(-) 1,3$ \\
\hline$\Delta L m 1$ - Comprimento médio dos Canais de Or & 0 & $(+) 0,3$ & $(-) 0,5$ & $(-) 0,1$ & $(+) 0,1$ \\
\hline ALm2 - Comprimento médio dos Canais de Ordem 2 & $(+) 0,6$ & 0 & $(-) 0,7$ & $(+) 1,6$ & $(+) 0,3$ \\
\hline$\Delta D d-$ Densidade de drenagem & $(-) 13$ & $(-) 8,1$ & $(-) 15$ & $\overline{(-) 8,6}$ & $(-) 9$ \\
\hline$\Delta D h$ - Densidade hidrográfica & $(-) 11$ & $(-) 15$ & $(-) 14$ & $(-) 7,3$ & $(-) 9,8$ \\
\hline$\Delta T t$ - Textura Topográfica & $(-) 15$ & $(-) 8,7$ & $(-) 17$ & $(-) 8,8$ & $(-) 11$ \\
\hline$\Delta R I_{(2-1)}-$ Razão entre comprimento médio $_{(2-1)}$ & $(+) 13$ & $(-) 6,7$ & $(-) 1,6$ & $(+) 16$ & $(+) 1$ \\
\hline$\Delta R b_{(1-2)}-$ Razão de bifurcação ${ }_{(1-2)}$ & $(+) 10$ & $(-) 7,8$ & $(-) 14$ & $(+) 13$ & $(+) 3,1$ \\
\hline
\end{tabular}

(+) Taxa de Variação Positiva

(-) Taxa de Variação Negativa

Quanto à hierarquia C1, C2, C3 e C4 foram classificadas como sub-bacias de Quarta

Ordem e C5, como de Quinta Ordem, para ambos os períodos (Figura 6.16).

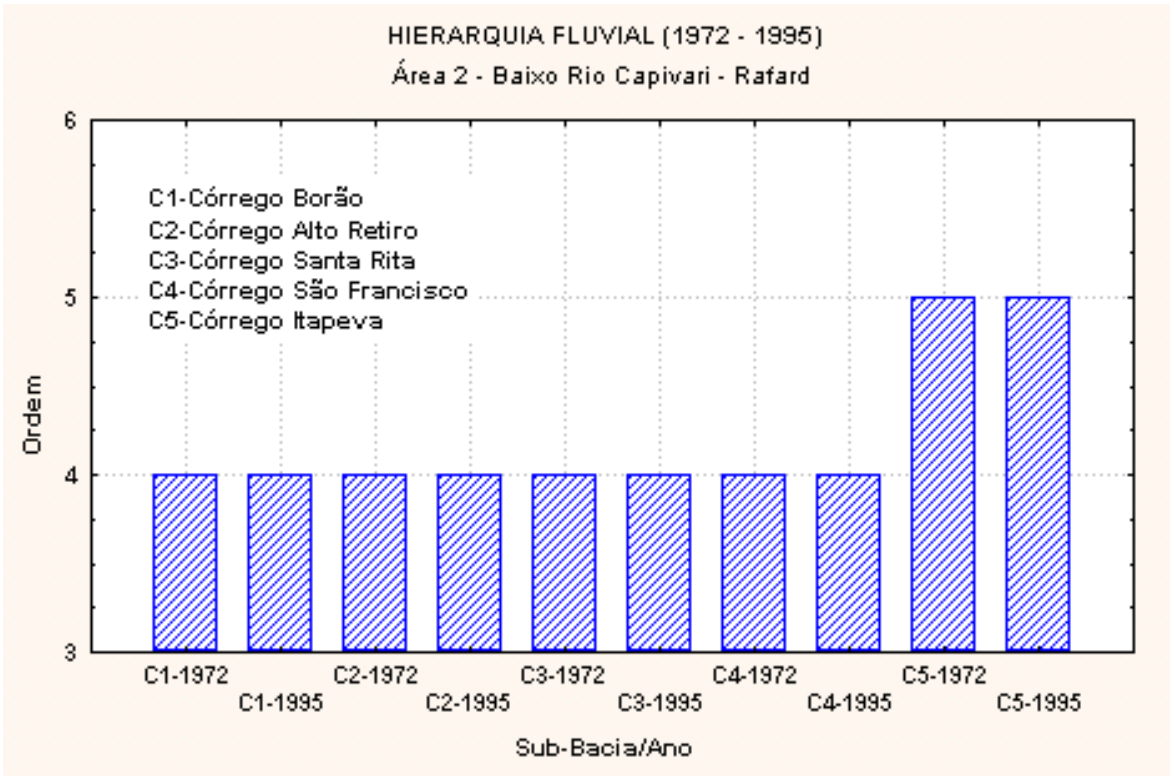

Figura 6.16 - Hierarquia das sub-bacias na Área 2 
Nas sub-bacias estudadas registrou-se, em 1995, redução no número de canais de Ordem 1 (N1). O desaparecimento dos canais de Primeira Ordem entre 5,5 a $12 \%$ no período estudado foi o responsável pela(figuras 6.17 e 6.18):

- Redução do número total de canais (Nt) entre 9,9 a 14\%; e,

- Diminuição de número de canais de Ordem 2 (N2) entre 1,4 a 4,2 \%, devido à mudança hierárquica de alguns canais de Ordem 2 que passaram a ser de Ordem 1, com exceção da Sub-Bacia Córrego Santa Rita.

A taxa de variação negativa mostrou a influência direta do desaparecimento dos canais de Ordem 1 na redução de Nt (Figura 6.17).

A mudança na ordem dos canais pouco afetou os canais de Ordem 3 e 4, como demonstrou a taxa de variação inferior a 1,2\% em todas as sub-bacias (Tabela 6.6).

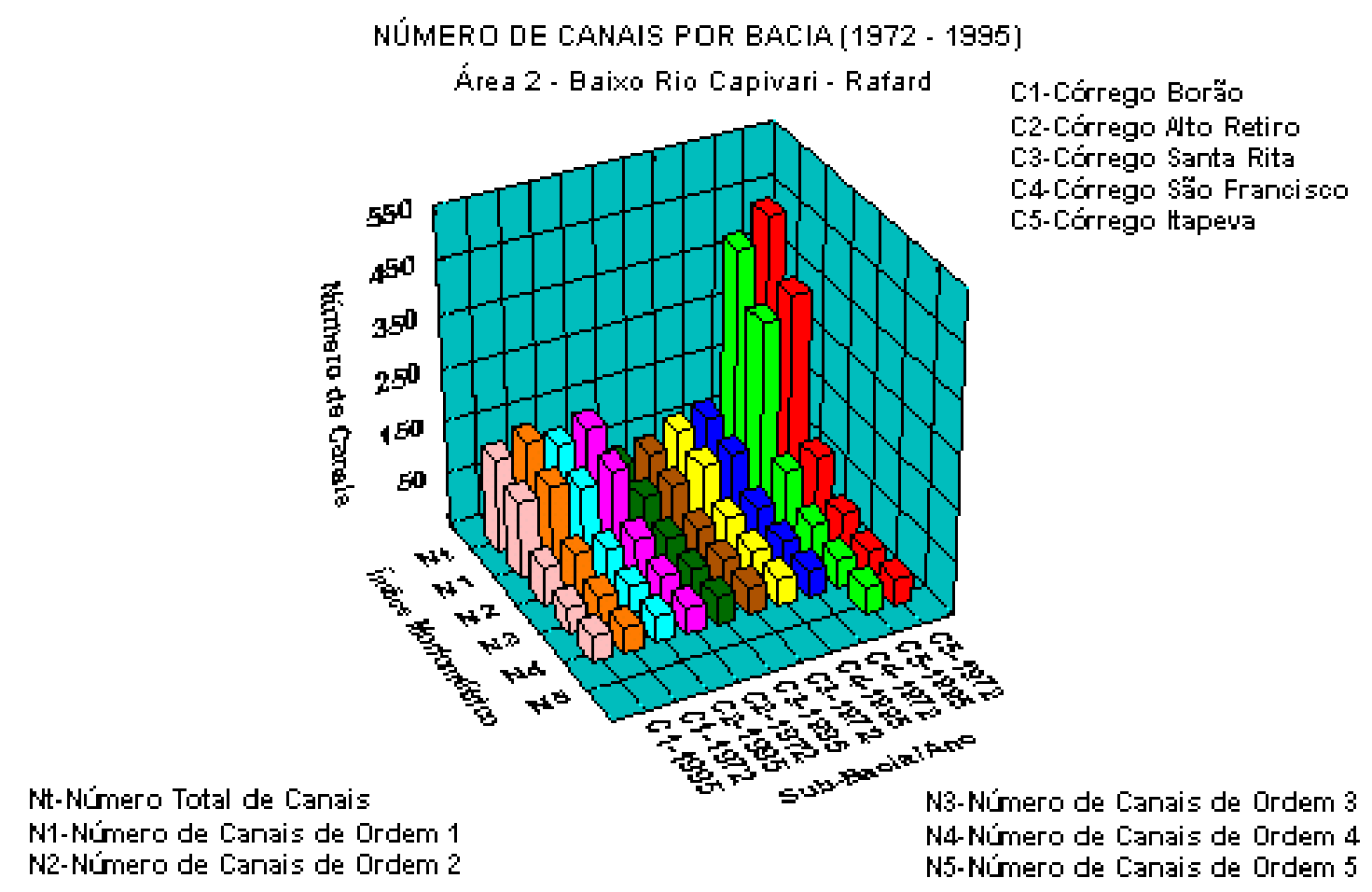

Figura 6.17 - Registro do Número de canais da Área 2 obtido para os anos analisados por sub-bacia 


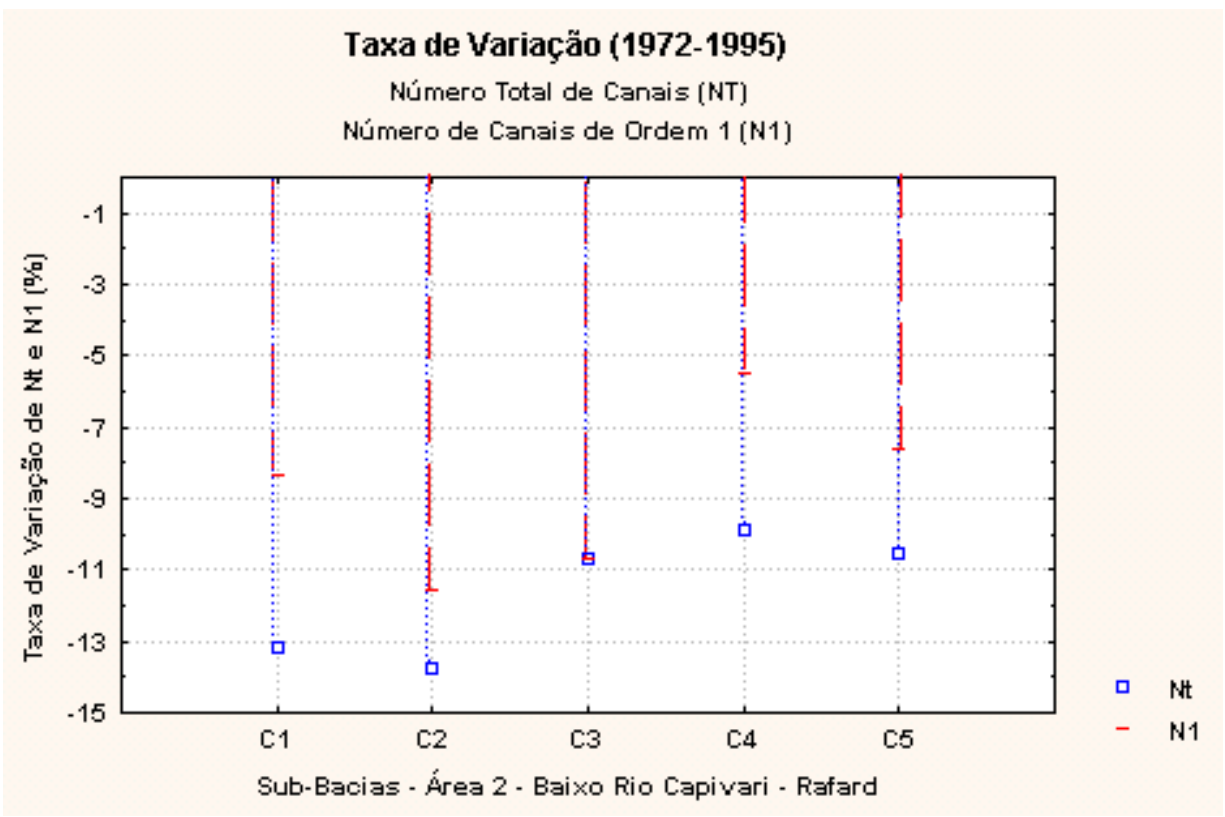

Figura 6.18 - Taxa de Variação para Nt e N1 das sub-bacias da área 2

Verificou-se que a redução do comprimento total da rede de drenagem (figuras 6.19 e 6.20) pode resultar tanto da diminuição da extensão dos canais por ordem devido as mudanças de ordem, quanto pela redução do número de canais principalmente os de Ordem 1.

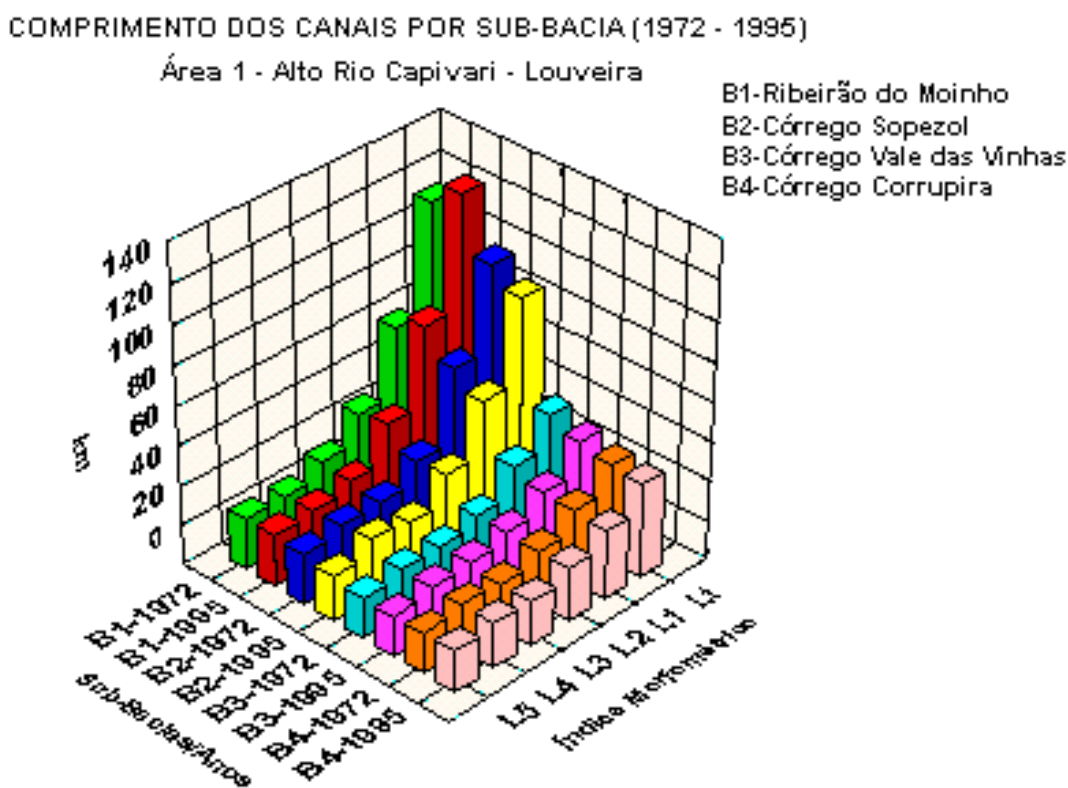

Lt-Comprimento Total da Rede de Drenagem

L3-Comprimento de Canais de Ordem 3 L1-Comprimento dos Canais de Ordem 1 L4-Comprimento de Canais de Ordem 4 L2-Comprimento dos Canais de Ordem 2

Figura 6.19 - Comprimento dos Canais por sub-bacia da Área 2 
O índice comprimento total da rede de drenagem sofreu influência direta da redução do comprimento dos canais de Ordem 1 como mostrou a taxa de variação de Lt e L1 (Figura 6.20). Enquanto que a taxa de variação dos comprimentos médio dos canais de Ordem 1 e 2, ao longo dos 23 anos nas sub-bacias estudadas, foi inferior a 2\% (Figura 6.21).

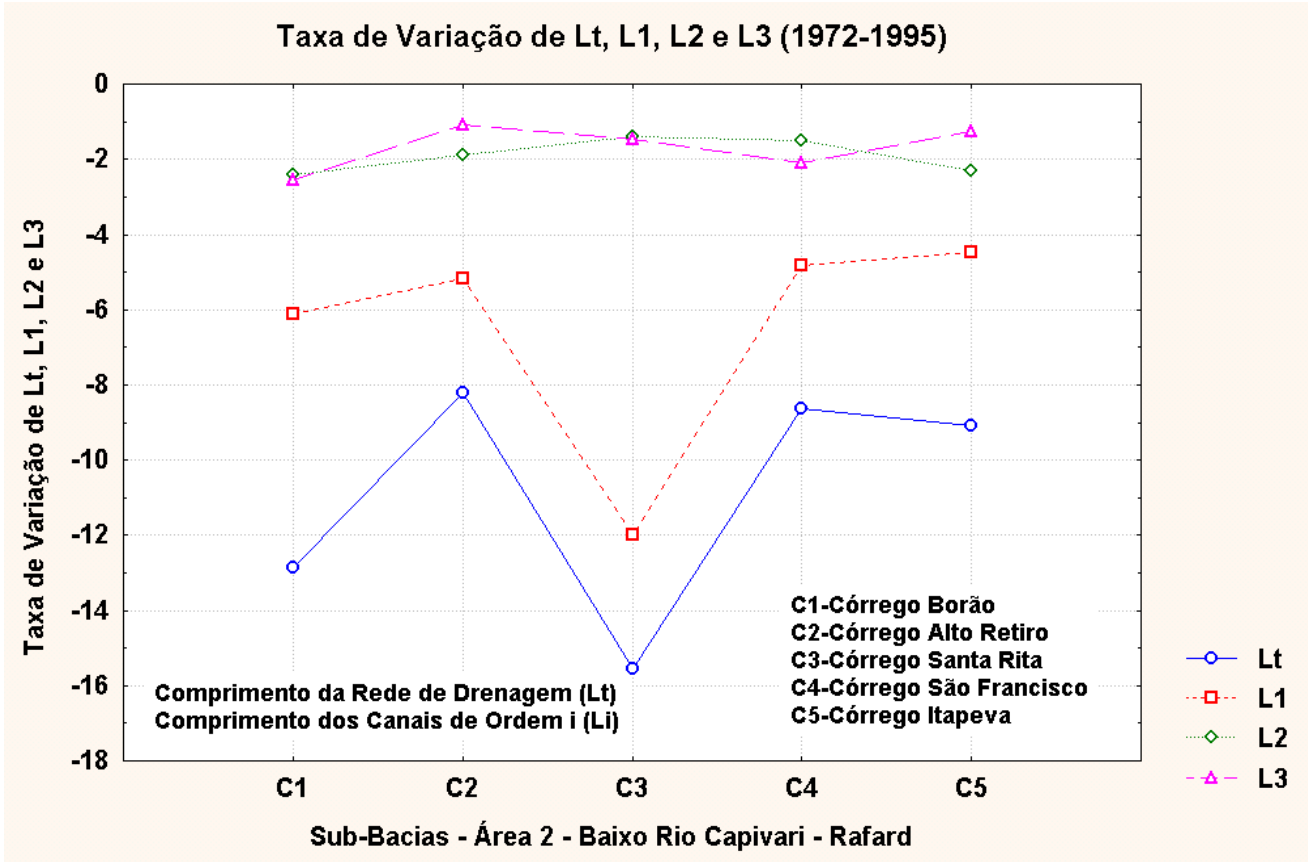

Figura 6.20 - Taxa de Variação de Lt, L1, L2 e L3 para as sub-bacias da Área 2

Taxa de Variação (1972 - 1995)

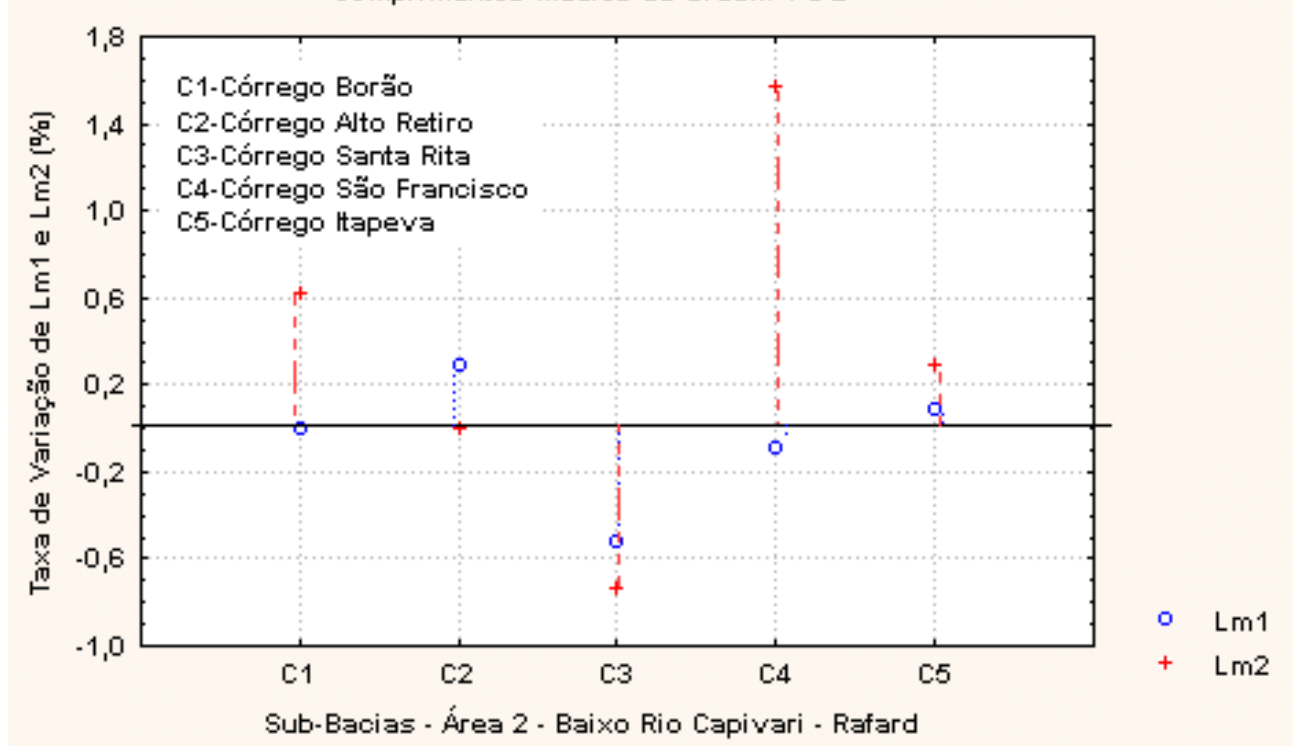

Figura 6.21 - Taxa de Variação para Lm1 e Lm2 das sub-bacias da Área 2 
Similarmente à área do Alto Rio Capivari, para ambos anos, os resultados obtidos indicaram uma baixa Densidade de Drenagem (Figura 6.22).

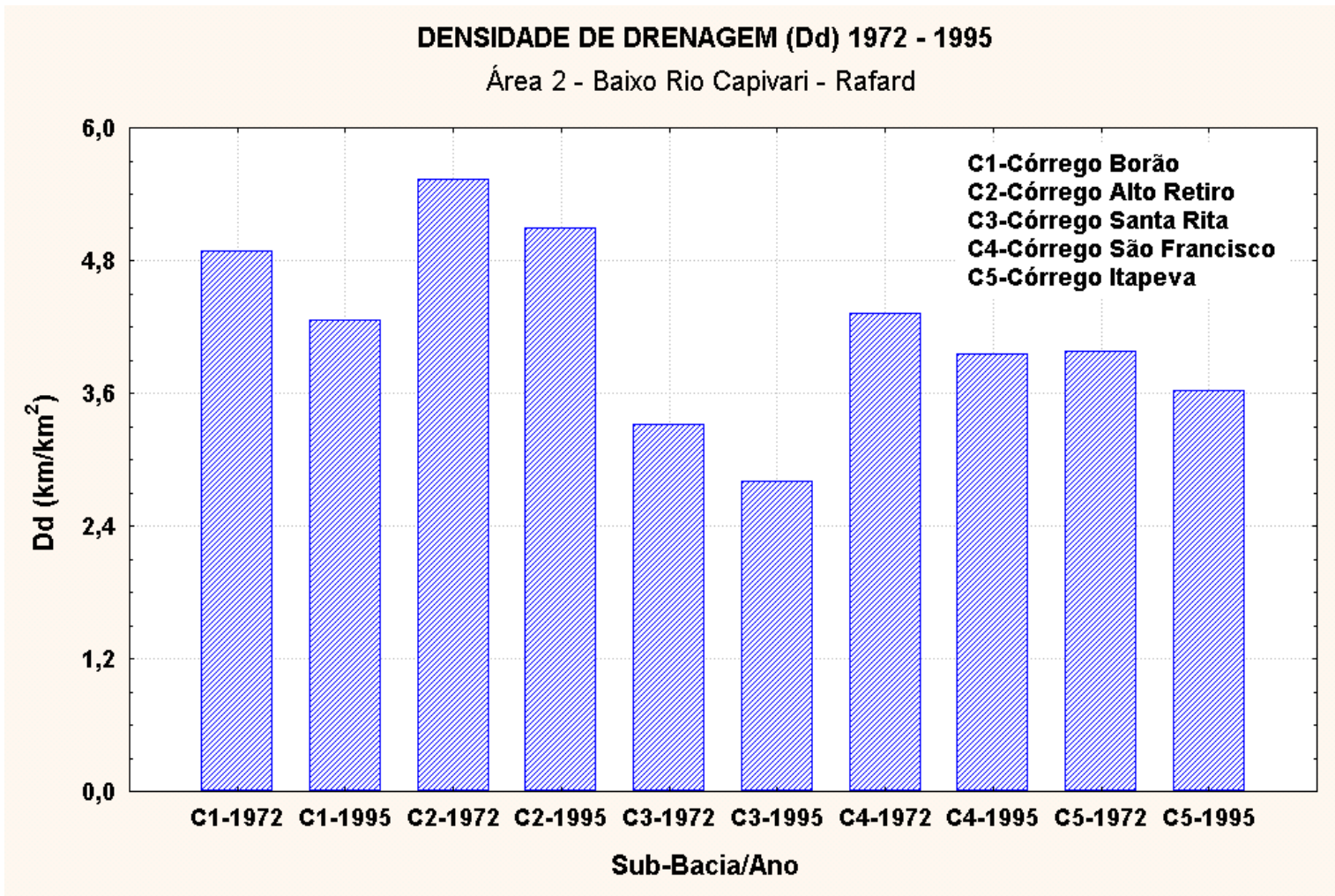

Figura 6.22 - Resultados obtidos para os anos de 1972 e 1995 de Densidade de Drenagem por Sub-Bacia referentes à Área 2

De acordo com Lollo (1996), pode-se classificar em 1972, as sub-bacias córregos Borão e Alto Retiro com muito alta freqüência de canais, enquanto todas as demais subbacias apresentaram alta Densidade Hidrográfica. Entretanto em 1995, apenas a Sub-Bacia Alto Retiro permaneceu com muito alta freqüência de canais (Figura 6.23).

Os resultados obtidos para Textura Topográfica das sub-bacias córregos Borão, Alto Retiro, São Francisco e Itapeva permitiram enquadrá-las na classe fina para as duas épocas estudadas de acordo com França (1968), enquanto a Sub-Bacia Santa Rita foi classificada com Tt média (Figura 6.24). Para Dd, Dh e Tt, a taxa de variação mostrou-se negativa em todas as sub-bacias. 


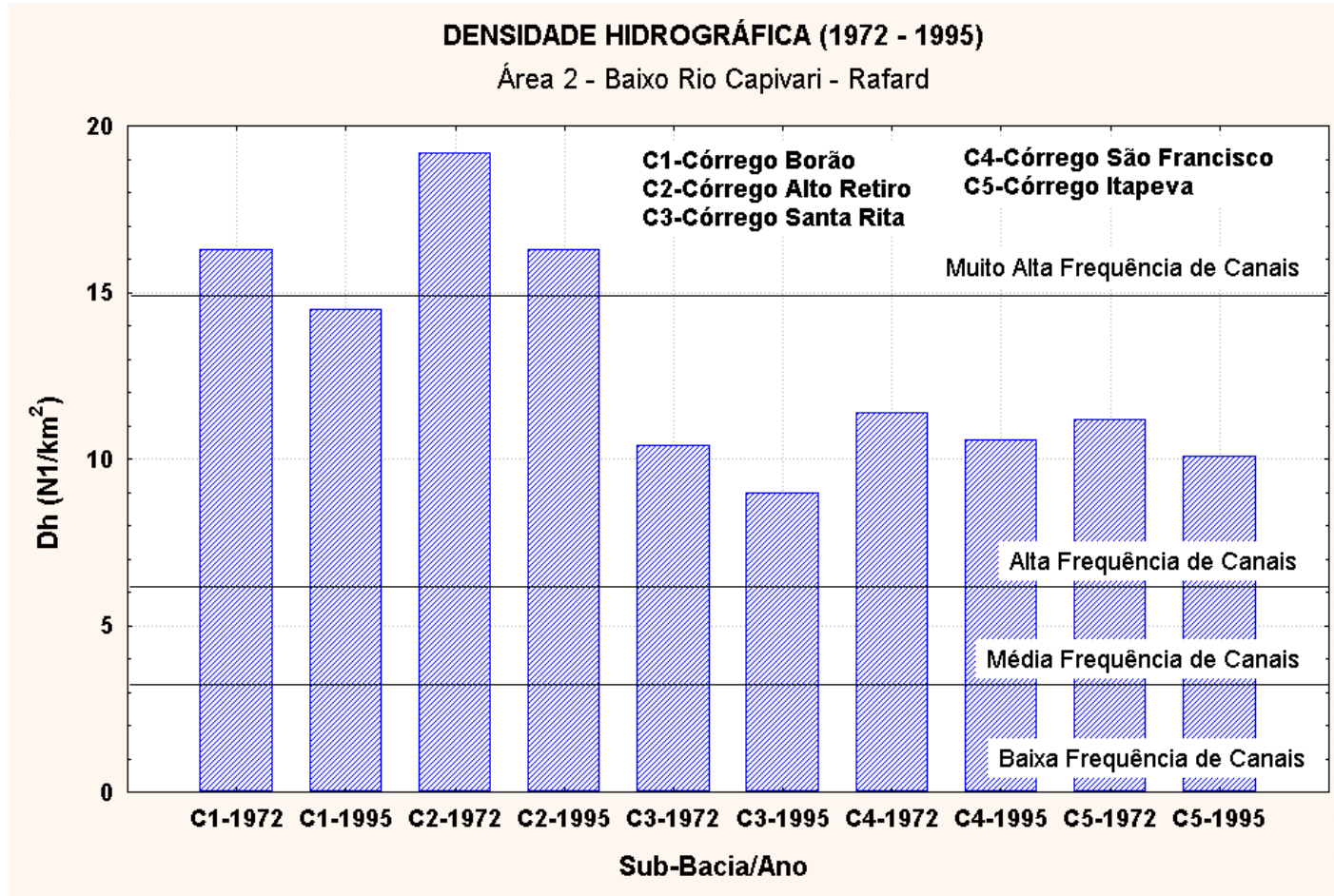

Figura 6.23 - Registro obtido para densidade hidrográfica nas sub-bacias estudadas no Baixo Rio Capivari para os anos de 1972 e 1995

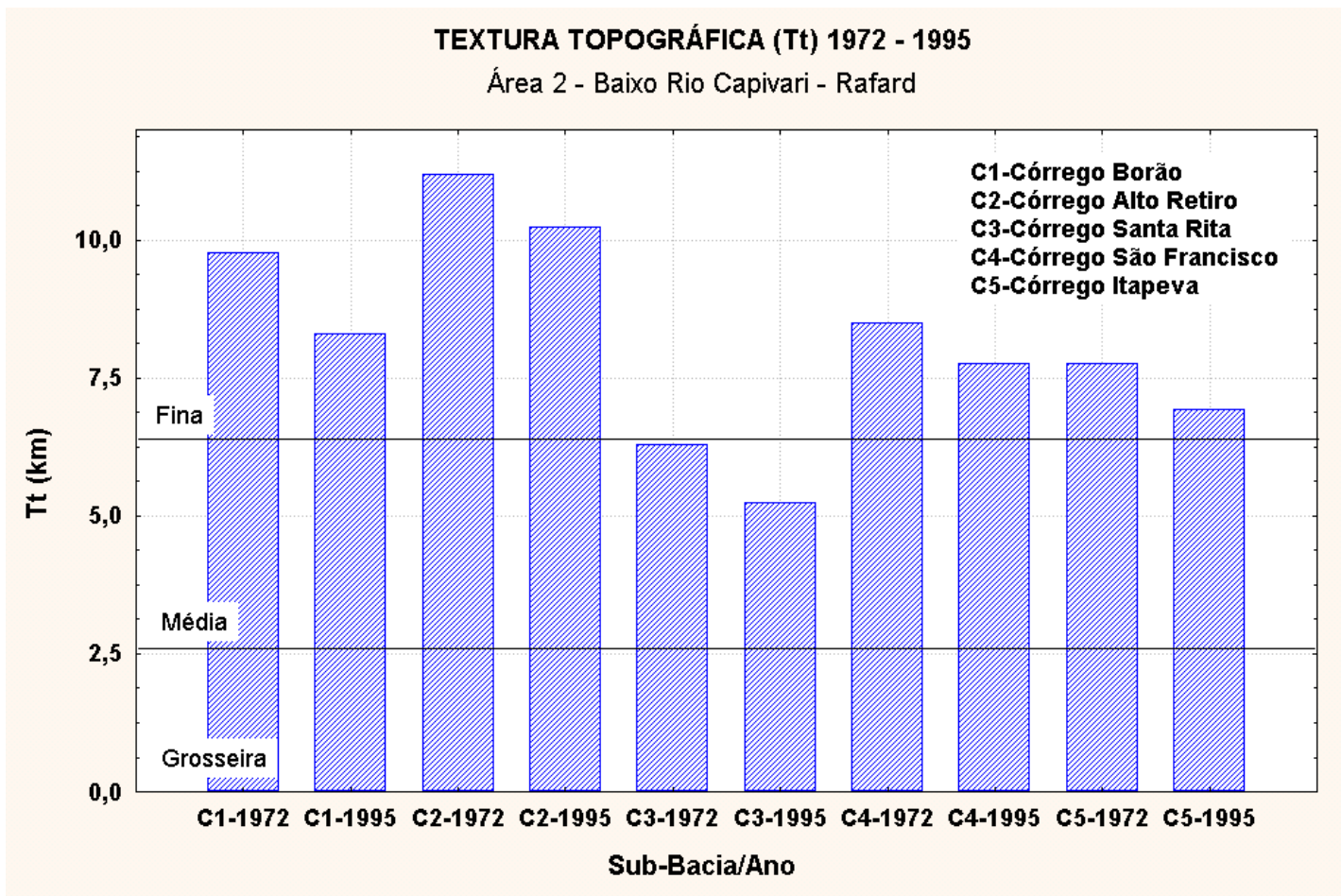

Figura 6.24 - Registro obtido para textura topográfica nas sub-bacias estudadas no Baixo Rio Capivari para os anos de 1972 e 1995 
A taxa de variação da razão entre comprimentos médios de canais de Ordem 2 e 1 se apresentou:

- positiva entre 13 a 16 \% para as sub-bacias córregos Borão e São Francisco, respectivamente; e,

- negativa entre 1,6 a 6,7\% para as demais sub-bacias (Tabela 6.6 e Figura 6.25).

O primeiro caso resultou do aumento de $\mathrm{Lm}_{2}$ e o segundo da redução de $\mathrm{Lm}_{1}$.

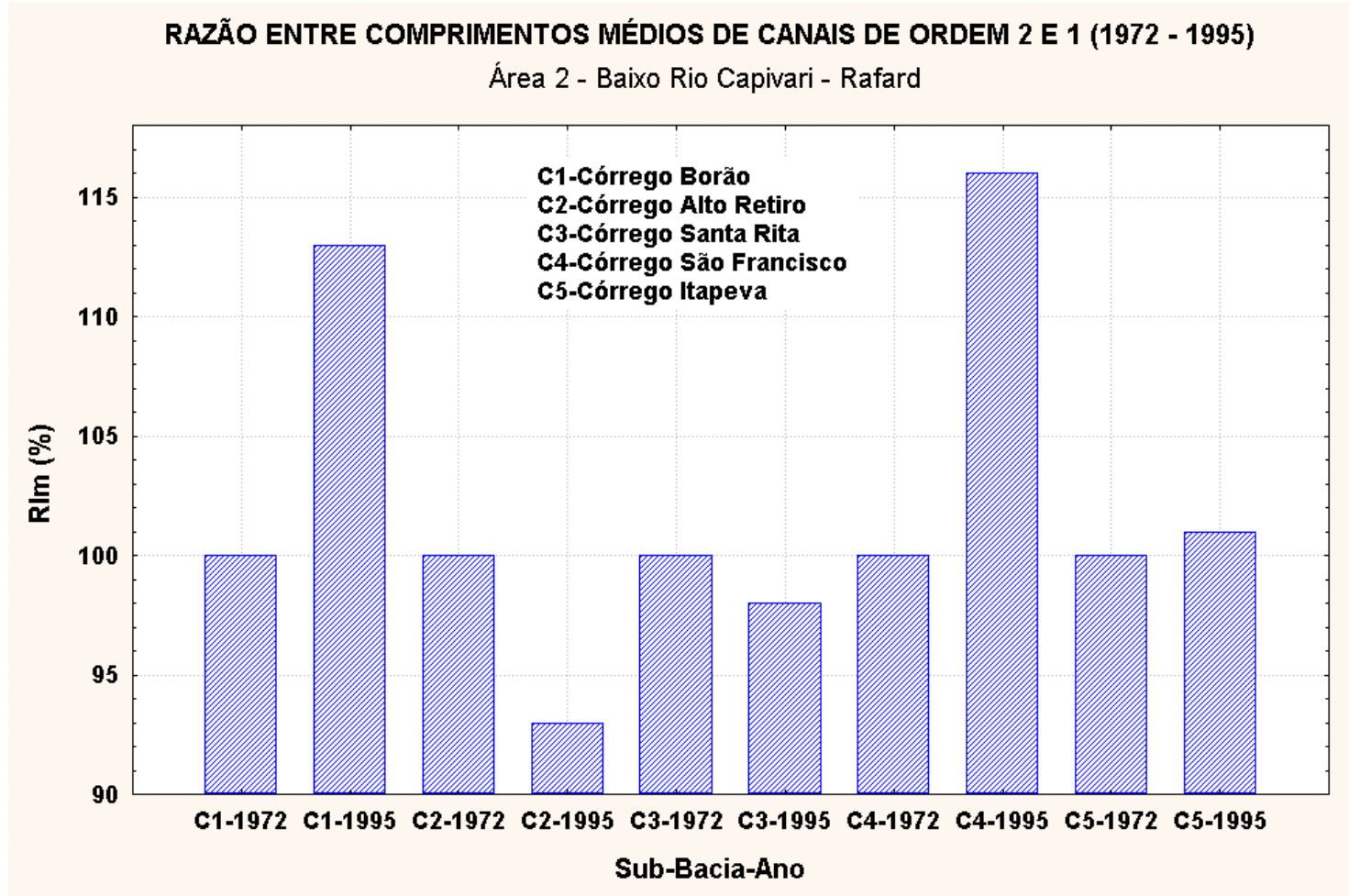

Figura 6.25 - Registro obtido para Razão entre Comprimento Médio $_{(2-1)}$ nas sub-bacias estudadas no Baixo Rio Capivari para os anos de 1972 e 1995

As sub-bacias córregos Borão, São Francisco e Itapeva apresentaram taxa de variação positiva para $\mathrm{Rb}_{1-2}$ enquanto as sub-bacias Córrego Alto Retiro e Córrego Santa Rita, taxa de variação negativa (Figura 6.26). 
RAZÃO DE BIFURCAÇÃo ENTRE CANAIS DE ORDEM 1 E 2 (1972 - 1995)

Área 2 - Baixo Rio Capivari - Rafard

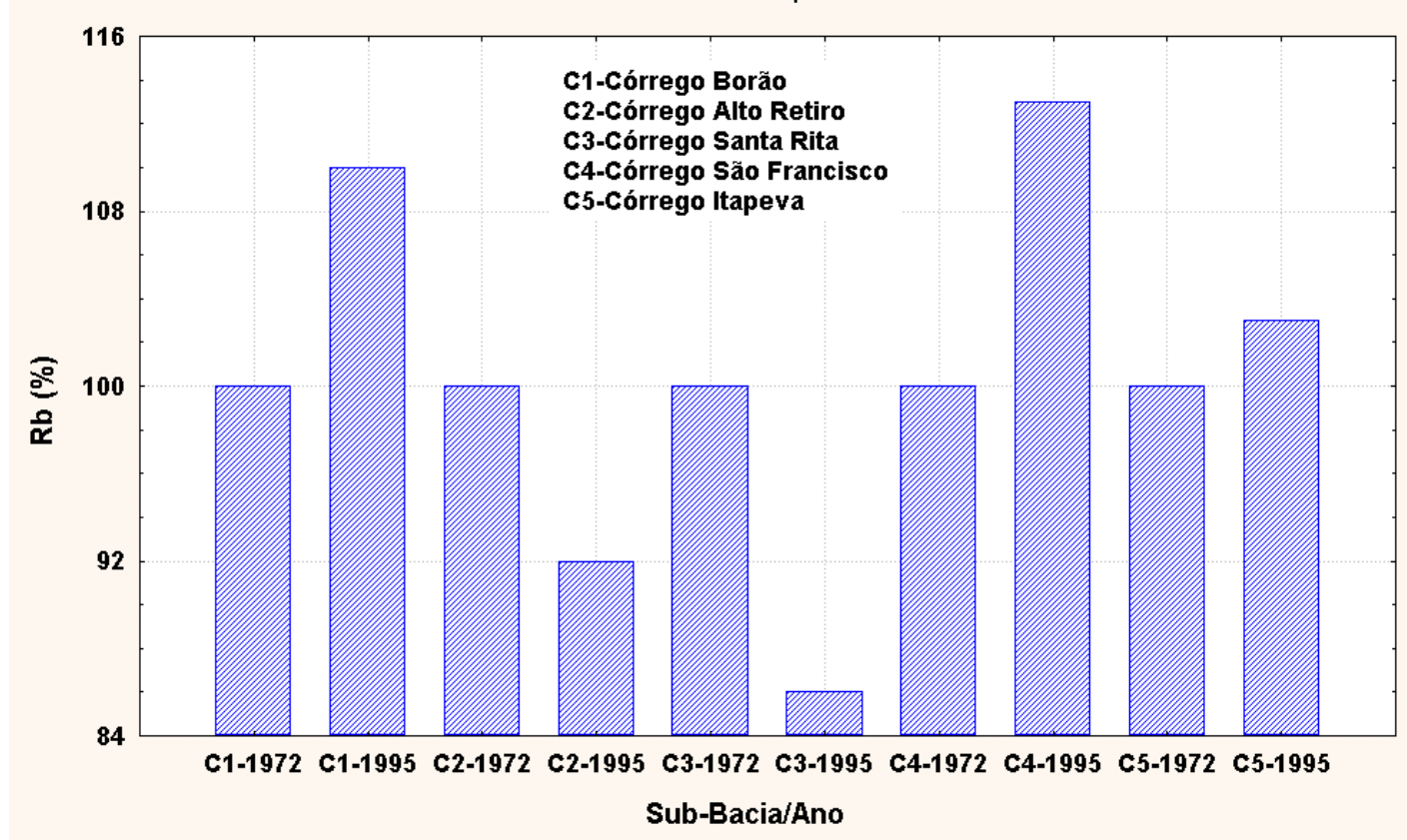

Figura 6.26 - Registro obtido para Razão de Bifurcação(1-2) nas sub-bacias estudadas no Baixo Rio Capivari para os anos de 1972 e 1995

\subsection{2 - Verificação Temporal de Modificações de Atividades Antrópicas}

Para a área 2 que contempla as sub-bacias córregos Borão (C1), Alto Retiro (C2), Santa Rita (C3), São Francisco (C4) e Itapeva (C5), no Baixo Rio Capivari (SP), definiu-se 5 classes de uso e ocupação, a saber: Cana (C), Hortifruti (H), Mata/Reflorestamento (M), Pasto/Mata Capoeira (P) e Represa (R).

A distribuição areal das classes por sub-bacia para as épocas analisadas e sua classificação, quanto ao predomínio da atividade antrópica desenvolvida, segundo Collares (2000), são apresentadas na Tabela 6.7. 
Tabela 6.7 - Distribuição areal das classes de uso e ocupação por sub-bacia

\begin{tabular}{|c|c|c|c|c|c|}
\hline \multirow[t]{3}{*}{ SUB - BACIA } & \multirow[t]{3}{*}{ CATEGORIA } & \multicolumn{4}{|c|}{ DISTRIBUIÇÃo AREAL POR CLASSE } \\
\hline & & \multicolumn{2}{|c|}{1972} & \multicolumn{2}{|c|}{1995} \\
\hline & & $K m^{2}$ & $\%$ & $\mathrm{~km}^{2}$ & $\%$ \\
\hline$\underline{\mathrm{C} 1}$ & Cana & 5,42 & 81,2 & 5,58 & 84 \\
\hline Córrego & Mata/Reflorestamento & 0,56 & 8,3 & 0,87 & 13 \\
\hline Do & Pasto/Mata Capoeira & 0,7 & 10,5 & 0,22 & 3,3 \\
\hline Borão & Represa & - & - & 0,01 & 0,2 \\
\hline & Classificação proposta por & \multirow{2}{*}{\multicolumn{4}{|c|}{ Rural Agrícola }} \\
\hline & CollaRES (2000) & & & & \\
\hline$\underline{\mathrm{C} 2}$ & Cana & 3,74 & 67,8 & 4,2 & 77 \\
\hline Córrego & Mata/Reflorestamento & 0,85 & 15,5 & 1,3 & 23 \\
\hline Alto & Pasto/Mata Capoeira & 0,92 & 16,7 & - & - \\
\hline Retiro & Classificação proposta por & \multirow{2}{*}{\multicolumn{4}{|c|}{ Rural Agrícola }} \\
\hline & COLLARES (2000) & & & & \\
\hline$\underline{\mathrm{C} 3}$ & Cana & 3,74 & 90,8 & 3,63 & 88 \\
\hline Córrego & Mata/Reflorestamento & 0,31 & 7,5 & 0,37 & 9 \\
\hline Santa & Hortifruti & 0,06 & 1,5 & 0,12 & 2,8 \\
\hline$\underline{\text { Rita }}$ & Represa & 0,01 & 0,2 & 0,01 & 0,2 \\
\hline & Classificação proposta por & \multirow{2}{*}{\multicolumn{4}{|c|}{ Rural Agrícola }} \\
\hline & COLLARES (2000) & & & & \\
\hline$\underline{\mathrm{C} 4}$ & Cana & 4,4 & 72,7 & 5,35 & $\mathbf{8 8 , 4}$ \\
\hline Córrego & Mata/Reflorestamento & 0,52 & 8,5 & 0,65 & 10,8 \\
\hline$\underline{\text { São }}$ & Pasto/Mata Capoeira & 1,13 & 18,6 & - & - \\
\hline \multirow[t]{4}{*}{ Francisco } & Hortifruti & - & - & 0,03 & 0,5 \\
\hline & Represa & 0,01 & 0,2 & 0,02 & 0,3 \\
\hline & Classificação proposta por & \multirow{2}{*}{\multicolumn{4}{|c|}{ Rural Agrícola }} \\
\hline & COLLARES (2000) & & & & \\
\hline C5 & Cana & 17,7 & 58,1 & 24,9 & 82 \\
\hline Córrego & Mata/Reflorestamento & 6,48 & 21,3 & 3,14 & 10,3 \\
\hline \multirow[t]{4}{*}{$\overline{\text { Itapeva }}$} & Pasto/Mata Capoeira & 6,13 & 20,2 & 2,22 & 7,3 \\
\hline & Hortifruti & 0,09 & 0,3 & - & - \\
\hline & Represa & 0,04 & 0,1 & 0,11 & 0,4 \\
\hline & $\begin{array}{c}\text { Classificação proposta por } \\
\text { COLLARES (2000) }\end{array}$ & \multicolumn{4}{|c|}{ Rural Agrícola } \\
\hline
\end{tabular}

Negrito destaque as categorias de maior percentagens que permitem classificar as sub-bacias

Observou-se na Tabela 6.7 e na Figura 6.27 que, ao longo do período estudado, não houve implantação de novas classes de atividades antrópicas.

Destaca-se na Figura 6.27 que houve um predomínio de áreas de cultivo de cana, para ambos os períodos. Esta consideração possibilitou classificar todas as sub-bacias estudadas como Rurais Agrícolas segundo Collares (2000). O registro das atividades antrópicas desenvolvidas nos dois períodos estudados não mostrou implantação de áreas urbanas em nenhuma das sub-bacias. 


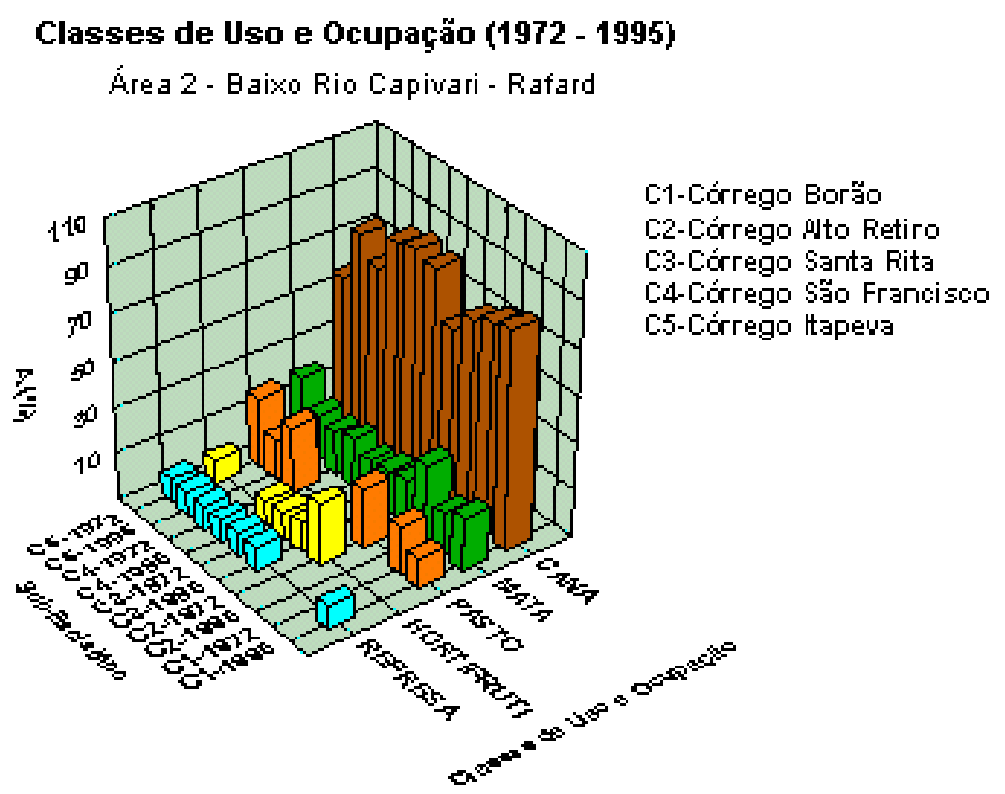

Figura 6.27 - Modificações observadas nas classes de atividades antrópicas nas Sub-Bacias no Baixo Rio Capivari (SP)

Observa-se na Figura 6.28 que nas sub-bacias córregos Borão, Alto Retiro, São Francisco e Itapeva, ao longo do período estudado, houve um acréscimo de áreas destinadas ao cultivo de cana entre 3 a $24 \%$.

A redução das áreas destinadas ao cultivo de cana na Sub-Bacia Santa Rita se justificou pelo aumento de reflorestamento e plantio de hortifruti (figuras 6.27 e 6.28).

As pastagens encontradas nas sub-bacias córregos Borão, Alto Retiro, São Francisco e Itapeva sofreram uma redução entre 7 a 19\%, sendo substituídas pelas áreas de cultivo de cana e reflorestamento (Figura 6.29).

Em 1995, pode-se constatar que houve um aumento, nas sub-bacias córregos Borão (C1), Alto Retiro (C2), Santa Rita (C3), São Francisco (C4), dos percentuais da classe mata/reflorestamento (1,5 e 7,5 \%), devido ao reflorestamento, principalmente próximo às cabeceiras dos córregos (Figura 6.30).

Observa-se que C5 sofreu redução da classe mata/reflorestamento, fato este que ocorreu devido à retirada da mata nativa para plantio de cana. 
Taxa de Variação (1972-1995)

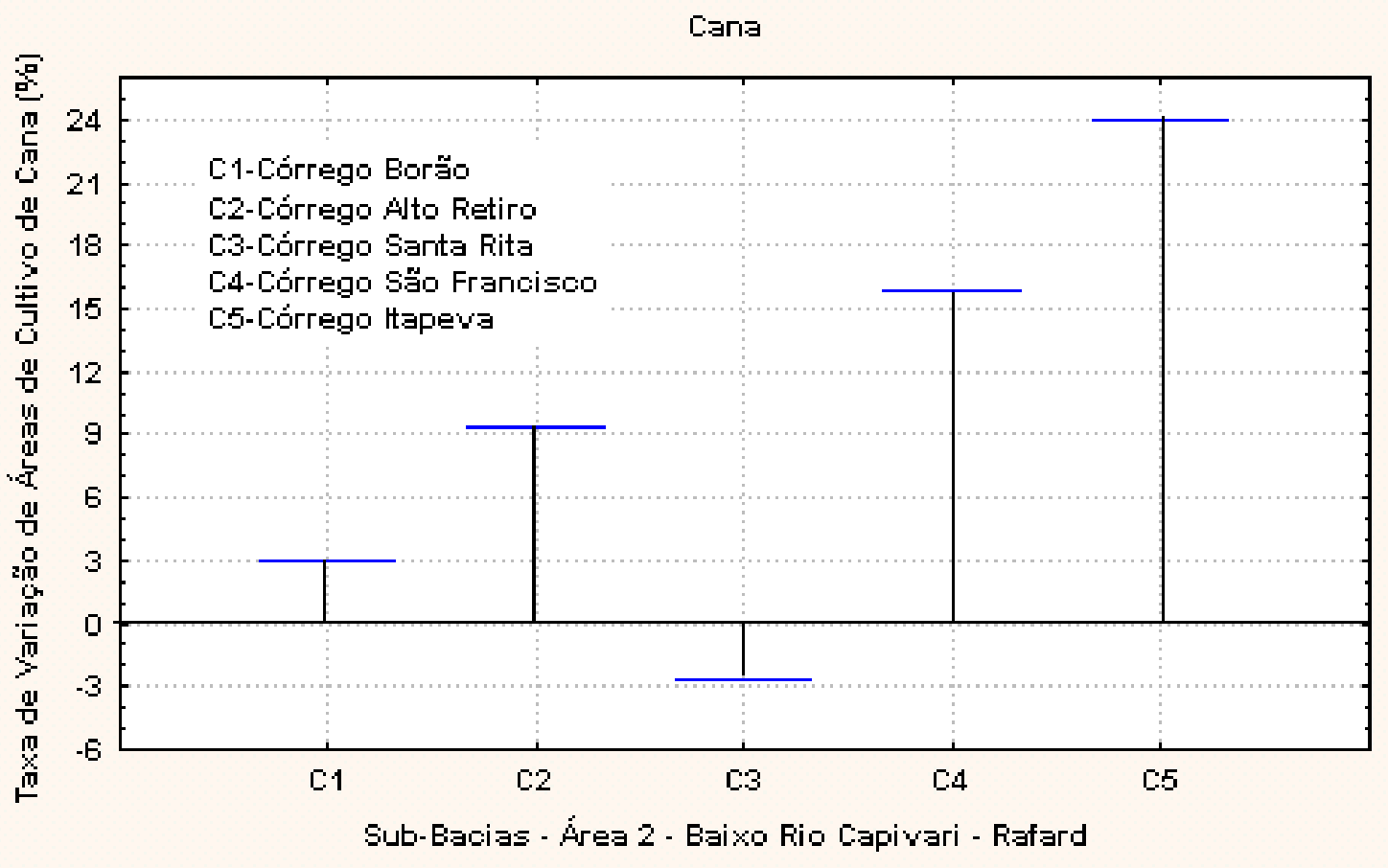

Figura 6.28- Taxa de Variação das áreas de plantio de cana entre 1972 e 1995

\section{Taxa de Variação (1972-1995)}

Pasto

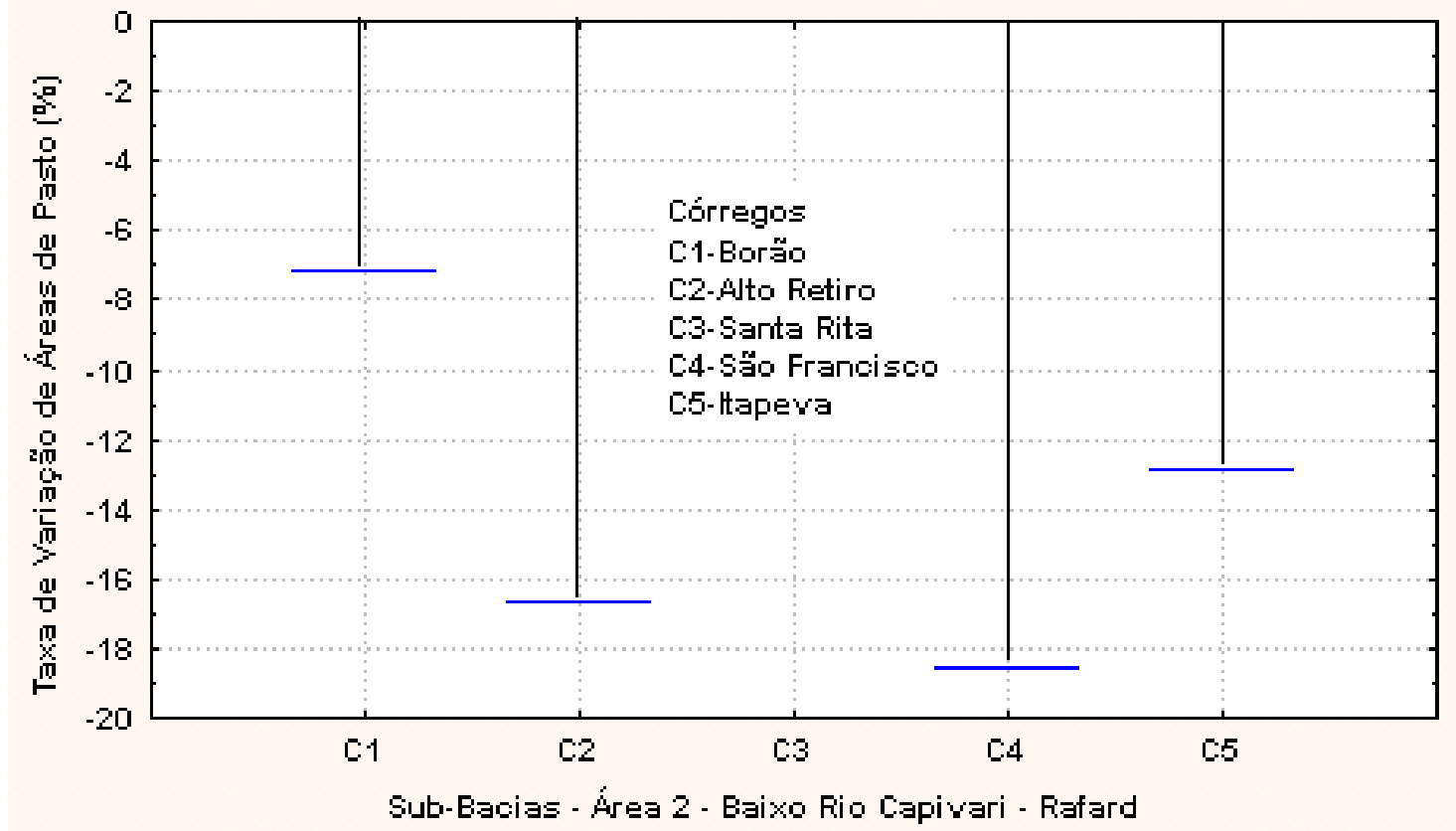

Figura 6.28 - Taxa de Variação das áreas de pasto entre 1972 e 1995 
Taxa de Variação (1972-1995)

Mata

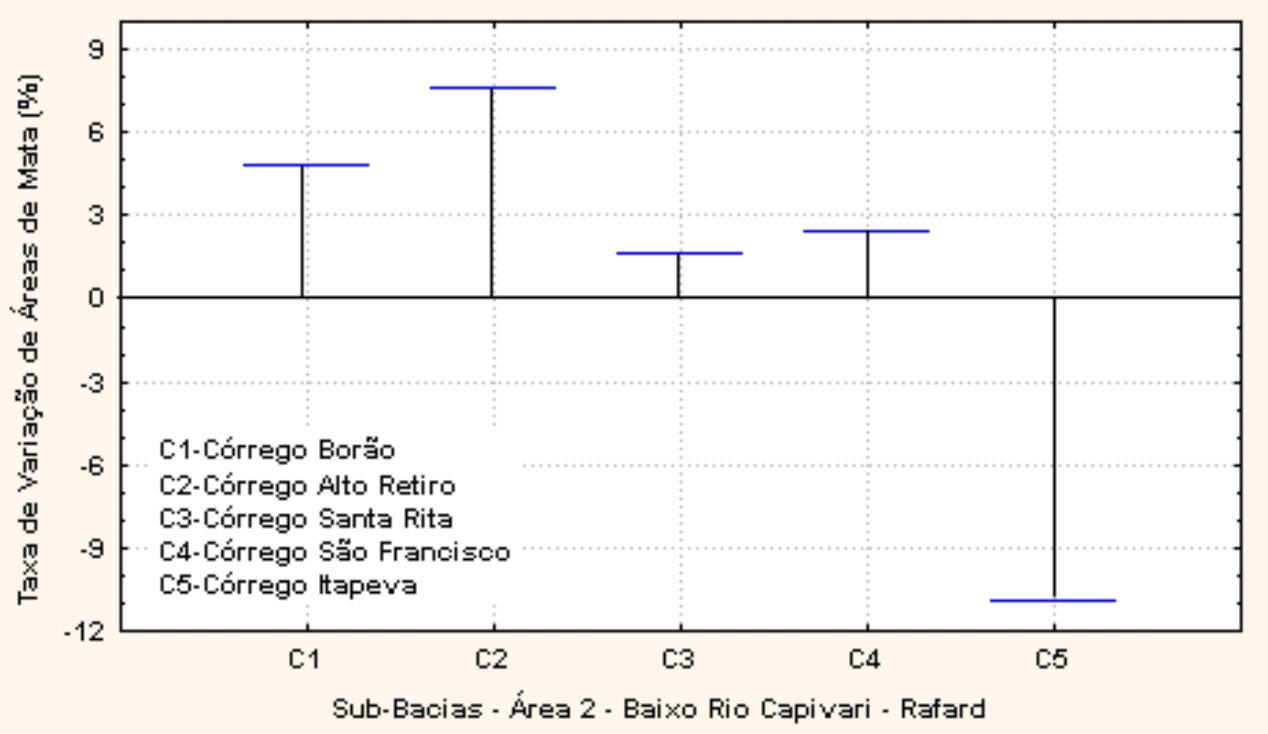

Figura 6.30 - Taxa de Variação para a classe mata/reflorestamento entre 1972 e 1995

A classe hortifruti, restrita às sub-bacias córregos Santa Rita, São Francisco em 1995, apresentou taxas de variação inferiores a 1,5\% (Figura 6.29). Essa classe, apesar de ser registrada na Sub-Bacia Córrego Itapeva em 1972, no ano de 1995 já não foi identificada, devido à sua substituição por áreas de pastagens.

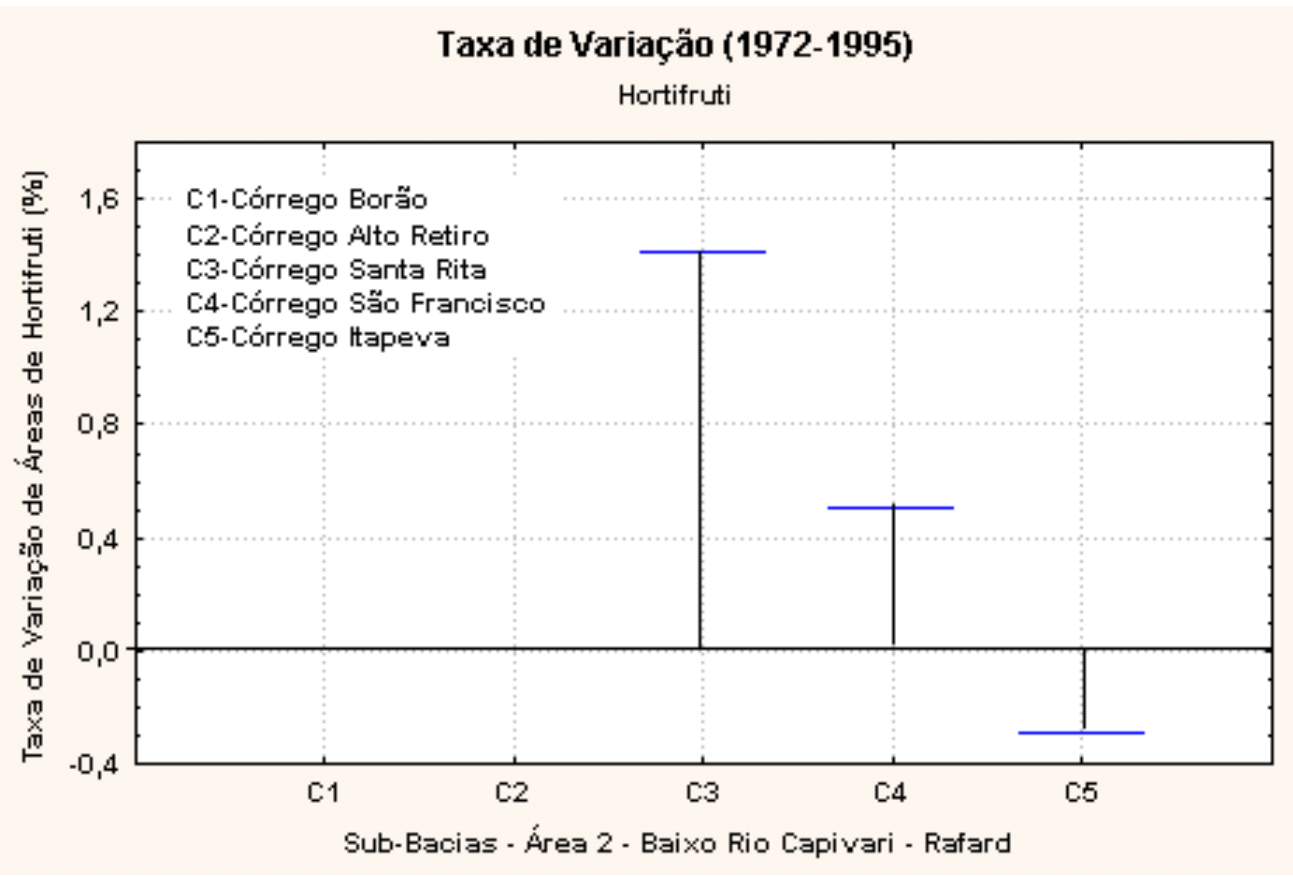

Figura 6.31 - Taxa de Variação para a classe Hortifruti entre 1972 e 1995 


\subsection{3 - Considerações Parciais - Sub-Bacias da Área 2}

Na análise morfométrica das sub-bacias córregos Borão, Alto Retiro, Santa Rita, São Francisco e Itapeva, localizada no Baixo Rio Capivari, identificou-se as mesmas interrelações definidas para as sub-bacias analisadas da Área 1, entre os parâmetros N1, Nt, Lt e L1, com influência direta em Dd, Dh e Tt.

Observou-se que a redução no número total de canais foi causada diretamente pela diminuição do número de canais de Ordem 1, que conseqüentemente tem influência na redução dos comprimentos de canais de Ordem 1 e que causaram modificações no comprimento total da rede de drenagem.

Concluiu-se que as alterações do número de canais de Ordem 1 e de seus comprimentos foram as responsáveis pelas mudanças na geometria interna na rede de drenagem das sub-bacias

Os índices comprimentos médios dos canais de Ordem 1 e 2 destas sub-bacias também apresentaram alterações pouco significativas ao longo do período analisado.

Todas as sub-bacias apresentaram taxas de variação negativas em torno de $10 \%$ para os índices número total de canais, comprimento total da rede de drenagem, densidade de drenagem, densidade hidrográfica e textura topográfica. Tal fato caracterizou uniformidade na alteração das variáveis da rede de drenagem no período analisado.

Cabe destacar que, mesmo havendo mudanças acentuadas na densidade hidrográfica, para as épocas analisadas, os resultados obtidos indicaram baixa densidade de drenagem para as sub-bacias analisadas.

Verificou-se para as sub-bacias córregos Alto Retiro e Santa Rita que o registro das taxas de alterações mais acentuadas de densidade hidrográfica foi em torno de -15\%, reflexo da redução do comprimento total da rede de drenagem.

As taxas de variação positivas de $\mathrm{Rb}_{1-2}$ para as sub-bacias córregos Borão e São Francisco, em torno de 10\%, resultaram da redução conjunta do número de canais de Ordem 1 e 2. Da mesma forma, as taxas de variação positivas de $\mathrm{Rlm}_{2-1}$ para as mesmas sub-bacias resultaram do aumento do comprimento do número de canais de Ordem 2.

Quanto às atividades antrópicas definidas para essas sub-bacias, diferentemente das sub-bacias da área 1 , todas foram consideradas rurais, para ambos os períodos, sem qualquer indício de focos de urbanização. O cultivo de cana foi a atividade antrópica predominante.

A uniformidade das classes das atividades antrópicas implica em alterações pouco significativas nas variáveis morfométricas. 
As modificações na rede de drenagem podem ser conseqüência da intensa atividade agrícola e também da substituição da atividade antrópica desenvolvida no período inicial de análise. Também foi comum o registro da substituição de áreas de mata nativa, hortifruti e pastagens por áreas de cultivo de cana. 


\section{VERIFICAÇÃO DAS ALTERAÇÕES NAS MICROBACIAS HIDROGRÁFICAS}

\section{1. - CONSIDERAÇÕES INICIAIS}

Para ambas as áreas foi feita inicialmente a delimitação das microbacias, mas na análise dos dados foram consideradas apenas àquelas comuns aos dois períodos.

Na área 1 definiu-se um total de 50 para 1972 e 49 para 1995, sendo comuns aos dois períodos 23 delas (Figuras 7.1 e 7.2 ). Já na área 2, delimitou-se 35 microbacias para 1972 e 30 para 1995, e dentre elas só, 26 foram analisadas considerando-se o critério exposto (Figuras 7.3 e 7.4 ).

Para a identificação das microbacias, adotou-se simbologia do tipo letra e número, distinta por área de estudo e por período analisado. Para a área 1, M referiu-se às microbacias pertinentes aos dois períodos, N às encontradas apenas em 1972 e O às relacionadas a 1995, respectivamente na área 2 utilizou-se D, E e F. 


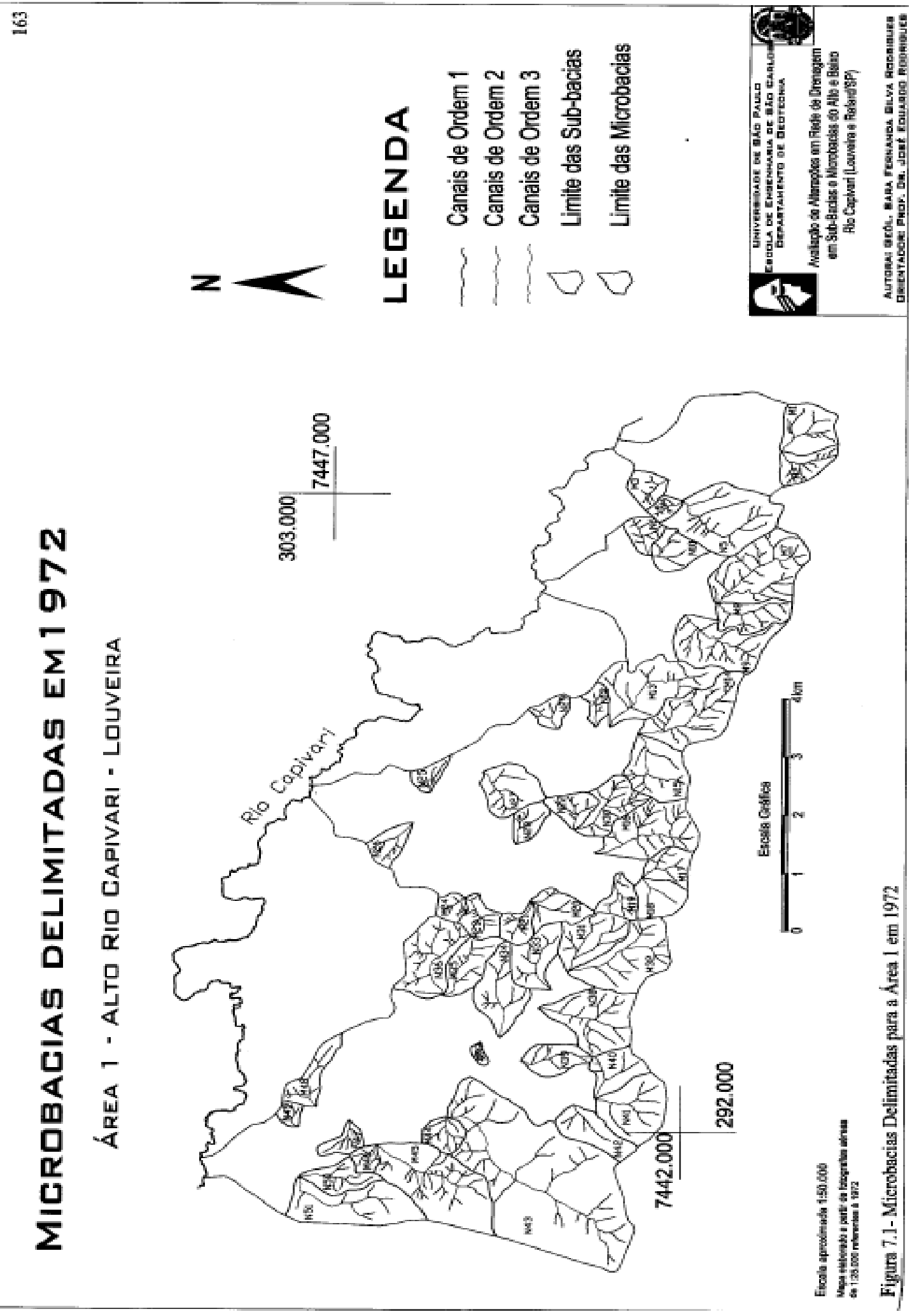

Figuras 7.1 - Microbacias Delimitadas para a área 1 em 1972 


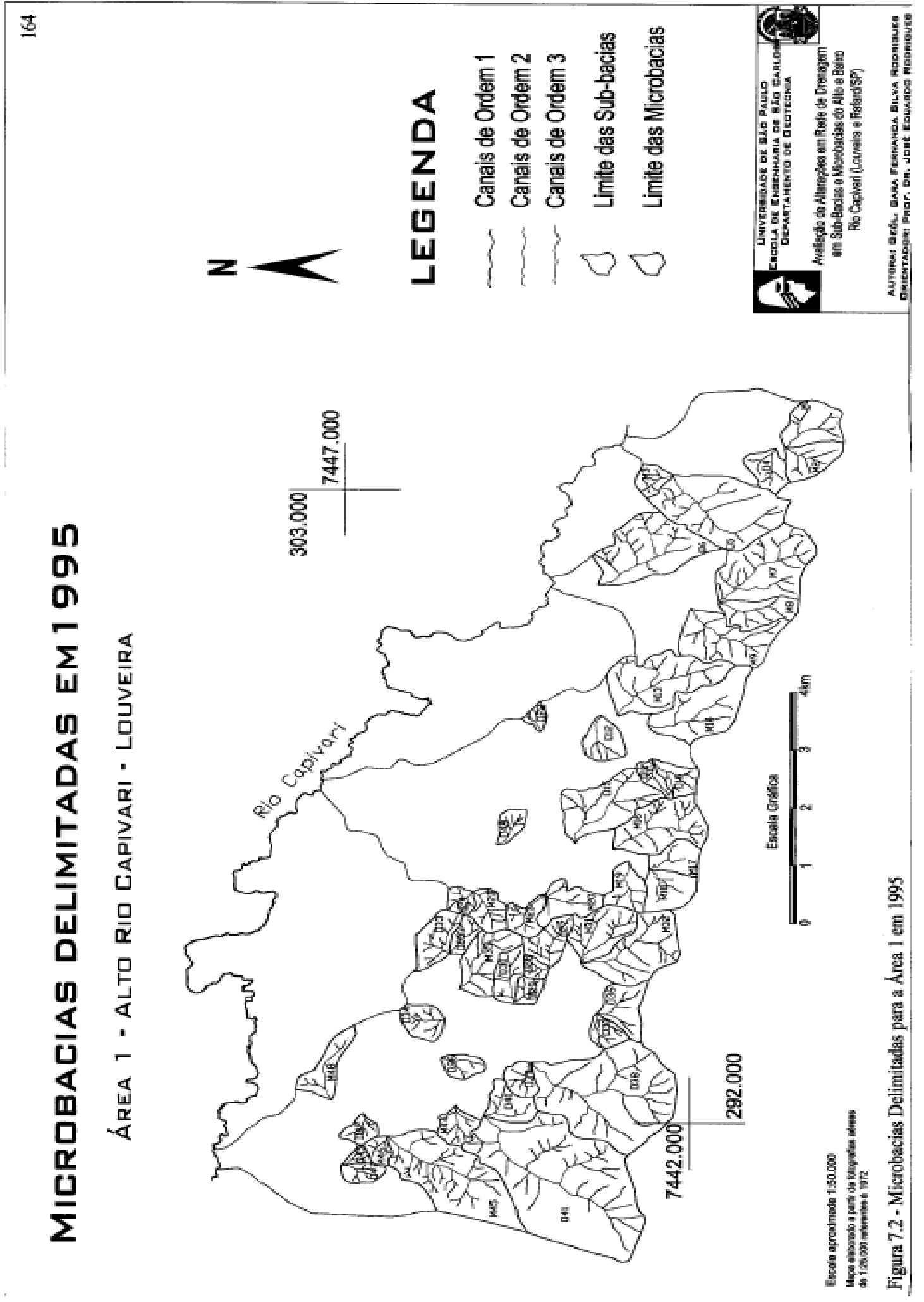

Figura 7.2 - Microbacias Delimitadas para a área 1 em 1995 
$\underline{8}$
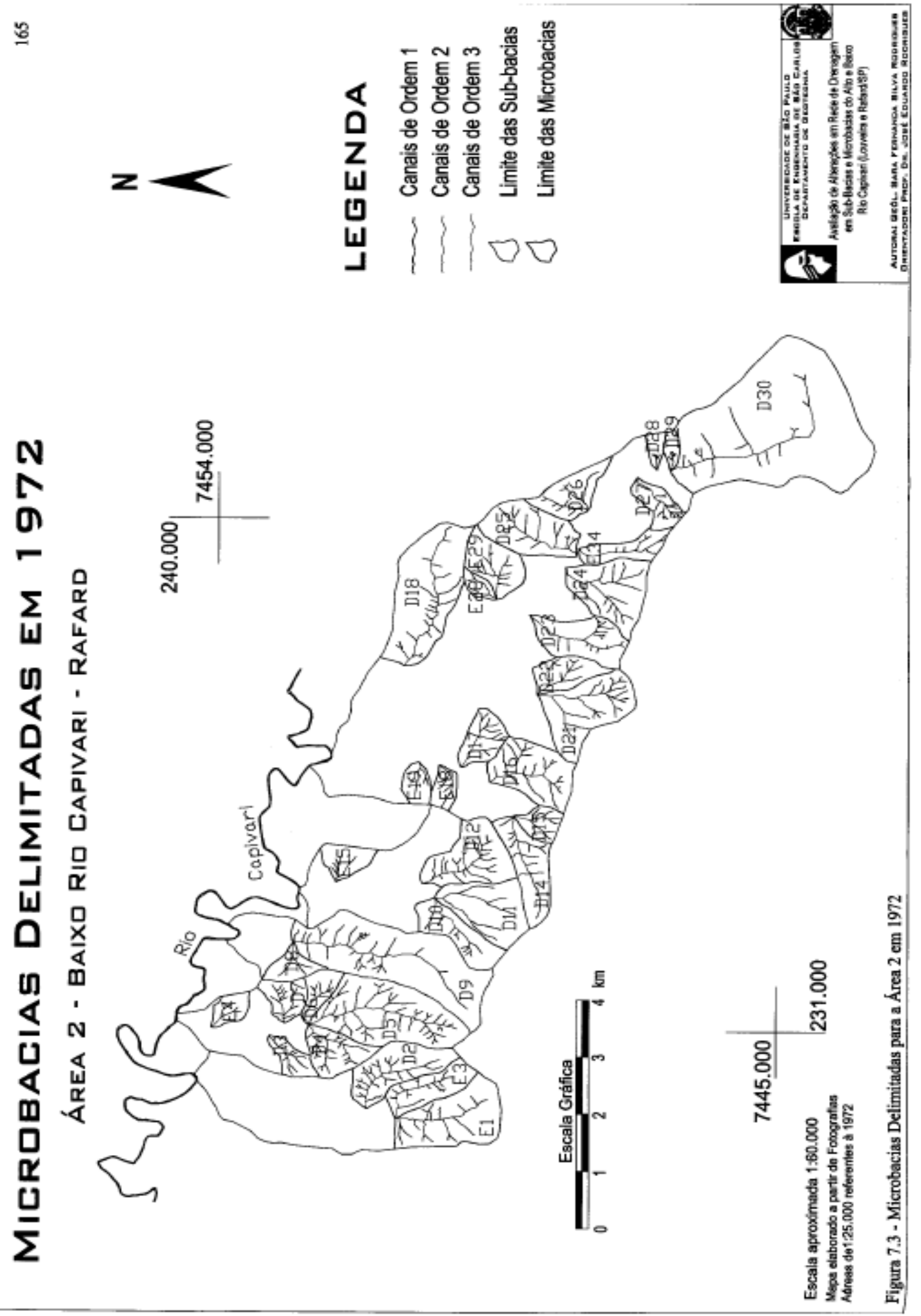

Figuras 7.3 - Microbacias Delimitadas para a área 2 em 1972 
$\stackrel{\circ}{\circ}$
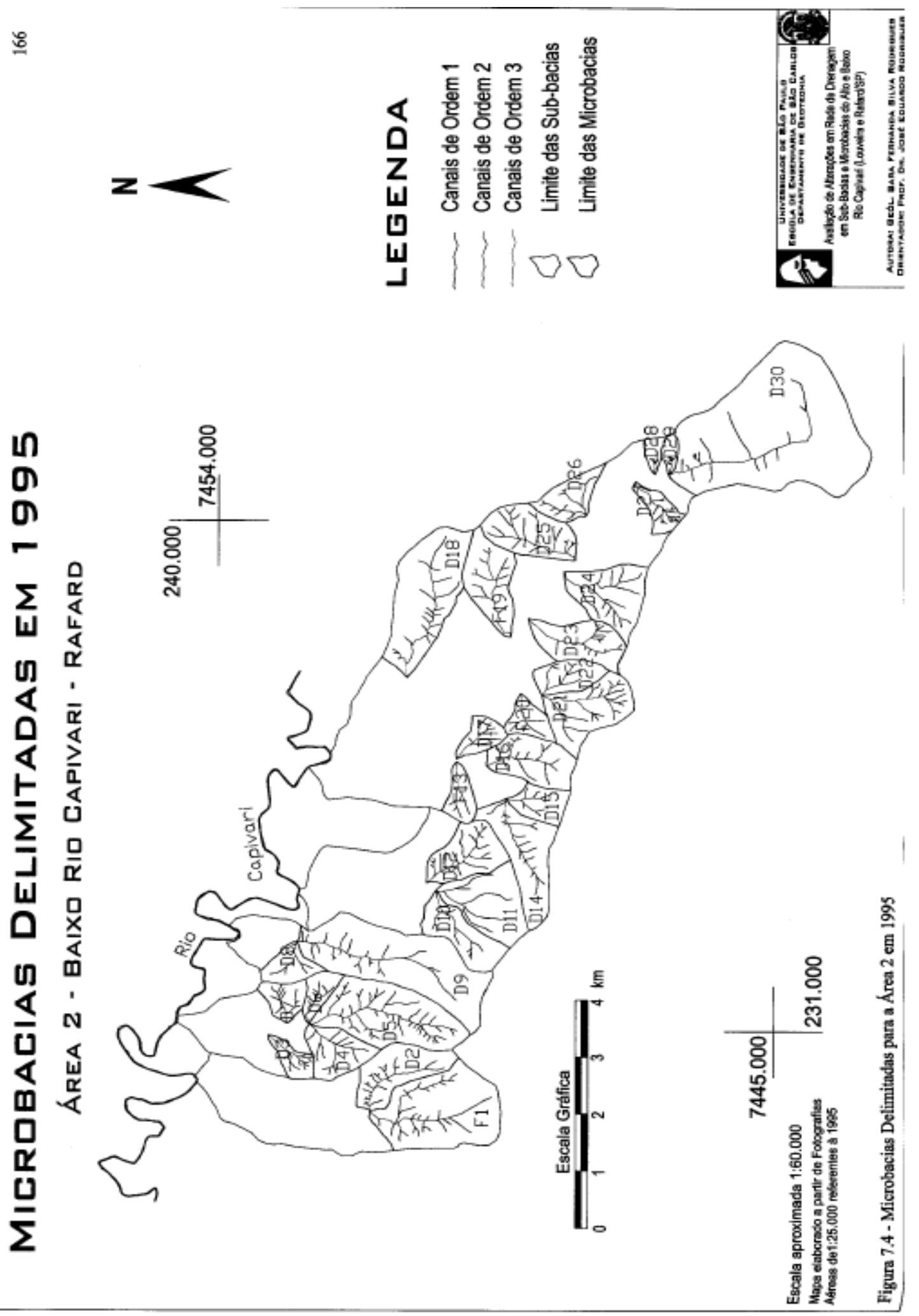

Figura 7.4 - Microbacias Delimitadas para a área 2 em 1995 
A Tabela 7.1 apresenta as microbacias pertinentes a cada sub-bacia avaliada no Capítulo 6 por área de estudo.

Tabela 7.1 - Microbacias delimitadas por área de estudo.

\begin{tabular}{|c|c|c|c|c|}
\hline \multirow{2}{*}{$\begin{array}{l}\text { ÁREA } \\
\text { DE } \\
\text { ESTUDo }\end{array}$} & \multirow[t]{2}{*}{ SUB-BACIA } & \multicolumn{3}{|c|}{ MicROBACIAS REFERENTES AO PERÍODO ESTUDADO } \\
\hline & & $\begin{array}{c}\text { Comum aos dois } \\
\text { anos }\end{array}$ & 1972 & 1995 \\
\hline 1 & $\begin{array}{c}\text { B1 } \\
\text { Ribeirão } \\
\text { Do } \\
\text { Moinho }\end{array}$ & $\begin{array}{c}\text { M31, M32, M35 } \\
\text { M44, M45, M46, } \\
\text { M48 }\end{array}$ & $\begin{array}{l}\text { N33, N34, N36, N37 } \\
\text { N38, N39, N40, N41 } \\
\text { N42, N43, N47, N49 } \\
\text { N50, N51 }\end{array}$ & $\begin{array}{c}\text { O26, O27, O28 } \\
\text { O29, O30, O33 } \\
\text { O37, O38, O39 } \\
\text { O40, O42, O43, O47 }\end{array}$ \\
\hline $\begin{array}{l}\text { Alto } \\
\text { Rio }\end{array}$ & $\begin{array}{c}\text { B2 } \\
\text { Córrego } \\
\text { Sopezol }\end{array}$ & $\begin{array}{c}\text { M13, M14, M16 } \\
\text { M17, M18, M19 } \\
\text { M20, M21, M23, } \\
\text { M24 }\end{array}$ & $\begin{array}{l}\text { N12, N15, N22 } \\
\text { N25, N26, N27 } \\
\text { N28, N29, N30 }\end{array}$ & $\begin{array}{l}\mathrm{O} 10, \mathrm{O} 11, \mathrm{O} 12 \\
\mathrm{O} 13, \mathrm{O} 15, \mathrm{O} 22\end{array}$ \\
\hline $\begin{array}{l}\text { Capivari } \\
\text { (Louveira) }\end{array}$ & $\begin{array}{c}\text { B3 } \\
\text { Córrego } \\
\text { Vale das } \\
\text { Vinhas }\end{array}$ & $\begin{array}{l}\text { M7 } \\
\text { M8 } \\
\text { M9 }\end{array}$ & $\begin{array}{l}\text { N6 } \\
\text { N10 }\end{array}$ & O6 \\
\hline & $\begin{array}{c}\text { B4 } \\
\text { Córrego } \\
\text { Corrupira } \\
\end{array}$ & $\begin{array}{l}\text { M1 } \\
\text { M2 } \\
\text { M3 } \\
\end{array}$ & $\begin{array}{l}\text { N4 } \\
\text { N5 }\end{array}$ & $\begin{array}{l}\mathrm{O} 4 \\
\mathrm{O} 5\end{array}$ \\
\hline 2 & $\begin{array}{c}\text { C1 } \\
\text { Córrego } \\
\text { Borão }\end{array}$ & $D 2$ & $\begin{array}{l}\text { E1 } \\
\text { E3 }\end{array}$ & F1 \\
\hline Baixo & $\begin{array}{c}\text { C2 } \\
\text { Córrego } \\
\text { Alto Retiro }\end{array}$ & $\begin{array}{l}\text { D3, D4 } \\
\text { D5, D6 } \\
\text { D7 }\end{array}$ & E4 & - \\
\hline $\begin{array}{c}\text { Rio } \\
\text { Capivari }\end{array}$ & $\begin{array}{c}\text { C3 } \\
\text { Córrego } \\
\text { Santa Rita }\end{array}$ & $\begin{array}{l}D 8 \\
D 9\end{array}$ & - & - \\
\hline (Rafard) & $\begin{array}{c}\text { C4 } \\
\text { Córrego } \\
\text { São } \\
\text { Francisco }\end{array}$ & $\begin{array}{l}\text { D10 } \\
\text { D11 } \\
\text { D12 }\end{array}$ & E15 & - \\
\hline & $\begin{array}{c}\text { C5 } \\
\text { Córrego } \\
\text { Itapeva }\end{array}$ & $\begin{array}{l}D 14, D 15, D 16 \\
D 17, D 18 D 21 \\
D 22, D 23, D 24 \\
D 25, D 26, D 27 \\
D 28, D 29, D 30\end{array}$ & $\begin{array}{c}\text { E18, E19 } \\
\text { E28, E29 } \\
\text { E34 }\end{array}$ & $\begin{array}{l}\text { F13 } \\
\text { F19 } \\
\text { F20 }\end{array}$ \\
\hline
\end{tabular}

Obs:. As Microbacias destacadas em itálico referem-se às analisadas

A própria modificação no número de microbacias de Ordem 3 no período analisado foi uma constatação da mudança na geometria da rede de drenagem nas áreas de estudo. Conjuntamente foi registrado que a identificação de novas microbacias em 1995 na área 2 foi inferior ao da área 1 , o que sugeriu menores alterações na rede de drenagem. 


\section{2 - PRINCIPAIS VARIÁVEIS MORFOMÉTRICAS APLICADAS NA ANÁLISE TEMPORAL}

O procedimento preliminar de análise consistiu na redução do número de variáveis morfométricas a ser avaliadas, de forma que as escolhidas refletissem as alterações sofridas pelos demais índices morfométricos da rede de drenagem. Dessa forma, utilizaram-se dois métodos estatísticos com esta finalidade sugeridos por Collares (2000).

Os métodos aplicados com o auxílio do software Statistica 4.3 basearam-se na distinção de grupos de variáveis interrelacionadas entre si e são abaixo destacados:

- O Método de Matriz de Correlação da Estatística Básica que possibilita distinguir variáveis com altos índices de correlação; e,

- O Método de Análise de Agrupamentos (Cluster Analysis) que tem como finalidade agrupar sucessivos conjuntos de índices com menor coeficiente de distância, o que reflete maior similaridade entre as variáveis. Seus resultados são apresentados num gráfico denominado de dendrograma e considera a medida de distância euclidiana como critério de similaridade.

Para a confecção da matriz de correlação foram utilizados os valores absolutos dos índices Nt, N1, Lt, L1, Dd, Dh, Tt, Rb 1-2 e Rlm 2-1 $_{2}$ obtidos para os anos de 1972 e 1995 referentes às microbacias estudadas por área de estudo. Na área do Alto Rio Capivari obtevese um total de 46 dados por variável e na Área 2, um total de 52 dados.

$\mathrm{Na}$ análise da matriz foram considerados os índices de correlação acima de 0,8. Nas duas áreas de estudo, como pode ser observado na Tabela 7.2, foi nítido o alto índice de correlação entre os seguintes conjuntos de variáveis: Nt, N1, Lt e L1; e Dd, Dh e Tt. Outro ponto importante a ser destacado foram os baixos índices de correlação de $R \operatorname{lm}_{2-1}, R b_{1-2}$, Lm1 e Lm2 com as demais variáveis. 
Tabela 7.2 - Matrizes de Correlação obtidas para as áreas de estudo

ÁREA 1 - ALTO RIO CAPIVARI - LOUVEIRA

MATRIZ DE CORRELAÇÃO - 11 VARIÁVEIS ANALISADAS

CORRELAÇÕES IMPORTANTES ACIMA DE 0,8

46 DADOS ANALISADOS REFERENTES A 1972 E 1995

\begin{tabular}{|c|c|c|c|c|c|c|c|c|c|c|c|c|}
\hline & $\mathrm{Nt}$ & N1 & $\mathrm{Lt}$ & & 1 & Lm1 & Lm2 & $\mathrm{Dd}$ & Dh & $\mathrm{Rlm}_{2-1}$ & $\mathrm{Rb}_{1-2}$ & $\mathrm{Tt}$ \\
\hline $\mathrm{Nt}$ & 1 & I & 1 & 0,93 & 0,92 & 0,18 & 0,12 & 0,03 & $-0,17$ & 0,03 & 0,25 & U \\
\hline N1 & $I$ & & 1 & 0,94 & 0,94 & 0,2 & 0,15 & 0,04 & $-0,17$ & 0,08 & 0,27 & 0,02 \\
\hline LT & 0,93 & 0,9 & & 1 & 0,99 & 0,48 & 0,34 & $-0,14$ & $-0,43$ & 0,03 & 0,33 & $-0,16$ \\
\hline L1 & 0,92 & 0,9 & & 0,99 & 1 & 0,5 & 0,3 & $-0,09$ & $-0,39$ & 0,03 & 0,33 & $-0,12$ \\
\hline Lm1 & 0,18 & 0,2 & & 0,48 & 0,5 & 1 & 0,52 & $-0,47$ & $-0,77$ & $-0,11$ & 0,27 & $-0,48$ \\
\hline Lm2 & 0,12 & 0,1 & & 0,34 & 0,3 & 0,52 & 1 & $-0,32$ & $-0,56$ & 0,28 & 0,46 & $-0,3$ \\
\hline Dd & 0,03 & 0,0 & & $-0,1$ & $-0,09$ & $-0,47$ & $-0,32$ & 1 & 0,81 & 0,15 & $-0,07$ & 0,97 \\
\hline Dh & $-0,2$ & $-0,17$ & & $-0,4$ & $-0,39$ & $-0,77$ & $-0,56$ & 0,81 & 1 & 0,13 & $-0,28$ & 0,79 \\
\hline $\operatorname{Rlm}_{2-1}$ & 0,03 & 0,08 & & 0,03 & 0,03 & $-0,11$ & 0,29 & 0,16 & 0,13 & 1 & $-0,46$ & 0,22 \\
\hline $\mathrm{Rb}_{1-2}$ & 0,25 & 0,2 & & 0,33 & 0,33 & 0,27 & 0,46 & $-0,07$ & $-0,28$ & $-0,46$ & 1 & $-0,1$ \\
\hline $\mathrm{Tt}$ & 0 & 0,0 & & $-0,2$ & $-0,12$ & $-0,48$ & $-0,3$ & 0,97 & 0,79 & 0,22 & $-0,1$ & 1 \\
\hline
\end{tabular}

ÁREA 2 - BAIXO RIO CAPIVARI - RAFARD

MATRIZ DE CORRELAÇÃO - 11 VARIÁVEIS ANALISADAS

CORRELAÇÕES IMPORTANTES ACIMA DE 0,8

52 DADOS ANALISADOS REFERENTES A 1972 E 1995

\begin{tabular}{l|rrrrrrrrrrrr}
\hline & \multicolumn{1}{|c}{$\mathrm{Nt}$} & \multicolumn{1}{c}{$\mathrm{N} 1$} & $\mathrm{Lt}$ & $\mathrm{L} 1$ & $\mathrm{Lm} 1$ & $\mathrm{Lm} 2$ & \multicolumn{1}{l}{$\mathrm{Dd}$} & $\mathrm{Dh}$ & $\mathrm{Rlm}_{2-1}$ & $\mathrm{Rb}_{1-2}$ & \multicolumn{1}{c}{$\mathrm{Tt}$} \\
\hline $\mathrm{Nt}$ & 1 & $\mathbf{0 , 9 4}$ & 0,75 & 0,77 & $-0,1$ & 0,02 & $-0,05$ & $-0,01$ & 0,08 & 0,27 & 0,05 \\
$\mathrm{~N} 1$ & $\mathbf{0 , 9 4}$ & 1 & $\mathbf{0 , 8 0}$ & $\mathbf{0 , 8 4}$ & $-0,1$ & 0,11 & $-0,01$ & $-0,08$ & 0,16 & 0,38 & 0,02 \\
$\mathrm{LT}$ & 0,75 & $\mathbf{0 , 8 0}$ & 1 & $\mathbf{0 , 9 3}$ & 0,28 & 0,49 & $-0,3$ & $-0,46$ & 0,28 & 0,47 & $-0,29$ \\
$\mathrm{~L} 1$ & 0,77 & $\mathbf{0 , 8 4}$ & $\mathbf{0 , 9 3}$ & 1 & 0,39 & 0,38 & $-0,24$ & $-0,47$ & 0,15 & 0,44 & $-0,21$ \\
$\mathrm{Lm} 1$ & $-0,13$ & $-0,08$ & 0,28 & 0,39 & 1 & 0,41 & $-0,29$ & $-0,63$ & $-0,1$ & 0,06 & $-0,29$ \\
$\mathrm{Lm} 2$ & 0,02 & 0,11 & 0,49 & 0,38 & 0,41 & 1 & $-0,4$ & $-0,6$ & $\mathbf{0 , 8 1}$ & 0,65 & $-0,45$ \\
$\mathrm{Dd}$ & $-0,05$ & $-0,01$ & $-0,3$ & $-0,24$ & $-0,3$ & $-0,4$ & 1 & 0,72 & $-0,2$ & $-0,3$ & $\mathbf{0 , 9 3}$ \\
$\mathrm{Dh}$ & $-0,01$ & $-0,08$ & $-0,5$ & $-0,47$ & $-0,6$ & $-0,6$ & 0,72 & 1 & $-0,3$ & $-0,3$ & 0,71 \\
$\mathrm{Rlm}$ & 0,08 & 0,16 & 0,28 & 0,15 & $-0,1$ & $\mathbf{0 , 8 1}$ & $-0,23$ & $-0,29$ & 1 & 0,65 & $-0,28$ \\
$\mathrm{Rb}_{1-2}$ & 0,27 & 0,38 & 0,47 & 0,44 & 0,06 & 0,65 & $-0,25$ & $-0,32$ & 0,65 & 1 & $-0,28$ \\
$\mathrm{Tt}$ & 0,05 & 0,02 & $-0,3$ & $-0,21$ & $-0,3$ & $-0,45$ & $\mathbf{0 , 9 3}$ & 0,71 & $-0,3$ & $-0,3$ & 1 \\
\hline
\end{tabular}

Na construção dos dendrogramas, utilizaram-se as taxas de variações $(\Delta)$ das variáveis no período analisado, expressas em porcentagens. Os resultados apresentados mostraram forte correlação entre $\Delta \mathrm{Nt}, \Delta \mathrm{N} 1$ e $\Delta \mathrm{Dh}$ e entre $\Delta \mathrm{Lt}, \Delta \mathrm{L} 1, \Delta \mathrm{Dd}$ e $\Delta \mathrm{Lm} 1$, tomandose como limite a distância euclidiana igual a 100 (figuras 7.5 e 7.6). Registrou-se fraca correlação desses conjuntos de variáveis com $\Delta \mathrm{Lm} 2, \Delta \mathrm{R} \operatorname{lm}_{2-1}$ e $\Delta \mathrm{Rb}_{1-2}$. 


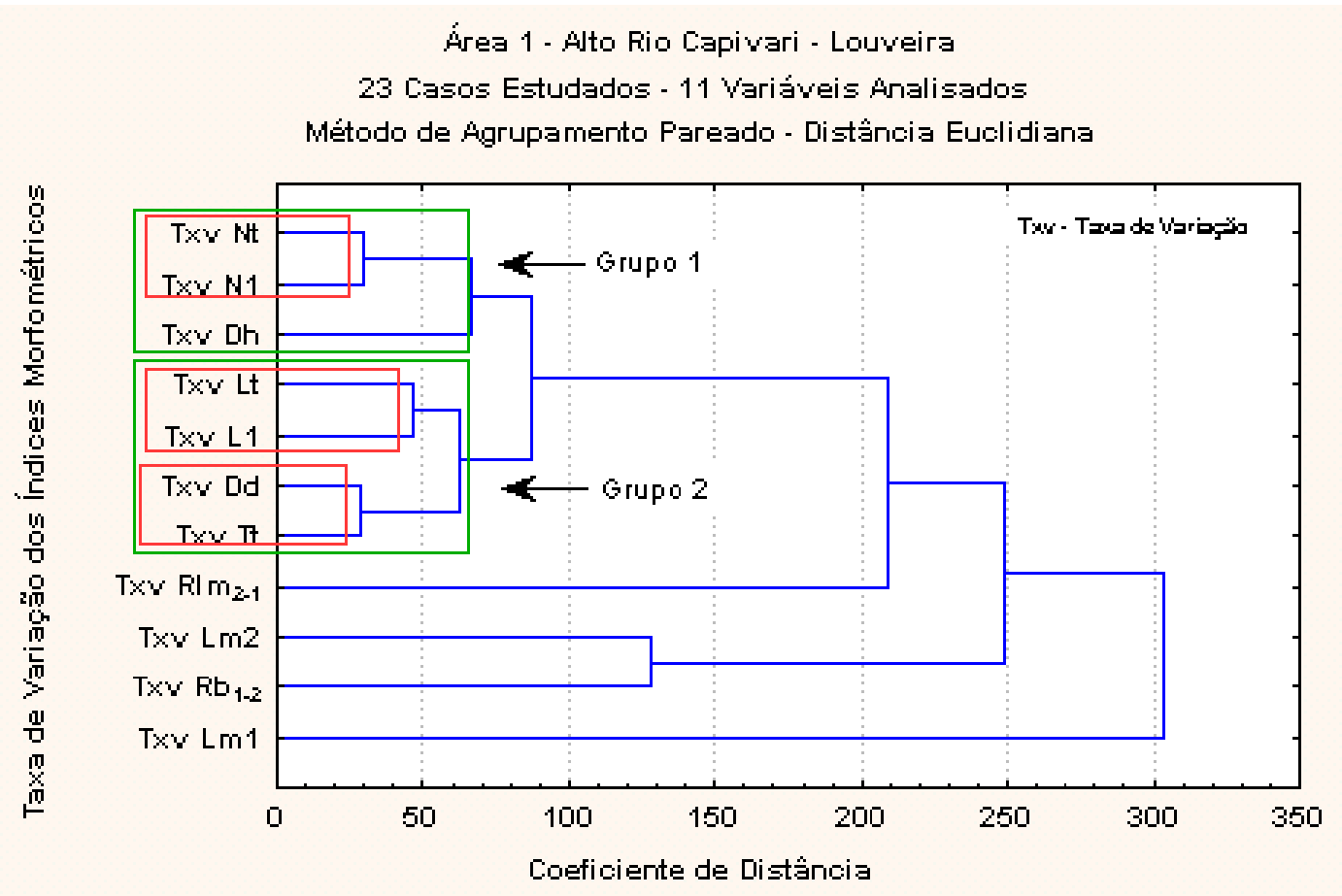

Figura 7.5 - Dendrograma das taxas de variações das microbacias da área 1 entre os anos de 1972 e 1995

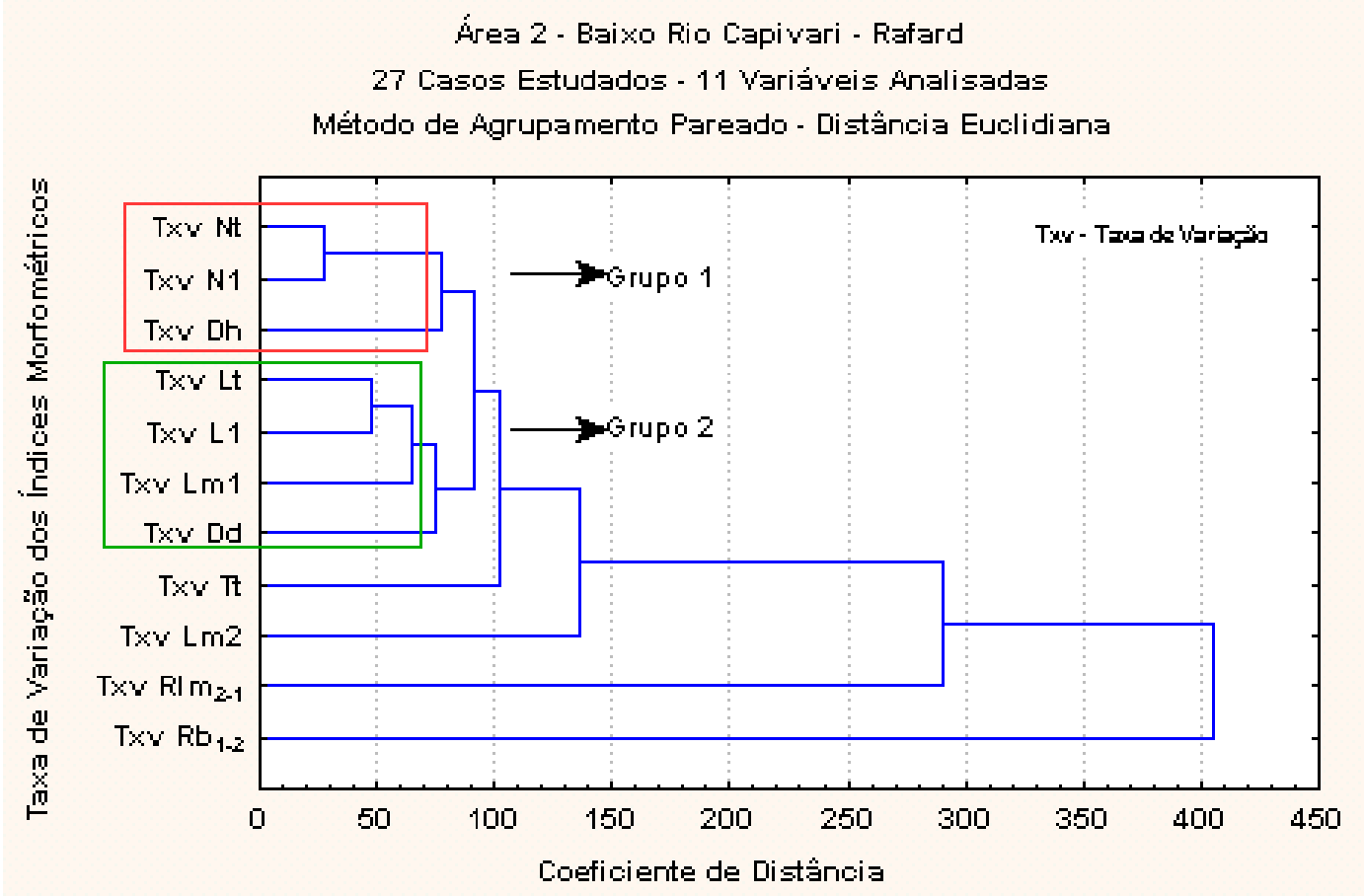

Figura 7.6 - Dendrograma das taxas de variações das microbacias da área 2 entre os anos de 1972 e 1995 
A alta correlação entre os grupos de variáveis observada na matriz de correlação, assim como entre as taxas de variação dos índices já era esperada e ar a sua interdependência já registrada na análise das sub-bacias no Capítulo 6.

Cabe aqui o registro da tendência de modificações observado tanto nas microbacias quanto nas sub-bacias analisadas anteriormente; mudanças no número de canais de Ordem 1 influenciaram diretamente no índice número total de canais e também afetaram os valores de comprimento de canais de Ordem 1 que levaram à modificação do comprimento total da rede de drenagem. Conseqüentemente a densidade hidrográfica $(\mathrm{Dh})$ refletiu diretamente as alterações no número de canais e a densidade de drenagem (Dd) as alterações no comprimento dos canais, retratando a sua disponibilidade para o escoamento linear.

A correlação acentuada entre os grupos permitiu que se definisse uma variável de cada grupo para representar as alterações ocorridas nas demais. Nesse contexto, a densidade de drenagem e densidade hidrográfica foram os parâmetros escolhidos em função de serem os mais aceitos e difundidos como significativos em estudos geoambientais de bacias hidrográficas.

Os resultados obtidos também mostraram para ambos métodos fracas correlações entre os índices $\mathrm{Rb}_{1-2}, \mathrm{Rlm}_{2-1}, \mathrm{Lm}_{1}$ e $\mathrm{Lm}_{2}$, com os demais parâmetros que fundamentalmente expressaram modificações no número ou no comprimento dos canais. Entretanto estudos anteriores mostram que $\mathrm{Rb}_{1-2}$ e $\mathrm{R} \operatorname{lm}_{2-1}$ podem sugerir alterações internas na hierarquização dos canais sendo adotados como parâmetros a serem avaliados nessa pesquisa. Collares (2000), entretanto, sugere cautela com a avaliação das alterações por meio desses índices, uma vez que estão altamente relacionadas com as características dimensionais das microbacias.

\section{3 - ÁREA 1 - ALTO RIO CAPIVARI}

\subsection{1 - Compartimentação das Microbacias}

As microbacias foram, primeiramente, subdivididas com base nas dimensões das suas áreas e depois agrupadas segundo suas faixas de valores predominantes, o que permitiu definir 4 classes (Figura 7.7):

- Classe 1: microbacias com áreas inferiores a 0,2 km² (M24 e M46);

- Classe 2: microbacias com áreas entre 0,2 a 0,8 km² (M1, M2, M3, M8, M17, M18, M19, M20, M21, M23, M31, M35, M44 e M48);

- Classe 3: microbacias com áreas entre 0,8 a 1,2 km² (M9, M13, M14, M16 e M32); e, 
- Classe 4: microbacias com áreas superiores a 1,2 km² (M7 e M45).

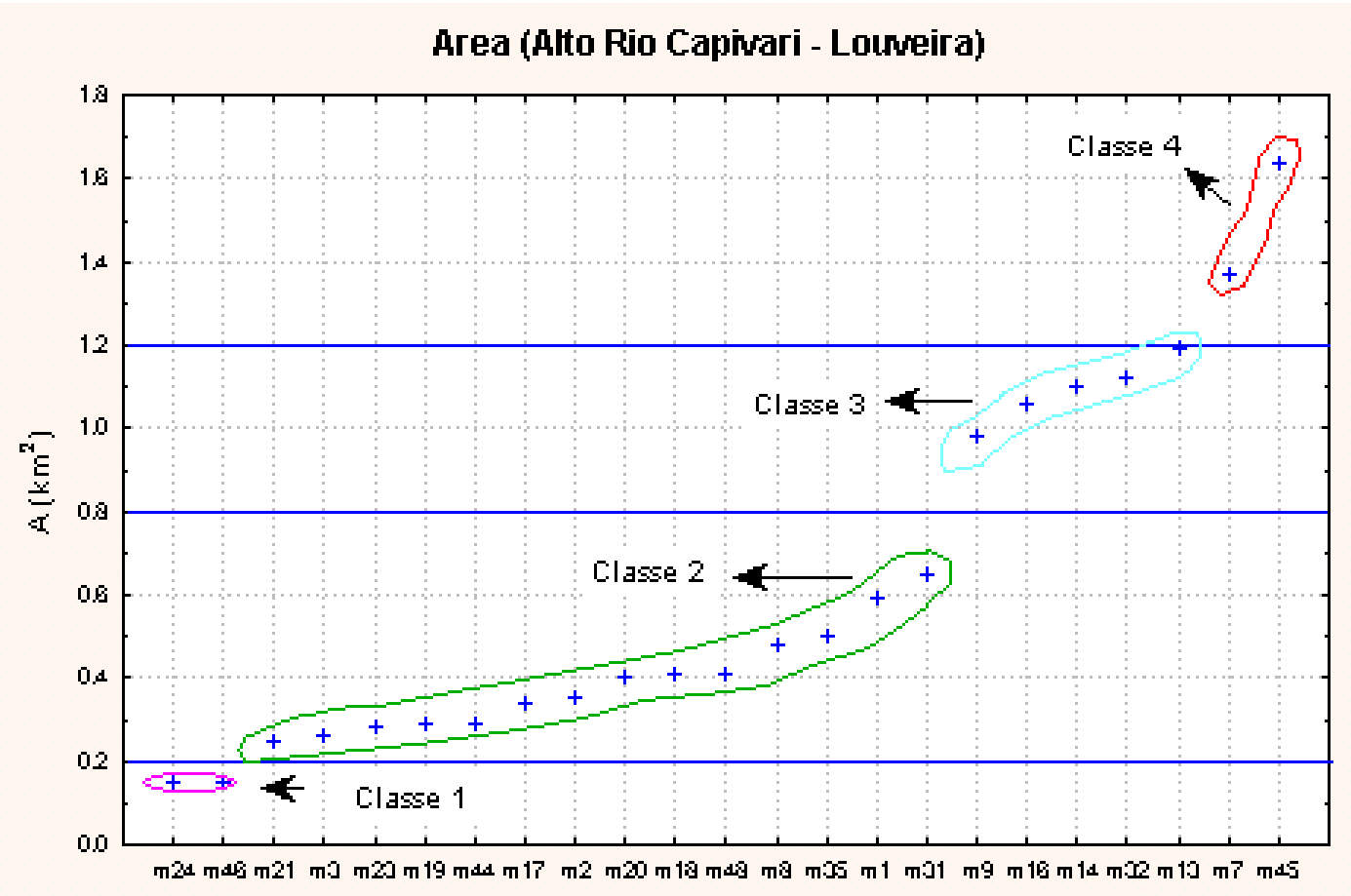

Figura 7.7 - Classes de Área para as microbacias estudadas na região do Alto Rio Capivari

O objetivo dessa subdivisão foi o de avaliar posteriormente a possível influência das dimensões das microbacias nas demais variáveis.

\subsection{2 - Faixas de Distribuição para as Variáveis Morfométricas}

A definição de faixas de distribuição em valores altos, médios e baixos para as variáveis morfométricas da área 1 teve como base os 23 dados obtidos para cada índice no levantamento morfométrico de 1972 e procurou mostrar tanto a tendência das microbacias, ou seja, os valores médios na área de estudo como destacar os valores extremados ou mais destoantes da média.

No processo de delimitação das faixas de distribuição utilizou-se o procedimento de estatística básica Percentis (Weiss e Hasset, 1991) que divide o conjunto de dados em dez partes iguais (percentis) sendo a mediana o limite correspondente a $50 \%$ dos dados. Para destacar as faixas de distribuição dos valores mais extremados, adotaram-se as faixas equivalentes a 10 e $90 \%$, a primeira referente ao limite entre valores baixos e médios e a segunda associada ao limite entre os valores médios e altos. 


\subsubsection{1 - Índice de Forma (k)}

As microbacias estudadas na área 1 apresentaram índice de forma valor médio de 1,22, desvio padrão de 0,11 e pequeno intervalo de faixa distribuição de valores médios de 0,23 (Tabela 7.3).

Tabela 7.3 - Estatísticas Descritivas e Faixas de Distribuição para os dados de k das Microbacias da Área 1

\begin{tabular}{|c|c|c|c|c|c|c|c|c|}
\hline \multicolumn{9}{|c|}{ EstatíSTICA BÁSICA -MÉTOdO dOS PERCENTIS } \\
\hline $\begin{array}{c}\text { Índice } \\
\text { Morfométrico }\end{array}$ & $\begin{array}{l}\text { Número } \\
\text { de Casos }\end{array}$ & Média & Mediana & $\begin{array}{c}\text { Valor } \\
\text { Mínimo }\end{array}$ & $\begin{array}{c}\text { Valor } \\
\text { Máximo }\end{array}$ & $\begin{array}{l}\text { Desvio } \\
\text { Padrão }\end{array}$ & $\begin{array}{c}\text { Valor } \\
\text { Limite } \\
10 \%\end{array}$ & $\begin{array}{c}\text { Valor } \\
\text { Limite } \\
90 \%\end{array}$ \\
\hline $\mathbf{k}$ & 23 & 1,22 & 1,24 & 1,05 & 1,48 & 0,11 & 1,09 & 1,32 \\
\hline $\mathbf{k}$ & Valor & Altos $>$ & 1,32 Valo & res Médio & $1,09-1,32$ & Valores & Saixos & 1,09 \\
\hline
\end{tabular}

A Figura 7.8 mostra pouca variação nos valores encontrados para as microbacias, onde $80 \%$ dos dados concentraram-se na faixa de valores médios. Com exceção de M13, M48, M24 e M44, que apresentaram valores muito destoantes da média, as duas primeiras apresentaram valores altos de $\mathrm{k}$ e as demais, baixos valores.

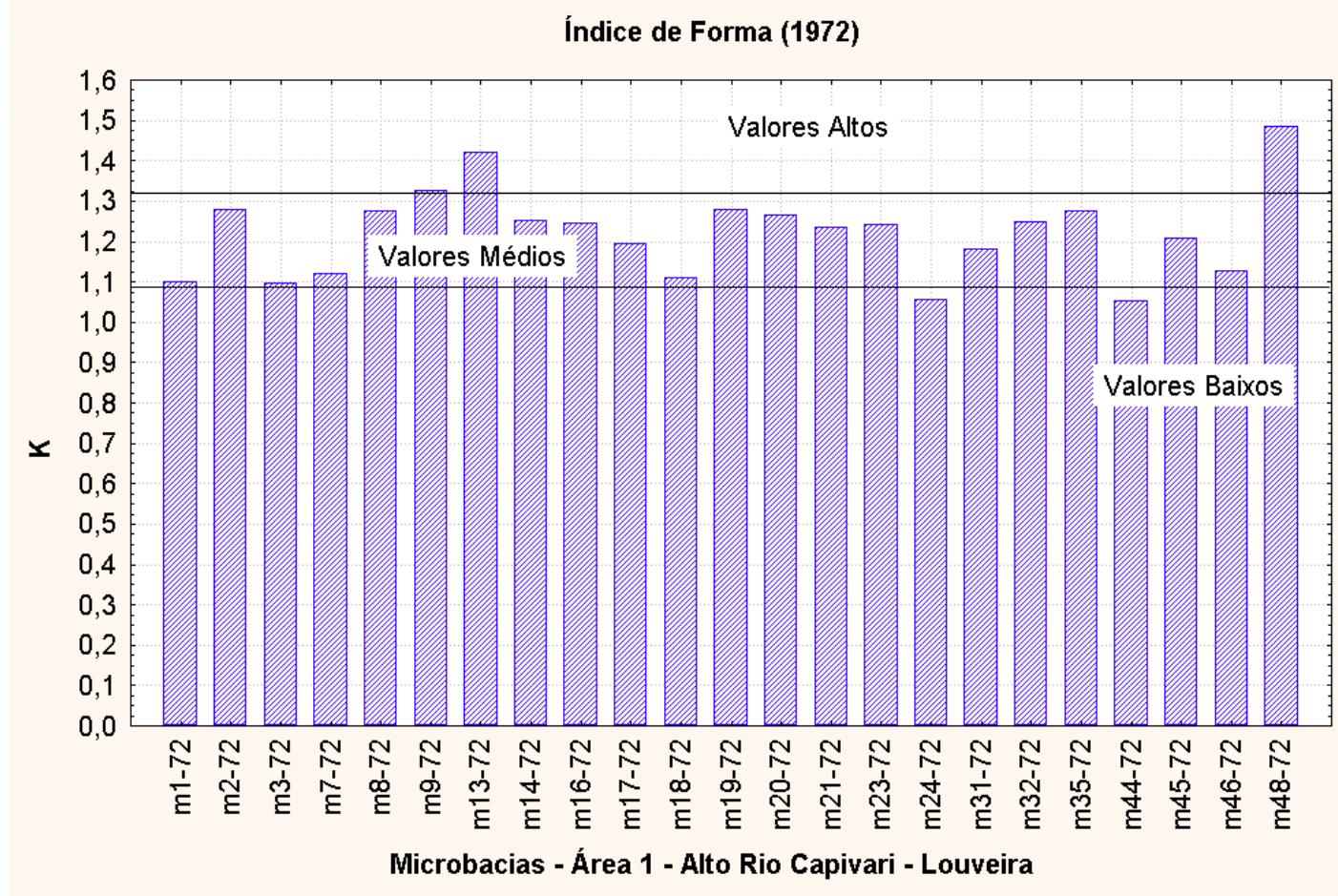

Figura 7.8 - Valores do Índice de Forma (k) para as microbacias estudadas na região do Alto Rio Capivari 


\subsubsection{2 - Densidade de Drenagem (Dd)}

O conjunto de dados referentes a densidade de drenagem apresentou média de 6,15 $\mathrm{km} / \mathrm{km}^{2}$ e desvio padrão de $1,01 \mathrm{~km} / \mathrm{km}^{2}$, com faixa de distribuição de valores médios correspondente a $2,47 \mathrm{~km} / \mathrm{km}^{2}$ (Tabela 7.4).

Tabela 7.4 - Estatísticas Descritivas e Faixas de Distribuição para os dados de Dd das Microbacias da Área 1

\begin{tabular}{|c|c|c|c|c|c|c|c|c|}
\hline \multicolumn{9}{|c|}{ Estatística BÁSICA -MÉTOdO dOS PERCENTIS } \\
\hline $\begin{array}{c}\text { Índice } \\
\text { Morfométrico }\end{array}$ & $\begin{array}{l}\text { Número } \\
\text { de Casos }\end{array}$ & Média & Mediana & $\begin{array}{c}\text { Valor } \\
\text { Mínimo }\end{array}$ & $\begin{array}{c}\text { Valor } \\
\text { Máximo }\end{array}$ & $\begin{array}{l}\text { Desvio } \\
\text { Padrão }\end{array}$ & $\begin{array}{c}\text { Valor } \\
\text { Limite } \\
10 \%\end{array}$ & $\begin{array}{c}\text { Valor } \\
\text { Limite } \\
90 \%\end{array}$ \\
\hline Dd $\left(\mathrm{km} / \mathrm{km}^{2}\right)$ & 23 & 6,15 & 6,4 & 4,45 & 8,10 & 1,01 & 4,71 & 7,18 \\
\hline $\mathbf{D d}\left(\mathrm{km} / \mathrm{km}^{2}\right)$ & Valor & Altos & 7,18 Valo & s Médios & $4,71-7,18$ & Valore & ixos & 7,18 \\
\hline
\end{tabular}

Observa-se na Figura 7.9, que com exceção de M2, M13, M20, M32 e M44, todas as demais microbacias encontraram-se na faixa de valores médios. Dentre elas, M13, M20 e M32 apresentaram baixos valores de densidade de drenagem e M2 e M44, altos valores de Dd.

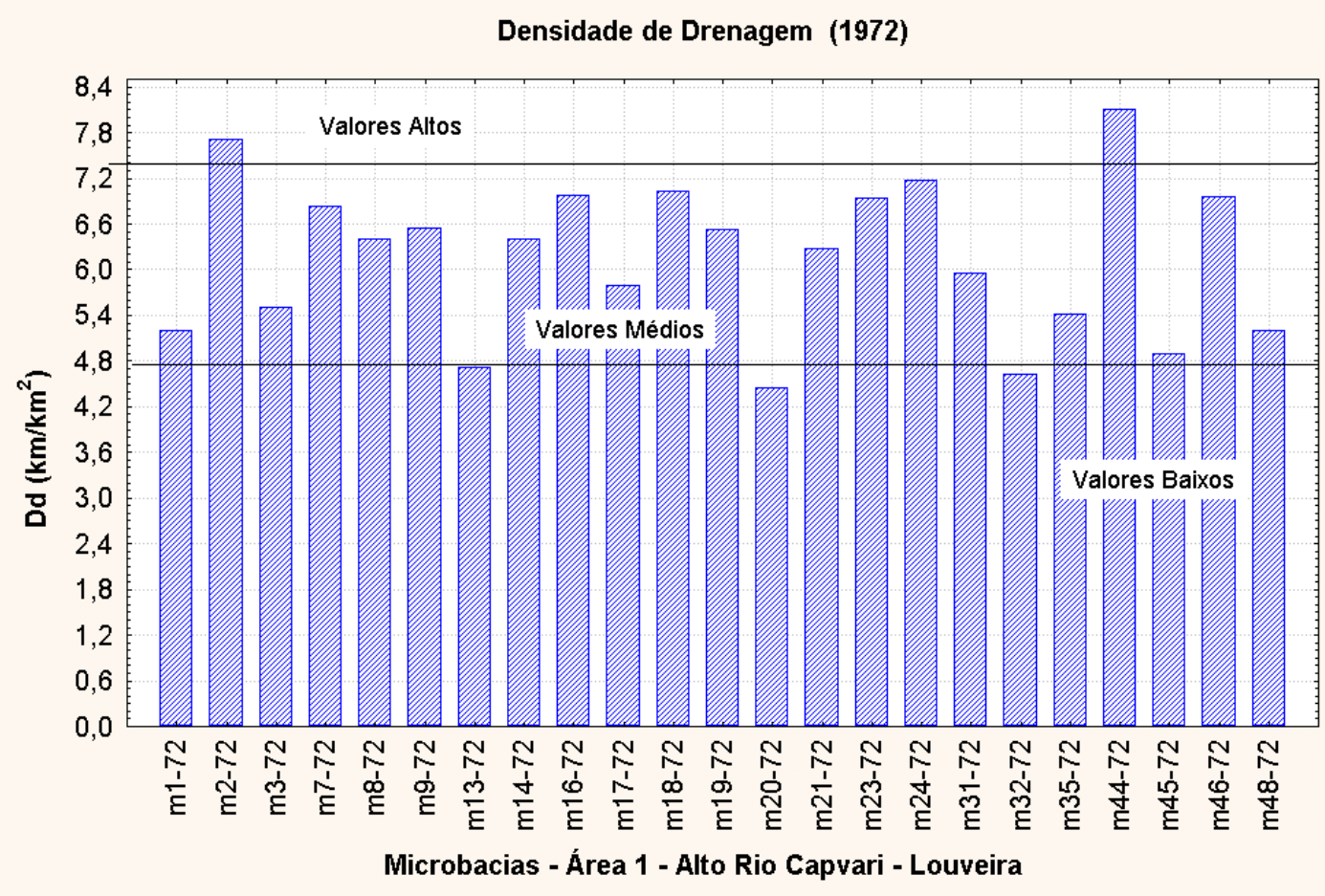

Figura 7.9 - Valores de Densidade de Drenagem (Dd) para as microbacias estudadas na região do Alto Rio Capivari 


\subsubsection{3 - Densidade Hidrográfica (Dh)}

Obteve-se para os valores de Dh, média de 22,60 N1/ $\mathrm{km}^{2}$, com desvio padrão elevado de 8,87 N1/ $\mathrm{km}^{2}$ (Tabela 7.5). Tal fato ocorreu devido a variação notória do conjunto de dados (Figura 7.7). Seu intervalo de variação entre os valores médios de $21 \mathrm{~N} 1 / \mathrm{km}^{2}$ foi considerado elevado.

Tabela 7.5 - Estatísticas Descritivas e Faixas de Distribuição para os dados de Dh das Microbacias da Área 1

\begin{tabular}{|c|c|c|c|c|c|c|c|c|}
\hline \multicolumn{9}{|c|}{ ESTATÍSTICA BÁSICA -MÉTODO dOS PERCENTIS } \\
\hline $\begin{array}{c}\text { Índice } \\
\text { Morfométrico }\end{array}$ & $\begin{array}{l}\text { Número } \\
\text { de Casos }\end{array}$ & Média & Mediana & $\begin{array}{c}\text { Valor } \\
\text { Mínimo }\end{array}$ & $\begin{array}{c}\text { Valor } \\
\text { Máximo }\end{array}$ & $\begin{array}{l}\text { Desvio } \\
\text { Padrão }\end{array}$ & $\begin{array}{c}\text { Valor } \\
\text { Limite } \\
10 \%\end{array}$ & $\begin{array}{c}\text { Valor } \\
\text { Limite } \\
90 \%\end{array}$ \\
\hline $\operatorname{Dh}\left(N 1 / k^{2}\right)$ & 23 & 22,60 & 20,58 & 10,92 & 46,66 & 8,87 & 12,30 & 33,33 \\
\hline $\operatorname{Dh}\left(N 1 / k^{2}\right)$ & Valor & Altos $>$ & $33,33 \mathbf{V a}$ & es Méd & $12,3-33$ & Valore & Baixos & 12,3 \\
\hline
\end{tabular}

Verifica-se na Figura 7.10, que M23, M24 e M46 apresentaram os valores mais altos de Dh, que variaram de 33,3 a 46,7, resultado de áreas pequenas para o número de canais registrados nessas microbacias. Entretanto os resultados obtidos para M32 e M13 registraram baixos valores de Dh. Este registro nessas microbacias teve como causa áreas consideravelmente grandes em relação ao número de canais presentes.

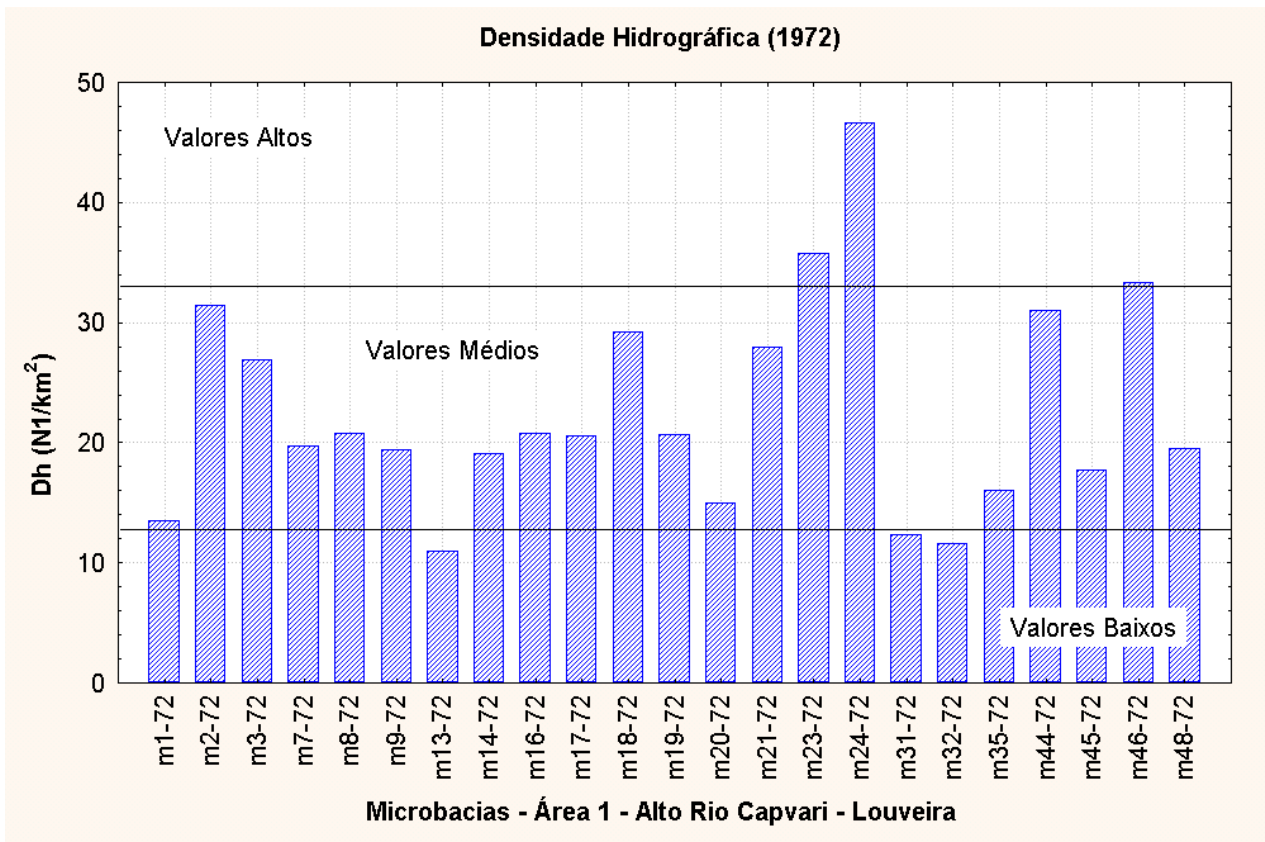

Figura 7.10 - Valores de Densidade Hidrográfica (Dh) para as microbacias estudadas na região do Alto Rio Capivari 


\subsubsection{4 - Textura Topográfica $(T t)$}

Encontrou-se para os valores de Tt, valor médio de 12,74 km e desvio padrão de 2,79 km (Tabela 7.6), com intervalo de variação entre os valores limites de 10 e $90 \%$ de 6,88 $\mathrm{km}$.

Tabela 7.6 - Estatísticas Descritivas e Faixas de Distribuição para os dados de Tt das Microbacias da Área 1

\begin{tabular}{|c|c|c|c|c|c|c|c|c|}
\hline \multicolumn{9}{|c|}{ EstatíSTICA BÁSICA -MÉTOdO dOS PERCENTIS } \\
\hline $\begin{array}{c}\text { Índice } \\
\text { Morfométrico }\end{array}$ & $\begin{array}{l}\text { Número } \\
\text { de Casos }\end{array}$ & Média & Mediana & $\begin{array}{c}\text { Valor } \\
\text { Mínimo }\end{array}$ & $\begin{array}{c}\text { Valor } \\
\text { Máximo }\end{array}$ & $\begin{array}{l}\text { Desvio } \\
\text { Padrão }\end{array}$ & $\begin{array}{c}\text { Valor } \\
\text { Limite } \\
10 \%\end{array}$ & $\begin{array}{c}\text { Valor } \\
\text { Limite } \\
90 \%\end{array}$ \\
\hline Tt $(\mathrm{km})$ & 23 & 12,74 & 13,15 & 8,7 & 17,64 & 2,49 & 9,3 & 16,18 \\
\hline Tt $(\mathrm{km})$ & Valo & s Altos & $16,18 \mathrm{Val}$ & ores Méd & s $9,3-16$, & Valores & Baixos $<$ & 9,3 \\
\hline
\end{tabular}

Registrou-se para M20 e M32 baixos valores de Tt e para M2, M18 e M44 altos valores de Tt enquanto todas as demais microbacias encontraram-se na faixa de distribuição de valores médios de Tt (Figura 7.11).

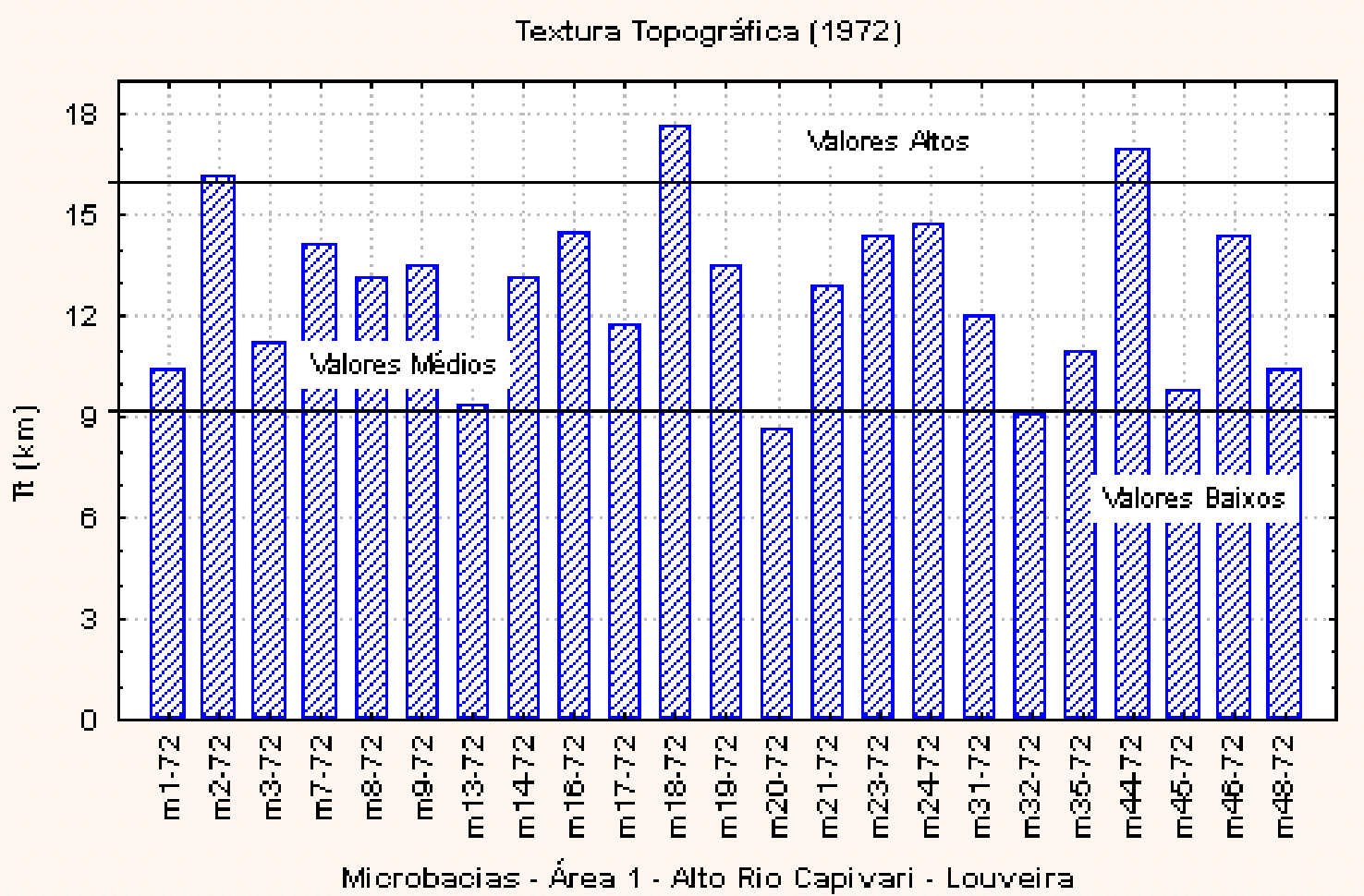

Figura 7.11 - Valores de Textura Topográfica (Tt) para as microbacias estudadas na região do Alto Rio Capivari 


\subsubsection{5 - Razão de Bifurcação entre Canais de Ordem 1 e 2 (Rb $\left.{ }_{1-2}\right)$}

As microbacias apresentaram 2,59 como média de valores para $\mathrm{Rb}_{1-2}$ e desvio padrão de 1,11(Tabela 7.7). Apesar da variação de valores distinta nas microbacias, como mostra a Figura 7.12, o intervalo de variação entre os valores limites de 10 e 90\% foi de apenas 2,81.

Tabela 7.7 - Estatísticas Descritivas e Faixas de Distribuição para os dados de $\mathrm{Rb}_{1-2}$ das Microbacias da Área 1

\begin{tabular}{|c|c|c|c|c|c|c|c|c|}
\hline \multicolumn{9}{|c|}{ Estatística BÁSICA -MÉTOdO dOS PERCENTIS } \\
\hline $\begin{array}{c}\text { Índice } \\
\text { Morfométrico }\end{array}$ & $\begin{array}{l}\text { Número } \\
\text { de Casos }\end{array}$ & Média & Mediana & $\begin{array}{c}\text { Valor } \\
\text { Mínimo }\end{array}$ & $\begin{array}{c}\text { Valor } \\
\text { Máximo }\end{array}$ & $\begin{array}{l}\text { Desvio } \\
\text { Padrão }\end{array}$ & $\begin{array}{c}\text { Valor } \\
\text { Limite } \\
10 \%\end{array}$ & $\begin{array}{c}\text { Valor } \\
\text { Limite } \\
90 \%\end{array}$ \\
\hline $\mathbf{R b}_{1-2}$ & 23 & 2,59 & 2,60 & 0,59 & 4,75 & 1,11 & 1,19 & 4,00 \\
\hline $\mathbf{R b}_{1-2}$ & Valo & Altos & 00 Val & s Médio & $1,19-4,0$ & Valore & $\operatorname{xos}<$ & 19 \\
\hline
\end{tabular}

As microbacias M13, M23 e M24 apresentaram muito baixos valores de $\mathrm{Rb}_{1-2}$ e a microbacia M9, muito alto valor de $\mathrm{Rb}_{1-2}$ em relação ao valor médio obtido. As demais microbacias encontraram-se na faixa de distribuição de valores médios (Figura 7.12).

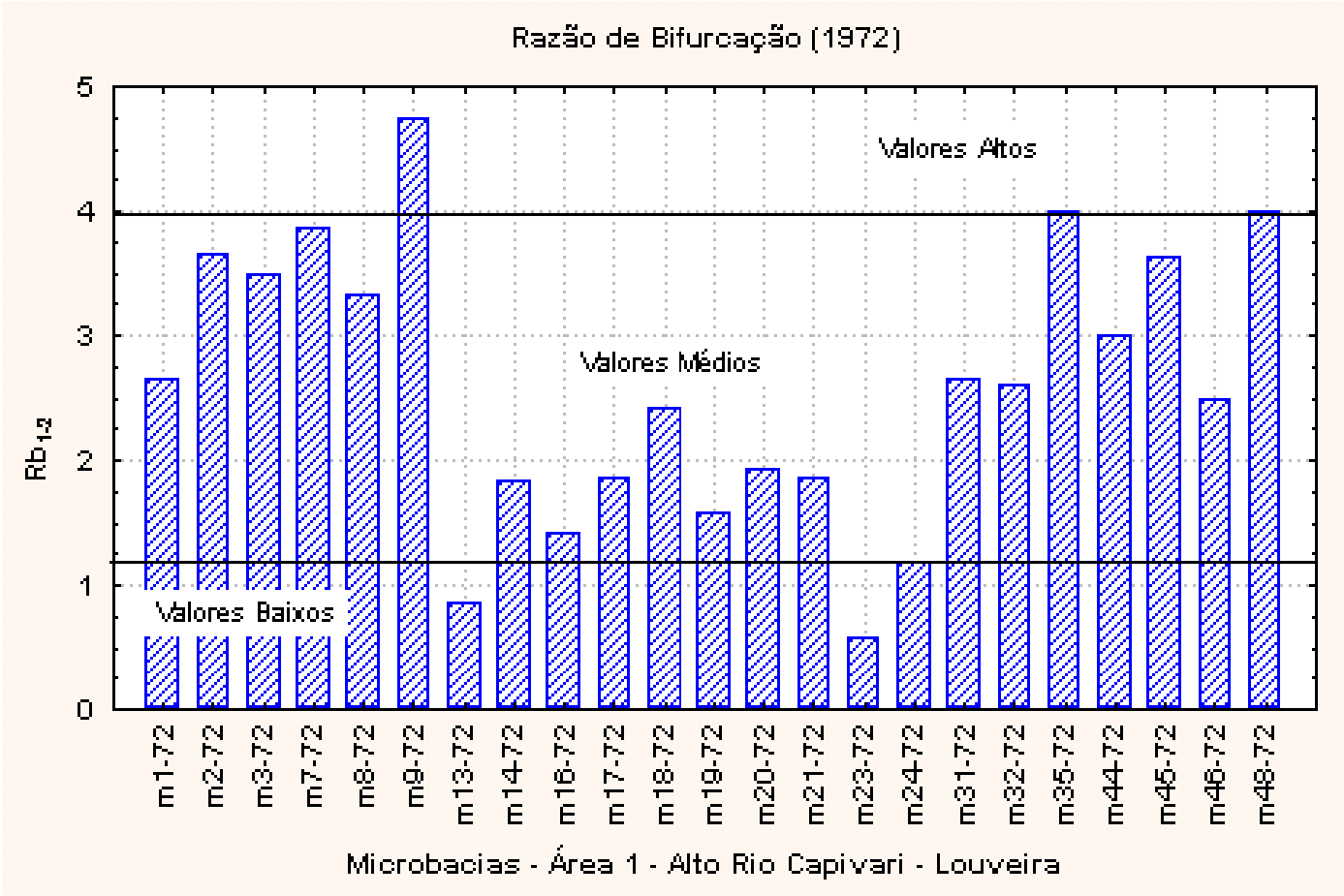

Figura 7.12 - Valores da Razão de Bifurcação entre canais de Ordem 1 e $2\left(\mathrm{Rb}_{1-2}\right)$ para as microbacias estudadas na região do Alto Rio Capivari 


\subsubsection{6 - Razão entre Comprimentos Médios dos Canais de Ordem 2 e 1 $\left(\operatorname{RIm}_{2-1}\right)$}

A média dos valores encontrados para $\operatorname{Rlm}_{2-1}$ foi de 2,68 e desvio padrão de 1,47 (Tabela 7.8). Apresentaram variação de valores inversa a $\mathrm{Rb}_{1-2}$, como mostra a Figura 7.13, e o intervalo de variação entre os valores limites de 10 e $90 \%$ foi de 3,79 .

Tabela 7.8 - Estatísticas Descritivas e Faixas de Distribuição para os dados de $R \operatorname{lm}_{2-1}$ das Microbacias da Área 1

\begin{tabular}{|c|c|c|c|c|c|c|c|c|}
\hline \multicolumn{9}{|c|}{ EsTATÍSTICA BÁSICA -MÉTODO DOS PERCENTIS } \\
\hline $\begin{array}{c}\text { Índice } \\
\text { Morfométrico }\end{array}$ & $\begin{array}{l}\text { Número } \\
\text { de Casos }\end{array}$ & Média & Mediana & $\begin{array}{c}\text { Valor } \\
\text { Mínimo }\end{array}$ & $\begin{array}{c}\text { Valor } \\
\text { Máximo }\end{array}$ & $\begin{array}{l}\text { Desvio } \\
\text { Padrão }\end{array}$ & $\begin{array}{c}\text { Valor } \\
\text { Limite } \\
10 \%\end{array}$ & $\begin{array}{c}\text { Valor } \\
\text { Limite } \\
90 \%\end{array}$ \\
\hline $\mathbf{R l m}_{2-1}$ & 23 & 2,68 & 2,53 & 0,82 & 6,00 & 1,47 & 1,21 & 5,00 \\
\hline $\mathbf{R I m}_{2-1}$ & Valo & Altos & 00 Va & es Méc & $1,21-5$, & Valore & ixos $<$ & ,21 \\
\hline
\end{tabular}

As microbacias M1, M32, M45 e M46 apresentaram baixos valores de Rlm 2-1 e a microbacia M16 e M18, altos valores de $\operatorname{Rlm}_{2-1}$. As demais microbacias encontraram-se na faixa de distribuição de valores médios (Figura 7.13).

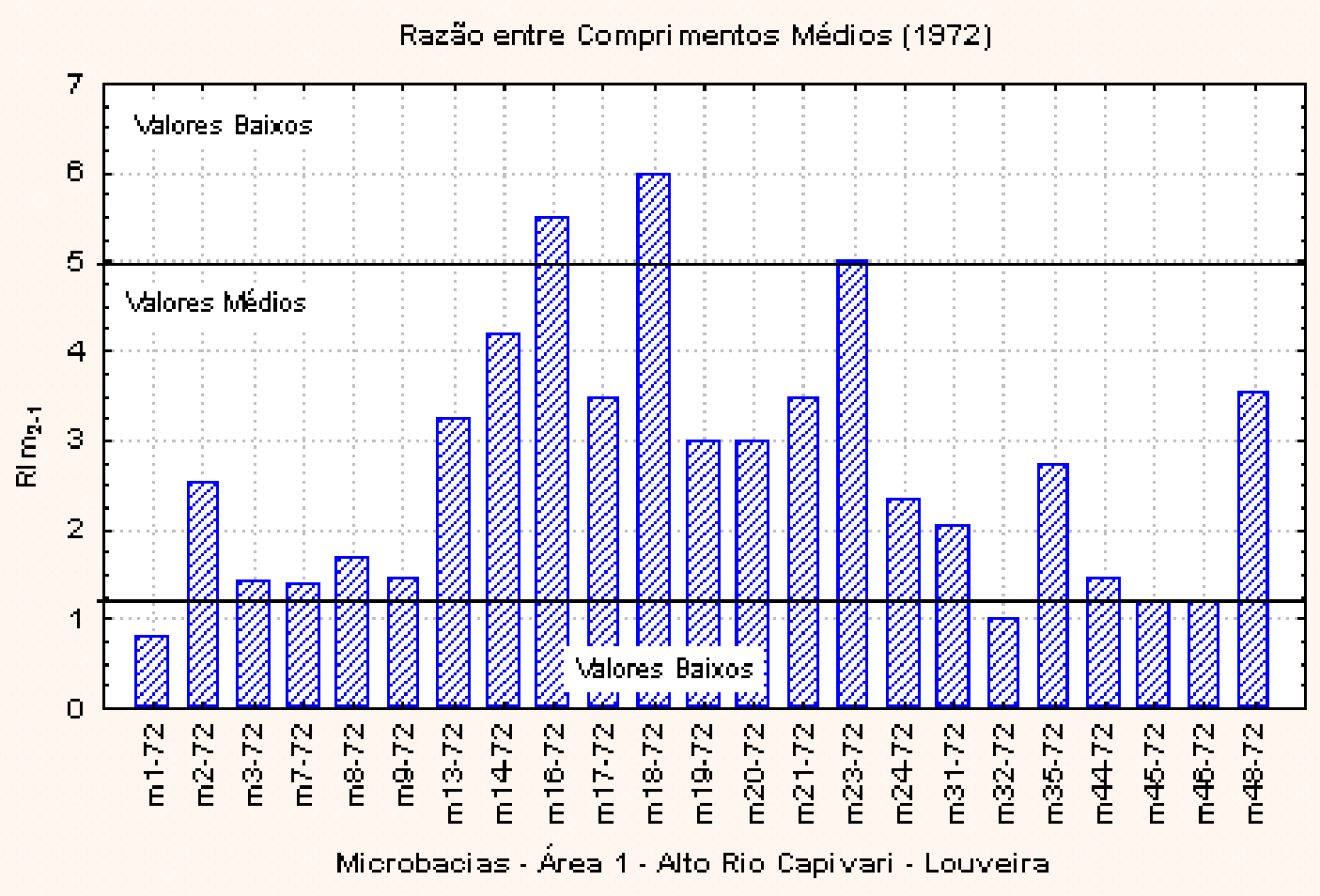

Figura 7.13 - Valores da Razão entre Comprimentos Médios dos canais de Ordem 2 e 1 $\left(\mathrm{Rlm}_{2-1}\right)$ para as microbacias estudadas na região do Alto Rio Capivari 


\subsection{3 - Relação entre as Variáveis Morfométricas}

Nos gráficos área versus densidade de drenagem e área versus densidade hidrográfica foi possível distinguir os seguintes comportamentos quanto as classes de área (figuras 7.14 e 7.15 ):

- A classe 1 referente à M24 e M46, apresentou valores altos para Dh e valores médios para Dd;

- A classe 2 apresentou-se quase que na totalidade de suas bacias com valores médios tanto para Dd quanto para Dh, com exceção de M2 e M44, M23, e M20 que apresentaram, respectivamente, altos valores de Dd, altos valores de Dh e baixos valores de $\mathrm{Dh}$;

- A classe 3 pode ser subdividida em dois grupos, o primeiro constituído por M14, M16 e M9, com valores médios de Dd e Dh e o segundo constituído por M13 e M32, com baixos valores de Dd e Dh;

- A classe 4, composta por M7 e M45, apresentou valores médios para as duas variáveis; e,

- As associações das classes 1 e 2; e grupo 3 (Classe 3) mostraram que quanto maior a área, menor os valores de Dh e Dd e que os demais dados apresentaram-se dispersos.

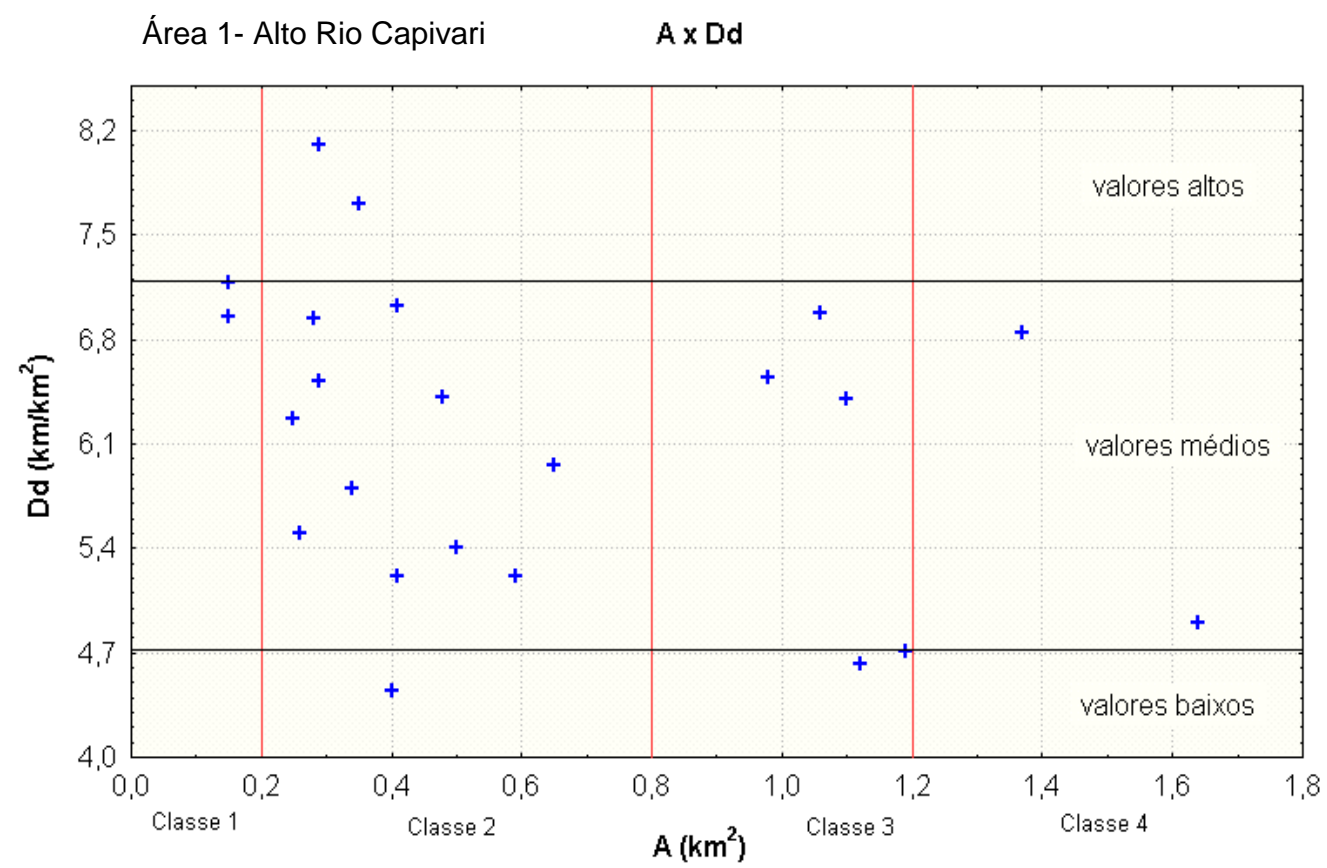

Figura 7.14 - Relação entre área e densidade de drenagem referente a 1972 na região do Alto Rio Capivari 


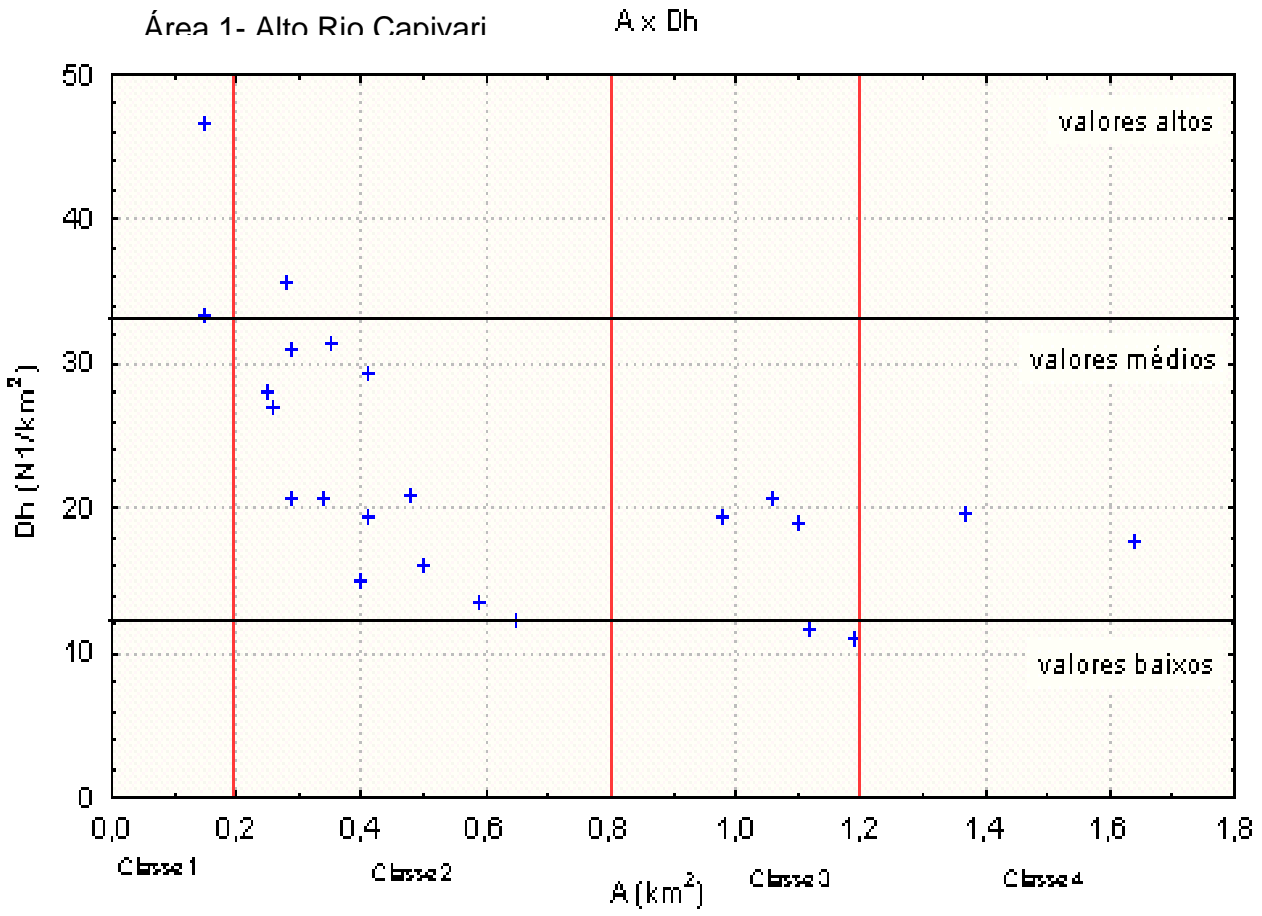

Figura 7.15 - Relação entre área e densidade hidrográfica referente a 1972 na região do Alto Rio Capivari

O gráfico densidade de drenagem versus densidade hidrográfica (Figura 7.16) mostra 4 tendências de comportamento: microbacias com valores baixos de Dd e Dh (A);, microbacias com valores médios de Dd e Dh (B), microbacias com valores altos de Dd e médios de Dh (C) e microbacias com valores médios de Dd e altos de Dh (D).

$\mathrm{O}$ registro na maioria das microbacias com comportamento A e B mostrou nítida correlação linear entre Dd e Dh, ou seja, quanto maior o valor de Dd, maior o de Dh e viceversa. Os dois últimos grupos, apesar de apresentarem valores dispersos, mostraram similaridades entre si, o que permitiu agrupá-los. 
$\mathrm{Dd} \times \mathrm{Dh}$

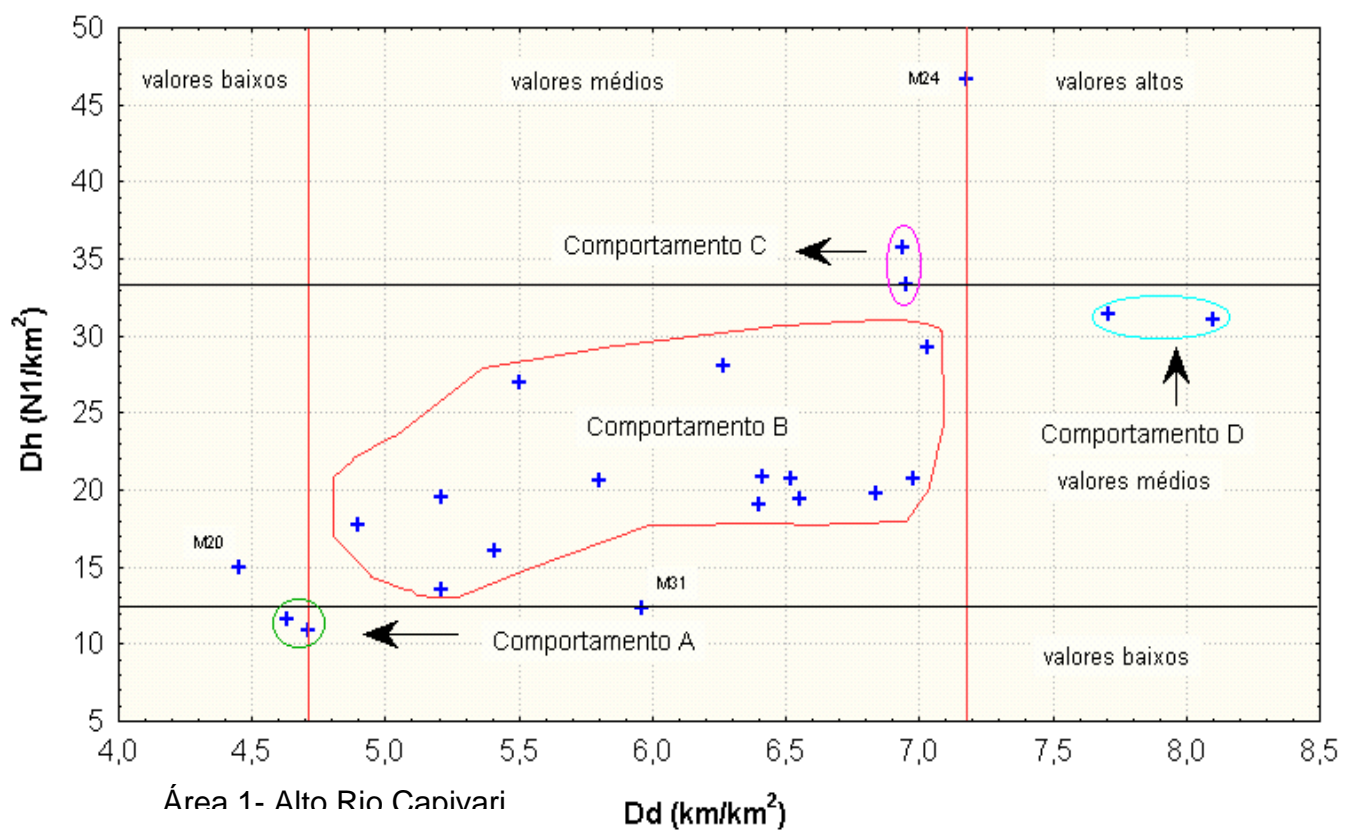

Figura 7.16 - Relação entre densidade de drenagem e densidade hidrográfica referente à 1972 na Área 1

\subsection{4 - Avaliação das Taxas de Variação dos Principais Índices Morfométricos}

As taxas de variação das alterações ocorridas nas variáveis da rede de drenagem entre 1972 e 1995 foram descritas em porcentagens, quando positiva indicou um aumento no valor da variável nesse período, em contrapartida, uma taxa negativa sugeriu um déficit no valor da variável.

Destaca-se que as taxas de variação inferiores a $10 \%$ foram consideradas pouco significativas nas análises uma vez que nesta faixa podem estar embutidos erros de fotointerpretação, mensuração ou de processamento de dados.

Nessa etapa de análise, o intuito foi avaliar as relações entre as taxas de variação dos parâmetros Dd e Dh e entre as taxas de variação de $\mathrm{Rlm}_{2-1}$ e $\mathrm{Rb}_{1-2}$; a primeira por refletir as mudanças na quantidade de número de canais e de seus comprimentos nas microbacias no intervalo de tempo estudado (23 anos) e a segunda por indicar as modificações na hierarquização dos canais da rede de drenagem no mesmo período.

Inicialmente, criou-se um dendrograma baseado nas taxas de variação de Dd e Dh com o objetivo de definir grupos de alteração quanto à sua significância, ou seja, quanto 
maior a porcentagem, quer indiquem ganho ou déficit nas variáveis, mais significativas foram as alterações (Figura 7.17). Exclui-se da análise todas as microbacias com dados de porcentagens das variações ou de Dd ou de Dh inferiores a 10 \%.

O dendrograma inicialmente mostrou dois ramos distintos, um referente a alterações positivas e outro pertinente a alterações negativas e foi possível distinguir cinco grupos.

Ao se plotar os dados num gráfico que relacionou a taxa de variação de densidade de drenagem versus a taxa de variação de densidade hidrográfica foi possível observar que a subdivisão proposta pelo dendrograma foi baseada principalmente em função das porcentagens da taxa de variação encontradas para densidade hidrográfica para taxas de densidade de drenagem superiores a 10\% (Figura 7.18).

Os grupos de microbacias foram então classificados quanto à significância da alteração, baseando-se fundamentalmente nas taxas de variação de Dh e foram descritos como:

- Microbacias com alterações significativas, com porcentagens entre 10 a 30\% da taxa de variação de Dh e $\Delta$ Dd maior que 10\% (M3, M7, M9, M20, M32 e M45);

- Microbacias com alterações muito significativas, com porcentagens entre 30 a 50\% da taxa de variação de Dh e $\Delta$ Dd superior a 10\% (M8 e M19); e,

- Microbacias com alterações altamente significativas, com porcentagens superiores a $50 \%$ da taxa de variação de Dh e $\Delta$ Dd maior que 10\% (M2, M14, M17 e M31).

As microbacias M13, M18, M21, M44 e M46 foram classificadas com alterações pouco significativas, ou seja, aquelas cujas porcentagens foram inferiores a $10 \%$ de $\Delta \mathrm{Dh}$ e de $\Delta \mathrm{Dd}$ e não foram incluídas na aplicação dos métodos estatísticos.

Pode-se destacar alguns casos particulares de microbacias M1, M16, M24 e M35 com $\Delta \mathrm{Dd}$ superior a $10 \%$ e $\Delta \mathrm{Dh}$ inferior a $10 \%$; e M23 e M48 com $\Delta \mathrm{Dd}$ inferior a $10 \%$ e $\Delta$ Dh superior a $10 \%$ que não foram incluídos na análise estatística, uma vez que as microbacias sofreram alterações positivas ou negativas superiores a $10 \%$ apenas para uma das taxas de variação dos índices. 


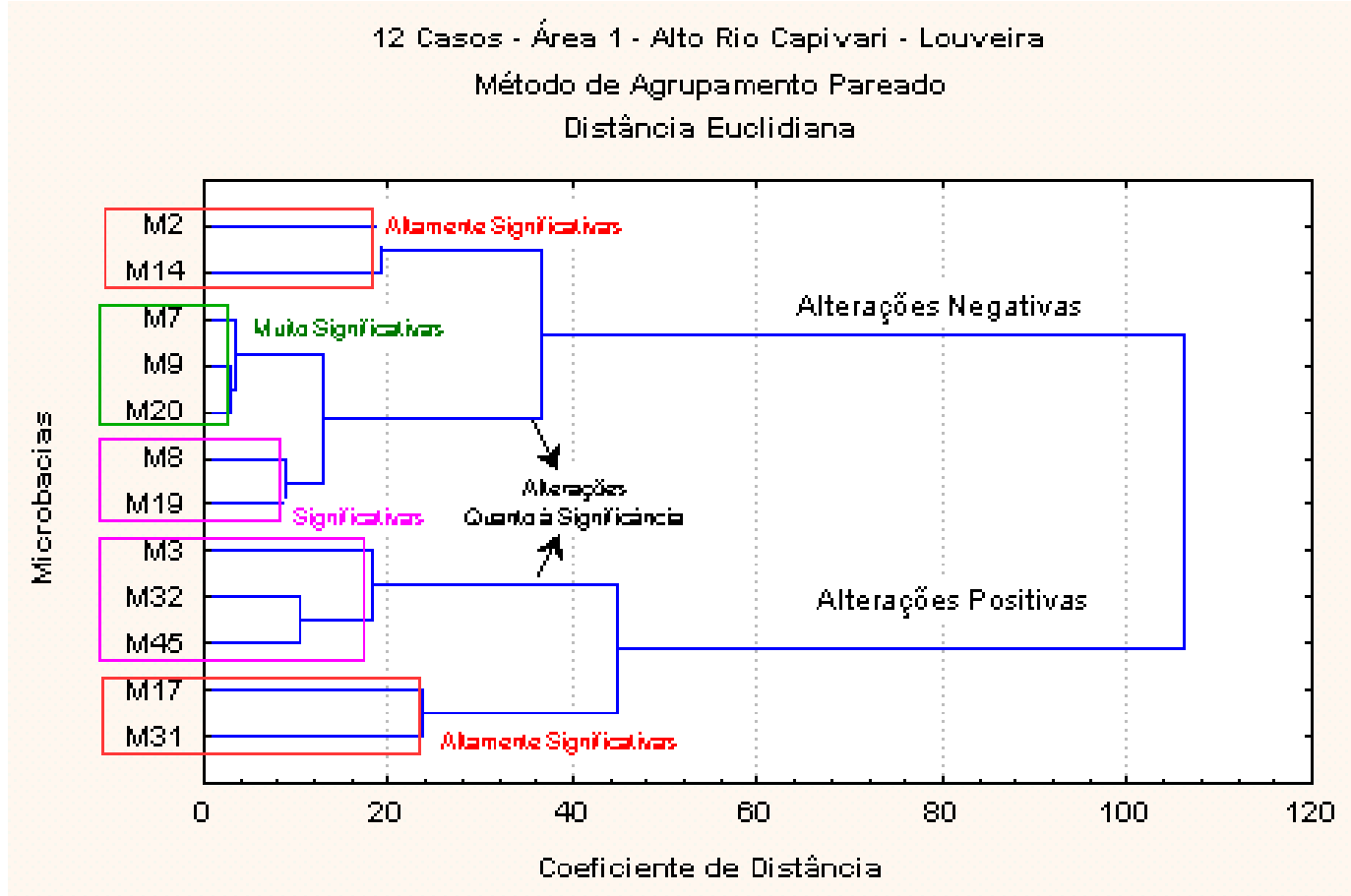

Figura 7.17 - Dendrograma dos dados de taxas de variações maiores que 10\% de densidade de drenagem e densidade hidrográfica entre 1972 e 1995

Taxa de Variação de Dd x Taxa de Variação de Dh

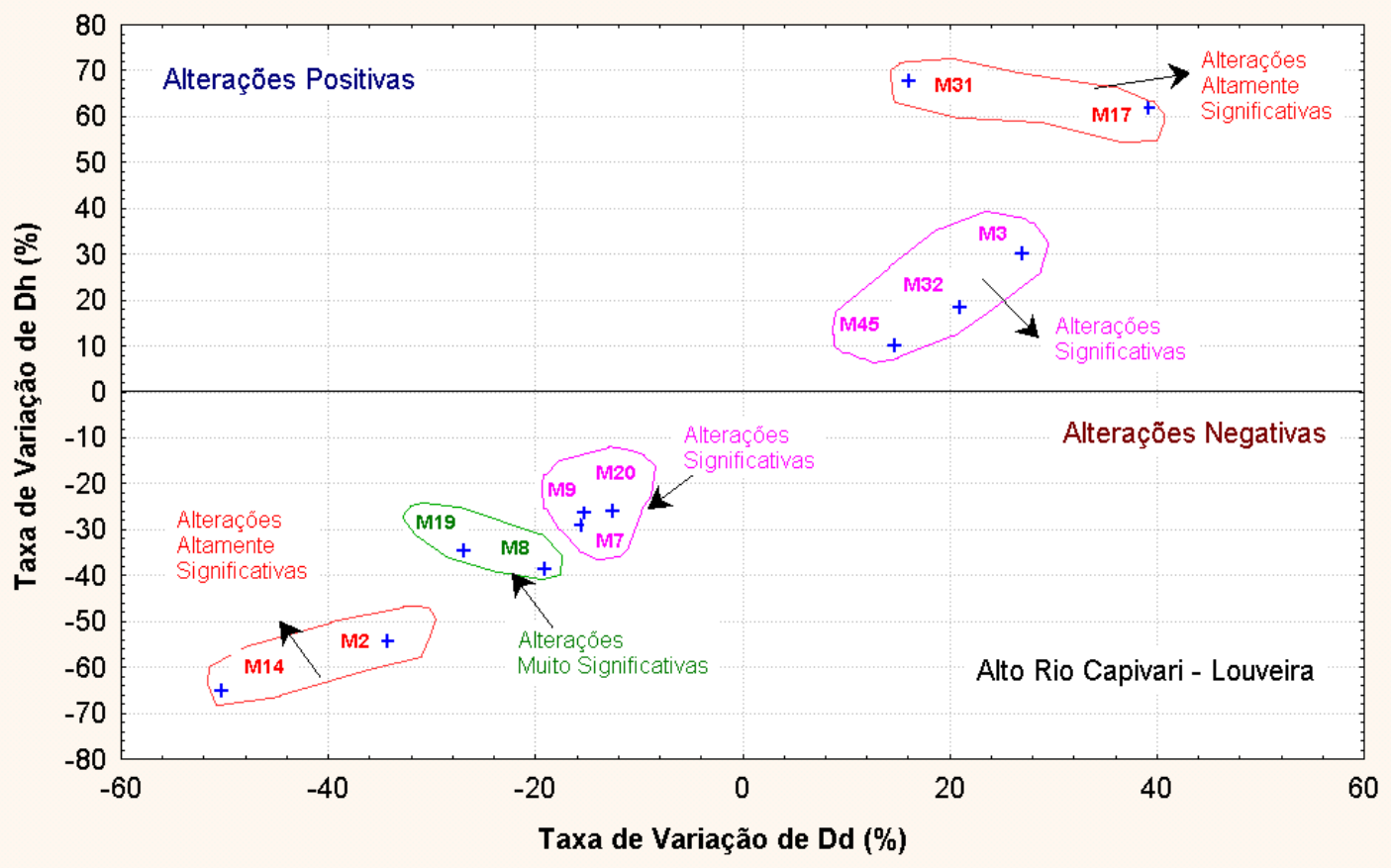

Figura 7.18 - Relação entre a Taxa de Variação de Densidade de Drenagem e Densidade Hidrográfica (\%) para as microbacias da Área 1 (Alto Rio Capivari) 
Os dados obtidos para a taxa de variação dos índices densidade de drenagem e densidade hidrográfica foram plotados no software Curve Expert 1.3, com o objetivo de verificar possível correlação entre os dados, de forma que fosse possível expressá-la por meio de uma equação. Deve ficar claro que a obtenção dessa expressão matemática só deve ser aplicada à área de estudo.

O gráfico ilustrado na Figura 7.19, em que o eixo y representa a taxa de variação de densidade hidrográfica e o eixo x, a taxa de variação de densidade de drenagem, mostrou correlação linear entre os dados com valor de $r^{2}$ de 0,84 e desvio padrão de 17,12.

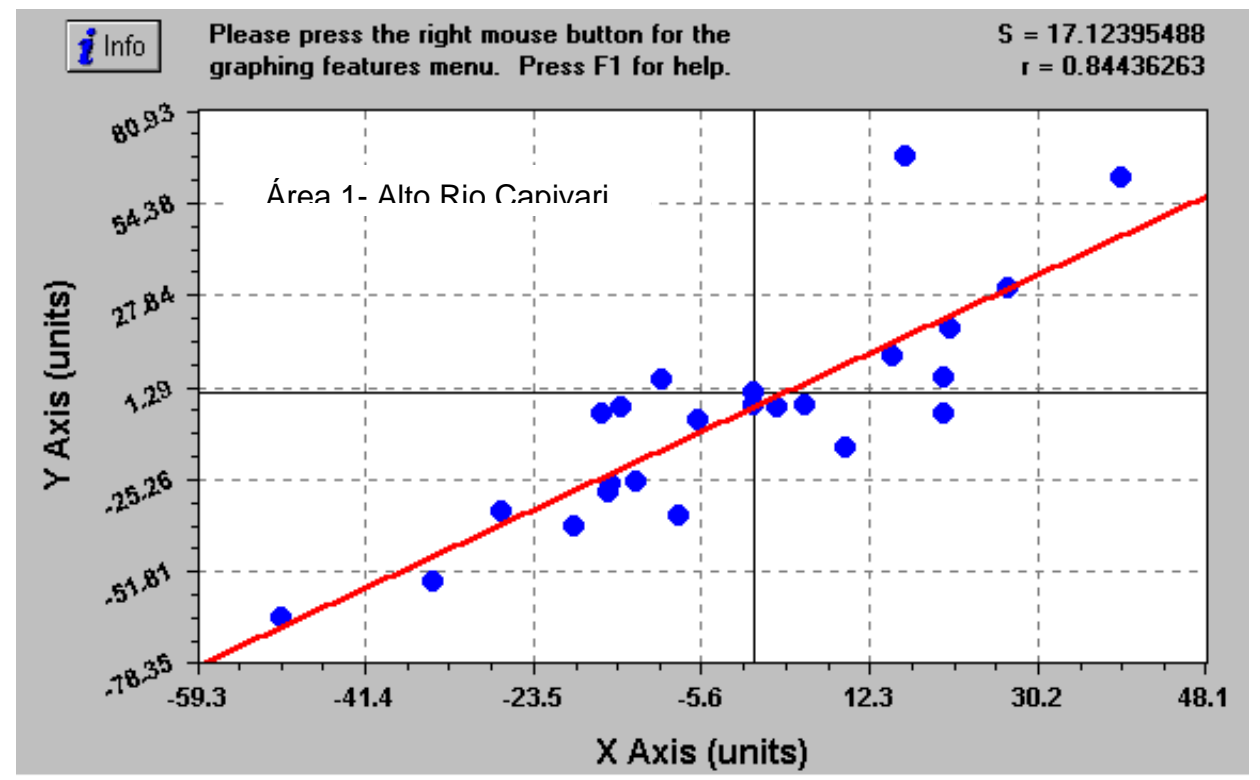

Figura 7.19 - Saída Gráfica do software Curve Expert 1.3 mostrando a relação entre taxa de Variação de Densidade de Drenagem (x) e a taxa de variação de Densidade Hidrográfica (y) para a Área 1 (Alto Rio Capivari)

Este programa permitiu a quantificação dessa relação numa fórmula matemática, como mostra a Figura 7.20, a qual sendo substituída pelos termos adequados pode ser expressa pela equação I:

$$
\Delta D h=-4,3+1,26 \Delta D d
$$




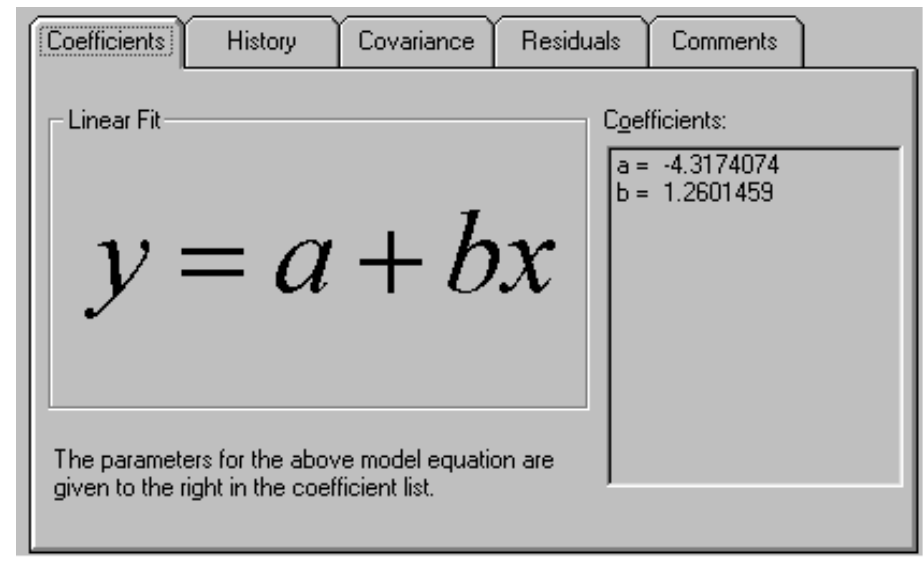

Figura 7.20 - Modelo linear proposto para as taxas de variação dos índices densidade de drenagem (x) e densidade hidrográfica (y) obtido com o uso do software Curve Expert 1.3 para a área do Alto Rio Capivari

Para a avaliação da relação entre a taxa de variação dos índices morfométricos $\mathrm{Rlm}_{2-}$ ${ }_{1}$ e $\mathrm{Rb}_{1-2}$, seguiu-se o mesmo procedimento, com o intuito de definir as microbacias que sofreram alterações internas na hierarquização dos canais e seu comportamento.

As microbacias que apresentaram taxas de variação inferior a $10 \%$, para quaisquer das variáveis $\mathrm{Rlm}_{2-1}$ e $\mathrm{Rb}_{1-2}$, foram desconsideradas na avaliação.

No dendrograma (Figura 7.21) foi possível definir quatro grupos e após plotar os dados no gráfico taxa de variação de razão de bifurcação entre os canais de Ordem 1 e 2 versus taxa de variação de razão entre comprimentos médios de Canais de Ordem 2 e 1 (Figura 7.22), observou-se que essa subdivisão foi baseada em perdas ou ganho expressos em porcentagens para ambas taxas de variação e podem ser descritas como:

- Grupo 1 formado pelas microbacias M1 e M45 apresentaram taxas de variação de Rb $b_{1-2}$ inferiores a $0 \%$ e taxa de variação de $\mathrm{R}_{2-1}$ superior a $0 \%$;

- Grupo 2 formado pelas microbacias M2, M9, M19, M20 e M21 apresentaram taxas de variação de $\mathrm{Rb}_{1-2}$ inferiores a $0 \%$ e taxa de variação de $\mathrm{R} \operatorname{lm}_{2-1}$ inferior a $0 \%$;

- Grupo 3 formado pelas microbacias M16, M23 e M35 apresentaram taxas de variação de $\mathrm{Rb}_{1-2}$ superiores a $0 \%$ e taxa de variação de $\mathrm{Rlm}_{2-1}$ inferior a $0 \%$; e,

- Grupo 4 formado pelas microbacias M13, M31 e M32 apresentaram taxas de variação de $\mathrm{Rb}_{1-2}$ e $\mathrm{Rlm}_{2-1}$ superiores a $0 \%$. 


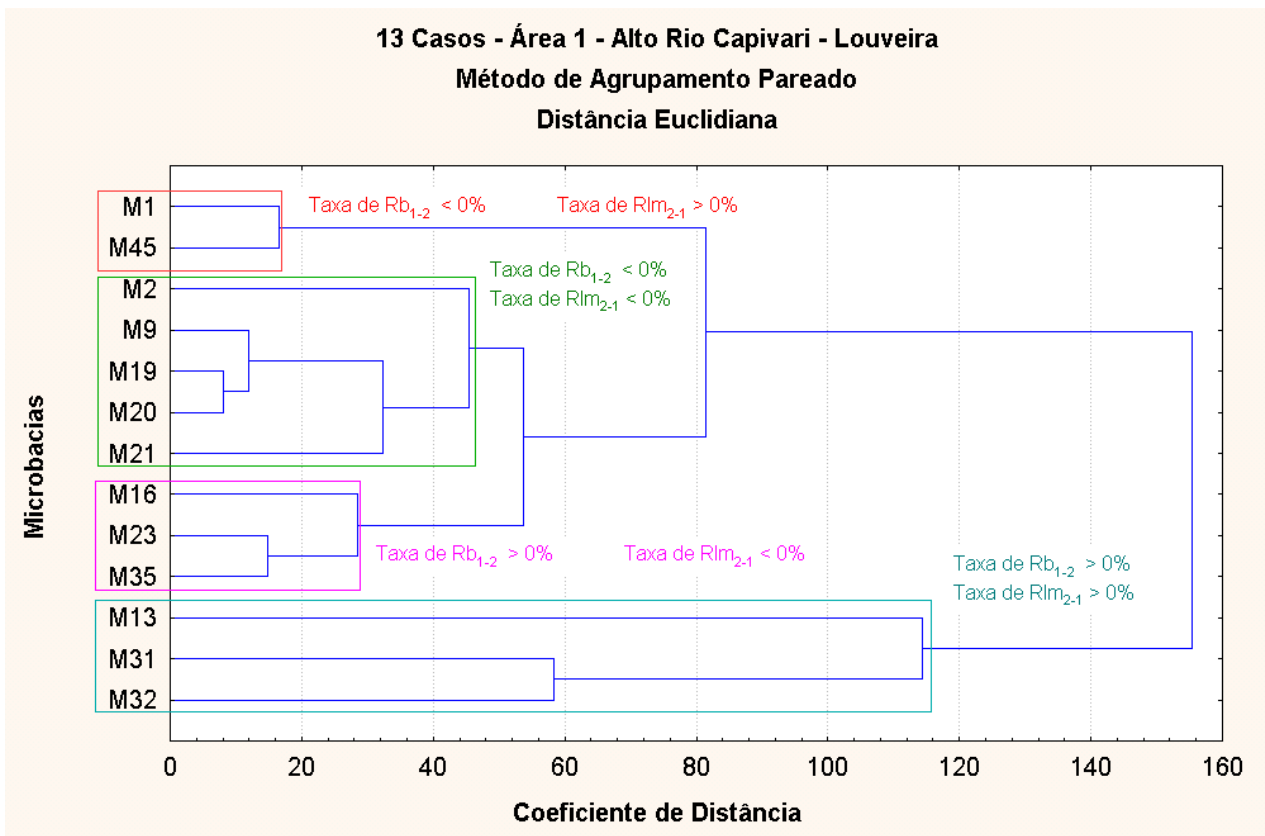

Figura 7.21 - Dendrograma dos dados de taxas de variações maiores que 10\% dos índices $\mathrm{Rlm}_{2-1}$ e $\mathrm{Rb}_{1-2}$ entre 1972 e 1995 para a Área 1

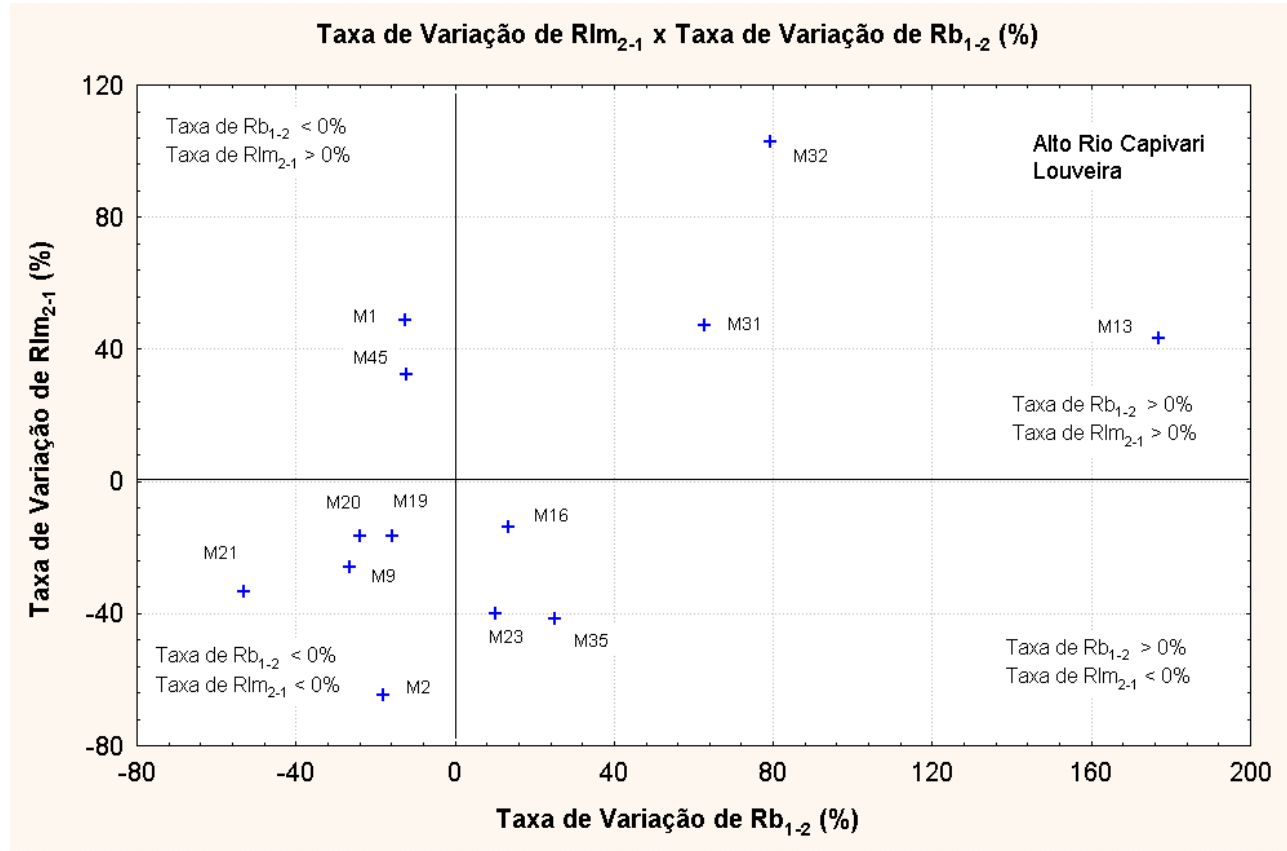

Figura 7.22 - Relação entre a taxa de variação dos índices $\operatorname{Rlm}_{2-1}$ e $\mathrm{Rb}_{1-2}$ entre os anos de 1972 e 1995 para a Área 1

Dentre as 13 microbacias analisadas, as que apresentaram taxas de variações mais elevadas, ou seja, $\mathrm{Rb}_{1-2}>40 \%$ e $\mathrm{Rb}_{1-2}<40 \%$ foram M13, M31, M32 e M21. Em contrapartida, para Rlm 2-1 podemos citar as três primeiras e acrescentar M1, M2, M23 e M35. 
Ao se plotar os dados obtidos nessa relação no Curve Expert 1.3, obteve-se uma fraca correlação linear com valor de $r^{2}$ de 0,49 e desvio padrão de 41,49. Tais dados mostraram que uma quantificação dessa relação levaria a resultados pouco confiáveis.

Um ponto importante a ser destacado foi que dentre as 23 microbacias, apenas M18, M44 e M46 não sofreram alterações significantes em relação a qualquer uma das taxas de variação dos índices estudados ( $\Delta \mathrm{Dd}, \Delta \mathrm{Dh}, \Delta \mathrm{Rlm}_{2-1}$ e $\left.\Delta \mathrm{Rb}_{1-2}\right)$.

\subsection{5 - Análise da Influência dos Dados Morfométricos Obtidos para 1972 Quanto à Taxa de Variação}

A relação entre o índice Dd referente a 1972 e a taxa de variação da densidade de drenagem (Figura 7.23) mostrou que a maioria das microbacias concentrou-se entre os intervalos $-20 \mathrm{a}+20 \%$ de $\Delta$ Dd.

As microbacias com alterações com perdas superiores a 20\% foram M2, M24, M14 e M19 e apresentaram valores de Dd acima do valor médio, já M3, M17, M32 e M35, apresentaram ganhos em suas porcentagens acima de $20 \%$ e concentraram-se abaixo do valor médio de Dd, com exceção de M24.

O gráfico taxa de variação de densidade hidrográfica versus densidade hidrográfica (Figura 7.24), mostrou que as alterações mais significativas aconteceram nas microbacias (M7, M8, M9, M14, M17, M19, M20, M31 e M48) com valores de Dh abaixo da média, com exceção de M2 e M3.

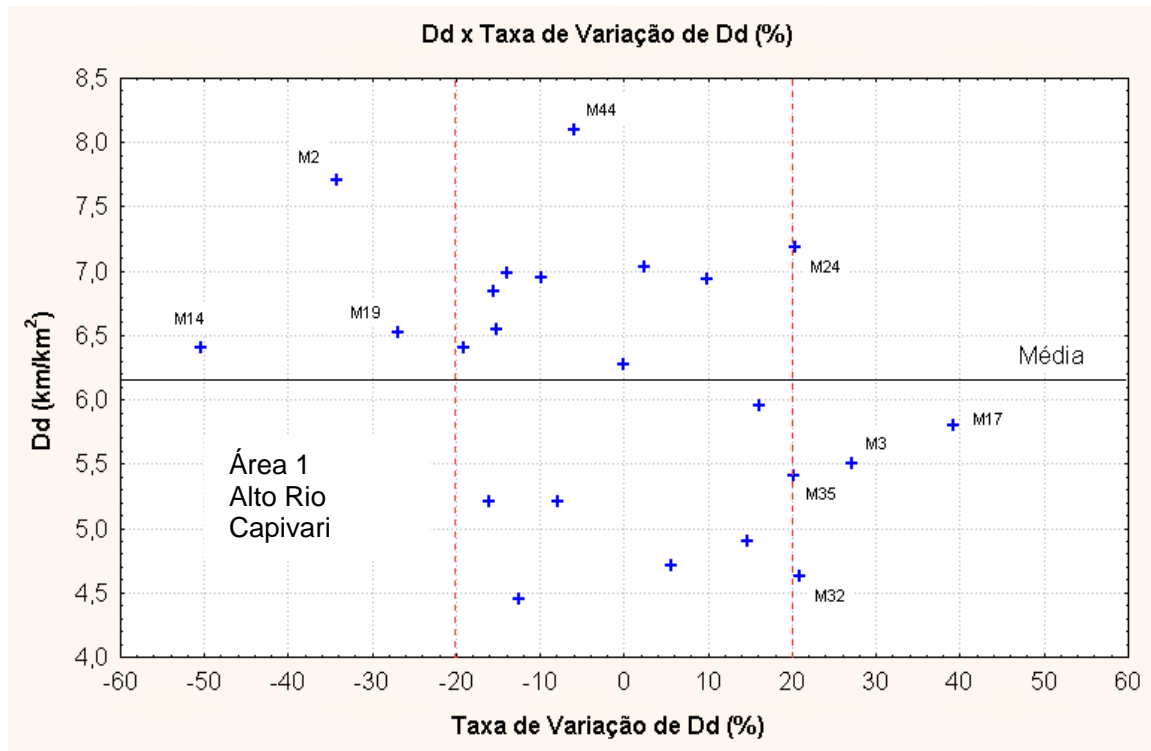

Figura 7.23 - Relação entre a $\Delta \mathrm{Dd}$ e Dd para as microbacias estudadas na área do Alto Rio Capivari 


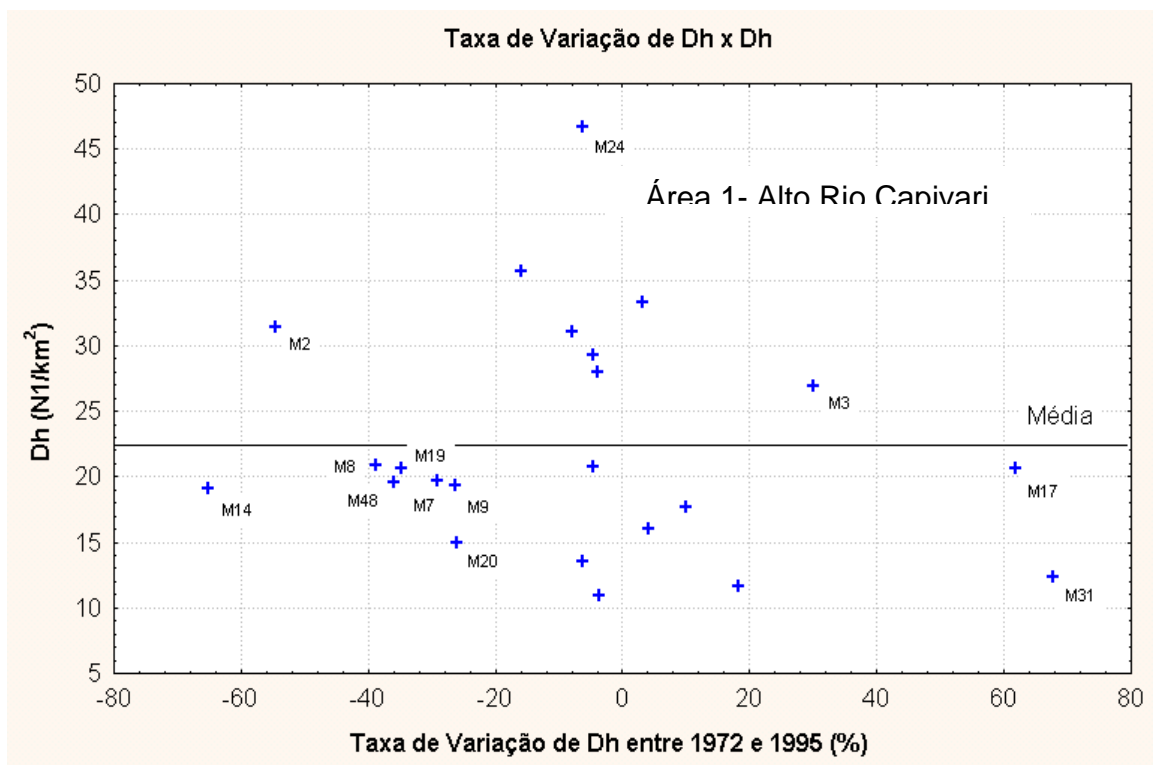

Figura 7.24 - Relação entre a $\Delta \mathrm{Dh}$ e Dh para as microbacias estudadas na área do Alto Rio Capivari

\subsection{6 - Avaliação da Influência do Meio Físico (substrato rochoso, landforms e materiais inconsolidados) na Taxa de Variação dos Índices Morfométricos}

As microbacias da área 1, apresentaram homogeneidade litológica quanto ao seu substrato rochoso devido ao fato de que quase todas serem sustentadas por biotita gnaisses, com exceção de M48, que apresentou pórfiro - gnaisses. Tal característica permitiu eliminar o substrato rochoso como causa provável das modificações na rede de drenagem.

Quanto à influência dos landforms nas alterações foram elaborados gráficos (Figura 7.25) que mostraram as relações entre as unidades de landforms encontradas para a área e as taxa de variação dos índices Dd e Dh.

Como resultado em ambos gráficos, definiu-se que as microbacias anteriormente delimitadas com alterações significantes (M7, M9, M20 e M23), muito significantes (M8 e M19) e altamente significantes (M2, M4 e M31) predominantemente foram associadas aos landforms D e E, com exceção de M3, M17 e M32, que respectivamente foram relacionadas aos landforms B, G e H.

Coube avaliar os resultados obtidos também para as microbacias que sofreram alterações significativas de $\Delta \mathrm{Rlm}_{2-1}$ e $\Delta \mathrm{Rb}_{1-2}$,as quais também foram relacionadas aos landforms D (M1 e M13) e E (M16, M21 e M23).

As microbacias M24, M35 e M48 que se referiram a casos particulares de alterações de Dd ou Dh foram associadas respectivamente aos landforms E, para as duas primeiras 
microbacias, e K para a terceira. Enquanto M18, M44 e M46 que permaneceram quase inalteradas quanto à geometria da rede de drenagem, foram relacionadas, respectivamente, às unidades de landforms G e J.

ALTO RIO CAPIVARI - LOUVEIRA

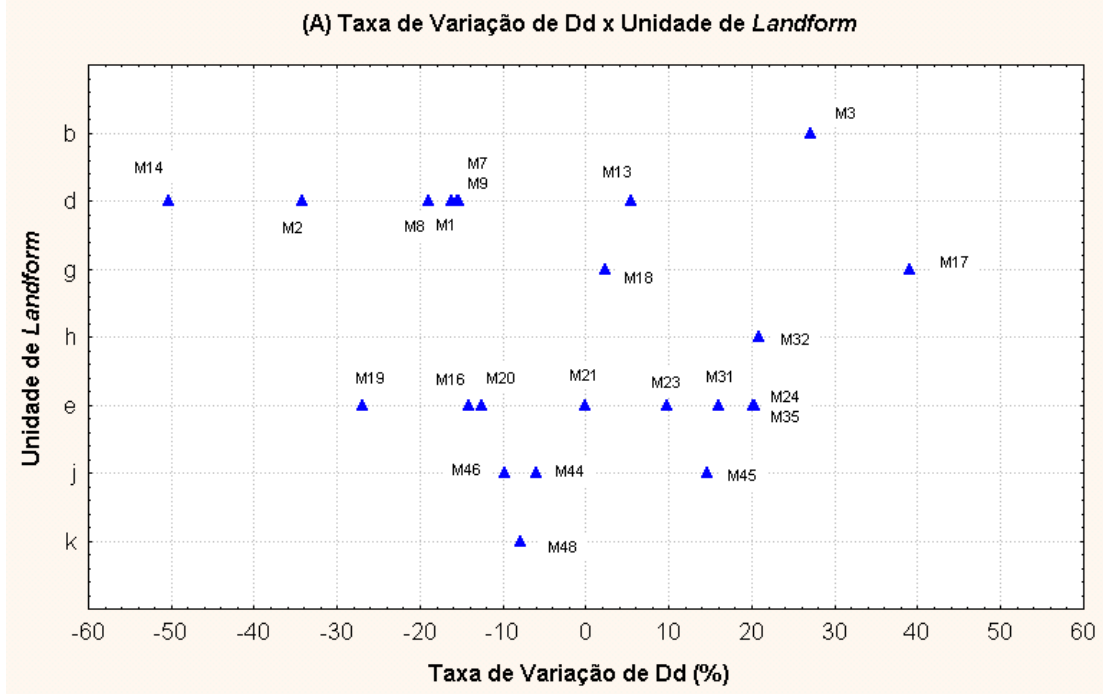

(B) Taxa de Variação de Dh $x$ Unidade de Landform

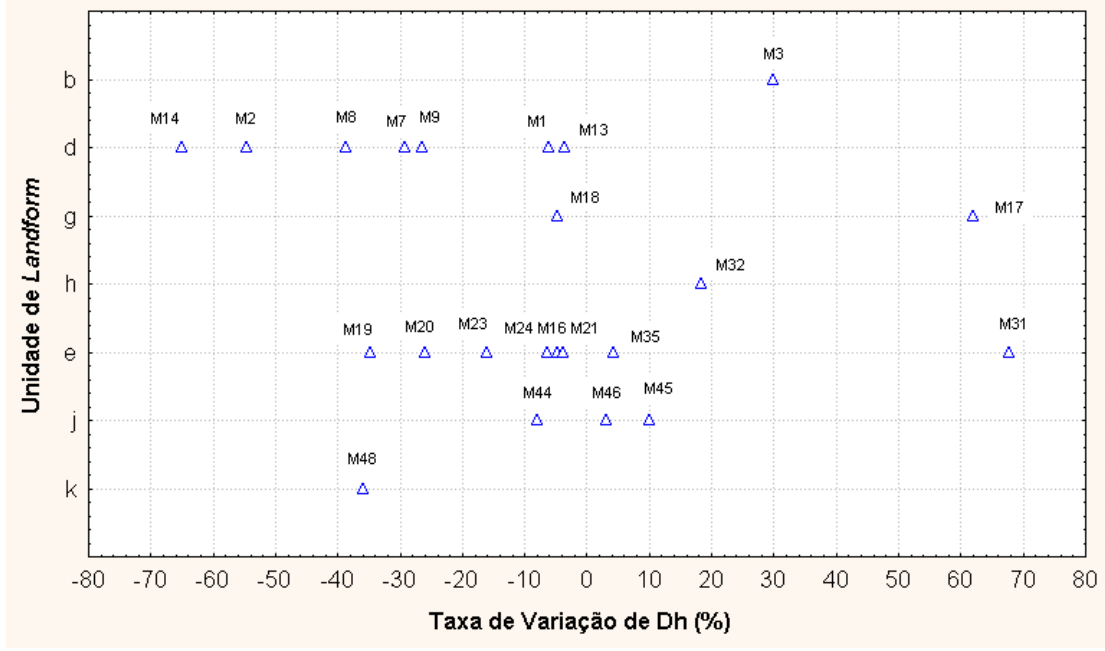

Figura 7.25 - Relação entre a Taxa de Variação de Dd (a) e Dh (b) e as unidades de Landform da Área 1

As relações entre as unidades de materiais inconsolidados e as taxas de variação de Dd e Dh, mostraram que (Figura 7.26):

- As associações entre as unidades I e IV (M1, M2, M7 e M8), I e V (M9, M17, M19) e, II e IV (M3, M20 e M31), foram as que envolveram um maior número de microbacias associadas a alterações maiores que $10 \%$ de Dd e Dh; 
- A microbacia M14, com altas taxas de variação de Dh e Dd, foi relacionada à associação das unidades I, IV e IX; e,

- A microbacia M32, com significativas alterações de Dd e Dh, foi relacionada à associação das unidades II e III.

ALTO RIO CAPIVARI - LOUVEIRA

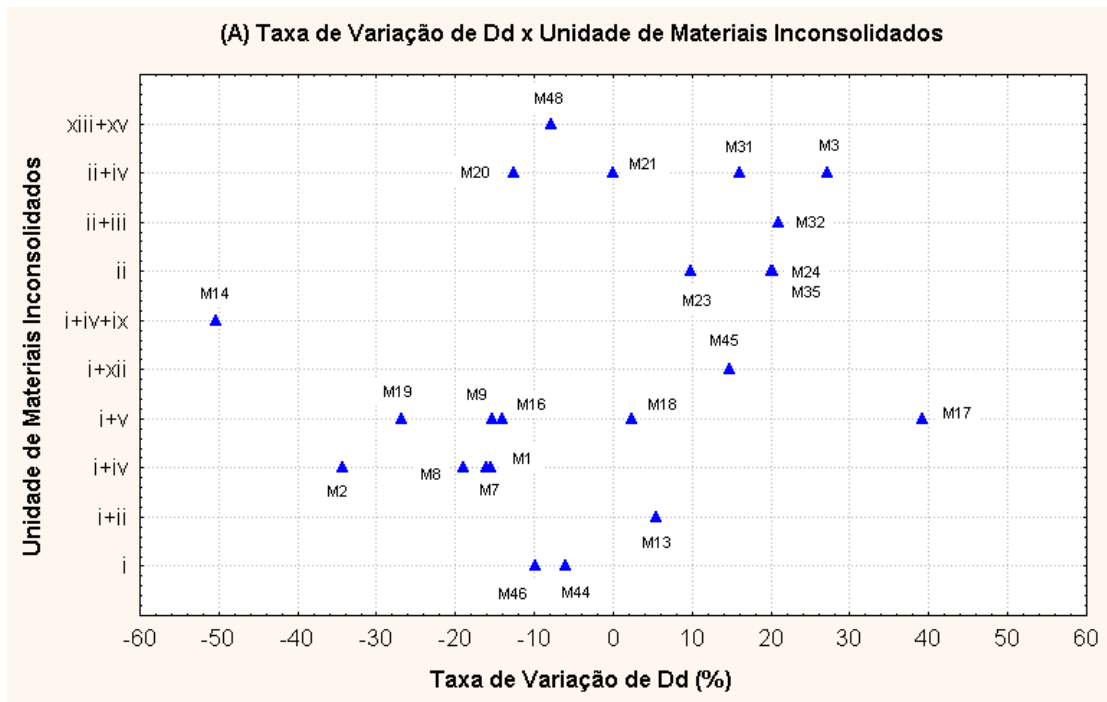

(B) Taxa de Variação de Dh $x$ Unidade de Materiais Inconsolidados

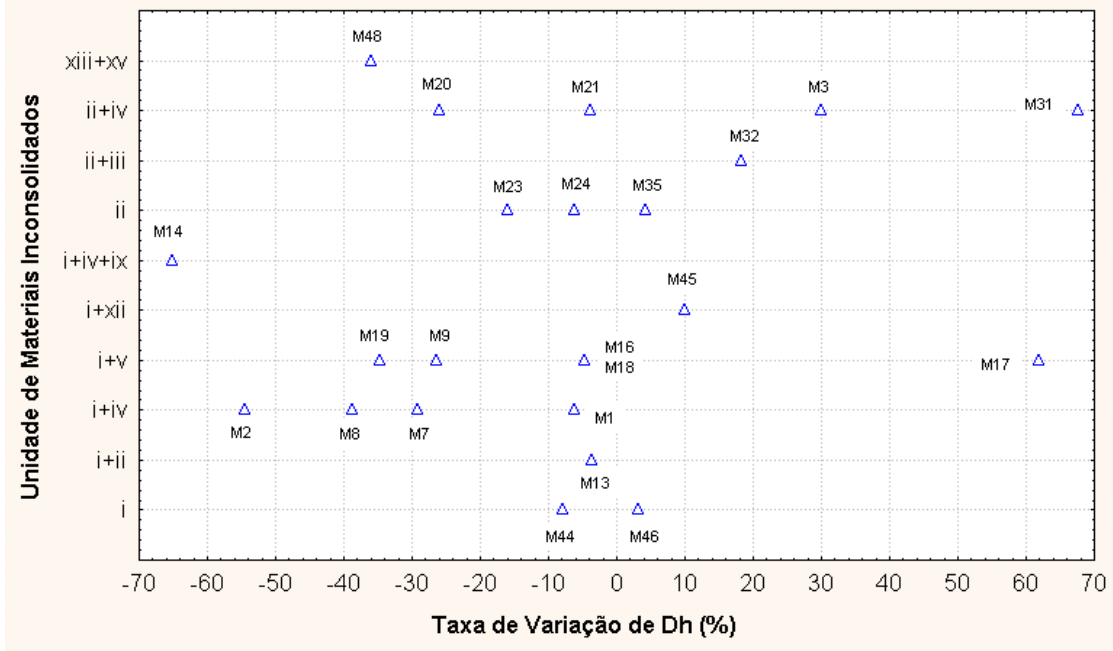

Figura 7.26 - Relação entre a Taxa de Variação de Dd (a) e Dh (b) com as unidades de Materiais Inconsolidados da Área 1

Para as microbacias que registraram alterações significativas dos índices $R \operatorname{lm}_{2-1}$ e $\mathrm{Rb}_{1-2}$ definiram-se as seguintes associações de unidades de materiais inconsolidados: I e II (M13), I e V (M1 e M16), II (M23) e, II e IV (M21). 
A microbacia M48 apresentou-se distinta das demais também em relação à associação de unidades de materiais inconsolidados (XII e XV). Os dois outros casos particulares, M24 e M35 foram relacionadas à unidade II.

Para as microbacias M18, M44 e M46 registrou-se, respectivamente, a associação de unidades de materiais inconsolidados I e V; e I, para as duas últimas.

\subsection{7 - Avaliação da Influência de Características de Uso e Ocupação nas Alterações Temporais}

Antes de relacionar o uso e ocupação às alterações dos principais índices morfométricos, cabe aqui mostrar um quadro generalizado sobre o registro das principais atividades nas microbacias. Quanto ao predomínio da atividade pode-se subdividir as microbacias em duas categorias principais: rural e urbana. Na categoria rural pode-se classificá-las quanto ao predomínio das atividades preponderantes, subdividindo-as em: microbacias com predomínio de áreas de pastagens, microbacias com predomínio de áreas agrícolas, microbacias em que não houve predomínio nem de áreas de pastos e nem de áreas agrícolas e microbacia rural com focos de urbanização (Tabela 7.9).

Tabela 7.9 - Classificação das Microbacias da Área 1 quanto ao uso e ocupação para 1972 e 1995

\begin{tabular}{|c|c|c|c|}
\hline \multirow{2}{*}{ MICROBACIAS } & \multicolumn{2}{|c|}{ ATIVIDADE PREDOMINANTE POR ANO } & \multirow{2}{*}{ CLASSIFICAÇÃO } \\
\hline & 1972 & 1995 & \\
\hline M1 & 1 & 5 & \multirow{4}{*}{$\begin{array}{c}1 \\
\begin{array}{c}\text { Rural com predomínio } \\
\text { de pastagens }\end{array}\end{array}$} \\
\hline M2 & 1 & 4 & \\
\hline M3 & 2 & 2 & \\
\hline M7 & 2 & 4 & \\
\hline M8 & 2 & 4 & \multirow{4}{*}{$\begin{array}{c}2 \\
\text { Rural com predomínio } \\
\text { de áreas agrícolas }\end{array}$} \\
\hline M9 & 2 & 4 & \\
\hline M13 & 4 & 4 & \\
\hline M14 & 4 & 4 & \\
\hline M16 & 1 & 3 & \multirow{4}{*}{$\begin{array}{c}3 \\
\text { Rural sem predomínio } \\
\text { de atividades }\end{array}$} \\
\hline M17 & 1 & 3 & \\
\hline M18 & 1 & 1 & \\
\hline M19 & 1 & 1 & \\
\hline M20 & 2 & 4 & \multirow{5}{*}{$\begin{array}{c}4 \\
\text { Rural com focos de } \\
\text { Urbanização }\end{array}$} \\
\hline M21 & 3 & 4 & \\
\hline M23 & 2 & 1 & \\
\hline M24 & 1 & 1 & \\
\hline M31 & 3 & 1 & \\
\hline M32 & 2 & 1 & \multirow{6}{*}{$\begin{array}{c}5 \\
\text { Urbana }\end{array}$} \\
\hline M35 & 1 & 1 & \\
\hline M44 & 1 & 1 & \\
\hline M45 & 1 & 1 & \\
\hline M46 & 1 & 1 & \\
\hline M48 & 1 & 1 & \\
\hline
\end{tabular}


A Figura 7.27 mostra a taxa de variação para as principais classes de uso e ocupação: Mata/Reflorestamento (M), Hortifruti (H), Pasto/Mata Capoeira (P) e Desenvolvimento Urbano (DU); esta última referiu-se às áreas de crescimento urbano de baixa e média urbanização e áreas industriais. As taxas de variação das classes represa e explotação de material de construção também foram registradas em algumas microbacias, mas não ultrapassam 5\% na maioria delas. Cabe destacar a exceção em M2, que apresentou redução das áreas de explotação de material de construção de 75 \% em substituição por áreas de pastagens.

Taxa de Variação das Classes de Uso e Ocupação (1972-1995)

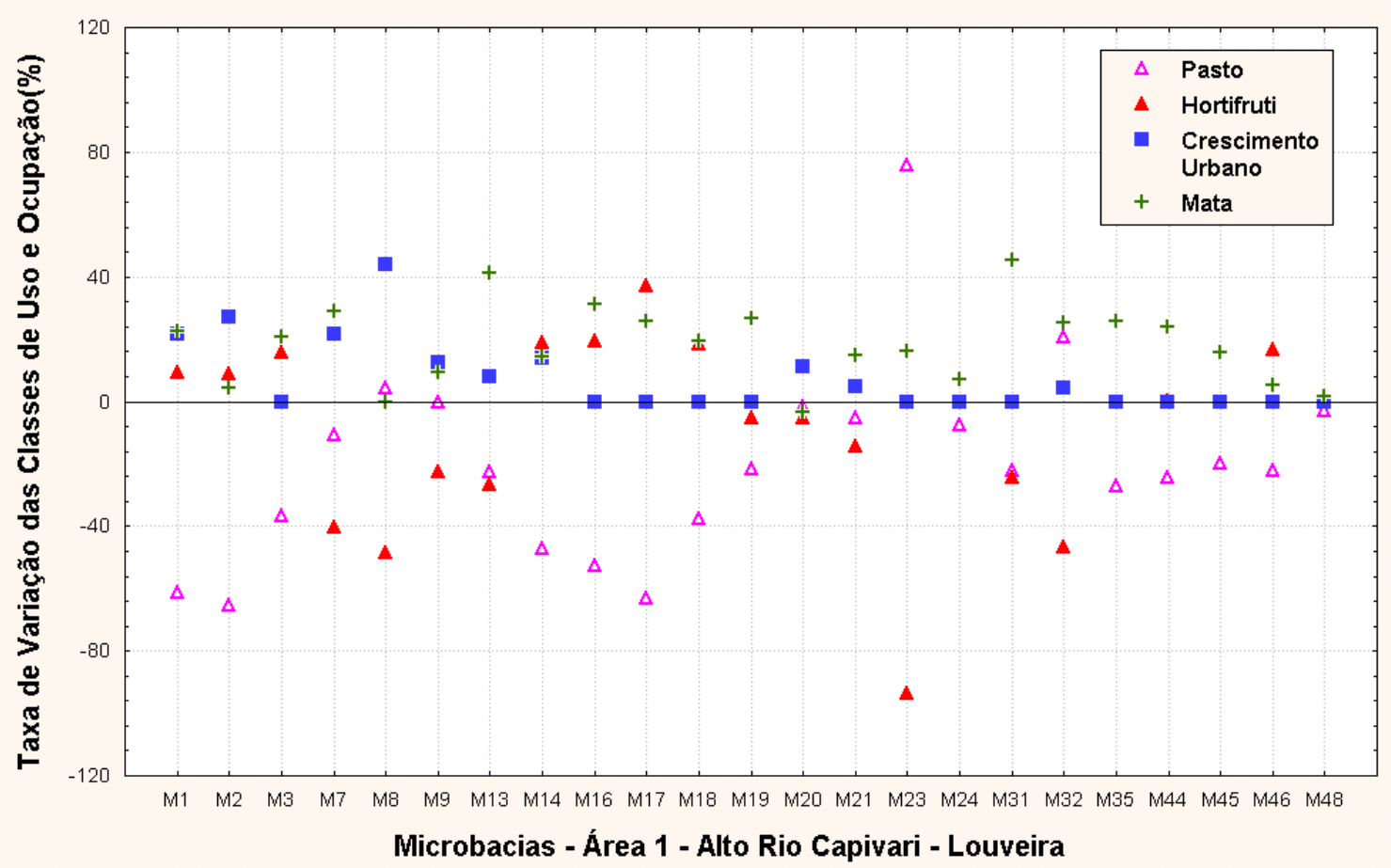

Figura 7.27 - Taxa de variação das principais classes de uso e ocupação na área do Alto Rio Capivari

Constatou-se no período avaliado, para as principais classes de atividades:

- Quase todas as microbacias apresentaram redução em suas áreas de pastagens, com exceção de M8, M23 e M32 que apresentaram crescimento nas áreas de pastagens respectivos de 4 , 76 e $21 \%$;

- Que as perdas mais acentuadas de áreas agrícolas ocorreram nas microbacias M7, M8, M9, M13, M21, M23, M31 e M32 e variaram de 14 a 93\%;

- Quase todas as microbacias apresentaram crescimento na classe mata/reflorestamento; 
- Que a taxa de crescimento urbano foi mais acentuada em M8 (44\%) e nas demais microbacias que sofreram crescimento urbano (M1, M2, M7, M9, M14, M20, M21 e M32) estas taxas variaram entre 4 a $27 \%$; e,

- Que M48 não sofreu modificações expressivas nas áreas das respectivas classes de uso e ocupação no período analisado.

Na análise da influência dessas mudanças sobre as alterações observadas na geometria da rede de drenagem foram feitas correlações entre as taxas de variação dos principais índices morfométricos estudados ( $\mathrm{Dd}$ e $\mathrm{Dh}$ ) e as porcentagens das atividades antrópicas predominantes no ano de 1995 e as taxas de variação das áreas de pastos, agrícolas e urbanas.

Na primeira análise utilizaram-se apenas as microbacias urbanas e rurais com focos de urbanização. Nesse caso consideraram-se as porcentagens referentes às atividades urbanas (áreas industriais, áreas com baixa e média urbanização) e às atividades rurais (áreas destinadas a pastagens e cultivo agrícola) exercidas nas áreas das microbacias (Figura 7.28). Os resultados mostraram que:

- M2 e M14, consideradas com alterações altamente significativas de Dh e Dd, apresentaram 30 a 40\% de suas áreas urbanizadas, em 1995;

- M9 e M20, microbacias com alterações significativas de Dh e Dd, apresentaram 10 a 20\% de áreas urbanizadas;

- M7 e M8, respectivamente, microbacias com alterações significativas e muito significativas de Dh e Dd, apresentaram 30 a 50\% de Dh; e,

- M1 e M13 com alterações significativas em $\mathrm{Rlm}_{2-1}$ e $\mathrm{Rb}_{1-2}$, apresentaram áreas urbanizadas em torno de $60 \%$ e $30 \%$, respectivamente.

No segundo caso foram utilizadas apenas as microbacias estritamente rurais como objeto de análise, consideraram-se as porcentagens de áreas de pastos (P) e áreas agrícolas (A).

Para a taxa de densidade de drenagem definiram-se os seguintes comportamentos quanto às áreas destinadas a pastagens (P) (Figura 7.29a):

- Microbacias com $\Delta \mathrm{Dd}>-10 \%$, M19 (100\% de P) e M16 (60\% de P); e,

- Microbacias com $\Delta \mathrm{Dd}>10 \%$, M24 e M35 (100\% de P), M31 e M32 (60\% de P), M17 (50\% de P) e M3 (0\% de P).

Dentre as microbacias analisadas observaram-se os seguintes comportamentos para a taxa de densidade hidrográfica (Figura 7.29b):

- $\Delta \mathrm{Dh}>-20 \%$ em áreas de pastagens superiores a 90\% (M19, M23 e M48);

- $\Delta \mathrm{Dh}>10 \%$ em áreas de pastagens entre 60 a 70\% (M31 e M32); 
- $\Delta \mathrm{Dh}>10 \%$ em áreas de pastagens com 50\% (M17); e,

- $\Delta \mathrm{Dh}>10 \%$ em áreas agrícolas (M3).

As microbacias M18, M44 e M46 que não sofreram modificações expressivas nos seus índices morfométricos foram consideradas rurais com predomínio de pastagens durante o período analisado. Em 1995, registraram-se porcentagens entre 77 a 99\% de áreas de pastagens nessas microbacias.

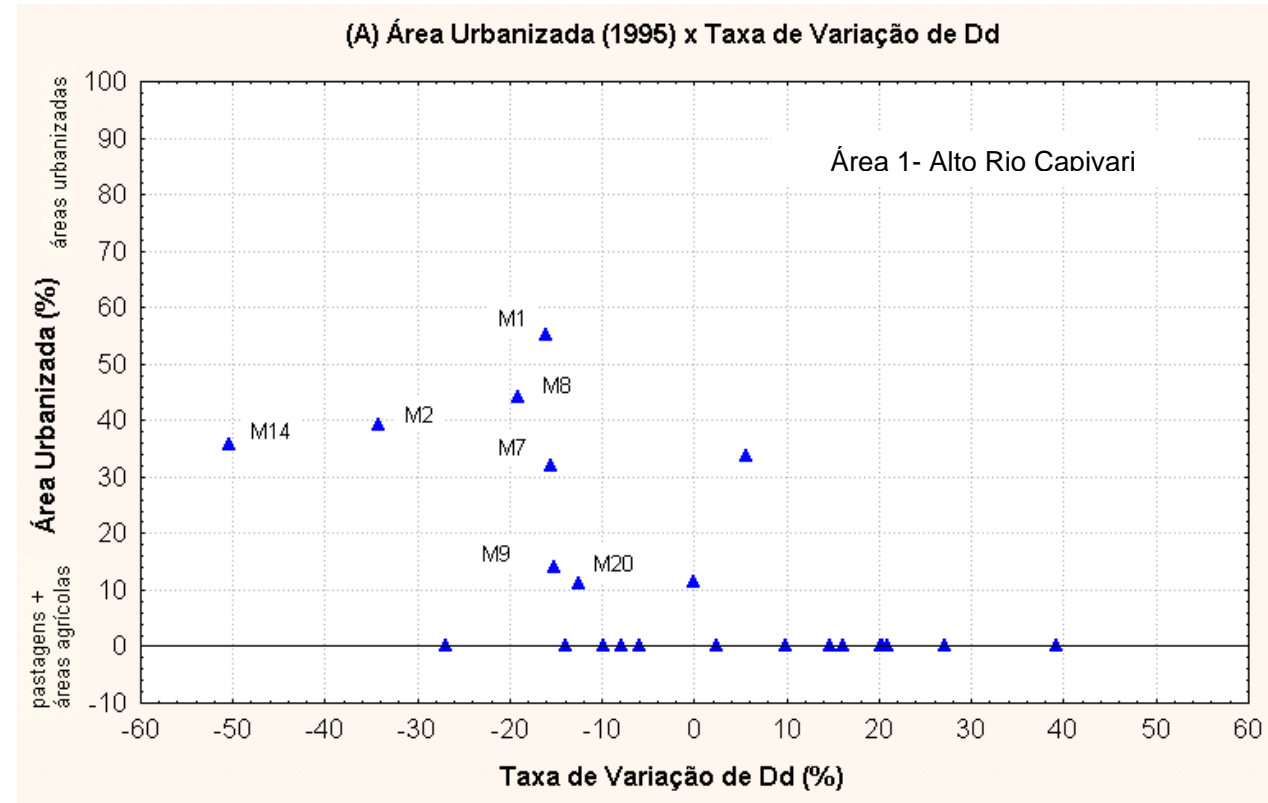

(B) Área Urbanizada (1995) x Taxa de Variação de Dh

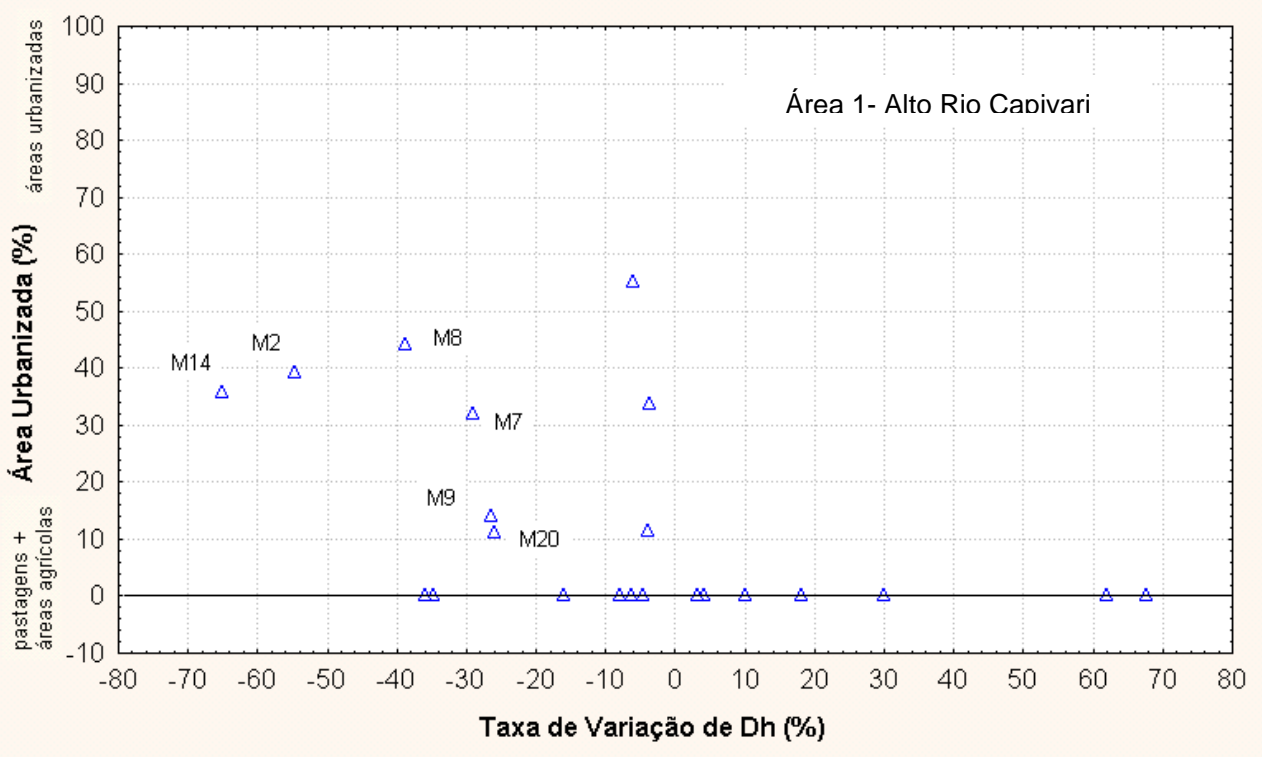

Figura 7.28 - Relação entre as taxas de variação de Dd (a) e Dh (b) com as porcentagens de áreas urbanizadas 
(A) Áreas de Pastagens (1995) x Taxa de Variação de Dd

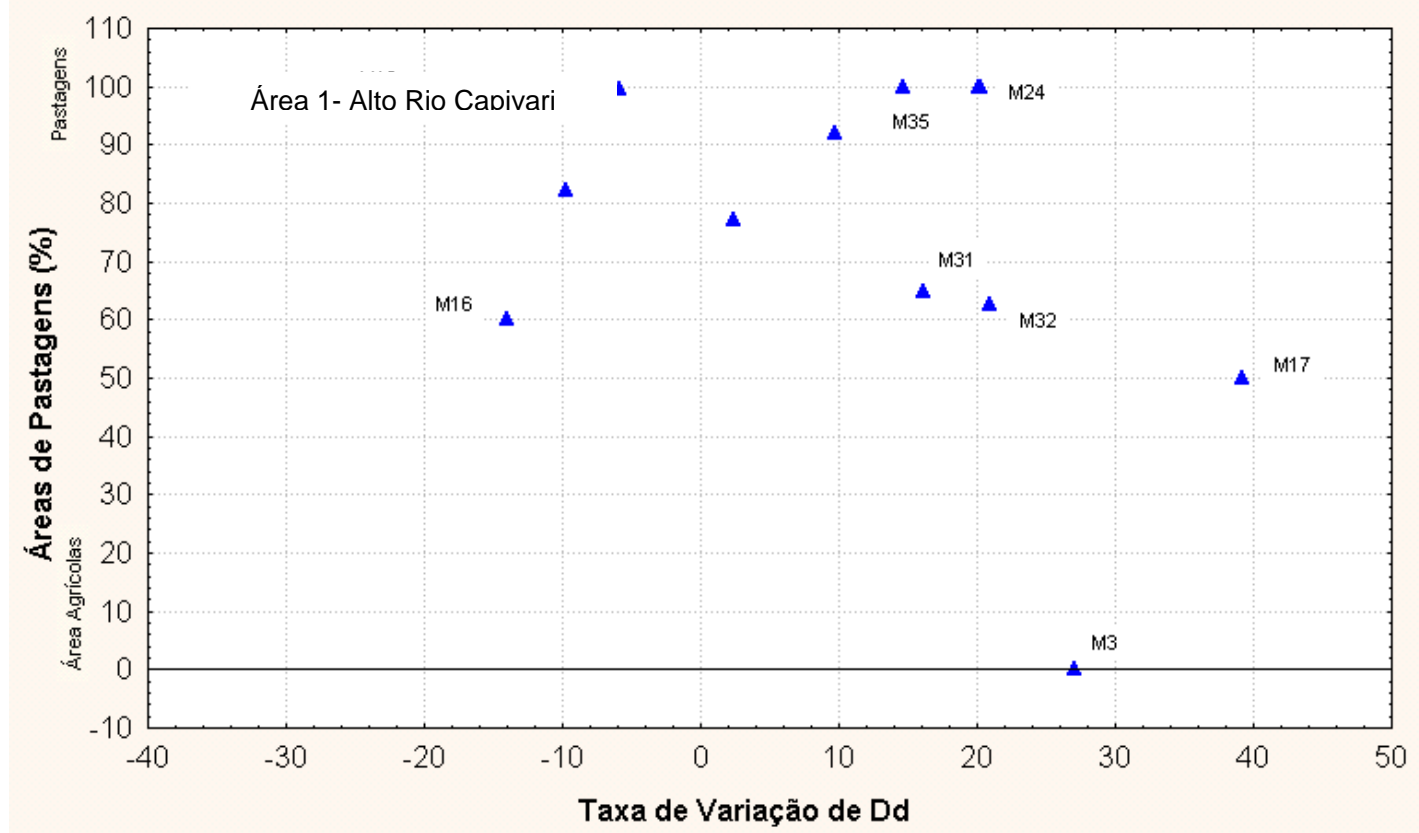

(B) Áreas de Pastagens (1995) x Taxa de Variação de Dh

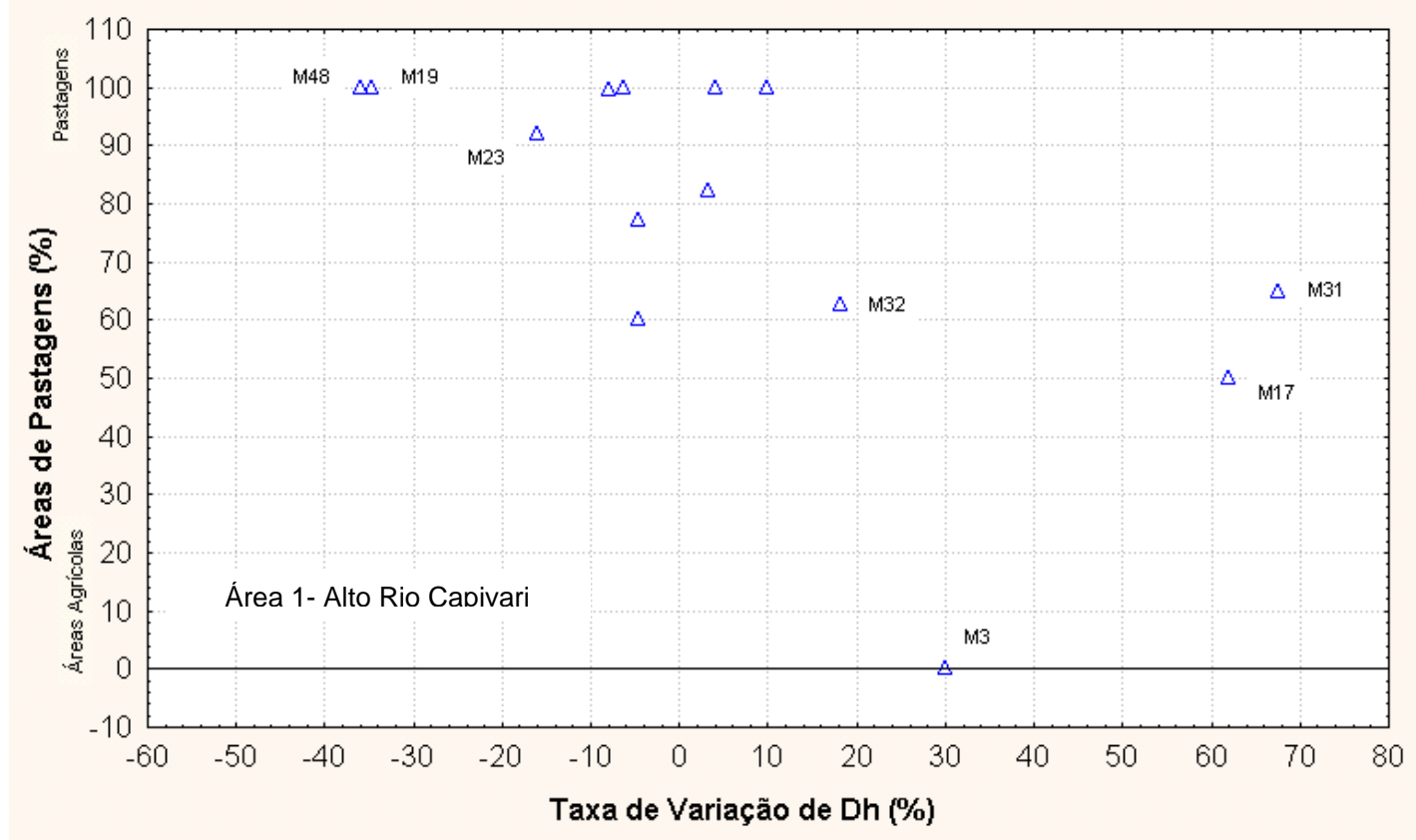

Figura 7.29 - Relação entre as taxas de variação de Dd (a) e Dh (b) com as porcentagens das áreas de pastagens da Área 1

Dentre as microbacias analisadas quanto à significância de suas alterações, no item 7.3.4, M2, M7, M8, M9, M14 e M20 foram consideradas urbanas, M3 e M17, rurais estritamente agrícolas e M19, M31 e M32, rurais com predomínio de pastagens. 
Para as microbacias a seguir descritas, pode-se estabelecer a taxa de variação de áreas de pasto, áreas agrícolas e áreas de crescimento urbano, que foram relacionadas quanto à significância das alterações em função das porcentagens da taxa de variação da densidade hidrográfica e densidade de drenagem (Figura 2.27):

- M2 e M14, caracterizadas por alterações altamente significantes de $\Delta$ Dd e $\Delta$ Dh, apresentaram redução de 40 a 60 \% de suas áreas de pastagens e crescimento urbano expressivo de 10 a 30\%;

- M17 e M31, caracterizadas por alterações altamente significantes de $\Delta \mathrm{Dd}$ e $\Delta \mathrm{Dh}$, apresentaram expansão de suas áreas agrícolas, em substituição das áreas de pasto e nenhum crescimento urbano;

- M8, considerada com alteração muito significante de $\Delta \mathrm{Dh}$ e $\Delta \mathrm{Dd}$, apresentou um crescimento urbano acentuado de 40 \% e consecutiva redução de suas áreas agrícolas em $50 \%$,

- M19, considerada com alteração muito significante de $\Delta \mathrm{Dh}$ e $\Delta \mathrm{Dd}$, caracterizou-se por crescimento urbano nulo e redução das áreas agrícolas e pastagens em substituição do replantio de árvores;

- M7, M9 e M20 caracterizaram-se por alterações significantes de $\Delta$ Dh e $\Delta$ Dd e apresentaram diminuição de suas áreas agrícolas entre 5 a 40\% e crescimento urbano expressivo entre 10 a $30 \%$.

- M3, M32 e M45 apresentaram alterações significantes de $\Delta \mathrm{Dh}$ e $\Delta \mathrm{Dd}$ e foram caracterizadas, respectivamente, por redução das áreas de pastagens (30\%); por redução das áreas agrícolas (40\%) e crescimento urbano restrito a pequenas áreas (10\%); e por perdas de áreas agrícolas (20\%).

$\mathrm{Na}$ análise foram consideradas, conjuntamente, as microbacias que apresentaram modificações em relação a $\mathrm{Rlm}_{2-1}$ e $\mathrm{Rb}_{1-2}$ e pode-se definir que:

- M1 apresentou redução em suas áreas de pasto e um crescimento urbano acentuado;

- M13 apresentou crescimento urbano superior a 30\% e, consequentemente, redução de suas áreas agrícolas e de pastagens;

- M16, M23 e M35 sofreram perdas de áreas agrícolas e, particularmente, em M23 a modificação das áreas agrícolas foi em função do crescimento de áreas de pastagens; e,

- M21 caracterizou-se por perdas de áreas agrícolas e crescimento urbano expressivo. 
ALTO RIO CAPIVARI - LOUVEIRA

Taxa de Variação de Dh $\times$ Taxa de Variação de Áreas de Pasto
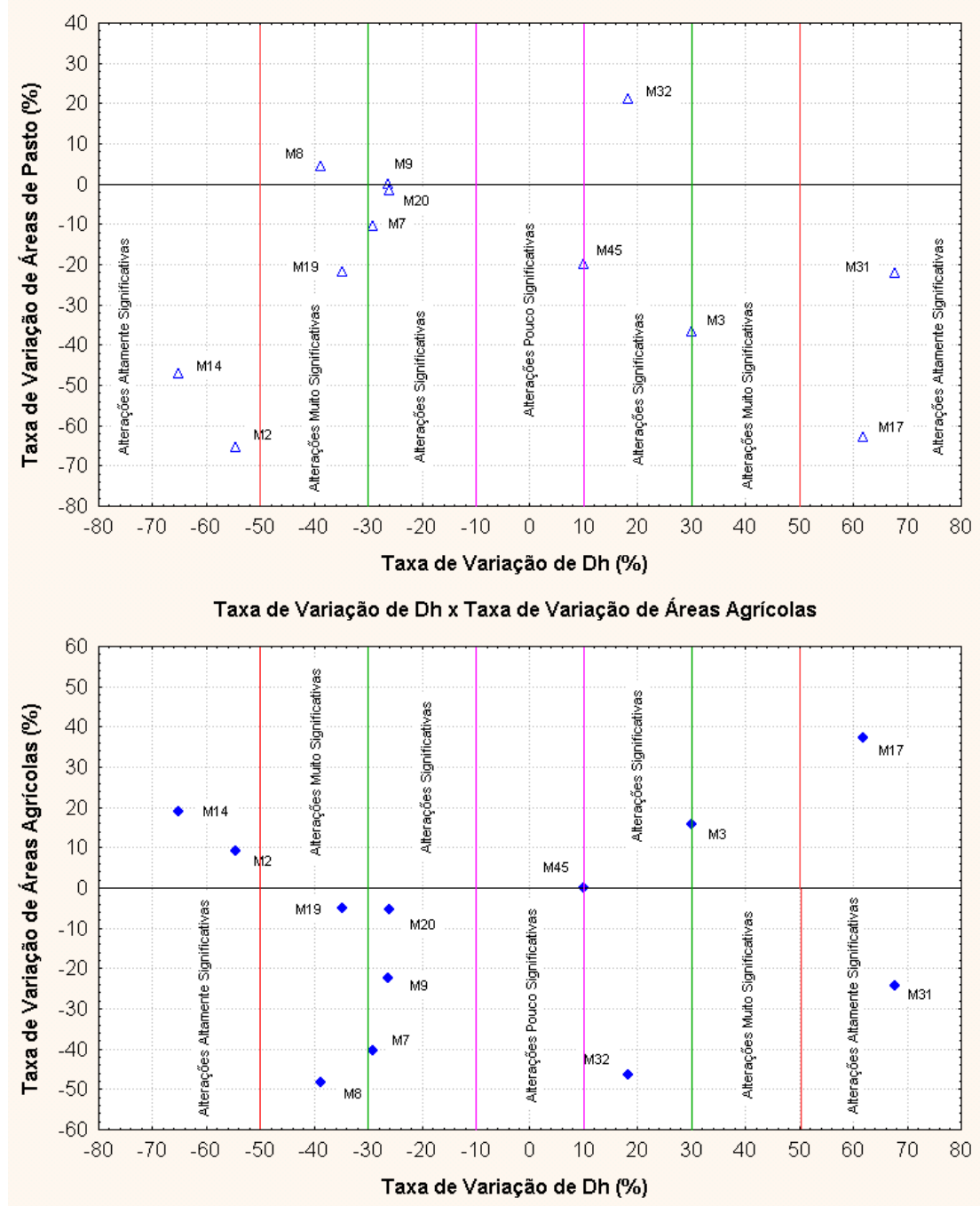

Taxa de Variação de Dh x Taxa de Variação de Crescimento Urbano

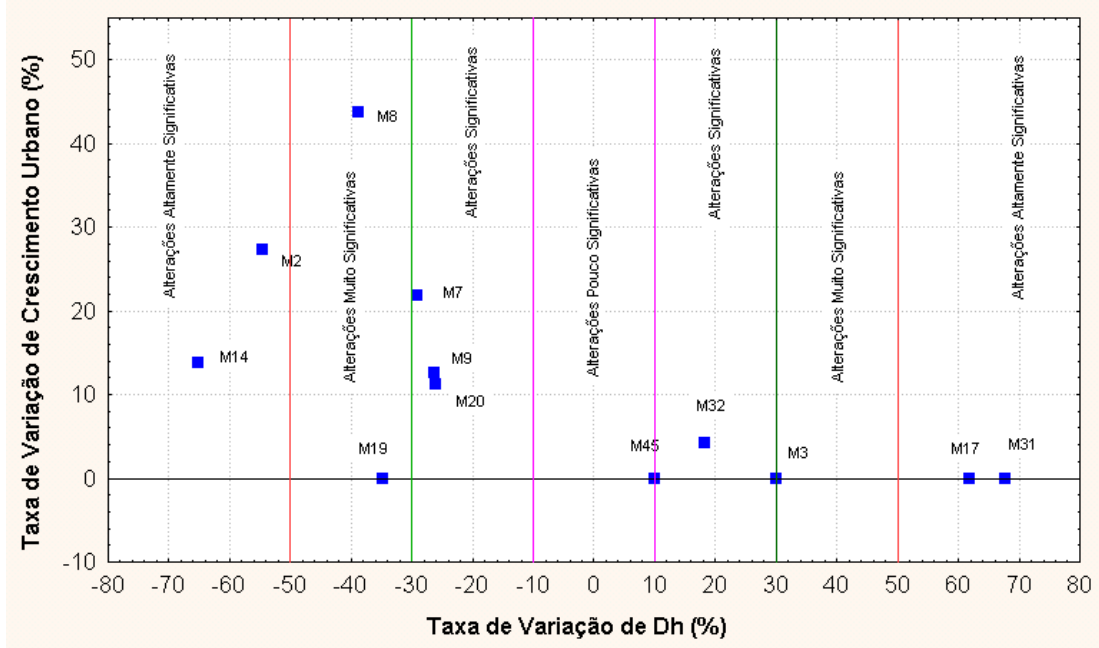

Figura 7.30 - Relação entre as taxas de variação de Dh com as taxas de variação das áreas de pasto, agrícolas e de crescimento urbano 


\subsection{8 - Considerações Parciais - Microbacias da Área 1}

\subsubsection{1 - Quanto às Características Morfométricas da Área 1}

Para os dados obtidos dos índices morfométricos que caracterizaram as microbacias da Área 1 no período inicial de análise, pode-se destacar que:

- Os valores de índices de forma apresentaram valor médio de 1,22 e desvio padrão de 0,11 (Figura 7.8);

- Os valores de densidade de drenagem caracterizaram-se por valor médio de 6,15 km/ $\mathrm{km}^{2}$ e desvio padrão de $1,01 \mathrm{~km} / \mathrm{km}^{2}$ (Figura 7.9);

- Os valores de densidade hidrográfica apresentaram valor médio de 22,6 N1/km² e desvio padrão de 8,87 N1/km²(Figura 7.10);

- Os valores de textura topográfica foram caracterizados por valor médio de 12,74 km e desvio padrão de 2,49 km (Figura 7.11);

- Os valores de razão de bifurcação entre os canais de Ordem 2 e 1 foram caracterizados por valor médio de 2,59 e desvio padrão de 1,11 (Figura 7.12); e,

- Os valores de razão entre comprimentos médios dos canais de Ordem 1 e 2 apresentaram valor médio de 2,68 e desvio padrão de 1,47 (Figura 7.13);

- Quanto maior as dimensões das microbacias, menores os valores de Dd e Dh (figuras 7.14 e 7.15); e,

- Os índices Dd e Dh apresentaram leve correlação linear, pois quanto maior a densidade de drenagem maior a densidade hidrográfica e vice-versa (Figura 7.16).

\subsubsection{2- Quanto às Relações obtidas para as Taxas de Variação dos Principais Índices Morfométricos da Área 1}

Para as relações obtidas para as taxas de variação de Dd e Dh foi possível definir quatro grupos de alteração em relação à sua significância em (figuras 7.17 e 7.18):

- Microbacias com alterações pouco significativas ( $<10 \%$ de $\Delta \mathrm{Dh}$ e $<10 \%$ de $\Delta \mathrm{Dd})$ M13, M18, M21, M44 e M46;

- Microbacias com alterações significativas (10 a 30\% de $\Delta \mathrm{Dh}$ e $>10 \%$ de $\Delta \mathrm{Dd}$ ) - M3, M7, M9, M20, M32 e M45;

- Microbacias com alterações muito significativas (30 a $50 \%$ de $\Delta \mathrm{Dh}$ e $>10 \%$ de $\Delta \mathrm{Dd}$ ) M8 e M19; e,

- Microbacias com alterações altamente significativas (> 50\% de $\Delta \mathrm{Dh}$ e $>10 \%$ de $\Delta \mathrm{Dd}$ ) M2, M14, M17 e M3). 
Alguns casos particulares de microbacias, que apesar de não se enquadrarem na classificação anterior, foram analisados: M1, M16, M24 e M35 com $\Delta$ Dd superior a $10 \%$ e $\Delta \mathrm{Dh}$ inferior a $10 \%$; e M23 e M48 com $\Delta \mathrm{Dd}$ inferior a $10 \%$ e $\Delta \mathrm{Dh}$ superior a $10 \%$.

A forte correlação linear entre $\Delta \mathrm{Dd}$ e $\Delta \mathrm{Dh}$ pode ser expressa pela equação I:

$$
\Delta D h=-4,3+1,26 \Delta D d
$$

Essa equação deve ser empregada apenas para a área de estudo.

As relações obtidas para $\Delta R \operatorname{lm}_{2-1}$ e $\Delta \mathrm{Rb}_{1-2}$, também permitiram definir quatro grupos de alteração em função principalmente do déficit ou ganho expresso em porcentagens de ambas taxas de variação em:

- $\Delta \mathrm{Rb}_{1-2}<0 \%$ e $\Delta \mathrm{R} \mathrm{Im}_{2-1}>0 \%$ - M1 e M45;

- $\Delta \mathrm{Rb}_{1-2}<0 \%$ e $\Delta \mathrm{Rlm}_{2-1}<0 \%$ - M2, M9, M19, M20 e M21;

- $\Delta \mathrm{Rb}_{1-2}>0 \%$ e $\Delta \mathrm{Rlm}_{2-1}<0 \%$ - M16, M23 e M35; e,

- $\Delta \mathrm{Rb}_{1-2}>0 \%$ e $\Delta \mathrm{Rlm}_{2-1}>0 \%$ - M13, M31 e M32.

As microbacias M18, M44 e M46, não sofreram alterações significantes na geometria da rede de drenagem.

\subsubsection{3 - Quanto à Influência do Meio Físico da Área 1}

A maioria das microbacias que apresentou alterações significantes quanto a um dos índices estudados foi associada aos landforms D e E (M1, M2, M7, M8, M9, M13, M14, M16, M19, M20, M21, M23, M24, M31 e M35). As associações entre as unidades de materiais inconsolidados I e IV (M1, M2, M7 e M8), I e V (M1, M9, M16, M17, M19) e, II e IV (M3, M20, M21 e M31) foram as que envolveram um maior número de microbacias associadas às alterações das variáveis analisadas, um total de 13. As características dos materiais inconsolidados bem como das unidades de landforms, podem ser dois dos fatores que auxiliaram nos processos de modificação da rede de drenagem.

\subsubsection{4 -Quanto à Influência das Atividades Antrópicas na Área 1}

As modificações na rede de drenagem podem ser conseqüência da substituição das atividades antrópicas desenvolvida no período inicial de análise por outras ao longo dos 23 anos analisados. Registrou-se que as microbacias classificadas como urbanas ou com focos de urbanização (M1, M2, M7, M8, M9, M13, M14, M20 e M21) sofreram alterações significantes de um dos índices analisados e foram caracterizadas pelo crescimento das áreas urbanas, em detrimento das áreas ou de pastagens ou de hortifruti ou ainda de mata nativa. 
Nas microbacias rurais com alterações nítidas das variáveis estudadas foram identificadas mudanças de áreas de hortifruti em função de áreas de pastagens e vice-versa, ao longo do período analisado.

\section{4 - ÁREA 2 - BAIXO RIO CAPIVARI}

\section{$\underline{\text { 7.4.1 - Compartimentação das Microbacias }}$}

O agrupamento das microbacias segundo suas faixas predominantes de dimensões, similarmente à Área 1, permitiu subdividir a área do Baixo Rio Capivari em 4 classes, descritas abaixo (Figura 7.31):

- Classe I: microbacias com áreas inferiores a 0,2 $\mathrm{km}^{2}$ (D28 e D29);

- Classe II: microbacias com áreas entre 0,2 a 0,8 km² (D3, D4, D6, D7, D8, D10, D15, D17,D22, D26 e D27);

- Classe III: microbacias com áreas entre 0,8 a 1,4 km² (D2, D11, D12, D14, D16, D23, D21, D24 e D25 ); e,

- Classe IV: microbacias com áreas acima de 1,4 km² (D5, D9, D18 e D30).

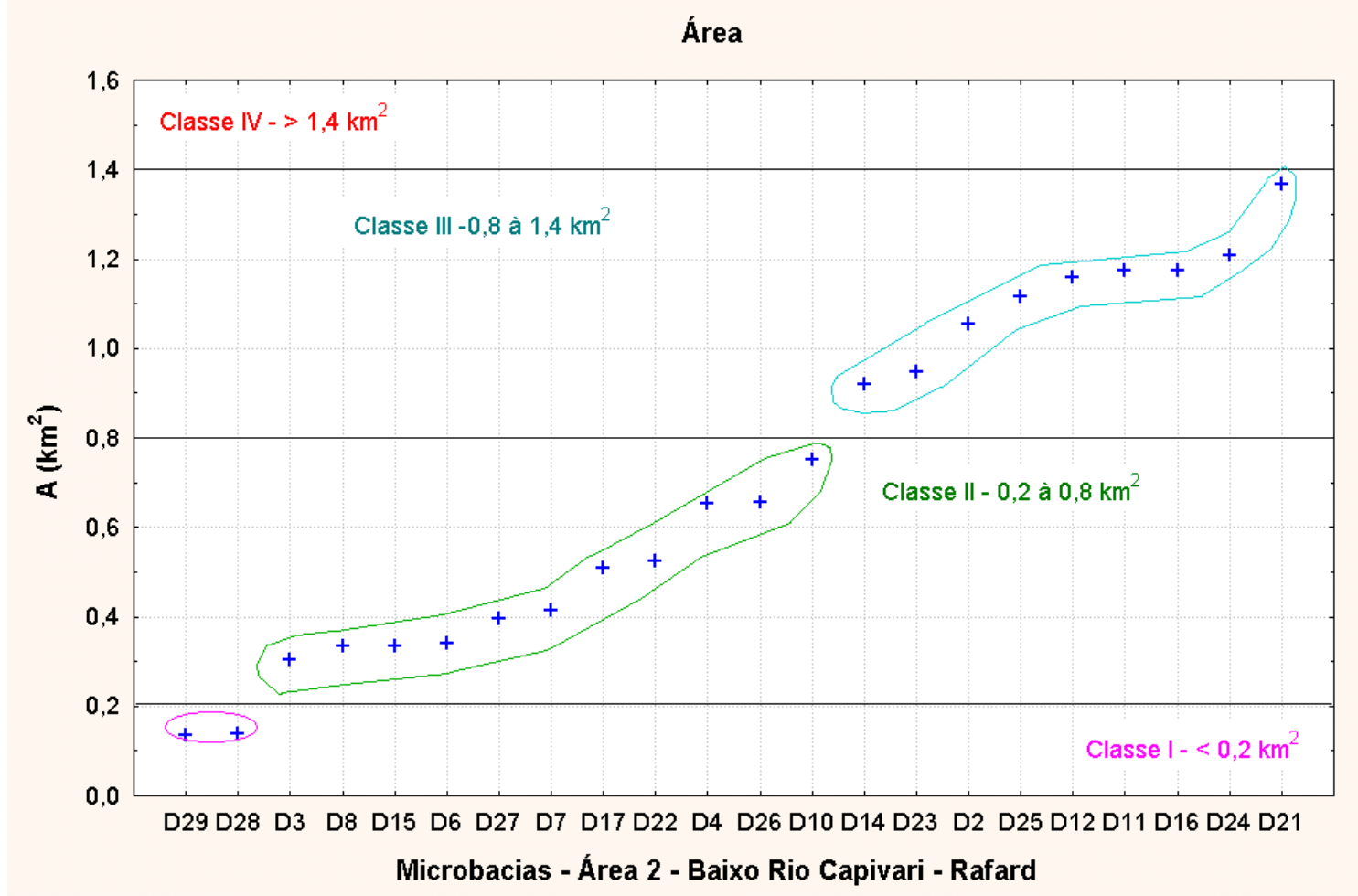

Figura 7.31 - Classes de Área para as microbacias estudadas na região do Baixo Rio Capivari 
Na Figura 7.31, não são ilustrados as microbacias da classe IV, devido a seus elevados valores de área em relação às demais.

\subsection{2 - Faixas de Distribuicão para as Variáveis Morfométricas}

Na Área 2, a delimitação das faixas de distribuição das variáveis morfométricas em valores altos, médios e baixos para as variáveis morfométricas foi baseada nos dados obtidos para as 27 microbacias referentes ao ano de 1972. Nesse item também foram registradas em análise comparativa as características morfométricas que mais se diferenciaram entre os terrenos cristalino e sedimentar.

\subsubsection{1 - Índice de Forma (k)}

Os dados obtidos para o índice de forma na área 2 apresentaram valor médio de 1,25, desvio padrão de 0,11 e intervalo de variação dos valores médios de 0,26. (Tabela 7.10).

Tabela 7.10 - Estatísticas Descritivas e Faixas de Distribuição para os valores de k das Microbacias da Área 2

\begin{tabular}{ccccccccc}
\hline \multicolumn{8}{c}{ ESTATística BÁsICA -MÉTODO DOS PERCENTIS } \\
\hline $\begin{array}{c}\text { Índice } \\
\text { Morfométrico }\end{array}$ & $\begin{array}{c}\text { Número } \\
\text { de Casos }\end{array}$ & Média & Mediana & $\begin{array}{c}\text { Valor } \\
\text { Mínimo }\end{array}$ & $\begin{array}{c}\text { Valor } \\
\text { Máximo }\end{array}$ & $\begin{array}{c}\text { Desvio } \\
\text { Padrão }\end{array}$ & $\begin{array}{c}\text { Valor } \\
\text { Limite } \\
\mathbf{1 0 \%}\end{array}$ & $\begin{array}{c}\text { Valor } \\
\text { Limite } \\
\mathbf{9 0 \%}\end{array}$ \\
\hline $\mathbf{k}$ & 26 & 1,25 & 1,25 & 1,08 & 1,45 & 0,99 & 1,14 & 1,40 \\
\hline $\mathbf{k}$ & Valores Altos $>1,40$ & Valores Médios & $1,14-1,40$ & Valores Baixos $<1,14$ \\
\hline
\end{tabular}

A maioria das microbacias encontrou-se na faixa de valores médios de $\mathrm{k}$, com exceção de D7, D11, D12, D15 e D25; e D10 e D14 que foram situadas na faixa de valores baixos e altos, respectivamente (Figura 7.32). 


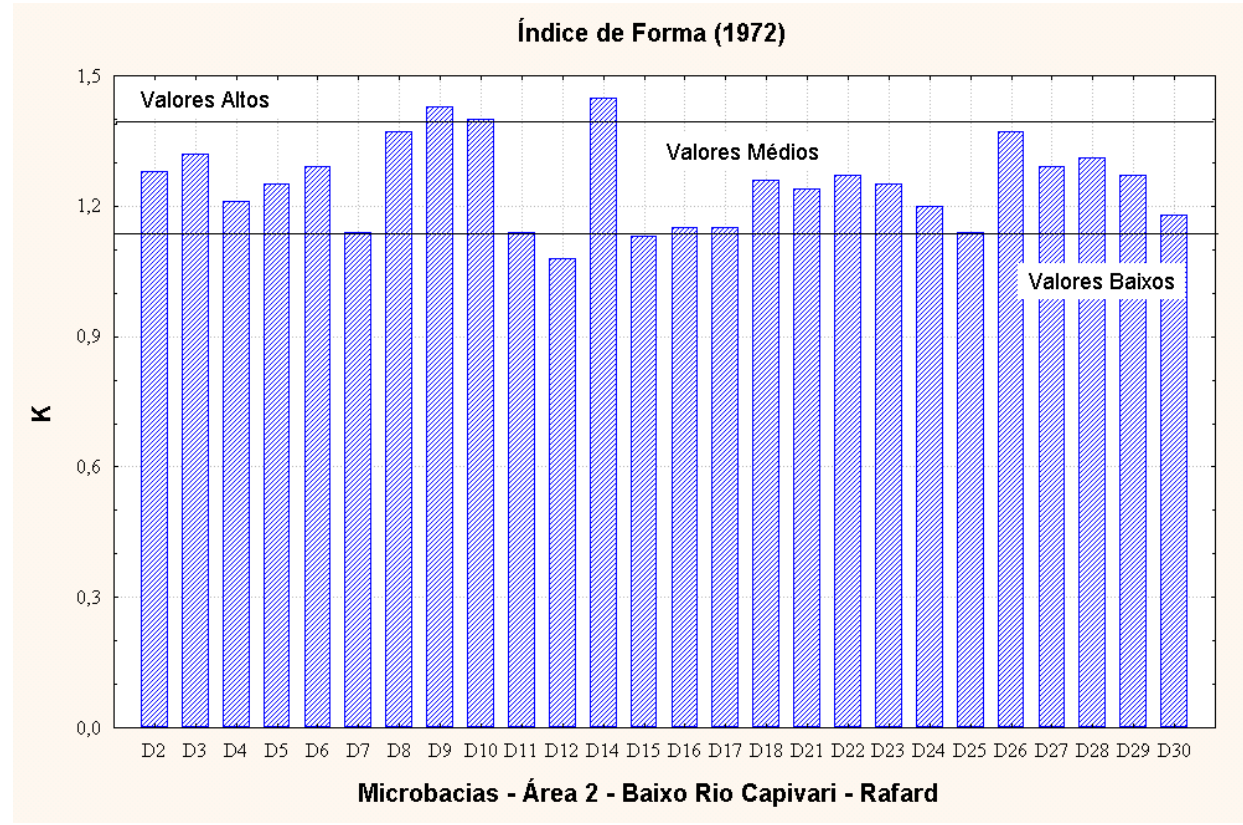

Figura 7.32 - Valores do Índice de Forma (k) para as microbacias estudadas na região do Baixo Rio Capivari

\subsubsection{2 - Densidade de Drenagem (Dd)}

Para os dados referentes à densidade de drenagem das microbacias da área 2, obtevese valor médio de $5,12 \mathrm{~km} / \mathrm{km}^{2}$ e desvio padrão de $1,45 \mathrm{~km} / \mathrm{km}^{2}$, com faixa de distribuição de valores médios de 3,69 km/ $\mathrm{km}^{2}$ (Tabela 7.11).

Tabela 7.11 - Estatísticas Descritivas e Faixas de Distribuição para os valores de Dd das Microbacias da Área 2

\begin{tabular}{|c|c|c|c|c|c|c|c|c|}
\hline \multicolumn{9}{|c|}{ ESTATÍSTICA BÁSICA -MÉTODO DOS PERCENTIS } \\
\hline $\begin{array}{c}\text { Índice } \\
\text { Morfométrico }\end{array}$ & $\begin{array}{l}\text { Número } \\
\text { de Casos }\end{array}$ & Média & Mediana & $\begin{array}{c}\text { Valor } \\
\text { Mínimo }\end{array}$ & $\begin{array}{c}\text { Valor } \\
\text { Máximo }\end{array}$ & $\begin{array}{l}\text { Desvio } \\
\text { Padrão }\end{array}$ & $\begin{array}{c}\text { Valor } \\
\text { Limite } \\
10 \%\end{array}$ & $\begin{array}{c}\text { Valor } \\
\text { Limite } \\
90 \%\end{array}$ \\
\hline $\mathbf{D d}\left(\mathrm{km} / \mathrm{km}^{2}\right)$ & 26 & 5,12 & 5,23 & 1,35 & 7,48 & 1,45 & 3,15 & 6,84 \\
\hline $\mathbf{D d}\left(\mathrm{km} / \mathrm{km}^{2}\right)$ & Valor & Altos & 84 Valo & Mes Médios & $3,15-6,84$ & Valores & aixos & 3,15 \\
\hline
\end{tabular}

Com relação a este índice, um total de 20 microbacias apresentou-se na faixa de valores médios. Entretanto, observa-se na Figura 7.33, nítidas variações de valores para esse intervalo, diferentemente dos dados encontrados para as microbacias da área 1 que mostraram uma uniformidade de valores na respectiva faixa.

Os resultados obtidos da análise estatística básica mostraram que os valores de Dd, definidos para as microbacias da área 2, foram menores que os das microbacias da área 1 
(Explicar pq). As microbacias D3, D4 e D27 foram as que apresentaram maiores valores de Dd e D9, D18 e D30, os menores valores de densidade de drenagem.

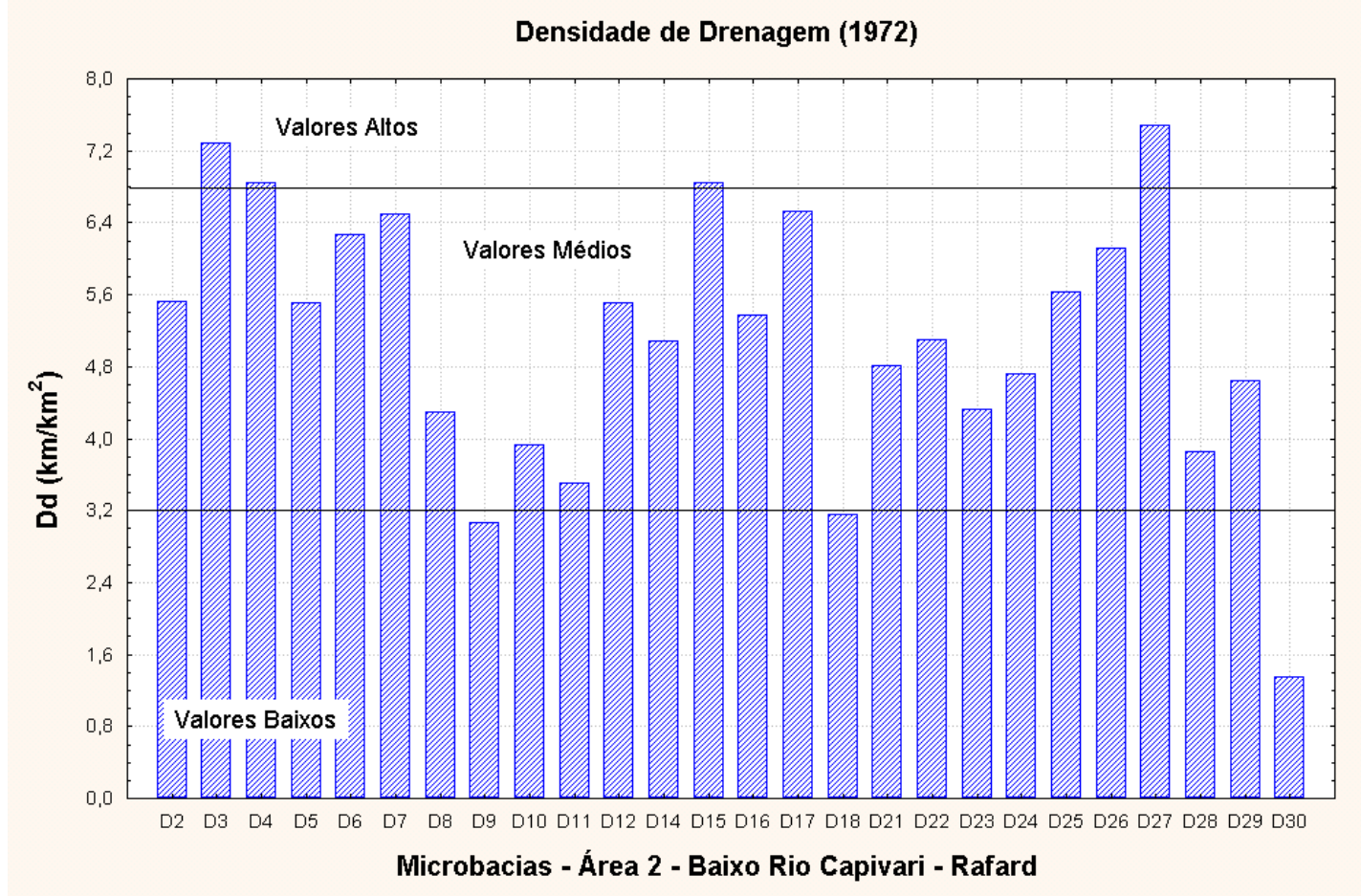

Figura 7.33 - Valores de Densidade de Drenagem (Dd) para as microbacias estudadas na região do Baixo Rio Capivari

\subsubsection{3 - Densidade Hidrográfica (Dh)}

Registrou-se para os valores de Dh, valor médio de 18,86 N1/ $\mathrm{km}^{2}$, desvio padrão de 9,93 N1/km² e intervalo de variação entre os valores médios de 21,45 N1/km² (Tabela 7.12).

Tabela 7.12 - Estatísticas Descritivas e Faixas de Distribuição para os valores de Dh das Microbacias da Área 2

\begin{tabular}{|c|c|c|c|c|c|c|c|c|}
\hline \multicolumn{9}{|c|}{ ESTATÍSTICA BÁSICA -MÉTODO dOS PERCENTIS } \\
\hline $\begin{array}{c}\text { Índice } \\
\text { Morfométrico }\end{array}$ & $\begin{array}{l}\text { Número } \\
\text { de Casos }\end{array}$ & Média & Mediana & $\begin{array}{c}\text { Valor } \\
\text { Mínimo }\end{array}$ & $\begin{array}{c}\text { Valor } \\
\text { Máximo }\end{array}$ & $\begin{array}{l}\text { Desvio } \\
\text { Padrão }\end{array}$ & $\begin{array}{c}\text { Valor } \\
\text { Limite } \\
10 \%\end{array}$ & $\begin{array}{c}\text { Valor } \\
\text { Limite } \\
90 \%\end{array}$ \\
\hline Dh $\left(N 1 / \mathrm{km}^{2}\right)$ & 26 & 18,86 & 16,54 & 3,09 & 45,63 & 9,93 & 9,20 & 30,65 \\
\hline Dh $\left(N 1 / \mathrm{km}^{2}\right)$ & \multicolumn{8}{|c|}{ Valores Altos $>30,65$ Valores Médios 9,20 - 30,65 } \\
\hline
\end{tabular}

Observa-se na Figura 7.34, uma variação ampla dos dados obtidos para esse índice. As microbacias que apresentaram valores mais destoantes da média foram D11, D18 e D30; 
e D27 e D29, respectivamente, foram consideradas com valores muito baixos e muito altos de Dh.

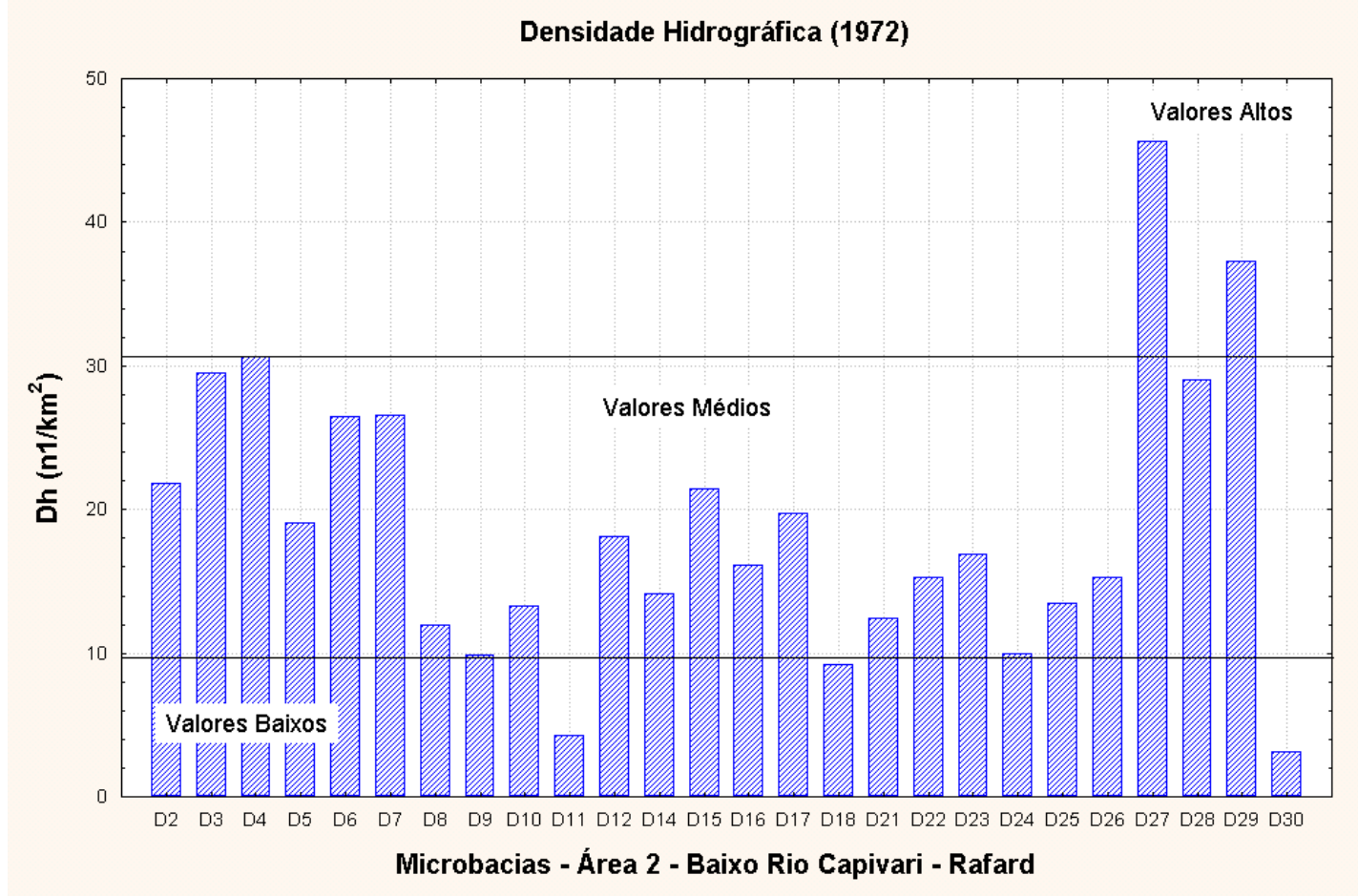

Figura 7.34 - Valores de Densidade Hidrográfica (Dh) para as microbacias estudadas na região do Baixo Rio Capivari

\subsubsection{4 - Textura Topográfica (Tt)}

Para o conjunto de valores de Tt foram definidos valor médio de 10,36 km e desvio padrão de 2,75 km (Tabela 7.13), com intervalo de variação entre os valores limites de 10 e $90 \%$ de $7,36 \mathrm{~km}$.

Tabela 7.13 - Estatísticas Descritivas e Faixas de Distribuição para os valores de Tt das Microbacias da Área 2

\begin{tabular}{ccccccccc}
\hline \multicolumn{7}{c}{ ESTATística BÁsICA -MÉTODO DOS PERCENTIS } \\
\hline $\begin{array}{c}\text { Índice } \\
\text { Morfométrico }\end{array}$ & $\begin{array}{c}\text { Número } \\
\text { de Casos }\end{array}$ & Média & Mediana & $\begin{array}{c}\text { Valor } \\
\text { Mínimo }\end{array}$ & $\begin{array}{c}\text { Valor } \\
\text { Máximo }\end{array}$ & $\begin{array}{c}\text { Desvio } \\
\text { Padrão }\end{array}$ & $\begin{array}{c}\text { Valor } \\
\text { Limite } \\
\mathbf{1 0 \%}\end{array}$ & $\begin{array}{c}\text { Valor } \\
\text { Limite } \\
\mathbf{9 0 \%}\end{array}$ \\
\hline $\mathbf{T t}(\mathbf{k m})$ & 26 & 10,36 & 9,88 & 5,75 & 15,48 & 2,75 & 6,76 & 14,12 \\
\hline $\mathbf{T t}(\mathbf{k m})$ & Valores Altos $>14,12$ & Valores Médios $6,76-14,12$ & Valores Baixos $<6,76$ \\
\hline
\end{tabular}

Os dados obtidos de Tt permitiram definir um intervalo maior na faixa de distribuição de valores médios para a área 2 em comparação com os da área 1 . Tal evidência 
refletiu uma ampla variação desse conjunto de dados, característica essa já nítida nos conjuntos de valores dos índices estudados anteriormente (Figura 7.35).

Outra característica registrada dessas microbacias foi que os valores de textura topográfica foram menores do que os encontrados nas microbacias da área do Alto Rio Capivari.

As microbacias com valores mais destoantes da média foram D9, D11e D28; e D3 e D27, as três primeiras foram registradas na faixa de valores baixos e as duas últimas, na faixa de valores altos.

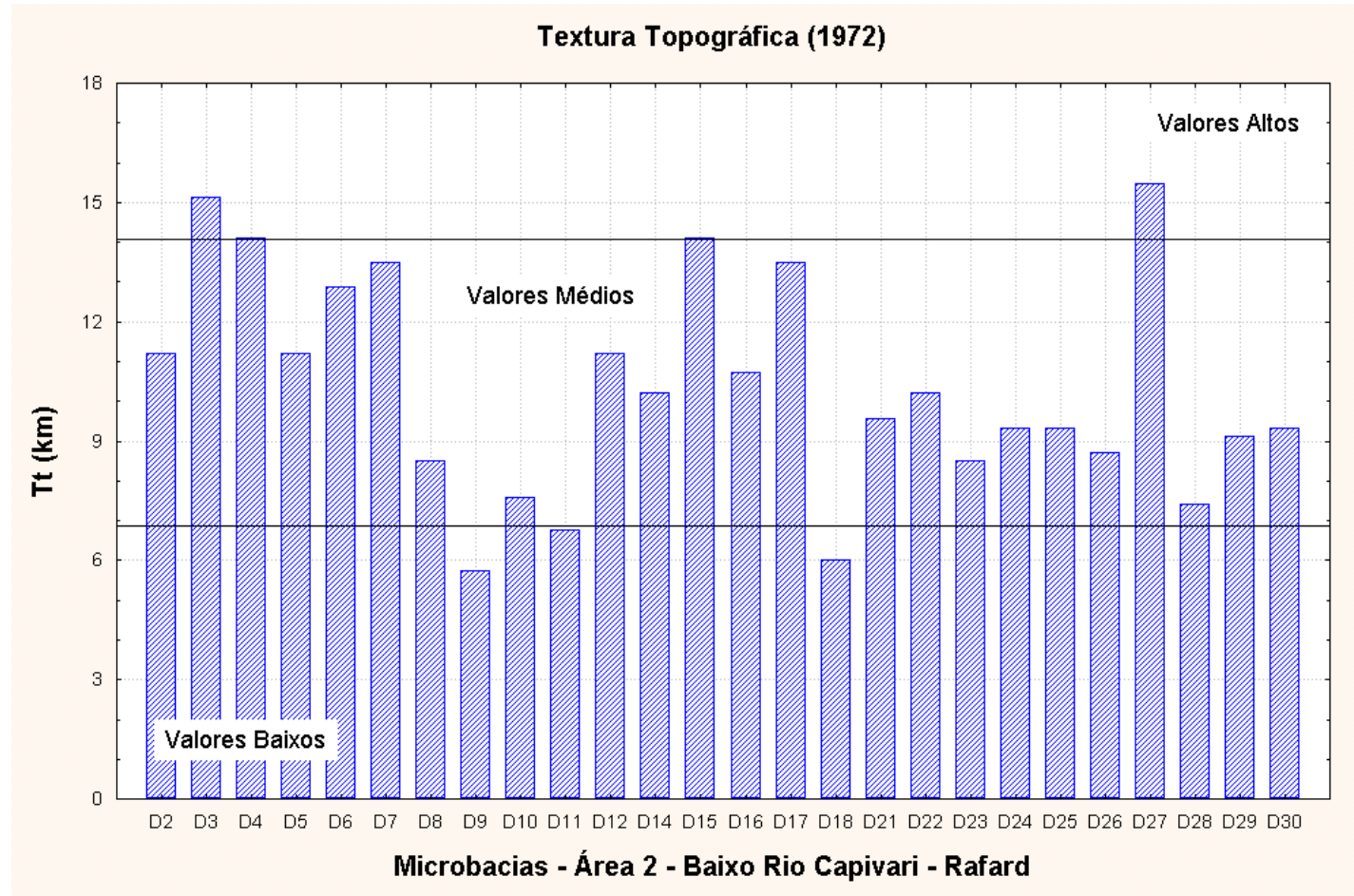

Figura 7.35 - Valores de Textura Topográfica $(\mathrm{Tt})$ para as microbacias estudadas na região do Baixo Rio Capivari

\subsubsection{5 - Razão de Bifurcação entre Canais de Ordem 1 e 2 (Rb1-2)}

A média de valores encontradas para $\mathrm{Rb}_{1-2}$ foi de 1,95 e desvio padrão de 0,95 (Tabela 7.14). Apresentou faixa de distribuição entre os valores limites de 10 e $90 \%$ de 2,2. 
Tabela 7.14. - Estatísticas Descritivas e Faixas de Distribuição para os valores de $\mathrm{Rb}_{1-2}$ das Microbacias da Área 2

\begin{tabular}{|c|c|c|c|c|c|c|c|c|}
\hline \multicolumn{9}{|c|}{ Estatística BÁSICA -MÉTOdO dOS PERCENTIS } \\
\hline $\begin{array}{c}\text { Índice } \\
\text { Morfométrico }\end{array}$ & $\begin{array}{l}\text { Número } \\
\text { de Casos }\end{array}$ & Média & Mediana & $\begin{array}{l}\text { Valor } \\
\text { Mínimo }\end{array}$ & $\begin{array}{c}\text { Valor } \\
\text { Máximo }\end{array}$ & $\begin{array}{l}\text { Desvio } \\
\text { Padrão }\end{array}$ & $\begin{array}{c}\text { Valor } \\
\text { Limite } \\
10 \%\end{array}$ & $\begin{array}{c}\text { Valor } \\
\text { Limite } \\
90 \%\end{array}$ \\
\hline $\mathbf{R b}_{1-2}$ & 26 & 1,95 & 1,71 & 0,66 & 4,54 & 0,95 & 0,95 & 3,15 \\
\hline $\mathbf{R b}_{1-2}$ & Valor & Altos & ,15 Val & es Méd & $0,95-3,15$ & Valores & $\operatorname{aixos}<0$ &, 95 \\
\hline
\end{tabular}

A maioria das microbacias sedimentares encontrou-se na faixa de valores médios sendo predominantes os valores em torno e abaixo da média, diferentemente dos dados obtidos para as microbacias da área 1, em que predominaram os acima da média(Figura 7.36). Os valores de $\mathrm{Rb}_{1-2}$ obtidos para as microbacias sedimentares foram predominantemente menores que os das microbacias cristalinas, o que indicou uma menor confluência de canais de Ordem 1 formando canais de Ordem 2 para a área 2.

As microbacias mais destoantes da média foram D8, D9 e D16 (< 10\%); e D18 e D25 (> 90\%).

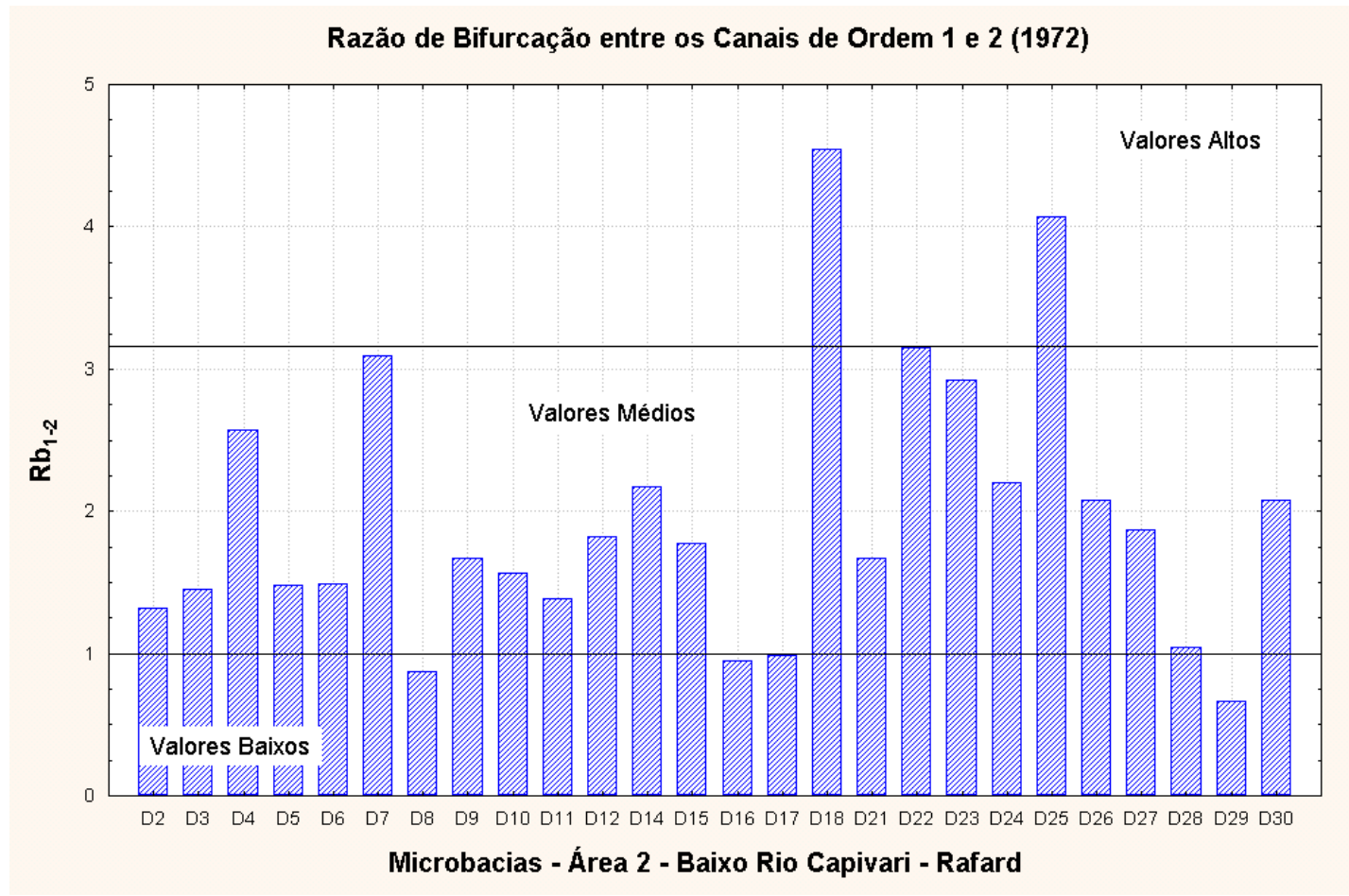

Figura 7.36 - Valores da Razão de Bifurcação entre canais de Ordem 1 e $2\left(\mathrm{Rb}_{1-2}\right)$ para as microbacias estudadas na região do Baixo Rio Capivari 


\subsubsection{6 - Razão entre Comprimentos Médios dos Canais de Ordem 2 e 1} $\left(R / m_{2-1}\right)$

As microbacias apresentaram 3,91 como média dos valores encontrados para $\operatorname{Rlm}_{2-1}$ e desvio padrão de 1,55. Seu intervalo de variação dos valores médios foi de 3,50 (Tabela $7.15)$.

Tabela 7.15 - Estatísticas Descritivas e Faixas de Distribuição para os valores de $\operatorname{Rlm}_{2-1}$ das Microbacias da Área 2

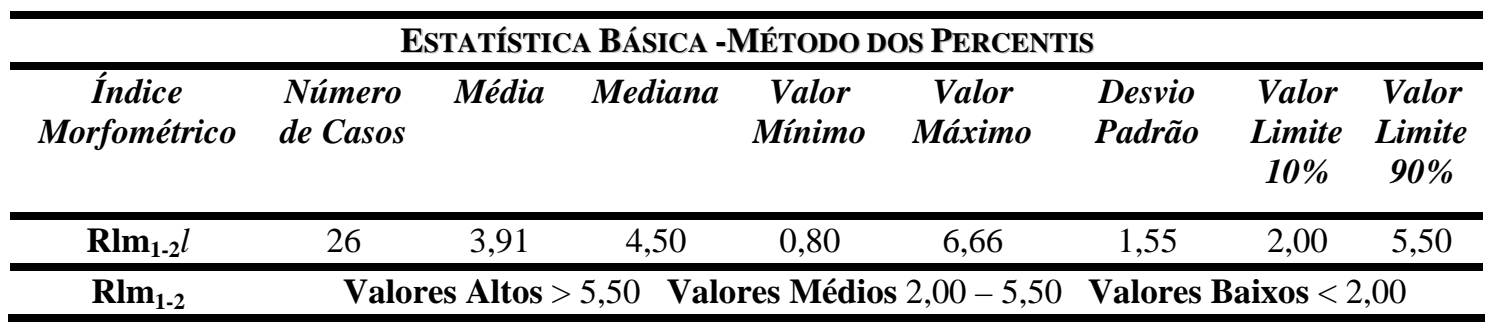

Um ponto importante a destacar foi que os valores encontrados para a faixa de distribuição de valores médios mostraram comportamento contrário aos de $\mathrm{Rb}_{1-2}$, ou seja concentram-se acima e em torno da média predominantemente.

As microbacias D8, D14, D15 e D28 apresentaram muito baixos valores de Rlm $\operatorname{lm}_{2-1}$ e D18 e D24, muito altos valores de $\mathrm{Rlm}_{2-1}$ em relação ao valor médio encontrado (Figura 7.37).

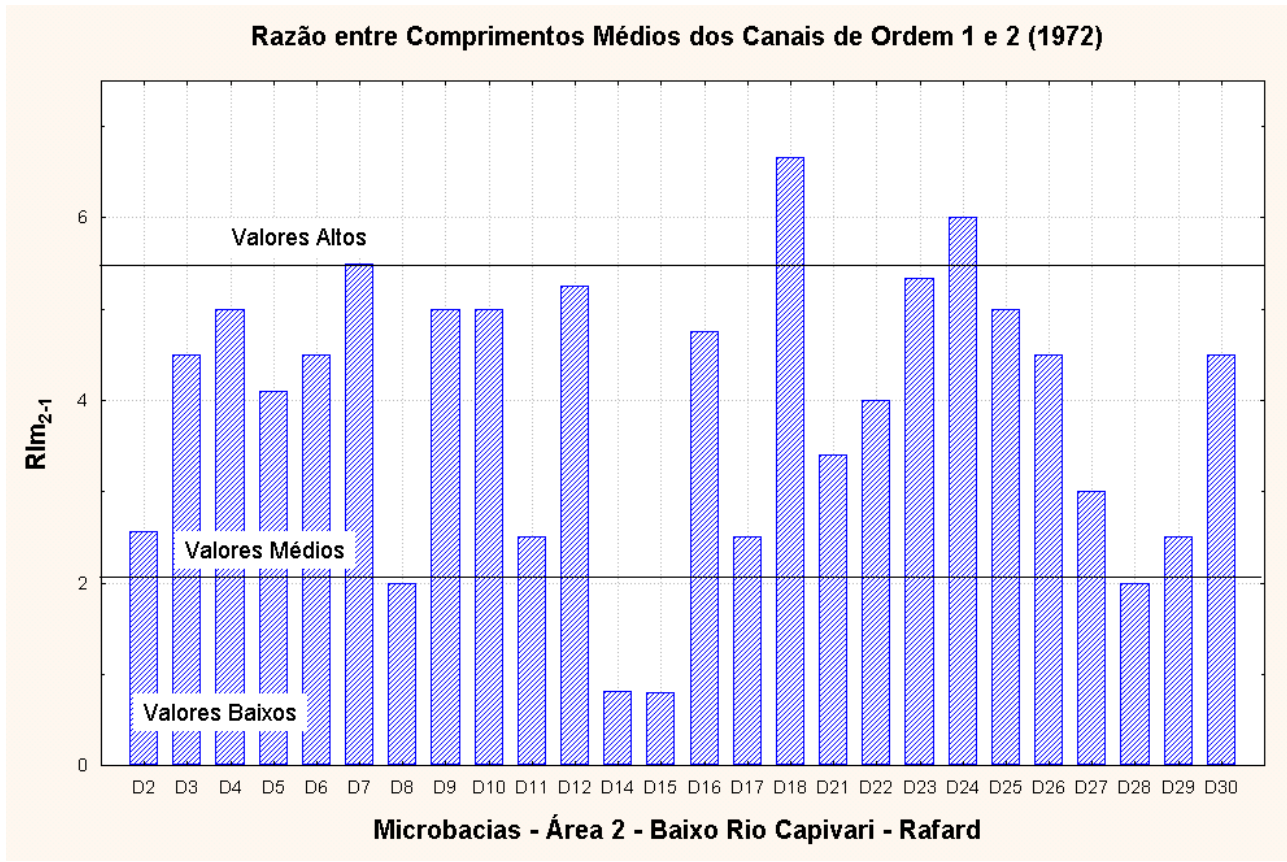


Figura 7.37 - Valores da Razão entre Comprimentos Médios dos canais de Ordem 1 e 2 $\left(R m_{2-1}\right)$ para as microbacias estudadas na região do Baixo Rio Capivari

\subsection{3 - Relacão entre as Variáveis Morfométricas}

Os gráficos, área versus densidade de drenagem e área versus densidade hidrográfica, mostraram os seguintes comportamentos generalizados das microbacias, quanto maior a Área (A) menor o valor da Densidade de Drenagem (Dd) e Densidade Hidrográfica (Dh) (figuras 7. 38 e 7.39).

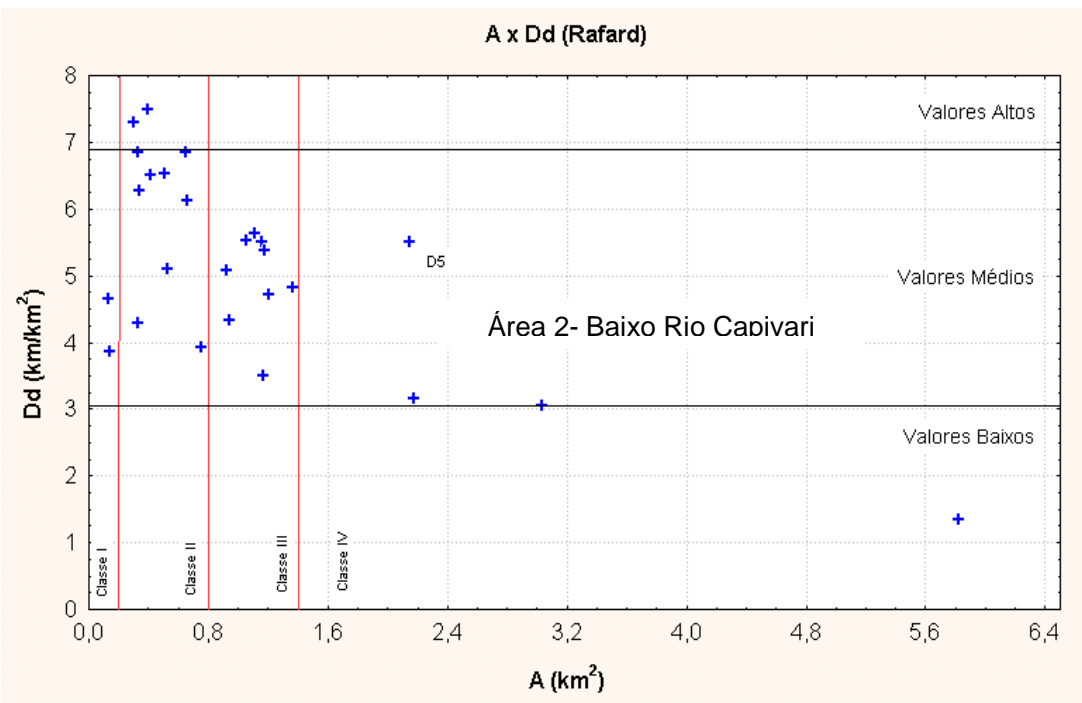

Figura 7.38 - Relação entre área e densidade de drenagem referente a 1972 para as microbacias da Área do Baixo Rio Capivari

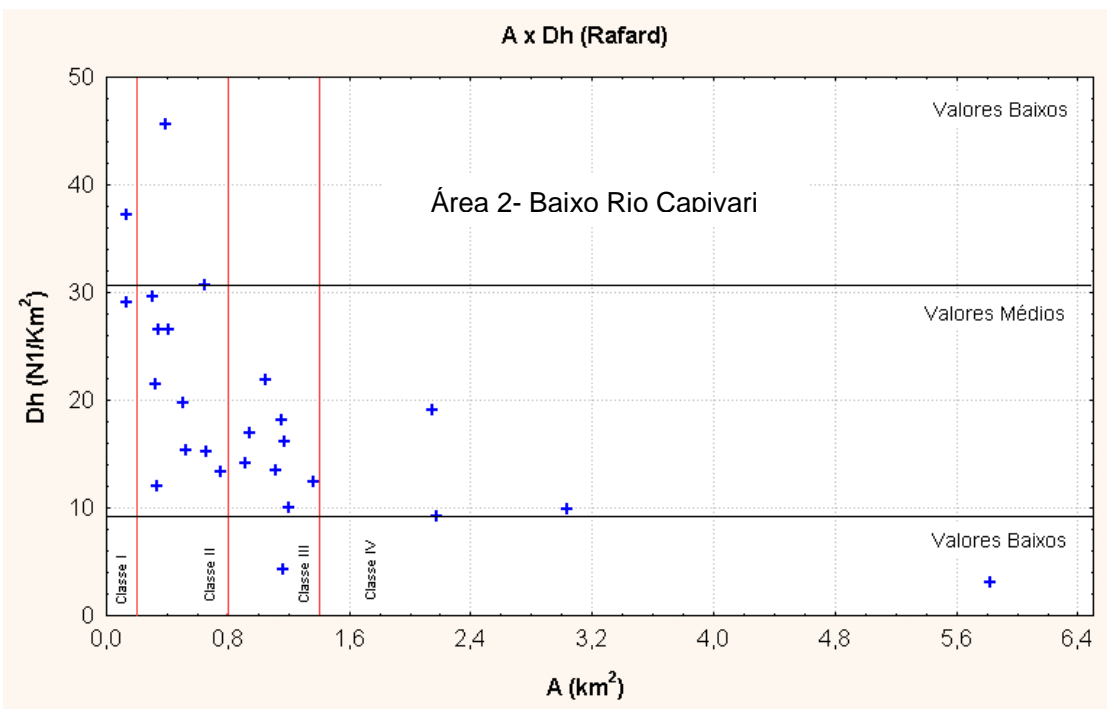


Figura 7.39 - Relação entre área e densidade hidrográfica referente a 1972 para as microbacias da Área do Baixo Rio Capivari

O gráfico, densidade de drenagem versus densidade hidrográfica (Figura 7.40), mostrou correlação entre as variáveis, onde menores valores de Dd corresponderam aos menores valores de Dh e vice-versa, com exceção de D28 e D29.

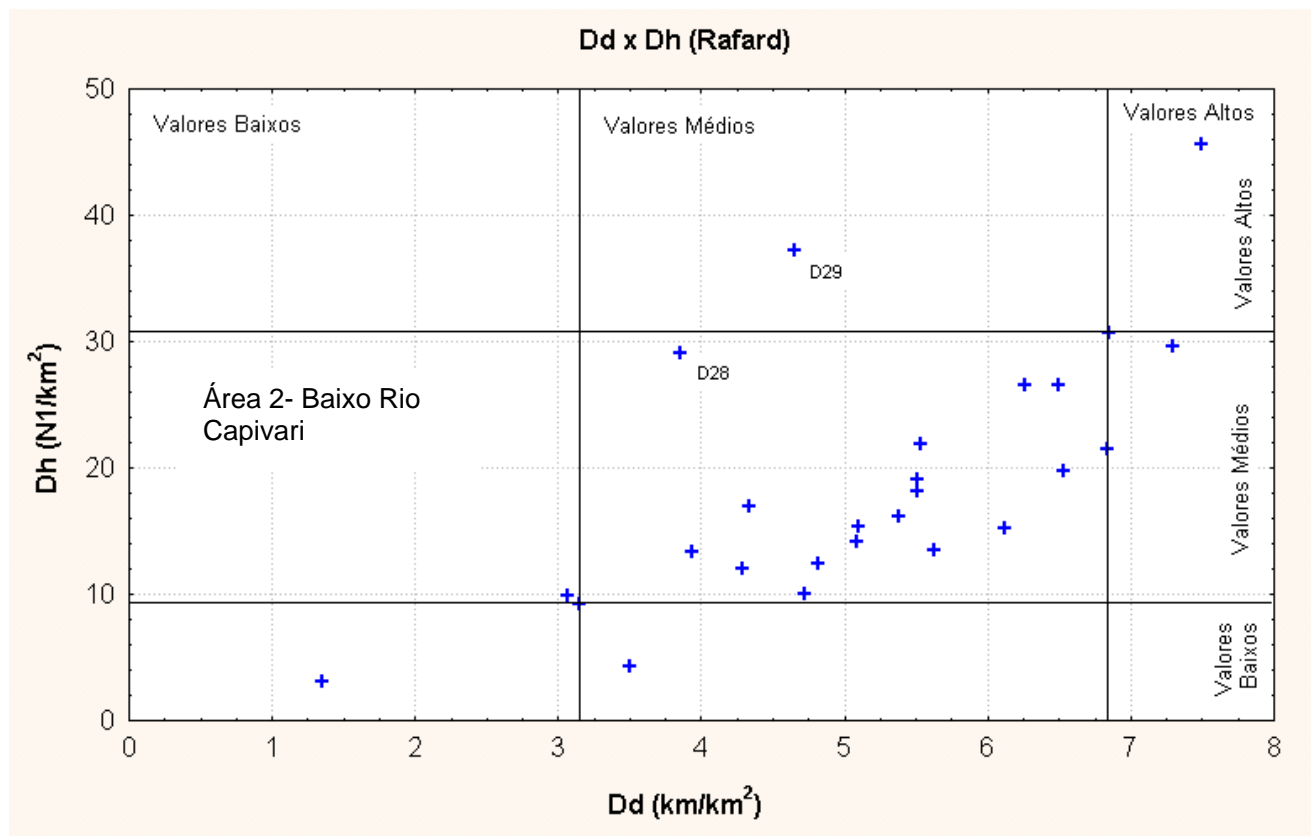

Figura 7.40 - Relação entre densidade de drenagem e densidade hidrográfica referente a 1972 para as microbacias da Área do Baixo Rio Capivari

\subsection{4 - Avaliação das Taxas de Variação dos Principais Índices Morfométricos}

O dendrograma criado para a área 2 a partir das taxas de variação dos índices Dd e Dh, semelhante a área 1 , mostrou dois ramos referentes às alterações positivas e negativas de Dh e 4 conjuntos de microbacias (Figura 7.41), que foram relacionadas à significância das alterações. Esta classificação, como mostra o gráfico taxa de variação de densidade de drenagem versus taxa de variação de densidade hidrográfica (Figura 7.42), também baseouse nas porcentagens de $\Delta \mathrm{Dh}$ com $\Delta \mathrm{Dd}$ maiores do que $10 \%$ e excluem-se da análise todas as microbacias com dados de porcentagens das variações ou de Dd ou de Dh menores que 10 $\%$.

Os grupos de microbacias foram classificados como: 
- Microbacias com alterações pouco significativas, com porcentagens inferiores a $10 \%$ da taxa de variação de Dh e $\Delta$ Dd inferior a $10 \%$ (D4, D5, D11, D18, D22, D23, D24, D28 e D29);

- Microbacias com alterações significativas, com porcentagens entre 10 a 30\% da taxa de variação de Dh e $\Delta$ Dd maior que 10\% (D6, D7, D9, D10, D16, D17, D21, D26 e D27);

- Microbacias com alterações muito significativas, com porcentagens entre 30 a 50\% da taxa de variação de Dh e $\Delta$ Dd superior a 10\% (D2 e D15); e,

- Microbacia com alteração altamente significativa, com porcentagens superiores a 50\% da taxa de variação Dh e $\Delta$ Dd maior que $10 \%$ (D4).

Pode-se destacar as microbacias D3, D8, D12, D14, D25 e D30 que apesar de mostrarem taxas de Dd menores que $10 \%$, apresentaram taxas de Dh maiores que 10\%, mas não foram incluídas na análise estatística.

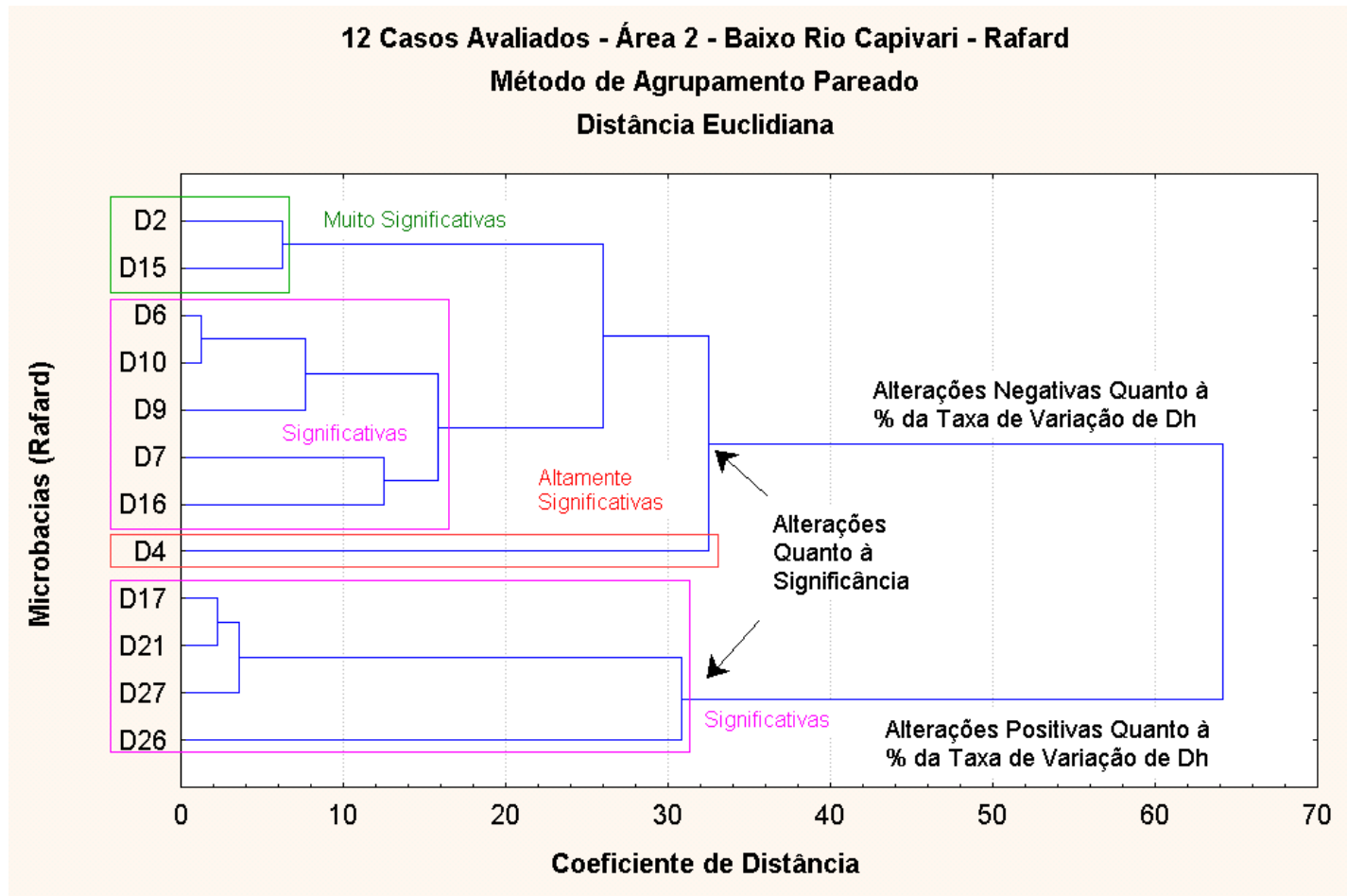

Figura 7.41 - Dendrograma dos dados de taxas de variações maiores que 10\% de densidade de drenagem e densidade hidrográfica para as microbacias da Área 2 


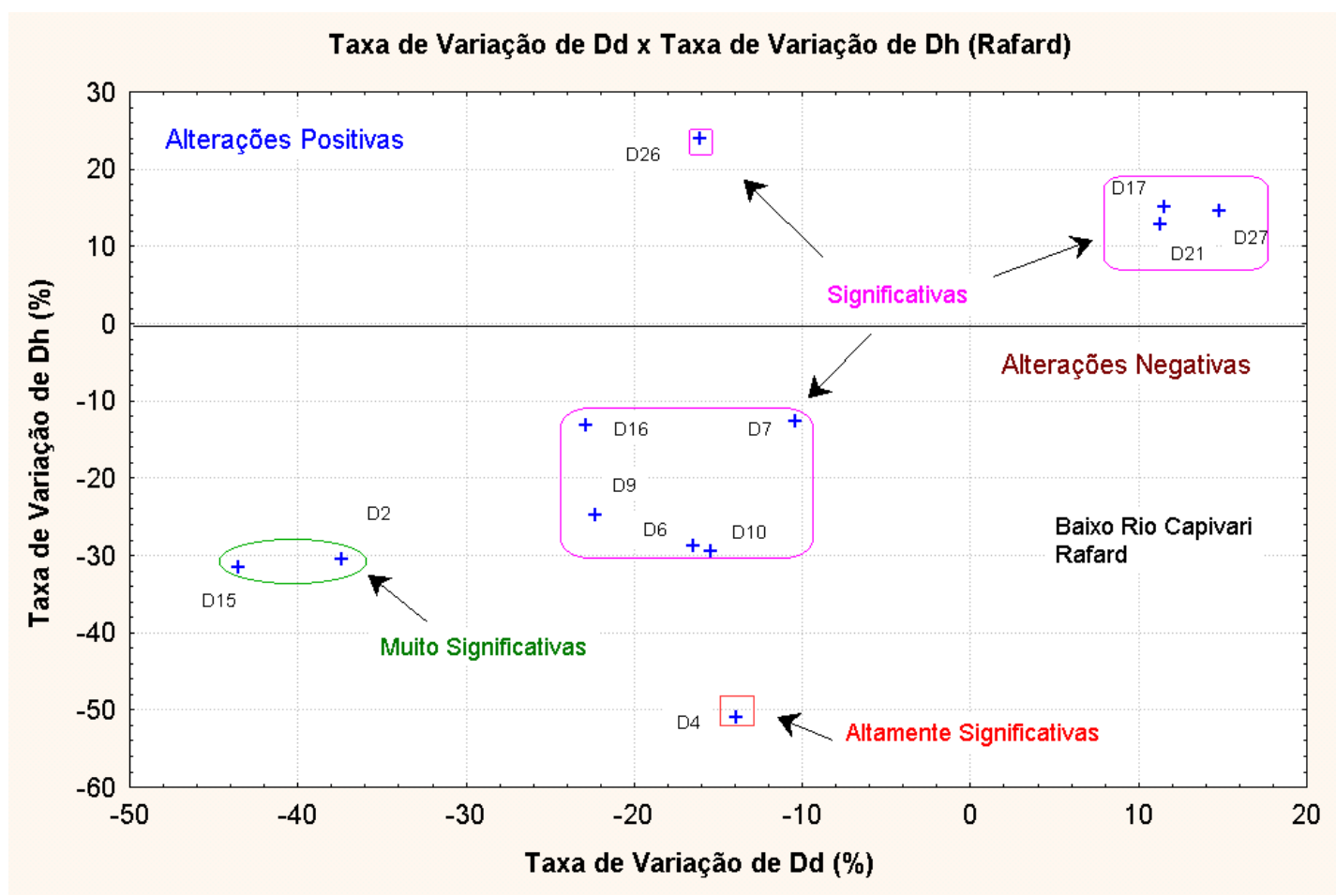

Figura 7.42 - Relação entre a Taxa de Variação de Densidade de Drenagem e Densidade Hidrográfica (\%) para as microbacias da Área do Baixo Rio Capivari

No dendrograma referente às taxas de variação dos índices morfométricos $\mathrm{Rlm}_{2-1} \mathrm{e}$ $\mathrm{Rb}_{1-2}$ (Figura 7.43) foi possível definir cinco grupos distintos.

Essa subdivisão foi baseada em perdas ou ganhos expressos em porcentagens para ambas taxas de variação (Figura 7.44), semelhante a área 1, e pode ser descrita como:

- Grupo 1 formado pelas microbacias D10 e D26 apresentaram taxas de variação de Rb 1-2 $_{1}$ entre -100 a $0 \%$ e taxa de variação de $\operatorname{Rlm}_{2-1}$ superior a $80 \%$;

- Grupo 2 formado pelas microbacias D4, D6, D7, D9 e D25 apresentaram taxas de variação de $\mathrm{Rb}_{1-2}$ entre -100 a $0 \%$ e taxa de variação de $\operatorname{Rlm}_{2-1}$ entre -80 a $80 \%$;

- Grupo 3 formado pelas microbacias D14 e D30 apresentaram taxas de variação de Rb $b_{1-2}$ entre 0 a $100 \%$ e taxa de variação de $\operatorname{Rlm}_{2-1}$ inferior a $80 \%$;

- Grupo 4 formado pelas microbacias D2, D5, D8, D17 e D18 apresentaram taxas de variação de $\mathrm{Rb}_{1-2}$ entre 0 a $100 \%$ e $\operatorname{Rlm}_{2-1}$ entre -80 a $80 \%$; e,

- Grupo 5 formado pela microbacia $\mathrm{D} 15$, onde $\mathrm{Rb}_{1-2}$ é superior a $100 \%$ e $\mathrm{Rlm}_{2-1}$ encontrase entre -80 a $80 \%$. 


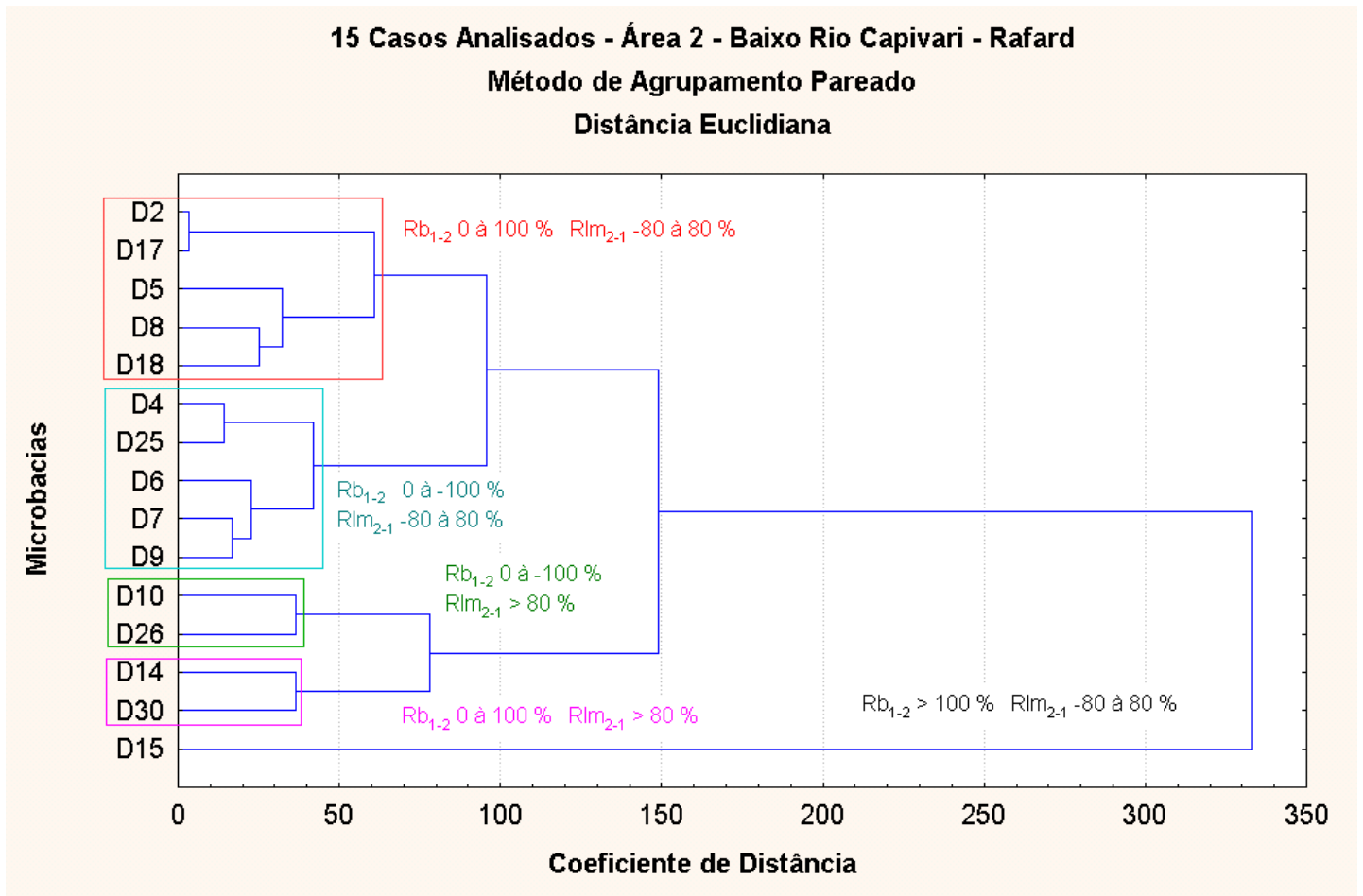

Figura 7.43 - Dendrograma dos dados de taxas de variações maiores que 10\% dos índices $\mathrm{Rlm}_{2-1}$ e $\mathrm{Rb}_{1-2}$ entre 1972 e 1995 para as microbacias da Área do Baixo Rio Capivari

Taxa de Variação de $\mathbf{R b}_{1-2} \times$ Taxa de Variação de $\mathbf{R I m}_{2-1}$

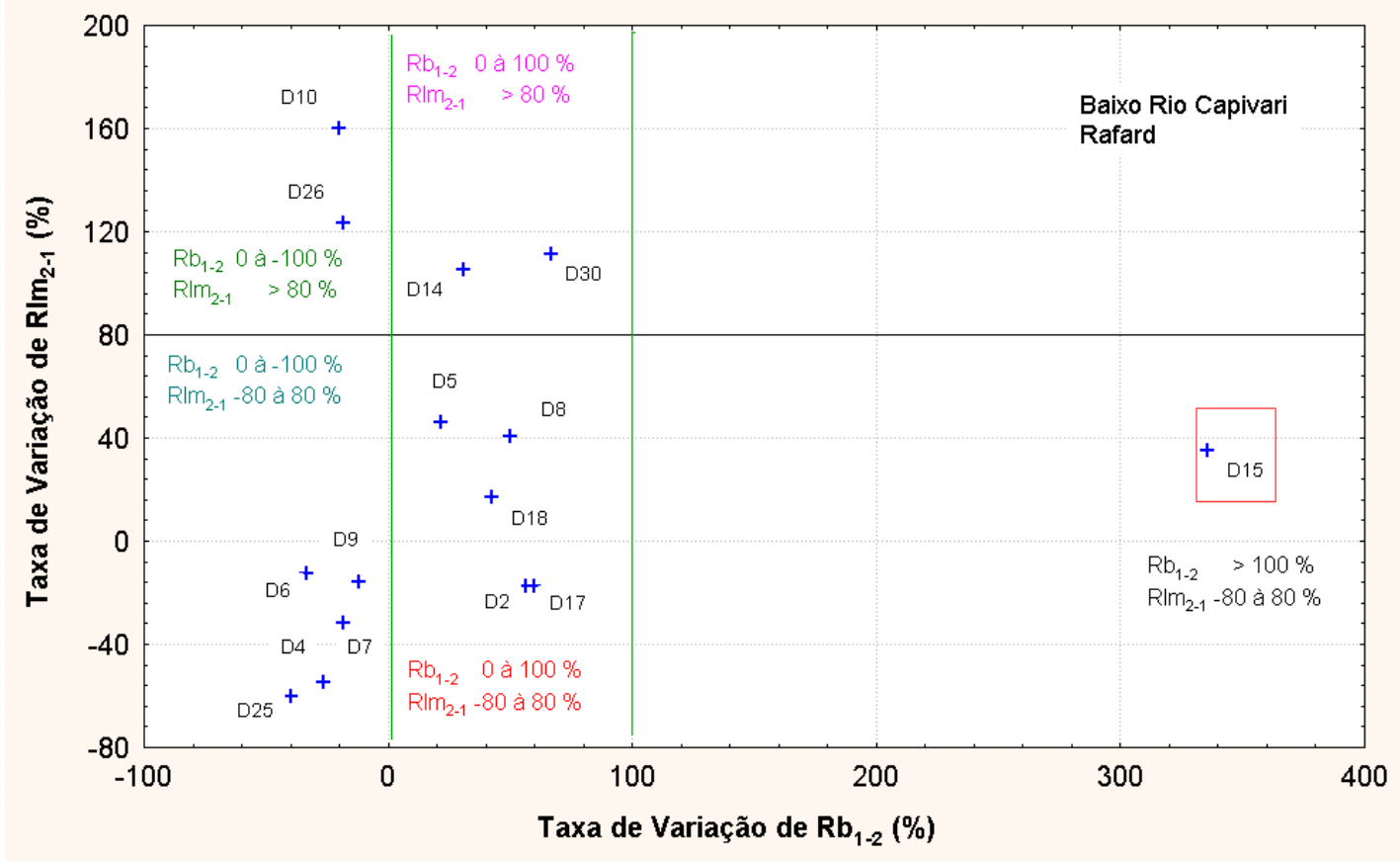

Figura 7.44 - Relação entre a taxa de variação dos índices $\operatorname{Rlm}_{2-1}$ e $\mathrm{Rb}_{1-2}$ entre os anos de 1972 e 1995 para as microbacias da Área do Baixo Rio Capivari 
Dentre as microbacias analisadas, as que apresentaram taxas de variações mais elevadas, ou seja, $\mathrm{Rb}_{1-2}>80 \%$ e $\mathrm{Rlm}_{1-2}>100 \%$ foram D10, D14, D26 e D30; e D15, respectivamente.

Os dados obtidos para as relações entre $\Delta D d$ versus $\Delta D h$ e $\Delta R b_{1-2}$ versus $\Delta R \operatorname{lm}_{2-1}$ ao serem plotados no software Curve Expert 4.3 mostraram correlações pouco significativas com valor de $r^{2}$ de 0,67 e 0,15 , respectivamente. Tais dados mostraram que não seria válido quantificar essas relações, uma vez que não expressaria matematicamente a tendência da alteração desses índices para as microbacias de área de estudo.

Cabe ressaltar que dentre as 27 microbacias analisadas, D5, D11, D22, D23, D24, D28 e D29 não sofreram alterações significantes em relação a qualquer uma das taxas de variação dos índices estudados ( $\Delta \mathrm{Dd}, \Delta \mathrm{Dh}, \Delta \mathrm{Rlm}_{2-1}$ e $\left.\Delta \mathrm{Rb}_{1-2}\right)$.

\subsection{5 - Análise da Influência dos Dados Morfométricos Obtidos para 1972 Quanto à Taxa de Variação}

A relação entre o índice Dd referente a 1972 e a taxa de variação da densidade de drenagem (Figura 7.45) mostrou que as maiores alterações em porcentagens de $\Delta \mathrm{Dd}(>-20 \%)$ foram registradas acima ou em torno da média, com exceção de D9.

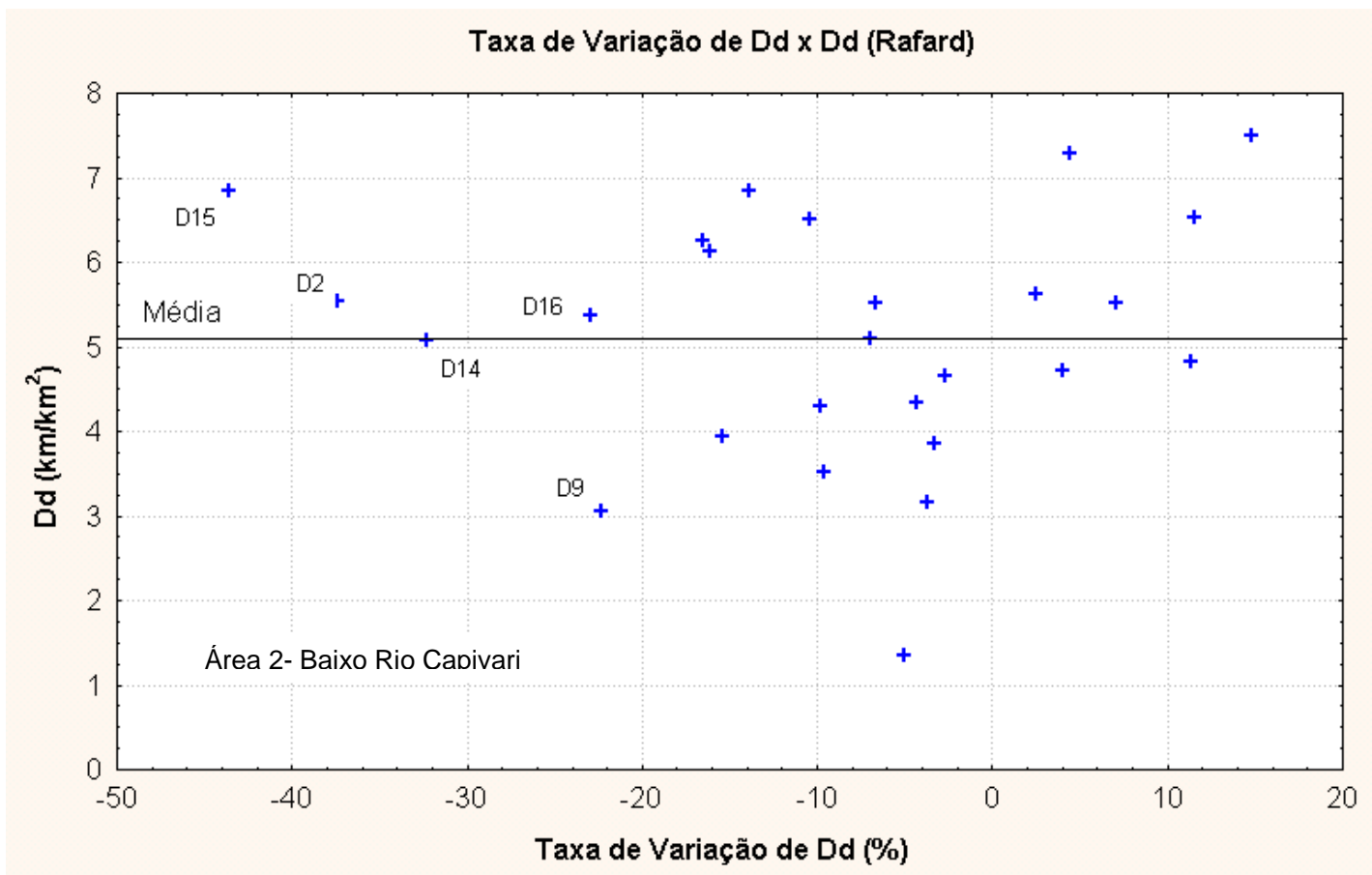

Figura 7.45 - Relação entre a $\Delta$ Dd e Dd para as microbacias estudadas na área do Baixo Rio Capivari 
O gráfico taxa de variação de densidade hidrográfica versus densidade hidrográfica (Figura 7.46), mostrou que as alterações com déficit superior a $20 \%$ predominantemente estavam acima da média, com exceção de D10 e as alterações com ganho superior a 20\% concentraram-se abaixo da média.

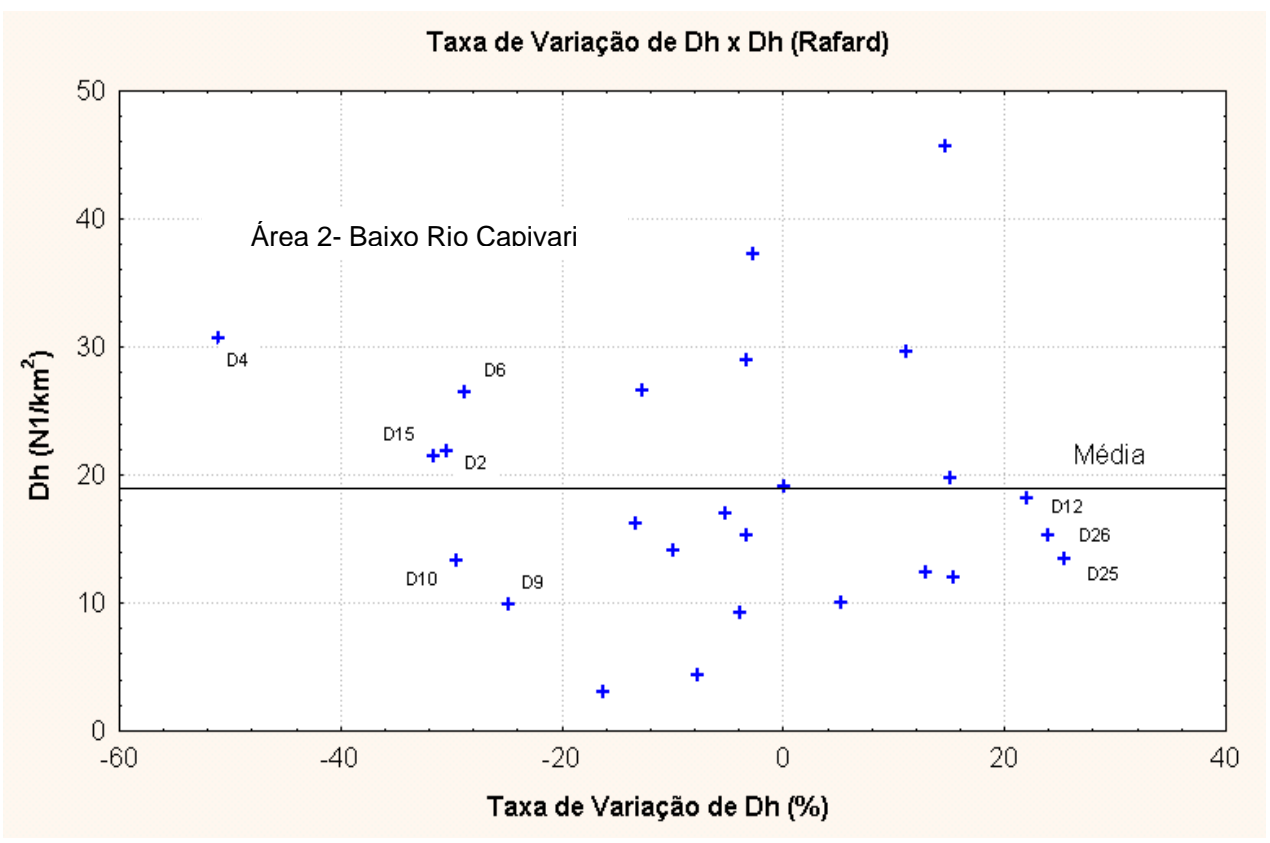

Figura 7.46 - Relação entre a $\Delta \mathrm{Dh}$ e Dh para as microbacias estudadas na área do Baixo Rio Capivari

\subsection{6 - Avaliação da Influência do Meio Físico (substrato rochoso, landforms e materiais inconsolidados) na Taxa de Variação dos Índices Morfométricos}

Quanto à geologia, definiram-se as litologias pertinentes as microbacias, sendo as subdivididas em:

- Microbacias com rochas intercaladas do Sub-Grupo Itararé de litotipos distintos e diabásios (I+D) - D5, D9, D12, D14, D17, D18 e D30;

- Microbacias apenas com rochas intercaladas do Sub-Grupo Itararé de litotipos distintos (I - siltitos, diamictitos, argilitos, arenitos) - D4, D15, D16, D21 e D27;

- Microbacias apenas com diamictitos de matriz siltíca, arenosa e argilosa intercalados (Di) - D22, D23 e D24; 
- Microbacias com siltitos cinza esbranquiçados e siltitos amarelo-avermelhados intercalados e diabásios (S + D) - D2, D7, D8, D10, D11 e D25; e,

- Microbacias com siltitos intercalados (S) - D3, D6, D26, D28 e D29.

Em relação à taxa de variação de Dd e Dh e os litotipos encontrados nas microbacias observou-se que, com exceção das microbacias referentes a apenas intercalados de siltitos (D22, D23 e D24) e as microbacias D18, D28 e D29, as demais apresentaram modificações superiores a $10 \%$, ou de $\Delta \mathrm{Dd}$, ou de $\Delta \mathrm{Dh}$. Dentre elas, as que apresentaram perdas superiores a $30 \%$ de $\Delta \mathrm{Dh}$ e $\Delta \mathrm{Dd}$ foram D14 associadas a rochas intercaladas do Itararé de litotipos distintos e diabásios, D4 e D15, relacionadas a rochas intercaladas do Itararé de litotipos distintos e D2, referentes a siltitos intercalados (Figura 7.47). O contraste entre a resistência dos litotipos pode facilitar os processos de modificação da rede de drenagem que podem ser intensificados pela exposição da área a atuação agrícola intensiva.

As microbacias que sofreram alterações importantes da $\Delta \operatorname{Rlm}_{2-1}$ e $\Delta \mathrm{Rb}_{1-2}$ e alterações significantes apenas em $\Delta \mathrm{Dh}$ mostraram-se associadas às rochas de siltitos intercalados (D25 e D8) e diabásios, às rochas intercaladas do Itararé de litotipos distintos e diabásios (D12, D14, D18 e D30) e às rochas apenas com siltitos intercalados (D3).

O maior número de microbacias com alterações superiores a $10 \%$ de Dd e Dh foi concentrado na unidade de landform 4 (D3, D4, D15, D16, D17 e D21) (Figuras 7.48a e $7.48 b)$.

As microbacias que apresentaram taxas de alteração de Dd e Dh superiores a 30\% foram relacionadas à unidade de landforms 4 (D4 e D15), à associação de unidades 4 e 10 (D14) e à associação de unidades 4 e 11 (D12).

As microbacias que sofreram alterações importantes de $R \operatorname{lm}_{2-1}$ e $R b_{1-2}$, foram relacionadas às associações de landforms 3 e 6 (D8), 4 (D3), 4 e 9 (D30), 4 e 10 (D12 e D14), 10 (D18) e, 8 e 12 (D25).

$\mathrm{O}$ registro da unidade de landform 4 nas microbacias que sofreram alterações significantes, indicou que possivelmente uma de suas características ou mais podem acentuar ou facilitar os processos que modificam a morfometria da sua rede de drenagem. Dentre as características pode-se citar o substrato rochoso constituído por diamictitos com intenso processo de empastilhamento e materiais inconsolidados com argilas nocivas a muito ativas.

As microbacias relacionadas às associações de unidades de landforms 4 (D22), 4 e 5 (D23), 7 e 10 (D11), 8 e 11 (D5, D28, D29 e D30) e, 5 e 9 (D24) não apresentaram alterações em Dd e Dh significantes. 
(A) Taxa de Variação de Dd x Geologia das Microbacias

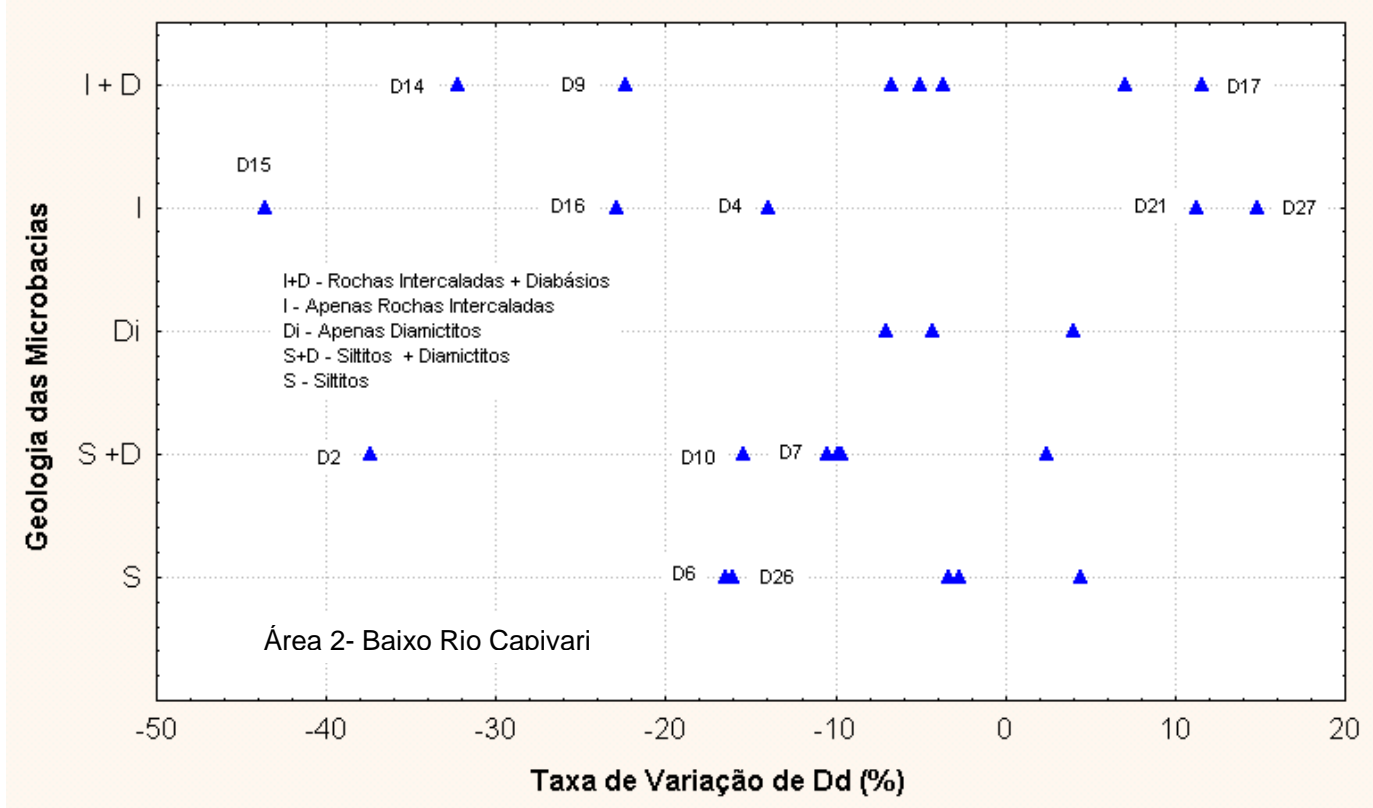

(B) Taxa de Variação de Dh x Geologia das Microbacias

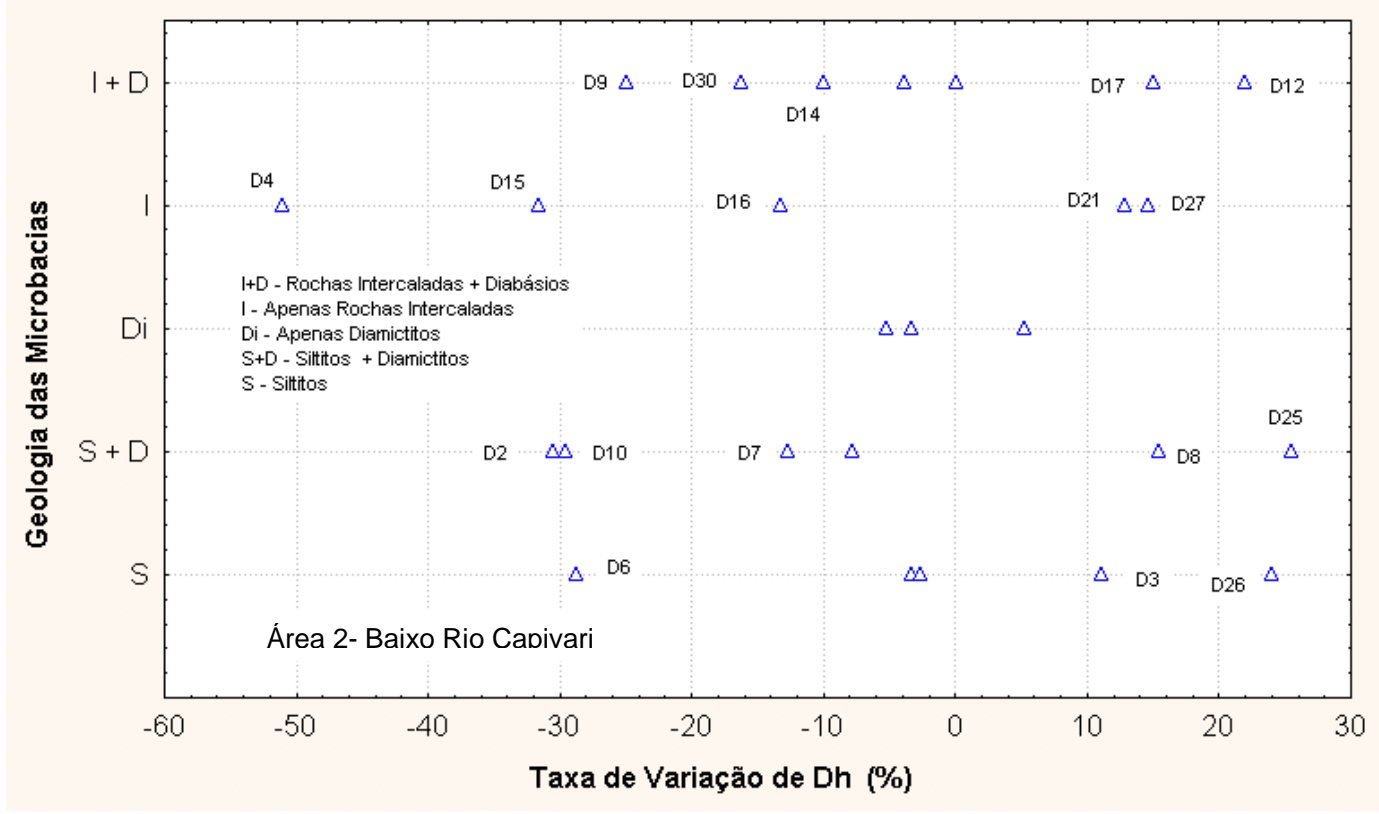

Figura 7.47 - Relação entre a Taxa de Variação de Dd (a) e Dh (b) com as litologias pertinentes as microbacias da Área do Baixo Rio Capivari 
(A) Taxa de Variação de Dd $x$ Unidade de Landforms

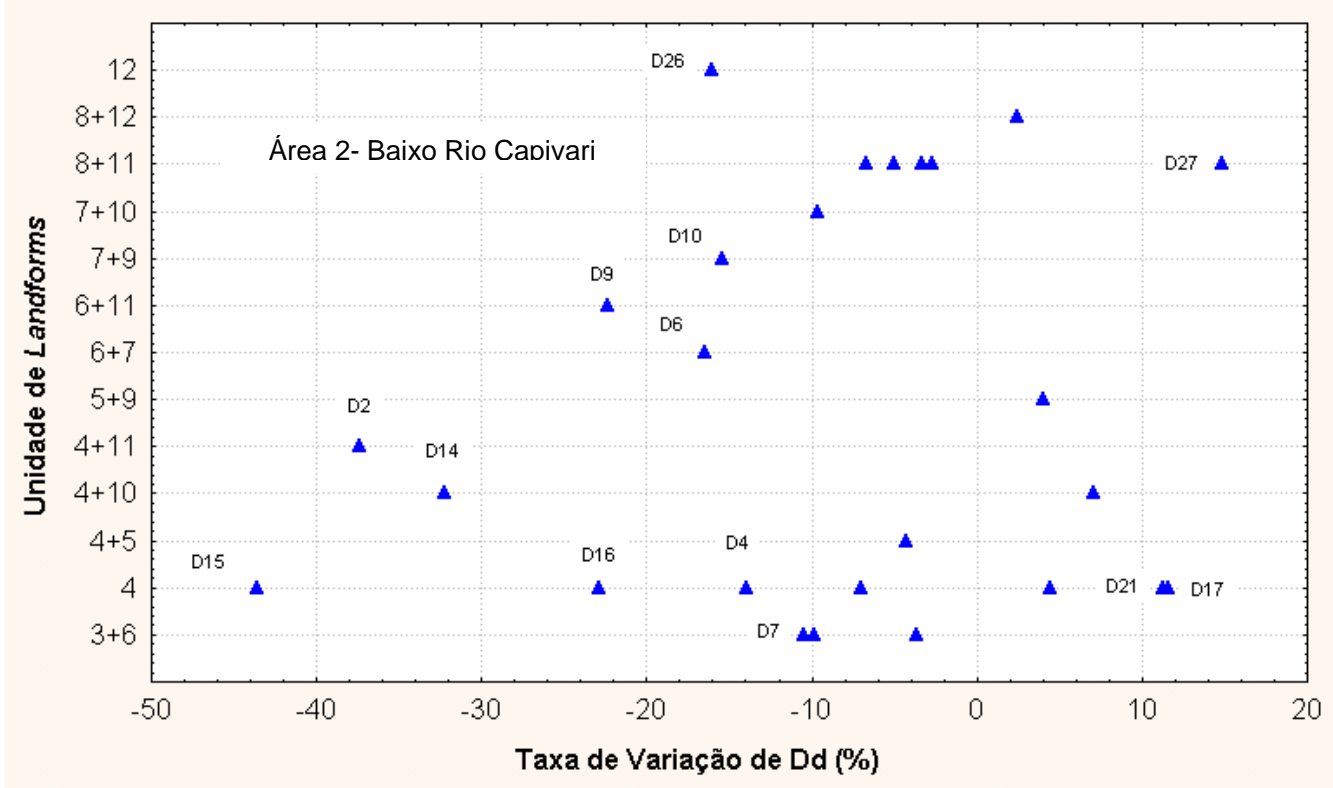

(B) Taxa de Variação de Dh $x$ Unidade de Landforms

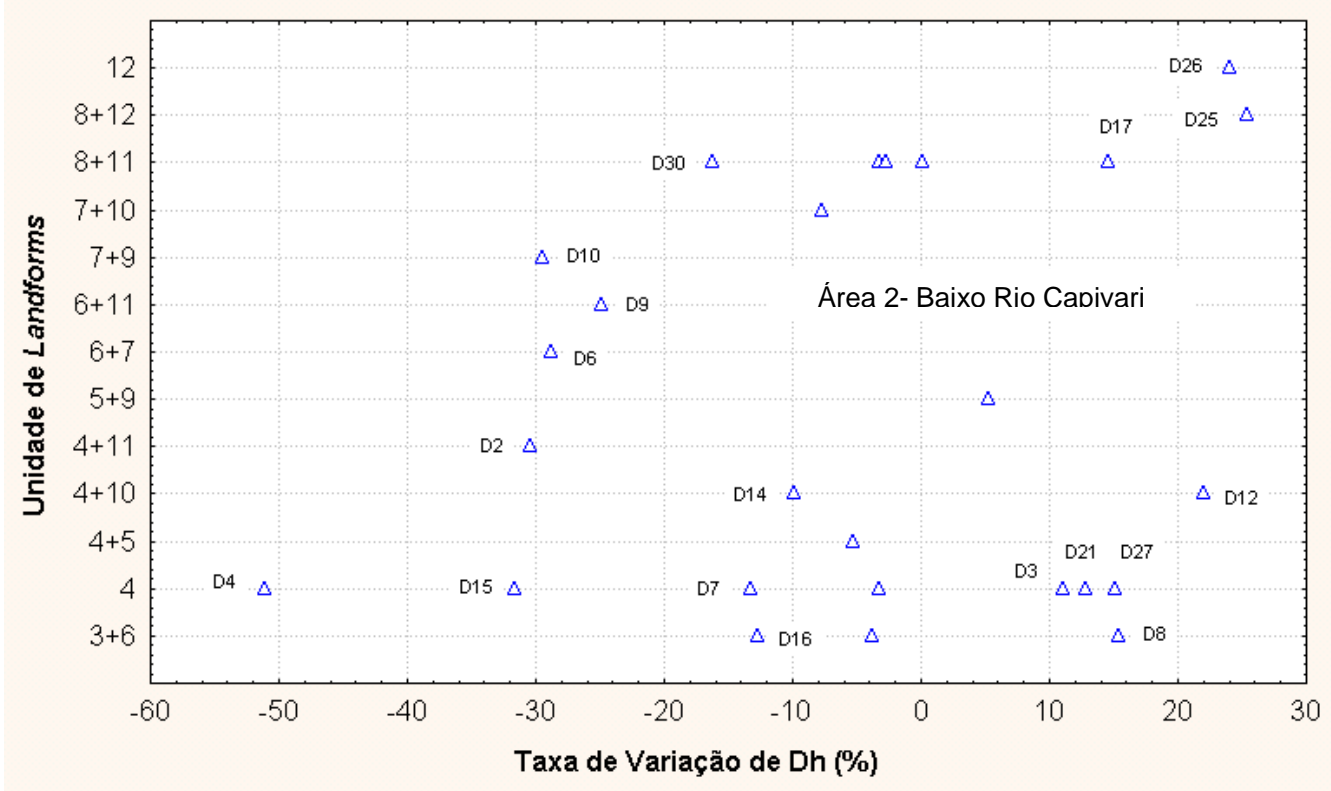

Figura 7.48 - Relação entre a Taxa de Variação de Dd (a) e Dh (b) e as unidades de landforms das microbacias da Área do Baixo Rio Capivari

As microbacias com taxas de variação de Dd apresentaram-se dispersas quando relacionadas às associações de materiais inconsolidados que as constituem e para registro pode-se definir que (Figura $7.49 \mathrm{~A}$ ):

- As alterações da taxa de variação referentes ao ganho ou déficit entre 10 a 20 \% foram relacionadas às associações de unidades de materiais inconsolidados A11 (D17 e D26), A9 e A11 (D10), A5 (D6 e D4), A4 e A9 (D27), A3 e A5 (D7); e, 
- As alterações de taxa de variação que apresentaram ganho ou déficit superiores a $20 \%$ foram relacionadas às associações de unidades de materiais inconsolidados A7 e A11 (D16), A7 (D15), A4 e A5 (D2 e D19) e, A3 e A7 (D14).

No gráfico referente à taxa de variação de Dh versus unidades de materiais inconsolidados, também, foi observada dispersão das microbacias e pode-se definir que (Figura 7.49B):

- As alterações da taxa de variação, referentes a ganho ou déficit entre 10 a 20 \% estão relacionadas às associações de unidades de materiais inconsolidados A11 (D17), A10 e A11 (D21), A7 e A11 (16), A5 (D3), A4 e A9 (D30 e D27) e A3 e A5 (D7 e D8); e,

- As alterações de taxa de variação que apresentaram a ganho ou déficit superiores a $20 \%$ foram relacionadas às associações de unidades de materiais inconsolidados A2 e A11 (D25), A3, A9 e A11 (D10), A4 e A5 (D2 e D9), A5 (D4 e D6), A7 (D15) e A11 (D26).

As microbacias relacionadas às associações de unidades de materiais inconsolidados A3 e A9 (D11), A5 e A4 (D5), A8 e A11 (D24), A9 (D28 e D29), e A10 e A11 (D22 e D23) não sofreram alterações significantes de Dh e Dd no período analisado.

Para o caso de microbacias com taxas de variação de Dd e Dh superiores a 30\%, constatou-se as seguintes relações:

- D15 associada à unidade A7;

- D14 relacionada à associação das unidades A3 e A7;

- D4 associada à unidade A5;

- D2 relacionada à associação das unidades A4 e A5.

As microbacias que apresentaram alterações importantes de $\mathrm{Rlm}_{2-1}$ e $\mathrm{Rb}_{1-2}$ foram relacionadas às associações de unidades de materiais inconsolidados A2 (D18), A2 e A11 (D25), A3 e A5 (D8), A3 e A7 (D14), A3, A9 e A11 (D12) e, A4 e A9 (D30).

Não houve um destaque nessa área a uma associação ou unidade de materiais inconsolidados diretamente relacionada às alterações dos índices estudados. 
(A) Taxa de Variação de Dd $x$ Unidade de Materiais Inconsolidados

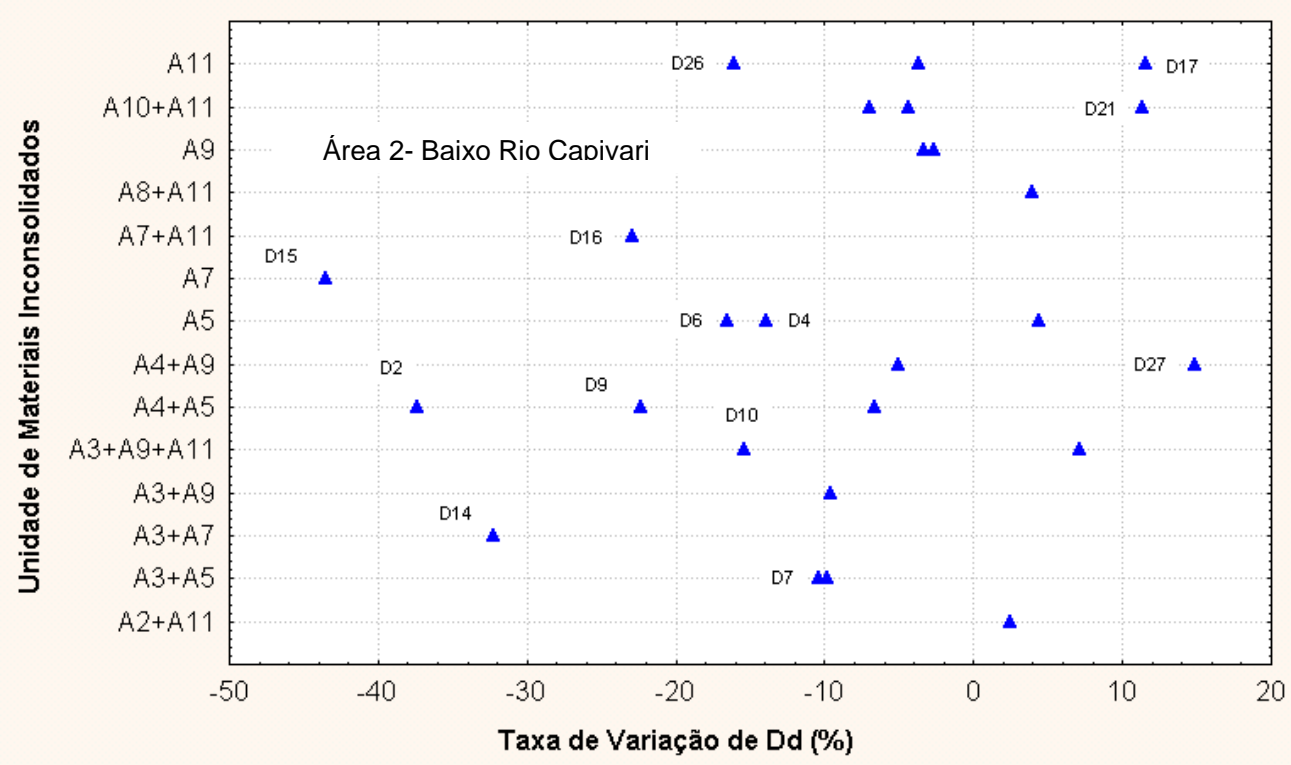

(B) Taxa de Variação de Dh $x$ Unidades de Materiais Inconsolidados

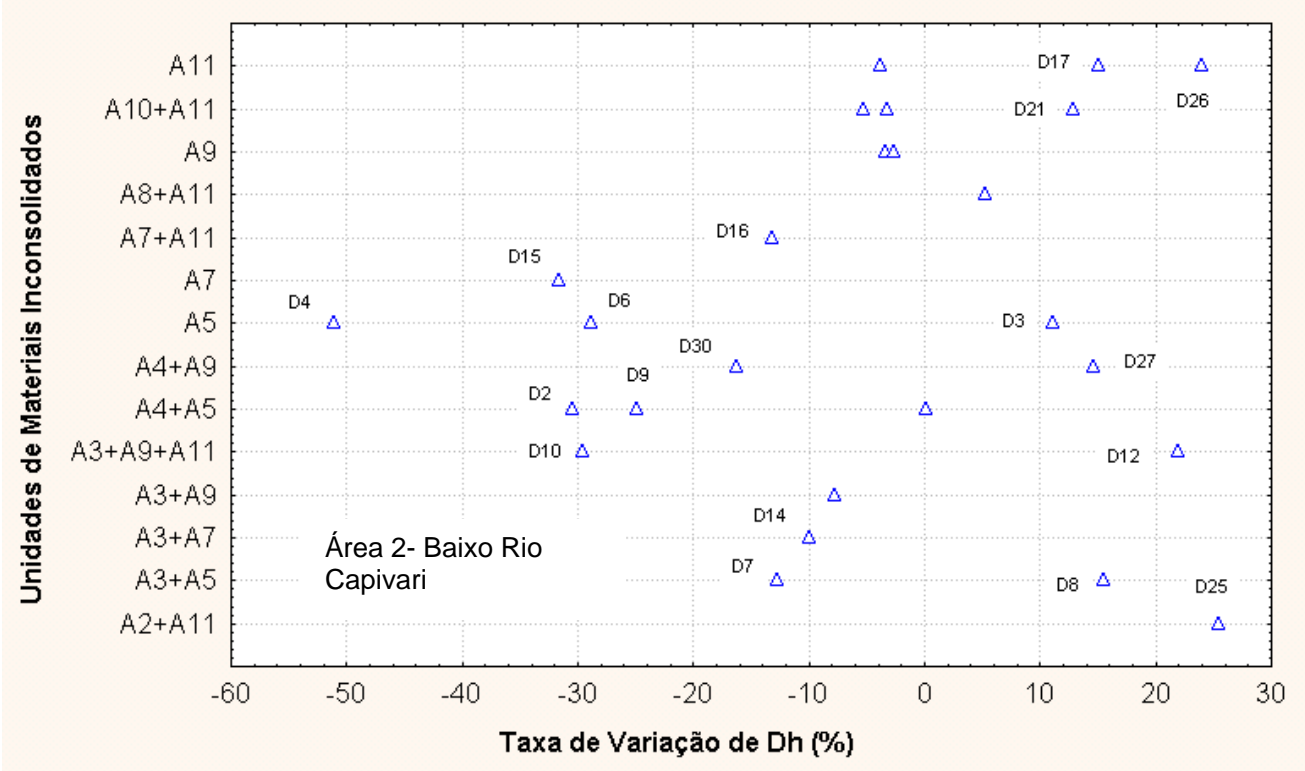

Figura 7.49 - Relação entre a Taxa de Variação de Dd (a) e Dh (b) e as unidades de materiais inconsolidados das microbacias da Área do Baixo Rio Capivari

\subsection{7 - Avaliação da Influência de Características de Uso e Ocupação nas Alterações Temporais}

A Área 2 foi caracterizada no Capítulo 6 como sendo estritamente rural, e pode-se subdividir as microbacias em cinco classes: microbacias com predomínio de pastagens, microbacias estritamente destinadas a cultivo de cana, microbacias com cultivo de cana e 
focos de pastagens, microbacias com cultivo de cana e focos de hortifruti e microbacias sem predomínio de atividades. A Tabela 7.16 mostra a classificação proposta para os anos de 1972 e 1995.

Tabela 7.16 - Classificação das Microbacias da Área 2 quanto ao uso e ocupação para 1972 e 1995

\begin{tabular}{|c|c|c|c|c|c|}
\hline \multirow[t]{2}{*}{ MICROBACIAS } & \multicolumn{2}{|c|}{$\begin{array}{l}\text { ATIVIDADE PREDOMINANTE } \\
\text { POR ANO }\end{array}$} & \multirow[t]{2}{*}{ MICROBACIAS } & \multicolumn{2}{|c|}{$\begin{array}{l}\text { ATIVIDADE PREDOMINANTE POR } \\
\text { ANO }\end{array}$} \\
\hline & 1972 & 1995 & & 1972 & 1995 \\
\hline$D 2$ & 2 & 3 & D16 & 1 & 1 \\
\hline D3 & 2 & 2 & $D 17$ & 1 & 2 \\
\hline D4 & 1 & 2 & D18 & 2 & 2 \\
\hline D5 & 3 & 2 & $D 21$ & 5 & 3 \\
\hline D6 & 2 & 2 & $D 22$ & 2 & 2 \\
\hline D7 & 2 & 2 & $D 23$ & 2 & 2 \\
\hline D8 & 4 & 2 & D24 & 1 & 2 \\
\hline D9 & 2 & 4 & $D 25$ & 1 & 2 \\
\hline D10 & 3 & 2 & $D 26$ & 2 & 2 \\
\hline D11 & 2 & 2 & D27 & 3 & 3 \\
\hline D12 & 3 & 2 & $D 28$ & 3 & 3 \\
\hline D14 & 1 & 3 & $D 29$ & 5 & 3 \\
\hline D15 & 1 & 1 & D30 & 3 & 3 \\
\hline & $\begin{array}{r}2 \\
3 \text { - Rural } \\
4 \text { - Rural }\end{array}$ & $\begin{array}{l}\text { CLAS } \\
\text { al com pre } \\
\text { ritamente } \\
\text { mínio de c } \\
\text { mínio de c } \\
\text { al sem pre }\end{array}$ & $\begin{array}{l}\text { ICAÇÃo } \\
\text { mínio de pastag } \\
\text { tinadas a cultiv } \\
\text { tivo de cana e fo } \\
\text { tivo de cana e fo } \\
\text { mínio de ativida }\end{array}$ & $\begin{array}{l}\text { ns } \\
\text { de cana } \\
\text { os de pasta } \\
\text { os de hortif } \\
\text { es- }\end{array}$ & \\
\hline
\end{tabular}

A Figura 7.50 mostra a taxa de variação para as principais classes de uso e ocupação: Mata/Reflorestamento (M), Hortifruti (H), Pasto/Mata Capoeira (P) e Cultivo de Cana (C).

Pode-se registrar, no período avaliado, para as principais classes de atividades que:

- As microbacias D4, D10, D11, D12, D14, D16, D17, D21, D24, D25, D28 e D29, mostraram reduções nas áreas de pasto entre 10 a 80\%;

- A microbacia D8 sofreu perdas em torno de 10\% da área de hortifruti; e,

- $\quad$ As microbacias D10, D15, D17, D18, D21, D2, D23, D24, D25, D27 e D30 sofreram diminuição das áreas de mata nativa (5 a 60\%).

Observou-se que a redução dessas classes de atividades foi devida à sua substituição por áreas de cultivo de cana. 


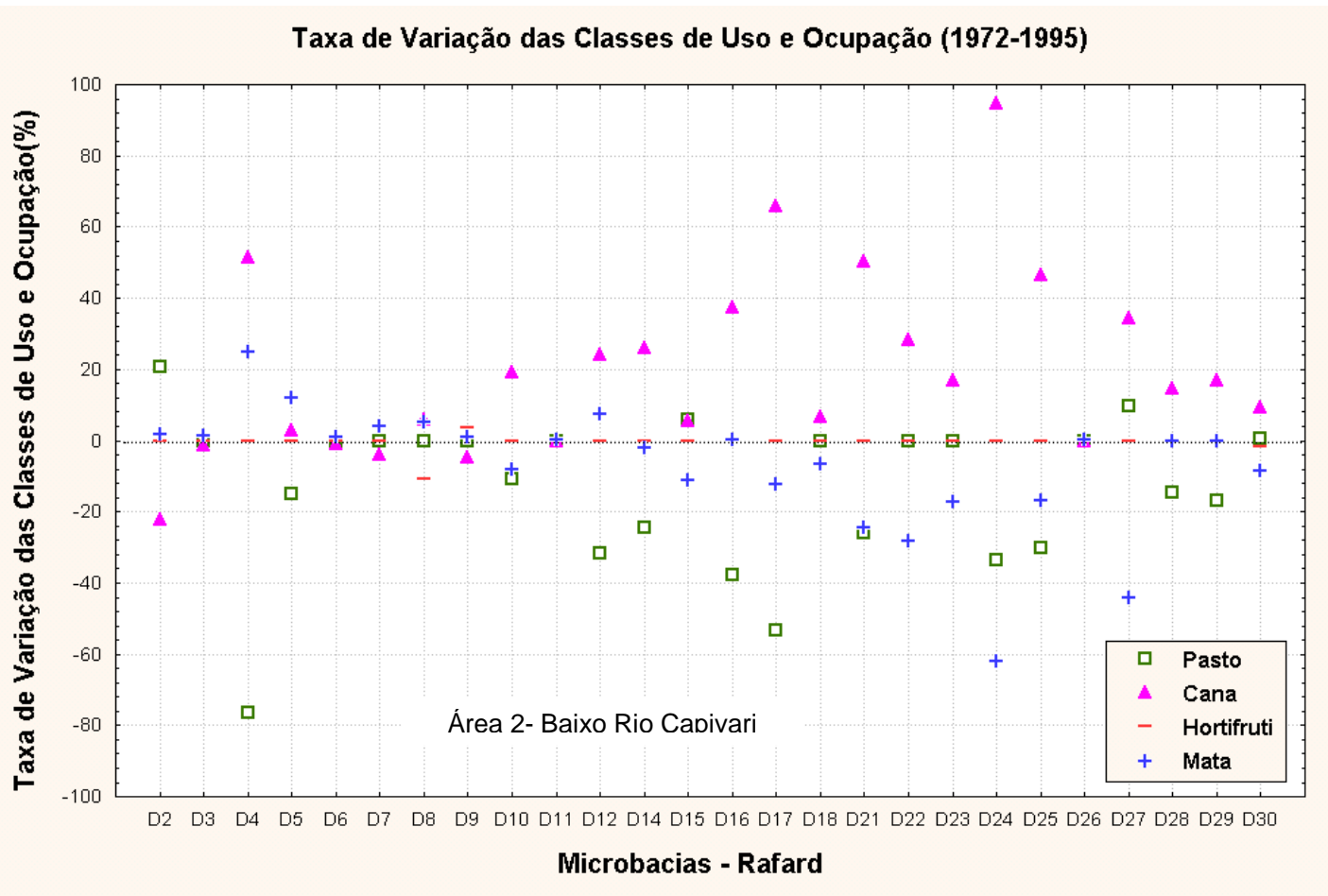

Figura 7.50 - Taxa de variação das principais classes de uso e ocupação na Área do Baixo Rio Capivari

Para a verificação da influência das atividades antrópicas sobre as alterações observadas na geometria da rede de drenagem, nas microbacias da área 2, foram feitas correlações entre:

- as taxas de variação dos principais índices morfométricos estudados (Dd e Dh) pelas porcentagens das áreas de cultivo de cana, hortifruti e pastagens referentes a 1995; e, - as taxas de variação de Dd e Dh pelas taxas de variação das áreas de cultivo de cana, pastos e hortifruti.

Na Figura 7.51a pode-se observar, para a taxa de variação de Dd entre 10 a $20 \%$ que a maioria das sub-bacias apresentou áreas destinadas ao cultivo de cana entre 80 a $100 \%$ (D4, D6, D7, D8, D10, D17, D21, D26 e D27), para $\Delta$ Dd entre 20 a 40\% que as áreas destinadas ao cultivo de cana variaram entre 40 a $80 \%$ (D2, D14 e D16) e para as taxas superiores a $40 \%$ de $\Delta \mathrm{Dd}$, as áreas de cultivo de cana foram restritas em torno de 5\% (D15).

Observou-se que as microbacias estritamente voltadas ao cultivo de cana ou com áreas de cultivo de cana superiores a $80 \%$ apresentaram intervalos distintos de variação de $\Delta$ Dh: entre 10 a 20\% (D3, D7, D8, D17, D21 e D30), 20 a 40\% (D6, D9, D10, D12, D25 e D26) e superiores a 40\% (D4). Cabe destacar as microbacias D2 e D15 por apresentarem alterações de Dh superiores a 30\%, com áreas de cana equivalentes a $80 \%$ e 5\%, 
respectivamente (Figura 7.51b). Tal fato mostrou que não há uma correlação nítida ente as porcentagens predominantes de uma determinada atividade com as taxas de variação de Dh.

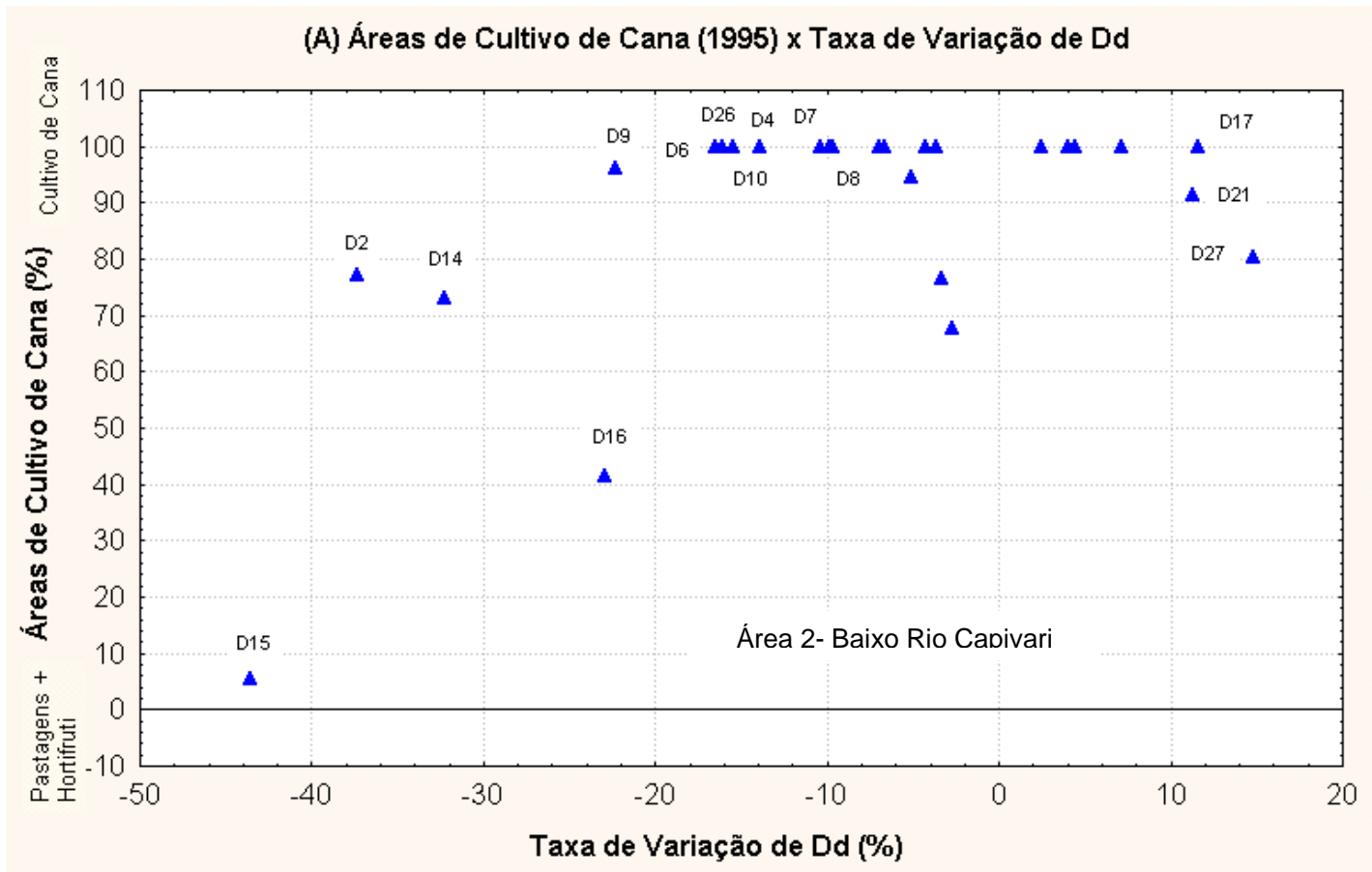

(B) Áreas de Cultivo de Cana (1995) x Taxa de Variação de Dh

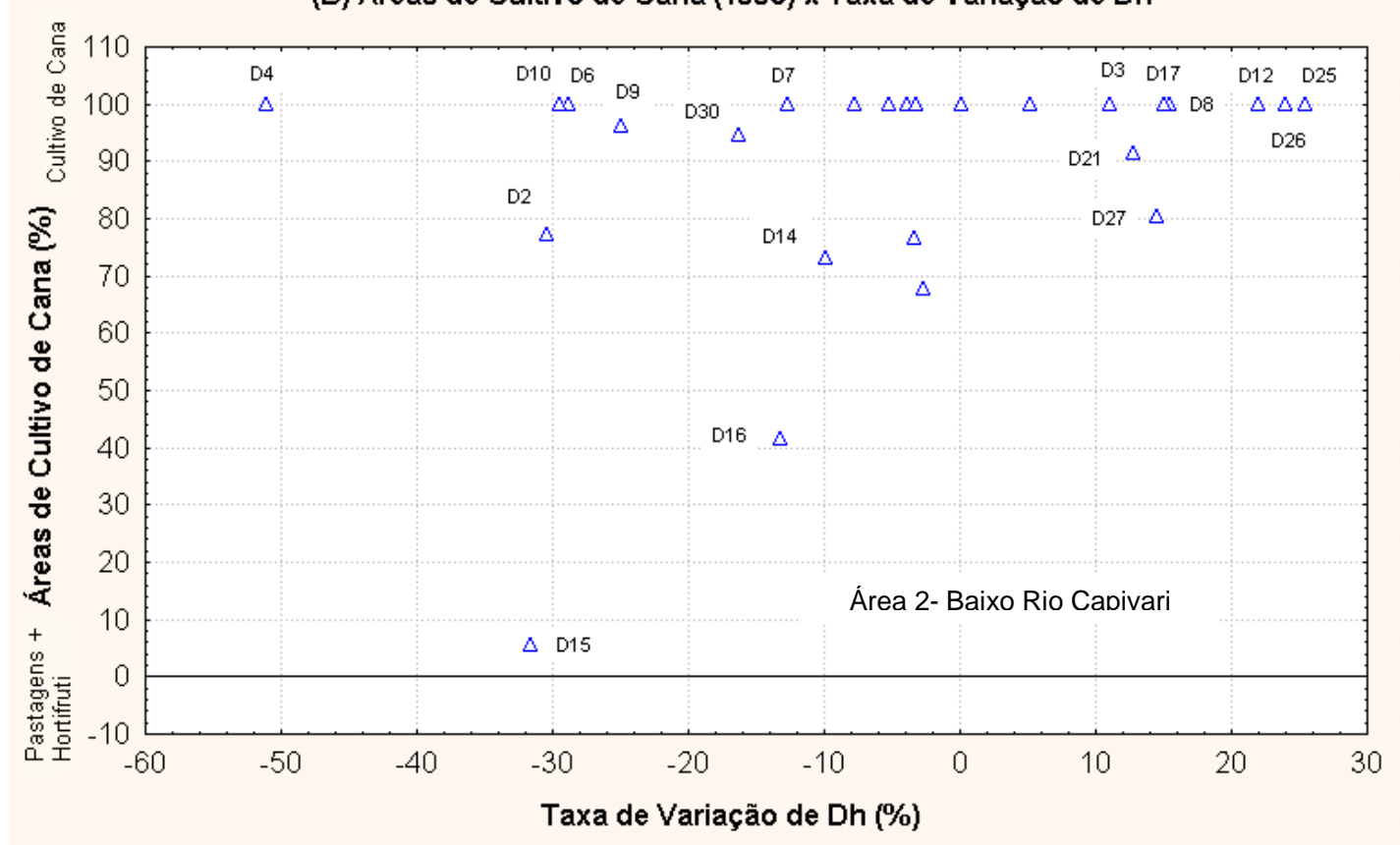

Figura 7.51 - Relação entre as taxas de variação de Dd (a) e Dh (b) com as porcentagens das áreas destinadas ao cultivo de cana nas microbacias da Área do Baixo Rio Capivari/SP 
Pode-se estabelecer relações entre a taxa de variação de áreas de cana, pasto e hortifruti quanto à significância das alterações em função das porcentagens da taxa de variação da densidade hidrográfica para as microbacias estudadas (Figura 7.52):

Para as taxas de variação de $\mathrm{Dh}$, consideradas com alterações significativas, as microbacias D10, D12, D14, D16, D17, D21, D25, D27 e D30 apresentaram taxa de variação de áreas de cultivo de cana entre 20 a 70\%.

Para a mesma taxa, pode-se verificar que D8, D10, D12, D14, D16, D21 e D25 apresentaram redução nas áreas de pastagens entre 10 a 60\%.

As taxas de variação de hortifruti foram muito pequenas na área de estudo. Essas áreas foram locais e reduzidas, cabendo destaque apenas a D8 que apresentou redução de suas áreas de hortifruti em torno de $12 \%$.

Nas taxas de variação de Dh, consideradas com alterações muito significativas, a microbacia D2 sofreu redução nas suas áreas de cultivo de cana em substituição por áreas de pastagens e D15 mostrou aumento nas áreas de pastagens e nas áreas de cultivo de cana, devido ao deflorestamento.

Nas taxas de variação de Dh, com alterações altamente significativas, representadas pela microbacia D4, observou-se perdas de áreas de pastos bem expressivas (70\%) e parte delas substituídas por áreas de cana (50\%) e partes por reflorestamento (30\%)

Aqui não cabe destacar as microbacias que sofreram alterações de $\operatorname{Rlm}_{2-1}$ e $\mathrm{Rb}_{1-2}$ por serem as mesmas analisadas como expressivas para $\Delta \mathrm{Dh}$. 
BAIXO RIO CAPIVARI - RAFARD

(A) Taxa de Variação de Dh $\times$ Taxa de Variação de Áreas de Cultivo de Cana

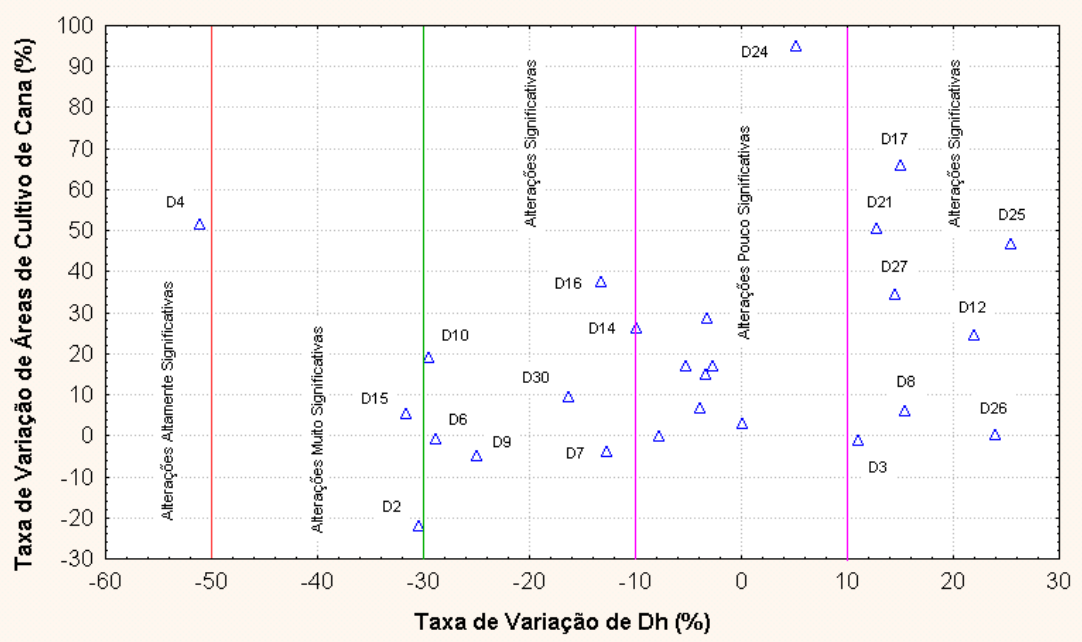

(B) Taxa de Variação de Dh x Taxa de Variação de Áreas de Pasto

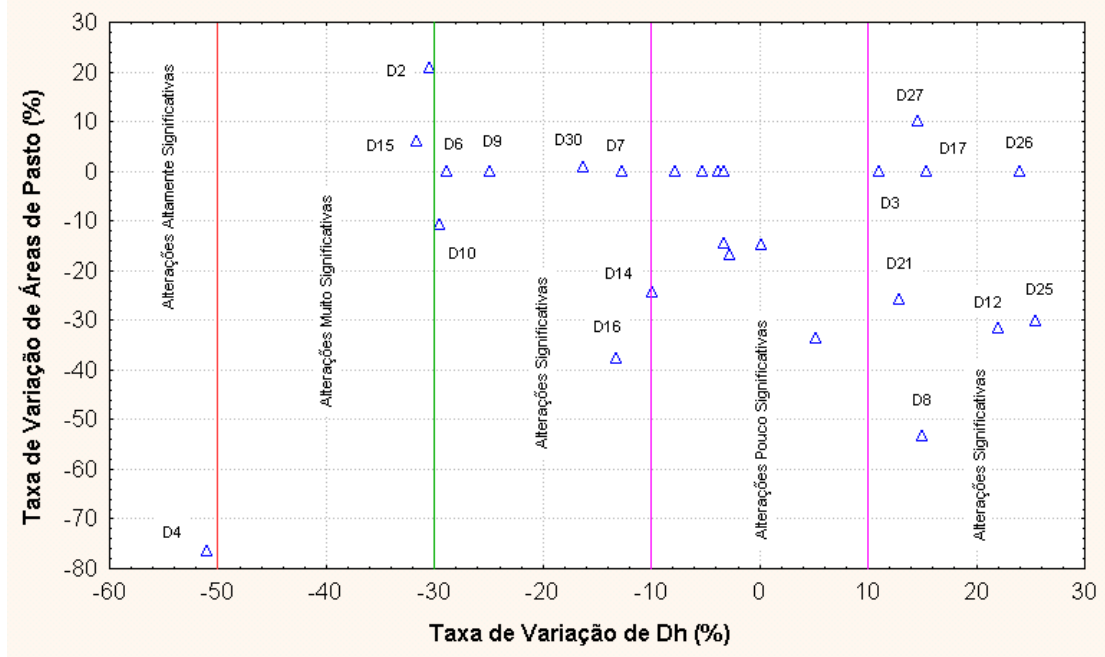

(C) Taxa de Variação de Dh x Taxa de Variação de Áreas de Hortifruti

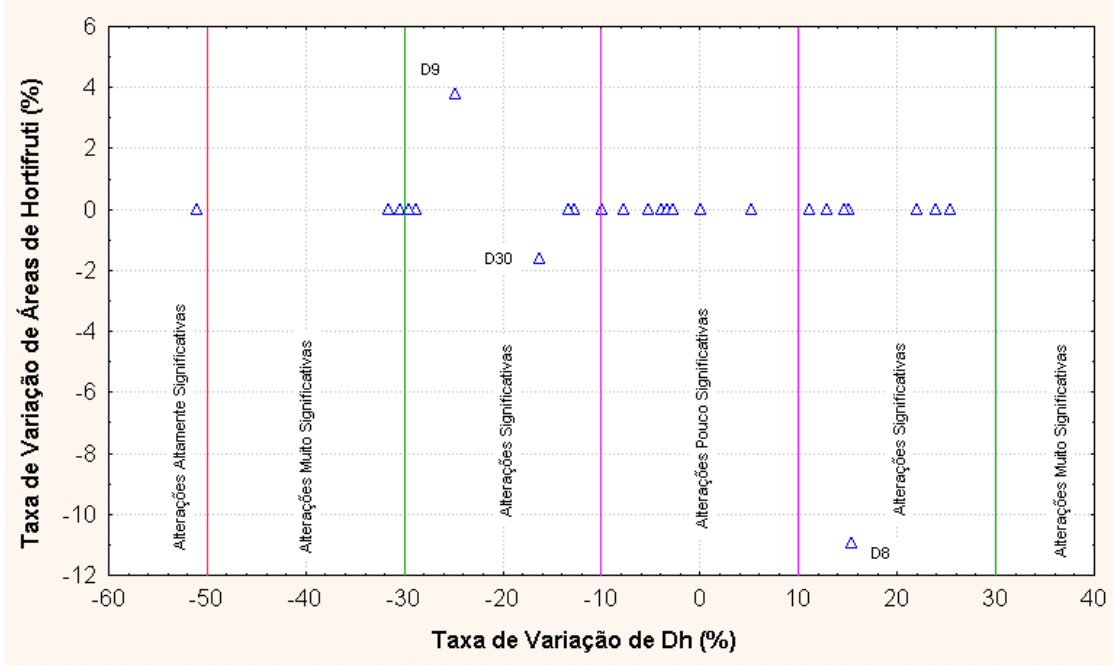

Figura 7.52 - Relação entre as taxas de variação de Dh com a taxa de variação de áreas de pasto, hortifruti e de cultivo de cana 


\subsection{8 - Considerações Parciais - Microbacias da Área 2}

\subsubsection{1 - Quanto às Características Morfométricas obtidas para a Área 2}

Para os dados obtidos dos índices morfométricos que caracterizaram as microbacias da Área 2 no período inicial de análise, pode-se destacar que:

- Os valores de índices de forma apresentaram valor médio de 1,25 e desvio padrão de 0,99 (Figura 7.32);

- Os valores de densidade de drenagem caracterizaram-se por valor médio de 5,12 km/ $\mathrm{km}^{2}$ e desvio padrão de $1,45 \mathrm{~km} / \mathrm{km}^{2}$ (Figura 7.33);

- Os valores de densidade hidrográfica apresentaram valor médio de 18,86 N1/ $\mathrm{km}^{2} \mathrm{e}$ desvio padrão de 9,93 N1/km² (Figura 7.34);

- Os valores de textura topográfica foram caracterizados por valor médio de 10,36 km e desvio padrão de 2,75 km (Figura 7.35);

- Os valores de razão de bifurcação entre os canais de Ordem 2 e 1 foram caracterizados por valor médio de 1,95 e desvio padrão de 0,95 (Figura 7.36); e,

- Os valores de razão entre comprimentos médios dos canais de Ordem 1 e 2 apresentaram valor médio de 3,91 e desvio padrão de 1,55 (Figura 7.37);

- Quanto maior as dimensões das microbacias, menores os valores de Dd e Dh (figuras 7.38 e 7.39); e,

- Os índices Dd e Dh apresentaram leve correlação linear, pois quanto maior a densidade de drenagem maior a densidade hidrográfica e vice-versa (Figura 7.40).

A análise estatística básica comparativa mostrou que os índices $\mathrm{Dd}$, $\mathrm{Tt}$ e $\mathrm{Rb}_{1-2}$ apresentaram resultados bem distintos entre os terrenos.

Estas características morfométricas refletem os condicionantes do meio físico tais como: substrato rochoso, materiais inconsolidados e estrutural estando diretamente ligada aos vários processos geológicos que sofreu.

\subsubsection{2- Quanto às Relações obtidas para as Taxas de Variação dos Principais Índices Morfométricos da Área 2}

Para as relações obtidas para as taxas de variação de Dd e Dh foi possível definir quatro grupos de alteração em relação à sua significância em:

- Microbacias com alterações pouco significativas ( $<10 \%$ de $\Delta$ Dh e $<10 \%$ de $\Delta$ Dd) - D4, D5, D11, D18, D22, D23, D24, D28 e D29; 
- Microbacias com alterações significativas (10 a 30\% de $\Delta$ Dh e > $10 \%$ de $\Delta$ Dd) - D6, D7, D9, D10, D16, D17, D21, D26 e D27;

- Microbacias com alterações muito significativas (30 a $50 \%$ de $\Delta$ Dh e $>10 \%$ de $\Delta \mathrm{Dd}$ ) D2 e D15; e,

- Microbacia com alteração altamente significativa (> $50 \%$ de $\Delta$ Dh e $>10 \%$ de $\Delta$ Dd) - D4.

Alguns casos particulares de microbacias que apesar de não se enquadrarem na classificação anterior foram analisados D3, D8, D12, D14, D25 e D30 com $\Delta$ Dd inferior a $10 \%$ e $\Delta$ Dh superior a $10 \%$.

As relações obtidas para $\Delta \mathrm{R} \operatorname{lm}_{2-1}$ e $\Delta \mathrm{Rb}_{1-2}$ também permitiram definir cinco grupos de alteração em função principalmente do déficit ou ganho expressos em porcentagens de ambas taxas de variação em:

- $\Delta \mathrm{Rb}_{1-2}-100$ a $0 \%$ e $\Delta \mathrm{Rlm}_{2-1}>80 \%$ - D10 e D26;

- $\Delta \mathrm{Rb}_{1-2}-100$ a $0 \%$ e $\Delta \mathrm{Rlm}_{2-1}-80$ a $80 \%$ - D4, D6, D7, D9 e D25;

- $\Delta \mathrm{Rb}_{1-2} 0-100 \%$ e $\Delta \mathrm{Rlm}_{2-1}<80 \%$ - D14 e D30;

- $\Delta \mathrm{Rb}_{1-2} 0-100 \%$ e $\Delta \mathrm{Rlm}_{2-1}-80$ a $80 \%$ - D2, D5, D8. D17 e D18; e,

- $\Delta \mathrm{Rb}_{1-2}>100 \%$ e $\Delta \mathrm{R} \operatorname{lm}_{2-1}-80$ a $80 \%$ - D15

D5, D11, D22, D23, D24, D28 e D29, não sofreram alterações significantes na geometria da rede de drenagem.

\subsubsection{3 - Quanto à Influência do Meio Físico da Área 2}

Na área localizada no Baixo Rio Capivari, a natureza geológica dos materiais foi a característica do meio físico de maior importância, possivelmente o contraste entre a resistência dos litotipos pode facilitar os processos de modificação da rede de drenagem, visto que apenas 6 microbacias não sofreram alterações significativas dos índices Dd, Dh, $\mathrm{Rlm}_{2-1}$, ou $\mathrm{Rb}_{1-2}$.

$\mathrm{O}$ registro da unidade de landform 4 nas microbacias que sofreram alterações significantes nos índices estudados sugeriu possível influência de uma de suas características ou mais nas modificações da rede de drenagem. Dentre as características pode-se citar o substrato rochoso constituído por diamictitos com intenso processo de empastilhamento e materiais inconsolidados composto por argilas nocivas a muito ativas. 


\subsubsection{4 -Quanto à Influência das Atividades Antrópicas na Área 2}

Quase todas as microbacias foram marcadas por um cultivo agrícola intensivo, atividade esta que pode ter sido a causa das modificações na rede de drenagem ao longo do período estudado. 


\section{CONCLUSÕES}

\section{1 - QUANTO AO METÓDO APLICADO}

A execução dos procedimentos propostos pelo Método de Collares (2000) para a verificação das alterações temporais da rede de drenagem na escala de trabalho adotada (1:25.000) tanto para áreas de Terreno Cristalino quanto para áreas de Terreno Sedimentar mostrou-se válida.

O estudo comparativo temporal das fotografias aéreas, como já constatado anteriormente por outros trabalhos, permitiu verificar as mudanças ocorridas tanto na rede de drenagem quanto no uso e ocupação, etapa fundamental do método.

A adição de ensaios de caracterização geotécnica ao método, procedimento esse já adotado por Silva (2000) e Ribeiro (2002), não só vem enriquecer o trabalho, mas foi fundamental para a compreensão das características do meio físico que possivelmente regem os processos e agentes modificadores das sub-bacias e microbacias.

O uso de microbacias de Ordem 3 como unidade de estudo foi válido uma vez que possibilitou a caracterização do quadro das alterações sofridos pela rede de drenagem. 


\section{2 - QUANTO À ANÁLISE MORFOMÉTRICA TEMPORAL}

Os resultados obtidos foram coerentes com os trabalhos já realizados na área (Collares, 2000; Silva, 2000; Ribeiro, 2002). A análise morfométrica obtida para os anos de 1972 e 1995 referentes às sub-bacias e as microbacias das áreas de Louveira e Rafard mostraram inter-relações entre os índices Nt, N1, Lt e L1 com forte influência nos parâmetros densidade de drenagem e densidade hidrográfica e relação direta entre os índices textura topográfica e densidade de drenagem.

Constatou-se que as alterações referentes ao aumento ou decréscimo do número de canais de Ordem 1 e de seus comprimentos foram as mais significativas e responsáveis pelas mudanças na geometria interna na rede de drenagem das sub-bacias.

Verificou-se na análise estatística básica que os índices $\mathrm{Dd}$, $\mathrm{Tt}$ e $\mathrm{Rb}_{1-2}$ foram os índices que mais caracterizaram as diferenças na morfometria da drenagem em 1972, evidenciando a influência direta da evolução geológico-estrutural de cada um.

Pode-se constatar que as relações encontradas entre as dimensões das áreas e os índices de Dd e Dh para as microbacias estudadas mostraram a tendência típica descrita por Horton (1945) e Cristofoletti (1979), de que quanto maior a área destas, menores os valores de Dd e Dh, assim como os índices Dd e Dh apresentaram uma leve correlação linear, ou seja, para maiores valores de Dd obteve-se maiores valores de Dh e vice-versa.

Dentre as 50 microbacias analisadas das áreas 1 e 2, só 10 não apresentaram modificações expressivas na sua rede de drenagem sendo 3 da área de terreno cristalino e 7 da área de terreno sedimentar.

Ficou claro a dificuldade em quantificar matematicamente as alterações sofridas no tempo pela rede de drenagem. Dentre as várias tentativas de encontrar relações que expressassem as alterações da rede de drenagem definiu-se apenas a relação entre $\Delta \mathrm{Dd}$ e $\Delta$ Dh para a área 1 , devido apresentar forte correlação linear de 0,84 , descrita pela fórmula I:

$$
\Delta D h=-4,3+1,26 \Delta D d
$$

Essa equação deve ser empregada apenas para a área 1. 


\section{3 - QUANTO AS CAUSAS DA ALTERAÇÃO DA REDE DE DRENAGEM}

O procedimento que envolveu a análise estatística das áreas permitiu avaliar tendências das possíveis causas da alteração na rede de drenagem.

Na área 1 a maioria das microbacias apresentaram alterações significantes quanto a um dos índices estudados foram associadas aos landforms D e E (M1, M2, M7, M8, M9, M13, M14, M16, M19, M20, M21, M23, M24, M31 e M35). Enquanto as associações entre as unidades de materiais inconsolidados I e IV (M1, M2, M7 e M8), I e V (M1, M9, M16, M17, M19) e, II e IV (M3, M20, M21 e M31) envolveram um maior número de microbacias associadas a alterações das variáveis analisadas. As características dos materiais inconsolidados bem como das unidades de landforms, podem ser fatores que auxiliaram nos processos de modificação da rede de drenagem.

Na área sedimentar, a natureza geológica dos materiais foi a característica do meio físico de maior importância, possivelmente o contraste entre a resistência dos litotipos pode facilitar os processos de modificação da rede de drenagem, visto que apenas seis microbacias não sofreram alterações significativas dos índices $\mathrm{Dd}, \mathrm{Dh}, \mathrm{Rlm}_{2-1}$, ou $\mathrm{Rb}_{1-2}$.

Ainda na área, o registro da unidade de landform 4 nas microbacias que sofreram alterações evidencia esta consideração uma vez que dentre as características que podem influenciar diretamente na modificação da rede de drenagem pode-se citar: o substrato rochoso constituído por diamictitos com intenso processo de empastilhamento e materiais inconsolidados composto por argilas nocivas a muito ativas.

Como era esperado, o somatório entre essas tendências em análise com os dados obtidos do meio físico e alterações das atividades antrópicas permitiu concluir que:

- O fator responsável pelas modificações na rede de drenagem da área 1 foi a intensa atuação humana caracterizada por modificações e/ou implantação de atividades antrópicas na área, principalmente pelo crescimento urbano e atividade agrícola intensiva; e,

- As modificações na rede de drenagem na área 2 resultam de um somatório entre as características do meio físico e a atividade agrícola intensiva da área de estudo. 


\section{0 - REFERÊNCIAS BIBLIOGRÁFICAS}

ABNT - Associação Brasileira de Normas Técnicas (1984). NBR 6508 - MB28 - Grãos de Solos que passam na Peneira de 4,8 $\mathrm{mm}$ - Determinação da massa Específica dos Sólidos. Rio de Janeiro/RJ.

ABNT - Associação Brasileira de Normas Técnicas (1984). NBR 7181 - MB32 - Solo: Análise Granulométrica. Rio de Janeiro/RJ.

ABNT - Associação Brasileira de Normas Técnicas (1989). NBR 10.703 - MB 2887 - Solo: Determinação da Massa Específica Aparente de Amostras Indeformadas com Emprego da Balança Hidrostática. Rio de Janeiro/RJ.

ABNT - Associação Brasileira de Normas Técnicas (1989). NBR 10.838 - Degradação do Solo. Rio de Janeiro/RJ.

AGUIAR, R. L. (1994). Análise do Mapeamento Geotécnico nos Processos de Gestão Ambiental. Seminários Gerais. EESC/USP. São Carlos. 88 p.

ALMEIDA, F. F. M. de (1964). Fundamentos Geológicos do Relevo Paulista. Boletim do Instituto Geográfico e Geológico. 41:169 - 263.

ALMEIDA, C. M.; BRUNA, G. C. (1996). Conceitos de Preservação, Recuperação, Renovação. Reabilitação e Revitalização Ambiental Urbana: Principais Exemplos e 
Técnicas Utilizadas. São Paulo: FAU/USP. Roteiro Geral de Disciplina sobre Gestão de Áreas Especiais.

ALMEIDA, L. E. G. (2000). Mapeamento Geotécnico de Casa Branca (SP): Ênfase no Uso da Técnica de Avaliação de Terrenos e Perfis Típicos de Materiais Inconsolidados. Dissertação de Mestrado. EESC/USP. 121 p.

BARBOSA, O; ALMEIDA, F. F. M. (1949). A Série Tubarão na bacia do Rio Tietê, Estado de São Paulo. DNPM/DGM, Rio de Janeiro, v. 48, p. 1- 16.

BARROSO, E. M. (1993). Estudo das Características Geológicas e do Comportamento Geotécnico de um Perfil de Intemperismo em Leptinito. Dissertação de Mestrado. IG/UFRJ. 185 p.

BARROW. C. J. (1998). River Development Planning and Management: A Critical Review. World Development. 1 (26):171 - 186.

BELCHER, D. J. (1948). Determination of Soils Conditions from Aerial Photographs. Photogrammetric Engineering. 1 (14):482 - 488.

BERGER, A R. (1996). The Geoindicator Concept and its Application: An Introduction. In: BERGER, A R.; IAMS, W. J., Geoindicator: Assessing Environmental Changes in Earth Systems. Editora A A Balkema. p. 1- 14.

BITAR, O Y.; FORNASARI FILHO, N.; VASCONCELOS, M. M. T. (1990a). Considerações Básicas para a Abordagem do Meio Físico em Estudos de Impacto Ambiental. In: BITAR, O Y.; FORNASARI FILHO, N.; BRAGA, T. DE O; LEITE, C. A G.; GLVES, M. L.; VASCONCELOS, M. M. T., O Meio Físico em Estudos de Impacto Ambiental. São Paulo, IPT (Boletim 56) p. 9 - 13.

BITAR, O Y.; CERRI, L. E. S.; NASAKAWA, V. A (1992). Carta de Risco Geológico e Carta Geotécnica: Uma Diferenciação a partir de Casos em Áreas Urbanas no Brasil. In: Simpósio Latinoamericano sobre Riesgo Geológico Urbano, 2; Conferência Colombiana de Geologia Ambiental, 2. Pereira, Anais. Colômbia. 517 p. 
BITAR, O Y.; FORNASARI FILHO, N. (1990). Estudos de Impacto Ambiental e a Geologia. In: BITAR, O Y.; FORNASARI FILHO, N.; BRAGA, T. DE O; LEITE, C. A G.; GLVES, M. L.; VASCONCELOS, M. M. T., O Meio Físico em Estudos de Impacto Ambiental. São Paulo, IPT (Boletim 56) p. 1- 3.

BITAR, O Y.; BRAGA, T. DE O (1995). O Meio Físico na Recuperação de Áreas Degradadas. In: BITAR, O Y., Curso de Geologia Aplicada ao Meio Ambiente. São Paulo. Série Meio Ambiente. ABGE/IPT. p. 165 - 179.

BITAR, O Y. (1997). Avaliação da Recuperação de Áreas Degradadas por Mineração na Região Metropolitana de São Paulo. Tese de Doutoramento. Escola Politécnica de Engenharia de Minas/USP. 184 p.

CAETANO - CHANG, M. R. (1984). Análise Ambiental e Estratigráfica do Subgrupo Itararé (PC) no Sudoeste do Estado de São Paulo. Tese de Doutoramento. IG/USP. 310 p.

CHORLEY, R.; SCHUMM, S.; SUGDEN, D. E. (1984). Geomorphology. Editora Methuen. $3166-371 \mathrm{p}$.

COGEOENVIRONMENT - Commission on Geological Sciences for Environmental Planning (1995). The 1995 Geoindicator Checklist: Tools for Assessing Rapid Environmental Changes. ITC Publicações. N 46. 102 p.

COllares, E. G. (1996). Degradação Ambiental: Bases Conceituais, Análise e Avaliação. Seminários Gerias. EESC/USP. São Carlos. 104 p.

COLlaRES, E. G. (2000). Avaliação das Alterações em Rede de Drenagem de Microbacias como Subsídio ao Zoneamento Geoambiental de Bacias Hidrográficas: Aplicação na Bacia Hidrográfica do Rio Capivari - SP. Tese de Doutoramento. EESC/USP. 2 v. 189 p.

COLTRINARI, L.; McCALL, G. J. H. (1998). Geoindicadores: Ciências da Terra e Mudanças Ambientais. Revista do Departamento de Geografia. 11:6 -11. 
CONAMA - Conselho Nacional do Meio Ambiente (1986). Resoluções do CONAMA $n^{\circ}$ 01/86. Brasília: SEMA.

COOKE, R. U.; DOORNKAMP, J. C. (1990). Mapping Geomorphology. In: COOKE, R. U., DOORNKAMP, J. C. Geomorphology in Environmental Management: A New Introduction. 2 ed.. Editora Clarence Press. p. 19 - 63.

CRISTOFOLETTI, A (1968). O Fenômeno Morfogenético no Município de Campinas (SP). Tese de Doutoramento. FFCL/UNICAMP. 209 p.

CRISTOFOLETTI, A (1969). Análise Morfométrica das Bacias Hidrográficas. Campinas. Notícias Geomorfológicas. 9 (18):19 - 34.

CRISTOFOLETTI, A (1970). Análise Morfométrica das Bacias Hidrográficas do Planalto de Poços de Caldas - MG. Tese de Livre Docência. FFCL/Rio Claro. 215 p.

CUNHA, S. B.; GUERRA, A J. (1996). Degradação Ambiental. In: GUERRA, A . J. T.; CUNHA, S. B., Geomorfologia e Meio Ambiente. Editora Bertrand Brasil. 291-335 p.

CONSTITUIÇÂO FEDERAL - DECRETO FEDERAL 9732 (1989). Dispõe sobre a regulamentação do artigo $2^{\circ}$, inciso VIII, da Lei $n^{\circ}$ 6.938, de 31 de agosto de 1981, e dá outras providências (áreas degradadas).

DAEE - Departamento de Água e Energia Elétrica (1982). Estudo de Águas Subterrâneas. Região Administrativa 5. Campinas, São Paulo. DAEE. 2 v.

DAEE - Departamento de Água e Energia Elétrica (1998). Banco de Dados Pluviométrico do Estado de São Paulo. Centro Tecnológico de Hidráulica e Recursos Hídricos Convênio DAEE/USP - CD-ROM. Versão 1.

DAEMON, R. F.; QUADROS, L. P. (1970). Bioestratigrafia do Neopaleozóico da Bacia do Paraná. In: Congresso Brasileiro de Geologia., 24. Brasília. Anais. SBG. p. 359 - 412.

DEARMAN, W. R. (1974). Weathering Classification in the Characterization of Rock for Engineering Purposes in British Practice. Bull Int. Assoc. Eng. Geol. 9:33 - 42 
DEARMAN, W. R.; BAYNES, F. J.; IRFAN, T. Y. (1978). Engineering Grade of Weathered Granite. Engineering Geology. 12: 45 - 374.

DEERE, D. U.; PATTON, F. D. (1971). Slope Stability in Residual Soils. In: Pan. Conf. Soil. Mech Found. Eng., 4. Porto Rico. Proceedings. ISSMFE. p. 87 -170.

DE MELLO, V. F. B. (1979), Apreciações sobre a Engenharia de Solo Aplicável a Solos Residuais. São Paulo. ABGE. 60 p. (Tradução n. 9)

DNPM - Departamento Nacional de Produção Mineral (1979). Mapas Geológicos 1:100.000. Projeto Sapucaí. Relatório Final. MME/DNPM. Estados de São Paulo, Rio de Janeiro e Minas Gerais. Brasília : SUREG/SP. Série Geologia 4, Secção Geológica Básica 2. $299 \mathrm{p}$.

DNPM/CPRM - Departamento Nacional de Produção Mineral / Companhia de Pesquisa de Recursos Minerais (1984). Projeto Mapas Metalogenéticos e de Previsão de Recursos Minerais. Folha SF.23-Y-A . Campinas. Escala 1:250.000. Convênio DNPM/CPRM. Estado de São Paulo. 2 v.

DUINKER, P. N.; BEANDLES, G. E. (1989). The Significance of Environmental Impacts: An Exploration of the Concept. Environmental Management. New York. 10 (2):166 170.

FAO - Food Agriculture Organization (1995). Land and Water Integration and River Basin Management. Roma. FAO Land and Water Bulletin. n. 1. 81 p.

FERREIRA, S. M. (1997). Ritmitos Várvicos do Subgrupo Itararé - O Exemplo da Pedreira de Varvitos de Itu. Dissertação de Mestrado. UNESP/IGCE. 1v. 159 p.

FERREIRA, M. C. (1999). Análise Espacial da Densidade de Drenagem em Sistema de Informação Geográfica através de um Modelo Digital de Distâncias Interfluviais. São Paulo. Geociências. 16 (1):243 - 255. 
FORNASARI FILHO, N.; BRAGA, T. DE O; GALVES, M. L.; BITAR, O Y.; AMARANTE, A (1992). Alterações no Meio Físico Decorrentes de Obras de Engenharia. São Paulo, IPT (Boletim 61). 165 p.

FORNASARI FILHO, N.; BITAR, O Y.; GALVES, M. L (1990). Processos do Meio Físico como Objeto da Geologia de Engenharia nos Estudos de Impacto Ambiental. In: BITAR, O Y.; FORNASARI FILHO, N.; BRAGA, T. DE O; LEITE, C. A G.; GALVES, M. L.; VASCONCELOS, M. M. T., O Meio Físico em Estudos de Impacto Ambiental. São Paulo, IPT (Boletim 56). p. 18 - 23.

FPC - Forest Practice Canada (1996). Channel Assessment Procedure Guidebook. http://www.for.gov.bc.ca.

FRANÇA, G. V. (1968). Interpretação de Fotografias de Bacias e de Redes de Drenagem Aplicadas a Solos da Região de Piracicaba. Tese de Doutoramento. ESALQ/USP. 151 p.

FÚlFARO, V. J.; STEVAUX, J. C.; SOUZA FILHO, E. F.; BARCELOS, J. H. (1984). A Formação Tatuí (P) no Estado de São Paulo. In: Congresso Brasileiro de Geologia, 33. Rio de Janeiro, Anais. Rio de Janeiro. v. 2. p. 711 - 724.

GAMA JR, E. G.; CAETANO, M. R.; WEYLER, G (1980). Divisão Faciológica do Grupo Itararé no Centro-Leste do Estado de São Paulo. In: Congresso Brasileiro de Geologia, 31. Camboríu, Anais. Santa Catarina. SBG. n. 2. p. 365.

GANDOLFI, N. (1968). Bacia do Mogi-Guaçu: Morfometria de Drenagem, Sedimentologia e Investigações Físico-Químicas. Tese de Doutoramento. EESC/USP. $123 \mathrm{p}$.

GANDOLFI, N. (1971). Investigações Sedimentológicas, Morfométricas e FísicoQuímicas nas Bacias de Mogi-Guaçu, do Ribeira e do Peixe. Tese de Livre Docência. EESC/USP. 108 p.

GOUDIE. A (1990). The Human Impact on the Natural Environment. Oxford. 3. Ed. 600 p. 
GUimARÃES, M. F.; CAERVALHO, W. A; FREIRE, O; PIEDADE, G. C. R. (1989). Relação entre Relevo, Material Erodido e Solos Provenientes de Rochas Eruptivas Básicas. Científica, São Paulo. 17 (1):97 - 101.

HASUY, Y.; OLIVEIRA, M. A F. (1984). Província Mantiqueira: Setor Central. In: ALMEIDA , F. F. M.; HASUI , Y., O Pré-Cambriano do Brasil. Editora Edgard Blücher Ltda. 378 p.

HORTON, R. E. (1945). Erosional Development of Streams and their Drainage Basins: Hydrophysical Approach to Quantitative Morphology. Geological Society American Bulletin. 56 (3):275 - 239.

HUNT, C. B. (1974). Geology of Soils. Editora W. H. Freeman. 344 p.

IG - Instituto Geológico (1993). Subsídios do Meio Físico Geológico ao Planejamento do Município de Campinas - SP. Programa: Cartas Geológicas e Geotécnicas para Planejamento Ambiental na Região entre Sorocaba e Campinas. Secretaria do Meio Ambiente do Estado de São Paulo - CINP. Relatórios Técnicos. 2 v.

IGC - Instituto Geográfico e Cartográfico do Estado de São Paulo (1979). Mapa Topográfico Bairro do Poste. Folha SF-23-Y-C-III-1-SO-A. São Paulo, IGC. Secretaria de Economia e Planejamento. Escala 1:10.000.

IGC - Instituto Geográfico e Cartográfico do Estado de São Paulo (1979). Mapa Topográfico Bairro do Tanquinho. Folha SF-23-Y-C-I-2-NE-F. São Paulo, IGC. Secretaria de Economia e Planejamento. Escala 1:10.000.

IGC - Instituto Geográfico e Cartográfico do Estado de São Paulo (1979). Mapa Topográfico Bairro Frio. Folha SF-23-Y-A-IV-4-SE-E. São Paulo, IGC. Secretaria de Economia e Planejamento. Escala 1:10.000.

IGC - Instituto Geográfico e Cartográfico do Estado de São Paulo (1979). Mapa Topográfico Bairro Rio Acima. Folha SF-23-Y-C-III-1-NO-F. São Paulo, IGC. Secretaria de Economia e Planejamento. Escala 1:10.000. 
IGC - Instituto Geográfico e Cartográfico do Estado de São Paulo (1979). Mapa Topográfico Bairro Sete Fogões. Folha SF-23-Y-C-I-2-NE-E. São Paulo, IGC. Secretaria de Economia e Planejamento. Escala 1:10.000.

IGC - Instituto Geográfico e Cartográfico do Estado de São Paulo (1979). Mapa Topográfico Bairro Tapera Grande. Folha SF-23-Y-C-III-1-NO-D. São Paulo, IGC. Secretaria de Economia e Planejamento. Escala 1:10.000.

IGC - Instituto Geográfico e Cartográfico do Estado de São Paulo (1979). Mapa Topográfico Bom Sucesso. Folha SF-23-Y-C-I-2-NO-D. São Paulo, IGC. Secretaria de Economia e Planejamento. Escala 1:10.000.

IGC - Instituto Geográfico e Cartográfico do Estado de São Paulo (1979). Mapa Topográfico Capivari I. Folha SF-23-Y-A-IV-4-SE-F. São Paulo, IGC. Secretaria de Economia e Planejamento. Escala 1:10.000.

IGC - Instituto Geográfico e Cartográfico do Estado de São Paulo (1979). Mapa Topográfico Costa Rica. Folha SF-23-Y-C-I-2-NO-B. São Paulo, IGC. Secretaria de Economia e Planejamento. Escala 1:10.000.

IGC - Instituto Geográfico e Cartográfico do Estado de São Paulo (1979). Mapa Topográfico Fazenda Barnabé. Folha SF-23-Y-C-I-2-NE-D. São Paulo, IGC. Secretaria de Economia e Planejamento. Escala 1:10.000.

IGC - Instituto Geográfico e Cartográfico do Estado de São Paulo (1979). Mapa Topográfico Fazenda Santa Lídia. Folha SF-23-Y-C-I-2-NE-C. São Paulo, IGC. Secretaria de Economia e Planejamento. Escala 1:10.000.

IGC - Instituto Geográfico e Cartográfico do Estado de São Paulo (1979). Mapa Topográfico Fazenda Serra Azul. Folha SF-23-Y-C-II-2-NE-F. São Paulo, IGC. Secretaria de Economia e Planejamento. Escala 1:10.000.

IGC - Instituto Geográfico e Cartográfico do Estado de São Paulo (1979). Mapa Topográfico Itapeva. Folha SF-23-Y-C-II-2-SE-B. São Paulo, IGC. Secretaria de Economia e Planejamento. Escala 1:10.000. 
IGC - Instituto Geográfico e Cartográfico do Estado de São Paulo (1979). Mapa Topográfico Jundiaí 1. Folha SF-23-Y-C-III-1-SO-B. São Paulo, IGC. Secretaria de Economia e Planejamento. Escala 1:10.000.

IGC - Instituto Geográfico e Cartográfico do Estado de São Paulo (1979). Mapa Topográfico Limoeiro. Folha SF-23-Y-C-I-2-NE-A. São Paulo, IGC. Secretaria de Economia e Planejamento. Escala 1:10.000.

IGC - Instituto Geográfico e Cartográfico do Estado de São Paulo (1979). Mapa Topográfico Louveira. Folha SF-23-Y-C-III-1-NO-E. São Paulo, IGC. Secretaria de Economia e Planejamento. Escala 1:10.000.

IGC - Instituto Geográfico e Cartográfico do Estado de São Paulo (1979). Mapa Topográfico Pirapora. Folha SF-23-Y-C-I-2-NO-F. São Paulo, IGC. Secretaria de Economia e Planejamento. Escala 1:10.000.

IGC - Instituto Geográfico e Cartográfico do Estado de São Paulo (1979). Mapa Topográfico Rafard. Folha SF-23-Y-C-I-2-NE-B. São Paulo, IGC. Secretaria de Economia e Planejamento. Escala 1:10.000.

IGC - Instituto Geográfico e Cartográfico do Estado de São Paulo (1979). Mapa Topográfico Toledos. Folha SF-23-Y-A-IV-4-SO-F. São Paulo, IGC. Secretaria de Economia e Planejamento. Escala 1:10.000.

IGC - Instituto Geográfico e Cartográfico do Estado de São Paulo (1979). Mapa Topográfico Vinhedo 2. Folha SF-23-Y-C-II-2-NE-D. São Paulo, IGC. Secretaria de Economia e Planejamento. Escala 1:10.000.

IGC - Instituto Geográfico e Cartográfico do Estado de São Paulo (1979). Mapa Topográfico Vinhedo 3. Folha SF-23-Y-C-III-1-NO-C. São Paulo, IGC. Secretaria de Economia e Planejamento. Escala 1:10.000.

IPT - Instituto de Pesquisa Tecnológicas (1981a). Mapa Geomorfológico do Estado de São Paulo - Escala 1:500.000. Governo do Estado de São Paulo, Secretaria da Indústria, 
Comércio, Ciência e Tecnologia : Divisão de Minas e Geologia Aplicada, Instituto de Pesquisas Tecnológicas do Estado de São Paulo. 2 v. Monografia 6.

IPT - Instituto de Pesquisa Tecnológicas (1981b). Mapa Geológico do Estado de São Paulo

- Escala 1:500.000. Governo do Estado de São Paulo, Secretaria da Indústria, Comércio, Ciência e Tecnologia : Divisão de Minas e Geologia Aplicada, Instituto de Pesquisas Tecnológicas do Estado de São Paulo. 2 v. Monografia 6.

JONES, D. K. C. (1993). Global Warming and Geomorphology. The Geographical Journal. 159:124-130.

KNIGHTON, D. (1984). Fluvial Forms and Process. London. Editora Edward Arnold. 212 p.

LAL, R.; HALL, G. F.; MILLER, F. P. (1989). Soil Degradation I: Basic Processes. Land Degradation \& Rehabilitation. 1(1):51- 69.

LEITE, C. A G.; FORNASARI FILHO, N.; BITAR, O Y. (1990). Estudos de Impacto Ambiental - Algumas Reflexões sobre Metodologia para o Caso da Mineração. In: BITAR, O Y.; FORNASARI FILHO, N.; BRAGA, T. DE O; LEITE, C. A G.; GALVES, M. L.; VASCONCELOS, M. M. T., O Meio Físico em Estudos de Impacto Ambiental. São Paulo, IPT (Boletim 56). p. 18 - 23.

LOLlo, J. A (1996). O Uso da Técnica de Avaliação do Terreno no Processo de Elaboração do Mapeamento Geotécnico: Sistematização e Aplicação na Quadrícula de Campinas. Tese de Doutoramento. EESC/USP. 2v.

LOLLO, J. A; ZUQUETTE, L. V. (1997). Avaliação do Terreno Aplicada a Elaboração do Processo de Mapeamento Geotécnico. Apostila SGS - 820. EESC/USP. 18 p.

LOPES, M.F.C. (1994). Condições de Ocorrência de Água Subterrânea nas Bacias dos Rios Piracicaba e Capivari. Dissertação de Mestrado. Faculdade de Engenharia Civil/Universidade Estadual de Campinas. 82p. 
MACARI, R. (1995). Mapeamento Geotécnico da Área de Expansão Urbana de Campinas - Porção NW. Seminários Gerias. EESC/USP. São Carlos. p. 32.

MACHADO, L. M. C. P. (1982). O Emprego de Médias Acumuladas na Aplicação do Modelo de Horton. Revista de Geografia, São Paulo. 1:65 - 75.

MITCHELL, C. W. (1991). Terrain Evaluation: Na Introductory Handbook to the History, Principles and Methods to Practical Terrain Assessment. Long Man Scientific \& Technical.

MOREIRA, I. V. D. (1990). Vocabulário Básico do Meio Ambiente. FEEMA/PETROBRÁS. Rio de Janeiro/RJ. 246 p.

NEIMANIS, V.; KERR, A (1996). Developing National Environmental Indicators. In: BERGER, A R.; IAMS, W. J., Geoindicator: Assessing Environmental Changes in Earth Systems. Editora A A Balkema. p. 360- 376.

OLIVEIRA, J. B.; MENK, J. R.; ROTTA, C. L. (1979). Levantamento Pedológico SemiDetalhado dos Solos do Estado de São Paulo - Quadrícula de Campinas, Rio de Janeiro. SUPREN - IBGE.

PASTORE, E L. (1992). Maciços de Solo Saprolíticos como Fundação de Barragens de Concreto Gravidade. Tese de Doutoramento. EESC/USP. 203 p.

PEJON, O J. (1992). Mapeamento Geotécnico da Folha de Piracicaba - SP. Escala 1:100.000 -Estudo de Aspectos Metodológicos de Caracterização e de Apresentação de Atributos. Tese de Doutoramento. EESC/USP. 2 v.

PETRI, S. (1964). Grupo Tubarão. Geologia do Estado de São Paulo. Boletim do. Instituto Geográfico e Geológico. n 41. p. 56 - 63.

PIEDADE, G. C. R.; CARVALHO, W. A (1981). Fotointerpretação Evolutiva da Rede de Drenagem de Áreas Voçorocadas no Município de Botucatu. Científica, São Paulo. 9(2):191-196. 
PIEDADE, G. C. R.; CARVAlHO, W. A; PFEIFER, R. M. (1984). Relações entre Parâmetros Dimensionais de Bacias Hidrográficas. Científica, São Paulo. 12 (1): 9 - 14.

PIRES, F. A (2001). Análise Paleoambiental e Estratigráfica do Subgrupo Itararé na Região do Médio Tietê, Estado de São Paulo. Tese de Doutoramento. UNESP/IGCE. $113 \mathrm{p}$.

PIRES, F.A; PETRI, S. (1991). O Subgrupo Itararé na Região de Capivari - Rafard, Estado de São Paulo. In: Simpósio Regional de Geologia do Sudeste, 2. São Paulo, Resumos. São Paulo SBG/NSP. p. 391 - 396.

PIRES, J. R. S.; SANTOS, J. E. dos (1995). Bacias Hidrográficas: Integração entre Meio Ambiente e Desenvolvimento. Ciência Hoje. 110 (19):40 - 45.

POLITANO, W.; AMARAL, C.; LOPES, L. R. (1995). Relacionamento entre Bacias Hidrográficas de Diferentes Ordens de Magnitude. Científica, São Paulo. 23 (1):73 - 83.

POLITANO, W.; FRANÇA, G. V.; CORSNI, P. C.; LOPES, L. R.; BANZANATTO, D. A (1991). Avaliação dos Critérios de Amostragem da Bacia Hidrográfica e Amostra Circular na Determinação de Características Quantitativas do Relevo e Rede de Drenagem, em Áreas de Solos Podzólicos Vermelho-Amarelos. Científica, São Paulo. 19 (1):71-81.

PONCE, V. M. (1989). Engineering Geology - Principles and Practices. Editora Prentice Hall. 640 p.

PRICE, D. G. (1993). A Suggested Method for the Classification of Rock Mass Weathering by a Rating Systems. Quarterly Journal Of Engineering Geology. (26): 69-76

RAWAT, J. S. (1987). Modeling of Water and Sediment Budget: Concepts and Strategies. In: ANHERT, F., Geomorphological Models: Teorical and Empirical Aspects. Catena Verlag. p. $147-60$.

RITTER, D. F.; KOCHEL, R. C.; MILLER, J. R. (1995). Process Geomorphology. Editora Wm. C. Brown. p. 137-228. 
ROSS, J. L. S. (1996). Geomorfologia aplicada aos EIAs-RIMAs. In: GUERRA, A J. T.; CUNHA, S. B., Geomorfologia e Meio Ambiente. Editora Bertrand Brasil. p. 337 - 376.

RUITENBEEK, H. J. (1991). Indicator of Ecologically Sustainable Development: Towards New Fundamentals. Ottawa. Canadian Environmental Advisory Council.

RUXTON, B. P.; BERRY, L. (1957). Weathering of Granite and Associated Erosional Features in Hong Kong. Bull. Geol. Soc. Amer. 68:1263-1292.

SAAD, A R. (1977). Estratigrafia do Subgrupo Itararé no Centro e Sul do Estado de São Paulo. Dissertação de Mestrado. IG/USP 107 p.

SANTOS, P. R. (1979). Distribuição Estratigráfica, Características e Fáceis de Diamicititos e Rochas Associadas do Subgrupo Itararé no Centro e Sul do Estado de São Paulo. Dissertação de Mestrado. IG/USP. 135 p.

SCHUMM, S. A (1956). Evolution of Drainage Systems and Slopes in Badlands at Perth Amboy. New Jersey. Bulletin of the Geological Society of America. 67:597-646.

SETZER, J. (1966). Atlas Climático e Ecológico do Estado de São Paulo. Comissão Interestadual da Bacia Paraná-Uruguai. São Paulo/CIPBU.

SHREVE, R. L. (1966). Statistical Law of Stream Numbers. Journal of Geology. 74 (1):1737.

SISNAMA - Sistema Nacional do Meio Ambiente (1981). Política Nacional do meio Ambiente. Lei ${ }^{\circ}$ 6.938/81.

SILVA, S. F. (2000). Avaliação das Alterações Ambientais na Sub-Bacia Hidrográfica do Ribeirão do Piçarrão, Campinas - SP. Dissertação de Mestrado. EESC/USP. 138 p.

SOARES, P. C. (1972). O Limite Glacial/Pós - Glacial do Grupo Tubarão no Estado de São Paulo. Anais da Academia Brasileira de Ciência. 44:333 - 342. 
SOARES, P. C.; FIORI, A P. (1976). Lógica e Sistemática na Análise e Interpretação de Fotografias Aéreas em Geologia. Notícias Geomorfológicas, Campinas. 16:71-104.

SOARES, P. C.; LANDIM, P. M. B.; SINELLI, O; WERNICK, E.; FU-TAI, W.; FIORI, A P. (1977). Associações Litológicas do Subgrupo Itararé e sua Interpretação Ambiental. Revista Brasileira de Geociências. 7(2):131-149.

SOBRAL, H. R. (1996). O Meio Ambiente e a Cidade de São Paulo. Editora McGraw-Hill. p. XI -XXI.

SOBREIRA, F. G. (1995). Estudo Geoambiental do Conselho de Sesimbra. Tese de Doutoramento. Departamento de Geologia, Faculdade de Ciências da Universidade de Lisboa. 347 p.

SOUZA, I. S. T. de; MEDINA, A I. M. (1997). Manejo Integrado de Sub - bacias Hidrográficas. Revista das Águas/CPRM. 1(1):59 - 66.

SOUZA FILHO, E. E. (1986). Mapeamento Faciológico do Subgrupo Itararé na Quadrícula de Campinas (SP). Dissertação de Mestrado. IG/USP. 121 p.

STEVAUX, J. C.; SOUZA FILHO, E. E.; TEIXEIRA, J. A.; LANDIM, P. M. B. (1987). Sistemas Deposicionais do Subgrupo Itararé $(\mathrm{P}-\mathrm{C})$ na bacia Hidrográfica do baixo Rio Capivari (SP): Um Modelo para a Prospecção de Água Subterrânea. In. Simp. Reg. Geol, 6. Rio Claro, Atas. São Paulo. SBG. v. 1. p. 335 - 374.

STRAHLER, A N. (1952). Hypsometric (Area Altitude) Analysis of Erosional Topography. Geology Society American Bulletin. 63 (10):1117 - 1142.

STRAHLER, A N. (1957). Quantitative Analysis of Watershed Geomorphology. Transaction of the American Geophysical Union. 38 (6): 913 - 920.

THOMAS, D. S. G.; ALLISON, R. J. (1993). Landscape Sensitivity. Editora John Wiley \& Sons. 347 p. 
TOMMASI, L. R. (1994). Estudo de Impacto Ambiental. São Paulo, CETESB: Terra Graph Artes e Informática. 354 p.

WEISS, N. A; HASSET, J. (1991). Introductory Statistics. 3 Ed. Addison - Wesley Publishing Company.

WOLLE, C. M. (1985). Peculiarities of "In Situ” Behavior of Tropical Soils: Slope Stability. Committee on Tropical Soils. In: ICCTLSS, 1 th, ISSMFE, Brasília.

ZUQUETTE, L. V. (1987). Análise Crítica da Cartografia Geotécnica e Proposta Metodológica para as Condições Brasileiras. Tese de Doutoramento. EESC/USP. 673 p.

ZUQUETTE, L. V. (1993). Importância do Mapeamento Geotécnico no Uso e Ocupação do Meio Físico: Fundamentos e Guia para Elaboração. Tese de Livre Docência. EESC/USP. 3 v. 673 p. 